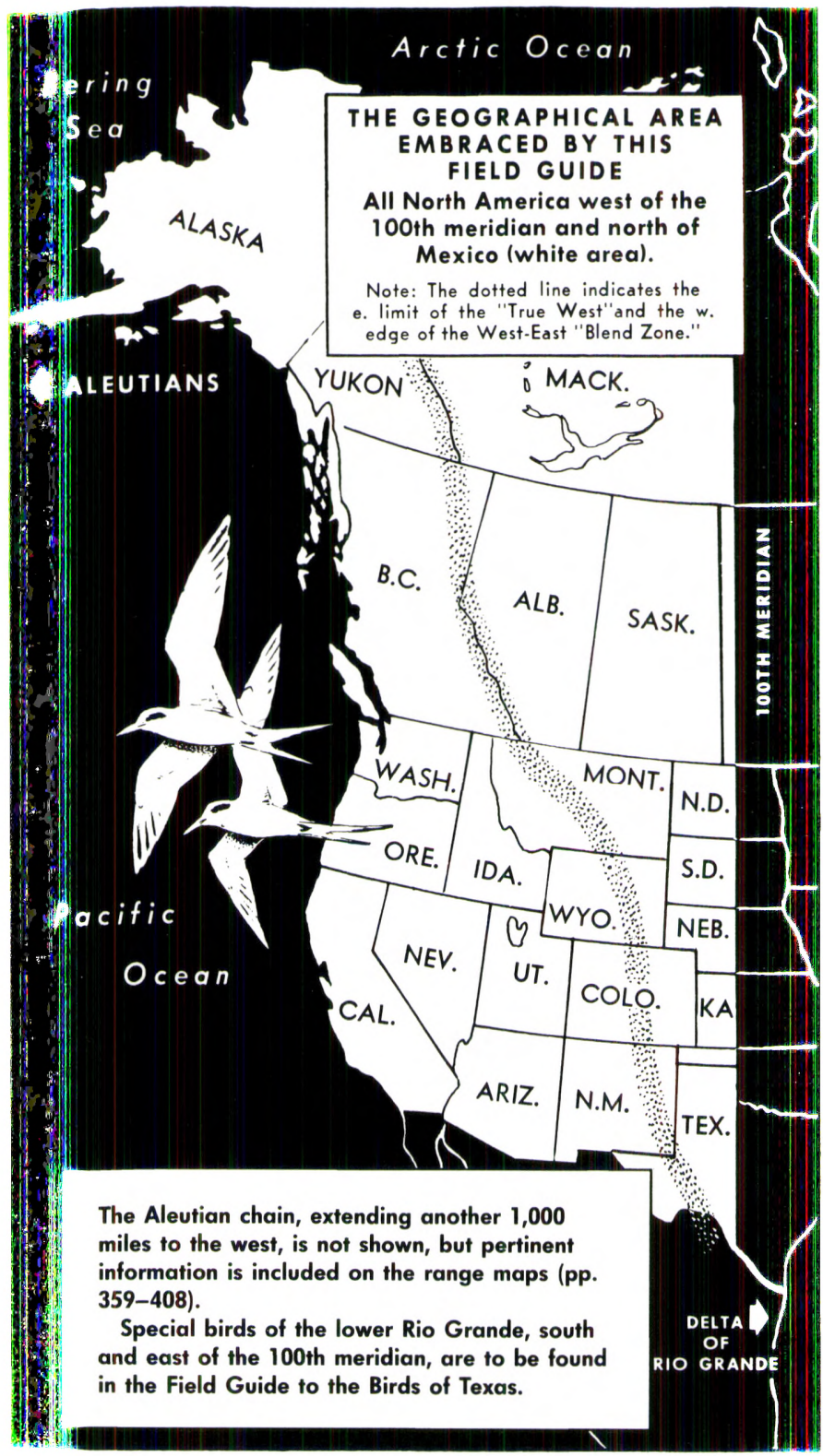




\title{
A Field Guide to Western Birds
}

\section{A Completely New Guide to}

Field Marks of All Species

Found in North America

West of the 100th Meridian and North of Mexico

\author{
Text and Illustrations by \\ ROGER TORY PETERSON \\ Maps by \\ VIRGINIA MARIE PETERSON
}

- Third Edition •

Completely Revised and Enlarged

Sponsored by the National Audubon Society,

the National Wildlife Federation, and the Roger Tory Peterson Institute 


\section{to the memory of}

CLARENCE BEAL

and

\section{JAMES FISHER}

Text and illustrations copyright (C) 1990 by Roger Tory Peterson Maps copyright (C) 1990 by Virginia Marie Peterson

All rights reserved.

For information about permission to reproduce selections from this book, write to Permissions, Houghton Mifflin Company, 215 Park Avenue South,New York, New York 10003

Visit our Web site: www.houghtonmifflinbooks.com

PETERSON FIELD GUIDES and PETERSON FIELD GUIDE SERIES are registered trademarks of Houghton Mifflin company.

Library of Congress Cataloging-in-Publication Data

Peterson, Roger Tory, (date)

A field guide to western birds: a completely new guide to field marks of all species found in North America west of the 100th meridian and north of Mexico / text and illustrations by Roger Tory Peterson; maps by Virginia Marie Peterson. - 3rd ed., completely rev. and enl. p. $\mathrm{cm}$ - (The Peterson field guide series; 2)

"Sponsored by the National Audubon Society, the National Wildlife Federation, and the Roger Tory Peterson Institute."

Includes index.

ISBN 0-395-91174-5

ISBN 0-395-91173-7 (pbk.)

ISBN 0-618-13218-X (Flexi-book)

1. Birds - West (U.S.) - Identification. 2. Birds - Canada,

Western-Identification. I. Peterson, Virginia Marie, (date).

II. National Audubon Society. III. National Wildlife Federation.

IV. Roger Tory Peterson Institute. V. Title. VI. Series. QL683.W4P4 1989

$598.2978-\operatorname{dc} 20 \quad 89-31517$

CIP

Printed in the United States of America

WCT $\begin{array}{lllllllll}20 & 19 & 18 & 17 & 16 & 15 & 14 & 13 & 12\end{array}$ 


\section{Introduction}

In 1934 my first Field Guide was published, covering the birds east of the 90th meridian in North America. Later this was extended to the 100th meridian on the Great Plains. This book was designed so that live birds could be readily identified at a distance by their "field marks," without resorting to the birdin-hand characters that the early collectors relied on. During the following half century the binocular and the spotting scope have replaced the shotgun.

The "Peterson System," as it now is called, is based on patternistic drawings with arrows that pinpoint the key field marks. These rather formal schematic illustrations and the direct comparisons between similar species are the core of the system, a practical method that has gained universal acceptance not only on this continent but also in Europe, where Field Guides now exist in 12 languages. This system, which is, in a sense, a pictorial key based on visual impressions rather than on technical features, has been extended to other branches of natural history and there are now about 40 titles in the Field Guide Series.

It was William Vogt, the first editor of Audubon magazine, who suggested that I put together a Field Guide using my visual approach to field identification, which I had already presented in articles in Nature Magazine and Field and Stream. After a preliminary draft of the book had been politely turned down by several publishers, Francis Allen, veteran editor of Houghton Mifflin, and a star birder himself, saw the validity of the new approach, and the rest is history. His successor, Paul Brooks, continued to carry on the editorial tradition.

Shortly after the first edition of the eastern Field Guide saw the light of day, Clinton G. Abbott, then director of the Natural History Museum at San Diego, asked why I didn't do a similar field guide for the West. I dismissed the idea at first, thinking that although the plan worked well for eastern North America, it would be a much more formidable task to attempt the same for the West. However, after prompting by Guy Emerson, then chairman of the National Audubon Society, I gave it a try. After tussling with a few of the problems, I concluded that field identification was not much more difficult in the West, and that most publications made things look more involved and clumsy than need be. There was already one excellent field handbook 
in use-Ralph Hoffmann's Birds of the Pacific States-but this covered only the states of Washington, Oregon, and California, whereas there was hardly anything of pocket size that was adequate for most other parts of the West.

This edition of A Field Guide to Western Birds is more than a revision; it is almost completely new, with 165 plates, as against 136 in the 1961 edition. None of the previous color plates of the western Field Guide has been retained. However, 24 plates have been borrowed from the latest eastern Field Guide to the Birds (1980), 30 others have been modified, and 111 plates are completely new. All species are now shown in color. The waterfowl are repeated in monochrome, because their flight patterns are more clearly diagnosed in that way.

There are also 441 three-color maps, a new feature. My wife, Virginia Marie Peterson, and I researched these together and she then carefully carried out their execution. Her trained hand and eye had previously been employed at the U.S. Coast Guard Research and Development Center, where she worked out critical methods for identifying oil spills by means of infrared spectroscopy. Virginia wrote the original Infrared Field Manual for Oil Spill Identification. She also prepared the 390 maps in the 1980 edition of the eastern Field Guide to the Birds.

With this new third edition, long overdue, the Field Guide to Western Birds has really come of age. Years ago I had concluded that for comparative purposes the ideal number of species per color plate would be about four (rather than ten or twelve, as in previous editions), but the cost factor prohibited this ideal format when we first broke ground. The success of the Field Guide, with its well-tested practical system, has grown steadily over the years, and the economics of distribution as well as technical advances in fine offset printing made it possible to surmount earlier restraints.

The Field Guide user will find one major format change that will be particularly helpful: species accounts, except in a few instances, now face the corresponding illustrations. Because of the success of this formula in the latest revision of the eastern Field Guide, many birders urged me to arrange text and plates of the western Field Guide in this way, and I have done so, but because of space limitations, maps are separate.

Area of this Field Guide: This guide covers North America west of the 100th meridian, as shown in the map on p. 2. Rather than a restrictive political boundary, an ecological one is more practical. In the U.S. the logical division of the avifauna is along the belt between the 100th meridian (midway across Oklahoma, Kansas, Nebraska, and the Dakotas) and the edge of the Rockies. This is by no means a sharp division, but people living in that ecological "twilight zone" will find that A Field Guide to Western Birds covers all species they are likely to encounter. In a 
general way, eastern birds follow the valleys west, while the western forms edge eastward along the more arid uplands. In Canada, eastern influences extend much further west, bridging the gap to the Rockies via the conifer forests north of the Great Plains.

The birds in the western third of Texas (the Panhandle and west of the Edwards Plateau) are covered in this Field Guide. Not so those in the lower Rio Grande Valley, where many western species reach their eastern outposts and a few very special Mexican species occur. These will be found in A Field Guide to the Birds of Texas (No. 13 in the Field Guide Series). Texas is the only state with its own Field Guide.

In the 1961 edition, I included a separate 32-page section on the Hawaiian Islands. Because of the excellent new Field Guide to the Birds of Hawaii and the Tropical Pacific by Douglas Pratt, Phillip Bruner and Delwyn Berrett, and also the latest edition of Hawaii's Birds edited by R.J. Shallenberger (published by the Hawaiian Audubon Society), I have chosen to omit that section and to devote those pages to a more in-depth treatment of Alaska, the Aleutians, and the Bering Sea area.

Drawings vs. Photographs: Because of the increasing sophistication of birders, I have leaned more toward detailed portraiture in the new illustrations while trying not to lose the patternistic effect developed in the earlier editions. A drawing can often do more than a photograph to emphasize field marks. A photograph is a record of a fleeting instant; a drawing is a composite of the artist's experience. The artist can edit out, show field marks to best advantage, and delete unnecessary clutter. He can also choose position and stress basic color and pattern unmodified by transitory light and shade. A photograph is subject to the vagaries of color-temperature (Kelvin), make of film, exposure, time of day, sunlight, open shade, use of flash, angle of view, skill of the photographer, and just plain luck. The artist has more options and far more control even though he may at times use photographs for reference. This is not a diatribe against photography; I am an obsessive photographer as well as a painter and therefore am fully aware of the pitfalls and the differences. Whereas a photograph can have a living immediacy, a good drawing is more instructive as a teaching device.

Subspecies: These simply represent subdivisions within the geographic range of a species. They are races, usually determined by morphological characteristics such as slight differences in measurements, shades of color, etc. These subtle subdivisions can usually be distinguished with accuracy only by collecting birds with a gun or a mist net and comparing them with museum specimens. The distinctions, often vague, are seldom apparent in the field. Subspecies have a meaning to the student 
of bird distribution and evolution and are of practical value to those involved in conservation and wildlife management practices. Should occasion demand, the scholar can refer to his copy of the older 5th edition of the Checklist of the American Ornithologists' Union (A.O.U.), which gave a detailed breakdown of races and their ranges. The 6th edition (1983) does so only in a very general way. However, in this new edition of the Field Guide, a few subspecies are recognized when field distinctions are obvious. One of the most controversial examples is the western "Bullock's" Oriole, which is now lumped with the eastern "Baltimore" Oriole under the new name Northern Oriole. "Myrtle" and "Audubon's" warblers are now lumped as the Yellow-rumped Warbler. Most of the juncos have also been lumped. The earlier names and a few others have been retained (in quotes) in deference to long-established usage. Names that were used in the 1961 edition of this book but which have since been changed by the Checklist Committee are in parentheses under the current name. We can expect further changes by the A.O.U.

The Ranges of Birds: A number of species have been added to the avifauna of western North America since the previous edition of this Field Guide was published in 1961. Notable is the Cattle Egret, which spread explosively after it arrived in the U.S. about 1952. Several eastern species are pushing west and a few exotic escapes, especially parrots, are doing well and may become established.

The ranges of many species have changed markedly during the past 50 years. Some are expanding because of decades of protection; others have diminished alarmingly or have dropped out of parts of their range due to environmental changes. The passion for bird feeding has had its effect on expanding the ranges of several species.

The Maps: Instead of detailed range accounts, maps are now employed; they have been conveniently assembled in a separate section (pp. 359-408). Because the projections are large enough to show state and provincial lines, ranges are now defined more critically. However, the Aleutians, extending more than 1,000 miles to the west of the Alaska Peninsula, are not shown, but any pertinent information about these islands is included in notes on the maps. For quick use, the map section is marked with a gray corner that serves as a thumb index. By grouping the maps we can update them more frequently without affecting the rest of the pagination. Our knowledge of bird distribution is becoming ever more exact because of the proliferation of field observers. Not only are some birds extending their ranges, but so are the birders.

Although many birds (waterfowl, game birds, seabirds) had already been mapped continentally in the Handbook of North 
American Birds (edited by R. S. Palmer) and in other books, Virginia Peterson and I researched our own maps using state and regional sources, but we found these very uneven. Some western states already had good to excellent "latilongs," but only now are they becoming involved in more detailed atlasing.

Acknowledgments: The specimen material used in the preparation of the new color plates came almost entirely from the cabinets of the American Museum of Natural History in New York City. I am deeply grateful to the staff and curators of the Department of Ornithology of that institution for their assistance, and specifically to Dean Amadon, Allison Andors, Chris Blake, John Bull, Robert Dickerman, Eugene Eisenmann, John Farrand, Stuart Keith, Wesley Lanyon, Mary Le Croy, Allan O'Connor, Lester Shortt, and Françoise Villeumier.

Space prevents me from listing again the mass of ornithological literature digested in the preparation of the earlier editions of the Field Guide to Western Birds, as well as the regional works, checklists, papers, and periodicals that went into the compilation of this one. Assiduously I consulted them all and intentionally ignored none. A list of these sources is on file and available in my library.

Nor shall I list again the 200 or more field companions, correspondents, and others who contributed notes or helped in other ways in previous editions and those who were involved in their production. Their names are in the Preface of the second edition (revised and enlarged, 1961). However, I would like to acknowledge again two people who played especially important roles: Edgar Kincaid, who sharpened my critical senses, and Barbara Peterson, who typed and retyped the manuscripts a number of times, offered suggestions, and helped in many other tangible ways.

In preparing the new maps, Virginia Peterson and I consulted all of the pertinent state and regional books in the Special Book Supplement prepared by American Birds, and, equally important, the files of American Birds, which is published by the National Audubon Society, 950 Third Avenue, New York, New York 10022.

The breeding birds of Canada had already been mapped in Birds of Canada by Earl Godfrey, who generously made the updated version of these maps available to us prior to publication. Paul Johnsgard was also very generous, letting us see much of his own material prior to publication in several of his books. Don Roberson's scholarly Rare Birds of the West Coast was indispensable when dealing with casuals and accidentals, as was the Distributional Checklist of North American Birds by David De Sante and Peter Pyle.

The problem of covering Alaska adequately was solved when Pete Isleib, a peerless and indefatigable observer, prepared for us 
three albums of large-scale maps, based largely on years of research by his associates, Dan Gibson and Brina Kessel. They were then checked further by Peter Connors, James King, and John Wright. These maps cover every species known to have occurred in Alaska.

Before my wife, Virginia, finalized her cartography, she sent out a number of selected maps to the following authorities for fine-tuning: Stephen Bailey (Calif.), Mark Collie (Idaho), Phillip Detrich (Calif.), Jon Dunn (Calif.), Kimball Garrett (Calif.), Eugene Hunn (Wash.), Kenn Kaufman (Ariz.), Hugh Kingery (Colo.), Paul Lehman (Calif.), Guy McCaskie (Calif.), Joseph Morlan (Calif.), Vince Mowbray (Nev.), Dennis Paulson (Wash.), Don Roberson (Calif.), Oliver Scott (Wyo.), Arnold Small (Calif.), Ella Sorensen (Utah), Rich Stallcup (Calif.), Allan Stokes (Utah), Stephen Summers (Ore.), Daniel Taylor (Idaho), Thede Tobish (Alaska), Charles Trost (Idaho), R. E. Walters, Jr. (Utah), Ralph Widrig (Wash.), Kevin Zimmer (N.M.), and Dale Zimmerman (N.M.).

The following people gave us additional help on specifics concerning the maps: Frederick and Margarite Baumgartner, Stephen Bissell, Tom Cade, William S. Clark, James Grier, Donald Klebenow, T. E. Lebedz, Richard and Robert Lewin, Carl Mortis, Harry Nehls, W. J. Plowden-Wardlaw, Noble Proctor, J. V. Remsen, Jr., T. D. Reynolds, Chandler S. Robbins, Thomas Rogers, S. E. Senner, J. M. Scott, Brian Sharp, Alison Speirs, Sally Spofford, S. Sturts, J. F. Stetter, J. B. Tatum, Joseph Taylor, Dan Varland, Linda Westervelt, Miriam Westervelt, Herb Wisner, and C. Zeillemaker.

In addition, the following birders, through correspondence, reading portions of the text, or personal contact, made suggestions for this revision or helped in some other way: Peter Alden (who fine-combed the entire text), Jeff Altman, Elisha Atkins, Harold Axtell, Larry Balch, Benton Basham, Chuck Bernstein, Laurence Binford, Eirik Blom, Jon Boone, Kenneth Brandes, Don Bronk, Ted Chandik, Allegra Collister, Susan Roney Drennan, Bruce Duncan, Brian A. Evans, Robert Frisch, Frank Gill, John D. Goodman, Campbell Grant, William E. Grenfell, Jr., William W. H. Gunn, James E. Halferty, Theodora Halladay, Ed Harper, Donald S. Heintzelman, John P. Hubbard, Douglas James, Joseph R. Jehl, Jr., H. A. Kantrud, Robert E. Kennedy, Ben King, Edward A. Kutac, Greg Lasley, Gary R. Lingle, Steve Makara, David Messineo, Gale Monson, Ron Naveen, Kerry Pado, Ted Parker, Allan R. Phillips, Richard Rimmer, Terry Root, Gary Rosenberg, Margaret Rusk, Stephen Russell, R. A. Rylander, Fred Ryser, Paul T. Schnell, Ralph Shreiber, P. S. Skaar, Rich Stallcup, Robert A. Sundell, Paul W. Sykes, Jr., Ross L. Teuber, Florence J. Thornburg, Francis B. Vanslager, Richard Veit, Robert E. Walters, Lilia and Gordon Weber, Claudia Wilds, David Wolf, Bryce Wood, and Alan Wormington. 
We owe special thanks to Seymour Levin, who devised a mapping system that protected the accuracy of Virginia Peterson's original cartography and saved her much time in preparing the final maps for the printer.

Putting a field guide together so that everything fits is a challenge comparable to a jig-saw puzzle or a game of chess. A thousand details were put in the hands of my secretary, Charles W. Schulze, who was helped by Jeannette Speirs and Dwight Macdonald, my studio assistants. In addition to handling an avalanche of correspondence, Mr. Schulze retyped the manuscript half a dozen times so that it would be in the best possible form for my editors.

At Houghton Mifflin, Harry Foster was on top of things from the beginning, working closely with Austin Olney and Jon Latimer. He was always just a phone call away and in turn relied on Barbara Stratton, a model of editorial thoroughness, who fine-tuned the manuscript and worked with Anne Chalmers, Brenda Lewis, Donna Muise, and Steve Pekich in readying everything for the typesetter and printer.

The quality of the color work is the result of close collaboration with the above people and the printer, Case-Hoyt of Rochester, N.Y., under the critical eyes of Dan Cooney, George Hannon, Jon Latimer, Brenda Lewis, Paul Nederlk, Wayne Oakley, Thomas Reetz, the color evaluator, Priscilla Sharpless, and Conrad Ward. In addition, Mrs. Peterson carefully checked all proofs of the maps with Dan Cooney, Brenda Lewis, Thomas Reetz, and Conrad Ward.

A field guide is a complex team effort, starting with the field observers and ending with the printer. I want to extend my deepest thanks to everyone involved. 


\section{Bird Songs and Calls}

Not everything useful for identifying birds can be crammed into a single pocket-sized Field Guide. In the species accounts I have included a brief entry on Voice, and I have done this in my own way, trying to give the reader some handle on the songs or calls he hears. Authors of bird books have attempted with varying success to fit songs into syllables, words, and phrases. Musical notations, comparative descriptions, mnemonics, and even ingenious systems of symbols have also been employed. But since the advent of sound recording these other techniques have been eclipsed. A visual spinoff of the tape recording is the sonogram, but most people are not sufficiently oriented technologically to be able to interpret sonograms easily.

Use the recently revised Field Guide to Western Bird Songs (No. 2A in the Field Guide Series); it is available on records and cassettes. This comprehensive collection of sound recordings includes the calls and songs of more than 500 land and water birds - a large percentage of all the species found in western North America. They were recorded and prepared under the direction of the Laboratory of Ornithology, Cornell University. To prepare yourself for your field trips play the records or cassettes; then read the descriptions in this Field Guide for clues.

Birding by Ear: Eastern and Central (No. 38 in the Field Guide Series) by Richard K. Walton and Robert Lawson is another excellent shortcut to learning songs. These new cassettes, published by Houghton Mifflin, compare similar songs and analyze them for you. In learning bird voices (and some birders do 90 percent of their field work by ear) there is no substitute for the actual sounds. Birding by Ear will help you to systematize things and get your act together. It is basically for the eastern parts of the continent, but a companion volume for the West (No. 41) will soon be published.

\section{Bird Nests}

Most birders are not too skilled at finding nests. In most cases there would be an appalling gap between the number of species ticked off on their checklists and the number of nests they have discovered. To remedy this, Hal Harrison, the premier nest photographer, has prepared A Field Guide to Western Bird Nests. This Field Guide (No. 25 in the Field Guide Series) will expand your ornithological expertise. 


\section{Contents}

Map of Area Covered by this Book 2

Introduction 5

Bird Songs and Calls; Bird Nests 12

Topography of a Bird 16

How to Identify Birds 17

Ducklike Birds (Miscellaneous Swimmers) 24-73

Loons: Gaviidae 24

Grebes: Podicipedidae 26

Cormorants: Phalacrocoracidae 28

Auks, etc.: Alcidae 32

Waterfowl (Swans, Geese, Ducks): Anatidae 38

Swans: Cygnini 38

Geese: Anserini 40

Geese and Swans in Flight 42

Whistling-Ducks: Dendrocygnini 44

Marsh Ducks: Anatini 44

Sea Ducks: Mergini (in part) $\quad 52$

Bay Ducks: Aythyini 56

Stiff-tailed Ducks: Oxyurini $\quad 58$

Mergansers: Mergini (in part) $\quad 60$

Miscellaneous Waterfowl from Asia 62

Ducklike Swimmers (Coots, Gallinules): Rallidae (in part) 64

Flight Patterns of Ducks 66

Seabirds, Gulls, etc. (Aerialists) 74-108

Albatrosses: Diomedeidae $\quad 74$

Shearwaters, Petrels, etc.: Procellariidae $\quad 76$

Storm-Petrels: Hydrobatidae $\quad 80$

Boobies: Sulidae $\quad 82$

Tropicbirds: Phaethontidae $\quad 82$

Pelicans: Pelecanidae $\quad 84$

Frigatebirds: Fregatidae $\quad 84$

Skuas, Jaegers, Gulls, Terns, Skimmers: Laridae 86

Skuas, Jaegers: Stercorariinae $\quad 86$

Gulls: Larinae $\quad 88$

Terns: Sterninae 104

Skimmers: Rynchopinae 108 
Long-legged Wading Birds

Herons, Bitterns: Ardeidae

Ibises, Spoonbills: Threskiornithidae

Storks: Ciconiidae

Cranes: Gruidae

Smaller Wading Birds

$118-157$

Rails: Rallidae (in part)

Oystercatchers: Haematopodidae

Avocets, Stilts: Recurvirostridae

Plovers: Charadriidae

Sandpipers, Snipe, Phalaropes: Scolopacidae

Fowl-like Birds

Turkeys: Phasianidae (in part)

Pheasants: Phasianidae (in part)

Grouse: Phasianidae (in part)

Partridges: Phasianidae (in part)

Quail: Phasianidae (in part)

Birds of Prey

Kites, Hawks, Eagles, etc.: Accipitridae (in part)

Kites: Accipitrinae (in part)

Harriers: Accipitrinae (in part)

Accipiters: Accipitrinae (in part)

Buteos: Accipitrinae (in part)

Eagles: Accipitrinae (in part)

American Vultures: Cathartidae

Osprey: Accipitridae, Pandioninae

Caracaras, Falcons: Falconidae

Caracara: Caracarinae

Falcons: Falconiniae

Birds of Prey Overhead

Owls: Tytonidae (Barn Owl) and Strigidae

\section{Nonpasserine Land Birds}

Trogons: Trogonidae

Kingfishers: Alcedinidae

Pigeons, Doves: Columbidae

Parrots, Parakeets: Psittacidae

Cuckoos and Allies: Cuculidae

Goatsuckers (Nightjars): Caprimulgidae

Hummingbirds: Trochilidae

Woodpeckers: Picidae

Swifts: Apodidae 
Passerine (Perching) Birds

Tyrant Flycatchers: Tyrannidae

Larks: Alaudidae

Pipits: Motacillidae

Swallows: Hirundinidae

Crows, Ravens, Jays, etc.: Corvidae

252

Chickadees, Titmice: Paridae

258

Verdin: Remizidae

Bushtit: Aegithalidae

Nuthatches: Sittidae

262

Creepers: Certhiidae

262

Wrens: Troglodytidae

264

Dippers: Cinclidae

266

Gnatcatchers: Sylviidae

Kinglets: Regulidae

Wrentit: Timaliidae

Mimic Thrushes (Thrashers, etc.): Mimidae

Thrushes: Turdidae

Shrikes: Laniidae

Starlings: Sturnidae

Waxwings: Bombycillidae

Silky-Flycatchers: Ptilogonatidae

Vireos: Vireonidae

Wood Warblers: Parulidae

Olive Warbler: Peucedramidae

Blackbirds, Orioles, etc.: Icteridae

Tanagers: Thraupidae

Sparrows, Towhees, Juncos, etc.: Emberizidae

Grosbeaks, Buntings: Cardinalidae

Finches: Fringillidae

Old World Sparrows: Passeridae

\section{Accidentals}

Accidentals from Mexico

Accidentals from Asia

\section{Endpapers}

Front: Roadside Silhouettes

Rear: Flight Silhouettes 


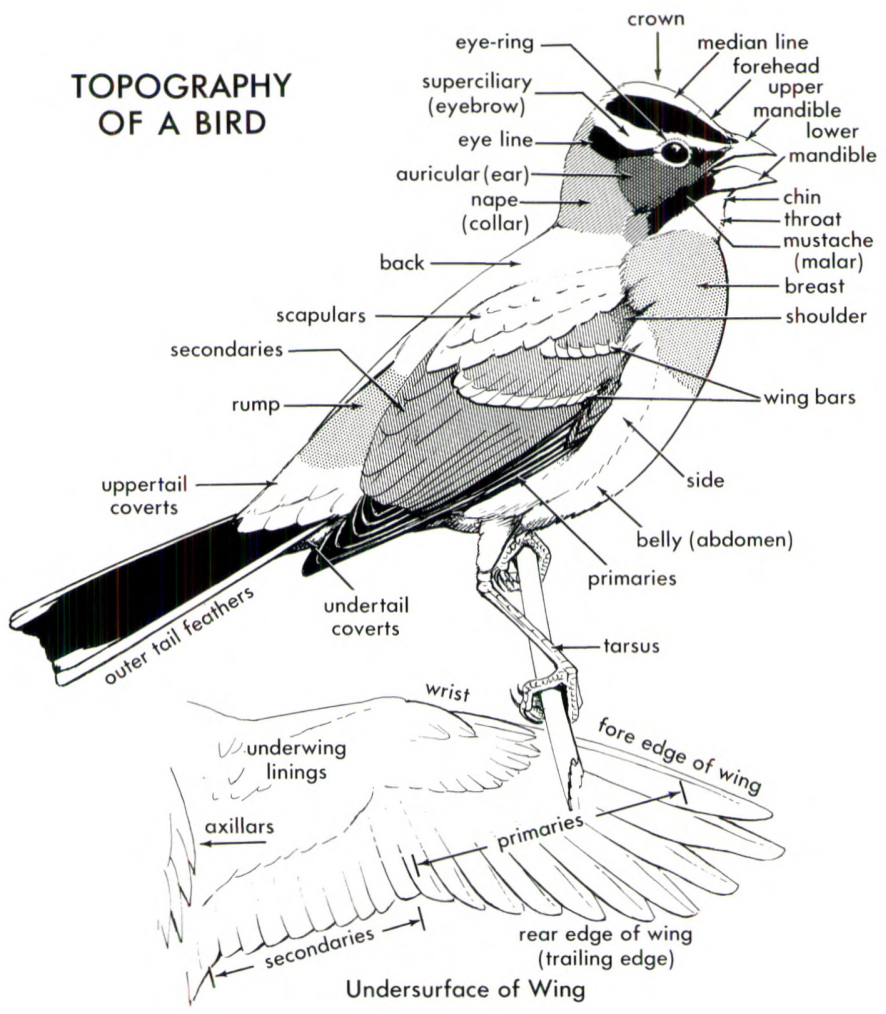

\section{Other Terms Used in this Book}

Sex symbols: $₫$ means male, $\$$ means female. These symbols are used frequently on the plates.

Accidental: In the area of this book, recorded fewer than a dozen times, far out of range (see maps, pp. 359-408). On the state level only one, two, or three records; might not be expected again.

Casual: Very few records, but might be expected again because the normal range of the species is in an adjacent state or province, or not too distant.

Introduced: Not native; deliberately released.

Exotic: Not native; either released or escaped.

In part: Subdivision of a family; or part of a species, such as a wellmarked subspecies. 


\section{How to Identify Birds}

Veteran birders will know how to use this book. Beginners, however, should spend some time becoming familiar in a general way with the illustrations. They are not arranged in systematic or phylogenetic order but are grouped in eight main visual categories:

(1) Swimmers-Ducks and ducklike birds

(2) Aerialists-Gulls and gull-like birds

(3) Long-legged Waders-Herons, cranes, etc.

(4) Smaller Waders-Plovers, sandpipers, etc.

(5) Fowl-like Birds-Grouse, quail, etc.

(6) Birds of Prey-Hawks, eagles, owls

(7) Nonpasserine Land Birds

(8) Passerine (Perching) Birds

Within these groupings it will be seen that ducks do not resemble loons, and gulls are readily distinguishable from terns. The needlelike bills of warblers immediately differentiate them from the seedcracking bills of sparrows. Birds that could be confused are grouped together when possible and are arranged in identical profile for direct comparison. The arrows point to outstanding "field marks," which are explained opposite. The text also gives aids such as actions, voice, habitat, etc., not visually portrayable, and under a separate heading often discusses species that might be confused. The brief notes on general range are keyed by number to detailed threecolor range maps in the rear of the book (pp. 359-408).

In addition to 160 plates of birds normally found in the area of this Field Guide there are five color plates depicting fifteen vagrants from Mexico and thirty-five strays or accidentals from Asia. With the exception of several parrots and two or three others unestablished escapes and exotics are not illustrated. However, if you see one, record it, so that if a pattern eventually emerges past information will not be lost.

\section{What Is the Bird's Size?}

Acquire the habit of comparing a new bird with some familiar "yardstick" - a House Sparrow, a Robin, a Pigeon, etc., so that you can say to yourself, "smaller than a Robin; a little larger than a House Sparrow." The measurements in this book represent lengths in inches (with centimeters in parentheses) from bill tip to tail tip of specimens on their backs as in museum trays. However, specimen measurements vary widely depending on the preparator, who may have stretched the neck a bit. In many cases the species accounts give minimum and maximum lengths, but in life, not lying in a tray, most birds are closer to the minimum lengths given. 


\section{What Is Its Shape?}

Is it plump like a starling (left) or slender like a cuckoo (right)?

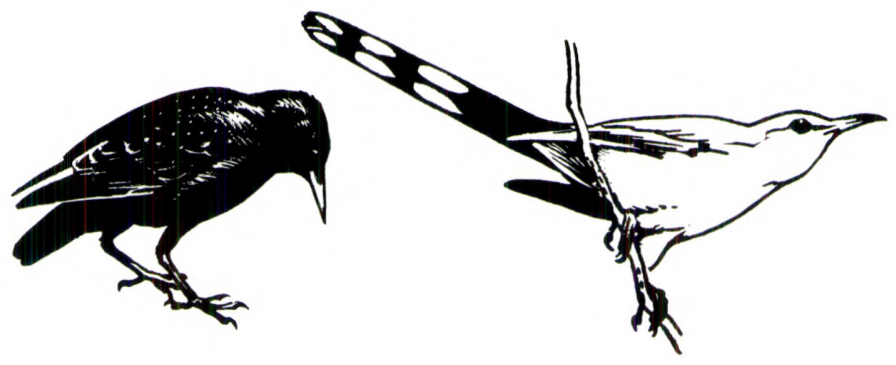

\section{What Shape Are Its Wings?}

Are they rounded like those of a quail (left) or sharply pointed like those of a Barn Swallow (right)? See also "Birds of Prey," pp. 168, 169.
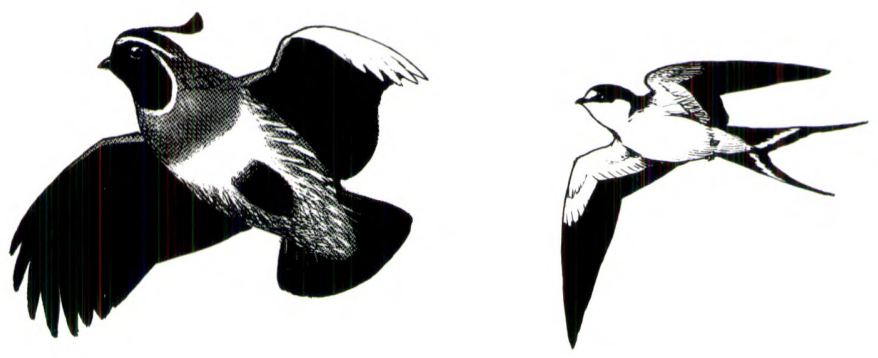

\section{What Shape Is Its Bill?}

Is it small and fine like a warbler's (1), stout and short like a seedcracking sparrow's (2), dagger-shaped like a tern's (3), or hook-tipped like that of a bird of prey (4)?

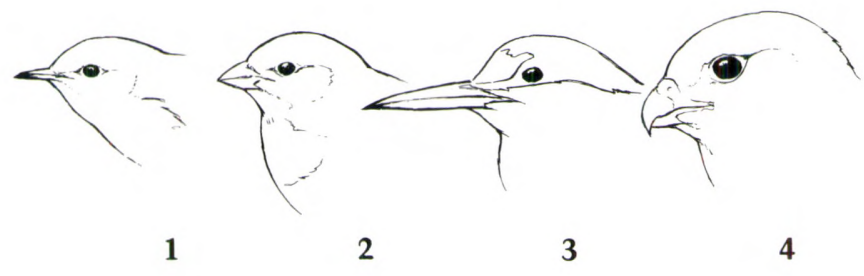




\section{What Shape Is Its Tail?}

Is it deeply forked like a Barn Swallow's (1), square-tipped like a Cliff Swallow's (2), notched like a Tree Swallow's (3), rounded like a jay's (4), or pointed like a Mourning Dove's (5)?
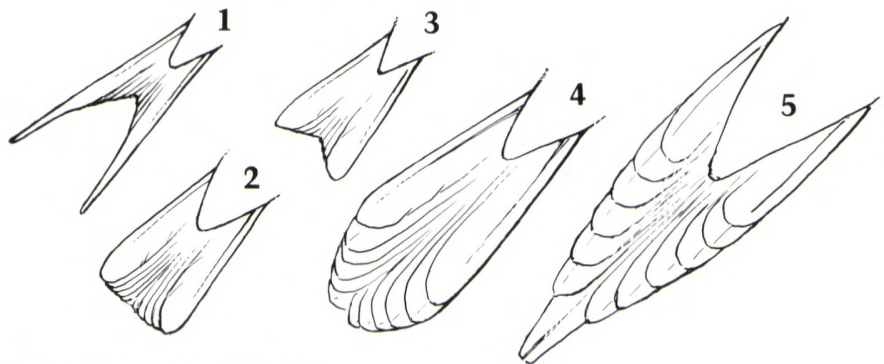

\section{How Does It Behave?}

Does it cock its tail like a wren or hold it down like a flycatcher? Does it wag, flick, or dip its tail? Does it sit erect on an open perch, dart after an insect, and return as a flycatcher does?
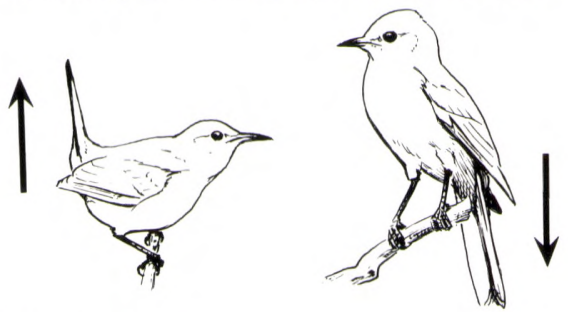

\section{Does It Climb Trees?}

If so, does it climb in spirals like a Creeper (left), in jerks like a woodpecker (center) using its tail as a brace, or does it go down headfirst like a nuthatch (right)?

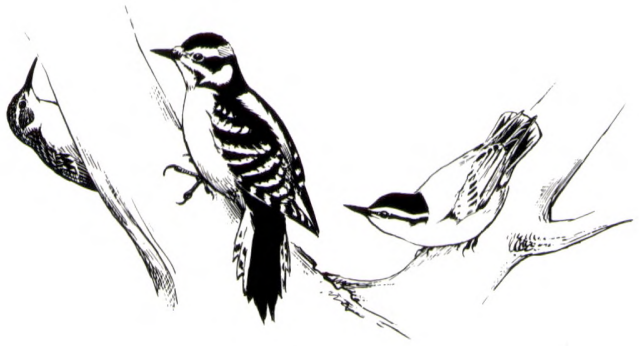




\section{How Does It Fly?}

Does it undulate (dip up and down) like a Flicker (1)? Does it fly straight and fast like a Mourning Dove (2)? Does it hover like a Kingfisher (3)? Does it glide or soar? See also "Birds of Prey," pp. $168,169$.

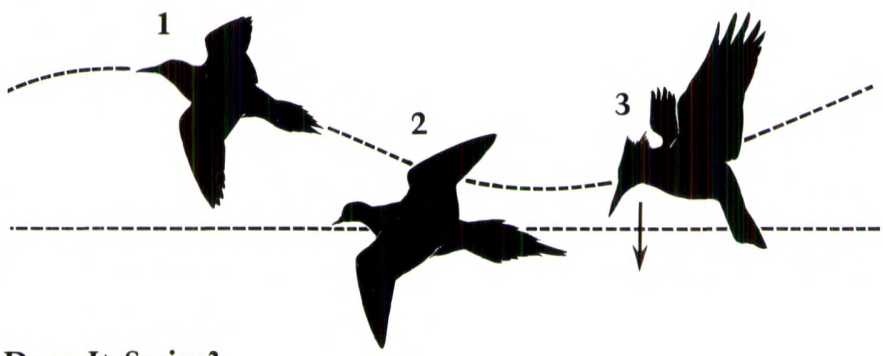

\section{Does It Swim?}

Does it sit low in the water like a Loon (1) or high like a Moorhen $(2)$ ? If a duck, does it dive like a deepwater duck (3) or does it dabble and up-end like a Mallard (4)?

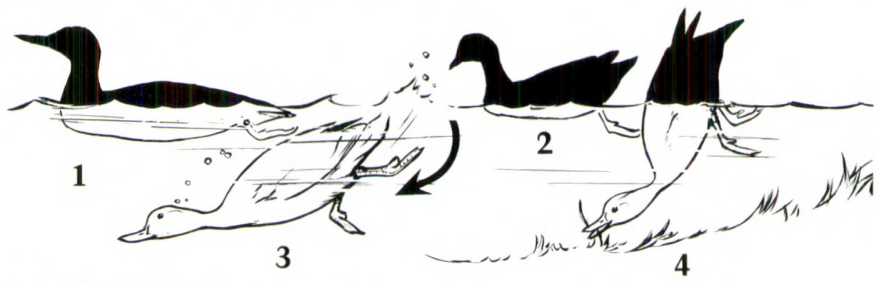

\section{Does It Wade?}

Is it large and long-legged like a heron, or small like a sandpiper? If one of the latter, does it probe the mud or pick at things? Does it teeter or bob? See also "Waders" (sandpipers, etc.), pp. 128, 129.

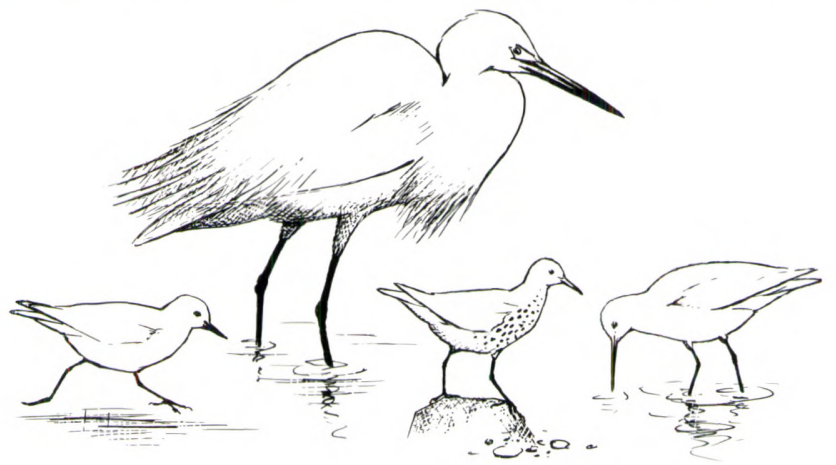




\section{What Are Its Field Marks?}

Some birds can be identified by color alone, but most birds are not that easy. The most important aids are what we call field marks, which are, in effect, the "trademarks of nature." Note whether the breast is spotted as in a thrush (1), streaked as in the Brown Thrasher (2), or plain as in a cuckoo (3). In this guide, important field marks are indicated by arrows.

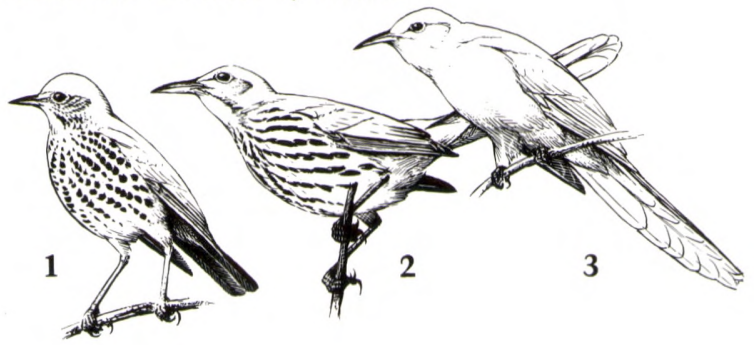

\section{Tail Patterns}

Does the tail have a "flash pattern" - a white tip as in the Eastern Kingbird (1), white patches in the outer corners as in a Towhee (2), or white sides as in a junco (3)?
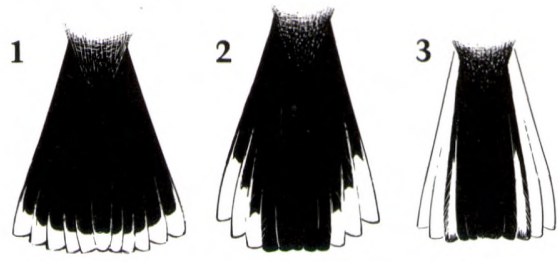

\section{Rump Patches}

Does it have a light rump like a Cliff Swallow (1) or Flicker (2)? The Harrier, Yellow-rumped Warbler, and many of the shorebirds also have distinctive rump patches.

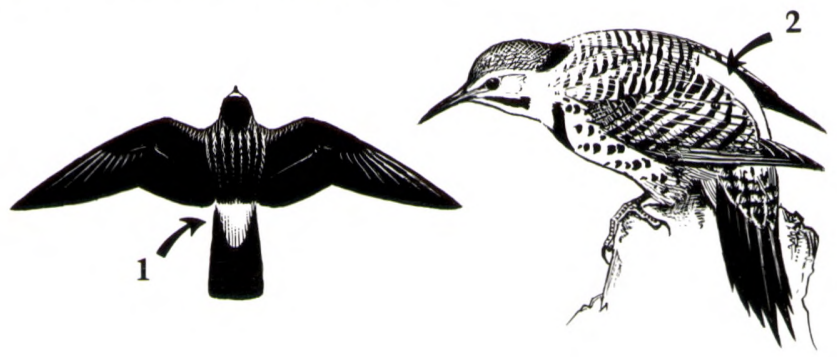




\section{Eyestripes and Eye-rings}

Does the bird have a stripe above, through, or below the eye, or a combination of these stripes? Does it have a striped crown? A ring around the eye, or "spectacles"? A "mustache" stripe? These details are diagnostic in many small songbirds.
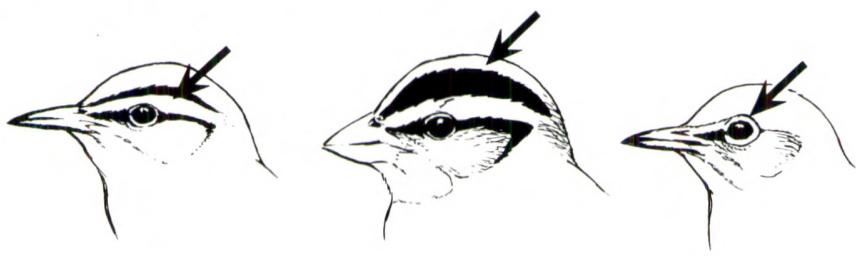

\section{Wing Bars}

Do the wings have light wing bars or not? Their presence or absence is important in sorting out many warblers, vireos, and flycatchers. Wing bars may be single or double, bold or obscure.
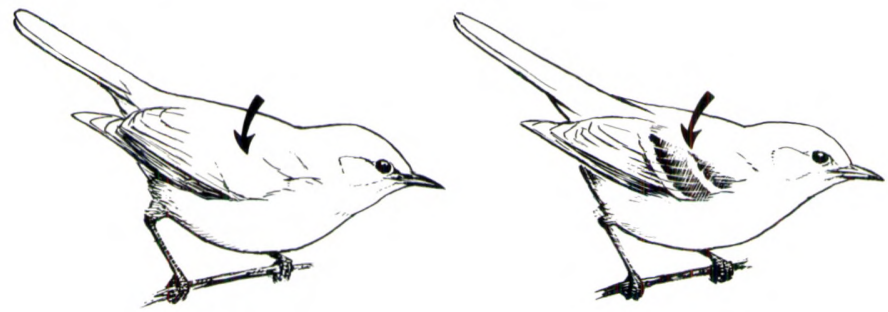

\section{Wing Patterns}

The basic wing patterns of ducks (shown below), shorebirds, and other water birds are very important. Notice whether the wings have patches (1) or stripes (2), are solidly colored (3), or have contrasting black tips (Snow Goose, etc.).

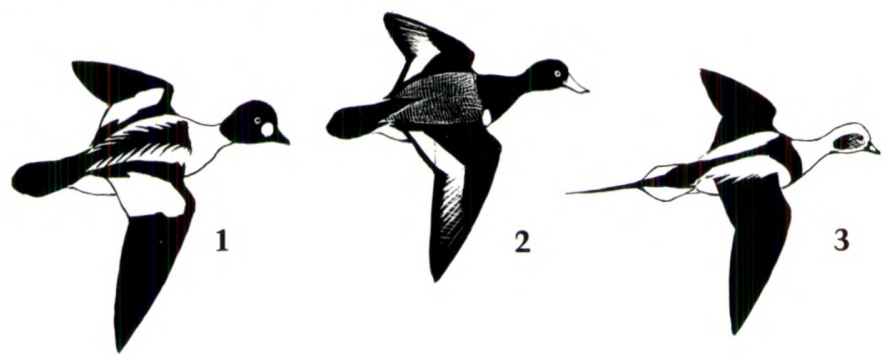


Caution in Sight Records: Fifty or sixty years ago, prior to the Field Guide era, most ornithologists would not accept sight records of unusual birds unless they were made along the barrel of a shotgun. Today it is difficult to secure a collecting permit unless one is an academic or a student training to be one. Moreover, rarities may show up in parks, refuges, or on other lands where collecting is out of the question. There is no reason why we should not trust our increasingly educated eyes.

To validate the sight record of a very rare or accidental bird-a state "first," for example - the rule has been that at least two competent observers should see the bird and document it in detail in their notes. A $35 \mathrm{~mm}$ camera equipped with a $400 \mathrm{~mm}$ lens or longer is becoming an increasingly useful tool for substantiating such sightings. Rarities are sometimes caught in mist nets by bird banders and can be photographed hand-held, and even videotaped for the record. For photographing birds in the hand, a $50 \mathrm{~mm}$ closeup lens, such as a Micro-Nikkor, is best and may be used with or without flash equipment.

There are some species-or plumages-where even the expert will hedge. And it is the mark of an expert to occasionally put a question mark after certain birds on his list: for example, accipiter, sp.?, or Empidonax, sp.?, or "peep," sp.?, or immature gull, sp.? Do not be embarrassed if you cannot name every bird you see. Not so long ago, Allan Phillips argued convincingly in American Birds that practically all of the Semipalmated Sandpipers so freely reported in winter on the southern coasts of the U.S. were really Western Sandpipers. It is quite impossible to identify many individuals of these two species correctly unless they are caught or collected for critical examination-or unless their distinctive call notes are heard.

Once at an A.B.A. gathering, my friend Jim Tucker, then editor of Birding, asked us; "How would you define a 'good' birder or a 'great' birder? Is it the guy with a Questar who is unhappy if he cannot put a name to every bird he sees?" After thinking about it, Kenn Kaufman, who had wrestled with the fine points of identification as much as anyone we know, then gave his views: "Let's face it-some birds are really tough to tell apart in the field. If you don't enjoy the challenge it is perfectly acceptable to call such birds 'unknown flycatchers' or 'unidentified gulls'... nobody can name them all. In fact, I would say that if you enjoy birding a lot you are a great birder. And as a great birder you should never allow those tricky identification problems to keep you from having a good time."

Suggestions for Further Reading: See p. 416. 
- LOONS. Family Gaviidae. Shown in flight on p. 31. Large, long-bodied swimmers with daggerlike bills; may dive from the surface or sink. Thrash along water on take-off. Seldom on land except at nest. Sexes alike. Immatures are more scaly above than winter adults. Food: Small fish, crustaceans, other aquatic life. Range: Northern parts of N. Hemisphere. No. of species: World 5; West 5.

RED-THROATED LOON Gavia stellata See also p. 30.

M1

$25^{\prime \prime}(63 \mathrm{~cm})$. Note the sharp thin bill, distinctly upturned. Summer: Plain back, gray head, striped nape, rufous throat patch. Winter: Similar to other loons but smaller, slimmer; profile snakier; back, head, and neck paler, with less contrast or pattern.

Voice: When flying, a repeated kwuk. In Arctic, falsetto wails.

Range: Arctic, circumpolar. Winters southward mainly along coasts to Mediterranean, China, Florida, n. Mexico. West: Map 1. Habitat: Coastal waters, bays, estuaries; in summer, tundra lakes.

PACIFIC LOON Gavia pacifica See also p. 30.

M2

$25^{\prime \prime}(63 \mathrm{~cm})$. Smaller than Common Loon, with a thinner, straight bill. Summer: Crown and nape rounded, pale gray. Back divided into four checkered patches. Winter: Note sharp separation of black and white neck pattern. Bill slender, straight (not upturned). Often has trace of a chin strap. Gregarious, often traveling in large flocks.

Voice: A deep, barking kwow. Falsetto wails, rising in pitch.

Range: E. Siberia, nw. N. America. Winters along coasts to Japan, nw. Mexico. West: Map 2. Habitat: Ocean, open water; in summer, tundra lakes.

\section{ARCTIC LOON Gavia arctica}

$27^{\prime \prime}(68 \mathrm{~cm})$. Formerly regarded as conspecific with Pacific Loon. A bit larger; in breeding plumage throat may be glossed more with green than purple (hard to see). In winter, said to show a whitish flank patch. Has bred in Alaska; accidental, British Columbia.

COMMON LOON Gavia immer See also p. 30.

28-36" (70-90 cm). Large, long-bodied, low-swimming; bill stout, daggerlike. Breeding: Black head and bill. Checkered back, broken white necklace. Winter: Dark above, whitish below. Note the stout, straight bill and irregular or broken neck pattern.

Voice: In summer, falsetto wails, weird yodeling, maniacal quavering laughter; at night, a tremulous ha-oo-oo. In flight, a barking kwuk. Usually silent in winter.

Range: Alaska, Canada, n. U.S., Greenland, Iceland. In winter, chiefly coastwise to n. Mexico, w. Europe. West: Map 3. Habitat: Conifer lakes, tundra ponds (summer); open lakes, bays, sea.

YELLOW-BILLED LOON Gavia adamsii

M4

33-38" (83-95 cm). Similar to Common Loon, but bill pale ivory or straw-colored, distinctly upturned; straight above, slightly angled below. In winter paler about head and neck than Common Loon; usually shows a dark ear patch; smaller eye. Caution: Bill shape is not always reliable. Bills of most winter Common Loons are pale but the culmen (upper ridge) is dark to the tip.

Range: Arctic, from n. U.S.S.R. to nw. Canada. Winters along coasts of n. Eurasia, nw. N. America. West: Map 4. Habitat: Tundra lakes in summer; coastal waters in winter. 


\section{LOONS}

I of

O

d-throated Loon
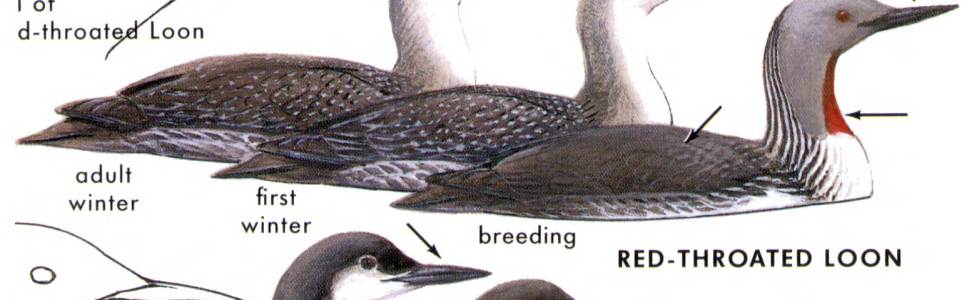

Il of

Icific Loon

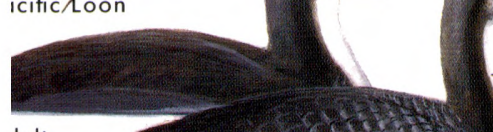

tult

nter

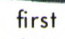

winter

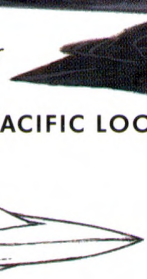

bill of

0

Commontoon
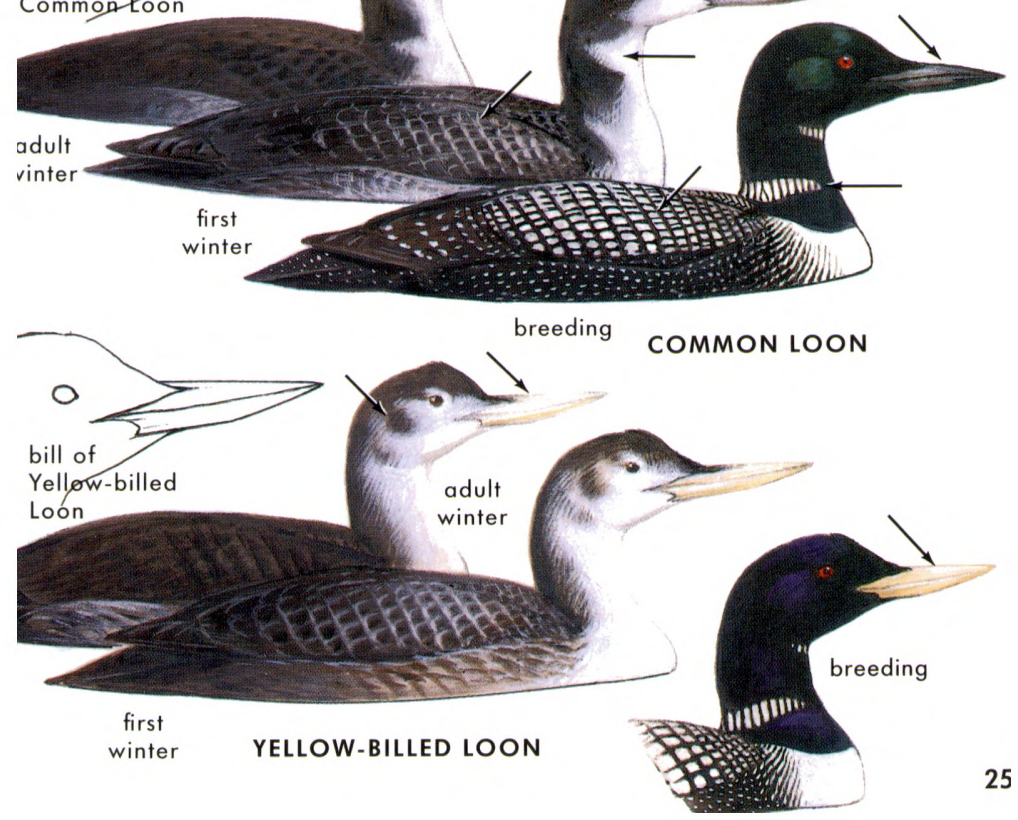
- GREBES. Family Podicipedidae. Ducklike divers with flat lobed toes, thin neck, tailless look. All but the Pied-bill have white wing patches, pointed bills. Sexes alike. Most young have striped heads. Grebes may dive from the surface or sink. Flight labored (with a sagging neck). Food: Small fish, other aquatic life. Range: Cosmopolitan. No. of species: World 20; West 7.

PIED-BILLED GREBE Podilymbus podiceps

M5

$13^{\prime \prime}(33 \mathrm{~cm})$. Note the thick, ungrebe-like "chicken bill" and puffy white stern. No wing patch. Breeding: Black throat patch and ring around pale bill. Winter: Throat patch and bill ring absent. Juvenile: Striped on head. A small brown diver of ponds, marshes.

Voice: Kuk-kuk-cow-cow-cow-cowp-cowp; also whinnying.

Range: S. Canada to Argentina. Migratory in North. West: Map 5. Habitat: Ponds, lakes, marshes; in winter, also salt bays.

HORNED GREBE Podiceps auritus

$12-15^{\prime \prime}(30-38 \mathrm{~cm})$. Breeding: Combination of golden ear tufts and chestnut neck. Winter: Dark above, white below, with its black cap clean-cut to eye level; white foreneck, thin straight bill.

Range: Northern parts of N. Hemisphere. Winters to s. U.S., s. Eurasia. West: Map 6. Habitat: Lakes, ponds; coastal waters.

EARED GREBE Podiceps nigricollis

12-14" (30-35 cm). Breeding: Crested black head, golden ear tufts, thin black neck. Winter: Similar to Horned Grebe, but neck thinner; bill slightly tilted; cap ill defined. The gray cheek sets off the white throat, white ear patch. The rump is raised well above the water. Very gregarious.

Range: Eurasia, Africa, w. N. America. West: Map 7. Habitat: Prairie lakes, ponds; in winter, open lakes, salt bays, ocean.

RED-NECKED GREBE Podiceps grisegena

$18^{\prime \prime}(45 \mathrm{~cm})$. A largish grebe. Breeding: Long rufous neck, light cheek, black cap, long bill with yellow base. Winter: Grayish (including neck); white crescent on face. In flight, double wing patch.

Range: Eurasia, n. N. America. Winters to n. Africa, s. U.S. West: Map 7. Habitat: Lakes, ponds; in winter, salt water.

LEAST GREBE Tachybaptus dominicus

$91 / 2^{\prime \prime}(24 \mathrm{~cm})$. A very small slaty grebe, smaller than the Pied-bill, with white wing patches (often concealed), puffy undertail coverts, a slender black pointed bill, golden or red eyes. In winter, throat white. Range: Ponds in tropical America. West: Resident, s. Texas; casual, se. California (has bred), s. Arizona.

WESTERN GREBE Aechmophorus occidentalis

M9

$25^{\prime \prime}(63 \mathrm{~cm})$. A large, slate and white grebe with a long, swanlike neck. Bill long, greenish yellow with a dark ridge.

Range: Western N. America. Winters to Mexico. West: Map 9. Habitat: Rushy lakes, sloughs; in winter, bays, ocean.

CLARK'S GREBE Aechmophorus clarkii

Formerly regarded as a pale morph of the Western Grebe. Intermediates are known. White around eye; bill is orange-yellow. Downy young are white, not gray. Voices are said to differ: Clark's, a one-note creet or criik; Western, two-noted crik-crick.

Range: Imperfectly known; overlaps that of Western Grebe. 

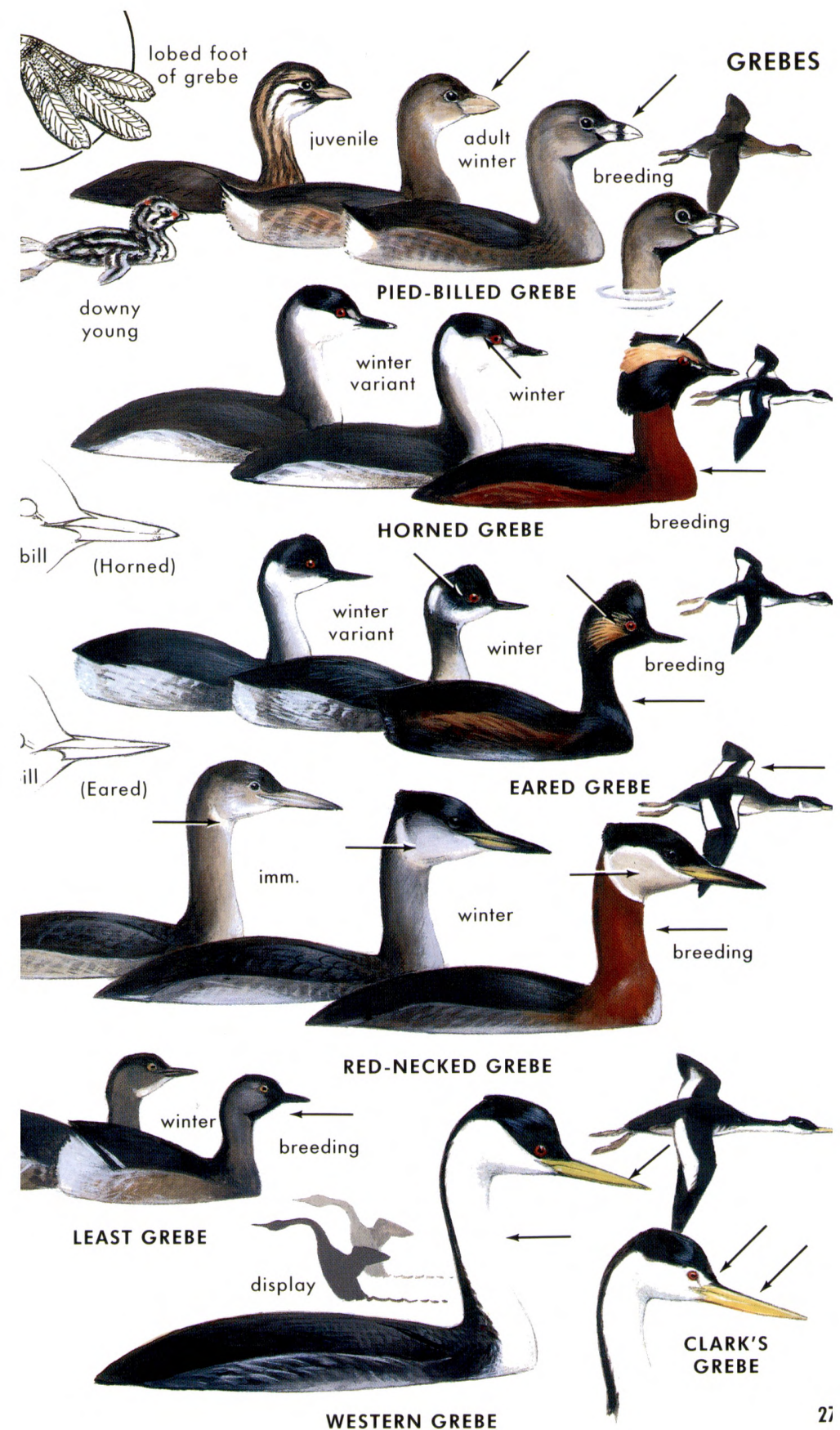
- CORMORANTS. Family Phalacrocoracidae. Shown in flight on p. 31. Large, blackish water birds that often stand erect on rocks or posts with the neck in an $S_{\text {; }}$ may strike a "spread-eagle" pose, with wings spread out to dry. Adults may have colorful face skin, throat pouch, and eyes. Bill slender, hook-tipped. Sexes alike. Cormorants swim low like loons, but with bill tilted up at an angle. Cormorants are silent except for occasional low grunts in nesting colonies. Food: Fish, crustaceans. Range: Nearly cosmopolitan. No. of species: World 29; West 5.

\section{DOUBLE-CRESTED CORMORANT Phalacrocorax auritus}

M16

30-36" (75-90 cm). Any cormorant found well inland can be called this species except some birds near the Mexican border (see Neotropic Cormorant). Coastally, it may be told from the others by its orange-yellow throat pouch. Crest seldom evident.

Range: Much of N. America, coast to coast. Winters south to Belize. West: Map 16. Habitat: Coasts, bays, lakes, rivers; nests colonially on sea cliffs, or in trees on lake margins.

NEOTROPIC CORMORANT Phalacrocorax brasilianus

25" $(63 \mathrm{~cm})$. Similar to the Double-crest but smaller, slimmer, and longer-tailed. Note the duller (less orange) chin pouch and, in summer, the narrow white border outlining the throat pouch. At very close range, note that the feathers of the back and scapulars are pointed, not rounded. Range: Gulf of Mexico to Argentina. West: Rare or local visitor in Mexican border states.

BRANDT'S CORMORANT Phalacrocorax penicillatus

M17

33-35" (83-88 cm). Size of Double-crest, but with a dark throat pouch (blue when breeding). Buffy brown band across throat behind pouch. If a young cormorant has a whitish breast it is a Double-crest; if the breast is buffy or pale brown with a pale Y it is most likely a Brandt's. If deep rich brown below, it is a Pelagic.

Range: Pacific Coast of N. America. Map 17. Habitat: Ocean, coast, littoral; nests colonially on sea cliffs.

PELAGIC CORMORANT Phalacrocorax pelagicus

M18

251/2-30" (64-76 cm). Noticeably smaller and more iridescent than other coastal cormorants, with a more slender neck, small head, and much thinner bill. When breeding (Feb.-June) it has a double crest and a white patch on each flank. Throat pouch and part of face dull red (obvious only at close range). Immature: deep brown all over, darkest on back. Note the thin bill.

Range: From Bering Sea to Japan and south along our West Coast. West: Map 18. Habitat: Coast, bays, sounds.

\section{RED-FACED CORMORANT Phalacrocorax urile}

$28-30 "(70-75 \mathrm{~cm})$. Note the bright red of the adult's face (extending to forehead and behind eye). Throat pouch bluish; bill pale. Otherwise, similar to Pelagic Cormorant, which has a dull red pouch, restricted dull red on face; thinner bill. Immature: Differs from Pelagic in having a thicker pale bill.

Range: Alaska, ne. Asia. West: Resident in Pribilofs and Aleutians; east locally to Kodiak I., Prince William Sound. 


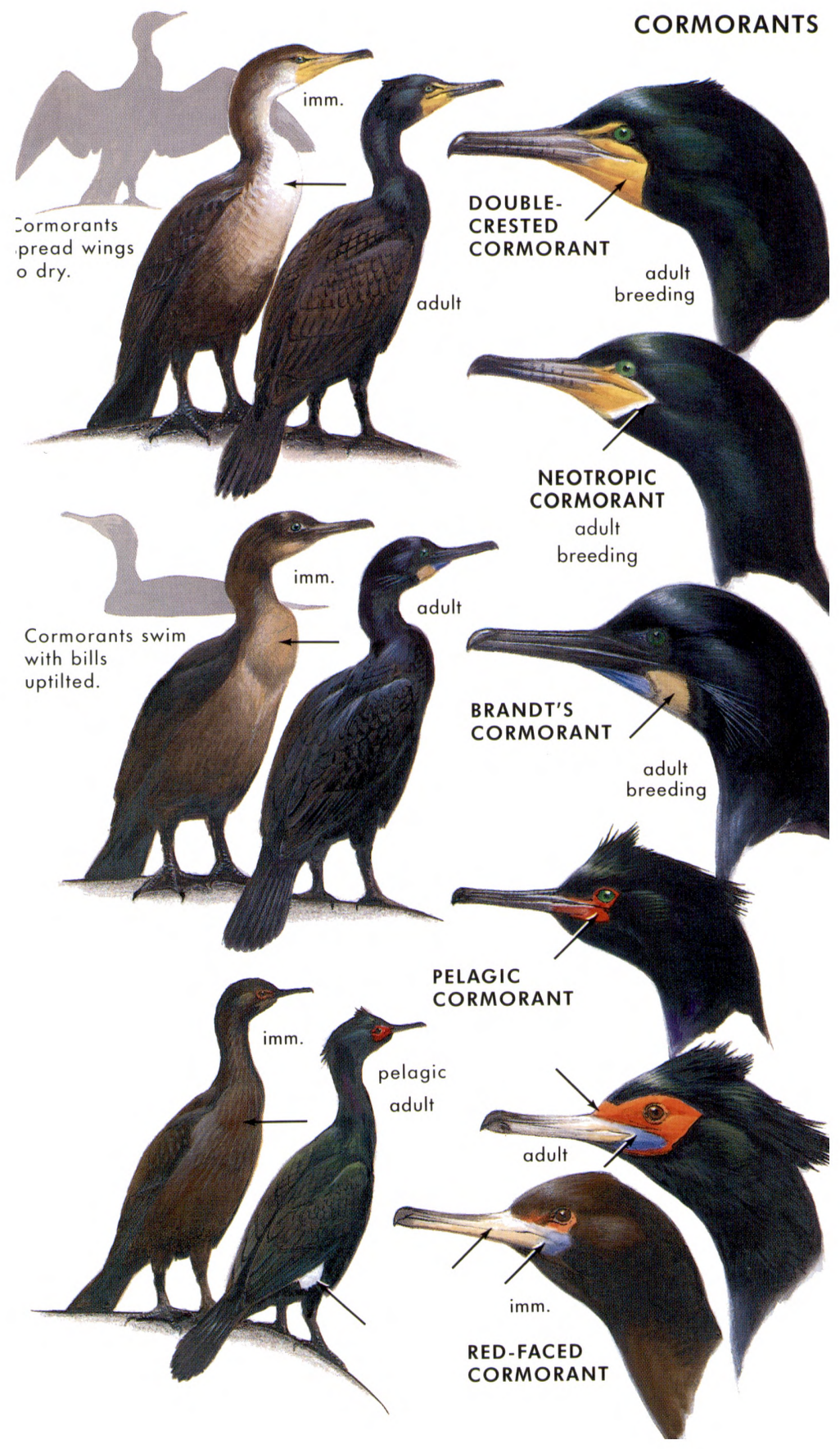




\section{LOONS IN FLIGHT}

Airborne, loons are slower than most ducks; their outline is hunchbacked, with a sagging look. The large webbed feet project rudderlike beyond the stubby tail.

COMMON LOON Gavia immer Text and
color plate

More heavily built than the next two species. Look for the especially large trailing feet and the stout straight bill. In winter plumage note the irregular (half-collared) neck pattern.

RED-THROATED LOON Gavia stellata

pp. 24,25

Has a slimmer look than the other loons; paler, with a slim, upturned bill. In winter there is no strong demarcation between the gray and white of the head and neck. May be sociable in winter.

PACIFIC LOON Gavia pacifica

pp. 24,25

Darker and more contrasty than Red-throated Loon; bill straight, not upturned. In winter plumage note the well-defined, straight separation of the blackish and white on the neck. Pacific Loons often travel in sizable flocks in offshore waters.

\section{CORMORANTS IN FLIGHT}

Cormorants often fly in lines or wedges, somewhat in the manner of geese, but are silent.

\section{DOUBLE-CRESTED CORMORANT}

Phalacrocorax auritus

Text and color plate

Note the kink in the neck and the yellow or orange gular (throat) pouch; tail longer than that of Brandt's Cormorant. Young birds tend to have lighter or whiter breasts than Brandt's Cormorant.

BRANDT'S CORMORANT Phalacrocorax penicillatus

pp. 28,29

Heavily built; no marked kink in the neck. Tail shorter than Double-crest's. Young birds are browner than young Double-crests. Throat pouch edged with buff. May have a pale Y on breast.

PELAGIC CORMORANT Phalacrocorax pelagicus

pp. 28,29

Note the slender neck (with no kink) and the much thinner bill. Tail longish. Breeding adults (Feb. to June) have a white flank patch. Immature birds are deep brown. 


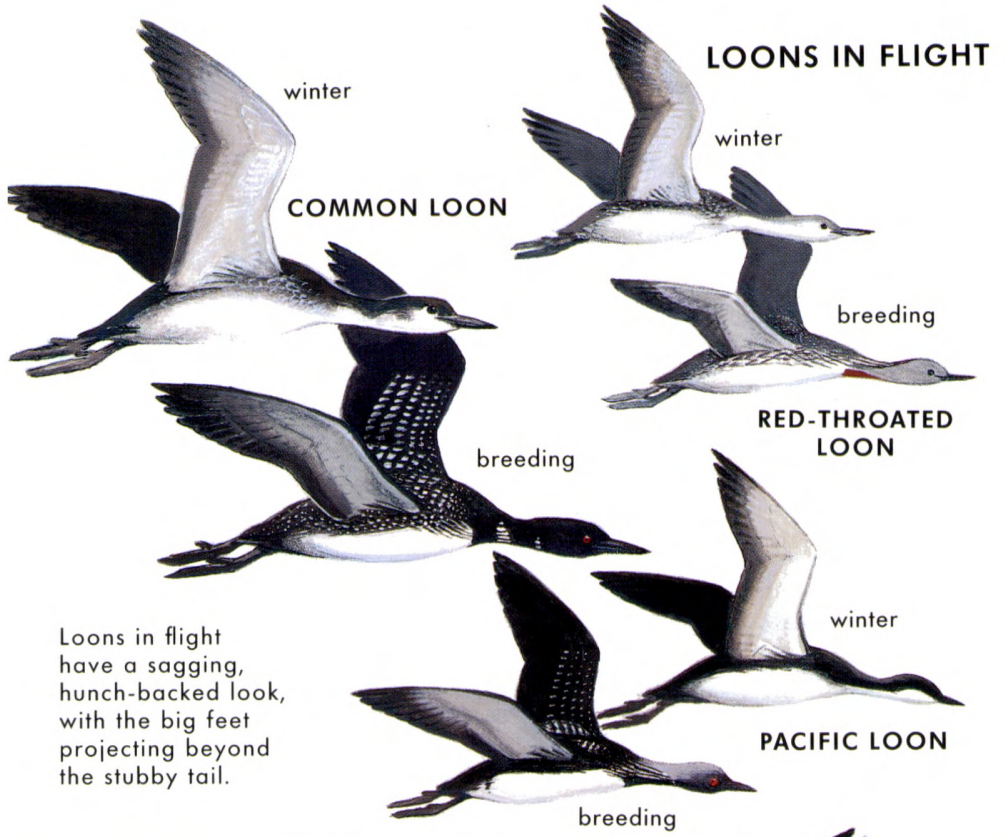

Loons in flight have a sagging, hunch-backed look with the big feet projecting beyond the stubby tail.

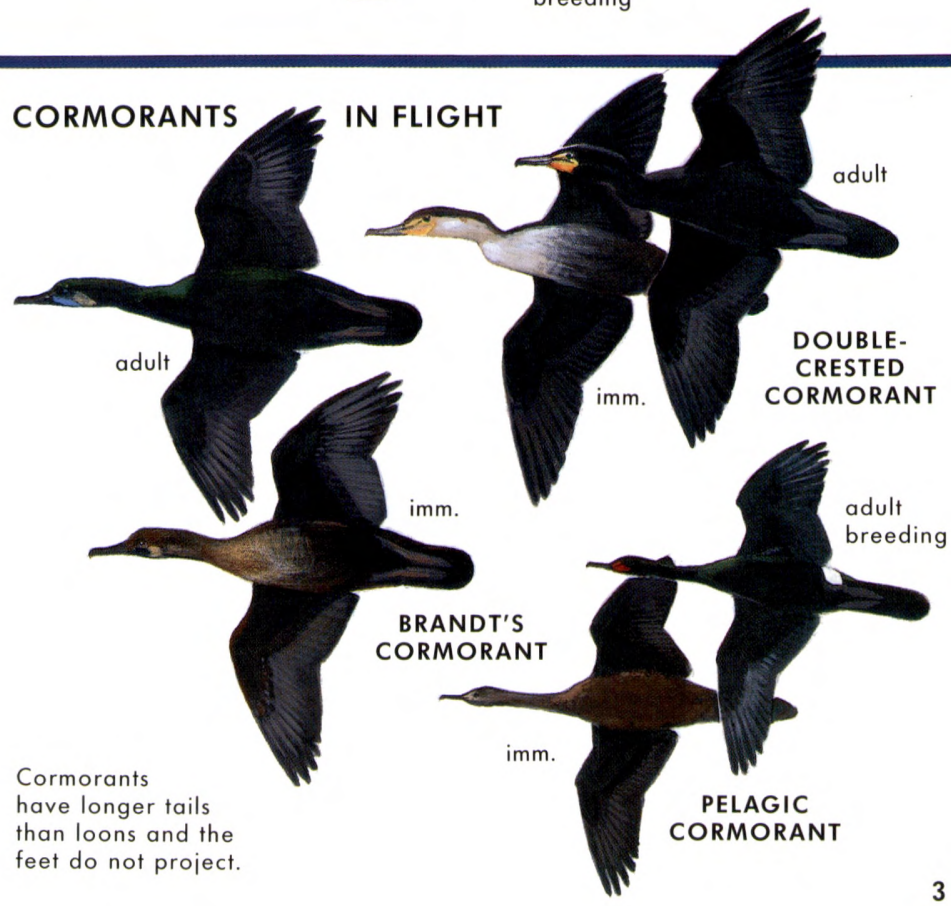


- AUKS, etc. Family Alcidae. The northern counterparts of the penguins, but auks fly, beating their small narrow wings in a whir, often veering. They have short necks and pointed, stubby, or deep and laterally compressed bills. Auks swim and dive expertly. Most species nest on sea cliffs in crowded colonies. Sexes alike. Food: Fish, crustaceans, mollusks. Range: N. Atlantic, N. Pacific, Arctic oceans. No. of species: World 22; West 18 (+1 vagrant).

COMMON MURRE Uria aalge

M176

16-17" $(40-43 \mathrm{~cm})$. Size of a small duck, with a slender pointed bill. Breeding: Head, neck, back, and wings dark; underparts, wing linings, and line on rear edge of wing white. Non-breeding: Similar, but throat and cheeks white. A black mark extends from eye onto cheek. Murres often raft on water, fly in lines; stand erect on sea cliffs. Chicks at sea may be mistaken for Xantus' Murrelet.

Range: Northern parts of N. Pacific, N. Atlantic. West: Map 176. Habitat: Ocean, large bays; colonies on sea cliffs.

THICK-BILLED MURRE Uria lomvia

M177

17-19" (43-48 cm). Similar to Common Murre, but a bit larger and blacker above. Bill shorter, thicker, with a whitish line along gape. White of foreneck forms an inverted V. In winter, head darker than Common Murre's, black crown extending well below eye; no dark line through white ear coverts. White bill mark less evident.

Range: Cold oceans of N. Hemisphere. West: Map 177. Habitat: Ocean, nesting colonially on ledges of sea cliffs.

TUFTED PUFFIN Fratercula cirrhata

M183

$15^{\prime \prime}(38 \mathrm{~cm})$. A stocky, dark seabird with a massive bill. Breeding: Blackish, with a large, triangular, orange-red bill; white face; and long, curved, ivory-yellow ear tufts. Feet orange. Winter adult: White face and ear tufts gone (a gray trace); a blackish bird with an orange-red bill (not as triangular as in summer). Immature: Light grayish below; bill smaller; no red.

Range: N. Pacific (both sides). West: Map 183. Habitat: Oceanic; nests colonially in burrows on sea cliffs.

HORNED PUFFIN Fratercula corniculata

M184

$14 \frac{1}{2} 2^{\prime \prime}(36 \mathrm{~cm})$. A puffin with clear white underparts and a broad black collar. Feet bright orange. Summer: Cheeks white, with a small, dark erectile horn above each eye. Bill massive, triangular, laterally flat; yellow with a red tip. Winter: Cheeks dusky; bill blackish with red tip. Young birds resemble winter adults with dusky cheeks, but the bill is smaller and all dark, lacking red.

Range: N. Pacific (both sides). West: Map 184. Habitat: Ocean, nesting colonially in burrows or crevices on sea cliffs.

RHINOCEROS AUKLET Cerorhinca monocerata

M182

$14-151 / 2^{\prime \prime}(35-39 \mathrm{~cm})$. A dark stubby seabird. Breeding plumage (acquired in late winter): White "mustaches," narrow white plume behind eye, short erect horn at base of yellowish bill. Non-breeding: Note the size and uniform dark color. The white plumes are shorter, the horn absent. Immature is similar, with smaller, darker bill.

Range: N. Pacific (both sides). West: Map 182. Habitat: Ocean, tiderips; nests colonially in burrows on islands. 


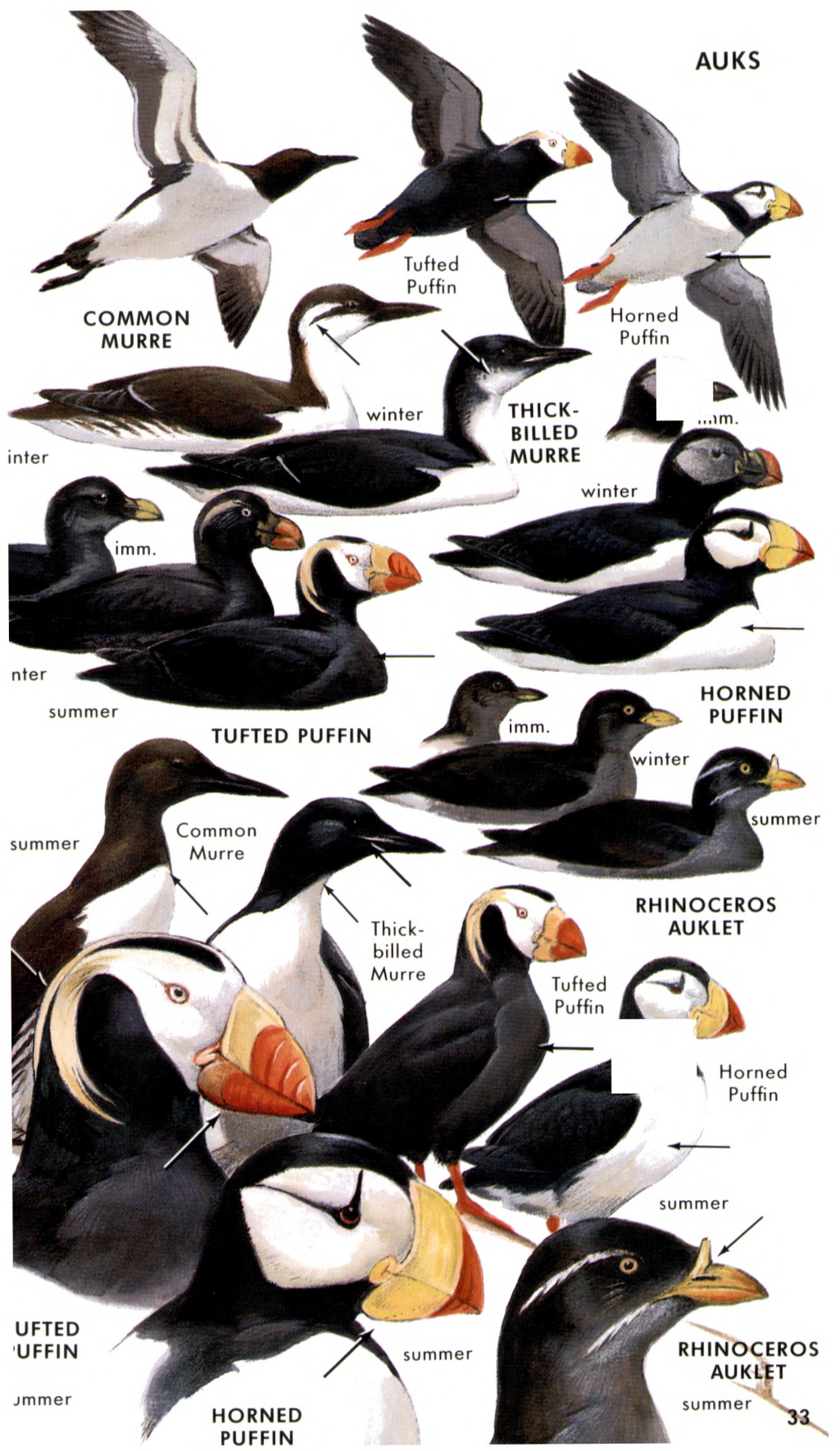


BLACK GUILLEMOT Cepphus grylle

M178

12-14" (30-35 cm). Very similar to Pigeon Guillemot, which it meets in n. Alaskan waters. White wing patch (lacks the black bar). Underwing linings white (dusky in Pigeon Guillemot). Winter and juvenile birds are paler than Pigeon Guillemot.

Range: Arctic coasts and n. coasts of Atlantic. West: Map 178.

PIGEON GUILLEMOT Cepphus columba

M178

12-14" (30-35 cm). Breeding: A small, black, pigeon-like water bird, with large white wing patches (subdivided by a black bar or wedge), red feet, a pointed black bill, and orange-red inside the open mouth. Non-breeding: Pale with white underparts and blackish wings with large white patches as in summer (mottled in juvenile).

Voice: A feeble, wheezy or hissing whistle, peeeeee.

Range: Bering Sea to Japan, s. California. West: Map 178. Habitat: Rocky coasts, inshore waters; less pelagic than other auks. Breeds in small groups or in solitary pairs among rocks.

CRESTED AUKLET Aethia cristatella

9 $1 / 2 "(24 \mathrm{~cm})$. A droll auklet of the Bering Sea. Completely slate-gray, darker on back; a thin white plume behind the eye. In summer, develops a fleshy gape on its stubby bright orange bill and a curious crest that curls forward over the bill. In winter, the orange gape on the bill is lost and the crest is shorter.

Range: Bering Sea, ne. Asia, w. Alaska. West: Breeds in Bering Sea south to Pribilofs; in Aleutians east to Shumagin and Semidi Is. Winters in s. Bering Sea and Aleutians. Accidental, California. Habitat: Open sea; nests in colonies on sea cliffs.

\section{WHISKERED AUKLET Aethia pygmaea}

7" $(18 \mathrm{~cm})$. Similar to the larger Crested Auklet, but in addition to the curled black plume on the forehead this bird has three thin white plumes on each side of the face. In winter the plumes are shorter.

Range: Bering Sea. Resident in Komandorskiye Is., s. Kuriles; locally in cen. Aleutians. Habitat: Ocean, tide-rips, rocky coasts.

PARAKEET AUKLET Aethia psittacula

$10 "(25 \mathrm{~cm})$. A small auk with a stubby, upturned red bill and white underparts. In summer the whole head is black, with a thin white plume behind the eye. In winter the bill shows less red and the throat is largely white.

Range: Breeds in ne. Siberia, islands in Bering Sea and Aleutians. Winters from Bering Sea south to Japan and California, but rare vagrant south of Alaska. Habitat: Ocean; nests in scattered pairs or in colonies on sea cliffs.

\section{ANCIENT MURRELET Synthliboramphus antiquus}

M180

91/2-101/2" (24-26 cm). Breeding: Note the sharply cut black throat patch and white stripe over eye. Bill yellow. Winter: Similar to Marbled Murrelet (p. 37), but without white stripe on scapulars. Back paler, contrasting with black cap. Throat may be dusky.

Range: Bering Sea and northern parts of N. Pacific (both coasts). West: Map 180. Habitat: Open ocean, sounds, rarely salt bays. 


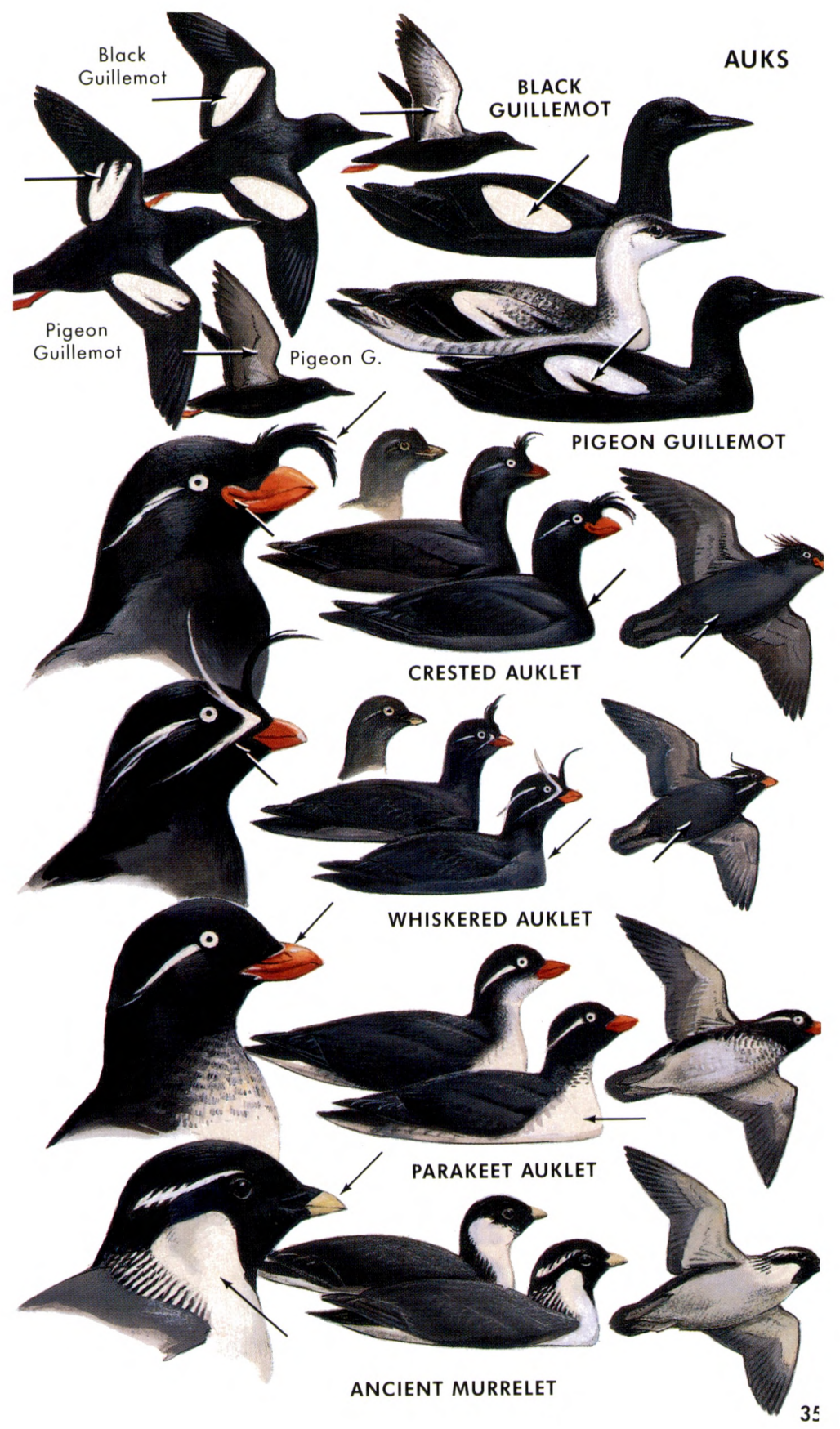


91/2" (24 cm). Breeding: Dark brown; heavily barred on underparts. The only alcid south of Alaska so colored (but from Glacier Bay north, see Kittlitz's Murrelet). Winter: A small, chubby, neckless-looking seabird, dark above and white below. May be known from all similar small alcids (except Kittlitz's) by the strip of white between the back and wings.

Voice: A sharp keer, keer or a lower kee.

Range: Kamchatka to Japan, n. Alaska to California. West: Map 179. Habitat: Coastal waters, bays. Breeds inland on mountains near coast, mainly high on limbs of mossy conifers.

\section{KITTLITZ'S MURRELET Brachyramphus brevirostris}

9" $(23 \mathrm{~cm})$. In summer, scaled below (as in Marbled Murrelet) but freckled with white above, giving a paler look. White outer tail feathers. In winter (not likely to be seen) similar to Marbled Murrelet, but white on face surrounds eyes.

Range: Summers locally along coast of Alaska from Pt. Barrow south at least to Glacier Bay. Winters in nw. Pacific (Kamchatka to Japan). Habitat: Ocean, glacier waters; nests presumably on barren slopes above timberline in coastal mountains.

\section{XANTUS'S MURRELET Synthliboramphus hypoleucus}

$7 \frac{1}{2}-10^{1 / 2} 2^{\prime \prime}(19-26 \mathrm{~cm})$. A small, black and white alcid, with a solid black back and thin black bill. Suggests a miniature murre. Very similar to Craveri's (next), but with white wing linings in flight. The hypoleucus race (inset) of Baja California, a rare fall visitor to California, has white around the eye.

Range: Breeds s. California (Anacapa and Santa Barbara Is.) to cen. Baja. Some winter north to Monterey; casually to Washington.

\section{CRAVERI'S MURRELET Synthliboramphus craveri}

Very similar to Xantus's Murrelet, but with a black half collar on breast and dusky (not white) underwing linings.

Range: Breeds on islands off Baja California; wanders north to Monterey Bay, California; casual, Oregon.

CASSIN'S AUKLET Ptychoramphus aleuticus

M181

$81 / 2 "(21 \mathrm{~cm})$. A small, stubby seabird; all dark except for the white belly; note the pale spot on lower mandible. In winter, all other small alcids in its range show much more white.

Range: Map 181. Habitat: Ocean; colonizes sea islands.

LEAST AUKLET Aethia pusilla

6" $(15 \mathrm{~cm})$. The tiniest auk, chubby, neckless. Black above, white below. In summer, a wide dark band across the upper breast. The tiny size and very stubby bill separate it from other wintering alcids of the Aleutians.

Range: Breeds in swarms on islands of Bering Sea south to Aleutians and Shumagins. Winters from Aleutians to n. Japan.

DOVEKIE Alle alle

71/2-9" (19-23 cm). Small size and distinctive pattern (opposite) identify this straggler from the Atlantic. West: Casual along Arctic coast to n. Bering Sea, where it may breed. 


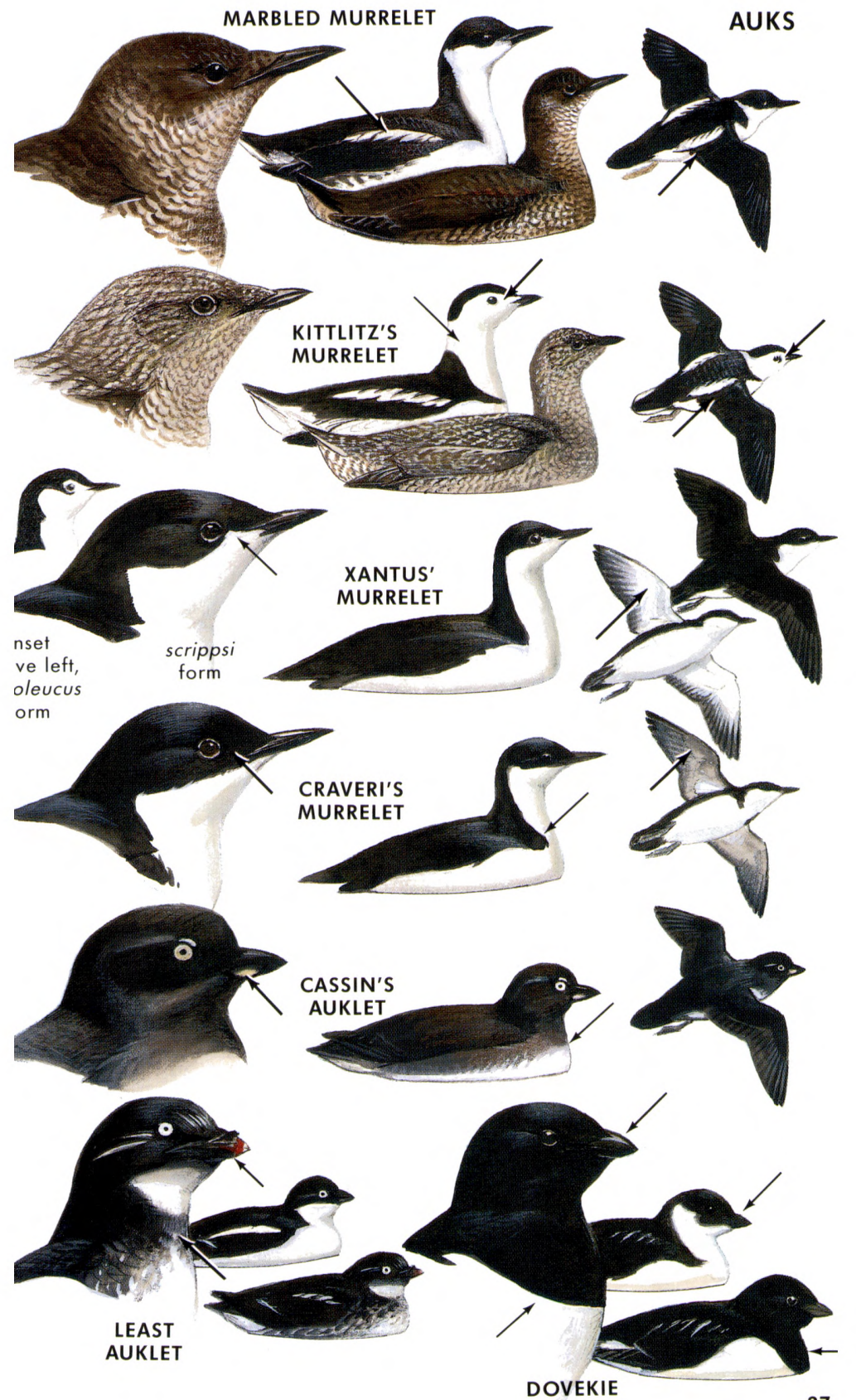


- SWANS, GEESE, DUCKS. Family Anatidae. Web-footed waterfowl; tribes discussed separately. Range: Worldwide. No. of species: World 157; West 41 (+9 casual or accidental).

- SWANS. Tribe Cygnini. Huge, all-white swimmers; larger and longer-necked than geese. Young pale gray-brown. Sexes alike. Swans migrate in lines or V's. Feed by immersing head and neck, or by "tipping up." Food: Aquatic plants, seeds.

TUNDRA SWAN Cygnus columbianus

M28

(Whistling Swan). 53" (133 cm); spread 6-7 ft. Our common native swan. Often heard long before the ribbonlike flock can be spotted. Bill black, usually with a small yellow basal spot. Immature: Dingy, with pinkish bill. Eurasian form ("Bewick's Swan"), casual or accidental from Alaska to California, has much yellow on the bill above the nostrils. Voice: A mellow, high-pitched cooing: wooho, woo-woo, woo-ho. Range: Breeds from arctic coast south to Alaska Peninsula and barren grounds of Canada. Winters to seaboards of e. and w. U.S. West: Map 28. Habitat: Tundra (summer), lakes, large rivers, bays, estuaries.

TRUMPETER SWAN Cygnus buccinator

M29

$581 / 2-72^{\prime \prime}(147-180 \mathrm{~cm})$. Larger than Tundra Swan, with a flatter head and a heavier, all-black bill. Black on lores wider, embracing the eyes and lacking the yellow basal spot (some Tundra Swans may also lack this spot). Trumpeters have louder, deeper voices.

Range: Nw. N. America. Map 29. Habitat: Lakes, ponds, large rivers; in winter, also bays.

SNOW GOOSE Chen caerulescens Tribe Anserini

M31

$25-38^{\prime \prime}(63-95 \mathrm{~cm})$. White with black primaries. Head often ruststained. Bill, feet pink. Immature: Pale gray; dark bill, dark legs.

Voice: A loud, nasal, double-noted houck-houck, in chorus.

Range: Ne. Siberia, arctic America. Winters to Japan, n. Mexico, Gulf Coast. West: Map 31. Habitat: Marshes, grain fields, ponds, bays; when breeding, tundra.

ROSS'S GOOSE Chen rossii Tribe Anserini

M32

$23^{\prime \prime}(58 \mathrm{~cm})$. Like a miniature Snow Goose, but neck shorter, head rounder. Bill stubbier, dark and warty at base, lacking the "grinning black lips." Young bird whiter than young Snow. "Blue" morphs are known; hybrids with Snow Goose occur. Voice: No loud notes; sounds like "Cackling" Goose (p. 40), not like Snow Goose. Range: Arctic Canada; winters mainly in sw. U.S. West: Map 32.

WHOOPER SWAN Cygnus cygnus

$56-70^{\prime \prime}(140-175 \mathrm{~cm})$. This Asian swan is a regular winter visitor to the Aleutians and rarely to the Pribilofs. Resembles Trumpeter Swan, but adult Whooper has extensive yellow base on its large bill. Compare with "Bewick's" race (Eurasian) of Tundra Swan.

MUTE SWAN Cygnus olor

$60 " 150 \mathrm{~cm})$. The graceful ornamental park swan often swims with an S-curve in the neck; wings often arched over back. The blackknobbed orange bill tilts downward. Dingy young have pinkish bills.

Range: Eurasia; introduced e. N. America, elsewhere. West: Kept locally in parks; escapes not yet established. 

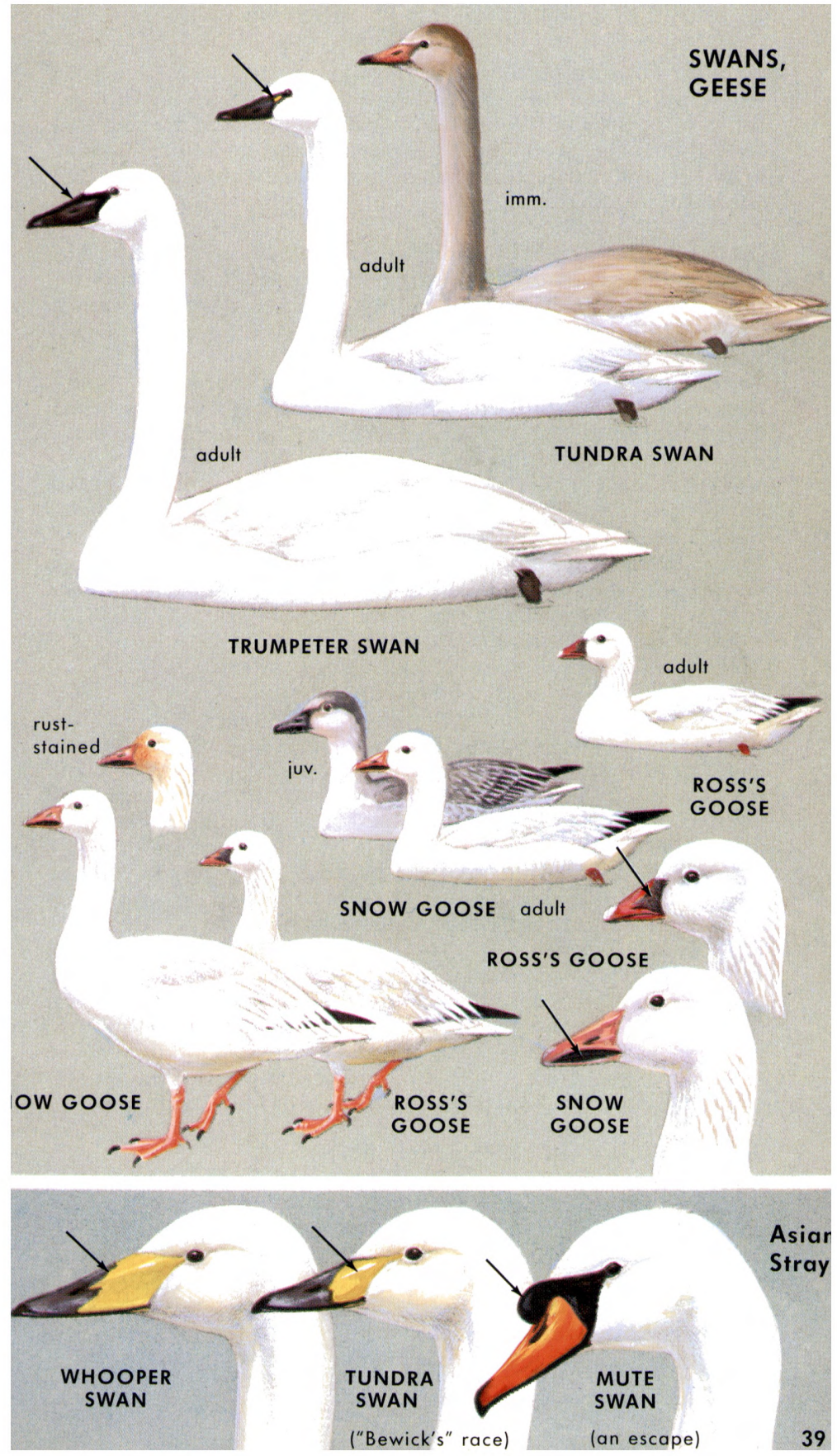
- GEESE. Tribe Anserini. Large, gregarious waterfowl; heavier-bodied, longer-necked than ducks; bills thick at base. Noisy in flight; some fly in lines or $\vee$ formations. Sexes alike. Geese are more terrestrial than ducks, often grazing (except Brant and Emperor Goose). Food: Grasses, seeds, aquatic plants; eelgrass (Brant); shellfish (Emperor Goose).

GREATER WHITE-FRONTED GOOSE Anser albifrons

M30

$30^{\prime \prime}(75 \mathrm{~cm})$. Gray-brown with a pink bill, white patch on front of face, and variable black bars on belly. The only other American goose with yellow or orange feet is the Emperor. Immature: Dusky with a pale bill, yellow or orange feet.

Voice: High-pitched tootling, kah-lah-a-luk, in chorus.

Range: Arctic; circumpolar. Winters to Mexico, Gulf states, n. Africa, India. West: Map 30. Habitat: Marshes, prairies, fields, lakes, bays; in summer, tundra.

EMPEROR GOOSE Chen canagica

M33

$26-28^{\prime \prime}(65-70 \mathrm{~cm})$. Alaskan. Adult: A small, blue-gray goose, scaled with black and white; identified by its white head and hind-neck. Throat black (not white as in "Blue" Goose, a stray). Golden legs. Range: Ne. Siberia, w. Alaska. West: Map 33. Habitat: In summer, tundra; in winter, rocky shores, mudflats, seaweed.

BEAN GOOSE Anser fabalis See p. 62.

This Eurasian species is a vagrant in North America.

CANADA GOOSE Branta canadensis

M35

$25-43^{\prime \prime}(63-108 \mathrm{~cm})$. The most widespread goose. Note the black head and neck or "stocking" that contrasts with the pale breast, and the white chin strap. Flocks travel in strings or in V's, "honking" loudly. Great variation in size and neck length between populations, from short-necked, Mallard-size "Cackling" Geese, to long-necked, almost swan-size birds.

Voice: A deep, musical honking or barking, ka-ronk or ka-lunk.

Range: Alaska, Canada, n. U.S. Winters to n. Mexico. West: Map 35. Habitat: Lakes, ponds, bays, marshes, fields.

BRANT Branta bernicla

M34

$22-26^{\prime \prime}(55-65 \mathrm{~cm})$. A small, black-necked goose, near the size of a Mallard. Has a white stern, conspicuous when it up-ends, and a fleck of white on the neck (absent in immature). Travels in large irregular flocks. Whereas Canada Goose's breast shows light above water, foreparts of Brant are entirely black. Brant is more strictly coastal. The eastern race (also shown), rare on the Pacific side, has a light belly.

Voice: A throaty cr-r-r-ruk or krr-onk, krrr-onk.

Range: Coasts of n. Eurasia, N. America. West: Map 34. Habitat: Salt bays, estuaries; in summer, tundra.

SNOW GOOSE (dark morph- "BLUE GOOSE") Chen caerulescens

25-30" $(63-75 \mathrm{~cm})$. This dark morph of the Snow Goose (p. 38) with a white head, suggests the Emperor, but has a white throat. Intermediates with white form of Snow are frequent. Immature: Similar to young White-front, but feet and bill dark. Most "Blue Geese" migrate through the prairies; rare in Pacific states. 


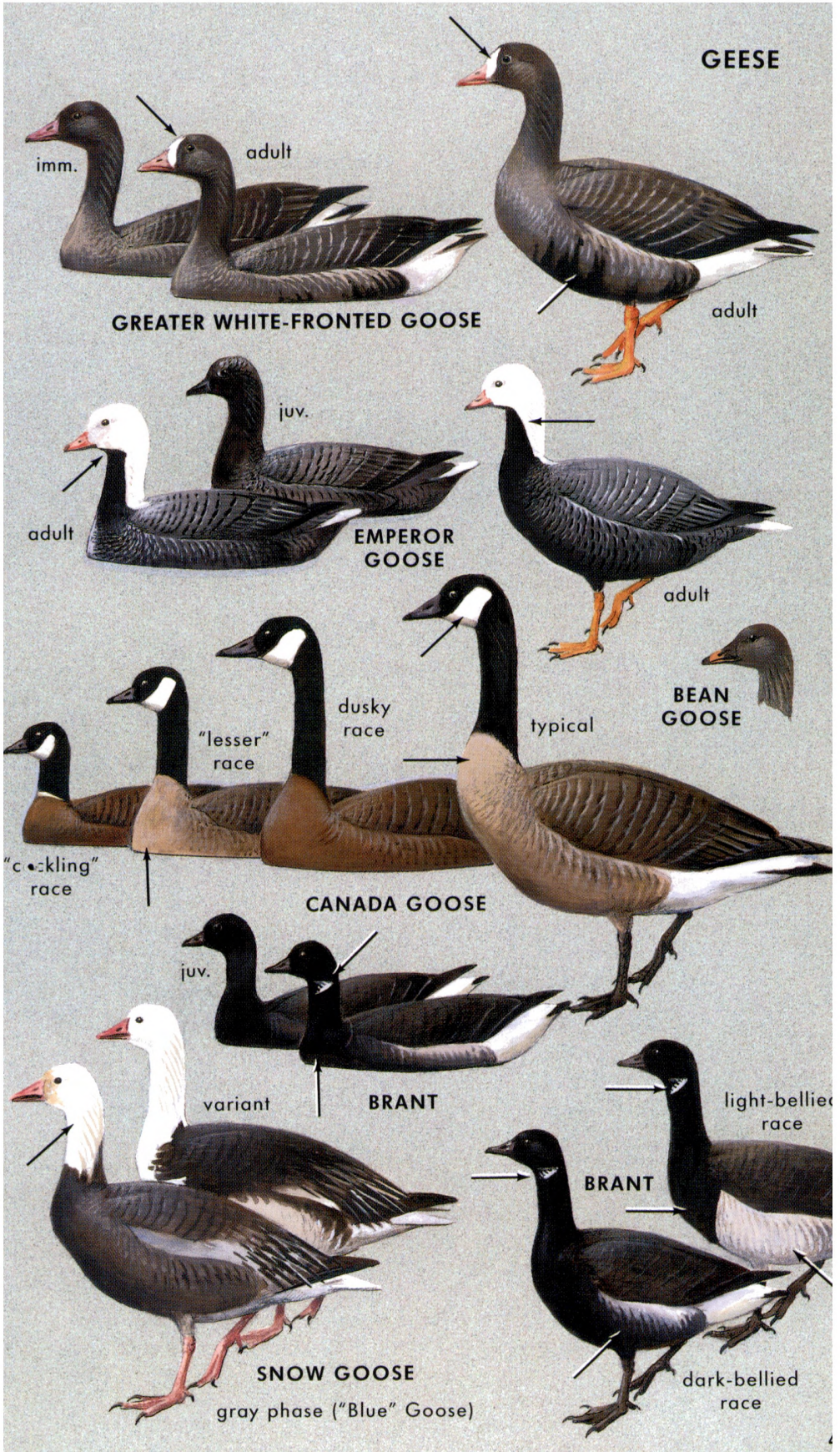




\section{GEESE AND SWANS IN FLIGHT}

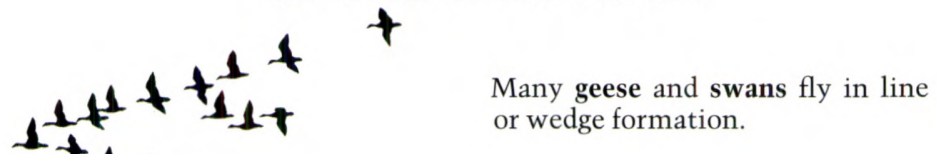

Many geese and swans fly in line $1+1+1+1+4$

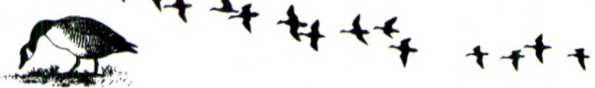

Text and color plate

CANADA GOOSE Branta canadensis

pp. 40, 41

Light chest, black neck "stocking," white chin strap. Size and neck length vary greatly between populations.

BRANT Branta bernicla

Small; black underparts, black head and neck, white stern.

GREATER WHITE-FRONTED GOOSE Anser albifrons

Adult: Gray neck, black splotches on belly.

pp. 40,41

Immature: Dusky, light bill, light feet.

इMPEROR GOOSE Chen canagica

pp. 40,41

Gray with white head, black throat.

IUNDRA SWAN Cygnus columbianus

pp. 38,39

Very long neck; plumage entirely white.

¡NOW GOOSE Chen caerulescens

pp. 38,39

Adult: White with black primaries.

2OSS'S GOOSE Chen rossii

Smaller, shorter-necked than Snow Goose.

pp. 38,39

- WHISTLING-DUCKS. Tribe Dendrocygnini. Shown on p. 45.

Formerly called "Tree-Ducks," these rather goose-like ducks with their long legs and erect necks are indeed more closely related to the geese (same subfamily) than they are to the other ducks, which taxonomists place in a different subfamily.

:ULVOUS WHISTLING-DUCK Dendrocygna bicolor

20" $(50 \mathrm{~cm})$. Long-legged, goose-like. Note the tawny body, dark back, pale side stripe. Flies with neck slightly drooped and feet trailing, showing black underwings, white ring on rump. See also p. 69.

Voice: A squealing slurred whistle, ka-whee-oo.

Range: Southern U.S. to Argentina; also s. Asia, subsaharan Africa. West: Breeds s. California (Imperial Valley); wanderers may turn up rarely elsewhere in w. U.S. Habitat: Fresh marshes, irrigated land. Seldom perches in trees.

\section{ILACK-BELLIED WHISTLING-DUCK Dendrocygna autumnalis}

$21 "$ (53 cm). A goose-like duck with long pink legs. Rusty with black belly, bright coral-red bill. Very broad white patch along forewing. Immature has gray bill and legs. Thrusts head and feet down when landing. Frequently perches in trees.

Range: S. Texas to n. Argentina. West: Resident, se. Arizona (breeds); casual, se. California, s. New Mexico, Colorado, w. Texas. Habitat: Ponds, fresh marshes. 


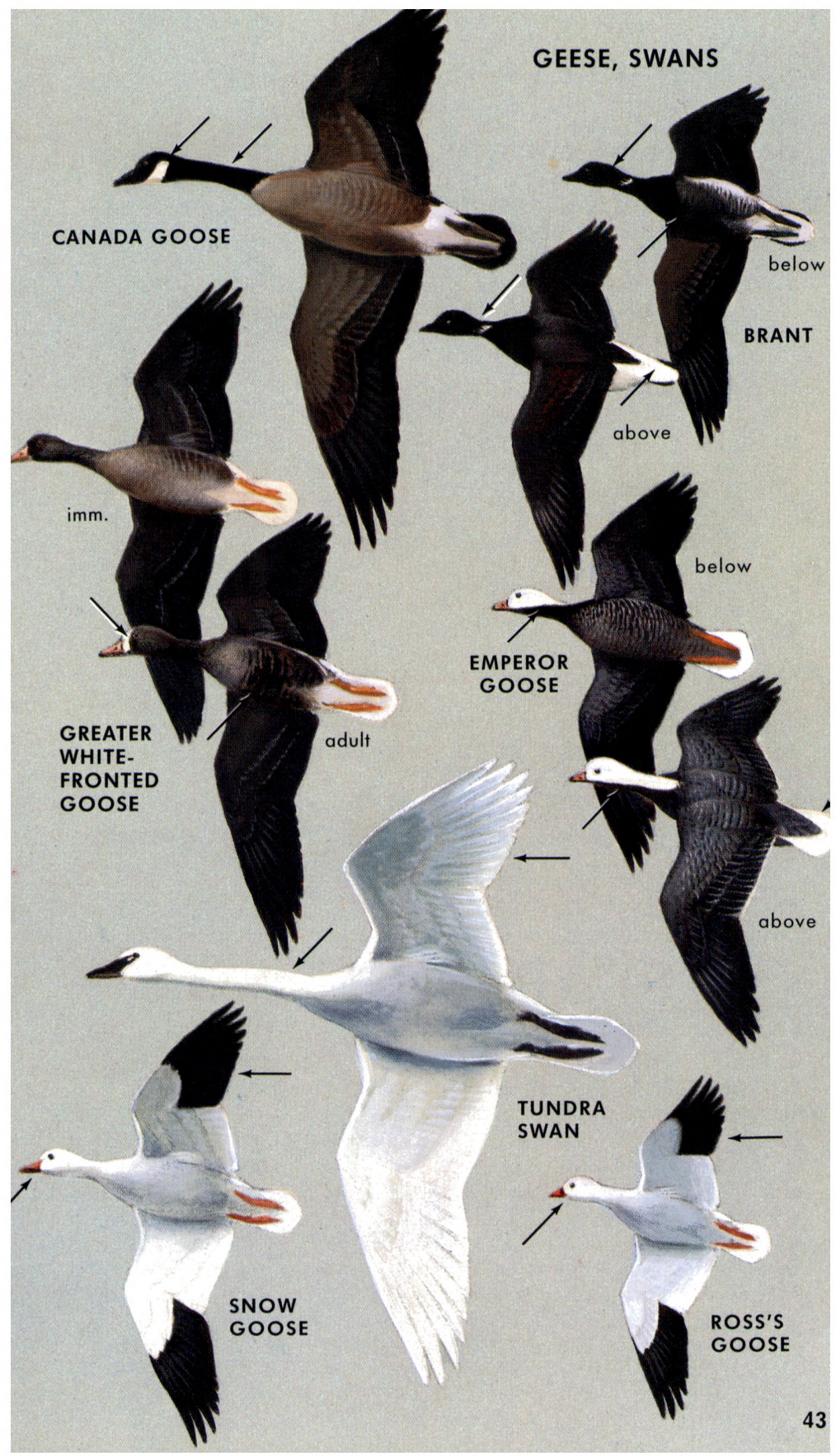




\section{WHISTLING-DUCKS. Tribe Dendrocygnini. Text on p. 42.}

\section{FULVOUS WHISTLING-DUCK \\ BLACK-BELLIED WHISTLING-DUCK}

- MARSH OR DABBLING DUCKS. Tribe Anatini. Surface-feeders of wetlands. Feed by dabbling and upending; sometimes feed on land. Take flight directly into the air. Most species have an iridescent speculum on the rear edge of the wing. Sexes are not alike; in late summer, males molt into drab "eclipse" plumage. Food: Aquatic plants, seeds, grass, small aquatic life, insects.

\section{"MEXICAN DUCK"}

(Mallard, in part) 20-22" (50-55 cm). This race of the Mallard was formerly regarded as a distinct species. Hybrids are frequent. Both sexes are very similar to the female Mallard but with a grayish brown instead of whitish tail. Bill of male like bill of male Mallard (unmarked yellowish green). Yellow-orange bill of female has a dark ridge. Not as dark overall as Black Duck; has a white border on both sides of metallic wing patch, as in female Mallard.

Range: Rare summer resident from n. New Mexico south in Rio Grande Valley to w. Texas; very local from sw. New Mexico to cen. Mexico. Accidental, Colorado, Nebraska.

AMERICAN BLACK DUCK Anas rubripes See also p. 68.

21-25" (53-63 cm). A dusky duck, much darker than female Mallard. In flight, shows flashing white wing linings. Sooty brown, with a paler head and violet wing patch; feet red or brown. Sexes similar, except for bills (yellow in male, dull green in female).

Range: Ne. N. America. Winters to Gulf Coast. West: Breeds in Saskatchewan. Straggler west of $100^{\circ}$, but recorded from most western states.

GADWALL Anas strepera See also p. 66.

19-23" (48-58 cm). Male: Gray with a black rump, white speculum on the rear edge of wing, and a dull ruddy patch on the forewing. When swimming, wing patches may be concealed; then note the black stern. Belly white, feet yellow, bill dark. Female: Brown, mottled, with a white speculum, yellow feet, yellow on bill.

Voice: Male has a low bek; a whistling call. Female quacks.

Range: Northern N. America, n. Eurasia. Winters to Mexico, Africa, India. West: Map 43. Habitat: Lakes, ponds, marshes.

MALLARD Anas platyrhynchos See also p. 68

20-28" (50-70 cm). Male: Note the uncrested glossy green head and white neck-ring; chestnut chest, white tail, yellowish bill, orange feet, blue speculum. Female: Mottled brown with a whitish tail. Bill patched with orange, feet orange. In flight, shows a white bar on both sides of the speculum.

Voice: Male, yeeb; a low kwek. Female, boisterous quacking.

Range: Northern parts of N. Hemisphere. Winters to Mexico, n. Africa, India. West: Map 38. Habitat: Marshes, wooded swamps, grain fields, ponds, rivers, lakes, bays, city parks. 

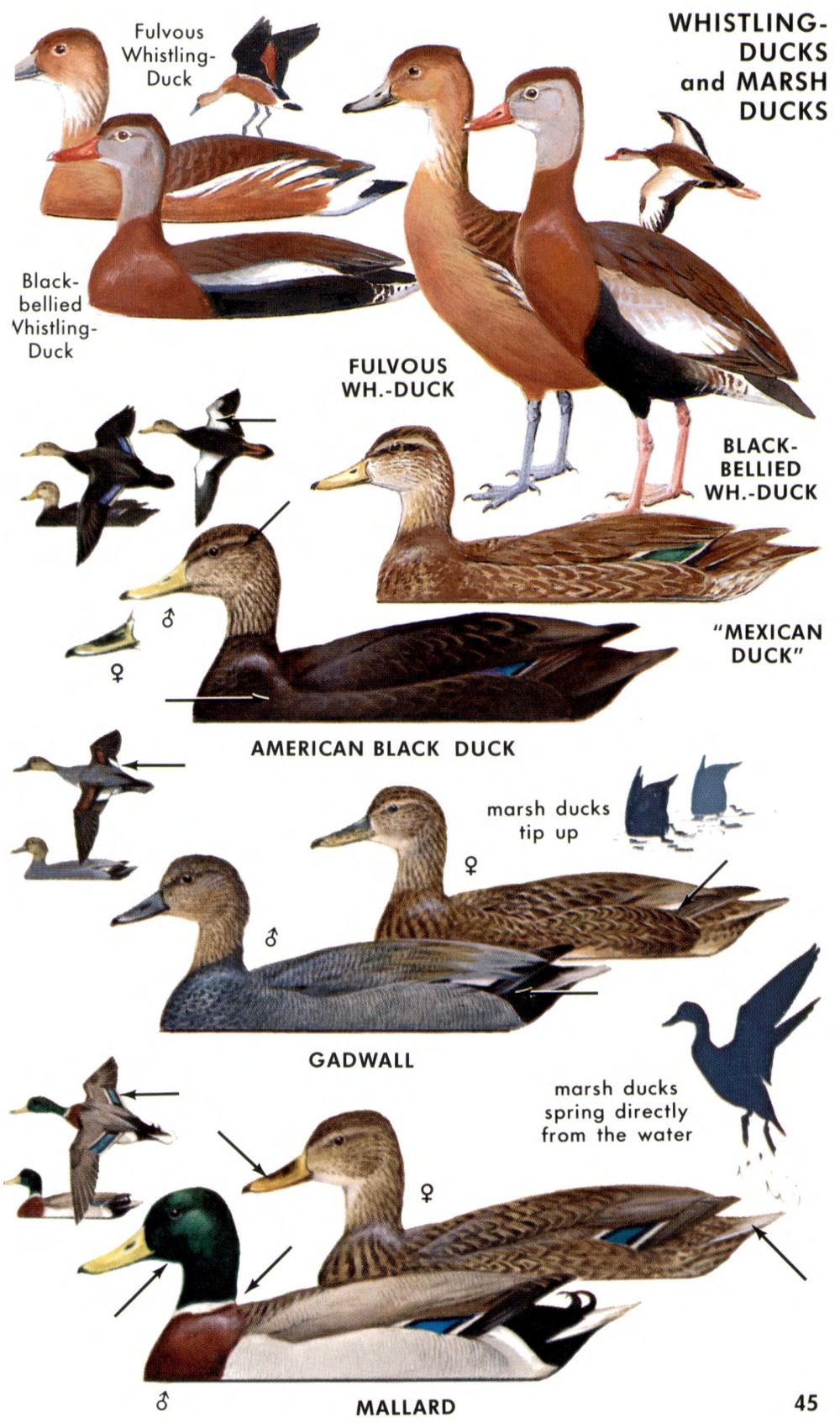
NORTHERN PINTAIL Anas acuta See also p. 66.

Male 28" $(70 \mathrm{~cm})$; female 21" $(53 \mathrm{~cm})$. Male: Slender, slim-necked, white-breasted, with a long, needle-pointed tail. A conspicuous white point runs onto the side of the dark head. Female: Mottled brown; note the rather pointed tail, slender neck, gray bill. In flight both sexes show a single light border on the rear edge of the brown speculum.

Voice: Male, a double-toned whistle: prrip, prrip; wheezy notes. Female, a low quack.

Range: Northern parts of N. Hemisphere. Winters to n. S. America, Africa, India. West: Map 39. Habitat: Marshes, prairies, ponds, lakes, salt bays.

AMERICAN WIGEON Anas americana See also p. 66.

M44

$18-23^{\prime \prime}(45-58 \mathrm{~cm})$. In flight, recognized by the large white patch on the forewing. (Similarly placed blue patches of Shoveler and Blue-winged Teal may often appear whitish). When swimming, it rides high, picking at water like a Coot. Often grazes on land. Male: Brownish; head gray with a deep green patch. Note the shining white crown (nicknamed "Baldpate"). Female: Brown; gray head and neck; belly and forewing whitish.

Similar species: Female easily confused with females of Gadwall and Pintail; note whitish patch on forewing, blue bill.

Voice: Male, a whistled whee whee whew. Female, qua-ack.

Range: Alaska, w. Canada, n. U.S. Winters to n. S. America, W. Indies. West: Map 44. Habitat: Marshes, lakes, bays, fields.

\section{EURASIAN WIGEON Anas penelope}

$18-20^{\prime \prime}(45-50 \mathrm{~cm})$. Male: Note the red-brown head, buff crown. A gray wigeon with a vinaceous breast. Female: Very similar to female American Wigeon, but in some females the head is tinged with rust; in others it is not. The surest point when this duck is held in the hand is the dusky (not white) axillars, or "wingpits."

Range: Breeds in n. Eurasia. Winters to s. Eurasia, n. Africa. West: Common transient in Aleutians. Most often recorded among flocks of American Wigeon from Alaska to California; less often in interior states.

WOOD DUCK Aix sponsa Tribe Cairinini See also p. 66.

M36

$17-20^{1} / 2^{\prime \prime}(43-51 \mathrm{~cm})$. Highly colored; often perches in trees. In flight, the white belly contrasts with the dark breast and wings. Note also the long, square, dark tail; the short neck; and the angle at which the bill points downward. Male: The bizarre face pattern, swept-back crest, and rainbow iridescence are unique. Female: Dullcolored; note the dark crested head and white eye patch.

Voice: Male, a loud, distressed whoo-eek; also a finch-like jeee, with rising inflection. Female, crrek, crrek.

Range: S. Canada, nw. and e. U.S., Cuba. Winters to Mexico, Cuba. West: Map 36. Habitat: Wooded swamps, rivers, ponds. 

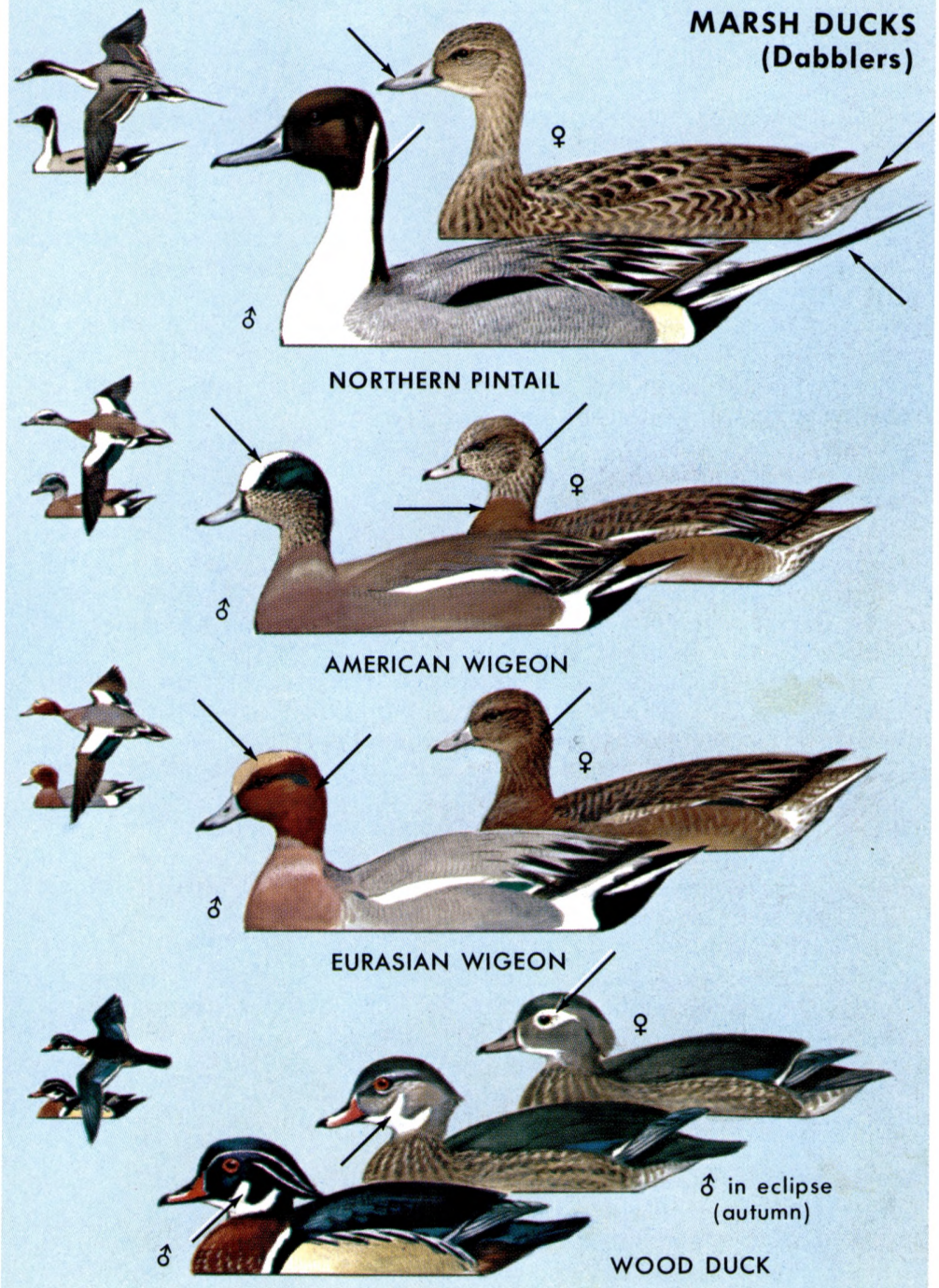

OSTURES OF DUCKS ON LAND

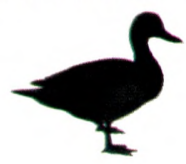

Marsh

Ducks

(dabblers)

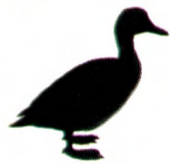

Sea and

Bay Ducks

(divers)

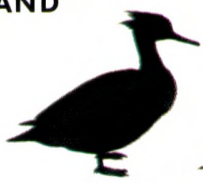

Mergansers

(divers)

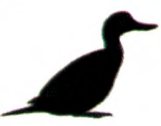

Ruddy

Duck

(diver)

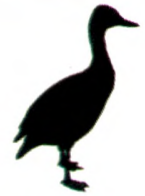

Whistling

Ducks

(dabblers) 
NORTHERN SHOVELER Anas clypeata See also p. 66.

$17-20 "$ " (43-50 cm). The long, spoon-shaped bill gives this small duck a front-heavy look. When swimming, it sits low, with the bill angled toward the water. Male: Belly and sides rufous; pale blue patch on forewing, orange feet. Female: Note the big bill, blue wing patch, orange feet. Bill color variable.

Range: N. Hemisphere. Winters to n. S. America, s. Eurasia, e. Africa. West: Map 42. Habitat: Marshes, ponds; in winter, also salt bays.

BLUE-WINGED TEAL Anas discors See also p. 66.

M40

15-16" $(38-40 \mathrm{~cm})$. A half-sized marsh duck. Male: Note the white facial crescent and large, chalky blue patch on the forewing. Molting males hold eclipse plumage late in the year, may resemble females. Female: Brown, mottled; blue on the forewing.

Range: Canada to s. U.S. Winters to Argentina. West: Map 40. Habitat: Fresh ponds, marshes.

GREEN-WINGED TEAL Anas crecca See also p. 66.

M37

$14 "$ " $35 \mathrm{~cm})$. Teal are small, fly in tight flocks. Green-wings lack light wing patches (speculum deep green). Male: Small, compact, gray with a brown head (a green head patch shows in sunlight). When swimming, note the vertical white mark near the shoulder. Female: A small speckled duck with a green speculum.

Similar species: Blue-winged Teal has light blue wing patches. In flight, males show dark bellies; Green-wings, white bellies. Females of Bluewing and Cinnamon Teal are larger, longer-billed.

Range: Northern parts of N. America. Winters to Cen. America, W. Indies. West: Map 37. Habitat: Marshes, rivers, bays.

GREEN-WINGED TEAL (Aleutian race) Anas crecca (in part)

Male: Longitudinal (not vertical) white stripe above wing. Resident in Aleutians from Akutan westward. Casual, Pribilofs. This or similar Eurasian race is accidental elsewhere in w. U.S.

CINNAMON TEAL Anas cyanoptera

M41

15-17" (38-43 cm). Male: A small, dark chestnut duck with a large, chalky blue patch on the fore edge of the wing. In flight, resembles Bluewinged Teal. Female: Very similar to female Blue-wing, but tawnier; bill a wee bit longer, line through eye less distinct.

Range: Sw. Canada, w. U.S., Mexico; S. America. West: Map 41. Habitat: Marshes, fresh ponds.

- ALASKAN STRAYS FROM ASIA. (See also heads on p. 63.)

GARGANEY Anas querquedula

$15 \frac{1}{2} \mathrm{l}^{\prime}(39 \mathrm{~cm})$. Male: Broad white eyebrow stripe. Female: Paler than female Blue-wing, less blue on wing. Rare visitor to Aleutians; accidental vagrant elsewhere in N. America.

BAIKAL TEAL Anas formosa

$17^{\prime \prime}(43 \mathrm{~cm})$. Male: Creamy cheek with circular pattern. Female: White spot near bill; broken supercilium (eyebrow stripe). Rare vagrant to Attu, Pribilofs, w. Alaska.

FALCATED DUCK Anas falcata

19" $(48 \mathrm{~cm})$. Male: Large crested head, banded white throat. Note the high-rumped look. Both sexes have a dark speculum bordered with white. Rare stray to w. Aleutians, Pribilofs. 

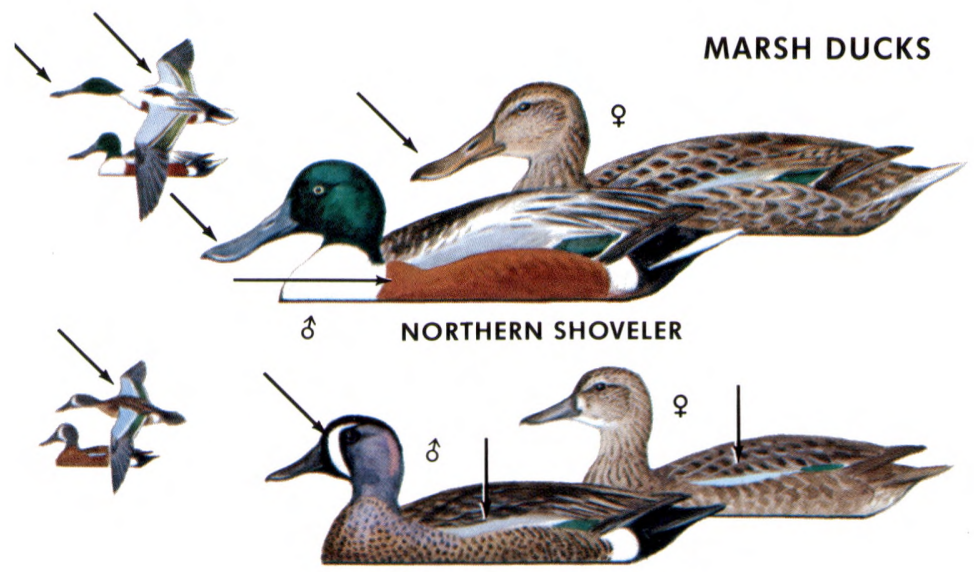

BLUE-WINGED TEAL
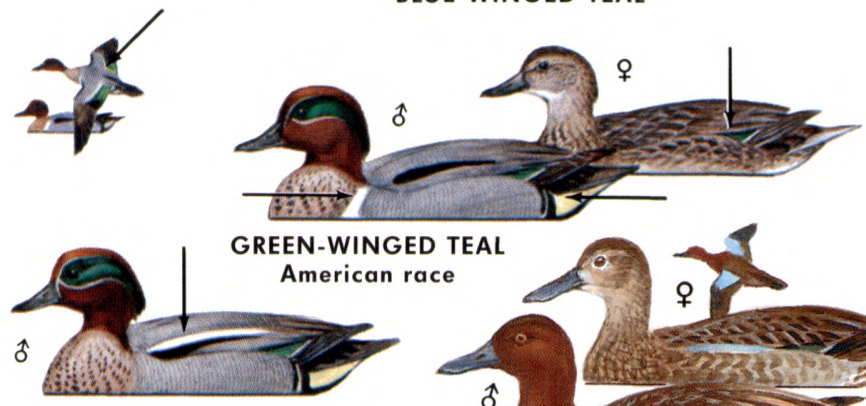

GREEN-WINGED TEAL

Eurasian race

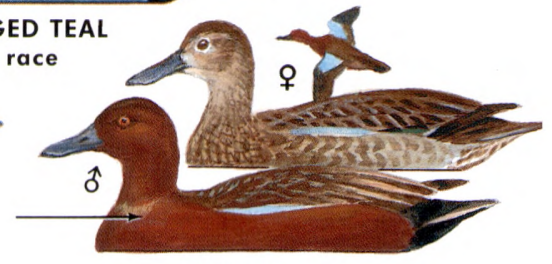

CINNAMON TEAL
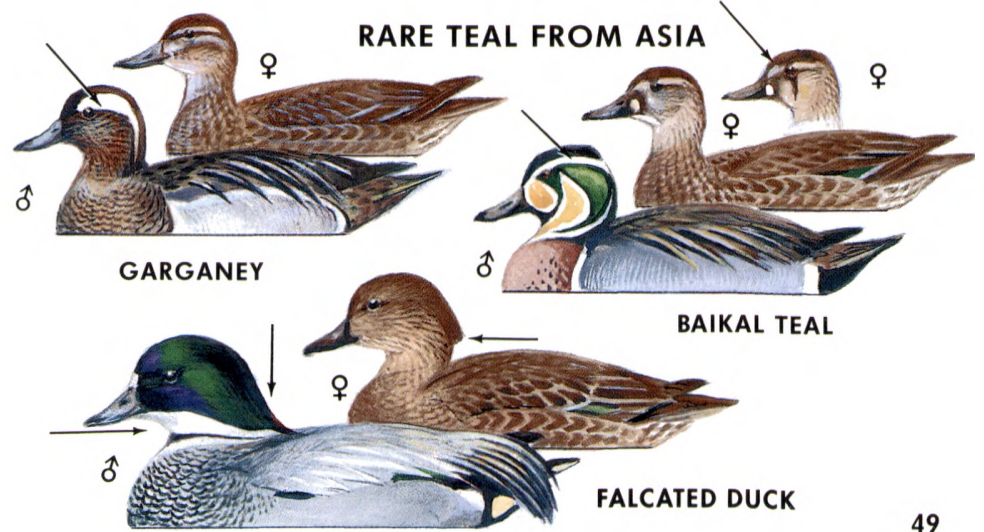
- SCOTERS. Tribe Mergini (in part). Scoters are the heavy, blackish ducks seen in large flocks along the coast. They are usually in companies of their own kind, but occasionally mix, so look them over carefully. The scoters, eiders, and their allies are collectively called "sea ducks," but some may also be found at times on bays and inland waters. All dive; dabbling ducks rarely do. In taking wing, scoters patter while getting under way. Sexes not alike. Scoters are usually silent, but during mating may utter low whistles, croaks, or grunting noises. Food: Mainly mollusks, crustaceans.

WHITE-WINGED SCOTER Melanitta fusca See also p. 70.

$21^{\prime \prime}(53 \mathrm{~cm})$. The White-wing, the largest of the three scoters, usually flies in lines or stringy formations. On the water, the white wing patch is often concealed (wait for the bird to flap or fly). Male: Black, with a tick of white near the eye; bill orange with a black basal knob. Female: Sooty, with a white wing patch and two light patches on the face (sometimes obscure; more pronounced on young birds). Range: N. Eurasia, Alaska, w. Canada; winters to w. Europe, Japan, s. U.S. (both coasts). West: Map 58. Habitat: Salt bays, ocean; in summer, lakes.

SURF SCOTER Melanitta perspicillata See also p. 70.

M57

19 " $(48 \mathrm{~cm})$. The "Skunk-duck." Male: Black, with one or two white patches on crown and nape. Bill patterned with orange, black, and white. Female: Dusky brown, with two light spots on side of head (sometimes obscure; more evident on young birds).

Similar species: Female White-wing has a similar head pattern, but note the wing patch (may not show until bird flaps).

Range: Alaska, n. Canada. Winters to s. U.S. (both coasts), Gulf of Mexico, Baja California. West: Map 57. Habitat: Ocean surf, salt bays, marinas; in summer, fresh arctic lakes, tundra.

BLACK SCOTER Melanitta nigra See also p. 70.

M56

(Common Scoter) 181/2" $(46 \mathrm{~cm})$. Male: A sea duck with entirely black plumage. The bright orange-yellow knob on the bill ("butternose") is diagnostic. In flight, the underwing shows a two-toned effect (silvery gray and black), more pronounced than in the other two scoters. Female: Sooty; the light cheeks contrasting with the dark cap.

Similar species: (1) Coot is blackish, but has a white bill, white patch under the tail. Gunners often call scoters "coots." (2) Some young male Surf Scoters may lack head patches and thus appear allblack, but look for a round black area at the base of the bill. (3) Female and immature scoters of the other two species have light spots on side of head. (4) Female Black Scoter may suggest winter Ruddy Duck (p. 59).

Range: Alaska, ne. Canada, Iceland, n. Eurasia. Winters to s. U.S., Mediterranean, Japan. West: Map 56. Habitat: Seacoasts; in summer, coastal tundra. 

EIDERS. Tribe Mergini (in part). Eiders, like the scoters, are "sea ducks," seldom seen ashore except in summer when breeding. They usually mass in flocks off shoals and rocky coasts and often fly in stringy formations. In flight males show white shoulders.

KING EIDER Somateria spectabilis See also pp. 70, 71.

M51

21-24" $(53-60 \mathrm{~cm})$. Male: A stocky sea duck; on the water the foreparts appear white, the rear parts black. Note the protruding orange bill shield. In flight, the wings show large white patches. Female: Stocky; warm brown, heavily barred. Note the facial profile as shown. Immature male: Dusky, with a light breast, dark brown head; may have a pinkish bill.

Similar species: (1) Male Common Eider has a white back. (2) Female Common has flatter profile, longer lobe before eye.

Voice: The courting male utters a low crooning phrase; the female makes grunting croaks.

Range: Arctic regions of N. Hemisphere. West: Map 51. Habitat: Rocky coasts, ocean.

COMMON EIDER Somateria mollissima See also pp. 70, 71. M50 $23-27^{\prime \prime}(58-68 \mathrm{~cm})$. These bulky, thick-necked ducks are oceanic, living in flocks about shoals. Flight sluggish and low; flocks usually in a line. Male: This and the Spectacled Eider are the only ducks in our area with black bellies and white backs. Forewing white; head white, with a black crown, greenish nape. Female: Large, brown, closely barred; long flat profile. Immature male: At first grayish brown; later dusky with a white collar; may develop chocolate head or breast; white areas come in irregularly.

Similar species: (1) Male King Eider has a largely black back; female has a different facial profile than other female eiders, as shown. (2) Female scoters are duskier, lack the heavy black barring of the female eiders.

Voice: Male, a moaning ow-ooo-urr. Female, a grating kor-r-r.

Range: Northern parts of N. Hemisphere. West: Map 50. Habitat: Rocky coasts, shoals; in summer, also islands, tundra.

SPECTACLED EIDER Somateria fischeri

M52

$201 / 2-22^{1 / 2} 2^{\prime \prime}(51-57 \mathrm{~cm})$. Note the white "spectacles." Male: Grotesque; black below, white above, suggesting a male Common Eider, but head largely pale green, with large white "goggles" narrowly trimmed with black. Female: Brown and barred like the other female eiders, but with a pale ghost image of the goggles. The feathering at the base of the bill extends over the nostril.

Range: Ne. Siberia, $\mathrm{n}$. Alaska. West: Map 52. Breeds on Arctic coasts of nw. Alaska from Pt. Barrow south to Yukon-Kuskoquim Delta. Probably winters mainly at the edge of the pack ice in the Bering Sea, but to be looked for off the Pribilofs and Aleutians at that season. Casual or accidental elsewhere along Alaskan coast and in British Columbia. 

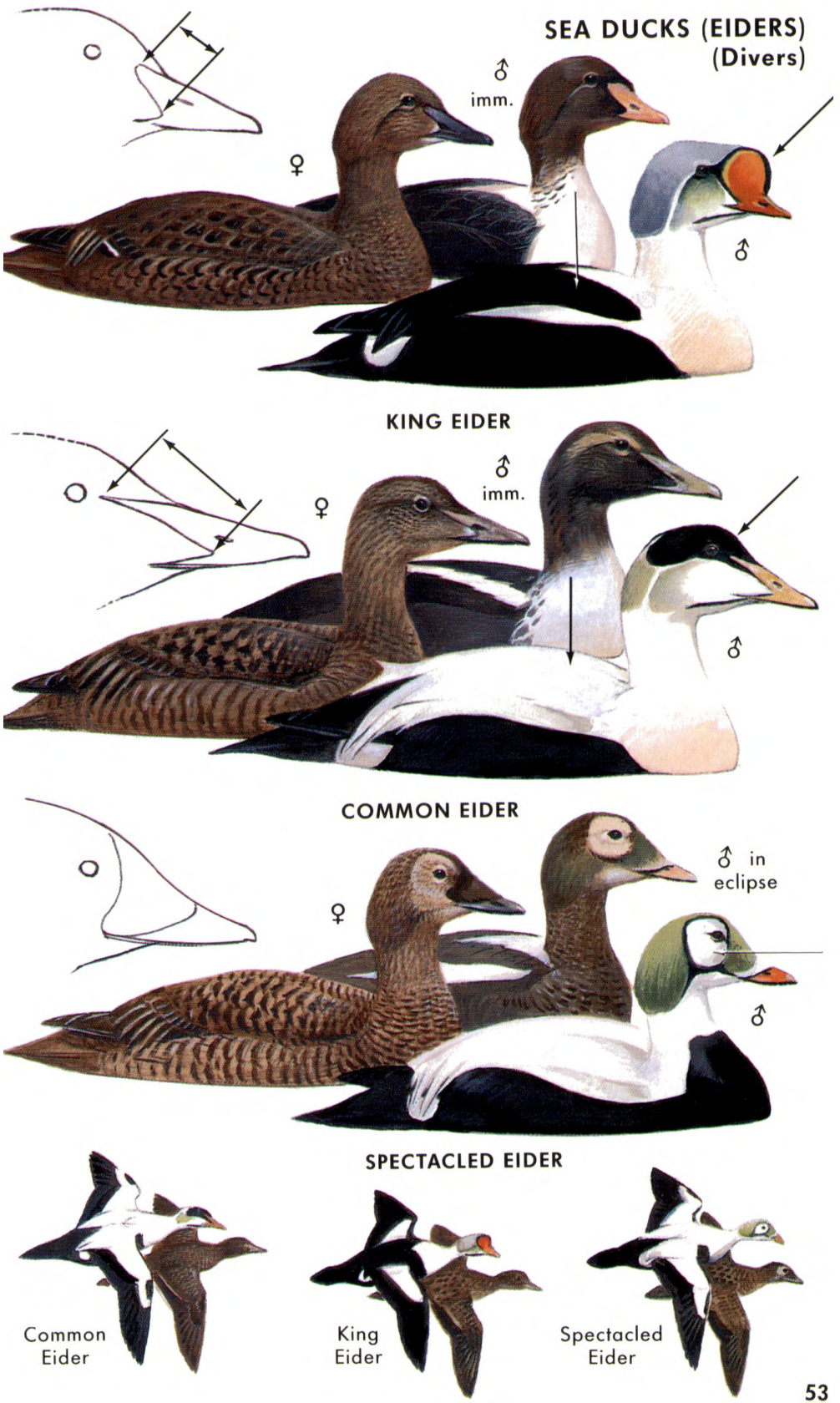
17-181/2" (43-47 cm). Male: Black and white, with yellow-buff underparts; white head, black throat, and green bump on the back of the head. Note the round black spot on the side of the breast. As in other eiders, the white forewing is conspicuous in flight. Female: Dark brown, mottled; distinguished from the other eiders by its much smaller size and the shape of its small head and bill. The white wing bar and purple speculum, visible at short range, suggest a female Mallard.

Voice: Male's crooning note resembles Common Eider's, but is quieter. Female has a low growl.

Range: Coasts of arctic Siberia, n. Alaska. West: Map 53. Breeds from arctic coast of Alaska south to the Yukon-Kuskokwim Delta. Winters in Pribilofs and Aleutians; east to Kodiak Island and base of the Alaskan Peninsula. Casual, British Columbia; accidental, California. Habitat: Coasts, ocean.

HARLEQUIN DUCK Histrionicus histrionicus See also p. $70 . \quad$ M54 18" $(45 \mathrm{~cm})$. Dark and bizarre. Male: A smallish, slaty duck with chestnut sides and odd white patches and spots. In flight, it has the stubby shape of a Goldeneye, but appears uniformly dark. Female: A small dusky duck with three round white spots on the side of the head; no wing patch.

Similar species: (1) Female Bufflehead has a white wing patch and only one face spot. (2) Female scoters are larger, with larger bills.

Voice: Male, a squeak; also gwa gwa gwa. Female, ek-ek-ek-ek.

Range: Ne. Asia, Alaska, Canada, w. U.S., Greenland, Iceland. West: Map 54. Habitat: Turbulent mountain streams in summer; rocky coastal waters in winter.

OLDSQUAW Clangula hyemalis See also p. 70.

Male 21" (53 cm); female 16" $(40 \mathrm{~cm})$. This is the only sea duck combining much white on the body and unpatterned dark wings. It flies in bunched, irregular flocks. Male, winter: Note the needlelike tail, pied pattern, dark cheek; summer: dark, with white flanks and belly. Note the white eye patch. Female, winter: Dark unpatterned wings, white face with dark cheek spot; summer: similar, but darker. Immatures lack the long tail feathers.

Voice: Talkative; a musical ow-owdle-ow, or owl-omelet.

Range: Arctic, circumpolar. Winters to s. U.S., cen. Europe, cen. Asia. West: Map 55. Habitat: Ocean, large lakes; in summer, tundra pools and lakes. 


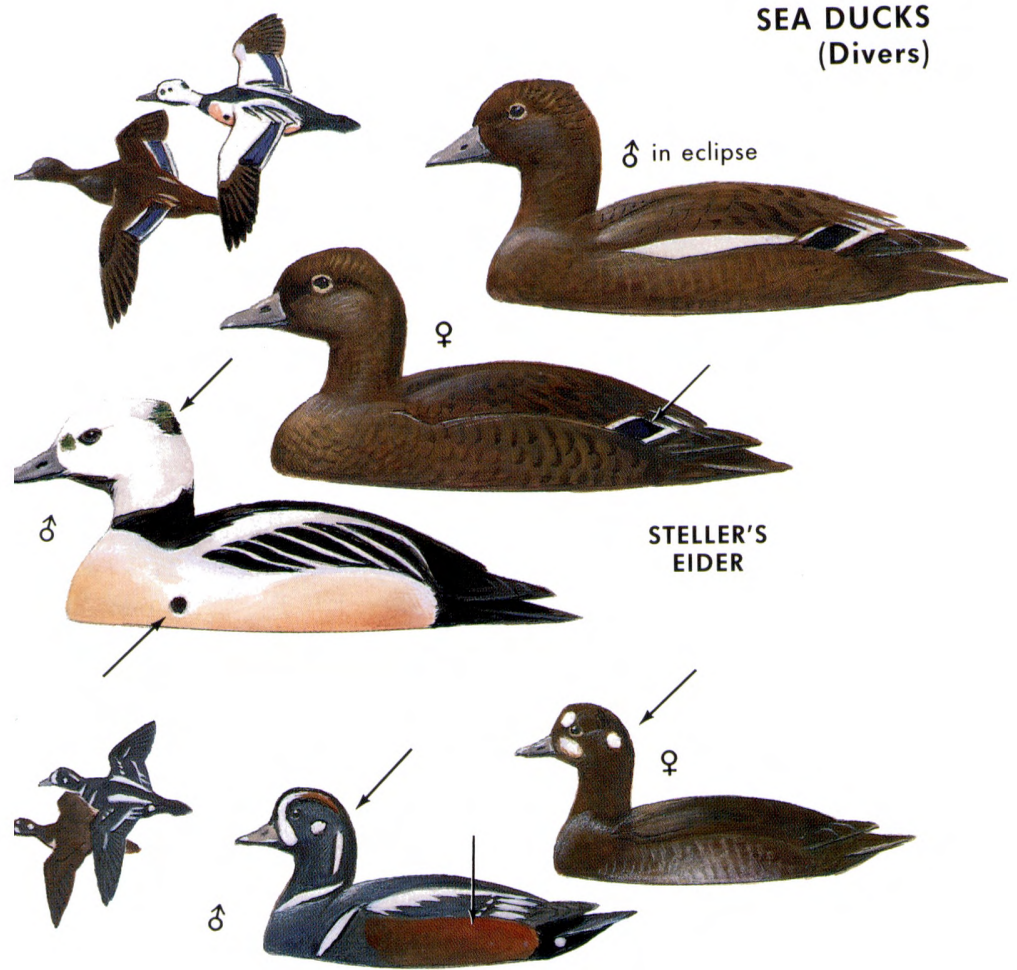

HARLEQUIN DUCK

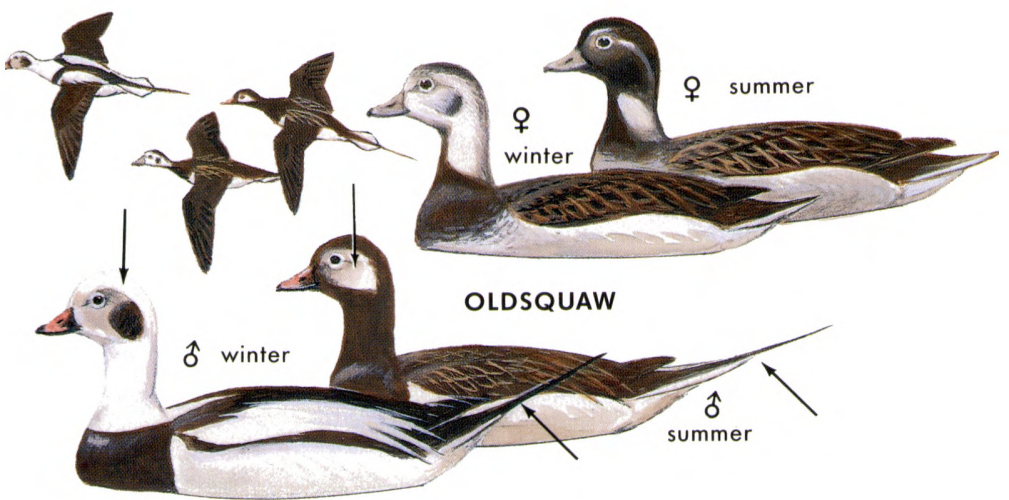


- BAY DUCKS. Tribe Aythyini. Scaups and Allies.

CANVASBACK Aythya valisineria See also pp. 72, 73.

20-24" (50-60 cm). Male: Very white-looking, with a chestnut red head sloping into the long blackish bill. Red eye, rufous neck, black chest. Female: Grayish, with a brown chest; pale rust on head and neck. Both sexes have the long, sloping profile. Flocks travel in lines or $\mathrm{V}$ formations.

Voice: Male, in courtship, cooing notes. Female, quacks, etc.

Range: Alaska, w. Canada, nw. U.S. Winters to Mexico, Atlantic and Gulf coasts. West: Map 45. Habitat: Lakes, salt bays, estuaries; in summer, fresh marshes.

REDHEAD Aythya americana See also pp. 72, 73.

M46

$18-23^{\prime \prime}(45-58 \mathrm{~cm})$. Male: Gray; black chest and round rufous head; bill bluish with a black tip. Female: Brown; suffused light patch near bill. Both sexes have a gray wing stripe.

Similar species: Male Canvasback is much whiter, with a sloping forehead and black bill. See female Ring-necked Duck.

Voice: Male, a harsh catlike meow; a deep purr. Female, quacks.

Range: W. Canada, w. and n.-cen. U.S. Winters to Mexico, W. Indies. West: Map 46. Habitat: Lakes, saltwater bays, estuaries; in summer, fresh marshes.

RING-NECKED DUCK Aythya collaris See also pp. 72, 73.

M47

15-18" (38-45 cm). Male: Like a scaup with a black back. Note the vertical white mark before the wing; bill crossed by a white ring. In flight, a broad gray (not white) wing stripe. Female: Shaped somewhat like female Lesser Scaup, but with an indistinct light face patch, dark eye, white eye-ring, and ring on bill. Wing stripe is gray.

Range: Canada, n. U.S. Winters to Panama. West: Map 47. Habitat: Wooded lakes, ponds, in winter, also rivers, bays.

TUFTED DUCK, A. fuligula, is a stray from Asia. See pp. 62, 63.

GREATER SCAUP Aythya marila See also pp. 72, 73.

M48

16-20" (40-50 cm). Very similar to Lesser Scaup, but male is whiter;

head rounder, less domed, glossed mainly with dull green rather than dull purple. Black tip on bill larger (apparent only at close range). Greater's white wing stripe is longer, extending onto primaries. Range: Alaska, Canada, n. Eurasia. Winters to California, se. U.S., Mediterranean, China. West: Map 48. Habitat: Lakes, rivers, salt bays, estuaries; in summer, tundra ponds.

LESSER SCAUP Aythya affinis See also pp. 72, 73.

M49

$15-18^{\prime \prime}(38-45 \mathrm{~cm})$. Scaups (both species) have a broad white stripe on the trailing edge of wing; it is shorter in the Lesser. Male: On water, black at both ends, whitish in the middle. Bill blue; head glossed with dull purple. Flanks and back finely barred. Female: Dark brown, with a clean-cut white mask near bill. May also have a pale crescent on ear coverts. See Greater Scaup.

Voice: A loud scaup; also purring notes. Male, a low whistle.

Range: Alaska, w. Canada, nw. U.S. Winters to n. S. America. West: Map 49. Habitat: Lakes, bays, estuaries; in summer, marsh ponds. 

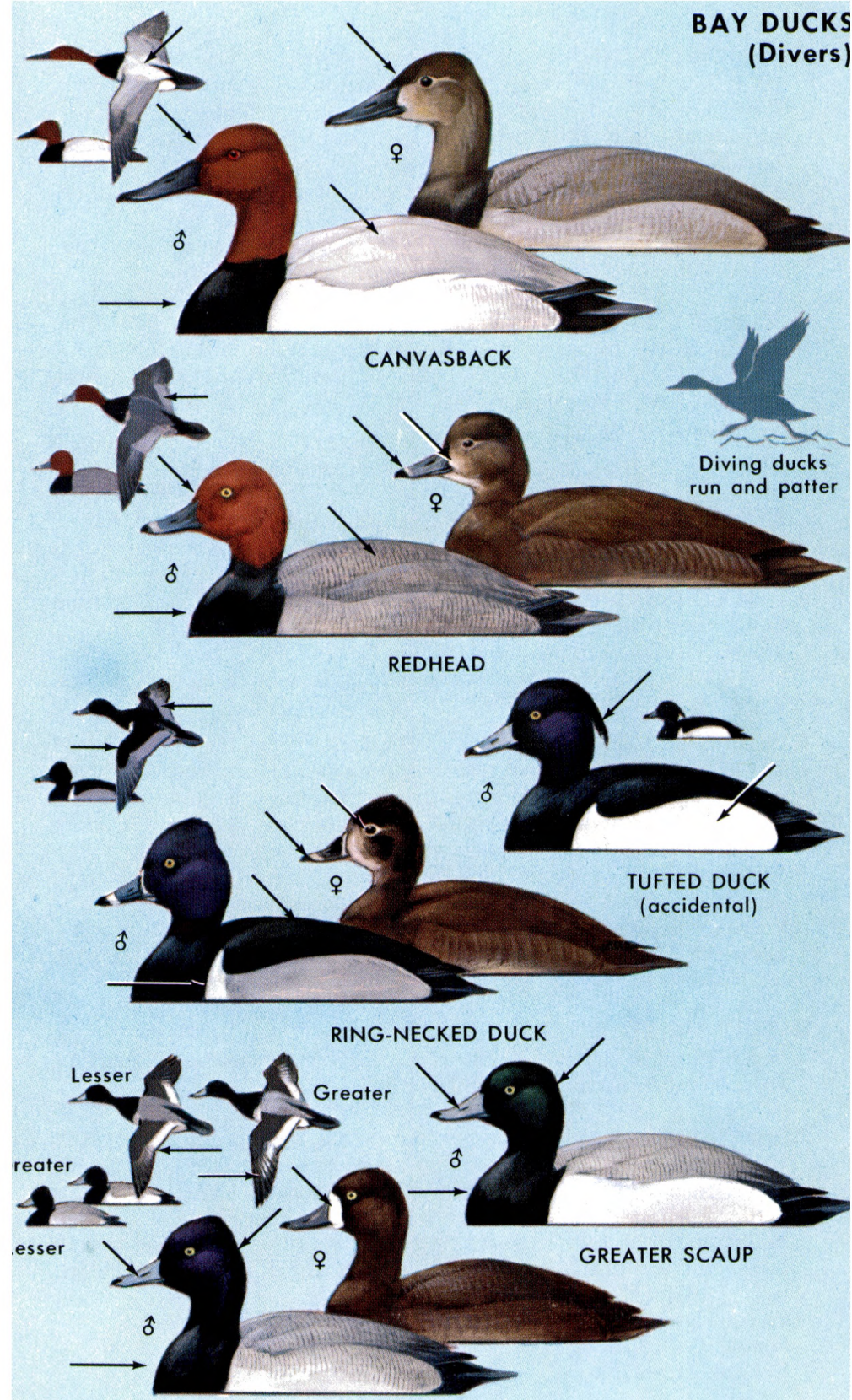
$20^{\prime \prime}(50 \mathrm{~cm})$. Male: Note the large round white spot before the eye. White-looking, with a black back and puffy, green-glossed head that appears black at a distance. In flight, short-necked; wings whistle or "sing," show large white patches. Female: Gray, with a white collar and dark brown head; wings with large square white patches that may show on the closed wing.

Similar species: See (1) Barrow's Goldeneye; (2) male scaups have black chests; (3) male Common Merganser is long, low.

Voice: Wings "whistle" in flight. Courting male has a harsh nasal double note, suggesting pee-ik of Nighthawk. Female, a quack.

Range: Northern parts of N. Hemisphere. Winters to Gulf Coast, cen. Eurasia. West: Map 59. Habitat: Forested lakes, rivers; in winter, also salt bays, seacoasts.

BARROW'S GOLDENEYE Bucephala islandica

M60

$21^{\prime \prime}(53 \mathrm{~cm})$. Male: Note the white face crescent. Similar to Common Goldeneye, but blacker above; head glossed with purple (not green); nape more puffy. Female: Similar to female Goldeneye; darker, bill shorter and more triangular, forehead more abrupt; less white in wing. In spring the bill may become all yellow, often a good field mark but subject to seasonal change. (Female Common Goldeneye may rarely have an all-yellow bill.)

Range: Alaska, Canada, nw. U.S., sw. Greenland, Iceland. West: Map 60. Habitat: Wooded lakes, beaver ponds. In winter, coastal waters; a few on inland rivers.

BUFFLEHEAD Bucephala albeola See also pp. 72, 73. M61

13-15" (33-38 cm). Small. Male: Mostly white, with a black back; puffy head with a large, bonnetlike white patch. In flight, shows a large white wing patch. Female: Dark and compact, with a white cheek spot, small bill, smaller wing patch.

Similar species: (1) Male Hooded Merganser has a spikelike bill, dark sides. (2) See winter Ruddy Duck (below).

Voice: Male, a hoarse rolling note; female, a harsh quack.

Range: Alaska, Canada. Winters to Mexico, Gulf Coast. West: Map 61. Habitat: Lakes, ponds, rivers; in winter, salt bays.

- STIFF-TAILED DUCKS. Tribe Oxyurini. Small, chunky divers; nearly helpless on land. Spiky tail has 18 or 20 feathers. Sexes not alike. Food: Aquatic life, water plants.

RUDDY DUCK Oxyura jamaicensis See also pp. 72, 73.

M65

15-16" (38-40 cm). Small, chubby; note the white cheek and dark cap. Often cocks tail vertically. Flight "buzzy." Cannot walk on land. Male, summer: Rusty red with white cheek, black cap, large blue bill. Male, winter: Gray with white cheek, dull blue or gray bill. Female: Similar to winter male but cheek crossed by a dark line.

Voice: Courting male, a sputtering chick-ik-ik-ik-k-k-k-kurrrr. Range: Canada south, locally to Grenada and Chile. West: Map 65. Habitat: Fresh marshes, ponds, lakes; in winter, salt bays. 

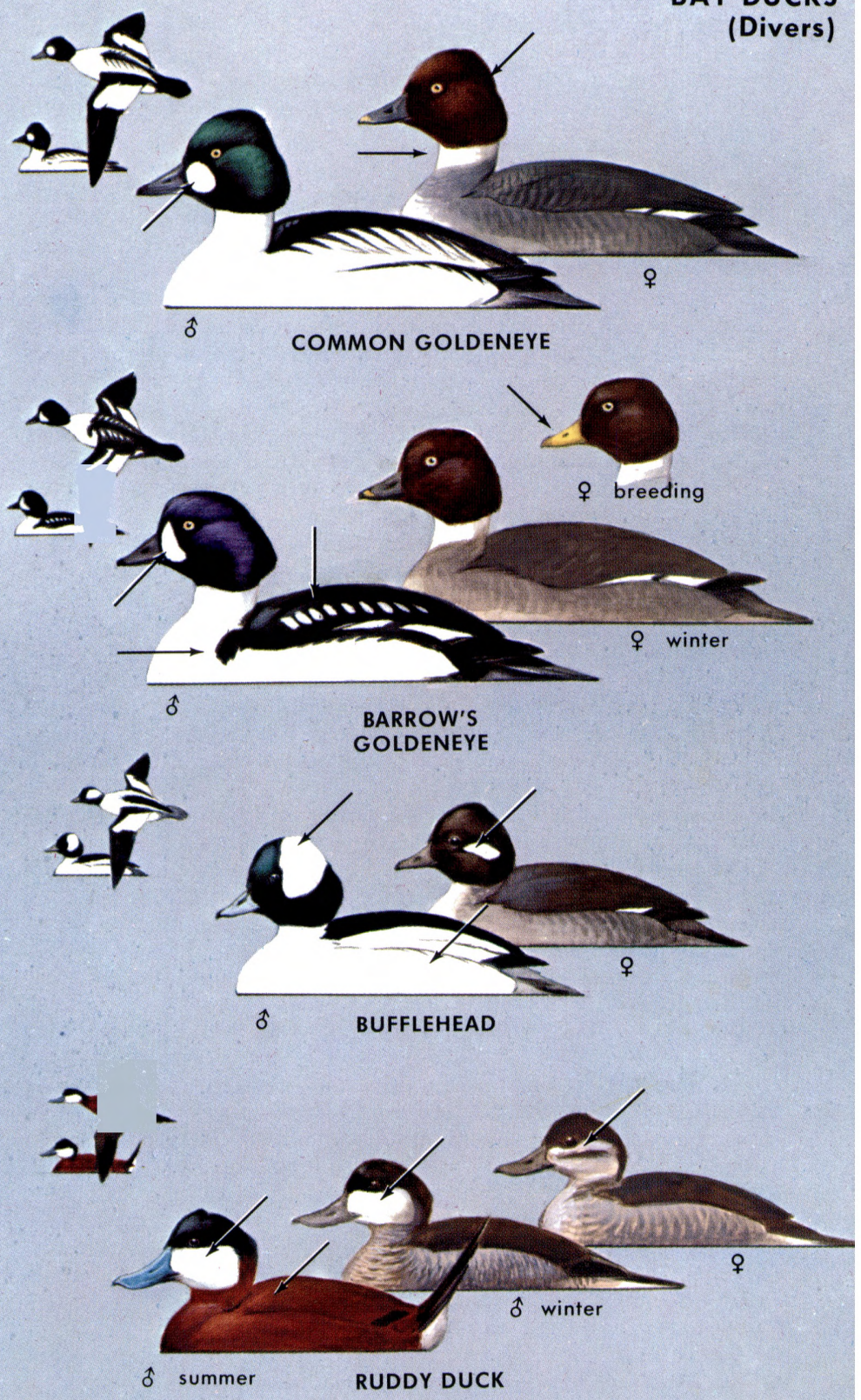
- MERGANSERS. Tribe Mergini (in part). Diving fish ducks with spikelike bills, saw-edged mandibles. Most species have crests and are long-lined, slender-bodied. In flight, the bill, head, neck, and body are held on a horizontal axis. Sexes not alike. Food: Chiefly small fish.

COMMON MERGANSER Mergus merganser See also p. 68.

M63

$22-27^{\prime \prime}(55-68 \mathrm{~cm})$. Male: Note the long whitish body, black back, green-black head. Feet and spikelike bill red; breast tinged delicate peach. Female: Gray, with a crested rufous head, clean white chest, and a large square white wing patch. Bill and feet red. (See female Red-breasted Merganser.) In flight, lines of these slender ducks follow the winding courses of streams. The whiteness of the males and the merganser shape (bill, neck, head, and body held horizontally) identify this species.

Similar species: (1) Female mergansers (rusty-headed) suggest male Canvasbacks or Redheads, which have black chests and no crests. (2) Male Goldeneye has a white face spot, is stockier, shorternecked, and puffy-headed.

Voice: Male, low staccato croaks; female, a guttural karrr.

Range: Northern parts of N. Hemisphere. Winters to Mexico, Turkey, s. China. West: Map 63. Habitat: Wooded lakes, ponds, rivers; in winter, open lakes and rivers, rarely coastal bays.

RED-BREASTED MERGANSER Mergus serrator See also p. 68.

M64

20-26" $(50-65 \mathrm{~cm})$. Male: Rakish; black head glossed with green and conspicuously crested; breast at waterline dark rusty, separated from the head by a wide white collar; bill and feet red. Female: Gray, with a crested rusty head, large white wing patch, red bill and feet.

Similar species: Male Common Merganser is whiter, without collar and breastband effect; lacks crest. In female Common, white chin and chest are sharply defined. In Red-breast, rufous of head is paler, blending into whitish chin and neck; bill is less thick at base.

Voice: Usually silent. Male, a hoarse croak; female, karrr.

Range: Northern parts of N. Hemisphere. Winters to Gulfs of Mexico and California; Mexico, n. Africa, s. China. West: Map 64. Habitat: Lakes, open water; in winter, coastal bays, sea.

HOODED MERGANSER Lophodytes cucullatus See also p. 68. M62 16-19" (40-48 cm). Male: Note the vertical fan-shaped white crest, which may be raised or lowered. Breast white, with two black bars on each side. Wing with a white patch; flanks brown. Female: Recognized as a merganser by its silhouette and spikelike bill; known as this species by its small size, dusky look, and dark head, bill, and chest. Note the loose tawny crest.

Similar species: (1) Male Bufflehead is chubbier, with white sides. (2) Other female mergansers are larger and grayer, with rufous heads, red bills. (3) In flight, the wing patch and silhouette separate female Hooded Merganser from female Wood Duck.

Voice: Low grunting or croaking notes.

Range: Se. Alaska, s. Canada, ne. U.S. Winters to n. Mexico, Gulf of Mexico. West: Map 62. Habitat: Wooded lakes, ponds, rivers. 


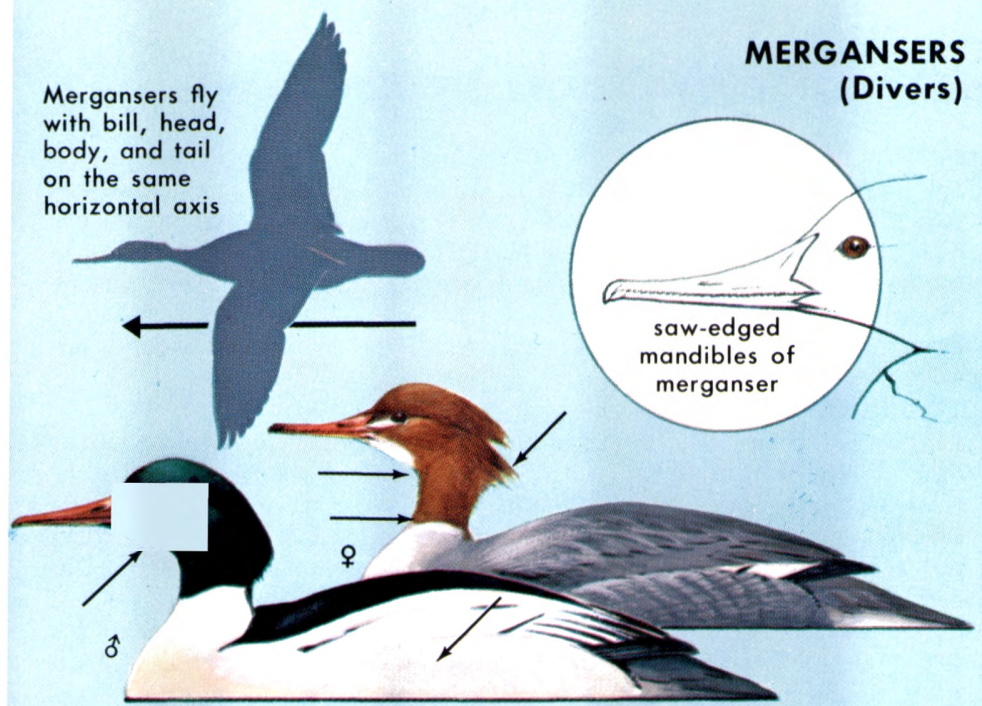

COMMON MERGANSER
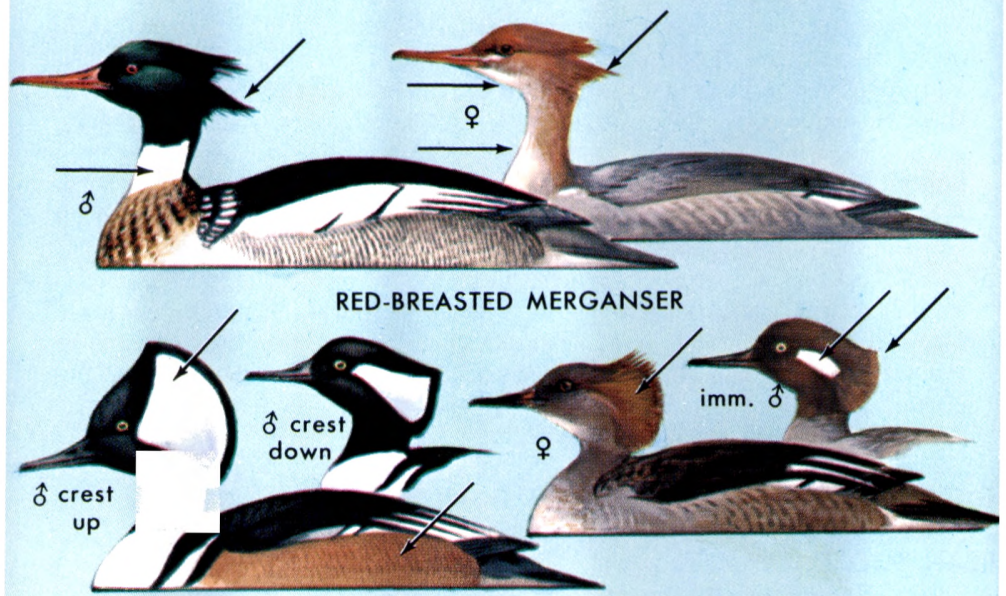

HOODED MERGANSER

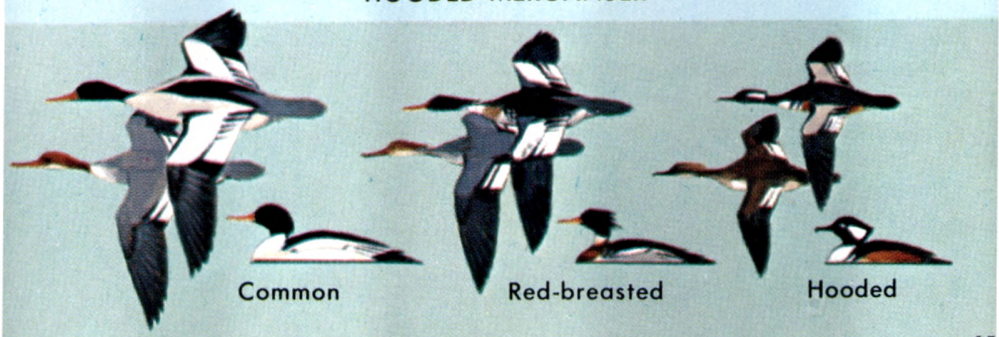




\section{- MISCELLANEOUS WATERFOWL (STRAYS FROM ASIA).}

COMMON POCHARD Aythya ferina

$18 "(45 \mathrm{~cm})$. This Eurasian species looks somewhat intermediate between the Redhead and the Canvasback. Head not as rounded as Redhead's; back paler. The clinching mark in both sexes is the broad blue band across the bill, set off by a black band at the base of the bill (absent in Redhead).

Range: Eurasia. Rare migrant in outer Aleutians, Pribilofs. Casual or accidental elsewhere in coastal Alaska.

TUFTED DUCK Aythya fuligula

15-18" (38-45 cm). The Eurasian counterpart of our Ring-necked Duck. Male differs from male Ring-neck in having a thin wispy crest, entirely white (not gray) sides, and a white (not gray) wing stripe. The female resembles female Rink-neck but is darker, lacking eye-ring and ring on bill. It has a faint trace of a crest and may or may not have white at the base of the bill.

Range: Eurasia. West: Regular but uncommon migrant and winter visitor to the outer Aleutians; rare winter visitor elsewhere in Alaska; casual vagrant southward along coast from British Columbia to California. Accidental, Wyoming.

SMEW Mergellus albellus

16" (40 cm). This Eurasian species is smaller and shorter-billed than the other mergansers. The male looks very white, with a black eye patch and a slight drooping black and white crest behind the eye. In flight, it shows conspicuous black and white wings. The female is small and gray, with white cheeks and a chestnut cap.

Range: Eurasia. Rare migrant and winter visitor in w. Aleutians (west of Adak). Casual vagrant elsewhere in s. Alaska. Accidental, British Columbia, Manitoba, Washington, California.

SPOT-BILLED DUCK Anas poecilorhyncha

22" (55 cm). This Asian dabbler has the look of a Black Duck or female Mallard, but note the black bill tipped with yellow. The name refers to red spots at the base of the bill, absent in the subspecies that has occurred in Alaska.

Range: Asia. Accidental in Alaska (Adak, Kodiak I.).

GARGANEY, BAIKAL TEAL, FALCATED DUCK. See p. 48.

\section{BEAN GOOSE Anser fabalis}

28-35" (70-88 cm). A large gray-brown goose with a dark head and neck; bill black with a yellow midsection, but variable.

Range: Eurasia. Rare spring transient in western Aleutians. Casual elsewhere in Bering Sea area. Accidental, Nebraska.

\section{GRAYLAG GOOSE Anser anser (not shown)}

Eurasia. Reported from Attu. See European Field Guide.

EURASIAN COOT Fulica atra Family Rallidae

16" (40 cm). Very similar to the American Coot, but its bill and frontal shield (forehead) are entirely white. The undertail coverts are all dark, showing no white.

Range: Eurasia. Has occurred accidentally in the Pribilofs. 

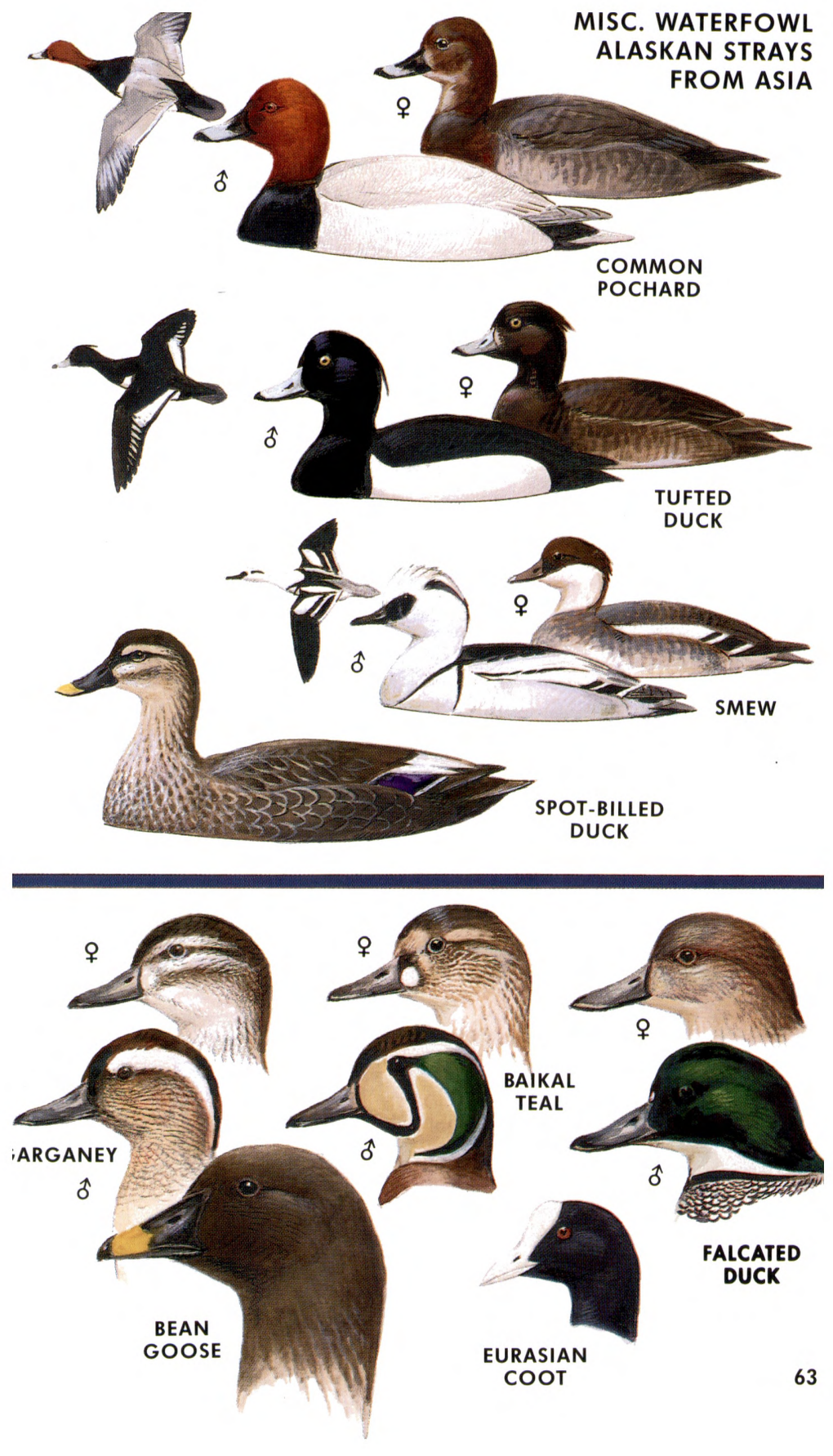


\section{DUCKLIKE SWIMMERS (COOTS, GALLINULES). Family}

Rallidae (in part). Coots and gallinules belong to the same family as the rails (see further family discussion on p. 118). Whereas the rails are more henlike and are basically secretive wading birds of the marshes, coots and gallinules (moorhens) are superficially more ducklike except for their smaller heads, forehead shields, and rather henlike bills. They spend most of their time swimming, although they may also feed on shores, lawns, and golf courses.

AMERICAN COOT Fulica americana

M111

$13-16^{\prime \prime}(33-40 \mathrm{~cm})$. A slaty, ducklike bird, with a blackish head and neck, white bill, and divided white patch under the tail. Its big feet are lobed ("scallops" on toes). Gregarious. When swimming, it pumps its head back and forth; it dabbles but also dives from the surface. Taking off, it skitters; flight labored; the big feet trail beyond the short tail; a narrow white border shows on rear of wing. Aberrant birds may show some white on the forehead above the bill. Immature: Paler, with a duller bill. Downy young has hairy, orange-red head and shoulders.

Similar species: Common Moorhen is smaller and has a red bill (with a yellow tip). Coots are more ducklike than moorhens, more widespread, and flock more on open water.

Voice: A grating kuk-kuk-kuk-kuk; kakakakakaka, etc.; also a measured ka-ha, ha-ha; various cackles, croaks.

Range: Canada to Argentina. West: Map 111. Habitat: Ponds, lakes, marshes; in winter, also fields, park ponds, salt bays.

COMMON MOORHEN Gallinula chloropus

M110

(Common Gallinule) 13" $(33 \mathrm{~cm})$. Note the rather henlike red bill, red forehead shield, and white band on the flanks. When walking, it flirts its white undertail coverts; while swimming, it pumps its head like a coot. The latter is stockier and shorter-necked; it has a gray back and white bill.

Voice: A croaking $k r-r$-ruk, repeated; a froglike kup; also kek, kek, kek and loud, complaining, henlike notes.

Range: S. Canada to Argentina; also Eurasia, Africa. West: Map 110. Habitat: Fresh marshes, reedy ponds.

\section{PURPLE GALLINULE Porphyrula martinica}

$13^{\prime \prime}(33 \mathrm{~cm})$. Very colorful; swims, wades, and climbs bushes. Size of Moorhen, but head and underparts deep violet-purple, back bronzy green. Shield on forehead pale blue; bill red with a yellow tip. Legs yellow, conspicuous in flight. Immature: Drab; dark above, pale below; no side stripe; bill dark.

Similar species: (1) Common Moorhen has a red frontal shield, greenish legs, and white side stripe; young Moorhen also has a similar whitish side stripe. (2) Young Coot has a pale bill; black divides the white patch under the tail.

Voice: A henlike cackling, kek, kek, kek; also guttural notes.

Range: Se. U.S. to $n$. Argentina. Winters mainly south of U.S. West: Casual in sw. states. Habitat: Fresh swamps, marshes, ponds. 

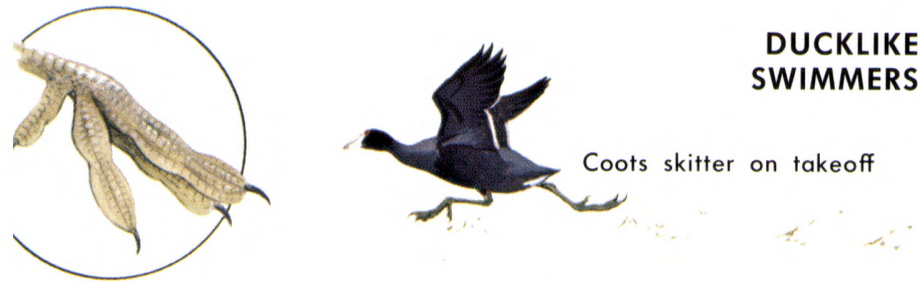

obed foot of Coot

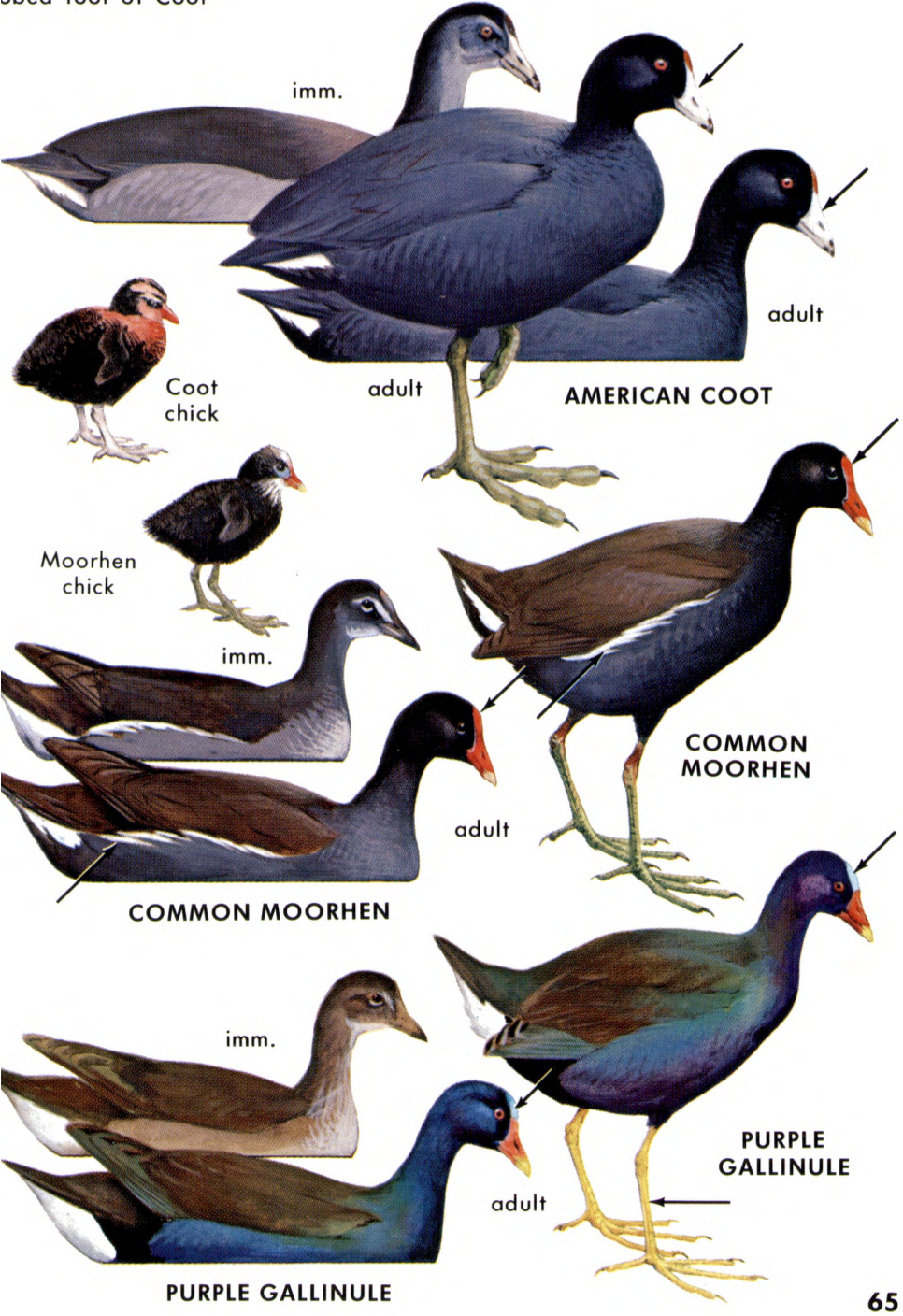




\section{FLIGHT PATTERNS OF DABBLING DUCKS}

Only males are diagnosed below. Although females are unlike the males, their wing patterns are quite similar. The names in parentheses are common nicknames used by gunners.

Text and color plate

NORTHERN PINTAIL (Sprig) Anas acuta pp. 46,47

Overhead: Needle tail, white breast, thin neck.

Topside: Needle tail, neck stripe, single white border on speculum (rear edge of wing).

WOOD DUCK Aix sponsa

Overhead: White belly, dusky wings, long square tail.

pp. 46,47

Topside: Stocky; long dark tail, white border on dark wing.

AMERICAN WIGEON (Baldpate) Anas americana

Overhead: White belly, dark pointed tail.

Topside: Large white shoulder patch.

NORTHERN SHOVELER (Spoonbill) Anas clypeata

Overhead: Dark belly, white chest, spoon bill.

Topside: Large pale bluish shoulder patch, spoon bill.

GADWALL Anas strepera

Overhead: White belly, square white patch (speculum)

pp. 44,45

on rear edge of wing.

Topside: White patch (speculum) on rear edge of wing.

GREEN-WINGED TEAL Anas crecca

Overhead: Small (teal-sized); light belly, dark head.

pp. 48,49

Topside: Small, dark-winged; green speculum.

BLUE-WINGED TEAL Anas discors

pp. 48,49

Overhead: Small (teal-sized); dark belly.

Topside: Small; large pale bluish shoulder patch.

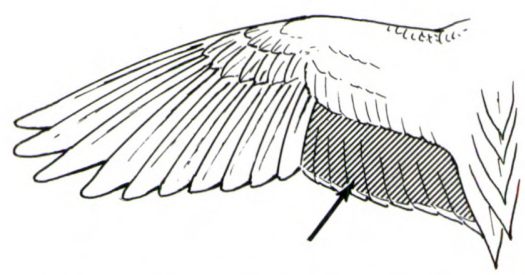

Wing of a dabbling duck, showing the iridescent speculum. 

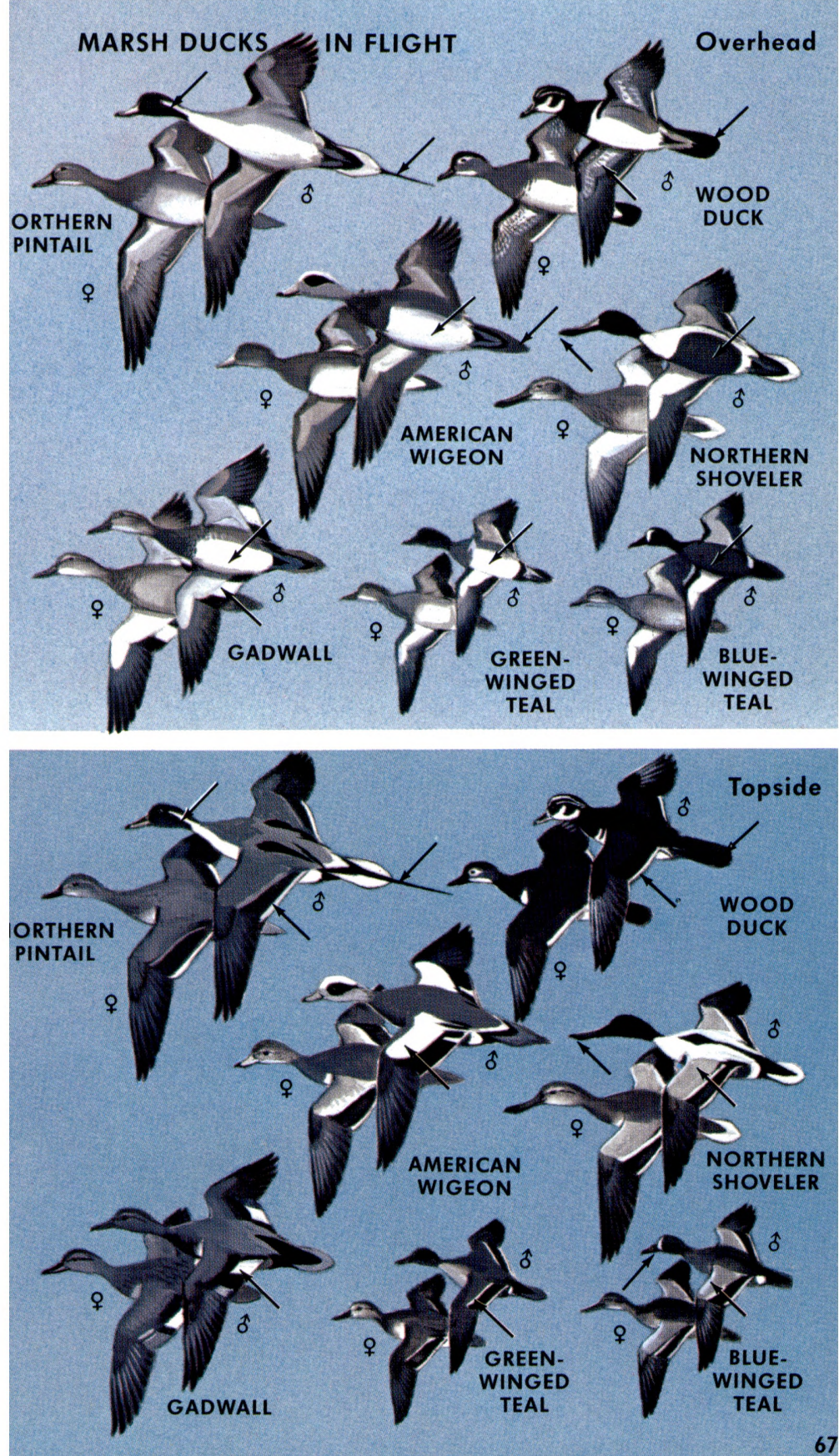


\section{FLIGHT PATTERNS OF MARSH DUCKS AND MERGANSERS}

Only males are diagnosed below. Although most females are unlike the males, their wing patterns are quite similar. Mergansers have a distinctive flight silhouette, with the bill, head, neck, body, and tail all on a horizontal axis. Duck hunters often call mergansers "sheldrakes" or "sawbills."

MALLARD Anas platyrhynchos

Overhead: Dark chest, light belly, white neck-ring.

Text and color plate

Topside: Dark head, neck-ring, two white borders on speculum.

AMERICAN BLACK DUCK Anas rubripes

Overhead: Dusky body, white wing linings.

pp. 44,45

Topside: Dusky body, paler head.

FULVOUS WHISTLING-DUCK Dendrocygna bicolor

Overhead: Tawny, with blackish wing linings.

Topside: Dark, unpatterned wings; white ring on rump.

COMMON MERGANSER Mergus merganser

Overhead: Merganser shape; black head, white body, pp. 44,45 white wing linings.

Topside: Merganser shape; white chest, large wing patches.

RED-BREASTED MERGANSER Mergus serrator

Overhead: Merganser shape; dark chest band, wide white collar.

Topside: Merganser shape; dark chest, large wing patches.

HOODED MERGANSER Lophodytes cucullatus

Overhead: Merganser shape; dusky wing linings.

pp. 60,61

pp. 44,45

Topside: Merganser shape; small wing patches. 

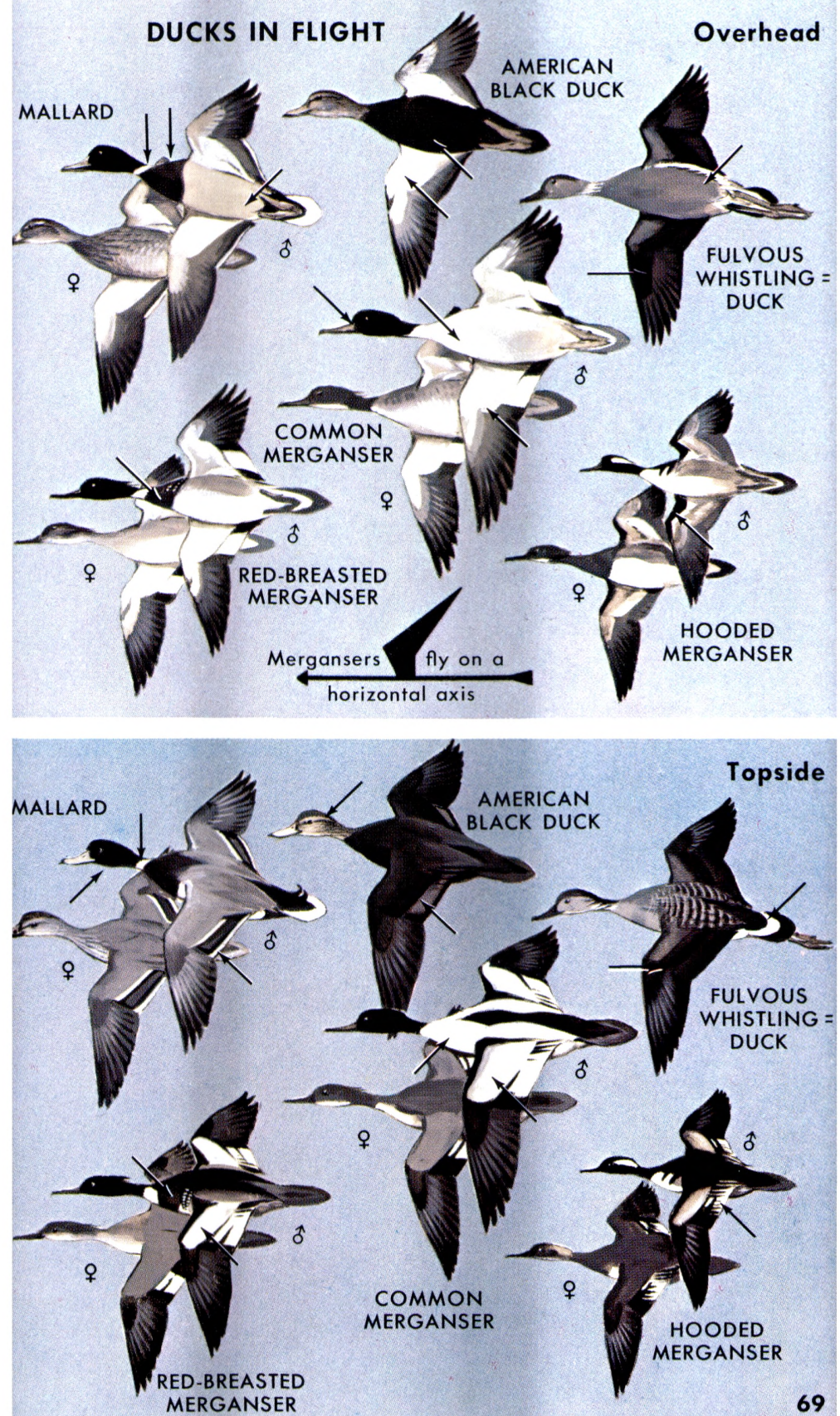


\section{FLIGHT PATTERNS OF SEA DUCKS}

Note: Only males are diagnosed below.

OLDSQUAW Clangula hyemalis

Text and

color plate

Overhead: Dark unpatterned wings, white belly.

pp. 54,55

Topside: Dark unpatterned wings, much white on body.

HARLEQUIN DUCK Histrionicus histrionicus

Overhead: Solid dark below, white head spots, small

pp. 54,55

bill.

Topside: Stocky, dark with white marks, small bill.

SURF SCOTER Melanitta perspicillata

Overhead: Black body, white head patches

(not readily visible from below).

Topside: Black body, white head patches.

BLACK SCOTER Melanitta nigra

pp. 50, 51

Overhead: Black plumage, paler flight feathers.

Topside: All-black plumage.

WHITE-WINGED SCOTER Melanitta fusca

pp. 50,51

Overhead: Black body, white wing patches.

Topside: Black body, white wing patches.

COMMON EIDER Somateria mollissima

Topside: White back, white forewing, black belly.

pp. 52,53

KING EIDER Somateria spectabilis

pp. 52,53

Topside: Whitish foreparts, black rear parts. 

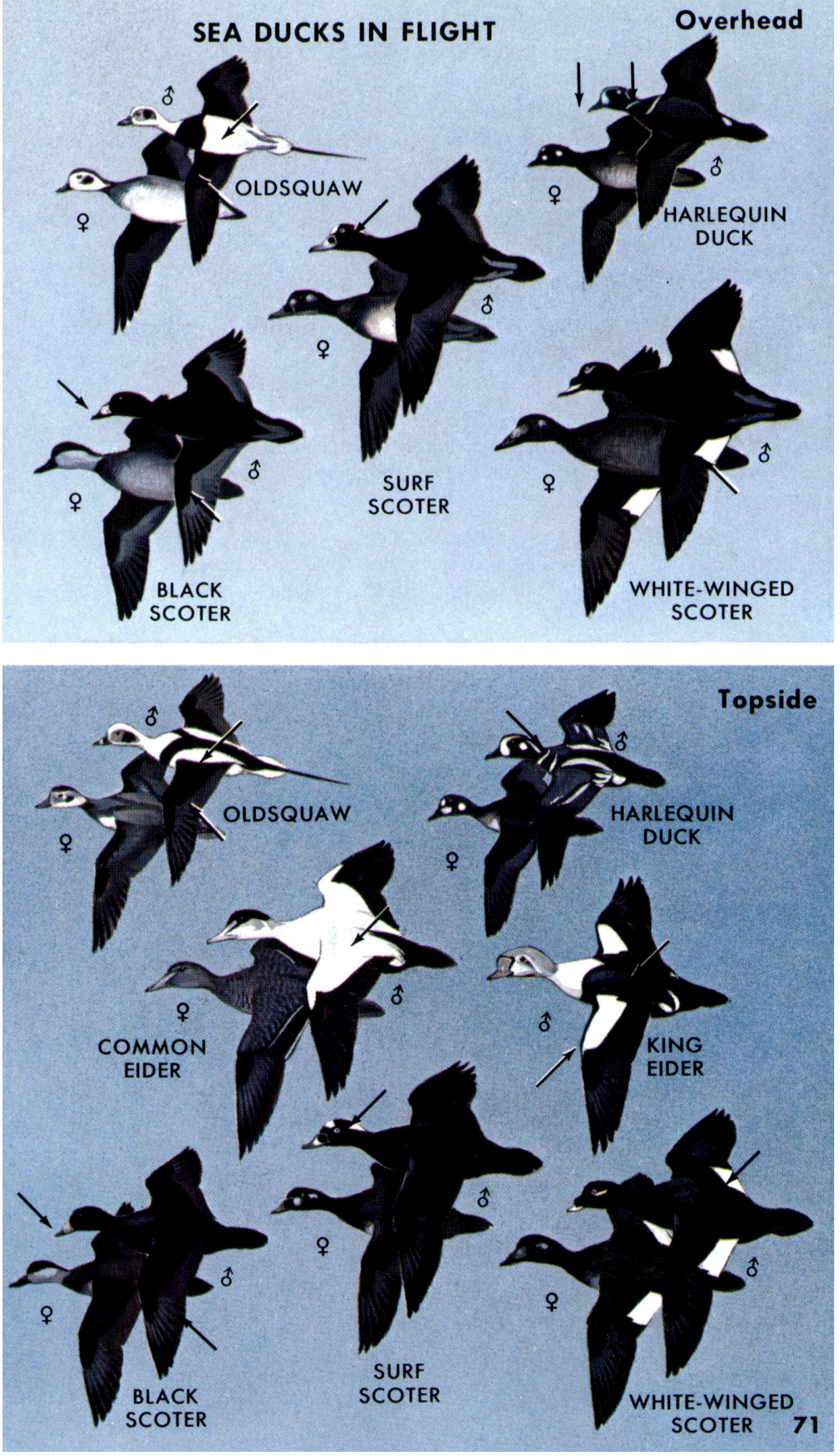


\section{FLIGHT PATTERNS OF BAY DUCKS, etc.}

Only males are diagnosed below. The first five all have black chests. The names in parentheses are common gunners' nicknames.

Text and color plate

CANVASBACK Aythya valisineria

Overhead: Black chest, long profile.

pp. 56,57

Topside: White back, long profile. Lacks contrasty wing stripe of next four species.

REDHEAD Aythya americana

pp. 56,57

Overhead: Black chest, roundish rufous head.

Topside: Gray back, broad gray wing stripe.

RING-NECKED DUCK Aythya collaris

pp. 56,57

Overhead: Not safe to tell from Scaup overhead.

Topside: Black back, broad gray wing stripe.

GREATER SCAUP (Bluebill) Aythya marila

pp. 56,57

Overhead: Black chest, white stripe showing through wing.

Topside: Broad white wing stripe (extending onto primaries).

LESSER SCAUP (Bluebill) Aythya affinis

Topside: Wing stripe shorter than that of Greater Scaup.

pp. 56,57

COMMON GOLDENEYE (Whistler) Bucephala clangula

Overhead: Blackish wing linings, white wing patches.

pp. 58,59

Topside: Large white wing square, short neck, black head.

RUDDY DUCK Oxyura jamaicensis

pp. 58,59

Overhead: Stubby; white face, dark chest.

Topside: Small; dark with white cheeks.

BUFFLEHEAD (Butterball) Bucephala albeola

Overhead: Like a small Goldeneye; note head patch.

pp. 58,59

Topside: Small; large wing patches, white head patch. 

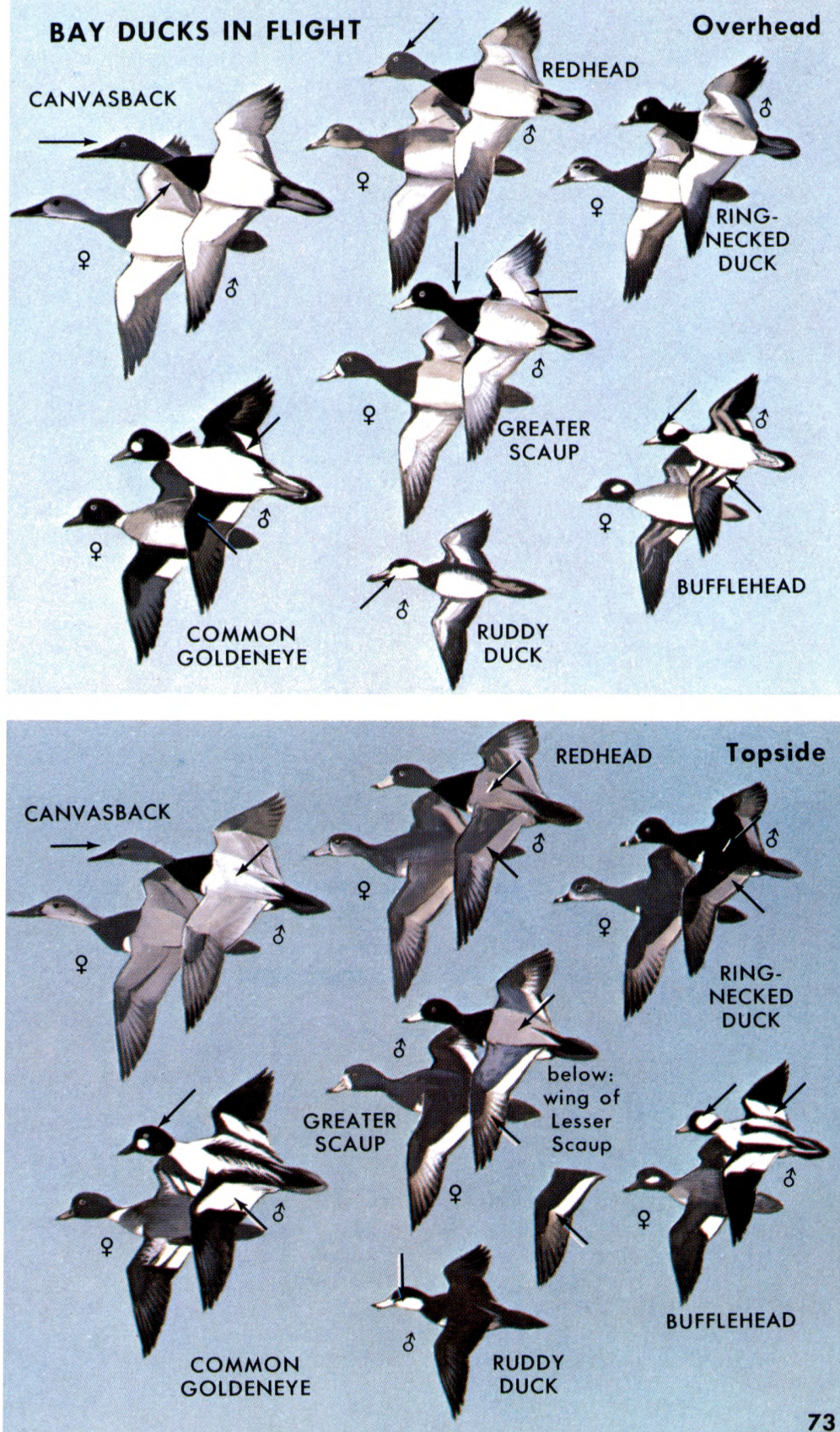
aLBATROSSES. Family Diomedeidae. Birds of the open ocean, with rigid gliding and banking flight. Much larger than gulls; wings proportionately longer. "Tube-nosed" (nostrils in two tubes); bill large, hooked, covered with horny plates. Sexes alike. Food: Cuttlefish, fish, other small marine life; some feeding at night.

Range: Mainly cold oceans of S. Hemisphere; three species nest north of equator in Pacific. No. of species: World 13; West 3 (+ 2 accidentals).

\section{BLACK-FOOTED ALBATROSS Phoebastria nigripes}

28-36" (70-80 cm); spread $7 \mathrm{ft}$. The great size, sooty color, tremendously long, saberlike wings, and rigid, shearwater-like gliding identify this species, the albatross found most regularly off our Pacific Coast. Seldom seen from shore. At close range this albatross shows a whitish face and pale areas toward the tips of wings. Bill and feet dark. Some birds, presumably adults, show white patches at the base of the tail

Similar species: Immature Short-tailed Albatross is dark, but has a pinkish bill and pinkish feet.

Range: Breeds on islands in cen. and w. Pacific /chiefly nw. Hawaiian chain). West: Ranges well offshore from Bering Sea and Aleutians to Baja California. Habitat: Open ocean.

\section{LAYSAN ALBATROSS Phoebastria immutabilis}

32" $(80 \mathrm{~cm})$; spread 61/2 ft. White-bodied, with a dark back and wings, suggesting a huge, dark-backed gull with extra-long wings. Bill and feet dull flesh color or pale flesh-gray. Immature similar.

Range: Breeds on nw. islands of Hawaiian chain. Ranges from Hawaii to N. Pacific. West: Ranges regularly to Aleutians and Gulf of Alaska. Rare but regular far off coasts of British Columbia, Washington, Oregon, California.

\section{SHORT-TAILED ALBATROSS Phoebastria albatrus}

30-37" (73-83 cm); spread 71/2 ft. Note the white back, pink bill, and yellowish nape on this oceanic rarity. A white albatross with black wings and black on tip of tail. The immature is very dark brown and resembles a Black-footed Albatross, but its bill and feet are pink or flesh-colored (not black); no strong white face patch.

Range: Breeds on Bonin Is. off Japan. Near extinction in 1956 (only 14 pairs on Toroshima), now over 250 birds. Formerly ranged from Bering Sea to Baja California; may again do so.

Note: The following two albatrosses, not shown, have been recorded accidentally off our West Coast. To learn more about them or other Pacific albatrosses, consult Seabirds, An Identification Guide by Peter Harrison (Houghton Mifflin).

\section{SHY ("WHITE-CAPPED") ALBATROSS Thalassarche cauta (not shown)}

Similar to Laysan Albatross (white body, dark back), but head pale gray, with a whiter crown. Underwing whiter, feet gray.

Range: Seas off Australia. Accidental, Washington.

WANDERING ALBATROSS Diomedea exulans (not shown)

Similar to Short-tailed Albatross, but larger, head entirely white.

Range: S. Hemisphere. Accidental in California. 


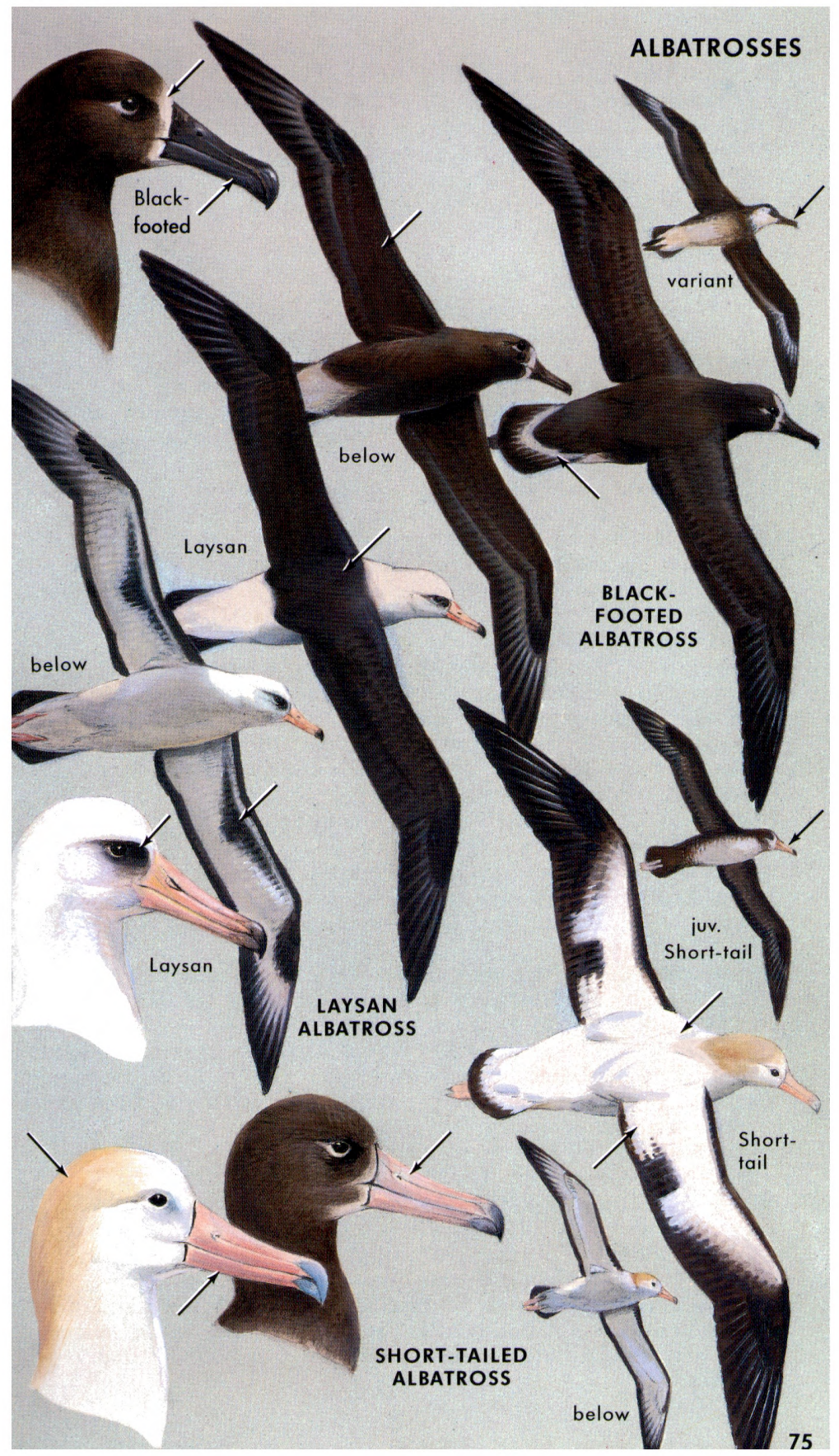


- SHEARWATERS, PETRELS, AND FULMARS, etc. Family Procellariidae. Gull-like birds of the open sea that glide low over the waves (usually with wings more stiffly extended than shown here). Wings narrower than those of gulls, tail smaller. Bills with tubelike external nostrils on top of bill. Food: Fish, squid, crustaceans, ship refuse. Range: Oceans of world. No. of species: World 61 ; West $8(+6$ casual or accidental).

\section{SOOTY SHEARWATER Puffinus griseus}

$17^{\prime \prime}(43 \mathrm{~cm})$. A somewhat gull-like seabird, often seen in massive flocks offshore. Looks all dark at a distance and scales over the waves on narrow rigid wings. In good light, note the whitish linings on the undersurface of the wings. Mainly a summer visitor.

Range: Breeds off s. Australia, New Zealand, s. S. America; ranges to N. Atlantic, N. Pacific. West: Offshore, Bering Sea to Baja California.

FLESH-FOOTED SHEARWATER Puffinus carneipes

$191 / 2^{\prime \prime}(43 \mathrm{~cm})$. A dark-bodied shearwater, larger than the Sooty; flight more sluggish. Distinguished by pale flesh or whitish bill (with dark tip), flesh-colored feet, dark wing linings.

Range: Breeds on islands off Australia, New Zealand. West: A rather rare visitor offshore, from Alaska to California.

SHORT-TAILED SHEARWATER Puffinus tenuirostris

13-14" (33-35 cm). Distinguished from the Sooty by smaller size, more rapid wingbeat, shorter bill and tail, and smoky gray wing linings. May have a whitish throat. Sooty has whiter wing linings. Range: Breeds on islands off s. Australia. West: Ranges north to Aleutians and Bering Sea and thence south off coast to Baja California. Best looked for in late fall or early winter.

PINK-FOOTED SHEARWATER Puffinus creatopus

$191 / 2^{\prime \prime}(49 \mathrm{~cm})$. Two common white-bellied shearwaters often associate with the abundant Sootys: Pink-foot is larger, with a blacktipped pink bill, slower wingbeats; Black-vented is smaller, blacker above, whiter on underwing, with a black bill. It has faster wingbeats.

Range: Breeds on islands off Chile. West: Spring, summer, and fall off California, Oregon; a few to British Columbia, se. Alaska.

BULLER'S SHEARWATER Puffinus bulleri

(New Zealand Shearwater) 161/2" $(91 \mathrm{~cm}$ ). A rather rare white-bellied shearwater; separated from the two other white-bellied species by a broad $M$ or $W$ formed by the contrasting pattern on back and wings. Tail wedge-shaped. Feet pale, but variable.

Range: Breeds n. New Zealand. West: Fall visitor off California (mainly off Monterey in Oct.); casual, Oregon, Washington.

BLACK-VENTED SHEARWATER Puffinus opisthomelas

$13^{\prime \prime}(33 \mathrm{~cm})$. A small shearwater, black above and white below; dark cap extends below the eye. The contrasting black and white pattern and gliding, bounding flight are distinctive.

Range: Breeds on sea islands off Pacific Coast of Baja California. West: Ranges north, mainly in fall and winter, along inshore waters of s. and cen. California, rarely or casually to Washington and Vancouver I. 
$18^{\prime \prime}(45 \mathrm{~cm})$. A stiff-winged oceanic glider, stockier than a shearwater; swims buoyantly. Note the bull neck, rounded forehead, stubby yellow bill, large dark eye, short tail. The primaries may show a pale flash or patch. Legs variable. Dark phase: Smoky gray, wing tips darker; bill yellowish. Intermediates are frequent.

Voice: A hoarse, grunting ag-ag-ag-arrr or ek-ek-ek-ek-ek.

Range: Northern oceans of N. Hemisphere. West: Map 10. Habitat: Open ocean; breeds colonially on open sea cliffs.

\section{mOSTLY RARE, CASUAL, OR ACCIDENTAL PETRELS.}

Some of these species, though rarely recorded in the past, may prove to be of regular occurrence far offshore due to the growing popularity of pelagic birding.

STREAKED SHEARWATER Calonectris leucomelas

$19^{\prime \prime}(48 \mathrm{~cm})$. The pale, lightly streaked head may look all white at a distance, suggesting that of a Fulmar. Forehead white, nape dark. Range: Western Pacific Ocean; casual or accidental off our coast in fall, mainly off Monterey Bay.

MURPHY'S PETREL Pterodroma ultima

$16^{\prime \prime}(40 \mathrm{~cm})$. A dark petrel with wholly dark underwing linings, a somewhat wedge-shaped tail, and pale legs.

Range: South Pacific. West: Rare offshore vagrant; recorded in California, Oregon.

SOLANDER'S PETREL Pterodoma solandri

$16^{\prime \prime}(40 \mathrm{~cm})$. A dark petrel. Head darker than body; white skua-like flash under primaries.

Range: Southwest Pacific (breeds Lord Howe I., e. Australia). West: Reported far offshore from California, Washington.

COOK'S PETREL Pterodroma cookii

$10^{1 / 2^{\prime \prime}}(26 \mathrm{~cm})$. The black $M$ across the upper wings suggests the much larger Buller's Shearwater, but note the paler head with a black ear patch and the light sides of the tail.

Range: Nests on islands off New Zealand and ranges across the Pacific, rarely as far as the Aleutians and California waters.

STEJNEGER'S PETREL Pterodroma longirostris

$10^{\prime \prime}(25 \mathrm{~cm})$. Very similar to Cook's Petrel, but darker; the cap is black, not gray. This petrel, which breeds off Chile and New Zealand, has been sighted off California.

MOTTLED PETREL Pterodroma inexpectata

(Scaled Petrel) 14" (35 cm). Dark $M$ across upper wings suggests Buller's Shearwater or Cook's Petrel, but note contrasting dark belly and heavy diagonal black bar across underwing. This New Zealand species ranges regularly to the Gulf of Alaska and Bering Sea; rarely south to California.

Note: WEDGE-TAILED SHEARWATER, Puffinus pacificus (not shown), of Hawaii, etc., has been sighted as an accidental in California. Size of Sooty; white-bellied (rarely dark-bellied), with a longish wedgeshaped tail and flesh-colored feet. 


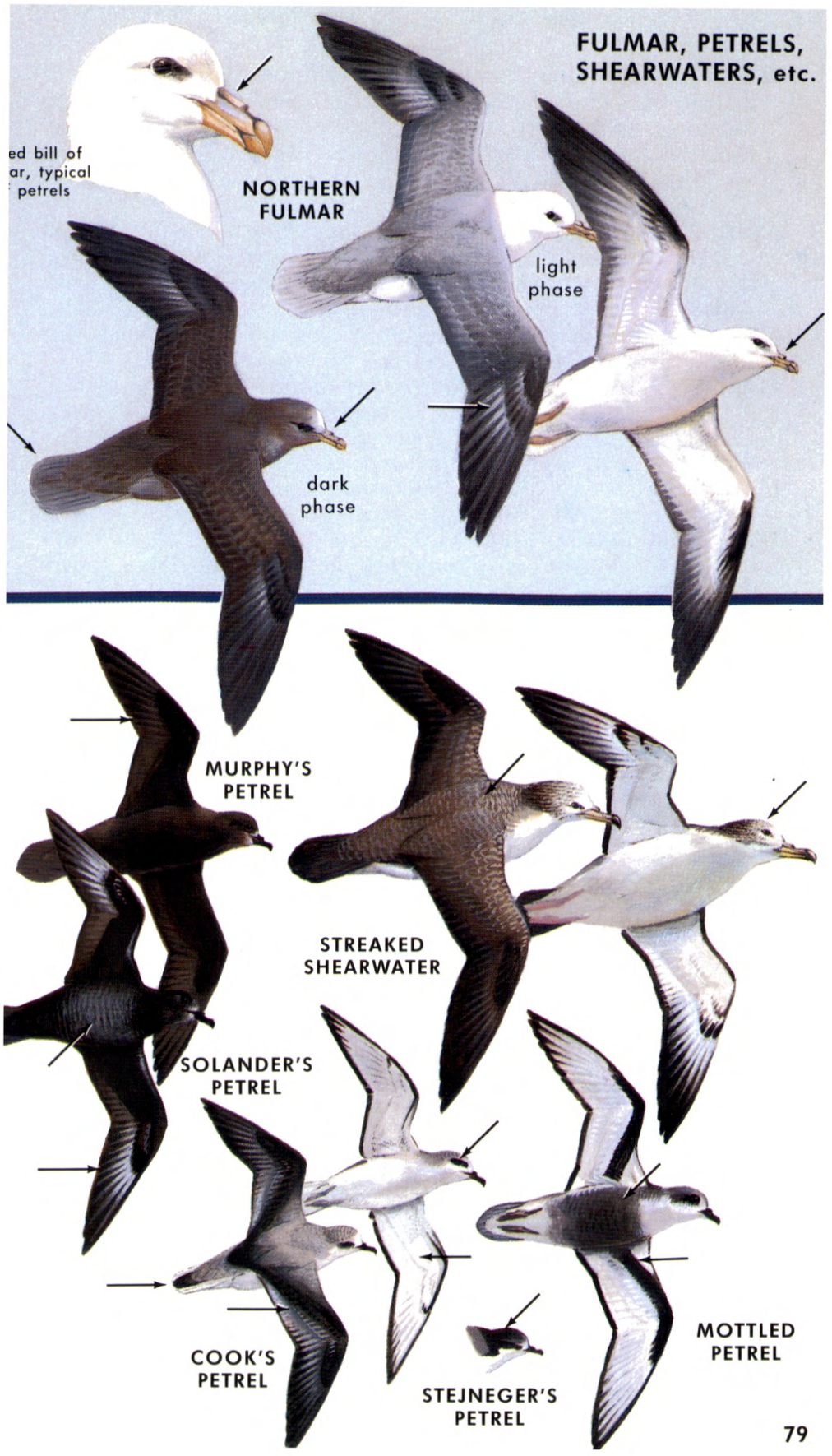


- STORM-PETRELS. Family Hydrobatidae. Little dark birds that flit over the ocean; they nest colonially on islands, returning to burrows at night. Nostrils in a fused tube over top of bill. Food: Plankton, crustaceans, small fish. Range: All oceans except Arctic. No. of species: World 20; West $6(+2$ casual).

ASHY STORM-PETREL Oceanodroma homochroa M13

$71 / 2^{\prime \prime}(19 \mathrm{~cm})$. Separated from Black Storm-Petrel by smaller size, shorter wings, more fluttery flight. At very close range, head looks ashy, wings show light mottling underneath.

Range: At sea from n. California (Pt. Reyes) to Baja California. Map 13. Breeds on Farallon, Channel, and Coronados Is.

BLACK STORM-PETREL Oceanodroma melania

$9^{\prime \prime}(23 \mathrm{~cm})$. The most common all-black petrel found off California. Larger than Ashy, with longer wings and more languid flight.

Voice: At night, in colony, puck-apoo-puck-puck-a-poo.

Range: Breeds on Coronados and other islands off Baja California. Ranges north along California coast to Pt. Reyes.

FORK-TAILED STORM-PETREL Oceanodroma furcata

$8-9^{\prime \prime}(20-23 \mathrm{~cm})$. Gray; paler below, unlike all our other stormpetrels, which are blackish.

Range: N. Pacific. West: Map 11.

LEAST STORM-PETREL Oceanodroma microsoma

$5 \frac{1}{2}-6^{\prime \prime}(14-15 \mathrm{~cm})$; very small. Only storm-petrel with a rounded or wedge-shaped tail. Flight erratic, batlike, close to water.

Range: Breeds on islands off Baja California. A few range north in late summer and early fall to San Diego and south to Ecuador.

WILSON'S STORM-PETREL Oceanites oceanicus

$7^{\prime \prime}(18 \mathrm{~cm})$. A small storm-petrel with a white rump patch; tail even at end. Feet yellow-webbed (hard to see), may show beyond tail. Skims like a swallow, pausing to flutter over water. Follows ships. Range: Breeds in the Antarctic. Ranges chiefly north to N. Atlantic. West: Rare but regular north to Monterey Bay, California.

LEACH'S STORM-PETREL Oceanodroma leucorhoa

M12

$8^{\prime \prime}(20 \mathrm{~cm})$. Note the obscurely divided white rump patch and forked tail. In flight it bounds about erratically, changing speed and direction (suggesting a Nighthawk). Does not follow ships. Baja California race is all dark, lacking white rump. There are intermediates.

Voice: At night, in flight on breeding grounds, rhythmic falsetto hooting notes. From burrows, long, crooning trills.

Range: N. Atlantic, N. Pacific. West: Map 12. Habitat: Open ocean; nests colonially in turf on offshore islands.

WEDGE-RUMPED STORM-PETREL Oceanodroma tethys

$6 \frac{1}{2} 2^{\prime \prime}(16 \mathrm{~cm})$. Very small, with a long, wedge-shaped, white rump that restricts the amount of black at end of tail.

Range: Breeds Galápagos Islands, Peru. West: Rare or casual visitor to California (Aug. to Jan.).

BAND-RUMPED STORM-PETREL Oceanodroma castro

9" $(23 \mathrm{~cm})$. A white-rumped storm-petrel, larger than Wilson's. Its feet do not project beyond the squarish tail. A stiff-winged flier.

Range: Tropical oceans. West: Accidental, s. California. 


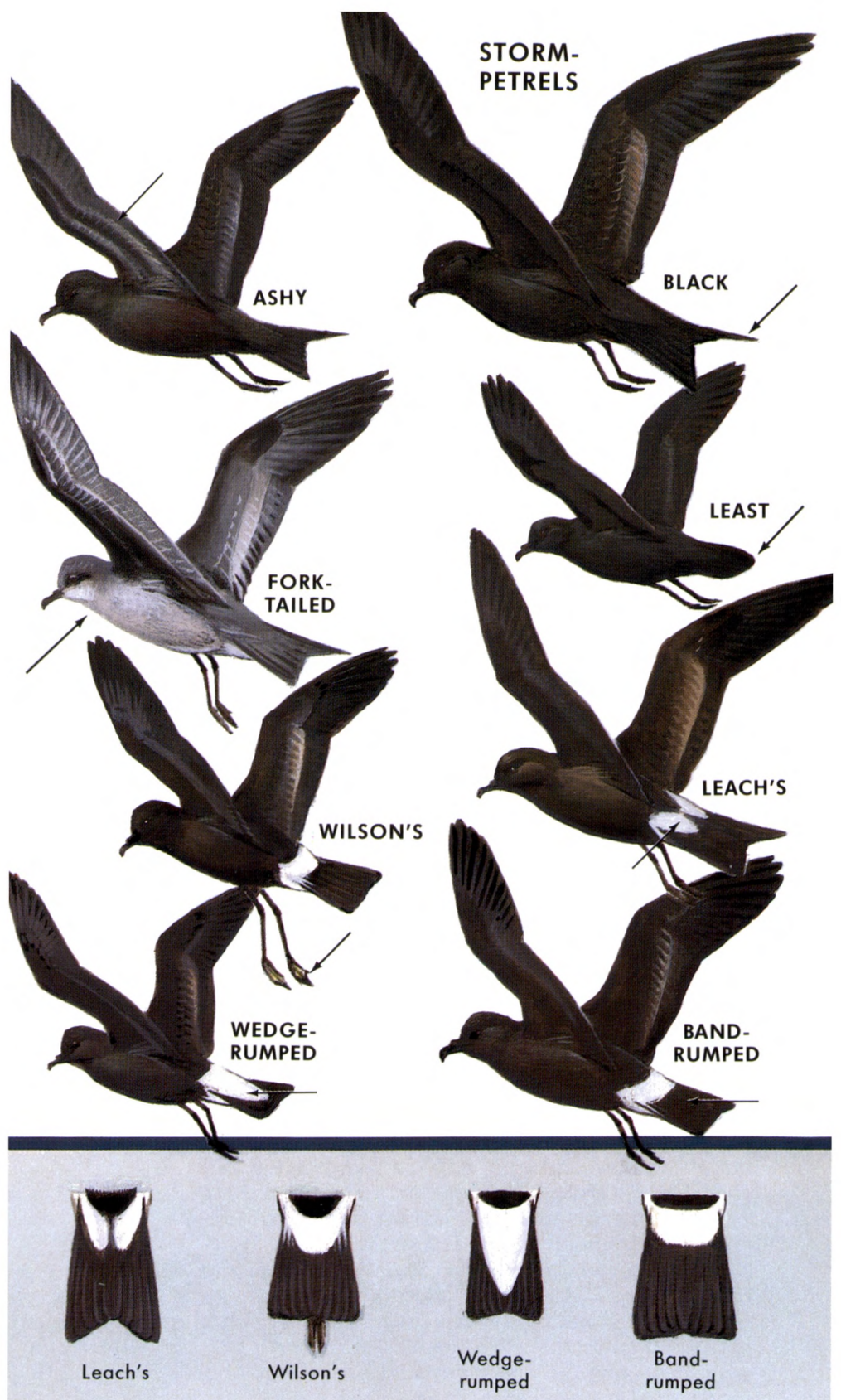


- BOOBIES. Family Sulidae. Seabirds with large, tapering bills and pointed tails. Larger than most gulls; neck longer. Sexes alike. Boobies sit on buoys; they fish by plunging from the air like Brown Pelicans. Food: Fish, squid. Range: Tropical seas. No. of species: World 6; West $2(+2$ casual or accidental).

BROWN BOOBY Sula leucogaster

$28-30^{\prime \prime}(70-75 \mathrm{~cm})$. A sooty brown booby, with a white belly in clean-cut contrast to its dark breast. Bill and feet yellowish. Males of the west Mexican race are pale around the head. Immature: Similar; but white of underparts smudged with dusky.

Range: Tropical oceans. West: A post-breeding wanderer from Gulf of California, mostly to Salton Sea, Imperial Valley, and lower Colorado R.; mainly immatures.

BLUE-FOOTED BOOBY Sula nebouxii

$32-34^{\prime \prime}(80-85 \mathrm{~cm})$. This booby, the one most frequent in our area, has a white body, whitish head, dark mottled back and wings, and big blue feet. Young birds have a brownish head; note the white patches on nape and rump.

Range: Breeds w. Mexico to Peru. West: Post-breeding wanderer to Salton Sea in California; also Lower Colorado R. in se. California and sw. Arizona. Accidental, Washington.

RED-FOOTED BOOBY Sula sula

$26-30^{\prime \prime}(65-75 \mathrm{~cm})$. Adults have bright red feet and may be white with black in wings, white tail, or light brown with a white tail. Immature: Tan with pink base of bill, dull pink feet.

Range: Tropical oceans. West: Accidental off California.

MASKED BOOBY Sula dactylatra (not shown)

$27^{\prime \prime}(68 \mathrm{~cm})$. A white booby with black in the wings and tail; accidental off s. California. See illustration in eastern Field Guide.

- TROPICBIRDS. Family Phaethontidae. These seabirds resemble large terns with two greatly elongated central tail feathers and stouter, slightly decurved bills. Tern-like, they dive headfirst, and swim with the tail held clear of the water. Sexes alike. Food: Squid, crustaceans. Range: Tropical oceans. No. of species: World 3; West 1 ( +2 accidental).

\section{RED-BILLED TROPICBIRD Phaethon aethereus}

24-40" $(60-100 \mathrm{~cm})$. A slender white seabird with two extremely long central tail feathers (1-2 ft.), a heavy red bill, a black patch through the cheek, black primaries, and a finely barred back. Young lack the long tail, have an orange-yellow bill.

Range: Tropical oceans worldwide. West: Rare but regular stray off s. California. Accidental, Arizona, Washington.

RED-TAILED TROPICBIRD Phaethon rubricauda

$24^{\prime \prime}(60 \mathrm{~cm})$, including $16^{\prime \prime}$ tail streamers. Whiter above than the other two tropicbirds; has red streamers.

Range: Tropical Pacific. West: Accidental well off California.

WHITE-TAILED TROPICBIRD Phaethon lepturus

32 " $(80 \mathrm{~cm})$, including $16^{\prime \prime}$ streamers. This accidental tropicbird may be known from the others by the diagonal black bar across each wing. The single bird recorded in our area at Malibu Beach, California tried to mate with a toy glider! 


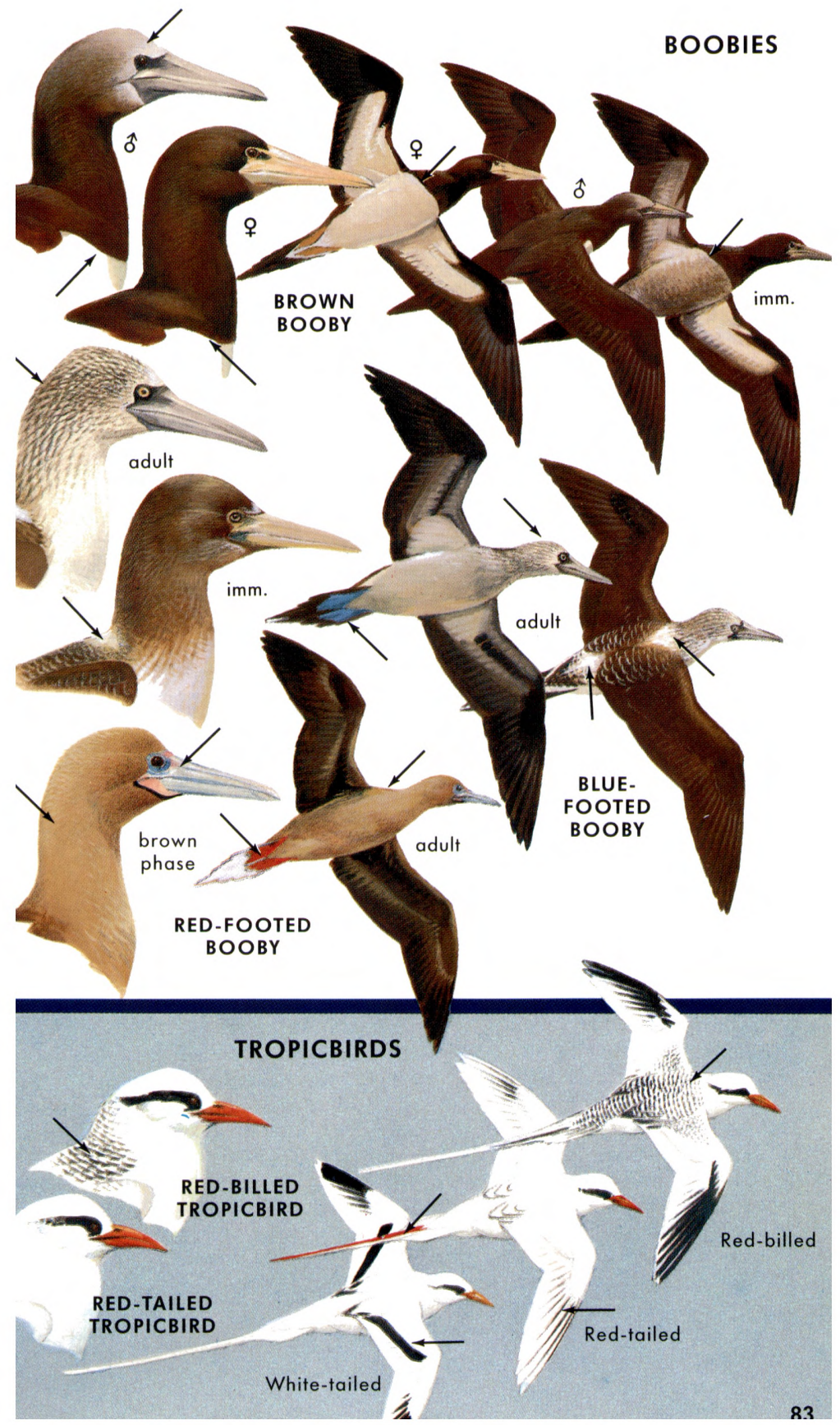


- PELICANS. Family Pelecanidae. Huge water birds with long flat bills and great throat pouches (flat when deflated). Neck long, body robust. Sexes alike. Flocks fly in lines, alternating several flaps with a glide. In flight, the head is hunched back on the shoulders, the long bill resting on the breast. Pelicans swim buoyantly. Food: Mainly fish, crustaceans. Range: N. and S. America, Africa, s. Eurasia, E. Indies, Australia. No. of species: World 8; West 2.

AMERICAN WHITE PELICAN Pelecanus erythrorhynchos

M14

$62 "$ (155 cm). Huge (wingspread 8-91/2 ft.). White, with black primaries and a great orange-yellow bill. Adults in breeding plumage have a "centerboard" on the ridge of the bill. Immatures have a dusky bill. This pelican does not plunge from the air like the Brown Pelican but scoops up fish while swimming, often working in groups. Flocks fly in lines, may circle high on thermals.

Similar species: (1) Swans have no black in wings. (2) Wood Ibis and (3) Whooping Crane fly with necks extended, long legs aft. (4) Snow Goose is much smaller, with a small bill; noisy.

Range: W. and cen. N. America; winters to se. U.S. and Cen. America. West: Map 14. Habitat: Lakes, marshes, salt bays, beaches.

BROWN PELICAN Pelecanus occidentalis

$50^{\prime \prime}(125 \mathrm{~cm})$; spread $6 \frac{1}{2} \mathrm{ft}$. A ponderous dark water bird; adult has much white about the head and neck. Immature has a dark head, whitish underparts. Size, shape, and flight (a few flaps and a glide) indicate a pelican; the dark color and habit of plunging bill-first proclaim it as this species. Lines of pelicans scale close to the water. Voice: Adults silent (rarely a low croak). Nestlings squeal.

Range: Coasts; s. U.S. to n. Brazil and Chile. West: Map 15. Habitat: Salt bays, beaches, ocean. Perches on posts, buoys.

- FRIGATEBIRDS. Family Fregatidae. Dark tropical seabirds with extremely long wings (greater span in relation to weight than that of any other birds). Bill long, hooked; tail deeply forked. Frigatebirds normally do not swim. Food: Fish, jellyfish, squid, young seabirds. Food snatched from water in flight, scavenged, or taken from other seabirds. Range: Pantropical oceans. No. of species: World 5; West 1.

\section{MAGNIFICENT FRIGATEBIRD Fregata magnificens}

38-41" (95-103 cm); spread 7-8 ft. A large black seabird with extremely long, angled wings and a scissorlike tail (often folded in a point). Soars with extreme ease. Bill long, hooked. Male: All black, with a red throat pouch (inflated like a balloon when in display). Female: White breast, dark head. Immature: Head and breast white. Similar species: GREAT FRIGATEBIRD, Fregata minor of Hawaii (not shown), is a remote possibility. Adult male retains light brown wing coverts; female has a whitish throat, red eye-ring.

Voice: Silent at sea. A gargling whinny during display.

Range: Gulf of Mexico to s. Brazil; Cape Verde Is; Baja California to Peru, tropical Atlantic, e. Pacific. West: Wanders irregularly along coast north to n. California. Casual, Oregon. Accidental, Arizona, New Mexico, Nevada. 


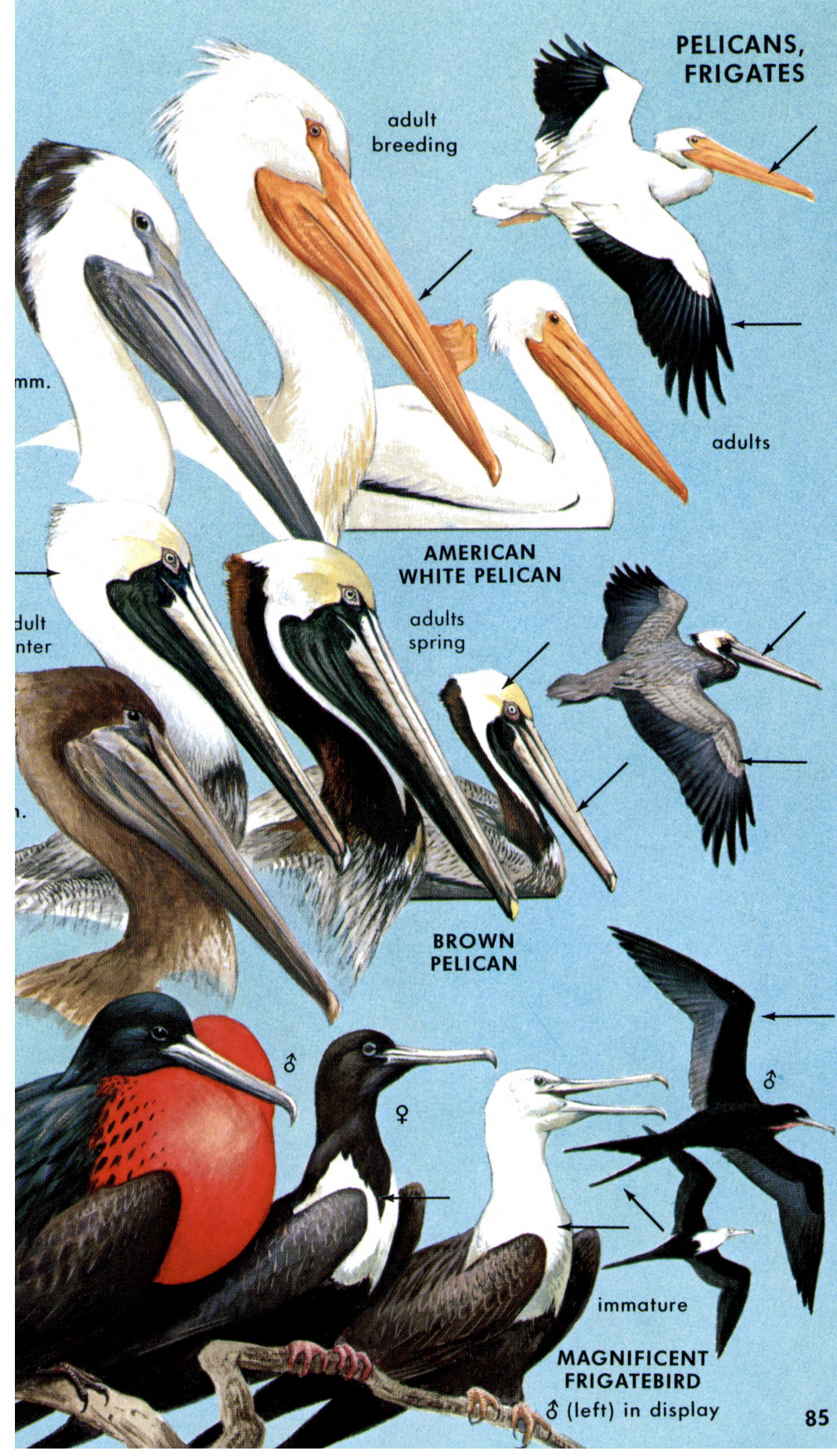


- SKUAS, JAEGERS. Subfamily Stercorariinae. Dark, hawk-like or falcon-like seabirds that harass gulls and terns, forcing them to disgorge. Light, intermediate, and dark phases; all have a flash of white in the primaries. Jaegers have two projecting central tail feathers, which are sometimes broken or missing. They are lacking in juveniles and immatures, which may be identified (tentatively) by relative size. Skuas lack tail points and are broader-winged. Sexes alike. Food: In the Arctic, lemmings, eggs, young birds. At sea, food taken from other birds or from water. Range: Seas of world, breeding in subpolar regions. No. of species: World 5 (or 7?); West 4.

\section{SOUTH POLAR SKUA Catharacta maccormicki}

$21^{\prime \prime}(53 \mathrm{~cm})$. Near size of Western Gull, but stockier, with a deepchested, hunch-shouldered look. Dark, with a short, slightly wedgeshaped tail and conspicuous white wing patch. "Blond" phase is much paler on head and underparts than dark phase. Flight strong and swift; harasses other seabirds. Dark jaegers may lack tail points, but skuas' wings are wider, with more striking white patches.

Range: Antarctic. Wanders into N. Atlantic as far as Greenland and in N. Pacific as far as Aleutians.

PARASITIC JAEGER Stercorarius parasiticus

M155

$18^{\prime \prime}(45 \mathrm{~cm})$. In the adult, the sharp tail points project $1 / 2-31 / 2$ in. Like other jaegers, it shows a white wing flash. It is the jaeger most frequently seen from shore. Varies from light to dark phases.

Range: Arctic, circumpolar. Winters at sea from s. U.S. to Tierra del Fuego. West: Map 155. Habitat: Ocean, coastal bays, lakes (rarely); tundra (summer).

POMARINE JAEGER Stercorarius pomarinus

M154

$22^{\prime \prime}(55 \mathrm{~cm})$. Broad and twisted central tail feathers project 2-7 in. Heavier than other jaegers; often heavily barred below, with a broad breastband and more white in primaries. Immature lacks the projections, is larger than other young jaegers, and has a heavier bill. Separating jaegers in obscure plumage can be difficult; then use size, proportions, and manner of flight.

Range: Arctic; circumpolar. Winters at sea from s. U.S. to S. Hemisphere. West: Map 154. Habitat: Open sea, coasts (offshore); tundra (summer).

LONG-TAILED JAEGER Stercorarius longicaudus

M156 $20-23^{\prime \prime}(50-58 \mathrm{~cm})$. The long tail streamers of adults may project 9-10 in. (usually 3-6 in.). More slender than other jaegers; whiter below, with no breastband. The black cap on its small head is separated by a broad white collar from the pale gray back. Bill short; legs blue-gray (black in Parasitic). Immature more slender than the others, with smaller head and bill, grayer upperparts, lighter flight. Range: Arctic, circumpolar. Winters in S. Hemisphere. West: Map 156. Habitat: Open sea; tundra (summer). Most pelagic of the jaegers. 


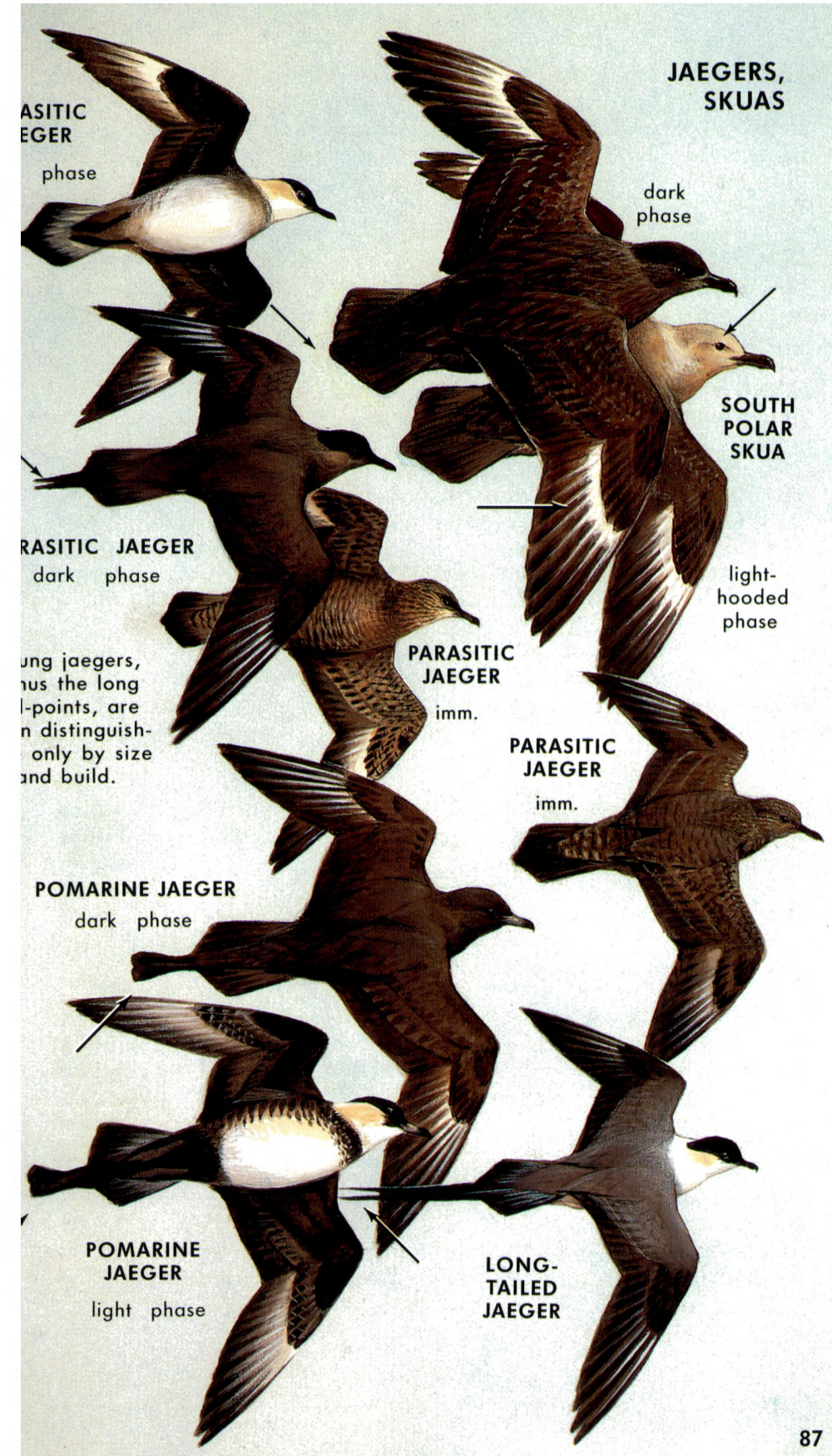


口 GULLS. Subfamily Larinae. Long-winged swimming birds with superb flight. More robust, wider-winged, and longer-legged than terns. Bills slightly hooked. Tails square or rounded (terns usually have forked tails). Gulls seldom dive (terms hover, then plunge head-first). Food: Omnivorous; marine life, plant and animal food, refuse, carrion. No of species: World 46; West 21 (+3 accidentals).

SEQUENCE OF PLUMAGES: On the page opposite, the well-known WESTERN GULL, a coastal species, has been chosen to illustrate the transition of plumages from juvenile to adult. The Western Gull is a four-year gull-it does not attain full breeding plumage until its fourth year. However, if you know what a gull looks like in its first-winter plumage (which in some species is not too much unlike that of the juvenile), you should be able to identify the bird as to species in any of its intermediate stages.

In this field guide, intended for identification on the species level, I have not given similar full-page treatment to any of the other gulls. That is the province of a handbook or technical manual. But should you wish this kind of in-depth analysis, I recommend Peter J. Grant's Gulls: A Guide to Identification, which often devotes from 10 to 20 pages per species. Study also Kenn Kaufman's Field Guide to Advanced Birding.

In summary:

Four-year gulls: This category includes most of the larger species, including the Western Gull, Glaucous-winged Gull, Glaucous Gull, Herring Gull, Thayer's Gull, California Gull, and Slaty-backed Gull.

Three-year gulls: Mostly medium-sized species, including the Ringbilled Gull, Mew Gull, Heermann's Gull, Laughing Gull, and Yellowlegged Gull.

Two-year gulls: Mostly smaller species, including Franklin's Gull, Bonaparte's Gull, Black-headed Gull, Little Gull, Ross's Gull, Black-legged Kittiwake, Red-legged Kittiwake, Sabine's Gull, and Ivory Gull.

Note: Three other gulls that have been reported as accidentals in the western states are not treated in the following pages. Two, the GREAT BLACK-BACKED GULL and the LESSER BLACK-BACKED GULL, are described and illustrated in the eastern book-A Field Guide to the Birds. The third is an Asian vagrant, the BLACK-TAILED GULL; it has been reported off Alaska and California (see p. 358).

Caution: Do not feel defeated if you cannot name every gull you see. There is considerable variation due to age, season, molt, wear, some hybridization, and even occasional albinism. Even the experts will put question marks after some of their observations if they are not sure. 


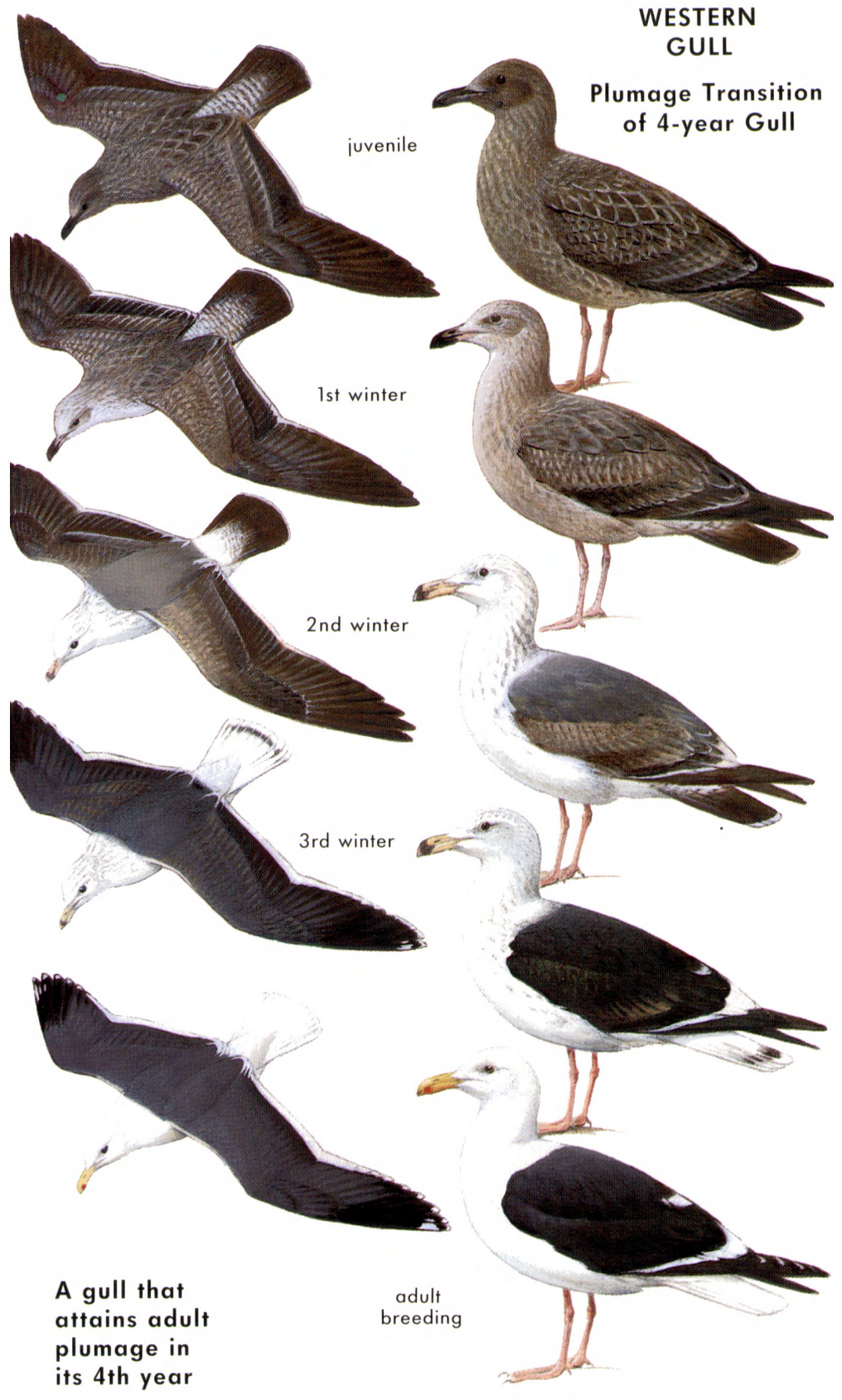


24-27" $(60-63 \mathrm{~cm})$. Note the very dark back and wings, contrasting with the snowy underparts. Feet dull pinkish. The northern race, occidentalis (cen. California to Washington) has a paler mantle, which, however, is still noticeably darker than that of the California Gull. The southern race, wymani, is blacker-backed. See the presentation of plumage sequences on pp. 88 and 89. Immature: See pp. $98,99$.

Note: There is some hybridization with the Glaucous-winged Gull where its breeding range overlaps with the Western's.

Voice: A guttural kuk kuk kuk: also whee whee whee and ki-aa. Range: Resident along coast from Baja California to nw. Washington. Map 165. Habitat: Coastal waters, estuaries, beaches, piers, city waterfronts, lower reaches of tidal rivers.

SLATY-BACKED GULL Larus schistisagus

$27^{\prime \prime}(68 \mathrm{~cm})$. Any large, dark-backed gull in the Bering Sea would most likely be this species. Adult is similar to Western Gull, but with more pinkish feet. Note how the broad white trailing edge of the wing invades the outer wing, forming a white bar crossing the black on the primaries. The primaries are gray beneath. Caution: Siberian race of Herring Gull occurs off w. Alaska.

Range: Kamchatka to Japan. West: Rare visitor to Alaska. Recorded at a number of points in the Pribilofs and Aleutians and along the coast of w. Alaska. Casual, British Columbia. Accidental, Missouri.

YELLOW-FOOTED GULL Larus livens

$27^{\prime \prime}(69 \mathrm{~cm})$. This large gull closely resembles the Western Gull, but the adult has yellow (not pinkish) feet. It matures in its third year, not the fourth, as the Western Gull does. The brown juvenile bird has a whitish belly and by the first winter already has some black on the back. The yellow feet are attained by the second winter.

Range: Breeding in w. Mexico, this gull occurs in our area as a postbreeding visitor only at Salton Sea. It would be casual or accidental anywhere else in California. Formerly regarded as a subspecies of Western Gull.

HEERMANN'S GULL Larus heermanni

M159

$18-21^{\prime \prime}(45-53 \mathrm{~cm})$. The easiest gull in the West to identify. Adult: Dark gray, with a black tail, whitish head, red bill. In winter the white head becomes gray. Immature: All dark, lacking the white head; bill brown or tipped with varying amounts of red. See p. 99. Voice: A whining whee-ee; also a repeated cow-auk.

Range: Breeds mainly on islands off coasts of nw. Mexico. West: Map 159. Habitat: Coast and nearby open ocean.

ROSS'S GULL Rhodostethia rosea

$12 \frac{1}{2}-14^{\prime \prime}(31-35 \mathrm{~cm})$. A rare gull of the drift ice. Note the wedgeshaped tail and blue-gray wing linings. Breeding: Rosy blush on underparts, fine black collar. Winter: Loses rosy blush and black collar. Immature: See pp. 102, 103.

Range: Breeds mainly in ne. Siberia; a few around Hudson Bay. West: Arctic coast of Alaska in migration, casual, Pribilofs. Accidental, British Columbia, Colorado. 


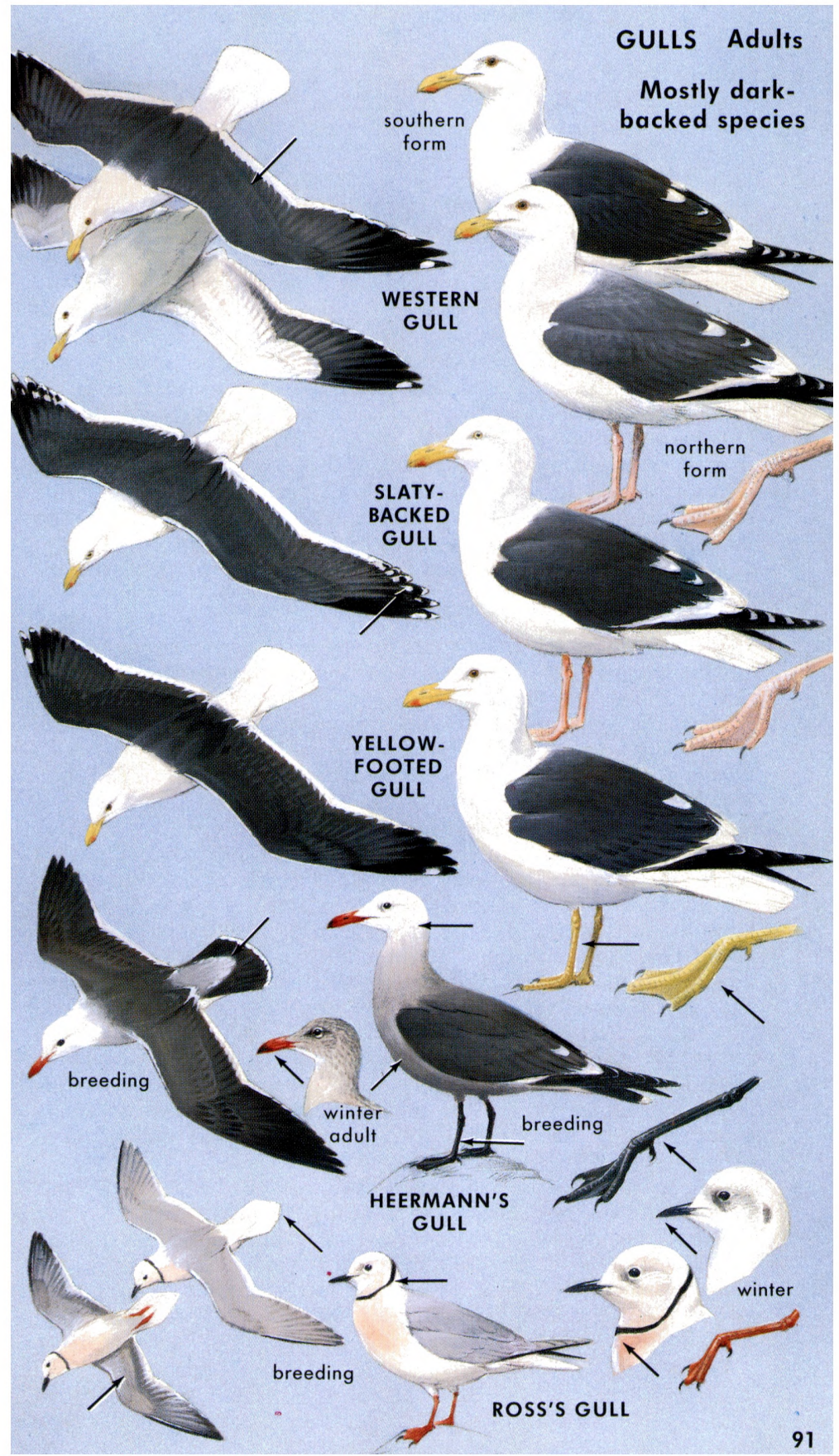


23-26" (58-65 cm). Adult: A common, widespread, large, graymantled gull with dull, flesh-pink legs. The outer primaries are black with white spots or "mirrors." Heavy yellow bill with a red spot on lower mandible. Immature: See pp. 100, 101.

Voice: A loud hiyak..hiyah....hyiah-hyak or yuk-yuk-yuk-yukyuckle-yuckle. Mewing squeals. Anxiety note: gah-gah-gah.

Range: Northern parts of N. Hemisphere. West: Map 163. Habitat: Coasts, bays, beaches, lakes, piers, farmlands, dumps.

THAYER'S GULL Larus thayeri

M164

$23-25^{\prime \prime}(58-63 \mathrm{~cm})$. Thayer's Gull, formerly thought to be a race of the Herring Gull and later designated as a full species, is regarded by some as a subspecies of the Iceland Gull. Very similar in appearance to Herring Gull. Typical adult has (1) pale to dark brown (not pale yellow) eyes, (2) little or no black on underside of primaries, (3) slightly darker mantle, (4) darker pink legs, (5) slighter bill. Overhead, the gray (not black) on the underside of the wing tips is distinctive. Some paler birds may have slate-gray rather than black in the outer primaries above (see immature, pp. 100, 101).

Range: Arctic Canada. Winters mainly on Pacific Coast. West: Map 164.

CALIFORNIA GULL Larus californicus

M162 20-23" $(50-58 \mathrm{~cm})$. Adult: This abundant gull resembles the smaller Ring-billed Gull (both may have yellowish green legs or not), but note the darker mantle, darker eye, and red and black spot on the lower mandible (not a black ring). Shows more white in wing tips than the Ring-bill does. Immature: pp. 100, 101.

Range: Mainly w. N. America, east to cen. N. Dakota. West: Map 162. Habitat: Seacoasts, lakes, farms, urban centers.

RING-BILLED GULL Larus delawarensis

M161

19" $(48 \mathrm{~cm})$. Adult: Similar to California Gull but smaller, with a lighter gray mantle; legs may be brighter yellowish green (but may also be quite gray in winter). Note the complete black ring encircling the bill. Immature: See pp. 92, 93.

Voice: Higher-pitched than Herring Gull's.

Range: Canada, n. U.S. Winters to Mexico, Virgin Islands. West: Map 161. Habitat: Lakes, bays, coasts, piers, dumps, plowed fields.

MEW GULL Larus canus

M160

16-18" (40-45 cm). Adult: Smaller than the Ring-billed Gull, with greenish legs, but with a small, short, unmarked greenish yellow bill. Back darker. Mew Gull shows larger white "mirrors" in its black wingtips than either California or Ring-billed gulls. Immature: See pp. 100, 101.

Similar species: Young Ring-billed Gull is larger and usually has the black of the tail confined to a narrow clean-cut band.

Voice: A low mewing (which gives the name), quee'u or mee'u. Also hiyah-hiyah-hiyah, etc., higher than voice of other gulls.

Range: N. Eurasia, w. N. America. Winters to coastal s. China, California, Mediterranean. West: Map 160. Habitat: Coastal waters, tidal rivers (winter); lakes (summer). 


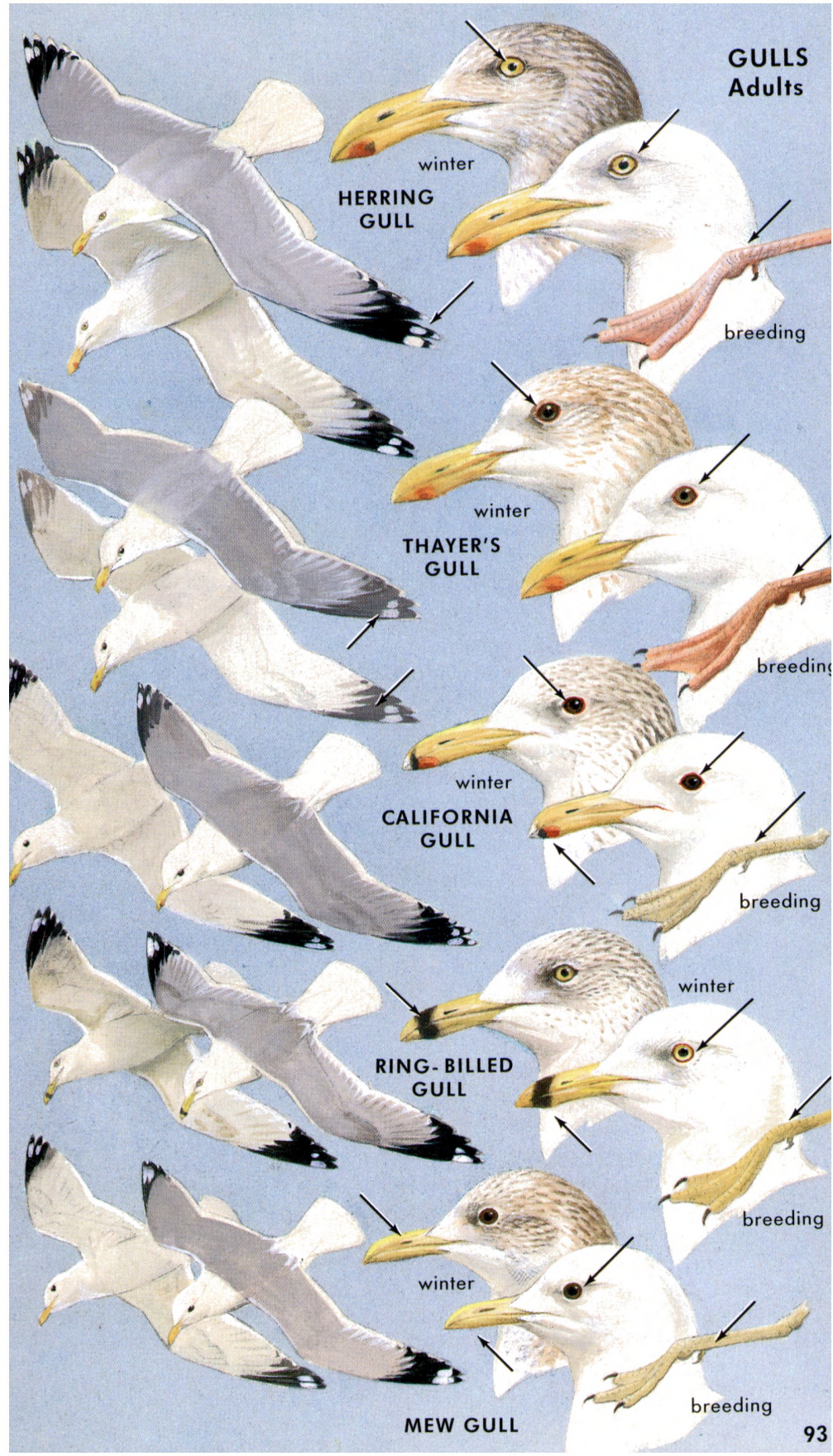


$24-27^{\prime \prime}(60-68 \mathrm{~cm})$. Adult: A pink-footed gull, with a pale gray mantle and gray pattern on the primaries (Herring Gull has black pattern in primaries). Immature: See pp. 98, 99. Hybridizes with Western Gull where their ranges overlap in Washington and British Columbia; also may hybridize with Herring Gull in Alaska.

Similar species: See Thayer's Gull, pp. 92, 93.

Voice: A low kak-kak-kak; a low wow; a high keer, keer.

Range: Komandorskie Is. to nw. Oregon. Winters to w. Mexico. Map 166.

GLAUCOUS GULL Larus hyperboreus

M167

$26-32 "(65-80 \mathrm{~cm})$. A large, chalky white gull, a bit larger than the Glaucous-winged Gull or Western Gull. Note the "frosty" wing tips. Adults have a pale gray mantle and unmarked white outer primaries. Immature: See pp. 98, 99.

Similar species: Glaucous-winged Gull is a bit smaller, with a smaller bill; the wing tips have various amounts of gray spotting. Adult may have a narrow dull red ring around eye (Glaucous has a yellow ring), but this is unreliable and hard to see.

Range: Arctic; circumpolar. Winters to U.S., Britain, n. China. West: Map 167. Habitat: Mainly coastal; some inland.

IVORY GULL Pagophila eburnea

$15-17 "(38-43 \mathrm{~cm})$. The only all-white gull with black legs. Pigeonsized; wings long, flight tern-like. Bill black, with a yellow tip. Immature: See pp. 102, 103.

Similar species: Glaucous Gull is much larger, with pale legs.

Voice: Harsh, shrill, ternlike cries: keeeer, etc.

Range: High Arctic; circumpolar. West: Not known to breed in our area. Arctic ice pack and drift ice of Alaska in migration and winter; accidental elsewhere (British Columbia, Alberta, Saskatchewan, Washington, Montana, Colorado).

BLACK-LEGGED KITTIWAKE Rissa tridactyla

M168

$17^{\prime \prime}(43 \mathrm{~cm})$. A small, buoyant oceanic gull. In adults the wing tips lack white spots and are solid black, almost straight across, as if dipped in ink. Bill small, pale, yellow, unmarked. Legs black. Immature: See pp. 102, 103.

Voice: At nesting colony, a raucous kaka-week or kitti-waak.

Range: Oceans in northern parts of N. Hemisphere. Winters to both coasts of U.S., Japan, Mediterranean, n. Africa. West: Map 168. Habitat: Chiefly oceanic; rarely on beaches.

\section{RED-LEGGED KITTIWAKE Rissa brevirostris}

14-153/4" (35-40 cm). Adult: Similar to Black-legged Kittiwake, but smaller; legs bright red (Bonaparte's Gull also has red legs). Has a similar wing pattern above, but darker; darkish gray underwing. Immature: Similar to young Black-leg, but darker-backed; tail lacks black terminal band; wing lacks dark diagonal bar.

Range: Bering Sea (Komandorskies, Pribilofs), w. Aleutians. Winters mainly in Bering Sea. Accidental, Yukon, nw. Oregon, Nevada. 


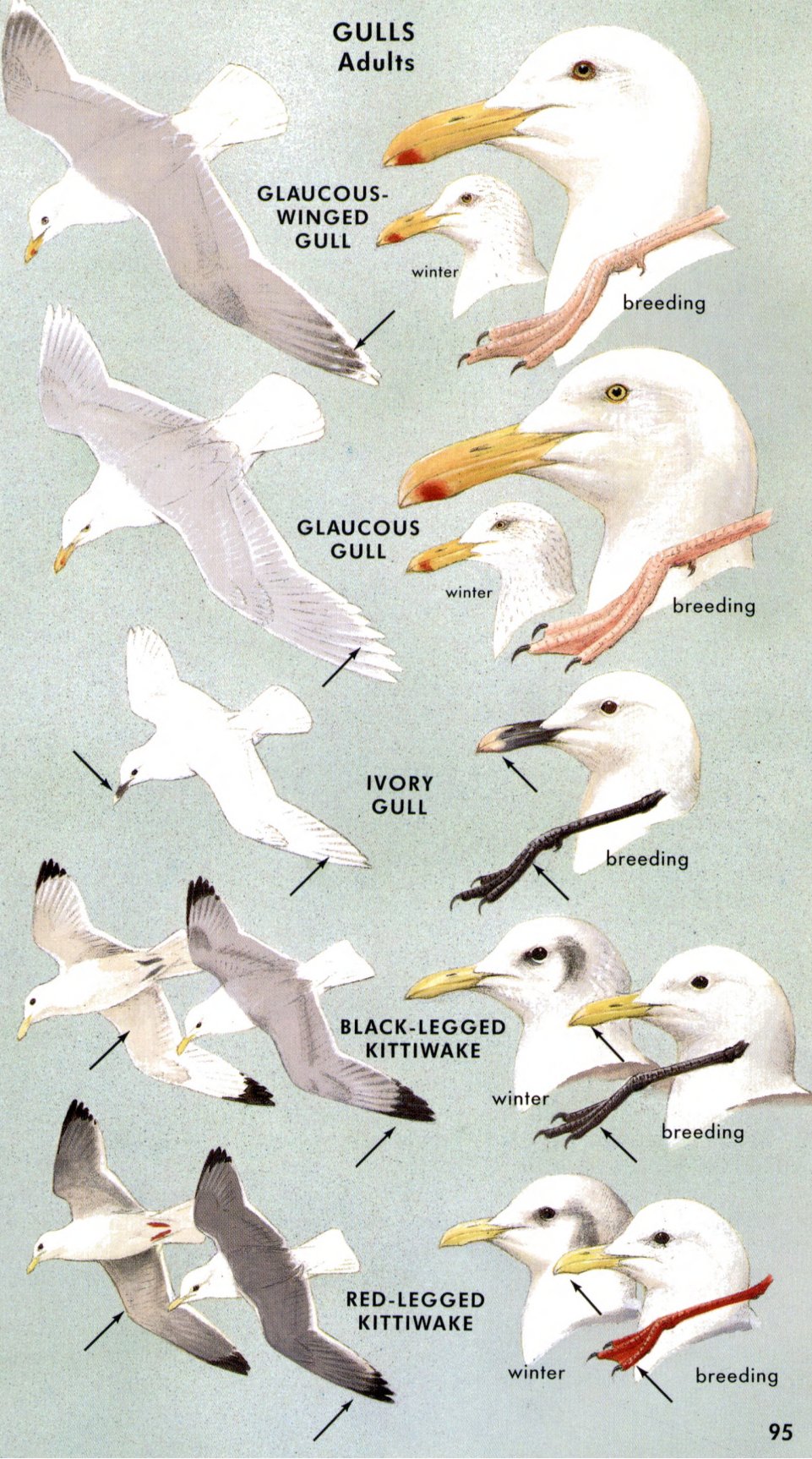


LAUGHING GULL Larus atricilla

16-17" (40-43 cm). A small coastal gull. The dark mantel blends into the black wing tips. A bold white trailing edge on dark wing. Head black in summer; white in winter, with a dark smudge across eye and nape. Bill may have red tip. Immature: See pp. 102, 103.

Voice: A strident laugh, ha-ha-ha-ha-ha-haah-haah-haah, etc.

Range: East Coast: Nova Scotia to Venezuela. Local, s. California, w. Mexico. Winters from s. U.S. south to Peru. West: Common post-breeding visitor to Salton Sea; has bred there. Casual, coastal California. Accidental north to Washington, Montana, Saskatchewan.

FRANKLIN'S GULL Larus pipixcan

M157

$14 \frac{1}{2} "(37 \mathrm{~cm})$. Note the white band on the wing, separating the black from the gray. In summer, the head is black and the breast has a rosy bloom. In fall, the head is white with dark cheeks and a dark nape. Immature: See pp. 102, 103.

Voice: A shrill kuk-kuk-kuk; also mewing, laughing cries.

Range: Breeds in w. Canada and nw. and n.-cen. U.S. Winters in Pacific from Guatemala to Chile. West: Map 157. Habitat: Prairies, inland marshes, lakes; in winter, coasts, ocean.

SABINE'S GULL Xema sabini

M169

13-14" (33-35 cm). Our only gull with a well-forked tail. Note the black outer primaries and triangular white wing patch. Bill black, with a yellow tip; feet black. This gull has a slaty hood in summer, lacking in winter. Immature: See pp. 102, 103.

Range: Arctic; circumpolar. Winters in Pacific to Chile; local in Atlantic. West: Map 169. Habitat: Ocean; nests on tundra.

\section{BLACK-HEADED GULL Larus ridibundus}

14-15" (35-38 cm). Similar in pattern to Bonaparte's Gull and associates with it; slightly larger. Shows much blackish on underside of primaries; bill dark red, not black. In winter loses its dark brown hood and has a black earshot. Immature: See pp. 102, 103.

Range: Eurasia, Iceland; increasingly frequent in e. N. America. West: Regular spring visitor to Aleutians, Pribilofs; rare elsewhere in Alaska. Casual stray to British Columbia, Pacific states.

BONAPARTE'S GULL Larus philadelphia

M158

$13 "(33 \mathrm{~cm})$. A petite, almost tern-like gull. Note the wedge of white on the fore edge of the wing. Legs red; bill small, black. Adult in summer has a blackish head. Winter adult has a white head with a black earspot. Immature: See pp. 102, 103.

Voice: A nasal cheeer or cherr. Some notes tern-like.

Range: Alaska, w. and cen. Canada. Winters from n. U.S. to Mexico, Puerto Rico. West: Map 158. Habitat: Ocean bays, lakes, muskeg.

LITTLE GULL Larus minutus

$11 "(28 \mathrm{~cm})$. The smallest gull; usually associates with Bonaparte's. Note the blackish undersurface of the rather rounded wing and absence of black above. Legs red. In summer the head is black, bill dark red, breast may be pinkish. In winter, head is dark-capped, bill is black. Immature: See pp. 102, 103.

Range: Eurasia, wintering to $\mathrm{n}$. Africa, Japan. A small population breeds in n.-cen. N. America. West: Casual or accidental, Alaska, nw. Canada, Pacific states, Nevada, Colorado, etc. 


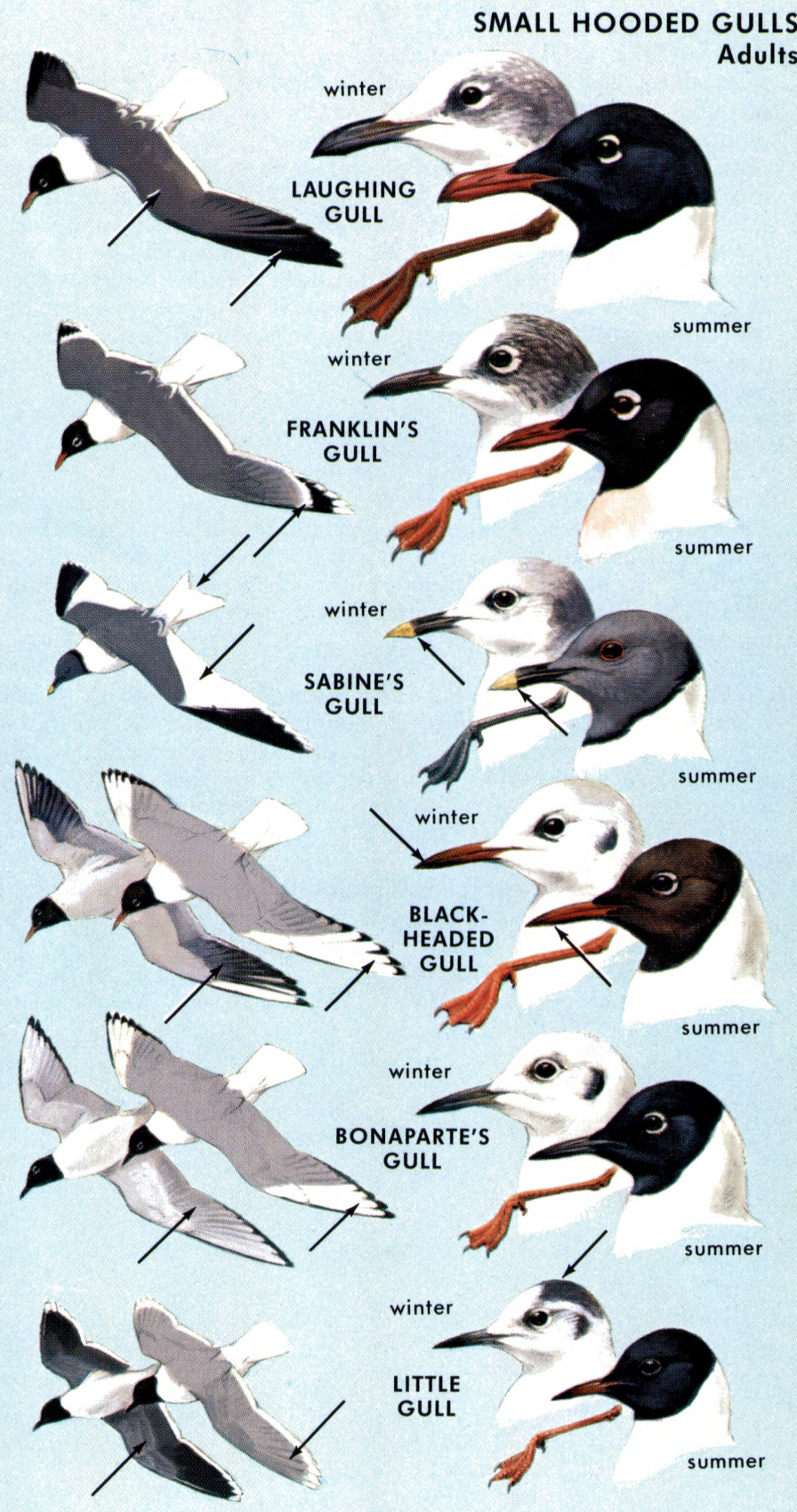


- IMMATURE GULLS. Immatures are more difficult to identify than adults. They are usually darkest the first year and lighter the second; in the larger species they may not develop their full adult plumage until the third or fourth year. See pp. 88, 89. Leg colors of most immatures are not as diagnostic as those of adults. However, in some cases bill colors may be helpful. Go mainly by pattern and size. The most typical plumages are shown in the following pages; intermediate and successive stages can be expected, but do not feel you must identify every immature gull. Because of variables such as the stage of molt, wear, age, individual variation, frequent hybridization, and even occasional albinism, some birds may remain a mystery even to the expert unless the specimen is in the hand. See also pp. 100-103.

GLAUCOUS GULL Larus hyperboreus

Adult, pp. 94, 95

A four-year gull. First winter: Recognized by its large size (a bit larger than Glaucous-winged or Western Gull), pale tan coloration, and unmarked frosty primaries, a shade lighter than the rest of the wing. Bill pale flesh pink with a dark tip. The pale gray mantle is acquired later, with approaching adulthood. Second year: Paler buff; occasional worn or faded birds may appear to be pure white throughout with only a hint of mottling.

GLAUCOUS-WINGED GULL Larus glaucescens

Adult, pp. 94, 95 . A four-year gull; variable. Size of Western Gull, and with a similar sequence of plumages (see p. 89), but primaries are much the same tone as the rest of the wing, not darker as in Western or Herring gulls, or paler, frosty, or translucent as in Glaucous Gull.

\section{WESTERN GULL Larus occidentalis}

A four-year gull; see sequences of plumages on pp. 88, 89. First-year birds are larger and less brown than first-year Herring Gulls.

HEERMANN'S GULL Larus heermanni Adult, pp. 90, 91.

A three-year gull. Readily told by its size and all-dark, sooty or slaty color. Note the bicolored bill. 


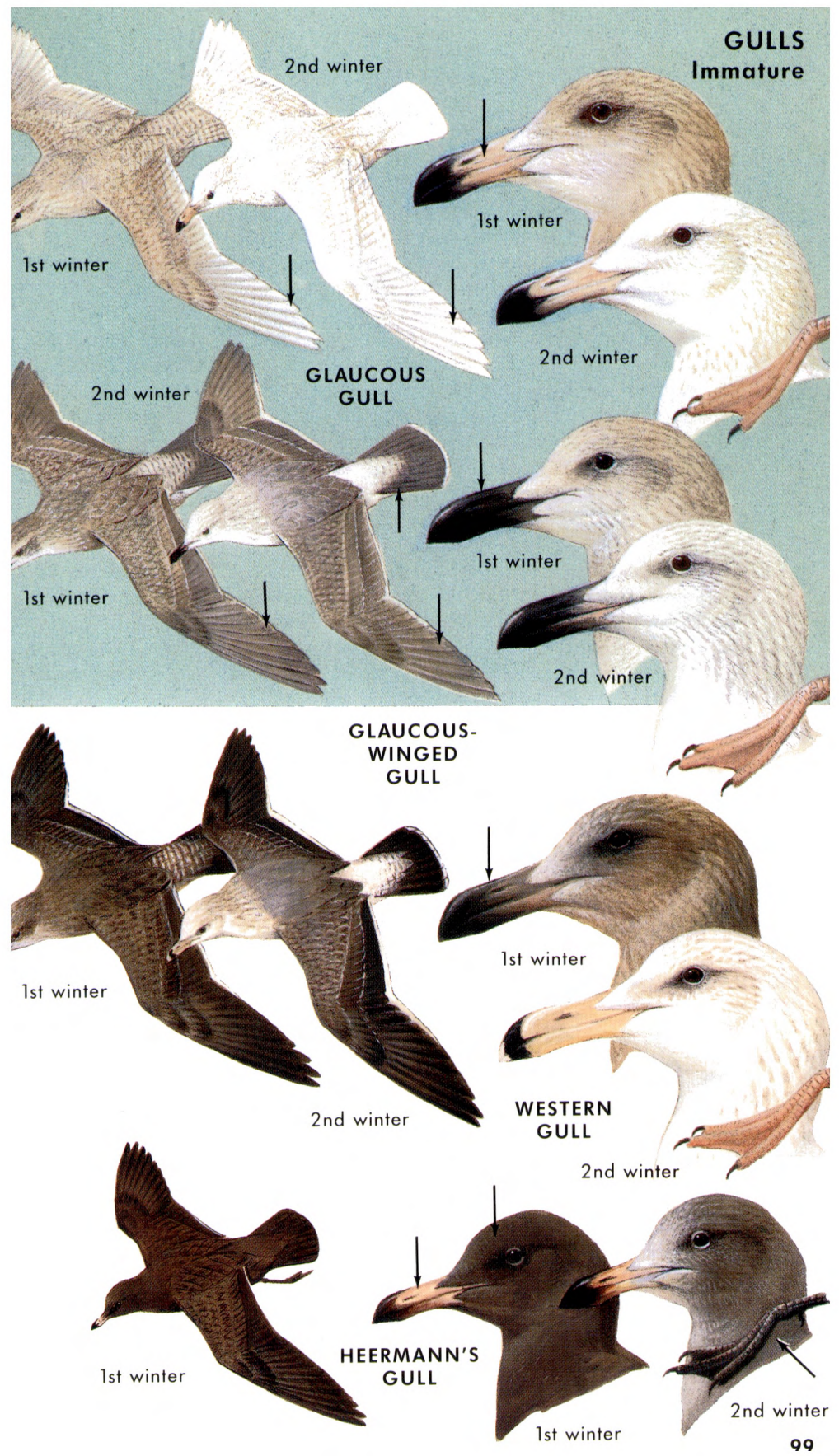


A four-year gull. Iuvenile: Relatively uniform dusky brown. First winter: Much like juvenile but not quite as dark. Bill all dark at first, becoming paler at base later. Second and third winter: Paler. Head and underparts whiter; tail feathers dark-tipped, contrasting with white rump; bill pale, dark-tipped. The gray mantle is acquired with approaching adulthood.

THAYER'S GULL Larus thayeri

Adult, pp. 92, 93.

A four-year gull. First winter: Gray-brown throughout; similar to first-winter Western and Herring gulls, but lighter; primaries usually the same gray-brown as the rest of the wing (not darker or blackish, as in Western or most other gulls). Second winter: Paler and grayer; primaries gray-brown. In any plumage, gray or pale graybrown wing tips from below.

Similar species: See immature Glaucous-winged Gull, p. 98.

CALIFORNIA GULL Larus californicus

Adult, pp. 92, 93.

A four-year gull. Juvenile: As dark as the somewhat larger juvenile Herring Gull, but with a smaller, bicolored bill. First winter: Similar but with paler mottling. Second winter: Much like first-winter Ring-bill (gray on back) but tail mostly all dark, not with a welldefined subterminal band.

RING-BILLED GULL Larus delawarensis

Adult, pp. 92, 93.

A three-year gull. Juveniles are much smaller, paler, and more speckled than juvenile Herring Gulls, but first-winter immatures may be confused with second- and third-winter Herring Gulls, which have a semblance of a ring near the tip of the longer bill. In the Herring Gull and California Gull the tail is mostly dark, terminating in a very broad, ill-defined band. The subterminal band in young Ring-bills is much narrower (a little over 1 in. wide) and usually (but not always) well defined. The leg color is not useful, as young Ring-bills have dull flesh-pink, flesh-gray, or grayish legs, not unlike those of certain other young gulls.

MEW GULL Larus canus

Adult, pp. 92, 93.

A three-year gull. Juvenile: Very dark; might suggest a young Heermann's Gull, but has a smaller, shorter bill and pale legs. First winter: More like a second-winter California Gull, but considerably smaller, with a rounder head and smaller, thinner bill. 


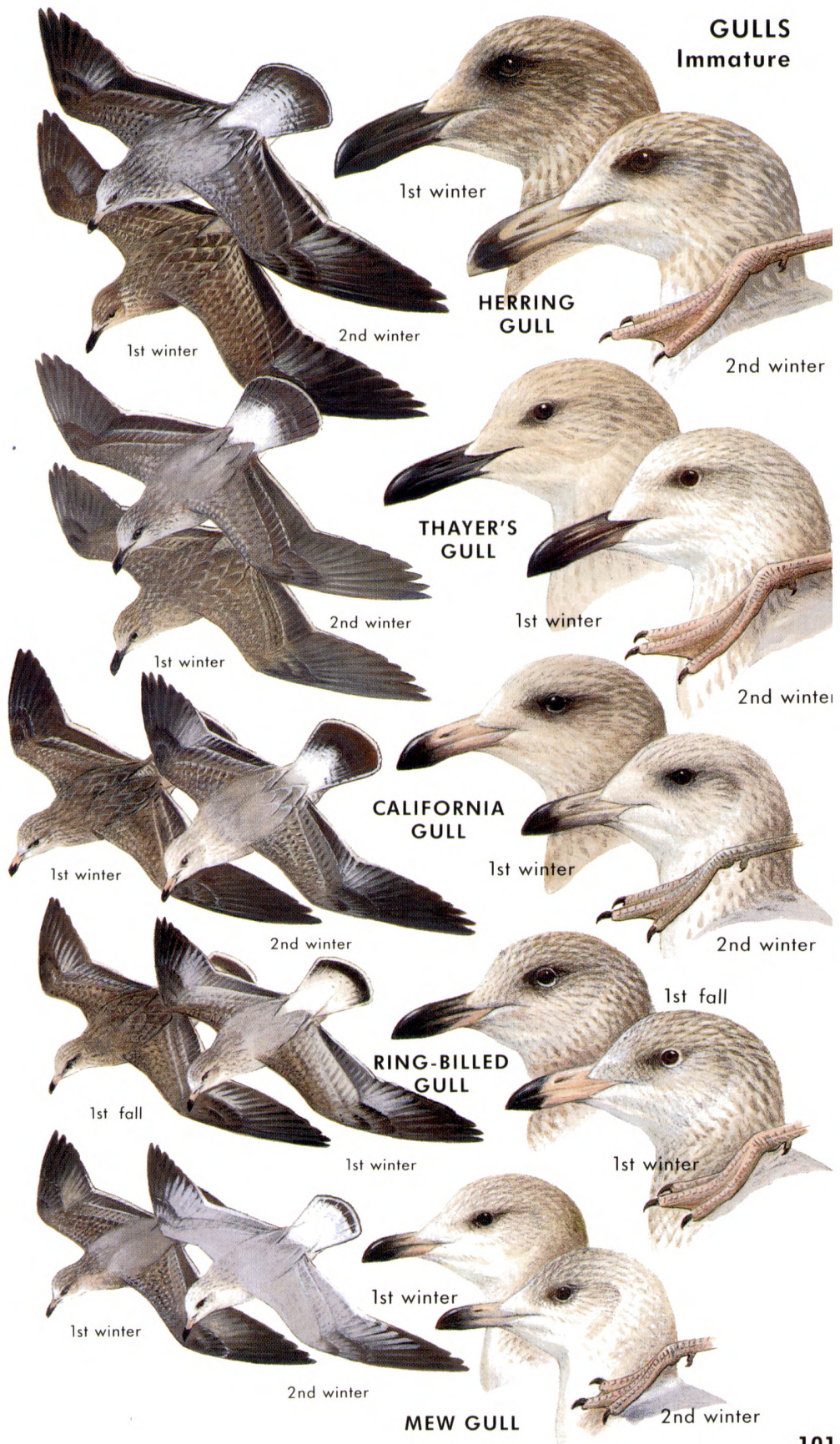




\section{IMMATURE GULLS: SMALLER SPECIES}

LAUGHING GULL Larus atricilla

Adult, pp. 96, 97.

A three-year gull. Juvenile: Very dark, with a white rump and a broad white border on the trailing edge of the dark wing. First winter: Paler or whiter on the chest and forehead; not easy to separate from young Franklin's Gull. Second winter: Similar to winter adult, but with a trace of black in the tail.

FRANKLIN'S GULL Larus pipixcan

Adult, pp. 96, 97.

A two-year gull. First winter: Very similar to first-winter Laughing Gull, but smaller-billed and more petite. It perhaps may best be distinguished by the incomplete tail band. Note also the darker cheek and more distinctly hooded effect. Outer tail feathers white. Juvenile Laughing Gull is separated from Franklin's by its brown breast and brown forehead, which become whiter as fall progresses.

SABINE'S GULL Xema sabini

Adult 96, 97.

A two-year gull. Juvenile and first winter: Dark grayish brown on the back, but with the adult's bold triangular wing pattern. Note the scaly pattern and also the forked tail. Young Kittiwake is similar, but has a dark bar on the nape, a diagonal bar across the wing, and only a slight tail notch.

BLACK-LEGGED KITTIWAKE Rissa tridactyla

Adult, pp. 94, 95. A two-year gull. First winter: Note the dark bar on the nape, the black outer primaries, and the dark bar across the inner wing. The tail may seem notched.

BONAPARTE'S GULL Larus philadelphia

Adult, pp. 96, 97.

A two-year gull. Petite, tern-like. First winter: Note the cheek spot, narrow black tail band, and pattern of black and white in the outer primaries.

BLACK-HEADED GULL Larus ridibundus

Adult, pp. 96, 97.

A two-year gull. First winter: Similar in pattern to immature Bonaparte's Gull, with which it associates, but slightly larger and less tern-like; the bill is longer, ochre at the base, black at the tip. Underwing as in adult Black-head, but not as dark.

IVORY GULL Pagophila eburnea

Adult, pp. 94, 95.

A two-year gull. First winter: A tern-like white gull, with irregular gray smudges on the face, a sprinkling of black spots above, and a narrow black border on the rear edge of its white wings.

LITTLE GULL Larus minutus

Adult, pp. 96, 97.

A two-year gull. First winter: Smaller than young Bonaparte's, with rounder wings and a blacker $M$ pattern formed by the outer primaries and the dark band across the wing. Note especially the dusky cap.

ROSS'S GULL Rhodosthethia rosea

Adult, pp. 90, 91.

A two-year gull. First winter: Similar in pattern to immature Blacklegged Kittiwake, but note the wedge-shaped tail (not square or notched) and the blue-gray linings of the underwing. It lacks the dark nape of the immature Kittiwake. 


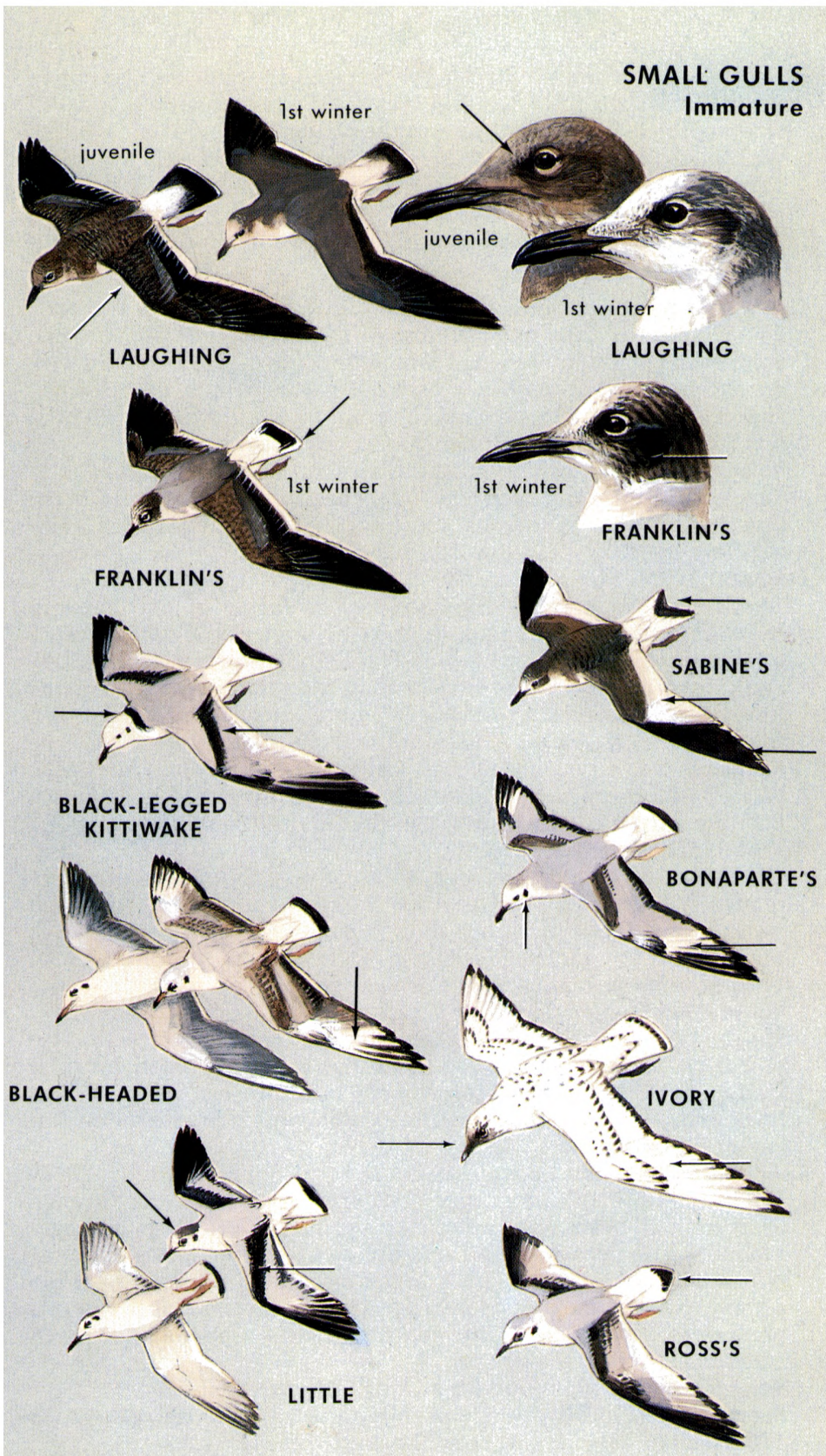


- TERNS. Subfamily Sterninae. Graceful water birds, more streamlined than gulls; wings more pointed, tail usually forked. Bill sharp-pointed, often tilted toward the water. Most terns are whitish with black caps; in winter, black of forehead replaced by white. Sexes alike. Terns often hover and plunge headfirst for fish. Normally they do not swim (gulls do). Food: Small fish, marine life, large insects. Range: Almost worldwide. No. of species: World 42; West 11.

\section{GULL-BILLED TERN Sterna nilotica}

$14^{\prime \prime}(35 \mathrm{~cm})$. Note the stout, almost gull-like black bill. Stockier and paler than Common Tern; tail much less forked; feet black. In winter the head is white with a dark ear patch, pale dusky on nape; suggests a small gull with a notched tail. Immature: Similar to nonbreeding adult. This tern often hawks for insects.

Voice: A throaty, rasping za-za-za; also kay-week, kay-week. Range: Breeds locally, wanders widely in many parts of world. West: Summer resident Salton Sea, California. Casual, sw. Arizona. Habitat: Salt marshes, fields, coastal bays.

ELEGANT TERN Sterna elegans

16-17" (40-43 cm). This Mexican species should be looked for in fall along the coast. In size, midway between Royal and Forster's terns. Bill orange-yellow, with no black tip (Forster's has black tip), and proportionately more slender than the more orange bill of the Royal. Its black crest is longer. In winter, it has a blacker crown than Royal Tern. Voice: A nasal karreek, or ka-zeek.

Range: Breeds on islands off Baja California. Winters Peru to Chile. West: Wanders irregularly (mainly Aug.-Oct.) north to San Francisco Bay; recently even to Washington. Breeds near San Diego.

\section{ROYAL TERN Sterna maxima}

$18-21^{\prime \prime}(45-53 \mathrm{~cm})$. A large tern, slimmer than Caspian, with a large orange bill (Caspian's bill is redder). Tail deeply forked. Although some Royal Terns in spring show a solid cap, they usually have much white on the forehead, the black feathers forming a crest. Whiter under primaries than Caspian.

Voice: Keer, higher than Caspian's note; also kaak or kak.

Range: Coasts of se. U.S. to Argentina; s. California to Peru; also w. Africa. Winters s. U.S. to Argentina; w. Africa. West: Irregular visitor (Sept.-Mar.) along coast north to Morro Bay, rarely to San Francisco. Has bred near San Diego. Habitat: Coasts, beaches, salt bays.

\section{CASPIAN TERN Sterna caspia}

19-23" (48-58 cm). Large size and large red bill set the Caspian apart from all other terns except the slimmer Royal. Caspian ranges inland, Royal does not. Tail of Caspian is shorter; bill is thicker, red rather than orange, with a touch of dark at the tip. Royal has a more crested look; its forehead is usually clear white (in this plumage, Caspian has a streaked forehead). Caspian shows much more black under the primaries.

Voice: A hoarse, low kraa-uh or karr; also repeated kaks.

Range: Breeds locally, wanders widely around the world. West: Map 170. Habitat: Large lakes, coastal waters, beaches, bays. 


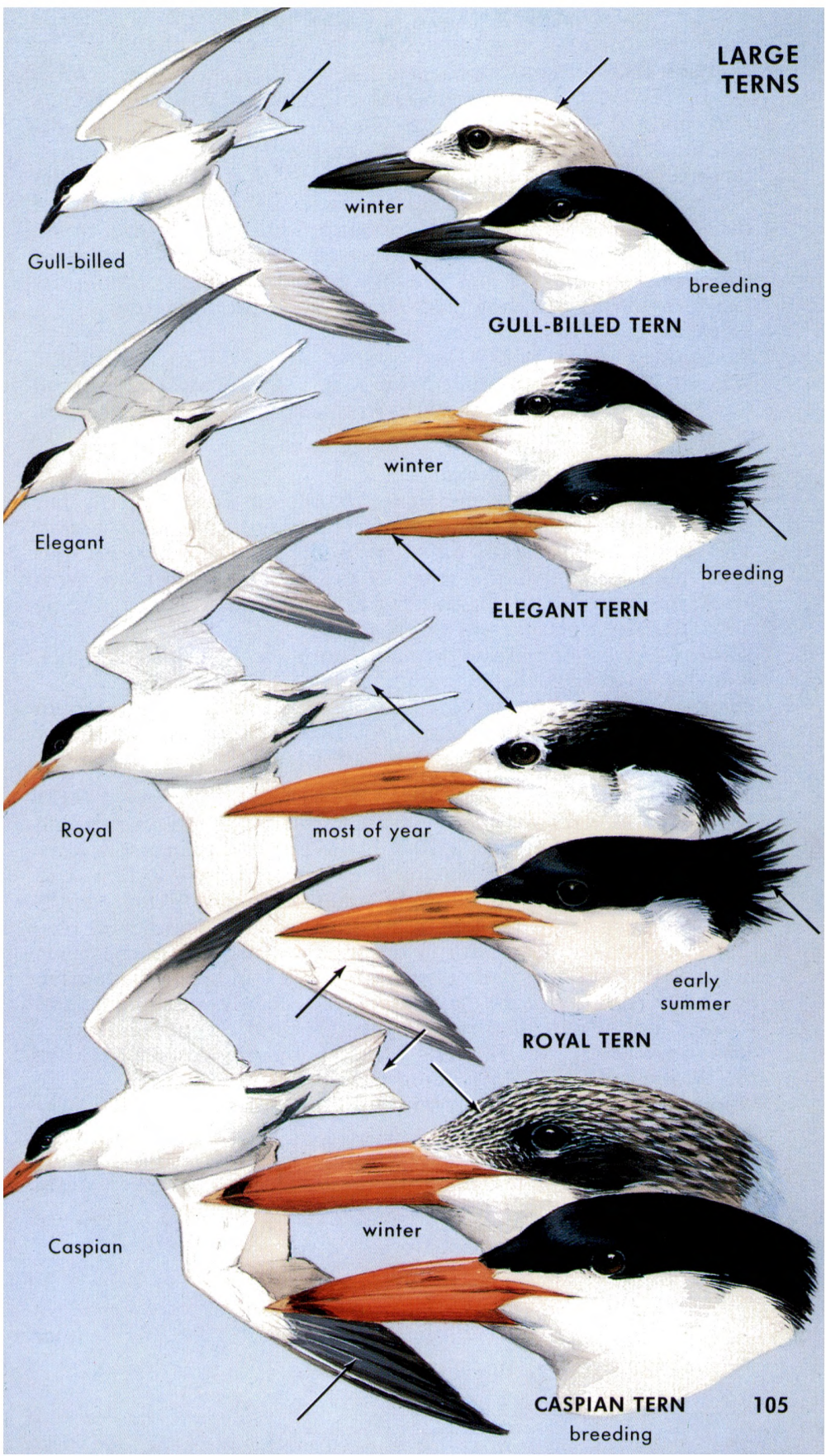


14-15" (35-38 cm). A slim, graceful, gull-like bird with a black cap; long, pointed wings; and a deeply forked tail. This, the most widespread of the three similar medium-sized terns in the West, is readily separated from the other two by its frosty wing tips. Very similar to the Common Tern, but paler; primaries lighter than the rest of the wing (darker in Common). Tail grayer; bill more orange. In fall and winter, adult and immature Forster's have a black mask or patch through the eye and ear (not around the nape). Immature: Lacks the dusky forewing (dark shoulder) of Common Tern.

Voice: A harsh, nasal za-a-ap and a nasal kyarr.

Range: W. Canada, w. U.S., and cen. Atlantic Coast to Tamaulipas. Winters s. U.S. to Guatemala. West: Map 173. The most widespread tern in the West. Habitat: Marshes (fresh, salt), lakes, bays, beaches, ocean. Nests in marshes.

\section{ARCTIC TERN Sterna paradisaea}

M172

14-17" (35-43 cm). Very similar to Common or Forster's terns, but grayer; the white cheeks contrast with the grayish throat and breast. The shorter bill is usually blood-red to the tip. Legs shorter. Overhead, note the translucent effect of the primaries and the narrow black trailing edge. In the fall the bill and feet of adults become dark. The most pelagic (sea-going) tern.

Voice: Kee-yah, similar to Common Tern's cry; less slurred, higher. A high keer-keer is characteristic.

Range: Northern parts of N. Hemisphere; circumpolar. Winters in sub-Antarctic seas. West: Map 172. Habitat: Open ocean, rocky coasts, islands; in summer, also tundra lakes.

COMMON TERN Sterna hirundo

M171

13-16" (33-40 cm). Summer: White, with a pearl gray mantle and black cap; bill red-orange with a black tip; feet orange-red. Very similar to Forster's Tern, but the five outer primaries form a dark wedge, contrasting with the light inner primaries. Winter adult: The black cap is incomplete, the bill blackish. The Siberian race (longipennis) is a rare visitor in the w. Aleutians and other islands in the Bering Sea. It is darker, with a black bill in breeding plumage and black feet. Immature: Similar to winter adult but shoulder and leading edge of wing darker than those of imm. Arctic Tern.

Similar species: (1) See Forster's Tern, the most widespread tern in the West. (2) Arctic Tern is more widespread at sea.

Voice: A drawling kee-arr (downward inflection); also kik-kik-kik; a quick kirri-kirri.

Range: Temperate zone of N. Hemisphere. Winters to S. Hemisphere. West: Map 171. Habitat: Lakes, ocean, bays, beaches; nests colonially on sandy beaches and small islands. 


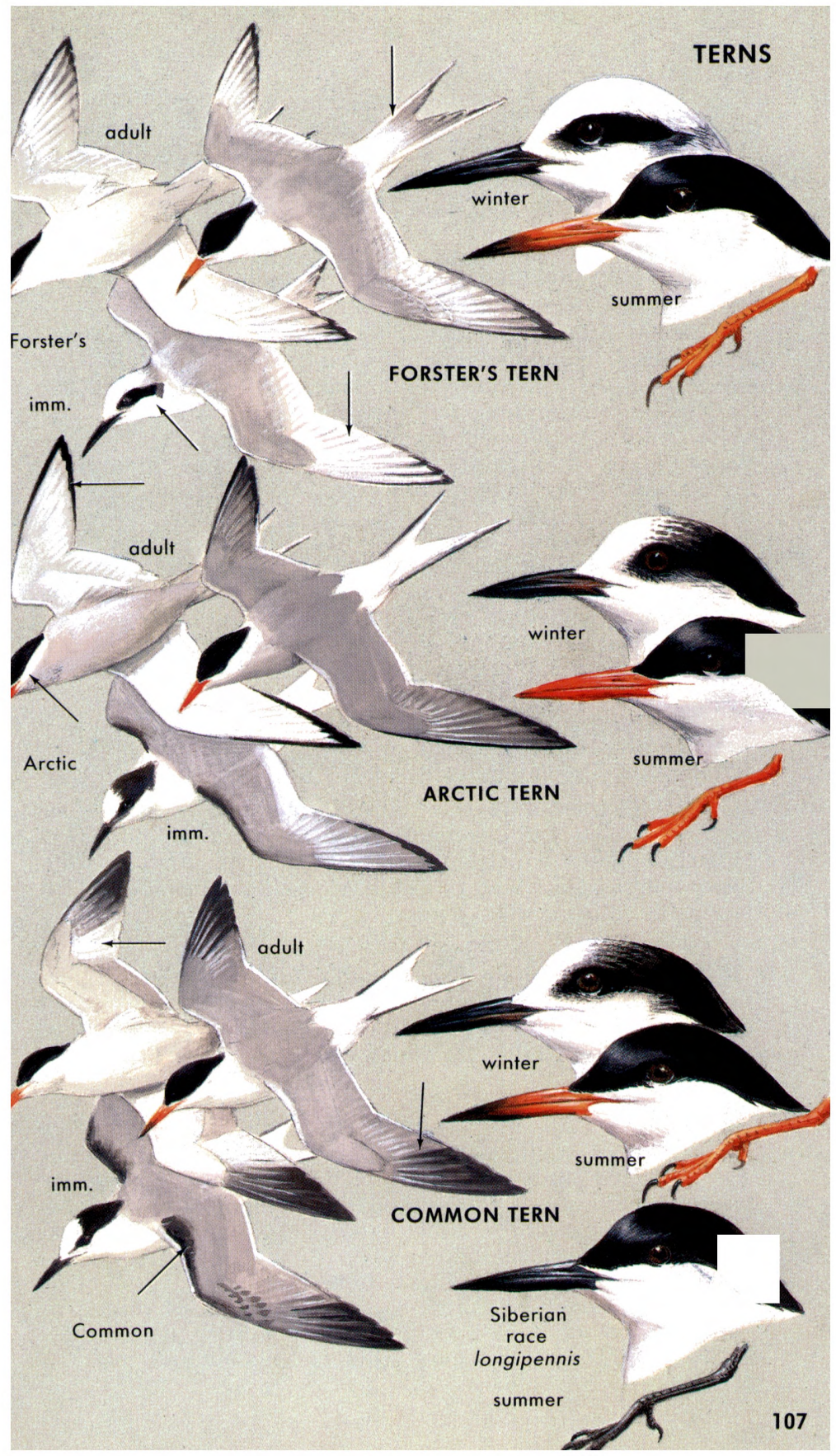


9" $(23 \mathrm{~cm})$. A very small, pale tern, with a yellow bill, yellow feet, and a white forehead. Flight more fluttery than that of other terns. Immature: Dark bill, dark nape, much dark on forewing. In the fall, all birds may have dark bills, but feet still show yellow.

Voice: A sharp, repeated kit; a harsh, squealing zree-eek or zeek; also a rapid kitti-kitti-kitti.

Range: Temperate and tropical oceans. Winters south of U.S. West: Map 174. Habitat: Sea beaches, bays; large rivers, bars.

ALEUTIAN TERN Sterna aleutica

$15^{\prime \prime}(38 \mathrm{~cm})$. A lead-colored tern of Alaskan coastal waters. Known from Arctic Tern by its much grayer color, blackish primaries, blackish or dark bill and feet, clean-cut white forehead. The gray body and mantle contrast with the white tail.

Voice: A three-syllable whistle, suggesting a shorebird.

Range: Breeds on Sakhalin I., Kamchatka, and locally in s. and w. Alaska north to Bering Straits and west sparsely through Aleutians. Winters in nw. Pacific.

BLACK TERN Chlidonias niger

M175

9-10" $(23-25 \mathrm{~cm})$. A black-bodied tern. Breeding: Head and underparts black; back, wings, and tail dark gray; wing linings white. By midsummer, molting birds are mottled, with the black largely replaced by white. Note the pied head, smudge on side of the breast. Immature: Similar to non-breeding adult.

Voice: A sharp kik, keek, or klea.

Range: Temperate N. America, w. Eurasia. Winters mainly in S. America, w. Africa. West: Map 175. Habitat: Fresh marshes, lakes; in migration, also coastal waters.

Note: WHITE-WINGED TERN, Chlidonias leucopterus of Eurasia, has occurred as a stray in extreme w. Aleutians (Nizki I.). In breeding plumage it differs from the Black Tern in having a largely white upperwing and black wing linings. In winter, paler than Black Tern, lacking the dark shoulder spot.

- SKIMMERS. Subfamily Rynchopinae. Slim, short-legged relatives of gulls and terns. Scissorlike red bill; lower mandible longer than upper. Food: Small fish, crustaceans. Range: Coasts, large rivers of warmer parts of world. No. of species: World 3; West 1.

\section{BLACK SKIMMER Rhynchops niger}

$16-20^{\prime \prime}(40-50 \mathrm{~cm})$. More slender than a gull, with extremely long wings. Black above, white below. Note the unequal scissorlike bill. The bright red bill (tipped with black) is long and flat vertically; lower mandible juts a third beyond upper. Immature: Brownish, speckled, smaller-billed. Primarily coastal; skims low, dipping knifelike lower mandible in water.

Voice: Soft, short, barking notes. Also kaup, kaup.

Range: Cape Cod, s. California, south to s. S. America. West: A recently established resident of s. California, nesting at Salton Sea and near San Diego. Occasional elsewhere on California coast; casual, Arizona, New Mexico. 


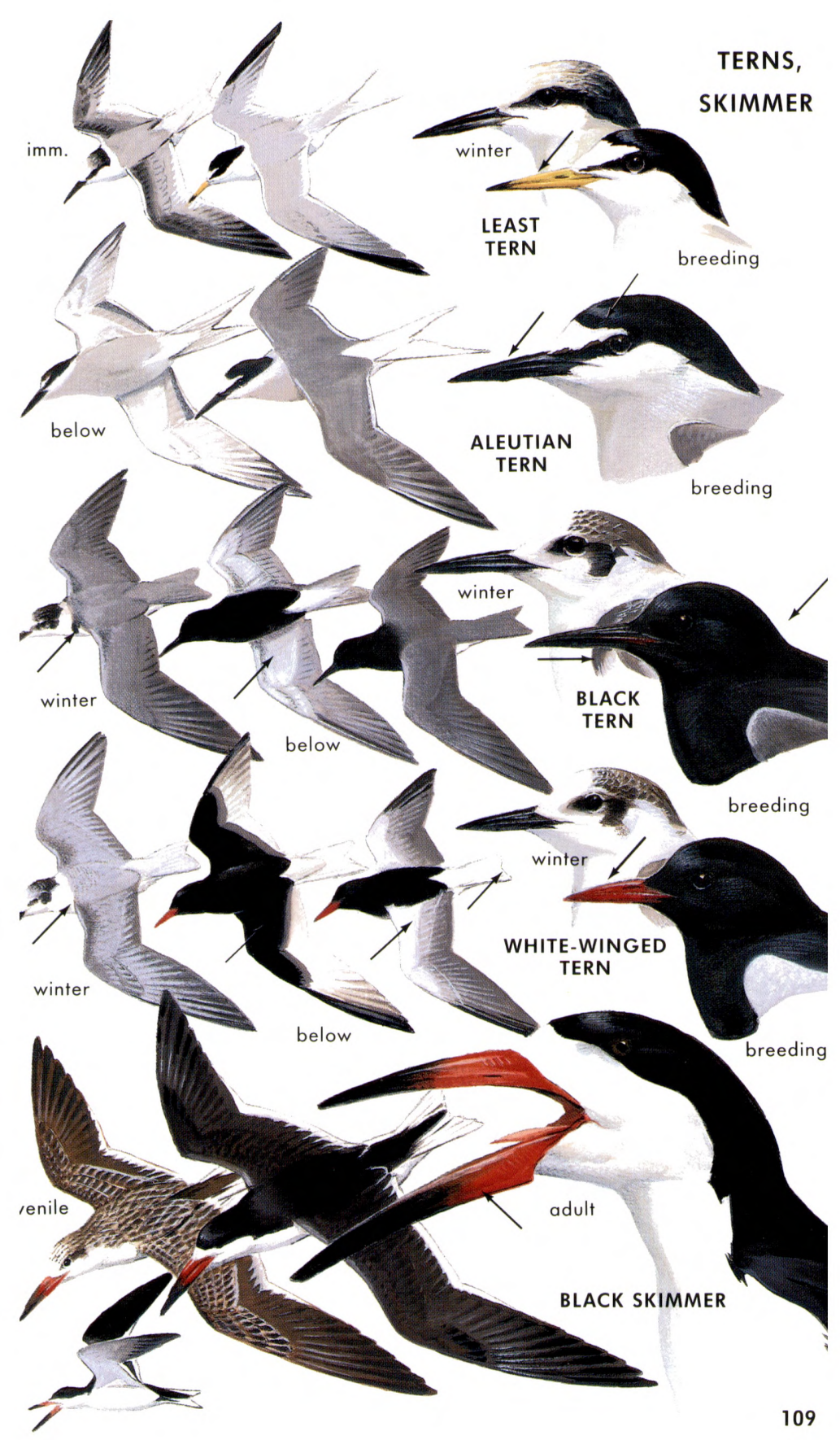


a HERONS, BITTERNS. Family Ardeidae. Medium to large wading birds with long necks, spearlike bills. They stand with the neck erect or the head back on the shoulders. In flight, the neck is folded in an $S_{;}$legs trail. Some herons may have plumes when breeding. Sexes similar. Food: Fish, frogs, crawfish, other aquatic life; mice, insects. Range: Worldwide except colder regions, some deserts and islands. No of species: World 67; West $13(+1$ accidental).

GREAT BLUE HERON Ardea herodias

M21

42-52" (105-130 cm). A lean gray bird, often miscalled a "crane" (pp. 116, 117); may stand $4 \mathrm{ft}$. tall. Its long legs, long neck, dagger-like bill, and, in flight, its folder neck indicate a heron. Great size and blue-gray color, white about the head (in adults), mark it as this species.

Voice: Deep harsh croaks: Frahnk, frahnk, frahnk.

Range: S. Canada to Mexico. Winters to n. S. America. West: Map 21. Habitat: Marshes, swamps, shores, tideflats.

LITTLE BLUE HERON Egretta caerulea

$24 "(60 \mathrm{~cm})$. A slender, rather small, dark heron. Adult: Bluish slate with a deep maroon-brown neck; legs dark, bill pale bluish with a dark tip. Immature: See pp. 112, 113. All white with grayish wing tips. Legs dull olive; bill pale bluish, tipped with black. Birds in transition are boldly pied white and dark.

Similar species: Adults may be mistaken for Reddish Egret.

Range: Eastern U.S. to Peru, Argentina. West: A rare visitor to the sw. states; most frequent in California (has bred there). Accidental, Washington, British Columbia.

GREEN HERON Butorides virescens

M25

$16-22 "(40-55 \mathrm{~cm})$. A small dark heron that in flight looks crow-like (but flies with bowed wingbeats). When alarmed it stretches its neck, elevates a shaggy crest, and jerks its tail. The comparatively short legs are greenish yellow or orange (when breeding). Back with a blue-green gloss; neck deep chestnut. The immature has a streaked neck and breast.

Voice: A series of kuck's; a loud skyow or skewk.

Range: Nw. U.S., se. Canada to Argentina; se. Asia, Africa, Australia. West: Map 25. Habitat: Lakes, ponds, marshes, streams.

TRICOLORED HERON Egretta tricolor

(Louisiana Heron) 26" $65 \mathrm{~cm})$. A very slender, dark heron with a contrasting white belly and white rump.

Range: Eastern U.S. to Brazil. West: A rare but regular visitor to s. California. Casual, other sw. states; accidental, Oregon, Alberta.

REDDISH EGRET Egretta rufescens

29" $(73 \mathrm{~cm})$. Note the pinkish, black-tipped bill. Neutral gray, with a rusty head and neck; paler than Little Blue Heron, which has pale bluish at base of bill. Loose-feathered, neck shaggy (adult). When feeding, lurches about, wings half spread; acts drunk. The white morph presumably does not occur in the West.

Range: Gulf states, W. Indies to n. Venezuela; Baja California to El Salvador. West: A rare visitor to s. California (especially the coast); accidental, Arizona, Colorado. 


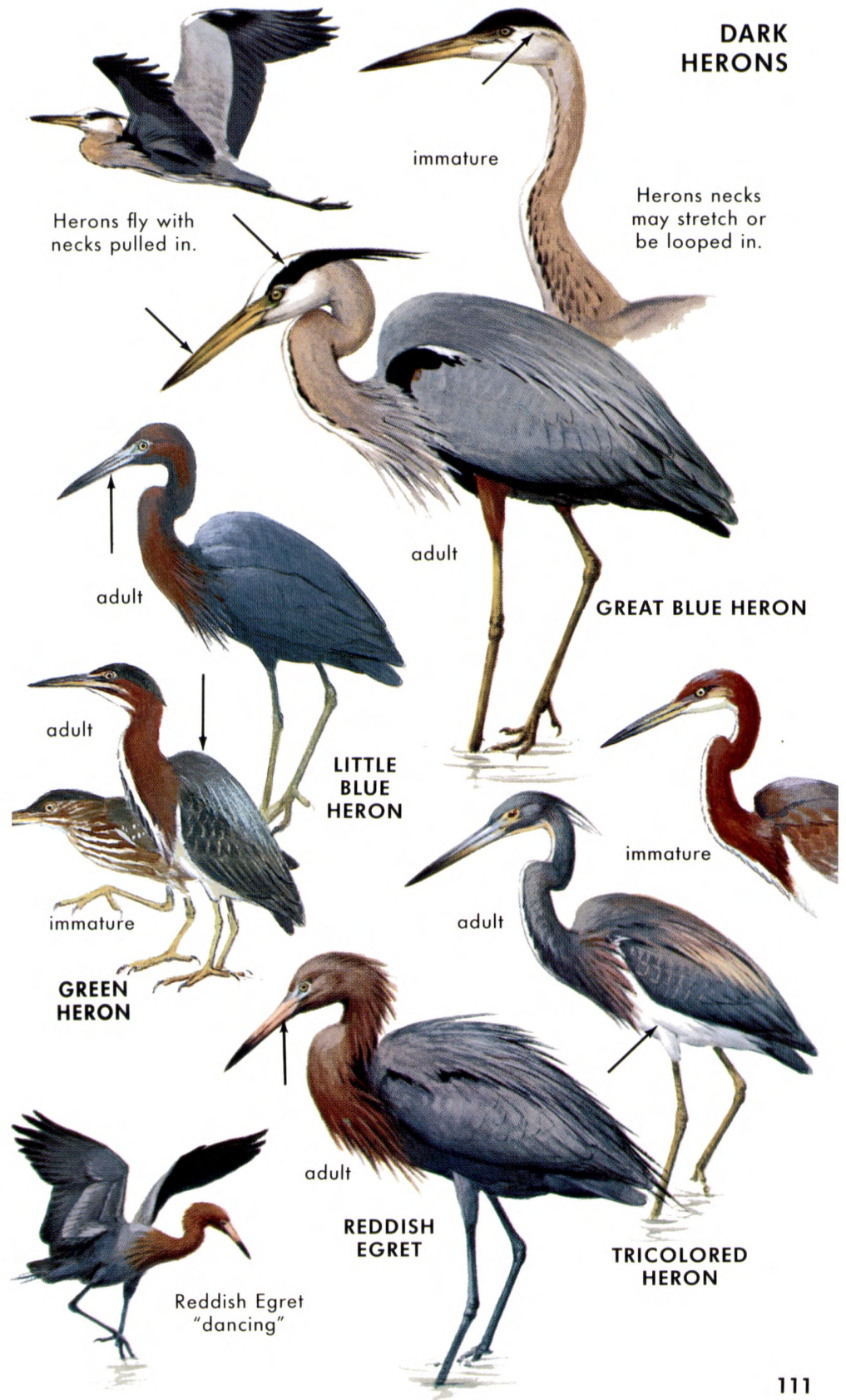


(Common Egret) 38" $95 \mathrm{~cm}$ ). A tall, stately, slender white heron with a largely yellow bill. Legs and feet black. When breeding, straight plumes on the back extend beyond the tail; bill may have a dark ridge. When feeding, the bird assumes an eager, forward-learning pose, with its neck extended.

Voice: A low, hoarse croak. Also, cuk, cuk, cuk.

Range: U.S. to s. S. America; warmer parts of Old World. West: Map 22. Habitat: Marshes, ponds, shores, mudflats.

SNOWY EGRET Egretta thula

20-27" (50-68 cm). Note the "golden slippers." A rather small white heron, with a slender black bill, black legs, and yellow feet. Recurved plumes on the back during breeding season. A yellow loral spot is before the eye (red when bird is breeding). When feeding, this heron rushes about, shuffling its feet to stir up food. Young birds may show yellowish or greenish on much of rear side of legs.

Voice: A low croak; in colony, a bubbling wulla-wulla-wulla.

Range: Northern U.S. to Argentina. West: Map 23. Habitat: Marshes, swamps, ponds, shores, tideflats.

LITTLE BLUE HERON Egretta caerulea

Adult, pp. 110, 111. Immature: White, with a touch of gray in the wing tips. Lores gray, legs dull greenish. May be confused with immature Snowy Egret.

CHINESE EGRET Egretta eulophotes

This endangered Asiatic bird has occurred once in the w. Aleutians (Aggatu I.). When breeding it resembles a Snowy Egret (black legs, yellow feet), but the bill is yellow, the lores dark.

CATTLE EGRET Bubulcus ibis

M24

$20 "(50 \mathrm{~cm})$. A recent invader. Slightly smaller, stockier than Snowy Egret. Breeding plumage shows a wash of buff on crown, breast, and back; little or none at other times. Bill relatively short, yellow (orangepink on nesting birds). Legs may be yellow, greenish, or coral-pink (on nesting birds), or dusky (immature).

Range: S. Eurasia, Africa; recent immigrant to N. and S. America, Australia. Introduced Hawaii. West: Map 24. Habitat: Farms, marshes, highway edges; often associates with cattle.

- IBISES AND SPOONBILLS. Family Threskiornithidae. Ibises are long-legged, heron-like marsh waders with slender, decurved bills. Spoonbills have spatulate bills. Both fly in V's or lines and, unlike herons, fly with necks outstretched. Food: Small crustaceans, small fish, insects, etc. Range: Tropical and warm temperate regions. No. of species: World 30; West 3.

WHITE IBIS Eudocimus albus

22-27" (55-68 cm). Note the red face, long decurved red bill, and restricted black wing tips. Immature is dark brownish; note the white belly, white rump, curved red bill. Immature Glossy Ibis differs in being uniformly dark with a dark bill.

Range: Se. U.S. to n. S. America. West: A casual stray to California, Arizona, New Mexico; accidental, Wyoming, Idaho, Dakotas.

ROSEATE SPOONBILL Ajaia ajaja

Adult shown on pp. 114, 115. Immature: Spatulate bill; pale pink plumage. 


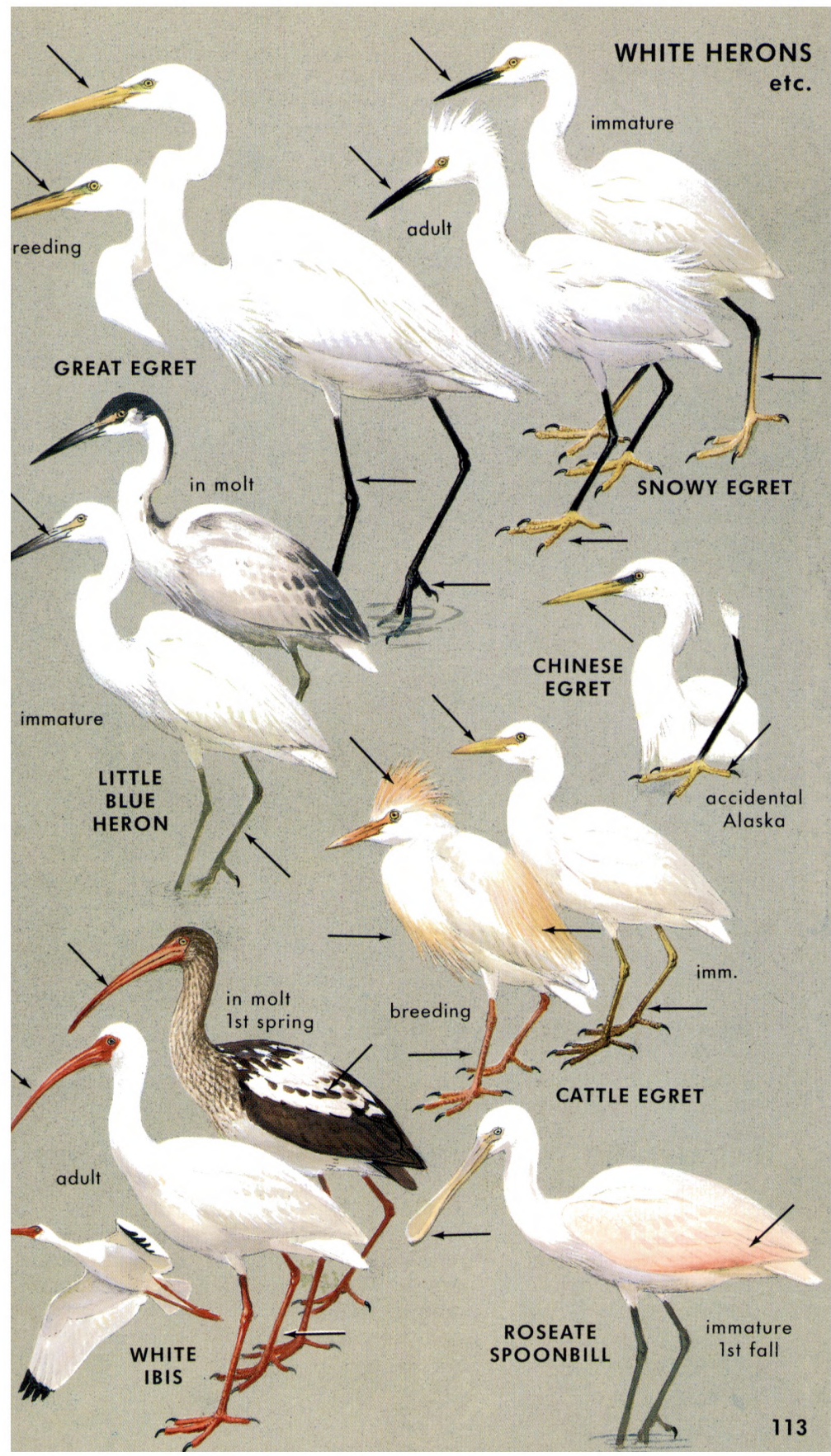


$23-28^{\prime \prime}(58-70 \mathrm{~cm})$. This stocky, thick-billed, short-legged heron is usually hunched and inactive; flies to feed at dusk. Adult: Black back and cap contrast with pale gray or whitish underparts. Eyes red; legs yellowish or greenish (pink when breeding). Breeding birds have two long white head plumes. Immature: Warm brown, streaked and spotted with buff and white.

Voice: A flat quok! or quark! Most often heard at dusk.

Range: S. Canada to Falklands; Eurasia, Africa, Pacific Is. West: Map 26. Habitat: Marshes, shores; roosts in trees.

\section{YELLOW-CROWNED NIGHT-HERON Nyctanassa violacea}

$22-28^{\prime \prime}(55-70 \mathrm{~cm})$. A chunky gray heron; head black, with a white cheek patch and crown. Immature: Similar to young Black-crown; duskier, more finely streaked and spotted. Bill thicker, legs longer. In flight, the entire foot extends beyond the tail.

Voice: Quark, higher pitched than note of Black-crown.

Range: Eastern U.S. to n. Peru and s. Brazil. West: Casual or accidental straggler west of $100^{\circ}$ to Saskatchewan, Montana, Wyoming, Colorado, New Mexico, Arizona, and California.

AMERICAN BITTERN Botaurus lentiginosus

M19

$23^{\prime \prime}(58 \mathrm{~cm})$. Stocky; size of a young Night-Heron, but warmer brown; black stripe on neck. In flight, outer wing blackish, bill held more horizontal. At rest, it may stand rigid, bill pointed up.

Voice: "Pumping," or song, a slow, deep oong- $k a^{\prime}$ choonk, oong- $k a^{\prime}$ choonk, oong-ka' choonk, etc. Flushing note, kok-kok-kok.

Range: Canada to Gulf states; winters to Panama. West: Map 19. Habitat: Marshes, reedy lakes. Seldom sits in trees.

LEAST BITTERN Ixobrychus exilis

M20

$11-14^{\prime \prime}(28-35 \mathrm{~cm})$. Very small, thin, furtive; straddles reeds. Note the large buff wing patch (lacking in rails).

Voice: Song, a low, muted coo-coo-coo, heard in the marsh.

Range: Se. Canada, U.S. to ne. Argentina. West: Map 20. Habitat: Fresh marshes, reedy ponds; not easy to flush.

ROSEATE SPOONBILL Ajaia ajaja (family on p. 112)

32 " $(80 \mathrm{~cm})$. A bright pink wading bird with a long, flat, spoonlike bill. Adults are shell-pink, with a blood-red "drip" on the shoulders; tail orange. Head naked, greenish gray. Immature: See pp. 112, 113. When feeding, the bill is swept from side to side. In flight, the neck is extended.

Range: Gulf states to Argentina, Chile. West: Irregular post-breeding visitor to s. California (Salton Sea, lower Colorado R.). Accidental, Nevada, Utah, Colorado, Arizona, New Mexico, w. Texas.

WHITE-FACED IBIS Plegadis chihi (family on p. 112)

M27

$22-25^{\prime \prime}(55-63 \mathrm{~cm})$. A long-legged marsh wader with a long, decurved bill. Deep purplish chestnut; suggests a large, blackish curlew. Flies in lines with its neck outstretched, alternately flapping and gliding. Breeding birds show a white border at the base of the bill; also red legs and red lores. Immatures and non-breeding adults lack the white on the face and the red legs.

Range: Western U.S. to Argentina. West: Map 27. Habitat: Fresh marshes, irrigated land, tules. 


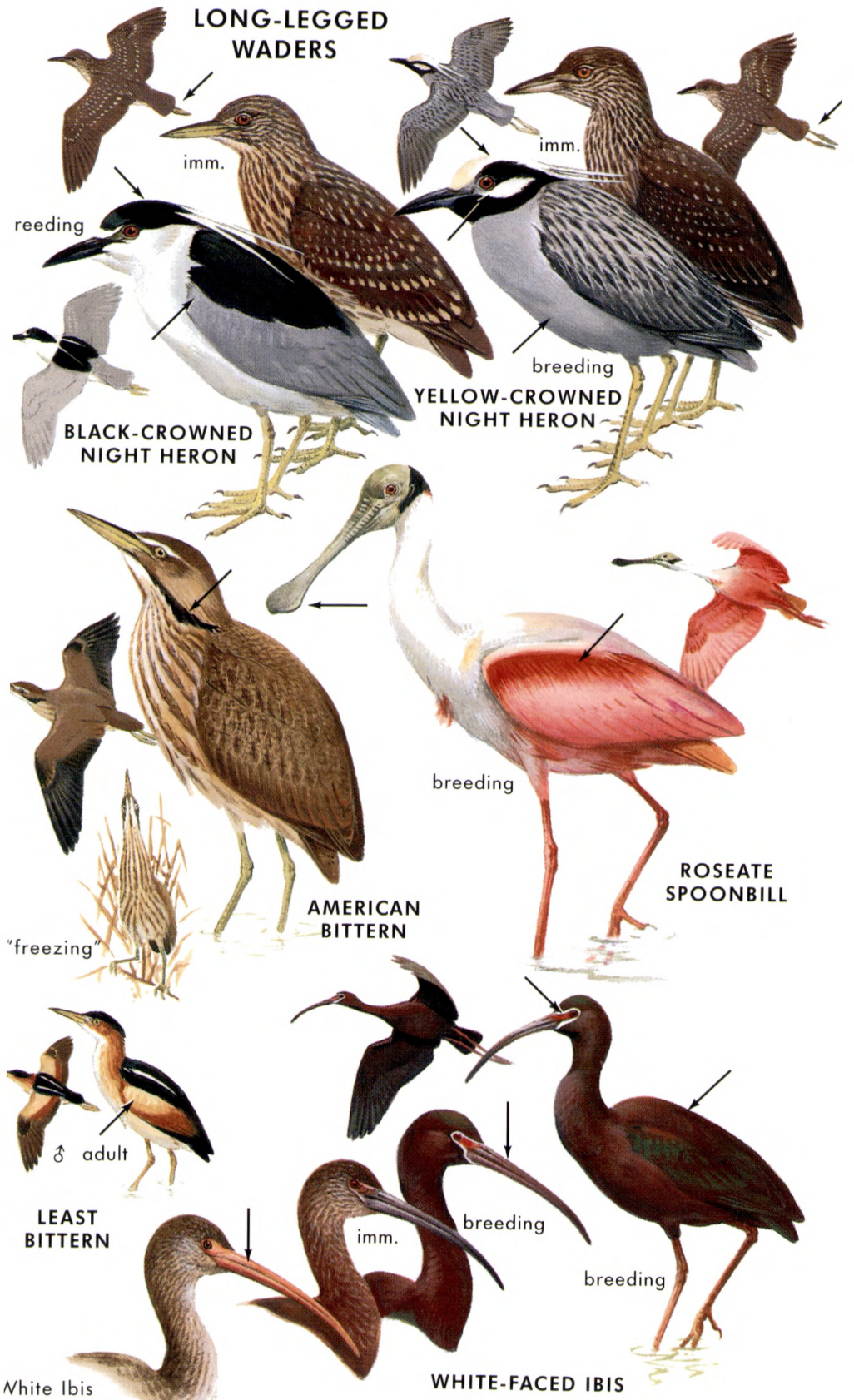

White lbis

mm. (1st fall),

or combarison 
- STORKS. Family Ciconiidae. Large, long-legged, and heronlike, with straight, recurved or decurved bills. Some have naked heads. Sexes alike. Walk is sedate; flight deliberate, neck and legs extended. Food: Frogs, crustaceans, lizards, rodents. Range: Southern U.S. to S. America; Africa, Eurasia, E. Indies, Australia. No. of species: World 18; West 1.

WOOD STORK Mycteria americana

$34-47^{\prime \prime}(85-118 \mathrm{~cm})$. Very large (spread $51 / 2 \mathrm{ft}$.). White, with a dark naked head and much black in the wing; black tail. Bill long, thick, decurved. Immature has a yellow bill. When feeding, keeps its head down and walks. In flight, it alternately flaps and glides.

Voice: A hoarse croak; usually silent.

Range: Southern U.S. to Argentina. West: Regular visitor in late summer and fall to s. California (especially Salton Sea), sw. and cen. Arizona, s. Nevada; casual or accidental to ne. California, British Columbia, Utah, Idaho, s. Montana, Wyoming, Colorado, New Mexico, and eastward. Habitat: Marshes, ponds, lagoons.

- CRANES. Family Gruidae. Stately birds, more robust than herons, often with red facial skin. Note the tufted appearance over the rump. In flight, neck extended; migrate in V's or lines like geese. Large herons are sometimes wrongly referred to as "cranes." Food: Omnivorous. Range: Nearly cosmopolitan except Cen. and S. America and Oceania. No. of species: World 15; West $2(+1$ accidental).

WHOOPING CRANE Grus americana

$50^{\prime \prime}(125 \mathrm{~cm})$; spread $71 / 2 \mathrm{ft}$. The tallest North American bird and one of the rarest. A large white crane with a red face. Primary wing feathers black. Young birds are washed with rust color, especially about the head.

Voice: A shrill, buglelike trumpeting, ker-loo! ker-lee-oo!

Range: Breeds in Wood Buffalo Park border of $\mathrm{n}$. Alberta and N.W.T.; migrates through Great Plains to coastal Texas. Reintroduced at Gray's Lake, Idaho (migrating via Colorado to Bosque Del Apache Refuge in New Mexico). Endangered but slowly increasing. SANDHILL CRANE Grus canadensis

M112 $40-48^{\prime \prime}(100-120 \mathrm{~cm})$; spread 6-7 ft. Note the bald red crown, bustlelike rear. A long-legged, long-necked, gray bird, often stained with rust. The immature is brown. In flight, the neck is extended and the wings beat with an upward flick.

Voice: A shrill, rolling garoo- $a-a-a$; repeated.

Range: Ne. Siberia, N. America, Cuba. Winters to Mexico. West: Map 112. Habitat: Prairies, fields, marshes; tundra.

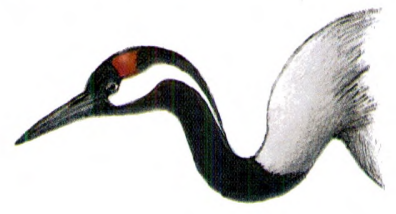

COMMON CRANE Grus grus

$41^{\prime \prime}(103 \mathrm{~cm})$. Eurasian. Note the black neck (left). May occur as a very rare vagrant in flocks of Sandhill Cranes. West: Has been recorded in Alaska, Alberta, New Mexico, Nebraska, and Texas. 
STORKS, CRANES

Below, for comparison:

left, White Ibis

right, Wood Stork

\section{Storks, ibises, and} cranes fly with iecks outstretched.

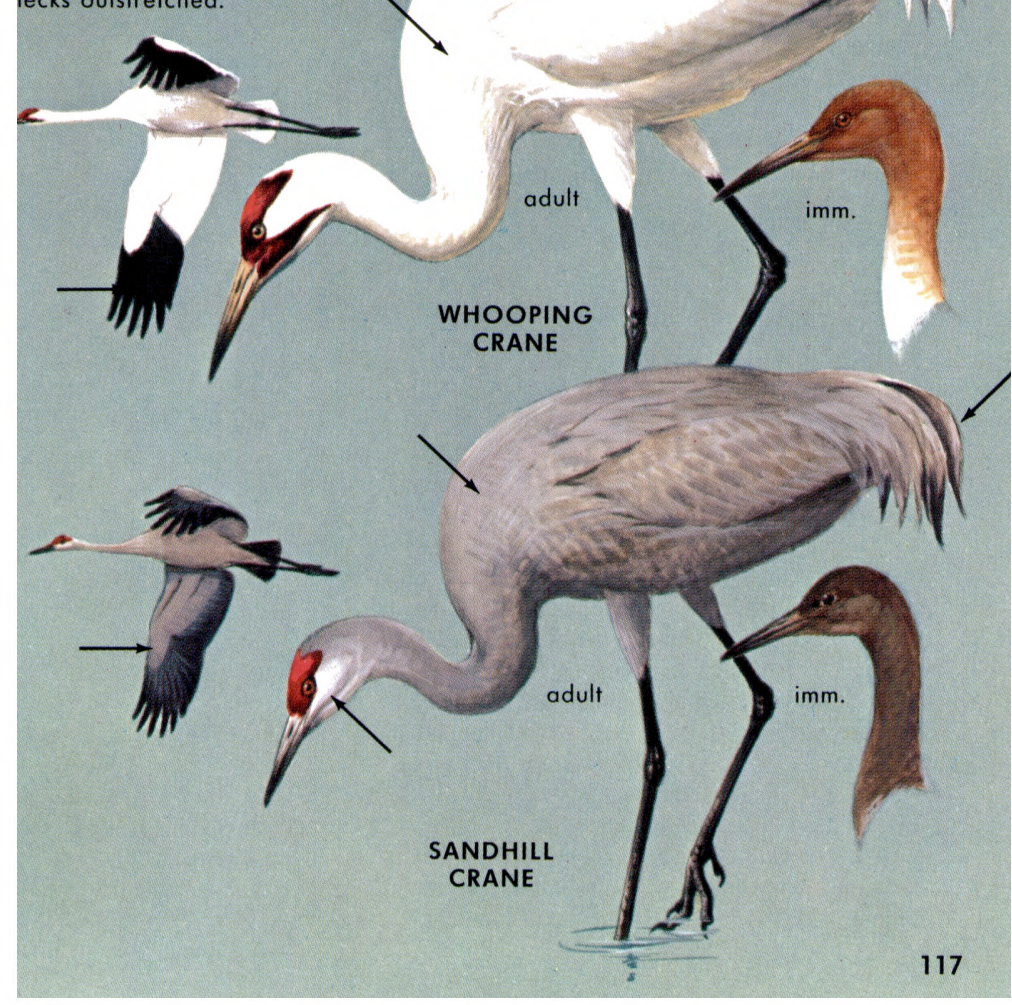


- RAILS, GALLINULES, AND COOTS. Family Rallidae (in part). Rails are rather hen-shaped marsh birds of secretive habits and mysterious voices, more often heard than seen. Their flight is brief and reluctant, with legs dangling. Gallinules and coots swim; they resemble ducks except for their smaller heads, forehead shields, and chicken-like bills. See them on pp. 64, 65; heads only are shown here. Food: Aquatic plants, seeds, insects, frogs, crustaceans, mollusks. Range: Nearly worldwide. No. of species: World 128; West $8(+2$ accidental).

SORA Porzana carolina

M109

$8-93 / 4^{\prime \prime}(20-24 \mathrm{~cm})$. Note the short yellow bill. The adult is a small, plump, gray-brown rail, with a black patch on the face and throat. The short, cocked tail reveals white or buff undertail coverts. Immature lacks the throat patch and is browner.

Voice: A descending whinny. In spring, a plaintive whistled kerwee? When hands are clapped, startled birds utter a sharp keek.

Range: Canada; w., n.-cen., and ne. U.S. Winters from s. U.S. to Peru. West: Map 109. Habitat: Fresh marshes, wet meadows; in winter, also salt marshes.

BLACK RAIL Laterallus jamaicensis

M106 $5-6 "(13-15 \mathrm{~cm})$. A tiny blackish rail with a small black bill; about the size of a young sparrow. Nape deep chestnut. Very difficult to glimpse, but may respond at night to a tape recording. Caution: All young rails in downy plumage are black.

Voice: Male at night, kiki-doo or kiki-krrr (or "kitty go").

Range: Ne. and cen. U.S. and cen. California south locally to W. Indies, Chile. West: Map 106. Habitat: Tidal marshes, (coast); grassy marshes, stubble fields (inland).

YELLOW RAIL Coturnicops noveboracensis

M105

$7 "(18 \mathrm{~cm})$. Note the white wing patch (in flight). A small buffy rail, suggesting a week-old chick. Bill very short, greenish. Back dark, striped and checkered with buff and black. Mouse-like; difficult to see or flush.

Voice: Nocturnal ticking notes, often in long series: tic-tic, tic-tictic, tic-tic, tic-tic-tic, etc., in groups of 2 and 3.

Range: Mainly Canada, n. U.S. east of Rockies. Winters se. U.S. West: Map 105. Habitat: Grassy marshes, meadows; rarely salt marshes.

VIRGINIA RAIL Rallus limicola

M108

9" $(23 \mathrm{~cm})$. A small rusty rail with gray cheeks, black bars on the flanks, and a long, slightly decurved, reddish bill. Near the size of a meadowlark; the only small rail with a long, slender bill. Grown young in late summer show much black.

Voice: Wak-wak-wak, etc., descending; also kidick, kidick, etc. and various "kicking" and grunting sounds.

Range: S. Canada to S. S. America. West: Map 108. Habitat: Fresh and brackish marshes; in winter, also salt marshes.

CLAPPER RAIL Rallus longirostris

14-16" (35-40 cm). The large tan and gray "marsh hen" of California coastal marshes. Note the henlike appearance; strong legs; long, slightly decurved bill; barred flanks; and white patch under the short cocked tail, which it flirts nervously. (continued on p.120) 
RAILS
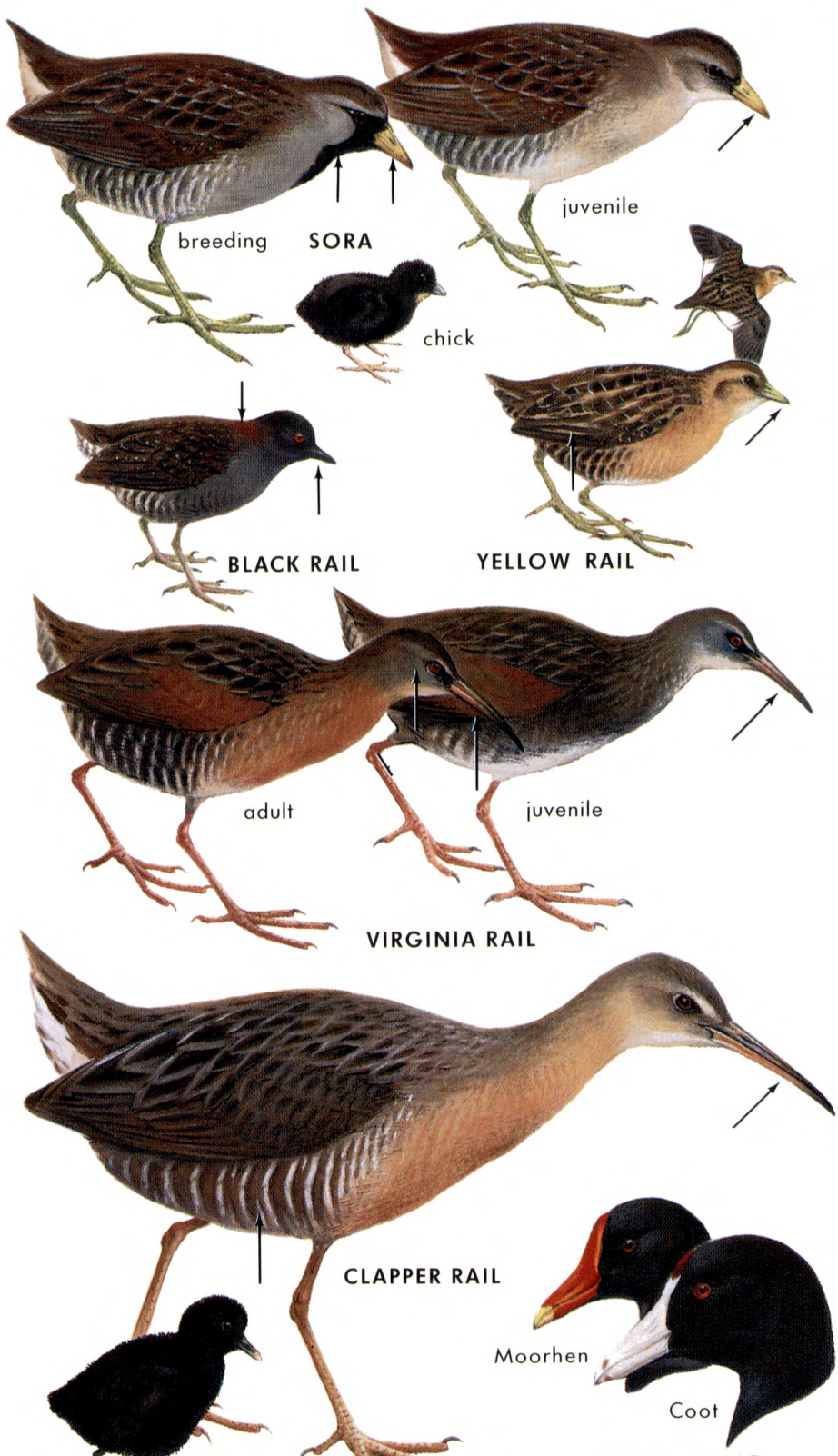

See pp. 64, 65 . 
CLAPPER RAIL (continued). See illustration on previous page.

Voice: A clattering kek-kek-kek-kek, etc., or cha-cha-cha, etc.

Range: Coasts of e. U.S. and California to n. S. America. West: Map 107. Habitat: Salt marshes and brackish marshes.

Note: The similar and closely related KING RAIL (Rallus elegans), a large rusty rail of marshes east of our area, has strayed west to Colorado. See illustration in eastern Field Guide.

- OYSTERCATCHERS. Family Haematopodidae. Large waders with long, laterally flattened, chisel-tipped, red bills. Sexes alike. Food: Mollusks, crabs, marine worms. Range: Widespread on the coasts of the world; inland in some areas of Europe and Asia. No. of species: World 7; West 2.

BLACK OYSTERCATCHER Haematopus bachmani M119 $17-171 \frac{1}{2}$ " (43-44 cm). A large, heavily built, blackish shorebird, with a straight red bill, flattened laterally. Legs a pale flesh color. Immature may have a black tip on the bill.

Voice: A piercing, sharply repeated, whistled wheep! or kleep!

Range: Resident from w. Aleutians (Attu), east and south along coast to Morro Bay, California; on offshore islands to Baja California. West: Map 119. Habitat: Rocky coasts, sea islets.

AMERICAN OYSTERCATCHER Haematopus palliatus

$17-21^{\prime \prime}(43-53 \mathrm{~cm})$. Differs from Black Oystercatcher in having a white belly and large white wing and tail patches. Its red bill and pale legs are like those of the Black Oystercatcher.

Range: Shores of Cape Cod south to Argentina; w. Mexico to Chile. West: Casual stray to California coast, Channel Islands, Salton Sea.

aVOCETS, STILTS. Family Recurvirostridae. Slim waders with very long legs and very slender bills (bent upward in avocets). Sexes similar. Food: Insects, crustaceans, other aquatic life. Range: U.S., Cen. and S. America, Africa, s. Eurasia, Australia, Pacific region. No. of species: World 9; West 2.

BLACK-NECKED STILT Himantopus mexicanus

M120 13-17" (33-43 cm). A large, extremely slim wader; black above, white below. Note the grotesquely long red legs and needle-like bill. In flight, the black unpatterned wings contrast strikingly with the white rump, tail, and underparts.

Voice: A sharp yipping: kyip, kyip, kyip. Range: W. and se. U.S. to Argentina. Winters mainly south of U.S. West: Map 120. Habitat: Grassy marshes, mudflats, pools, shallow lakes (fresh and alkaline). AMERICAN AVOCET Recurvirostra americana

M121 16-20" $(40-50 \mathrm{~cm})$. A large, slim shorebird with a very slender, upturned, somewhat godwit-like bill, more upturned in the female. This and the striking white and black pattern make this bird unique. In breeding plumage, the head and neck are pinkish tan; in winter this is replaced with pale gray. Avocets feed with a scythelike sweep of the head and bill.

Voice: A sharp wheek or kleet, excitedly repeated. Range: Breeds sw. Canada, w. U.S. Winters from s. U.S. to Guatemala. West: Map 121. Habitat: Beaches, flats, shallow lakes, prairie ponds. 


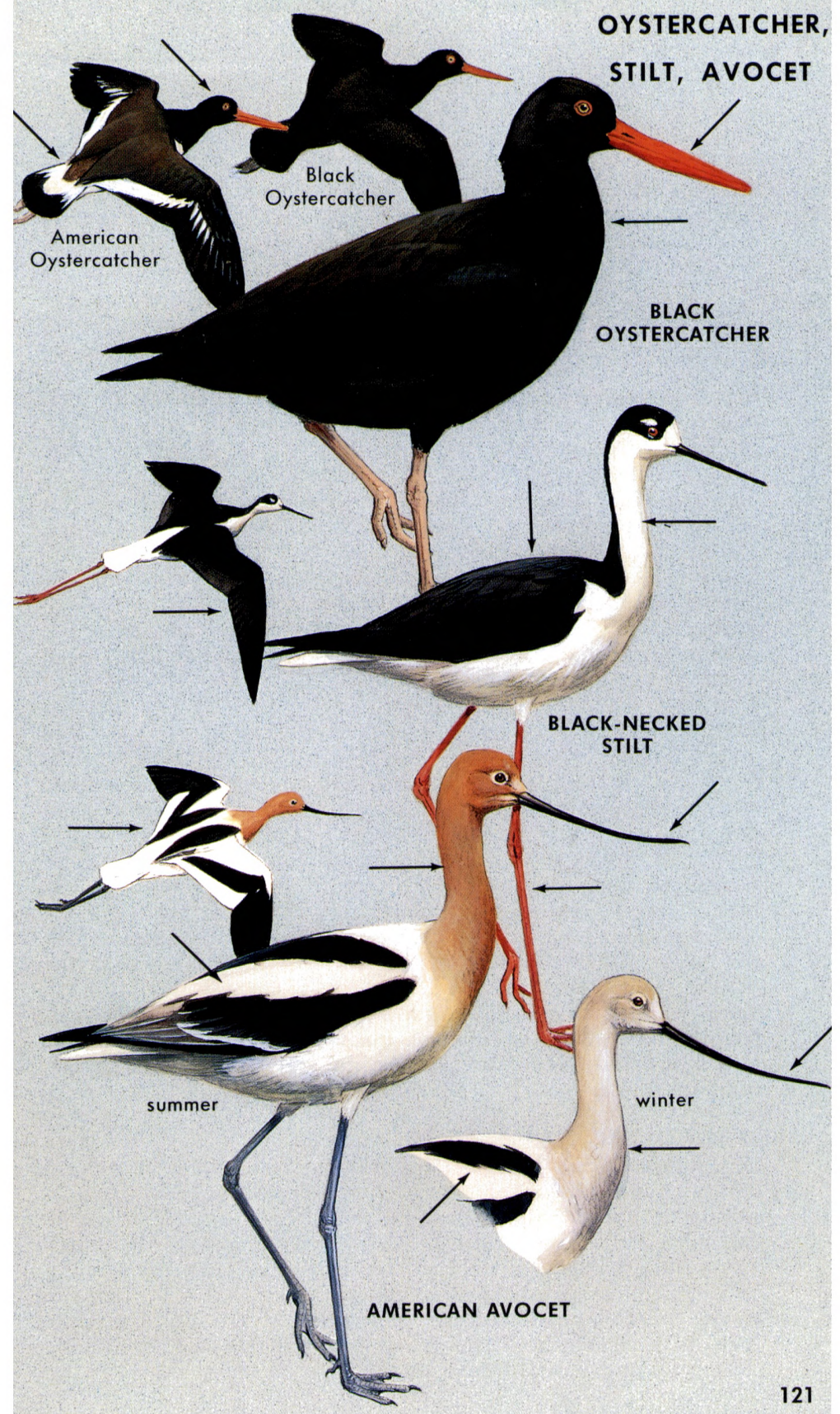


- PLOVERS. Family Charadriidae. Wading birds, more compactly built and thicker-necked than most sandpipers, with shorter, pigeon-like bills and larger eyes. Call notes assist identification. Unlike most sandpipers, plovers run in short starts and stops. Sexes alike. Note: The turnstones (pp. 142, 143) until recently were assigned to the plover family, but are now regarded as more closely allied to the sandpipers, Scolopacidae. Food: Small marine life, insects, some vegetable matter. Range: Nearly worldwide. No. of species: World 67; West $12(+1$ accidental).

BLACK-BELLIED PLOVER Pluvialis squatarola

M113

$10^{1 / 2}-13^{1 / 2} 2^{\prime \prime}(26-34 \mathrm{~cm})$. A large plover. In breeding plumage adults have a black breast and pale speckled back. Winter birds and immatures are gray-looking, but can be recognized as plovers by their stocky shape; hunched posture; and short, pigeon-like bill. In flight, in any plumage, note the black axillars ("wingpits") and the white rump and tail.

Similar species: American Golden-Plover and Pacific Golden-Plover are browner and lack the pattern of white in the wings and tail. Their axillars are gray, not black.

Voice: A plaintive slurred whistle, tlee-oo-eee or whee-er-ee (middle note lower).

Range: Arctic; circumpolar. Winters from coastal U.S. and s. Eurasia to S. Hemisphere. West: Map 113. Habitat: Mudflats, open marshes, beaches; in summer, tundra.

AMERICAN GOLDEN-PLOVER Pluvialis dominica

M114

(Lesser Golden-Plover) 91/2-11" (24-28 cm). Size of Killdeer. Breeding adults are dark, spangled above with whitish and pale yellow spots; underparts black. A broad white stripe runs over the eye and down the sides of the neck and breast. Young birds and winter adults are brown, darker above than below. In flight, they can be recognized from Black-bellied Plovers by their browner look and lack of pattern in wings and tail.

Similar species: Formerly this bird was lumped as one species with the Pacific Golden-Plover; collectively they were known as the "Lesser Golden-Plover."

Voice: A whistled queedle or que-e-a (dropping at end).

Range: Breeds in arctic America; migrates mainly east of Rockies to s. S. America. West: Map 114. Habitat: Prairies, mudflats, shores; tundra (summer).

PACIFIC GOLDEN-PLOVER Pluvialis fulva

M114

Very similar to the American Golden-Plover, overlapping in summer only in nw. mainland Alaska. It is the species most likely to be seen in the Pacific states. The white neck stripe extends along the flank (but molting American Golden-Plovers may have this look). The golden spangles on the back are brighter. Winter and juvenile birds are also more golden than the other species.

Range: Breeds across n. Siberia and in nw. Alaska. Winters in se. Asia, Australia, Pacific islands. West: A few migrate along the Pacific Coast to winter in California. Map 114. 


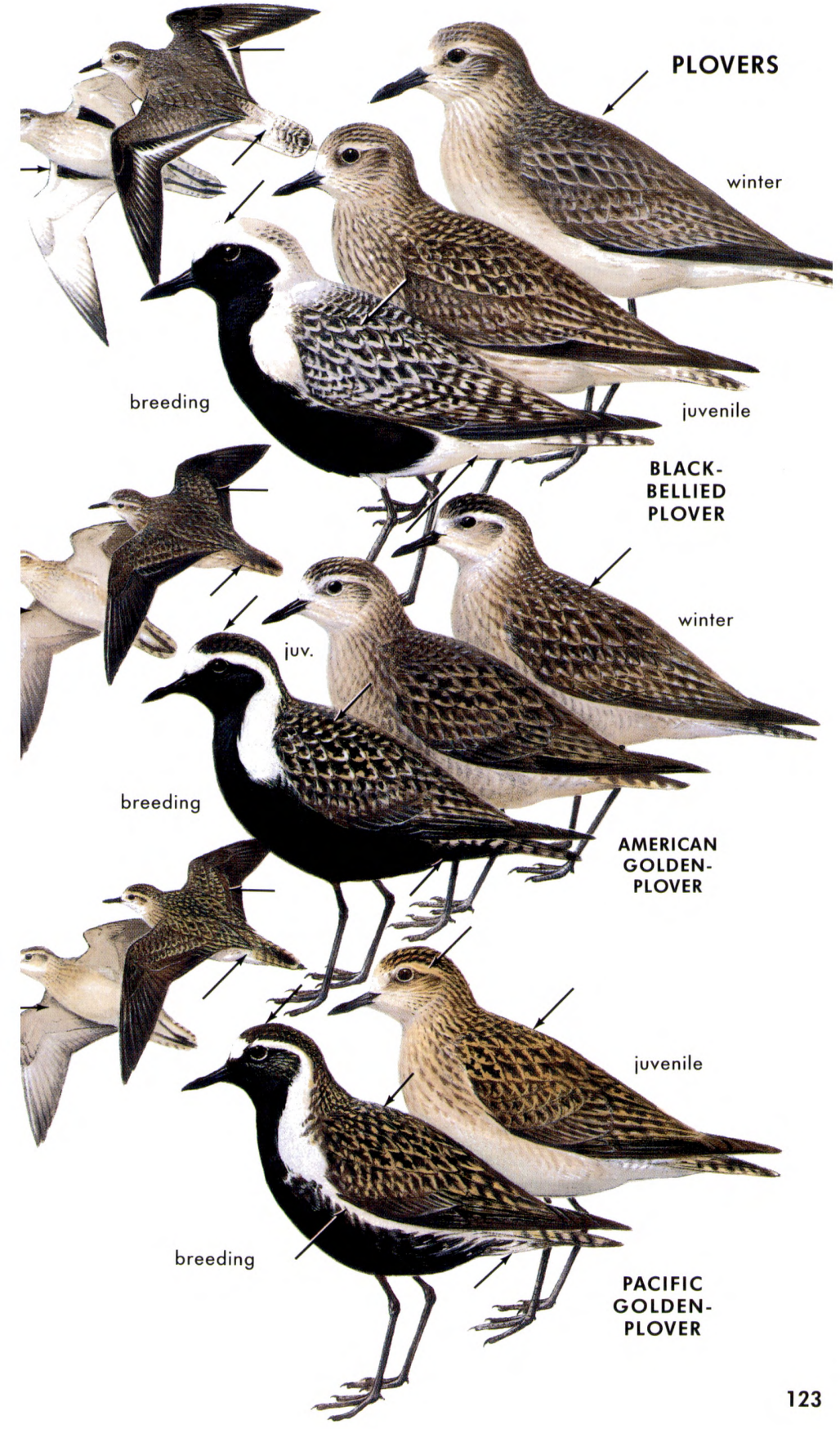


$61 / 2-712^{\prime \prime}(16-19 \mathrm{~cm})$. A small, plump, brown-backed plover, half the size of a Killdeer, with a single dark breastband. Bill deep yellow with a black tip, or (in winter) nearly all dark. Legs bright orange or yellow. Whereas the Piping and Snowy plovers are pale-the color of dry sand-the Semipalmated is darker, like wet sand or mud.

Voice: A plaintive, upward-slurred chi-we or too-li.

Range: Arctic and subarctic America. Winters to S. America. West: Map 116. Habitat: Shores, tideflats, tundra.

PIPING PLOVER Charadrius melodus

M115

$6-7 \frac{1}{2} 2^{\prime \prime}(15-19 \mathrm{~cm})$. As pallid as a beach flea or sand crab-the color of dry sand. A complete or incomplete dark ring around the neck. Legs yellow or orange; bill yellow with a black tip. In non-breeding plumage the black on the collar is indistinct or lacking and the bill is black. Note the tail pattern.

Voice: A plaintive whistle; peep-lo (first note higher).

Range: Breeds s. Canada to ne. and cen. U.S. Winters s. Atlantic and Gulf coasts. West: Map 115. Habitat: Sandy beaches.

SNOWY PLOVER Charadrius alexandrinus

M115

$61 / 2^{\prime \prime}(16 \mathrm{~cm})$. A pale plover of the beaches. Similar to the Piping Plover, which replaces it to the east and north (see map), but male Snowy has a slim black bill, dark (sometimes pale) legs, and a dark ear patch. Females and juveniles may lack the black in their plumage. Juvenile and winter Piping Plovers may also have dark bills, but they have white on the rump, visible in flight.

Voice: A musical whistle; pe-wee-ah or o-wee-ah.

Range: Southern U.S., cen. and S. America, s. Eurasia, Africa, Australia. West: Map 115. Habitat: Beaches, sandy flats.

\section{COMMON RINGED PLOVER Charadrius hiaticula}

$71 / 4^{\prime \prime}(19 \mathrm{~cm})$. A Eurasian stray, very similar to the Semipalmated Plover; distinguished in the hand by the presence of a basal web between only two toes. The breastband may be wider. Best recognized from Semipalmated by voice, a softer, more minor poo-eep or too-li.

Range: N. Eurasia, Greenland, arctic Canada. West: Casual visitor to w. Aleutians and St. Lawrence I., where it has bred.

LITTLE RINGED PLOVER Charadrius dubius

6" $(15 \mathrm{~cm})$. Resembles Common Ringed Plover, but decidedly smaller. Best distinguished by a bright yellow eye-ring and, in flight, lack of a white wing bar. Legs flesh-colored (not orange), but color not reliable when legs are muddy. Different voice.

Voice: A high, piping tee-u.

Range: Eurasia, n. Africa, New Guinea. West: Accidental, w. Aleutians.

WILSON'S PLOVER Charadrius wilsonia

7-8" (18-20 cm). A "ringed" plover of the Mexican beaches, larger than the Semipalmated, with a much longer heavy black bill. Legs flesh-gray. Tends to have a heavier breastband.

Voice: An emphatic whistled whit! or wheet!

Range: New Jersey, and w. Mexico to n. S. America. West: Casual, s. California. 


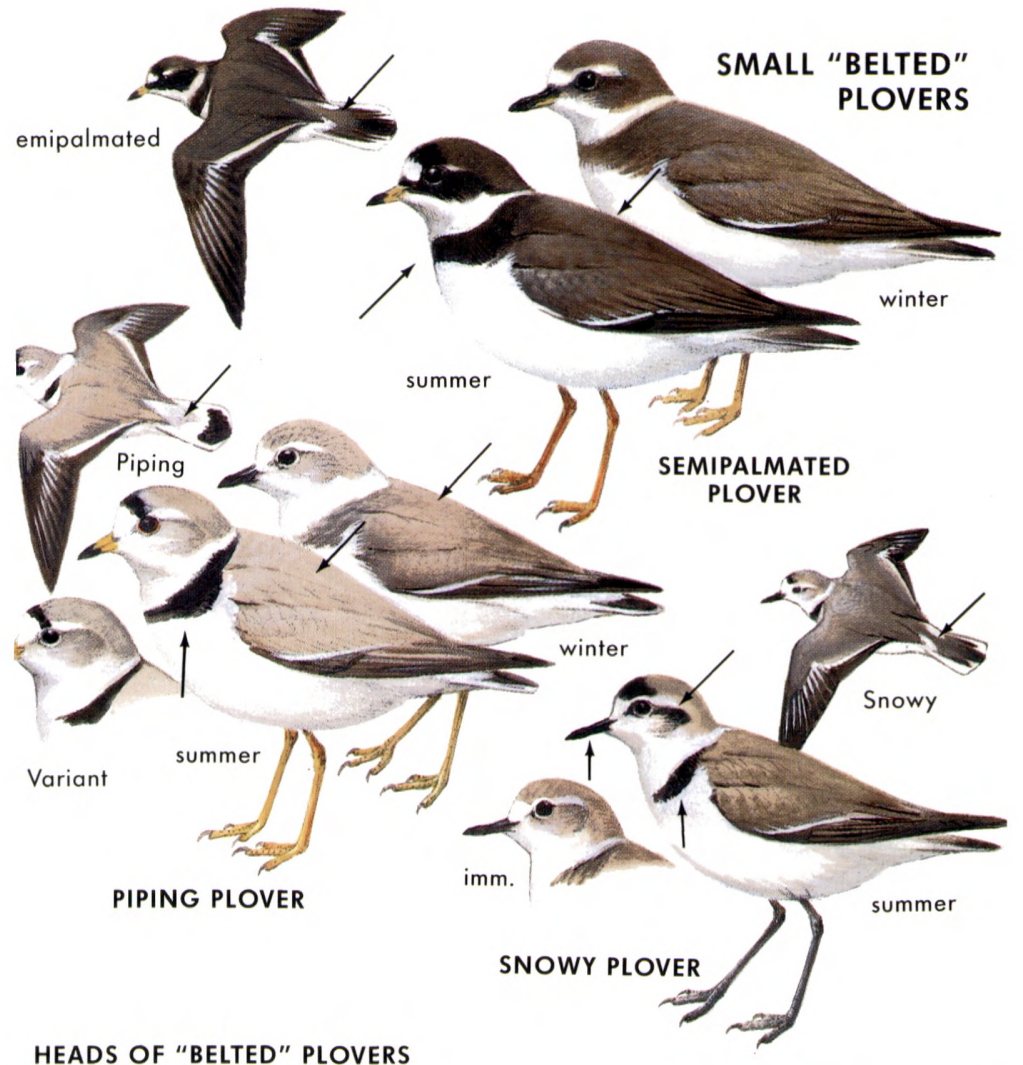

HEADS OF"BELED"PLOVERS

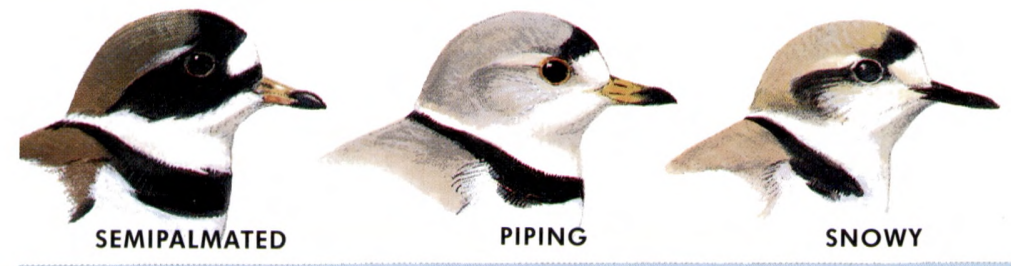

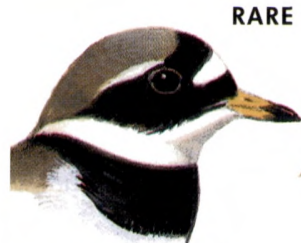

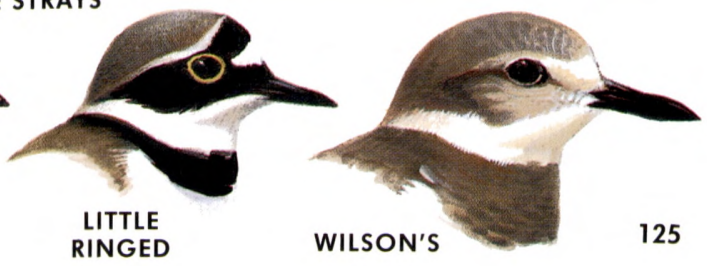


9-11" $(23-28 \mathrm{~cm})$. The common noisy breeding plover of the farm country. Note the two black breastbands (the chick has only one band). In flight, or distraction display near the nest, shows a goldentawny rump; longish tail, white wing stripe.

Voice: Noisy; a loud, insistent kill-deeah, repeated; a plaintive deeee (rising), dee-dee-dee, etc. Also a low trill.

Range: S. Alaska, Canada to cen. Mexico, W. Indies; also coastal Peru. West: Map 117. Habitat: Fields, airports, lawns, river banks, mudflats, shores.

MOUNTAIN PLOVER Charadrius montanus

M118

$8-91 \frac{1}{2} "(20-24 \mathrm{~cm})$. Somewhat like a small Killdeer, but with no breast-rings. In breeding season, has a white forehead and line over the eye, contrasting with a dark crown. In nondescript winter plumage, it may be told from winter Golden-Plovers by its grayer back (devoid of mottling), pale legs, light wing stripe, and dark tail band. Voice: A low whistle; variable.

Range: Western Great Plains. Map 118. Habitat: Semi-arid plains, grasslands, plateaus.

\section{EURASIAN DOTTEREL Charadrius morinellus}

$81 / 2^{\prime \prime}(21 \mathrm{~cm})$. In breeding plumage the narrow white stripe crossing mid-breast identifies this dark plover. Belly russet orange. The broad white eyebrow stripes join in a broad " $\mathrm{V}$ " on the nape. Throat white. Non-breeding adults and juveniles are paler, but show enough of the basic pattern to be recognized.

Voice: A repeated piping: titi-ri-titi-ri, running into a trill.

Range: Eurasia. West: Breeds locally on the high tundra of nw. Alaska and St. Lawrence I. It has been recorded in fall in the w. Aleutians and as an accidental in Washington and California.

MONGOLIAN PLOVER Charadrius mongolus

$71 / 2^{\prime \prime}(19 \mathrm{~cm})$. This Asian plover is very distinctive in breeding plumage, with its broad cinnamon breastband separating its white throat from its white belly. The female is duller. The rufous band is absent in non-breeding or juvenile birds.

Range: Asia, migrating to e. Africa, India, Australia. West: Rare migrant in the western Aleutian Islands. Occasional on the northern and western mainland of Alaska (has bred there). Accidental in Oregon and California. 

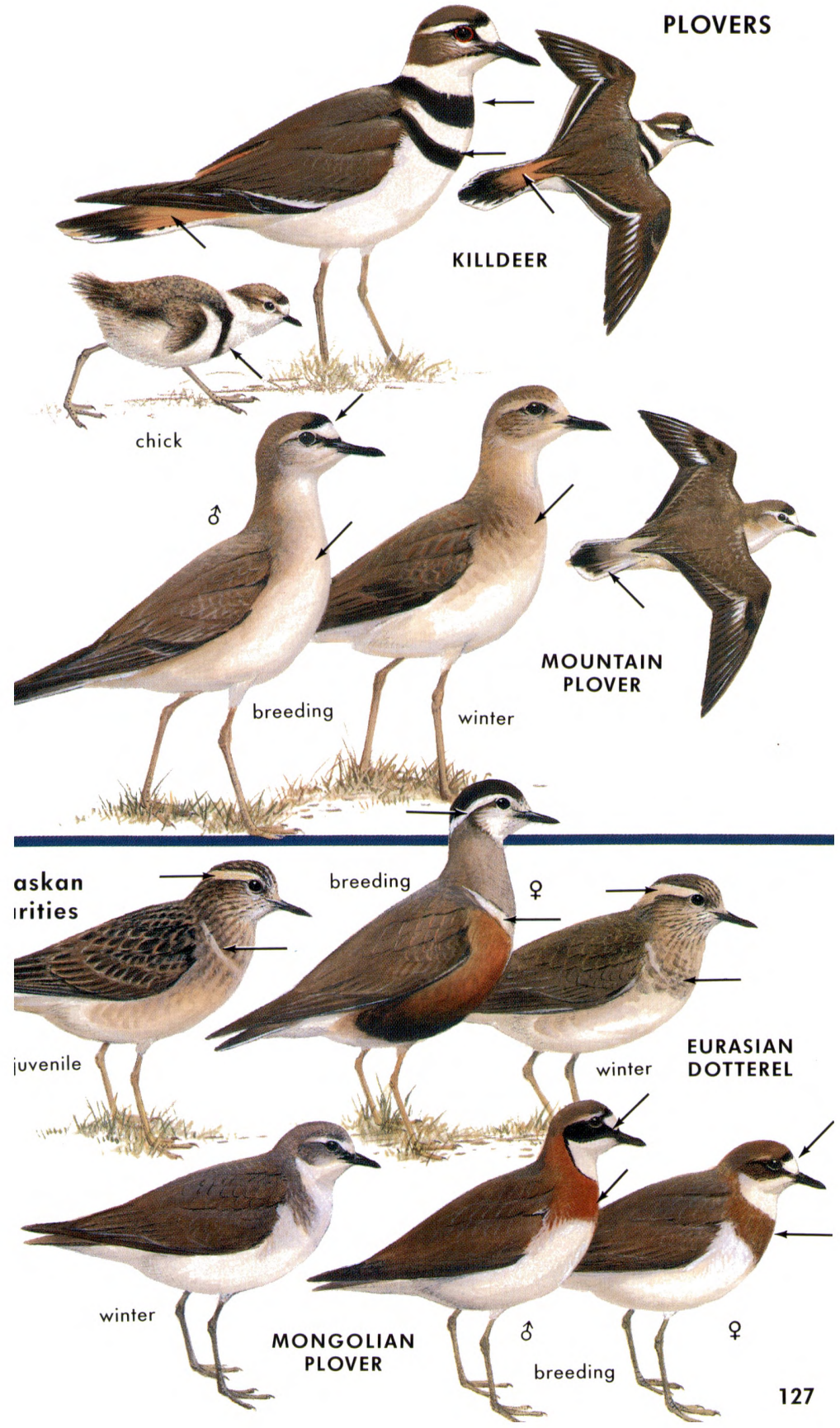


\section{SHOREBIRDS}

The shorebirds (or "waders," as they are often called) are real puzzlers to the novice. There are a dozen plovers in our area and nearly 60 sandpipers and their allies, not to mention the very obvious oystercatchers, stilts, and avocets. To start with, here are a few things to look for:

\section{Plovers vs. Sandpipers}

Plovers are usually more compact and thicker-necked than most sandpipers, with pigeon-like bills and larger eyes. They run in short starts and stops.

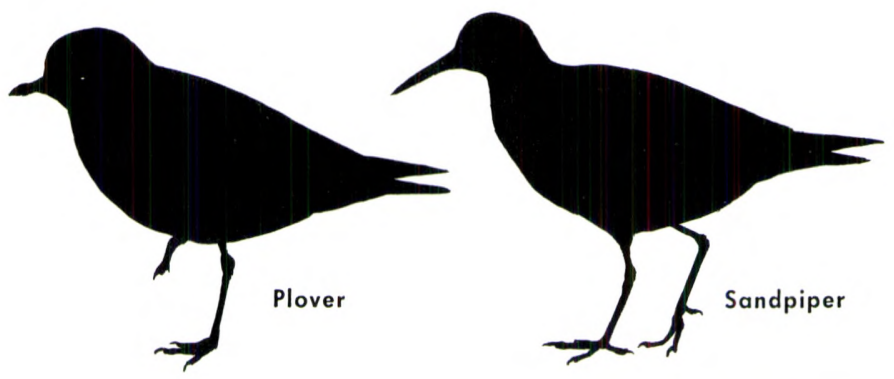

\section{BILL SHAPES OF SHOREBIRDS}

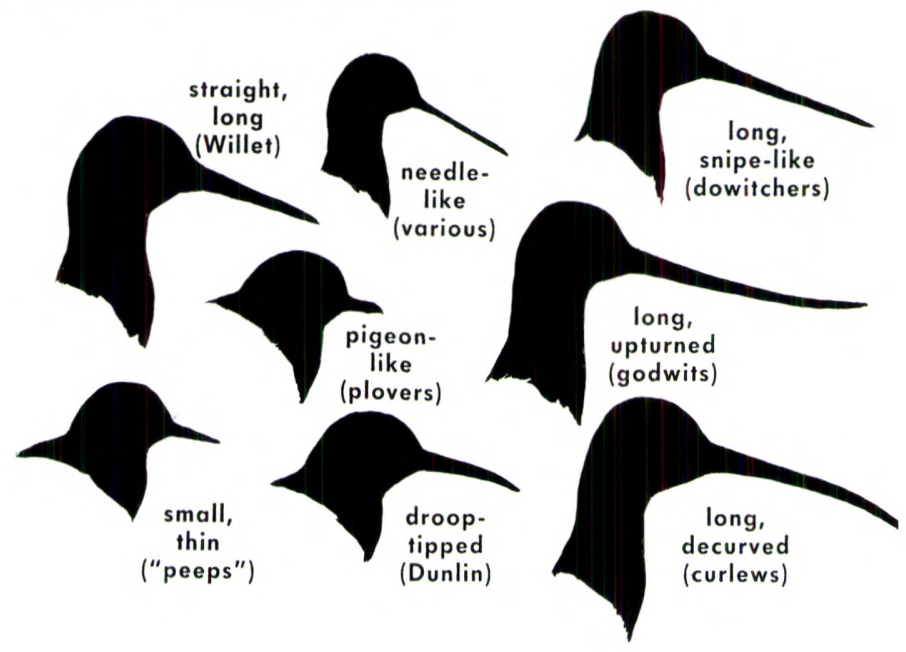


- SANDPIPERS, PHALAROPES. Family Scolopacidae. Small to medium-sized waders. Bills more slender than those of plovers. Sexes similar, except in phalaropes (swimmers that were formerly regarded as a separate family). Food: Insects, crustaceans, mollusks, worms, etc. Range: Cosmopolitan. No. of species: World 129; West $51(+7$ accidental).

\section{SOME BASIC BODY}

SHAPES AND ACTIONS

OF SANDPIPERS
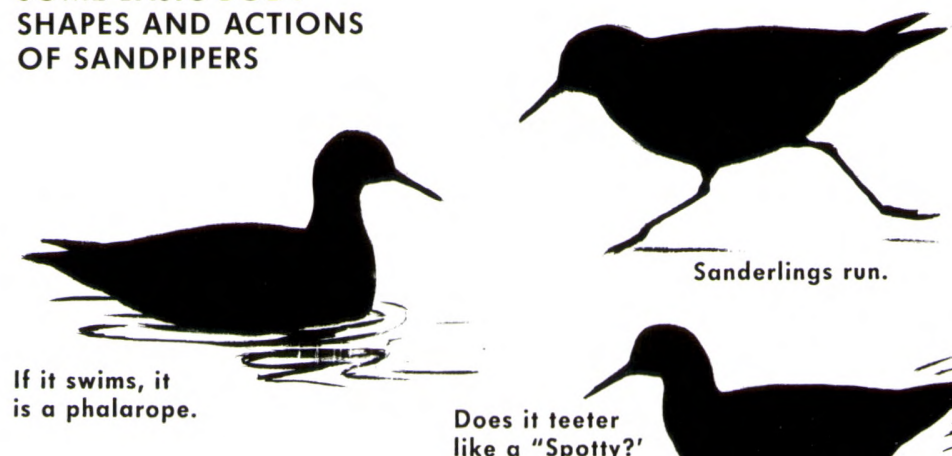

Sanderlings run.

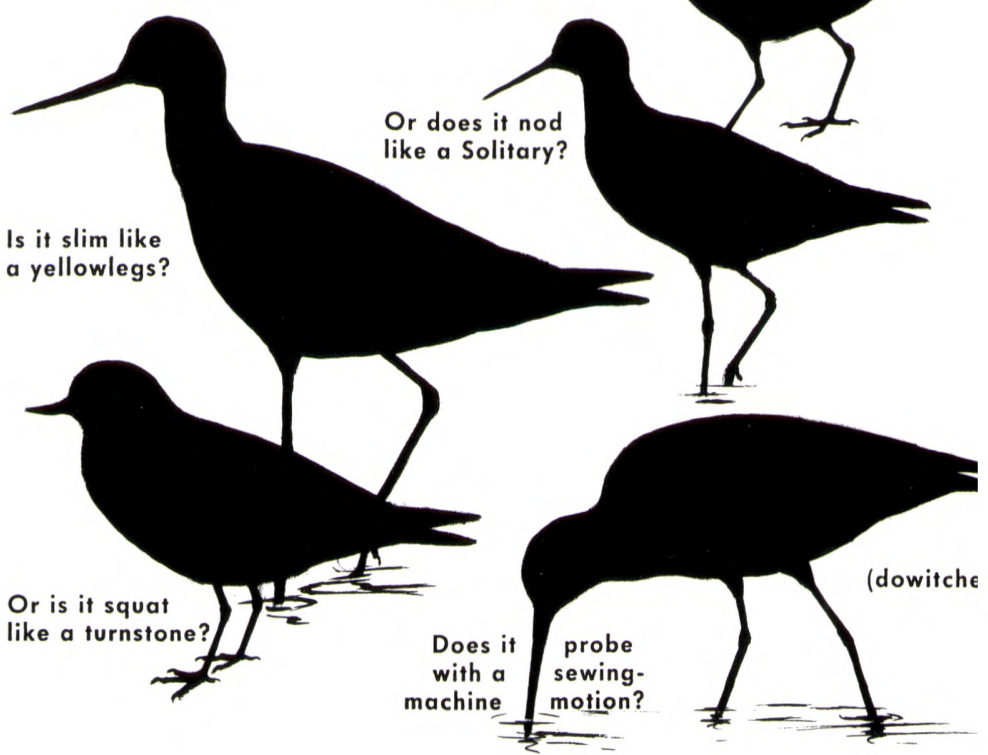




\section{HUDSONIAN GODWIT Limosa haemastica}

$13-16^{\prime \prime}(33-40 \mathrm{~cm})$. Note the flight pattern (p. 133). The rather large size and long, straight or slightly upturned bill mark this wader as a godwit; the black tail is ringed broadly with white. The blackish wing linings proclaim it as this species. In spring the male is ruddybreasted; the female duller. In fall, both sexes are gray-backed, palebreasted.

Similar species: The Black-tailed Godwit, a stray from Asia, is shown on p. 153.

Voice: Tawit! (or godwit!); higher-pitched than Marbled Godwit's.

Range: Mainly arctic Canada; winters in S. America. West: Breeds locally in s. Alaska (Cook Inlet), probably w. Alaska (Kotzebue and Norton Bay), Mackenzie and nw. British Columbia. Migrates in spring through Great Plains; very rare west to Pacific states. Habitat: Beaches, prairie pools; in summer, tundra.

MARBLED GODWIT Limosa fedoa

M132

16-20" $(40-50 \mathrm{~cm})$. Godwits are large shorebirds with long, straight or slightly upturned bills. The rich, mottled buff-brown color identifies this species. The linings of the underwing are cinnamon.

Voice: An accented kerwhit! (godwit!); also raddica, raddica.

Range: N. Great Plains; locally sw. Alaska. Winters s. U.S. to n. S. America. West: Map 132. Habitat: Prairies, pools, shores, tideflats.

LONG-BILLED CURLEW Numenius americanus

M130 $20-26 "(50-65 \mathrm{~cm})$. Note the very long, sickle-shaped bill (4$\left.81 / 2^{\prime \prime}\right)$. Much larger than the Whimbrel and more buffy; lacks the bold crown stripes. Overhead, shows cinnamon wing linings. In young birds the bill may be scarcely longer than that of the Whimbrel (see inset).

Voice: A loud cur-lee (rising inflection); a rapid, whistled kli-li-lili. "Song," a trilled, liquid curleeeeeeeeuuu.

Range: Sw. Canada, w. U.S. Winters s. U.S. to Guatemala. West: Map 130. Habitat: High plains, rangeland. In winter, also cultivated land, tideflats, beaches, salt marshes.

WHIMBREL Numenius phaeopus

M129

$15-19^{\prime \prime}(38-48 \mathrm{~cm})$. A large, gray-brown wader with a long, decurved bill. Grayer than the Long-billed Curlew; bill shorter (23/4-4 in.), crown striped. Whimbrels fly in lines. The pale-rumped Eurasian race (not shown) is a rare migrant in the Bering Sea area of Alaska. Voice: Five to seven short, rapid whistles: ti-ti-ti-ti-ti-ti.

Range: Arctic, circumpolar. Winters to s. S. America. West: Map 129. Habitat: Shores, mudflats, marshes, prairies, tundra.

ESKIMO CURLEW Numenius borealis

$12-14^{\prime \prime}(30-35 \mathrm{~cm})$. Much smaller than the Whimbrel. Bill shorter $\left(1^{3 / 4}-2^{1 / 2^{\prime \prime}}\right)$ and thinner, only slightly curved. More patterned above than the Whimbrel. Linings of raised wing cinnamon. Legs slategray. Note the unbarred primaries. See Little Curlew (p. 152).

Voice: Tee-dee-dee, or a repeated tee-dee.

Range: Near extinction. Formerly arctic America, wintering in s. S. America. Migrated down East Coast in fall, through Great Plains in spring. West: Bred formerly in nw. Canada, perhaps Alaska. A very few pairs apparently still breed in nw. Canada. 

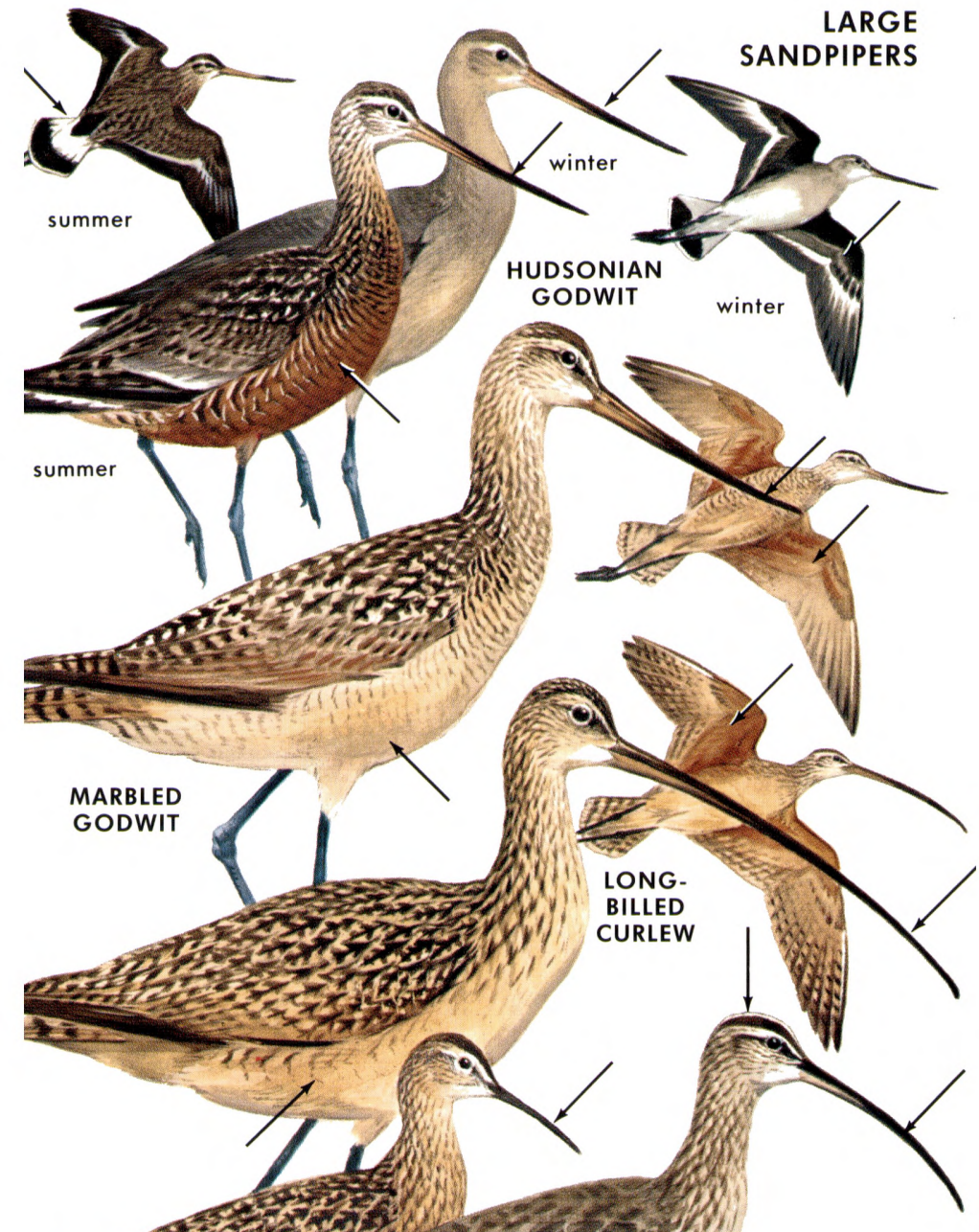

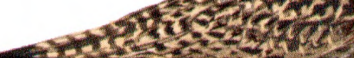

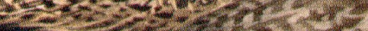

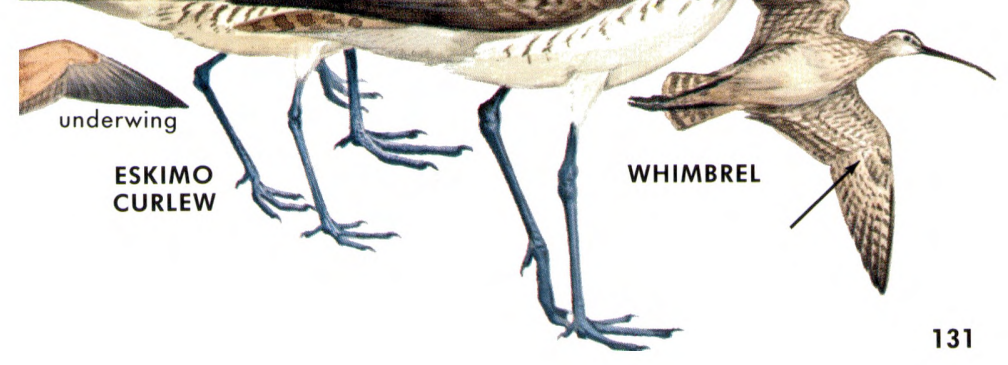




\section{LARGE SHOREBIRDS IN FLIGHT}

Learn to know their flight calls, which are quite diagnostic.

HUDSONIAN GODWIT Limosa haemastica

Upturned bill, white wing stripe, ringed tail. Overhead,

Text and color plate shows blackish wing linings.

Flight call, tawit!, higher-pitched than Marbled's.

WILLET Catoptrophorus semipalmatus

Contrasty black, gray, and white wing pattern.

pp. 134,135

Overhead, the wing pattern is even more striking.

Flight call, a whistled whee-wee-wee.

MARBLED GODWIT Limosa fedoa

Long upturned bill, tawny brown color. Overhead, shows

pp. 130,131 cinnamon wing linings.

Flight call, an accented kerwhit! (or godwit!).

WHIMBREL Numenius phaeopus

Decurved bill, gray-brown color, striped crown.

pp. 130,131

Overhead, grayer than next species, lacks cinnamon wing linings.

Flight call, 5-7 short rapid whistles: ti-ti-ti-ti-ti-ti.

LONG-BILLED CURLEW Numenius americanus

Very long, sickle-like bill; no head striping. Overhead,

pp. 130,131

shows bright cinnamon wing linings.

Flight call, a rapid, whistled kli-li-li-li.

\section{BAR-TAILED GODWIT}

Limosa lapponica (shown below)

pp. 152,153

Upturned bill, barred tail, a mottled rump.

\section{BRISTLE-THIGHED CURLEW}

Numenius tahitensis (shown below)

Decurved bill, tawny-buff rump.

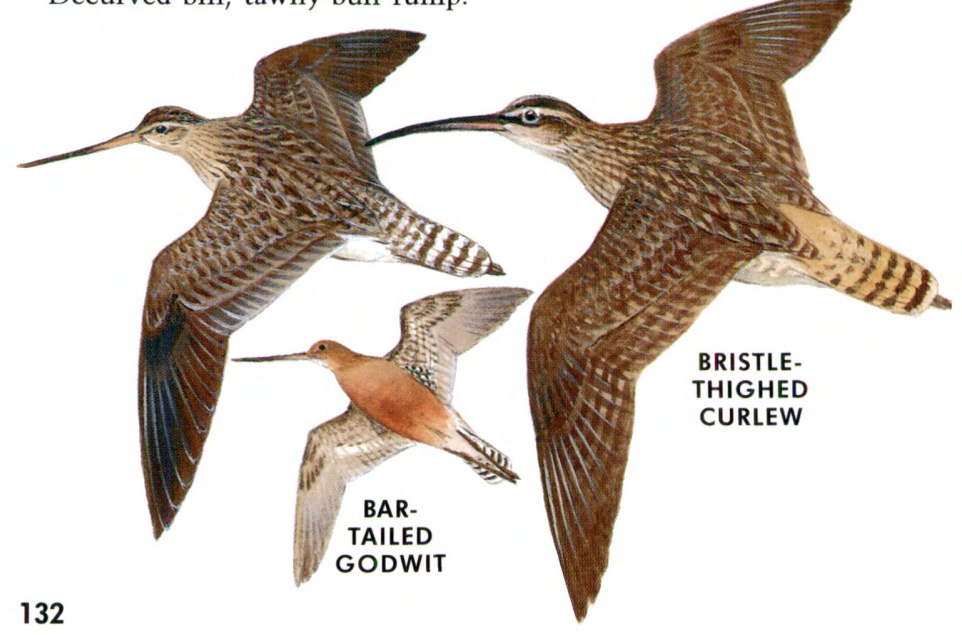




\section{WADERS IN FLIGHT}
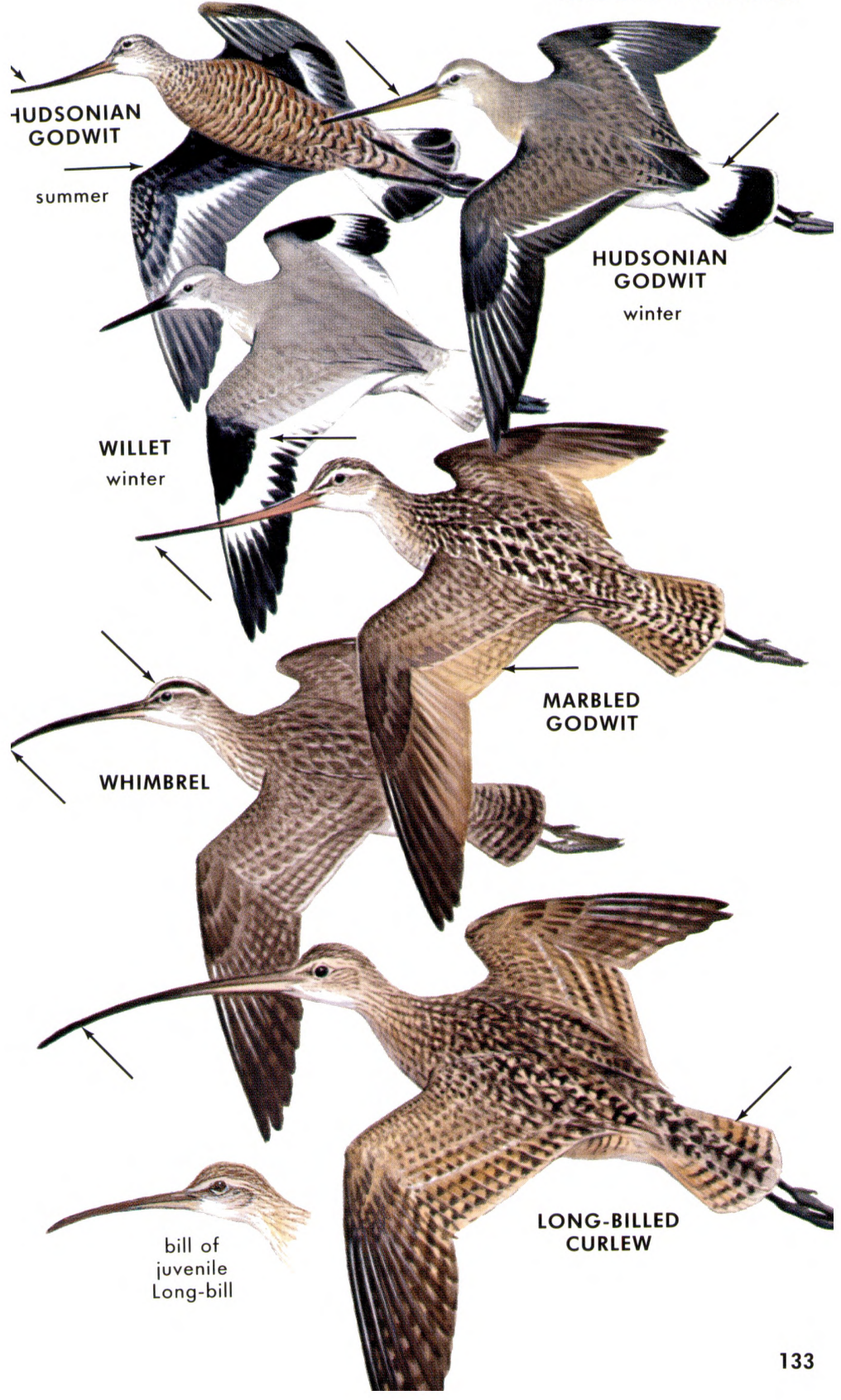
14-17" (35-43 cm). When standing, stockier than the Greater Yellowlegs; has a grayer look, heavier bill, bluish legs. In flight, note the striking black and white wing pattern. At rest, when the banded wings cannot be seen, this large wader is rather nondescript: gray above, somewhat scaled below in summer, unmarked below in fall and winter; legs bluish gray.

Voice: A musical, repetitious pill-will-willet (in breeding season); a loud kay-ee (second note lower). Also a rapidly repeated kip-kip-kip, etc. In flight, whee-wee-wee.

Range: Cen.-s. Canada to Gulf of Mexico, W. Indies. Winters s. U.S. to Brazil and Peru. West: Map 125. Habitat: Marshes, wet meadows, mudflats, beaches.

\section{GREATER YELLOWLEGS Tringa melanoleuca}

M122

$14^{\prime \prime}(35 \mathrm{~cm})$. Note the bright yellow legs (shared with the next species, but leg joints thicker). A slim gray sandpiper; back checkered with gray, black, and white. In flight, it appears dark-winged (no stripe), with a whitish rump and tail. Bill long, slightly upturned, paler at base.

Voice: Three-noted whistle, whew-whew-whew, or dear! dear! dear!

Range: Alaska, Canada. Winters U.S. to Tierra del Fuego. West: Map 122. Habitat: Open marshes, mudflats, streams, ponds; in summer, wooded muskegs, spruce bogs.

\section{LESSER YELLOWLEGS Tringa flavipes}

M123

$10-11^{\prime \prime}(25-28 \mathrm{~cm})$. Like the Greater Yellowlegs, but noticeably smaller. Its shorter, slimmer, all-black bill is quite straight; that of Greater appears slightly uptilted. Readily separated by voice.

Similar species: (1) Stilt Sandpiper and (2) Wilson's Phalarope in the fall have flight patterns similar to that of Yellowlegs.

Voice: Yew or yu-yu (usually one or two notes); lower, less forceful than the clear, three-syllabled whistle of Greater Yellowlegs.

Range: Alaska, Canada. Winters from s. U.S. to Argentina. West: Map 123. Habitat: Marshes, mudflats, shores, pond edges; in summer, open boreal woods.

SOLITARY SANDPIPER Tringa solitaria

M124

$8-9^{\prime \prime}(20-23 \mathrm{~cm})$. Note the dark wings and conspicuous white sides of the tail (crossed by bold black bars). A dark-backed sandpiper, whitish below, with a light eye-ring and greenish legs. Nods like a yellowlegs. Usually alone, seldom in groups.

Similar species: (1) Lesser Yellowlegs has bright yellow (not greenish) legs, white (not dark) rump. (2) Spotted Sandpiper teeters more and has a white wing stripe; it has a stiff, shallow wing arc. (Solitary has a darting, almost swallow-like wing stroke.)

Voice: Peet! or peet-weet-weet! (higher than Spotted's).

Range: Alaska, Canada. Winters Gulf of Mexico to Argentina. West: Map 124. Habitat: Streamsides, wooded swamps and ponds, fresh marshes.

STILT SANDPIPER Calidris himantopus See pp. 144, 145.

Fall: Long, yellow-green legs; white rump; light eyebrow.

WILSON'S PHALAROPE Phalaropus tricolor See pp. 136, 137.

Fall: Needle bill, clear white underparts; dull yellow legs. 


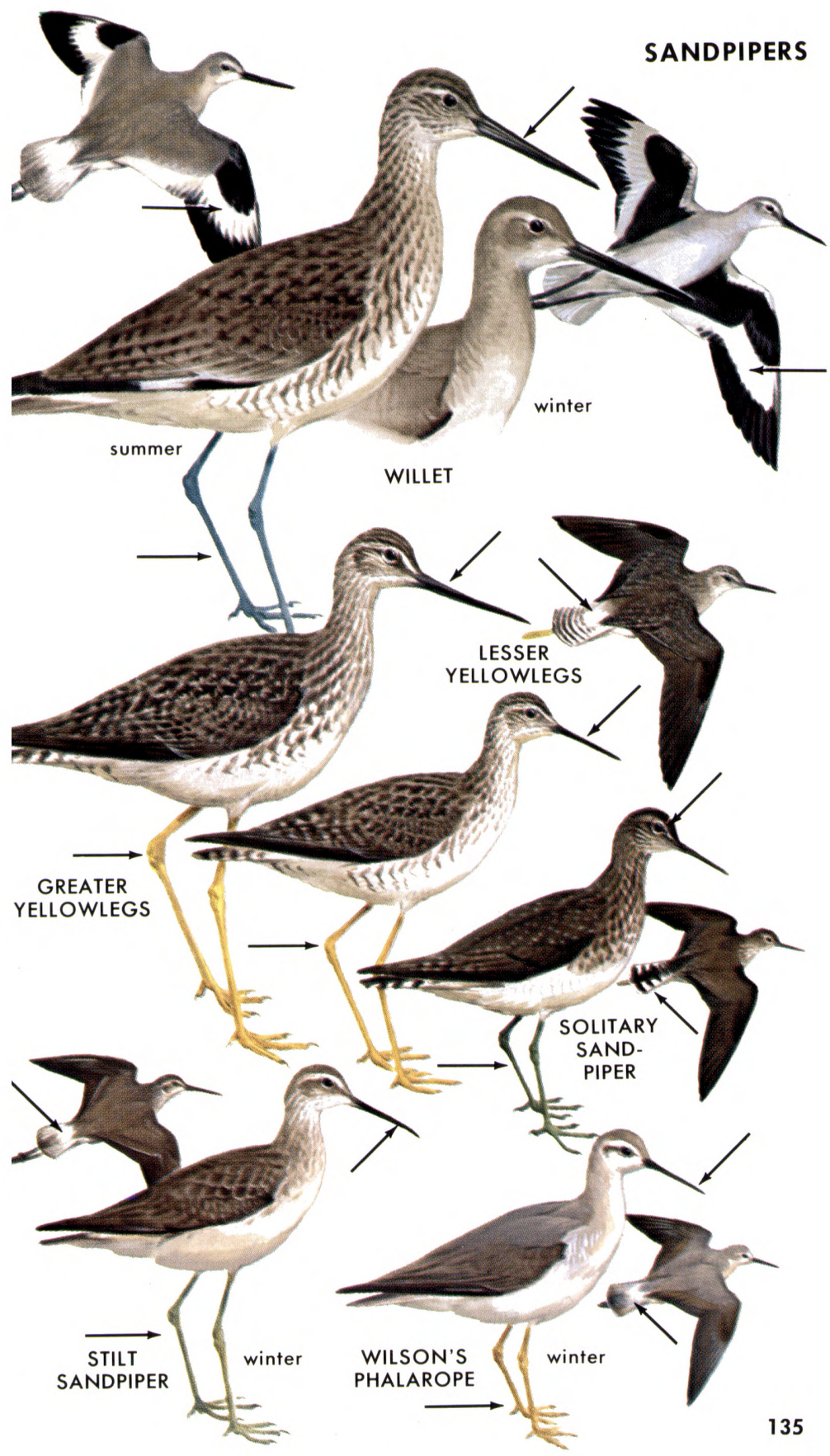


- PHALAROPES. Subfamily Phalaropodinae. Sandpiper-like birds with lobed toes; equally at home wading or swimming. Placed by some taxonomists in a family of their own, Phalaropodidae. When feeding, phalaropes often spin like tops, rapidly dabbling at the disturbed water for plankton, brine shrimp and other marine invertebrates, mosquito larvae, and insects. Females are larger and more colorful than males. Two of the three species are circumpolar, wintering at sea; the other species breeds on the N. American plains and winters in S. America.

\section{WILSON'S PHALAROPE Phalaropus tricolor}

M151

$9^{\prime \prime}(23 \mathrm{~cm})$. This trim phalarope is dark-winged (no stripe), with a white rump. The breeding female is unique, with a broad black face and neck stripe blending into cinnamon. Males are duller, with just a wash of cinnamon on the sides of the neck and a white spot on the hind-neck. Fall: Suggests a Lesser Yellowlegs (dark wings, white rump), but whiter below, with no breast streaking; bill needle-like; legs greenish or straw-colored (not canary yellow). The other two phalaropes show white wing stripes.

Voice: A low nasal wurk; also check, check, check.

Range: Sw. Canada, w. U.S. and Great Lakes. Winters in s. S. America. West: Map 151. Habitat: Shallow prairie lakes, fresh marshes, pools, shores, mudflats; in migration, also salt marshes.

\section{RED-NECKED PHALAROPE Phalaropus lobatus}

M152

(Northern Phalarope) 7-8" (18-20 cm). A sanderling-like bird at sea is most likely to be a phalarope. This is the commonest of the two "sea snipes" and the one most likely to occur inland. In the fall, both sexes are gray above (strongly streaked) and white below. Note the dark "phalarope patch" through the eye and the needle-like black bill. Breeding females are gray above, with a patch of rufous on the neck and a white throat. Males are browner, but similar in pattern.

Voice: A sharp kit or whit, similar to note of Sanderling.

Range: Circumpolar. Winters at sea, to S. Hemisphere. West: Map 152. Habitat: Ocean, bays, lakes, ponds; tundra (summer).

\section{RED PHALAROPE Phalaropus fulicaria}

M153

$8-9 "(20-23 \mathrm{~cm})$. The sea-going habits (swimming buoyantly like a tiny gull) distinguish this as a phalarope; in breeding plumage, the deep reddish underparts and white face and yellow bill designate it as this species. Male duller than female. In fall and winter, both sexes are gray above, white below; in flight suggests a Sanderling, but with a dark patch through the eye.

Similar species: Fall Red-necked Phalarope is darker, with a strongly striped back, blacker crown. Its wing stripe contrasts more; its bill is more needle-like. Thicker bill of fall Red Phalarope may be yellowish at base (usually not). Immature has a black bill.

Voice: Similar to Red-necked Phalarope's whit or prip.

Range: Arctic; circumpolar. Winter range at sea poorly known; from s. U.S. to S. Hemisphere. West: Map 153. Habitat: More strictly pelagic than Northern. In summer, tundra. 


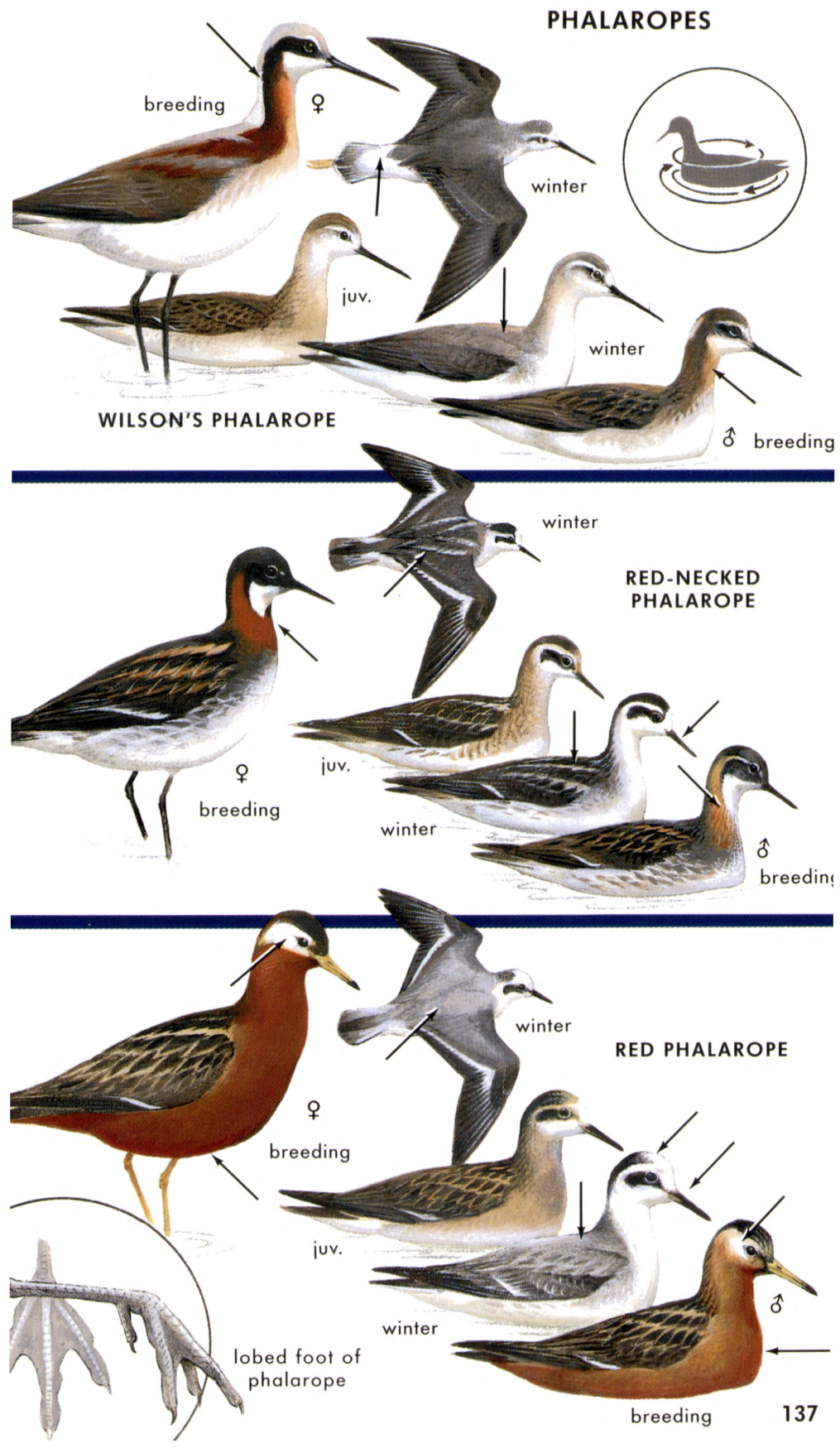


$11^{\prime \prime}(28 \mathrm{~cm})$. A tight-sitting bog-prober; note the extremely long bill. Brown, with buff stripes on the back and a sriped head. When flushed, flies off in a zigzag, showing a short orange tail and uttering a rasping note.

Voice: A rasping scaip. Song, a measured chip- $a$, chip-a, chip- $a$, etc. In high aerial display, a winnowing huhuhuhuhuhuhu.

Range: Northern N. America, n. Eurasia. Winters to Brazil, cen. Africa. West: Map 150. Habitat: Marshes, bogs, wet meadows.

Note: The AMERICAN WOODCOCK, Scolopax minor, has been recorded casually or accidentally west of $100^{\circ}$ as far as Saskatchewan, Montana, Wyoming, Colorado, and New Mexico. See eastern Field Guide.

SHORT-BILLED DOWITCHER Limnodromus griseus

M148

$10 \frac{1}{2}-12^{\prime \prime}(26-30 \mathrm{~cm})$. A snipe-like bird of the open mudflats. Note the very long bill, and in flight, the long white wedge up the back. In breeding plumage the underparts are rich rusty with some barring on the flanks; by fall, the bird is gray. Dowitchers feed with a sewing-machine motion. The Short-bill is very similar to the Longbilled Dowitcher, but the bill averages shorter. The race most likely to be seen in the West (caurinus) has wider white bars on the tail than the Long-bill; this gives the tail a paler look. The two are more easily separated by voice, providing they speak up.

Voice: A staccato tu-tu-tu; pitch of Lesser Yellowlegs'.

Range: S. Alaska, Canada. Winters s. U.S. to Brazil. West: Map 148. Habitat: Mudflats, tidal marshes, pond edges. More frequent on saltwater margins than the Long-billed Dowitcher.

LONG-BILLED DOWITCHER Limnodromus scolopaceus

M149

$11-12 \frac{1}{2}{ }^{\prime \prime}(28-31 \mathrm{~cm})$. Bill lengths of the two dowitchers overlap, but birds of this species with very long bills $\left(3^{\prime \prime}\right)$, usually females, may be recognized with a fair degree of certainty in any plumage; many other individuals can be rather indeterminate unless they call. In breeding plumage the underparts are rusty to the lower belly (may be whitish in Short-bill). The dark bars on the tail are denser, giving the tail a darker look. In fall the bird is gray; then the best clue is voice.

Voice: A single thin keek is distinctive. Occasionally the notes are doubled or trebled, but thinner than the Short-bill's.

Range: Breeds ne. Siberia to nw. Canada. Winters s. U.S. to Guatemala. West: Map 149. Habitat: Mudflats, shallow pools, margins. More addicted to fresh water than other dowitcher.

RED KNOT Calidris canutus

M136

$10-11^{\prime \prime}(25-28 \mathrm{~cm})$. Larger than the Sanderling (p. 140). Stocky, with a moderately short bill and short legs. Spring: Face and underparts pale robin-red; back mottled with black, gray, and russet. Fall: A dumpy wader with a washed-out gray look; short bill, pale rump, greenish legs. At close range shows scaly feather edgings, especially in juvenile birds.

Voice: A low knut; also a low, mellow tooit-wit or wah-quoit.

Range: Arctic; circumpolar. Winters to S. Hemisphere. West: Map 136. Habitat: Tidal flats, shores; tundra when breeding. 
$71 / 2^{\prime \prime}(19 \mathrm{~cm})$. The most widespread sandpiper along the shores of small lakes and streams. Teeters up and down as if a bit too delicately balanced. In summer, note the round breast spots. In fall and winter, no spots; olive-brown above, with a white line over the eye. A dusky smudge enclosing a white wedge near the shoulder is a good aid. The flight is distinctive: the wings beat in a shallow arc, giving a stiff, bowed appearance. The underwing is strongly striped. Voice: A clear peet or peet-weet! or peet-weet-weet-weet-weet.

Range: Alaska, Canada to cen. U.S. Winters s. U.S. to n. Argentina. West: Map 127. Habitat: Pebbly lake shores, ponds, streamsides; in winter, also seashores.

DUNLIN Calidris alpina

M145

$8-9^{\prime \prime}(20-23 \mathrm{~cm})$. Slightly larger than the Sanderling, with a downward droop toward the tip of its rather long, stout bill. When feeding, the bird's posture is hunched. Summer: Rusty red above, with a black patch across the belly. Winter: Unpatterned gray-brown above, with a grayish wash across the breast (not clean white as in the Sanderling). Juvenile is rusty above, with a buffy breast and streaked flanks. In all plumages note the longish, droop-tipped bill. Voice: A nasal, rasping cheezp or treezp.

Range: Arctic; circumpolar. Winters from coasts of U.S., s. Eurasia to Mexico, n. Africa, India. West: Map 145. Habitat: Tidal flats, beaches, muddy pools; in summer, wet tundra.

SANDERLING Calidris alba

M137

$7-8^{\prime \prime}(18-20 \mathrm{~cm})$. A plump, active sandpiper of the outer beaches, where it chases the retreating waves like a clockwork toy. Note the bold white wing stripe on birds in flight. Breeding plumage: Bright rusty about the head, back, and breast. Winter plumage: The palest sandpiper; snowy white below, plain pale gray back, black shoulders. Juvenile birds differ from winter adults by having a pattern of black on the back.

Voice: A short twick or quit is distinctive.

Range: Arctic; circumpolar. Winters from U.S., Britain, China to S. Hemisphere. West: Map 137. Habitat: Outer beaches, tideflats, lake shores; when nesting, stony tundra.

\section{BASIC FLIGHT PATTERNS OF SANDPIPERS}

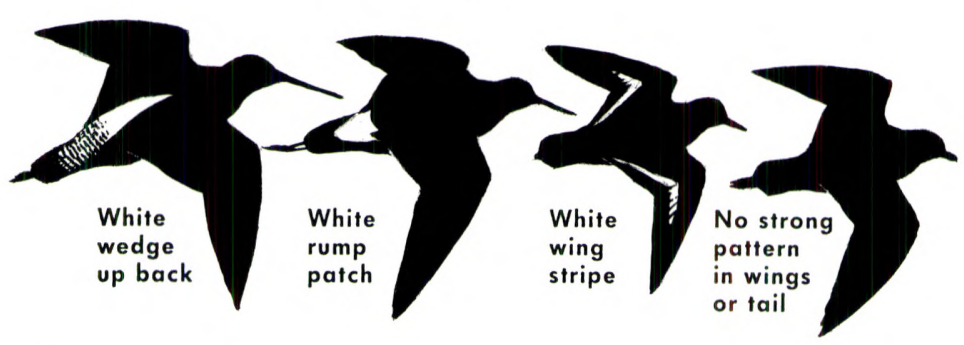




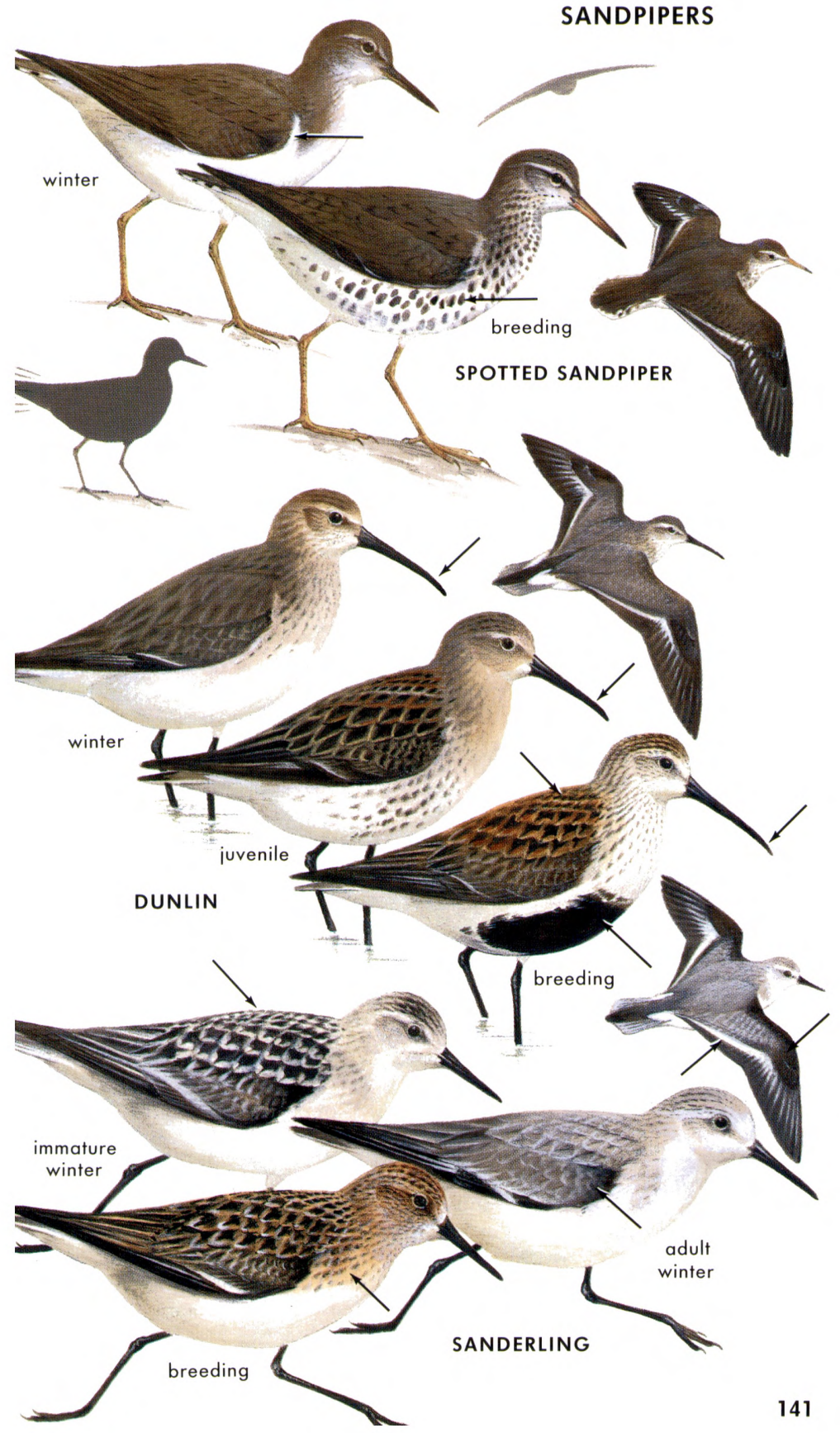


$10^{1 / 2}-11^{1 / 2} 2^{\prime \prime}(26-29 \mathrm{~cm})$. Recognized at any time from the other shorebirds that inhabit similar rocks by its lack of pattern in flight. Solid grayish above; light line over the eye, dark line through it. Legs yellowish. In breeding plumage, underparts narrowly barred. In fall and winter, gray-chested, with no barring. Bobs and teeters like the Spotted Sandpiper.

Voice: A clear whee-we-we-we, less sharp than Greater Yellowlegs; or tweet-tweet-tweet, similar to Spotted Sandpiper's call.

Range: Breeds nw. N. America; winters coastally south to Ecuador and on many Pacific islands. West: Map 126. Habitat: Rock coasts, pebbly beaches. Nests near mountain streams above timberline.

$10^{\prime \prime}(25 \mathrm{~cm})$. A stocky dark sandpiper of wave-washed rocks. Note the conspicuous white tail tipped with a broad black band. Breeding: Heavily streaked and spotted with blackish above and below; golden scapulars. Winter: Solid gray above and across breast. Bill short, yellow at base; legs yellowish.

Voice: A sharp pee-weet or key-a-weet.

Range: Breeds in Alaska, Yukon. Winters on coast to s. S. America. West: Map 135. Habitat: Rocky coasts; nests on mountain tundra.

ROCK SANDPIPER Calidris ptilocnemis

M144

$8-9$ " $(20-23 \mathrm{~cm})$. In breeding plumage suggests a Dunlin, with rusty back, black splotch on breast (but the Dunlin is redder, with black splotch lower down, black legs; see p. 141). In winter, similar to the Purple Sandpiper of the Atlantic, but paler. Stocky and slaty, with a white belly, white wing stripe. Legs dull yellow or greenish. Its rock-feeding associates, the Black Turnstone and the Surfbird, both show a broad white band across the base of the tail.

Voice: A flicker-like $d u-d u-d u$. When breeding, a trill.

Range: Ne. Siberia, w. Alaska; winters along coast to California Map 144. Habitat: Rocky shores; nests on mossy tundra.

BLACK TURNSTONE Arenaria melanocephala

M134

$9^{\prime \prime}(23 \mathrm{~cm})$. A squat, blackish shorebird with a blackish chest and white belly. In spring, a round white spot before the eye, and white speckling. Flight pattern similar to Ruddy Turnstone's. Legs dark.

Voice: A rattling note, higher than note of Ruddy Turnstone.

Range: Breeds in Alaska. Winters along coast to w. Mexico. Map 134. Habitat: Strictly coastal. Rocky shores, breakwaters, bay shores, surf-pounded islets; nests on coastal tundra.

\section{RUDDY TURNSTONE Arenaria interpres}

M133

$8-10^{\prime \prime}(20-25 \mathrm{~cm})$. A squat, robust, orange-legged shorebird, with a harlequin pattern. In breeding plumage, with its russet back and curious face and breast pattern, the bird is unique, but in flight it is even more striking. Winter adults and young birds are duller, but retain enough of the basic pattern to be recognized.

Voice: A staccato tuk-a-tuk or kut-a-kut; also a single kewk.

Range: Arctic, sub-Arctic; circumpolar. Winters coastal U.S., Hawaii, s. Eurasia to S. Hemisphere. West: Map 133. Habitat: Beaches, mudflats, jetties, rocky shores; in summer, tundra. 


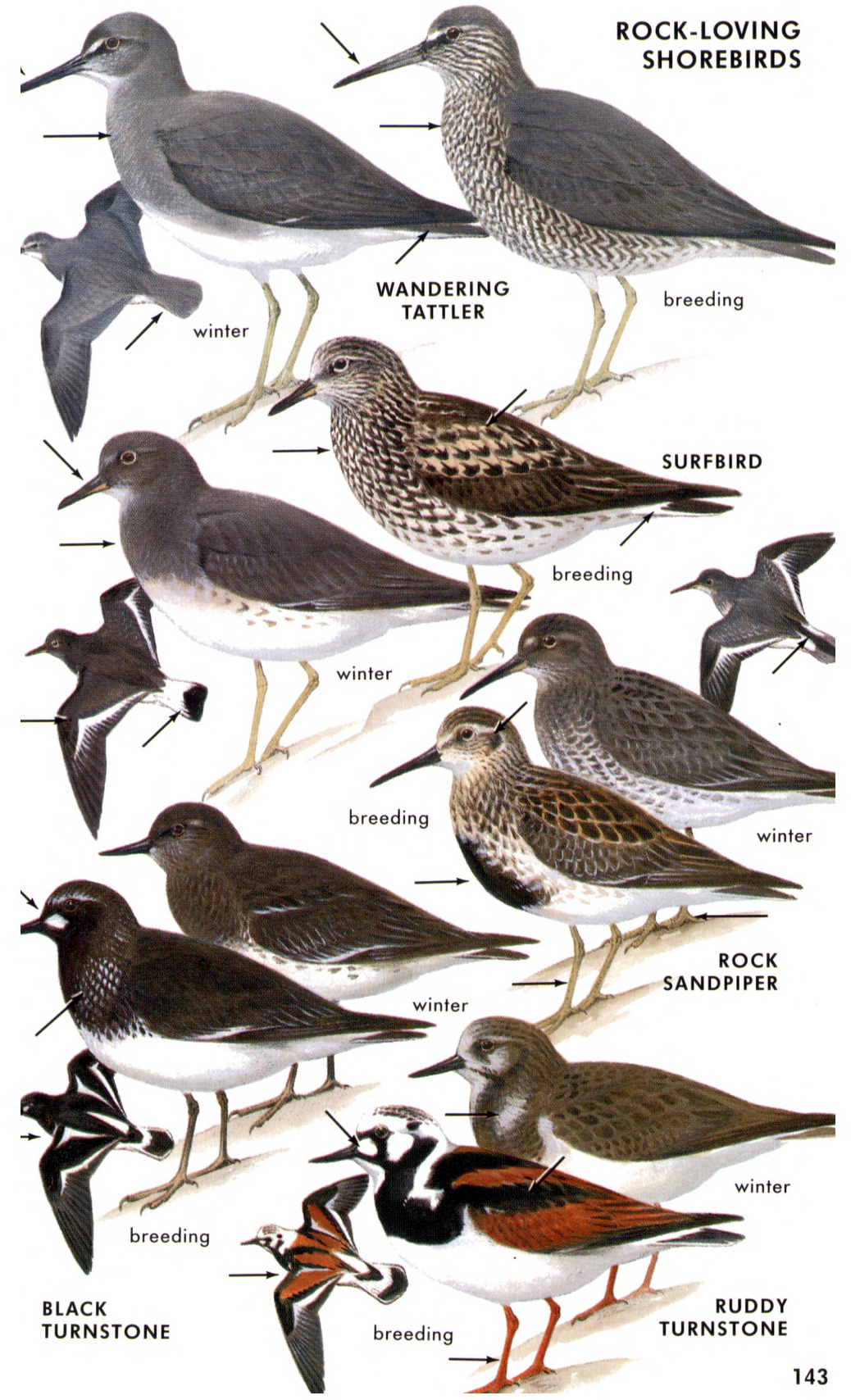


$8^{\prime \prime}(20 \mathrm{~cm})$. In spring, heavily marked below with transverse bars. Note rusty cheek patch. In fall, yellowlegs-like; gray above, white below; dark-winged and white-rumped; note the greenish legs and white eyebrow. Bill long, with a slight droop at tip. Feeds like a Dowitcher (sewing-machine motion).

Voice: A single whu (like Lesser Yellowlegs but lower, hoarser).

Range: American Arctic. Winters s. U.S. to Argentina. West: Map 146. Habitat: Shallow pools, mudflats, marshes; tundra (summer).

BUFF-BREASTED SANDPIPER Tryngites subruficollis

M147

$71 / 2^{\prime \prime}(19 \mathrm{~cm})$. No other small shorebird is as buff below (paling to whitish on undertail coverts). A tame buffy wader, with an erect stance, small head, short bill, and yellowish legs. The dark eye stands out on a plain face. In flight or in "display," the buff body contrasts with the underwing (white with a marbled tip). Juveniles are very scaly above, paler on the belly (most Pacific Coast birds are in this plumage).

Voice: A low, trilled pr-r-r-reet. A sharp tik.

Range: Breeds in nw. Arctic. Winters in Argentina. West: Map 147. Habitat: Shortgrass prairies; in summer, tundra ridges.

UPLAND SANDPIPER Bartramia longicauda

(Upland Plover) 111/2" (29 cm). A "pigeon-headed" brown sandpiper; larger than a Killdeer. The short bill, small head, shoe-button eye, thin neck, and long tail are helpful points. Often perches on fenceposts and poles; upon alighting, holds wings elevated.

Voice: A mellow, whistled kip-ip-ip-ip, often heard at night. Song, weird windy whistles: whoooleeeeee, wheeloooooooooo.

Range: Mainly Canada, n. U.S. Winters on pampas of Argentina. West: Map 128. Habitat: Grassy prairies, open meadows, fields.

RUFF Philomachus pugnax

Male 12" (30 cm); female 9" $(23 \mathrm{~cm})$. Male ("Ruff"), summer: Unique, with erectile ruffs and ear tufts that may be black, brown, rufous, buff, white, or barred, in various combinations. Legs may be greenish, yellow, orange, or pink. Bill also variable. Male, winter: Rather plain, a small-headed, thick-necked shorebird with a scaly gray-brown back, whitish underparts with a mottling of gray across the breast, and a whitish area on the lower face. Note the erect stance and (in flight) the oval white patch on each side of the dark tail. Female ("Reeve"): Smaller than the male; when breeding lacks ruffs, breast heavily blotched with dark. Juvenile birds are buffy below and very scaly on the back. See Sharp-tailed Sandpiper.

Voice: Flight note, a low too-i or tu-whit.

Range: N. Eurasia; winters in s. Eurasia, Africa. Rare visitor to N. America. West: Rare but regular spring and fall migrant in outer Aleutians and Bering Sea area (has bred in Alaska). Rare fall migrant along coast south to s. California, where it may winter. Accidental inland in West. 


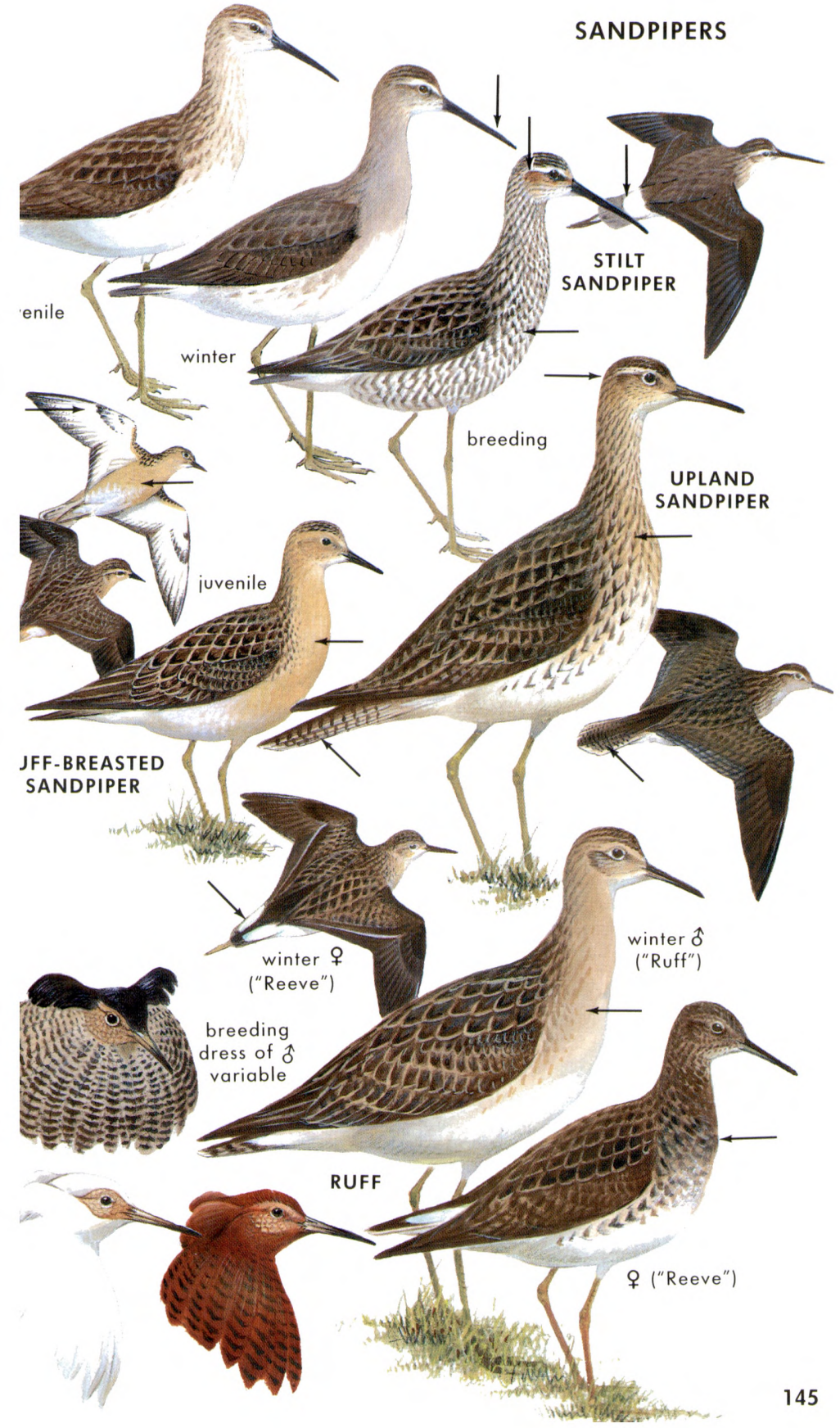


$7-8^{\prime \prime}(18-20 \mathrm{~cm})$. Larger than the Semipalmated Sandpiper, smaller than the Pectoral. The only small streaked sandpiper with a completely white rump, conspicuous in flight. At rest, the bird has an attenuated look, with wing tips extending well beyond the tail; sides show streaks below the wings, a good point. Bill yellow at base of lower mandible. In spring, adults are quite rusty; in fall, adults are grayer than the other "peeps," but juveniles have rusty edges on the crown and back.

Voice: A mouselike jeet, like two flint pebbles scraping.

Range: Arctic N. America. Winters in s. S. America. West: Map 141. Habitat: Prairies, shores, mudflats; in summer, tundra.

BAIRD'S SANDPIPER Calidris bairdii

M142

$7-71 / 2^{\prime \prime}(18-19 \mathrm{~cm})$. Larger than the Semipalmated or Western Sandpiper, with a more pointy look (wings extend $1 / 2 "$ beyond tail tip). Browner, buffier across the breast. Suggests a large Least Sandpiper with black legs. Back of juvenile has a more scaled look.

Similar species: (1) Buff-breasted Sandpiper is buffier below, without streaks, and has yellowish (not blackish) legs. See also (2) breeding Sanderling; (3) Pectoral Sandpiper.

Voice: Note, kreep or kree; a rolling trill.

Range: Ne. Siberia and N. American Arctic. Winters from Andean Ecuador to Tierra del Fuego. West: Map 142. Habitat: Rainpools, pond margins, mudflats, shores.

PECTORAL SANDPIPER Calidris melanotos

M143

$8-9^{\prime \prime}(20-23 \mathrm{~cm})$. Medium-sized (but variable); neck longer than in smaller "peeps." Note that the heavy breast streaks end rather abruptly, like a bib. The dark back is lined (snipe-like) with white; the wing stripe is faint or lacking; the crown is rusty. The legs usually are dull yellowish green. Bill may be pale yellow-brown at base.

Voice: A reedy churrt or trrip, trrip.

Range: Siberian and American Arctic. Winters in S. America, se. Australia. West: Map 143. Habitat: In migration, prairie pools, muddy shores, fresh and tidal marshes; in summer, tundra.

SHARP-TAILED SANDPIPER Calidris acuminata

$81 / 2^{\prime \prime}(21 \mathrm{~cm})$. Similar to the Pectoral Sandpiper, but in fall the breast is rich buffy (juvenile) or pale gray-buff (adult), spotted lightly on the sides only. Crissum is streaked. In no plumage is there the sharp contrast between the white belly and streaked breast, as in the Pectoral. The juvenile is especially distinctive, with its rich orangebuff breast and rufous cap.

Voice: A low, trilled prreeet or trrit-trrit, sometimes twittered.

Range: Breeds in $\mathrm{n}$. Siberia. Winters in Australian region. West: Fall migrant along coasts of Alaska, British Columbia; rarely south to California (usually juveniles). Accidental in interior. Habitat: Grassy borders of salt marshes. 


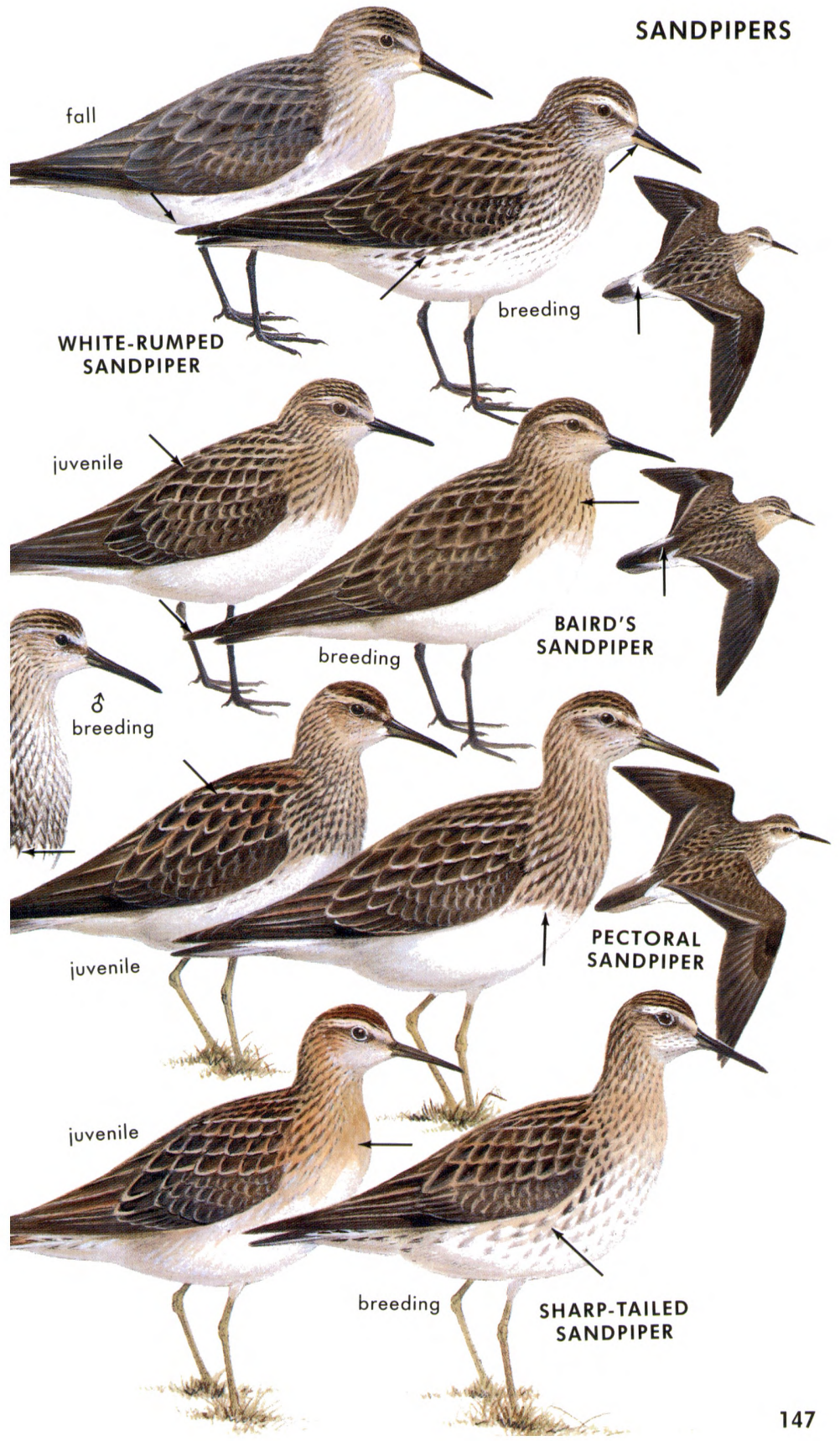


- "PEEPS." Collectively, the three common, streaked, sparrowsized sandpipers resident in North America are nicknamed "peeps." The British call their similar ones "stints."

LEAST SANDPIPER Calidris minutilla

M140

$5-61 / 2^{\prime \prime}(13-16 \mathrm{~cm})$. The Least may be known from the other two common peeps by its smaller size, browner look, yellowish or greenish (not blackish) legs, and slighter bill.

Voice: A thin krreet, kree-eet. More drawn out than the jeet of the Western. Very unlike the chit or chet of the Semipalmated.

Range: Alaska, Canada. Winters s. U.S. to Brazil. West: Map 140. Habitat: Mudflats, grassy marshes, rainpools, shores. More addicted to marshy areas than the other "peeps."

SEMIPALMATED SANDPIPER Calidris pusilla

M138

$51 / 2-61 / 2^{\prime \prime}(14-16 \mathrm{~cm})$. Compared to the Western Sandpiper (which also has blackish legs), the "Semi" is a trifle smaller, grayer in spring, and usually has a shorter, straighter bill. In fall it lacks the rusty on the scapulars often shown by the Western.

Similar species: (1) Typical Western Sandpiper (especially the female) has a longer bill, thicker at the base, slightly drooped at the tip. Some males in fall or winter may not be safely separable in the field except by voice. (2) Least Sandpiper is smaller, browner, and thinner-billed; it has yellowish or greenish legs and in the fall has a more streaked breast.

Voice: Note chit or cheh (lacks ee sound of Least, Western).

Range: Breeds in N. American Arctic. Migrates mainly east of the Rockies (scarcer on West Coast) to S. America. West: Map 138. Habitat: Beaches, mudflats; in summer, tundra.

WESTERN SANDPIPER Calidris mauri

M139

$6-7 "(15-18 \mathrm{~cm})$. This and the Least Sandpiper are the two common small "peeps" in most of the West (west of the Plains). The Western is the larger bird; its bill is very noticeably longer (especially in females), thicker at the base, and droops slightly at the tip. Legs black. Breeding adults are heavily streaked on the breast. They show rusty on the scapulars and have a rusty crown and ear patch. (A trace of rusty may persist on the scapulars in fall, giving a twotoned effect.) In winter, gray or gray-brown; perhaps the palest "peep."

Similar species: Because of their shorter bills, many males in fall or winter plumage are almost impossible to separate from Semipalmateds except by voice. The latter species does not winter on the West Coast, but the Western does. If the birds do not call, it is fairly safe to assume they are Westerns.

Voice: A thin jeet, not as drawn out as note of Least.

Range: Breeds in Alaska. Winters from s. U.S. to Peru. West: Map 139. Habitat: Shores, beaches, mudflats; in summer, dry tundra. 

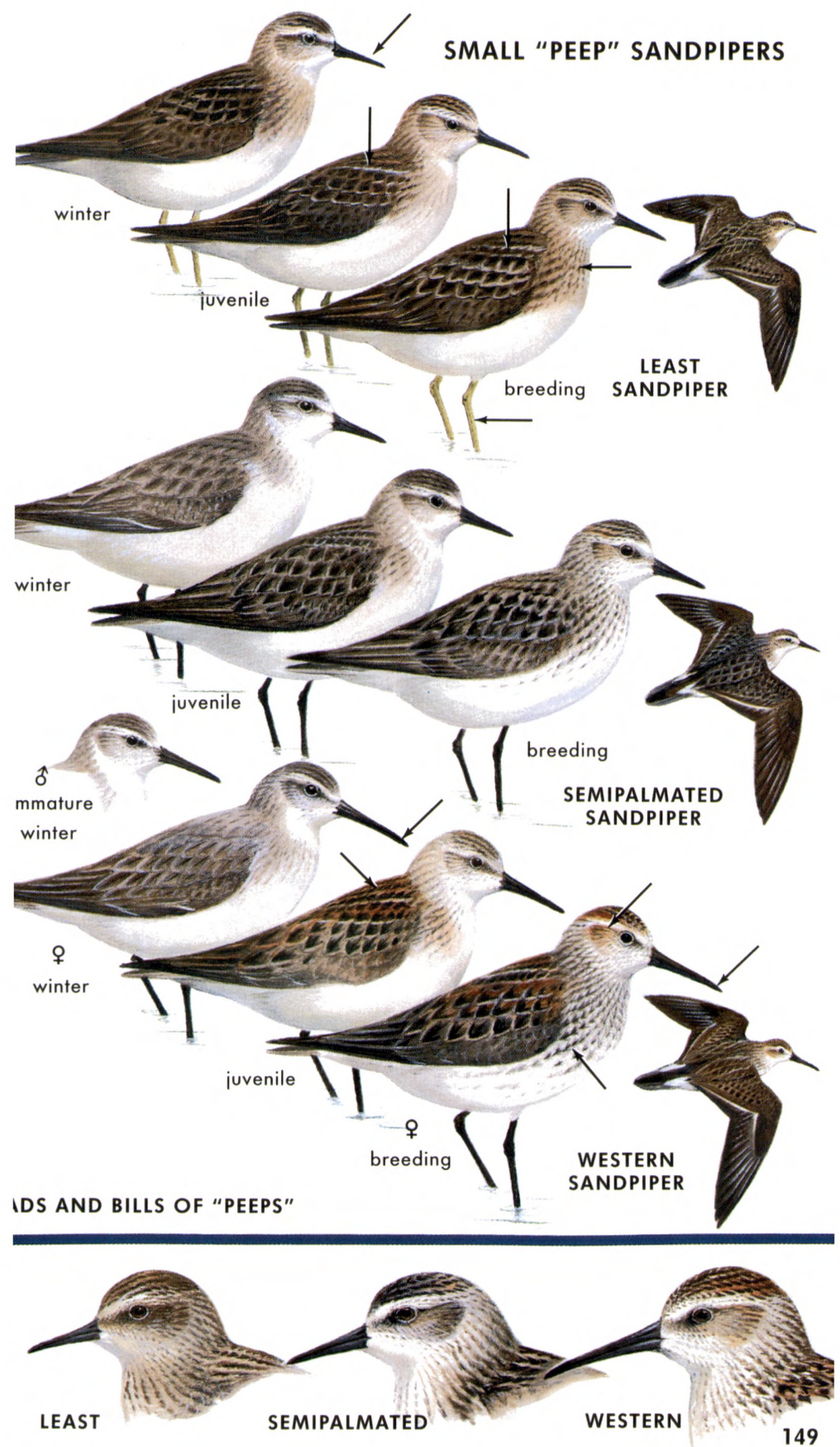
- "STINTS." Alaskan Strays from Asia. Whereas we may affectionately refer to our small, sparrow-sized sandpipers as "peeps," the British usually call the Eurasian species "stints." Within our geographic limits, stray "stints" from Asia occur as overshoots in migration most frequently in the outer Aleutians (Attu, etc.), but might turn up casually or accidentally elsewhere. Identification can be tricky; for further analysis and color plates of subtle plumage variations, see Viet and Jonsson in American Birds (Sept.-Oct. 1984).

\section{LITTLE STINT Calidris minuta}

6" (15 cm). Size of the Least Sandpiper but rustier above, with black legs. Toes lack webbing (unlike those of the larger Semipalmated and Western sandpipers). Similar to some Rufous-necked Stints but body less elongated, stance more erect; tarsi longer. Call, a sanderling-like tit. West: Accidental, w. Aleutians, Bering Sea area.

\section{TEMMINCK'S STINT Calidris temmincki}

6" (15 cm). A distinctive stint; gray, with irregular black spots on the scapulars. Has an elongated, crouching look; short, dull yellow legs. In flight, shows white outer tail feathers. Call in flight, a high ringing trree, often repeated in a cricketlike trill. West: A very rare overshoot in migration to outer Aleutians and other Bering Sea islands.

\section{LONG-TOED STINT Calidris subminuta}

$61 / 4^{\prime \prime}(16 \mathrm{~cm})$. Much like the Least Sandpiper (which is unlikely to occur in the outer Aleutians), but brighter in color, with more erect stance, longer legs, more spindly toes, and an even thinner bill. Call, a purring prrp. West: Regular migrant in outer Aleutians (may breed); vagrant Pribilofs, St. Lawrence I., etc. Prefers marshes.

\section{SPOONBILL SANDPIPER Eurynorhynchus pygmeus}

$6 \frac{1}{2} "(16 \mathrm{~cm})$. A stint-sized sandpiper, with a curious spoonlike tip on the bill. In spring, it has a bright rusty head and breast and could be mistaken for a Rufous-necked Stint until it turns head-on. West: Accidental, n. Alaska, outer Aleutians, British Columbia.

\section{RED-NECKED STINT Calidris ruficollis}

$6 \frac{1}{2} "(16 \mathrm{~cm})$. This rare stray is recognized in breeding plumage by its bright rusty head and upper breast. In non-breeding plumage it is very much like Western and Semipalmated sandpipers (black legs, clear breast), but bill is slighter, forehead whiter, and (at close range) toes unwebbed. Call, a short, clipped chit, or chit chit, suggesting Semipalmated. Also a squeak, lower in pitch than Western's call. Basically Eurasian, but breeds n. and w. Alaska (Pt. Barrow, Seward Peninsula, etc.). Migrant in Aleutians, Pribilofs, Bering Sea coasts, and casually (perhaps regularly) south along coast to $\mathrm{s}$. California.

\section{BROAD-BILLED SANDPIPER Limicola falcinellus}

$63 / 4 "(17 \mathrm{~cm})$. The key mark is the forked white eyebrow stripe. Its long bill, dropped at tip, suggests a small Dunlin, but its back is dark, striped like a Snipe's. West: Vagrants (juveniles) have occurred in fall in the outer Aleutians. 
$15-18^{\prime \prime}(38-45 \mathrm{~cm})$. This Alaskan godwit is near the size of the Whimbrel. In summer, male is rich reddish chestnut, particularly on head and underparts; female duller. In non-breeding plumage both are grayish above, white below. Alaskan birds have a mottled rump and whitish tail crossed by narrow dark bars. See also p. 132 for additional illustration of bird in flight.

Voice: Flight note, a harsh kirrick; alarm, a shrill krick.

Range: N. Eurasia, Alaska. Winters cen. Eurasia to n. Africa, Australia. West: Map 131. Habitat: Mudflats, shores, tundra.

\section{BLACK-TAILED GODWIT Limosa limosa}

$153 / 4^{\prime \prime}(40 \mathrm{~cm})$. The small Asian race of this elegant godwit resembles the Hudsonian Godwit (white rump, white wing stripe, black tail), but the bill is straighter. In breeding plumage it has chestnut head and neck, black-and-white barred belly. The best field distinction is this: the underwing linings are white in the Black-tail, black in the Hudsonian. This holds for all plumages.

Voice: The flight call is a clear reeka-reeka-reeka.

Range: Eurasia, migrating to Africa, Australia. A rare spring migrant in the outer Aleutians; casual on other Bering Sea islands.

\section{BRISTLE-THIGHED CURLEW Numenius tahitiensis}

$17^{\prime \prime}(43 \mathrm{~cm})$. Very similar to the Whimbrel, but tawnier, especially about tail; tawny, unbarred rump. Breast less streaked, bill paler. See additional illustration of bird in flight on p. 132.

Voice: A slurred chi-u-it (Inuit name); suggests the call of the Blackbellied Plover. Also like a "wolf whistle," whee-wheeo (A. A. Allen). Range: Breeds in w. Alaska (near mouth of Yukon). Recorded elsewhere in w. Alaska. Winters on islands in cen. and s. Pacific. Habitat: Tundra (Alaska); reefs and beaches.

\section{FAR EASTERN CURLEW Numenius madagascariensis}

$25^{\prime \prime}(63 \mathrm{~cm})$. The largest curlew; resembles the Long-billed Curlew (pp. 130-133), but lacks the cinnamon tones. Length of bill variable. The surest point is the heavily barred whitish underwing (deep cinnamon in Long-billed Curlew).

Range: Ne. Asia. Very rare spring vagrant to outer Aleutians, Pribilofs, nw. Alaska.

\section{LITTLE CURLEW Numenius minutus}

12 " $(30 \mathrm{~cm})$. The tiniest curlew, even smaller than the nearly extinct Eskimo Curlew. Bill very short. Breast washed with buff, finely streaked. At rest, wing tips are even with the tail tip (they extend beyond tail in Eskimo Curlew). Note difference in underwing pattern (pale buff, not cinnamon).

Range: N. Siberia. Accidental, California.

ESKIMO CURLEW Numenius borealis See pp. 130, 131. 
$8^{\prime \prime}(20 \mathrm{~cm})$. At all seasons resembles the Spotted Sandpiper in nonbreeding plumage (no spots). Best feature is the longer tail. At rest, wing tips of Common reach only halfway to the tip of the tail, whereas those of Spotted reach closer to the tip. The dusky wedge on the side of the breast is more diffuse. Legs grayer. Less contrast between base of bill and tip. Flight note, twee-see-see, similar to Spotted's call but thinner. Rare but regular, mostly in spring, in the outer Aleutians; casual elsewhere in the Bering Sea area.

\section{GREEN SANDPIPER Tringa ochrophus}

$83 / 4^{\prime \prime}(22 \mathrm{~cm})$. Similar to the Solitary Sandpiper, but a bit stockier, with a white rump (not dark). Underwings dark, as in Solitary. Call, when flushed, a thin, high-pitched weet weet weet. Accidental in extreme w. Aleutians (Attu).

\section{TEREK SANDPIPER Xenus cinereus}

$91 / 4^{\prime \prime}(23 \mathrm{~cm})$. Note the upturned bill and short, orange-yellow legs. In breeding plumage this bird has a jagged black stripe along the scapulars that is nearly lacking in fall adults. Juveniles are brown, with a trace of this stripe. Often bobs like a "Spotty." In flight, a broad white band at rear edge of wing. Voice a fluty dudududu or a sharp piping, twita-wit-wit-wit. Vagrants occur regularly in outer Aleutians, casually on Bering Sea islands. Accidental on mainland Alaska.

\section{WOOD SANDPIPER Tringa glareola}

$73 / 4^{\prime \prime}(19 \mathrm{~cm})$. Shape of Solitary Sandpiper, but has whitish (not dark) underwings. Upperparts paler and browner, heavily spotted with pale buff. Rump patch white (Solitary has a dark rump). Legs dull yellow. Voice, a sharp, high chew-chew-chew or chiff-chiff-chiff. Regular migrant in outer Aleutians (rare breeder); also Pribilofs, St. Lawrence I.; rarely on mainland of nw. Alaska.

\section{CURLEW SANDPIPER Calidris ferruginea}

$7-9$ " $(18-23 \mathrm{~cm})$. In spring, dark russet on head and underparts (do not mistake for Red Knot). In fall, resembles a fall Dunlin but longer-legged, less streaked on breast; bill curved slightly throughout. Main distinction is the whitish rump. Most birds seen in fall are juveniles, which have buff edges on feathers of back that give a very scaly look. Breast tinged with buff. Call, a liquid chirrip, less grating than Dunlin's note. Vagrant in Alaska (w. Aleutians, St. Lawrence I.), w. and n. coasts (has bred Pt. Barrow); accidental, British Columbia, Alberta, Montana, Washington, Oregon, California.

\section{GREAT KNOT Calidris tenuirostris}

$10^{1 / 2 "}(26 \mathrm{~cm})$. Shaped somewhat like the Red Knot, but larger. In spring, when this species is most likely to occur, it lacks the Red Knot's brick red underparts. Breast heavily blotched with dark, which extends down the sides as bold, chevronlike spots. Scapulars bright rusty. In flight, shows more contrast between rump and tail than Red Knot. Very rare spring vagrant in w. Aleutians, Pribilofs, St. Lawrence I., Seward Peninsula. 
STRAY SANDPIPERS FROM ASIA
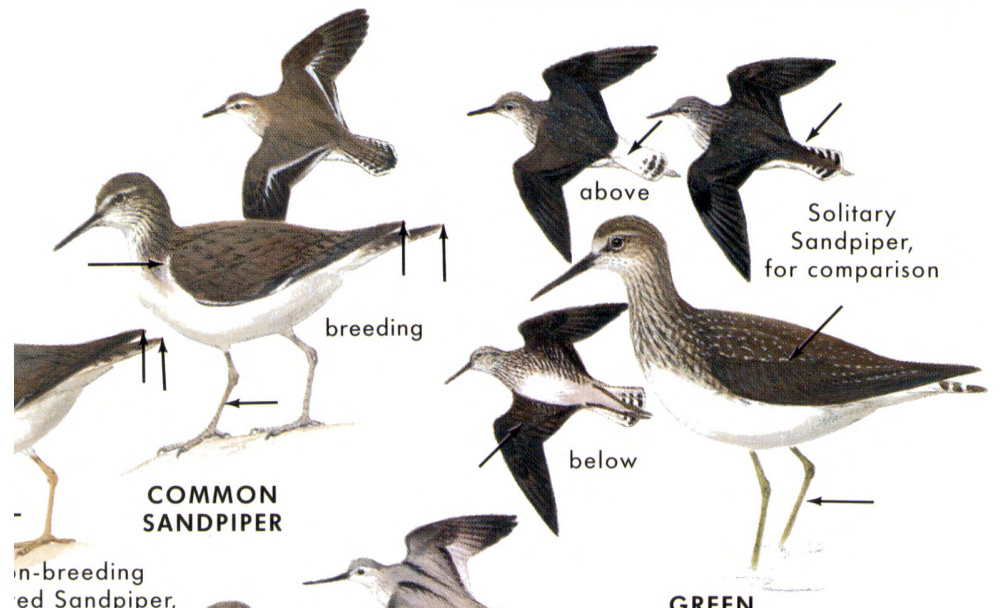
ed Sandpiper, comparison

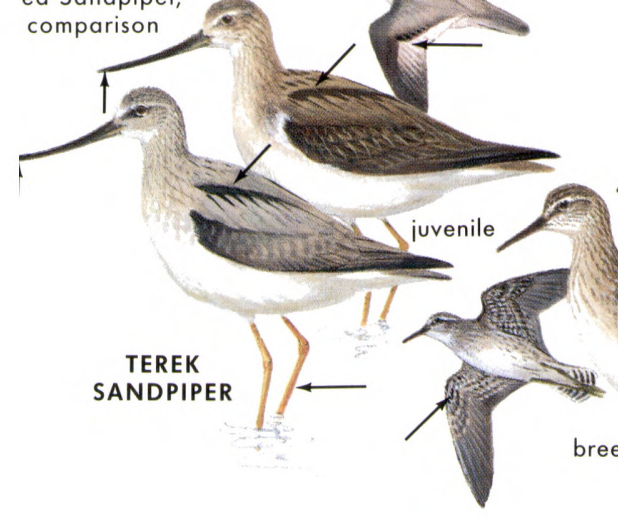

\section{SANDPIPER}

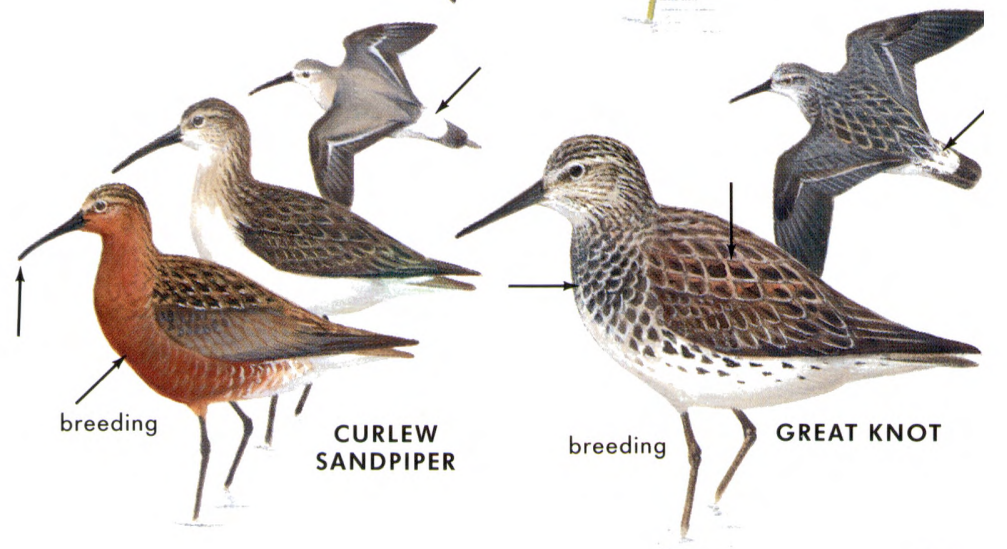


MARSH SANDPIPER Tringa stagnatilis

$91 / 4^{\prime \prime}(23 \mathrm{~cm})$. A bit smaller than the Lesser Yellowlegs, this slim Tringa can be told from that bird by its more needle-like bill and long, spindly olive-green legs. The white rump patch extends up the back in a wedge, like that of a Dowitcher (or a Greenshank). Thus, the Marsh Sandpiper might be compared to the Greenshank in the way the Lesser Yellowlegs might be compared to the Greater. Accidental, w. Aleutians.

GRAY-TAILED TATTLER Heteroscelus brevipes

(Polynesian Tattler) 10" $(25 \mathrm{~cm})$. Very similar to Wandering Tattler (pp. 142, 143), but in breeding plumage the underparts are not as strongly barred. At rest, the wing tips of the Wandering extend further beyond the tail. In fall migration the two are more difficult to separate. Best distinguished by voice, a sharp, upslurred whistletoo-weet' or tu-whip', with the accent on the second syllable. Rare, but regular migrant in outer Aleutians and Bering Sea islands; casual, n. Alaska. Also called Siberian Tattler.

\section{SPOTTED REDSHANK Tringa erythropus}

$12^{\prime \prime}(30 \mathrm{~cm})$. A slender, long-legged, long-billed wader; in breeding plumage it is sooty black, with minute white speckles on back and wings, making the bird appear a trifle paler above. The long legs are dark red; the long black bill is red basally. In non-breeding plumage this bird is gray and somewhat yellowlegs-like, but legs deep red, bill orange-red basally. In flight, a long white wedge shows on the back, as in Greenshank or Dowitcher. Note, a sharp, whistled tcheet', with rising inflection. Casual migrant (spring and fall) in outer Aleutians, Pribilofs. Accidental, British Columbia, Oregon, Nevada, California.

\section{COMMON GREENSHANK Tringa nebularia}

$12 \frac{1}{2 \prime}(31 \mathrm{~cm})$. Size and shape of the Greater Yellowlegs, but legs dull greenish (not bright yellow). The wedgelike white rump patch runs farther up the back, as in the Dowitcher. Call, a ringing, whistled tew tew tew, similar to Greater Yellowlegs'. Rare but regular migrant, mainly in spring, in the outer Aleutians, Pribilofs.

ORIENTAL PRATINCOLE Glareola maldivarum Family Glareolidae $91 / 4^{\prime \prime}(23 \mathrm{~cm})$. Pratincoles are long-winged, fork-tailed shorebirds that look somewhat like terns or giant swallows. This species is darkwinged, with a white rump and a creamy throat outlined with black. The wing linings are chestnut. Accidental, in outer Aleutians (Attu).

\section{JACK SNIPE Lymnocryptes minimus}

$7^{\prime \prime}(18 \mathrm{~cm})$. A small Old World snipe, the size of a Dunlin. It has a shorter bill than Common Snipe, no white or orange on its wedgeshaped tail, and lacks bars on its flanks. Usually silent when flushed; does not zig-zag. Accidental, Pribilofs, California. See Broad-billed Sandpiper (pp. 150, 151). 
- GALLINACEOUS OR FOWL-LIKE BIRDS (Turkeys, Pheasants, Grouse, Partridges, and Quail) Family Phasianidae. Turkeys are very large, with wattles and fanlike tails. Pheasants (introduced) have long, pointed, sweeping tails. Grouse are plump, chicken-like birds, without long tails. Partridges (of Old World origin) are intermediate in size between grouse and quail. Quail are the smallest. Food: Insects, seeds, buds, berries. Range: Nearly cosmopolitan. No. of species: World 207; West $17 \mid+3-4$ introduced successfully; others have failed). Often called "upland game birds."

\section{WILD TURKEY Meleagris gallopavo}

M99

Male $48^{\prime \prime}(120 \mathrm{~cm})$; female $36^{\prime \prime}(90 \mathrm{~cm})$. A streamlined version of the barnyard Turkey, with buffy white tips on the tail feathers in most southwestern birds (but tail feathers may have rusty tips in some other populations). Head naked; bluish with red wattles, intensified in male's display. Tail of male is erected like a fan during display. Bronzy iridescent body; barred wings (primaries and secondaries); "beard" on breast. The female is smaller, with a smaller head; less iridescent, and less likely to have a beard.

Voice: "Gobbling" of male like domestic Turkey's. Alarm, pit! or put-put! Flock call, keow-keow. Hen clucks to brood.

Range: E. and sw. U.S. to cen. Mexico. Introduced widely elsewhere. West: Map 99. Habitat: Woods, mountain forests, wooded swamps.

SAGE GROUSE Centrocercus urophasianus

M96

Male 26-30" (65-75 cm); female 22-23" (56-58 cm). A large, grayish grouse of open sage country, as large as a small Turkey; identified by its contrasting black belly patch and spikelike tail feathers. The male is considerably larger than the female, has a black throat, and, in communal dancing display, puffs out its white chest, exposing two yellow air sacs on the neck, at the same time erecting and spreading its pointed tail feathers in a spiky fan.

Voice: Flushing note, kuk kuk kuk. In courtship display the male makes a popping sound.

Range: Western N. America. Map 96. Habitat: Sagebrush plains; also foothills and mountain slopes where sagebrush grows.

RING-NECKED PHEASANT Phasianus colchicus

Male 30-36" (75-90 cm); female 21-25" (53-63 cm). A large, chicken-like or gamecock-like bird. Note the long, sweeping, pointed tail. Runs swiftly; flight strong, take-off noisy. Male highly colored and iridescent, with scarlet wattles on its face and a white neck-ring (not always present). The female is mottled brown, with a moderately long, pointed tail.

Voice: Male when crowing has a loud double squawk, kork-kok, followed by a brief whir of wings. When flushed, utters harsh croaks. The roosting call is a two-syllabled kutuck-kutuck, etc.

Range: Eurasia. Introduced widely in N. America and elsewhere. West: Map 89. Habitat: Farms, fields, marsh edges, brush. 


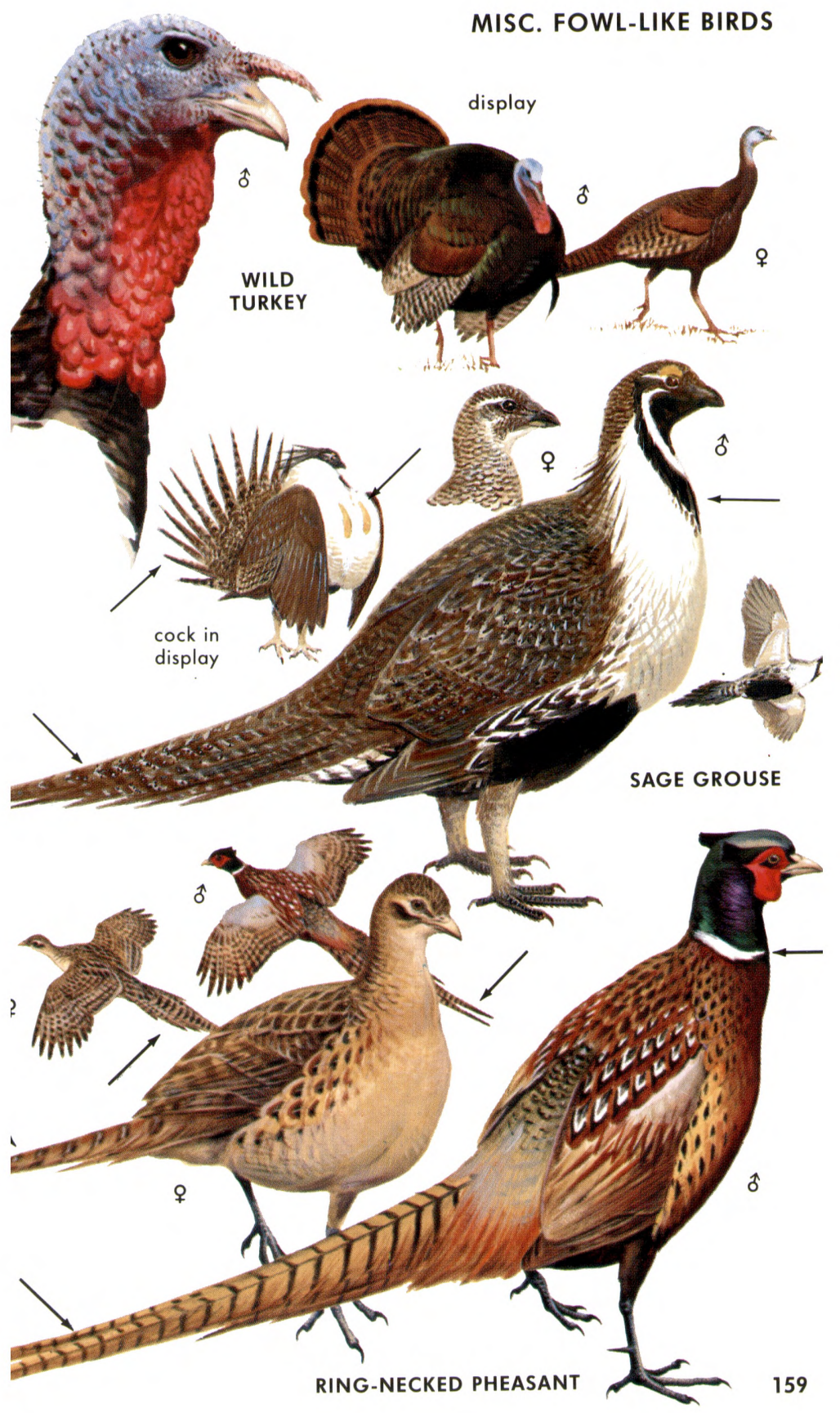


- GROUSE. Subfamily Tetraoninae. Ground-dwelling, chickenlike birds; larger than quail and lacking the long tails of pheasants. Food: Insects, seeds, buds, berries. Range: N. America, Europe, Asia. No. of species: World 17; West 10.

RUFFED GROUSE Bonasa umbellus

M95

$16-19^{\prime \prime}(40-48 \mathrm{~cm})$. Note the fan-shaped tail, with a broad black band near the tip. A large, red-brown or gray-brown, chicken-like bird of brushy woodlands, usually not seen until it flushes with a startling whir. Two color morphs: "Red" birds with rufous tails, and "gray" birds with gray tails. Red birds are more common in southern parts of range, gray birds northward or at higher altitudes. Voice: Drumming of male suggests a distant motor starting up. Muffled thumping starts slowly, accelerating into a whir: Bup ... bup . . bup . . bup . . bup, bup,up,r-rrrrrr.

Range: Alaska, Canada, n. U.S. West: Map 95. Habitat: Ground and understory of deciduous or mixed woodlands.

SHARP-TAILED GROUSE Tympanuchus phasianellus

M98

$15-20^{\prime \prime}(38-50 \mathrm{~cm})$. A pale, speckled brown grouse of prairie brush. Note the short pointed tail, which in flight shows white at the sides. Displaying male inflates purplish neck sacs.

Similar species: (1) Prairie-chickens have short, rounded, dark tails. (2) Female Pheasant (p. 159) has a long, pointed tail. (3) Ruffed Grouse has a large, banded, fan-shaped tail, and black neck ruff.

Voice: A cackling cac-cac-cac, etc. Courting note, a single low coo-oo, accompanied by quill-rattling, foot-shuffling.

Range: Alaska, Canada, nw. and n.-cen. U.S. West: Map 98. Habitat: Prairie, brushy groves, open thickets, forest edges, clearings, coulees, open burns in coniferous forests, etc.

GREATER PRAIRIE-CHICKEN Tympanuchus cupido

M97

$17-18^{\prime \prime}(43-45 \mathrm{~cm})$. A henlike bird of prairies. Brown, heavily barred. Note the short, rounded dark tail (black in males, barred in females). Courting males in communal "dance" inflate orange neck sacs and erect black, hornlike neck feathers.

Similar species: (1) See Lesser Prairie-Chicken. (2) Sharp-tailed Grouse, often called "Prairie-Chicken," has a whitish tail. (3) Female Pheasant (p. 159) has a long, pointed tail.

Voice: "Booming" male in dance makes a hollow oo-loo-woo, suggesting the sound made by blowing across the mouth of a bottle.

Range: Canadian prairies (where it is now extirpated, or nearly so) to coastal Texas. West: Map 97. Habitat: Native tallgrass prairie, now very limited; some agricultural land.

LESSER PRAIRIE-CHICKEN Tympanuchus pallidicinctus

M97

$16^{\prime \prime}(40 \mathrm{~cm})$. A small, pale prairie-chicken; best identified by range (see Map 97). The gular sacs of the male are dull purplish or plumcolored (not yellow-orange as in Greater Prairie-Chicken).

Voice: Courtship "booming" not as rolling nor as loud as Greater Prairie-Chicken's. Both have clucking, cackling notes.

Range: Resident southwest of the range of the Greater PrairieChicken, as shown on the map. Habitat: Sandhill country (sage and bluestem grass, oak shinnery). 


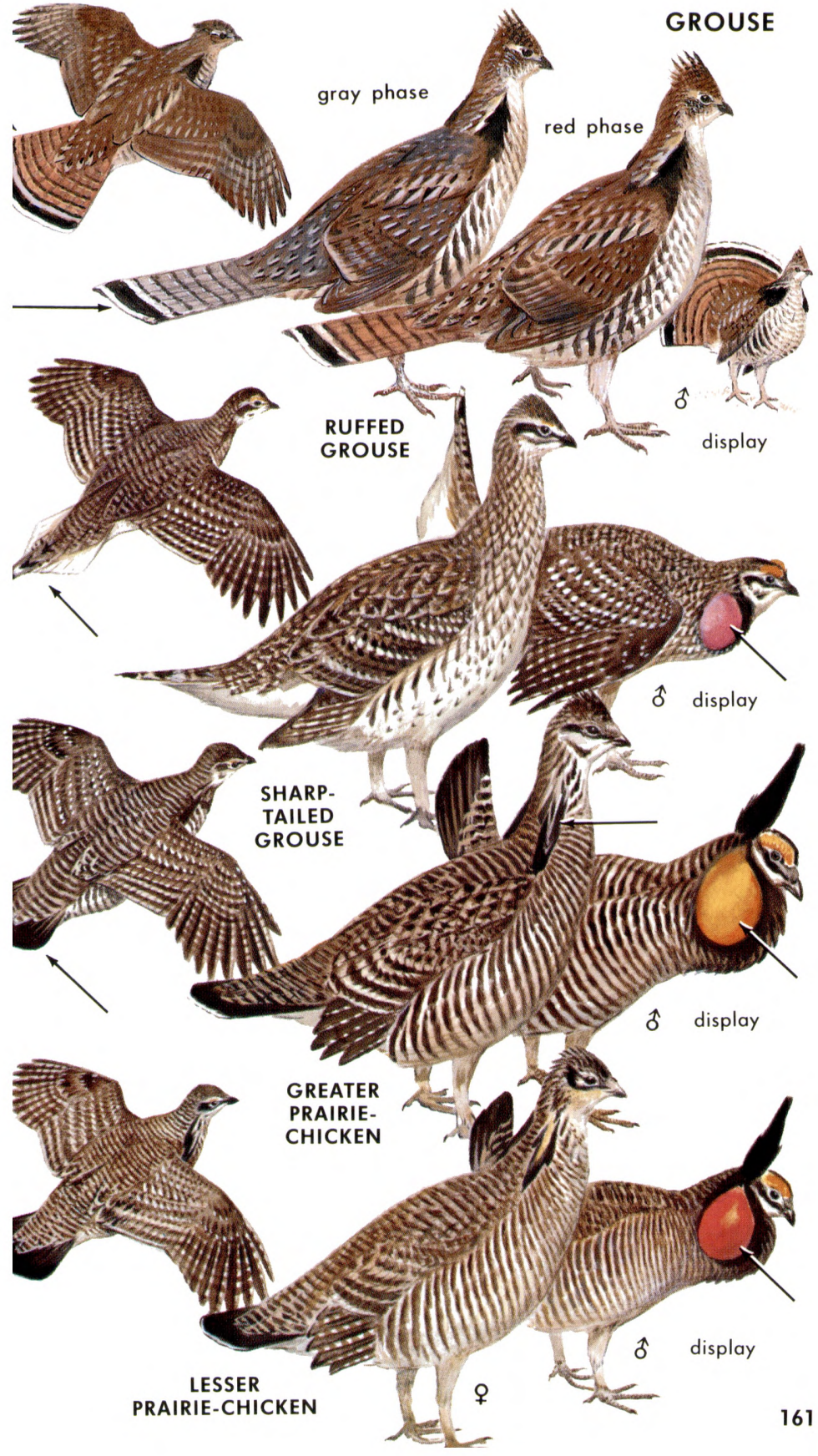


- PTARMIGANS. These hardy arctic and alpine grouse with feathered feet molt three times a year, camouflaging themselves to match the seasons; they change from dark plumage in summer to white in winter. During the spring and fall molts they have a patchy look. A red comb above the eye may be erected or concealed.

WILLOW PTARMIGAN Lagopus lagopus

M92

$16^{\prime \prime}(40 \mathrm{~cm})$. The Willow and Rock Ptarmigan are similar; in summer variable, brown or gray, with white wings and a white belly; in winter, white with black tails. In breeding plumage the male Willow Ptarmigan is more deeply chestnut about the head and body than the Rock. There is much variation between various molts.

Similar species: Some races of the Rock Ptarmigan are decidedly gray, finely barred. The bill is always smaller and more slender. In winter, male Rocks have a black mark between the eye and bill, lacking in both sexes of Willow Ptarmigan. Habitats differ; the Rock prefers higher, more barren hills.

Voice: Deep raucous calls, go-out, go-out. Male, a staccato crow, kwow, kwow, tobacco, tobacco, etc., or go-back, go-back.

Range: Arctic regions; circumpolar. West: Map 92. Habitat: Tundra, willow scrub, muskeg; in winter, sheltered valleys at lower altitudes.

ROCK PTARMIGAN Lagopus mutus

M93

$13^{\prime \prime}(33 \mathrm{~cm})$. The most hardy ptarmigan. The male in summer is usually grayer than the Willow, lacking the rich chestnut around the head and neck, but populations vary greatly. Some may be even paler than shown here or like the dark bird from Attu figured opposite. Females of the two species are similar but the Rock has a smaller bill. In winter, the white males have a black mark between the eye and the bill. This is absent in most females, which may be told from female Willows by their smaller bills.

Voice: Croaks, growls, cackles; usually silent.

Range: Arctic and alpine regions of N. Hemisphere. West: Map 93. Habitat: Above timberline in mountains (to lower levels in winter); also near sea level in bleak tundra of northern coasts.

WHITE-TAILED PTARMIGAN Lagopus leucurus

M94

$12-13^{\prime \prime}(30-33 \mathrm{~cm})$. The only ptarmigan normally found south of Canada. Note the white tail. In summer, this ptarmigan is brown, with a white belly and white wings and tail. In winter, it is pure white except for the black eyes and bill. The other two ptarmigan are larger and have black tails.

Voice: Cackling notes; clucks, soft hoots.

Range: Western N. America. Map 94. Habitat: Rocky alpine tundra; mountains above timberline. 


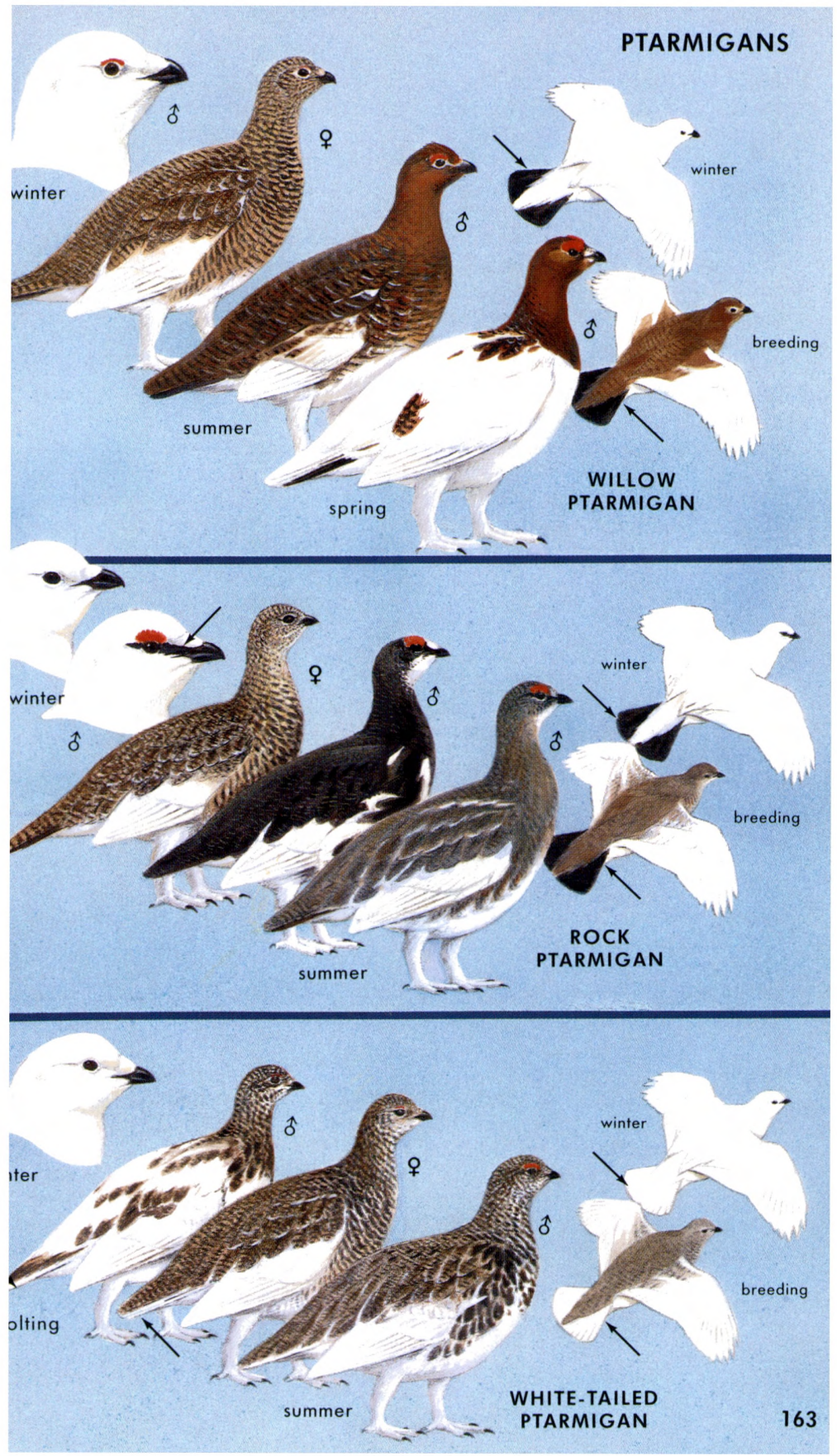


$15-17 "$ " $38-43 \mathrm{~cm})$. Look for this very tame, dusky grouse in the deep, wet conifer forests of the North. The male has a sharply defined black breast, with some white spots or bars on the sides and a chestnut band on the tip of the tail. A comb of erectile red skin above the eye is visible at close range. Birds of the $\mathrm{n}$. Rockies and Cascades, known as "Franklin's Grouse," lack the chestnut tip and have large white spots on the upper tail coverts. Female is dark rusty or grayish brown, thickly barred; tail short and dark, with a rusty tip (except in "Franklin's" form).

Range: Alaska, Canada, n. U.S. West: Map 90. Habitat: Conifer forests, jack pines, muskeg, blueberry patches, etc.

\section{BLUE GROUSE Dendragapus obscurus}

M91

$151 / 2-21^{\prime \prime}(39-53 \mathrm{~cm})$. The male is a dusky or sooty grouse. At the tip of its blackish tail is a broad pale band (absent in populations in the n. Rockies). Above each eye is a yellow or orange comb, erectile in display. In courtship display, coastal birds have yellow neck sacs; in birds of the Rockies, the neck sacs are purplish. Females are brown, mottled with black, and pale-bellied; their dark tails are somewhat like those of the males. Ruffed Grouse may be confused with female Blue Grouse, but both sexes of that bird have a lighter tail, with a bold black band near the tip.

Voice: Male in courtship gives a series of 5-7 low, muffled, booming or hooting notes, ventriloquial.

Range: Western N. America. Map 91. Habitat: Deciduous and mixed forests in mountains in summer; in conifer forests at higher elevations in winter.

\section{GRAY PARTRIDGE Perdix perdix}

$12-14 "(30-35 \mathrm{~cm})$. A rotund grayish partridge, larger than a quail; when flushed, note the short rufous tail, rusty face, chestnut bars on sides. Male has a dark, U-shaped splotch on the belly.

Similar species: Chukar (which also has a rufous tail) has a red bill and feet, and a black "necklace."

Voice: A loud, hoarse kar-wit, kar-wit.

Range: Eurasia. Introduced in N. America. West: Map 87. Habitat: Cultivated land, hedgerows, bushy pastures, meadows.

\section{CHUKAR Alectoris chukar}

M88

13" (33 cm). Like a large, sandy-colored quail; gray-brown with bright red legs and bill; light throat bordered by a clean-cut black "necklace." Sides boldly barred. Tail rufous.

Similar species: (1) Gray Partridge lacks the black necklace, has a dark gray bill and dark feet. (2) Mountain Quail is darker, with a long head plume. (3) The related RED-LEGGED PARTRIDGE, A. rufa, introduced into ne. Colorado, is darker; its necklace breaks into short streaks.

Voice: A series of chuck's; a sharp wheet-u.

Range: Asia, e. Europe. West: Introduced and established in w. N. America. Map 88. Habitat: Rocky, grassy, or brushy slopes; arid mountains, canyons. 

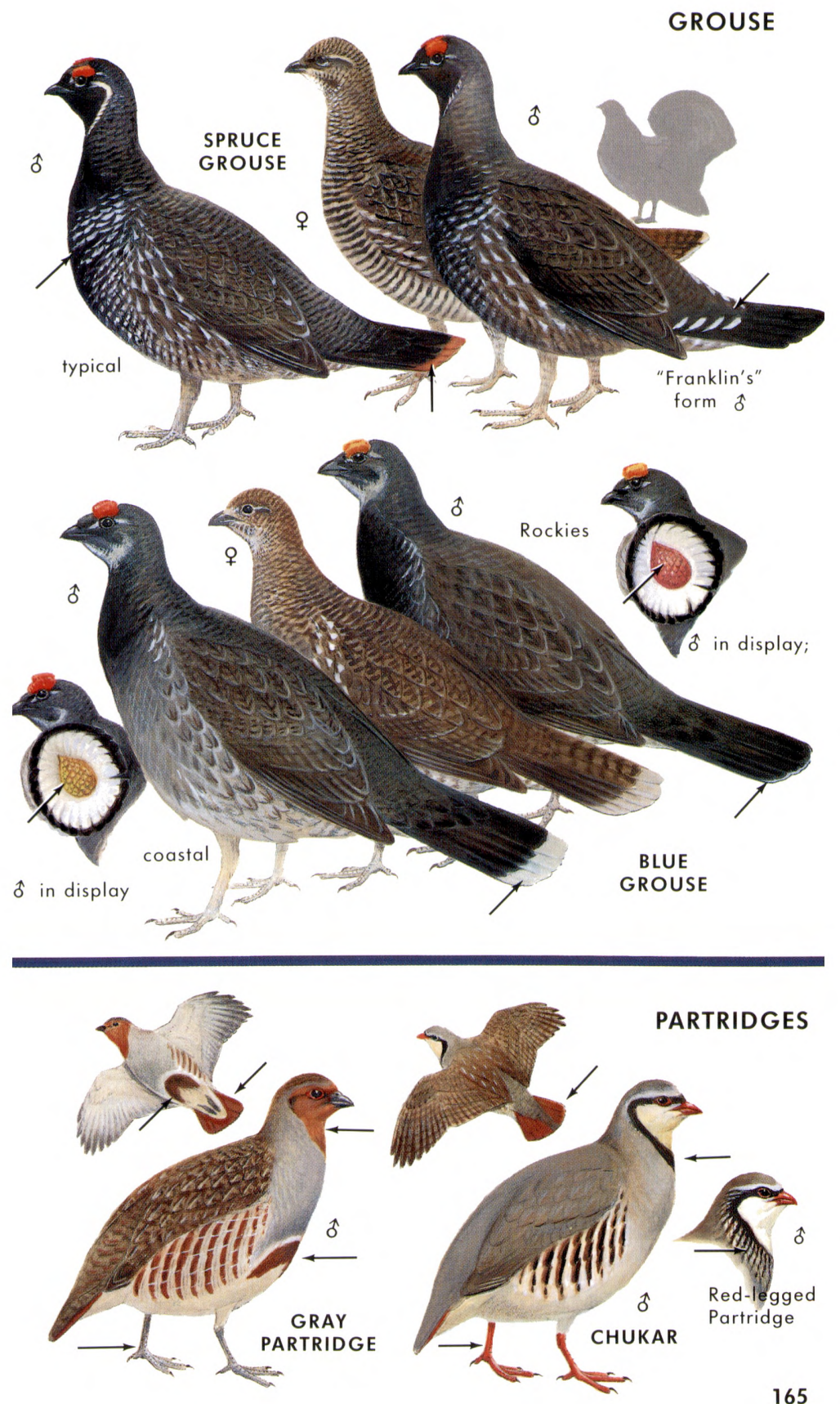
91/2-11" (24-28 cm). A small, plump, grayish, chicken-like bird, with a short black plume curving forward from the crown. Males have a black and white face and throat pattern. Females are duller. Voice: A three-syllabled qua-quer'go, or Chi-ca'go. Also light clucking notes. Male on territory, a loud kurr.

Range: Resident, British Columbia to Baja California; see Map 104. On western edge of Mojave and Colorado deserts where ranges of California and Gambel's quail overlap, hybrids occur. Habitat: Broken chaparral, woodland edges, coastal scrub, parks, estates, farms.

GAMBEL'S QUAIL Callipepla gambelii

M103

$10-11 \frac{1}{2} 2^{\prime \prime}(25-29 \mathrm{~cm})$. Replaces the California Quail in the deserts. Similar to that bird, but male has a black patch on a light, unscaled belly; flanks and crown more russet (a local name is "Redhead"). Female also lacks scaly pattern on belly.

Range: Resident sw. U.S., nw. Mexico. Map 103.

MOUNTAIN QUAIL Oreortyx pictus

M100

$10^{1 / 2}-11^{1} \frac{1}{2}$ " $(26-29 \mathrm{~cm})$. A gray and brown quail of the mountains. Distinguished from California Quail by a long straight head plume and chestnut (not black) throat. Note the chestnut and white side pattern. Female similar to male but duller, with a shorter plume.

Voice: A mellow wook? or to-wook?, repeated at intervals by male.

Range: Western U.S. to n. Baja California. Map 100.

SCALED QUAIL Callipepla squamata

M102

$10-12^{\prime \prime}(25-30 \mathrm{~cm})$. Note the bushy white crest or "cotton top." A pale grayish quail ("Blue Quail") of arid country, with scaly markings on breast and back. Runs; often reluctant to fly.

Voice: A guinea-hen-like chekar' (also interpreted as pay-cos).

Range: Sw. U.S. to cen. Mexico. Map 102. Habitat: Grasslands, brush, arid country.

NORTHERN BOBWHITE Colinus virginianus

(Common Bobwhite) 81/2-101/2" (21-26 cm). A small, rotund fowl, near the size of a Meadowlark. Ruddy, barred and striped, with a short, dark tail. Male has a conspicuous white throat and white eyebrow stripe; in the female these are buff. A dark Mexican form, "MASKED BOBWHITE," with a black throat and rusty underparts once lived in s. Arizona, where it has been reintroduced.

Voice: A clearly whistled Bob-white! or poor, Bob-whoit! Covey call, ko-loi-kee?, answered by whoil-kee!

Range: Cen. and e. U.S. to Guatemala, Cuba. West: Map 101. Habitat: Farms, brushy open country, roadsides, wood edges.

MONTEZUMA QUAIL Cyrtonyx montezumae

M100

(Harlequin Quail) 8-91/2" $(20-24 \mathrm{~cm})$. A rotund quail of Mexican mountains. Note the male's oddly striped clown's face, bushy crest on the nape, and spotted body. Females are brown, with less obvious facial stripings. Tame (called "Fool's Quail").

Voice: A soft, whinnying or quavering cry; ventriloquial.

Range: Resident sw. U.S. to s. Mexico. Map 100. Habitat: Grassy oak canyons, wooded mountain slopes with bunch grass. 


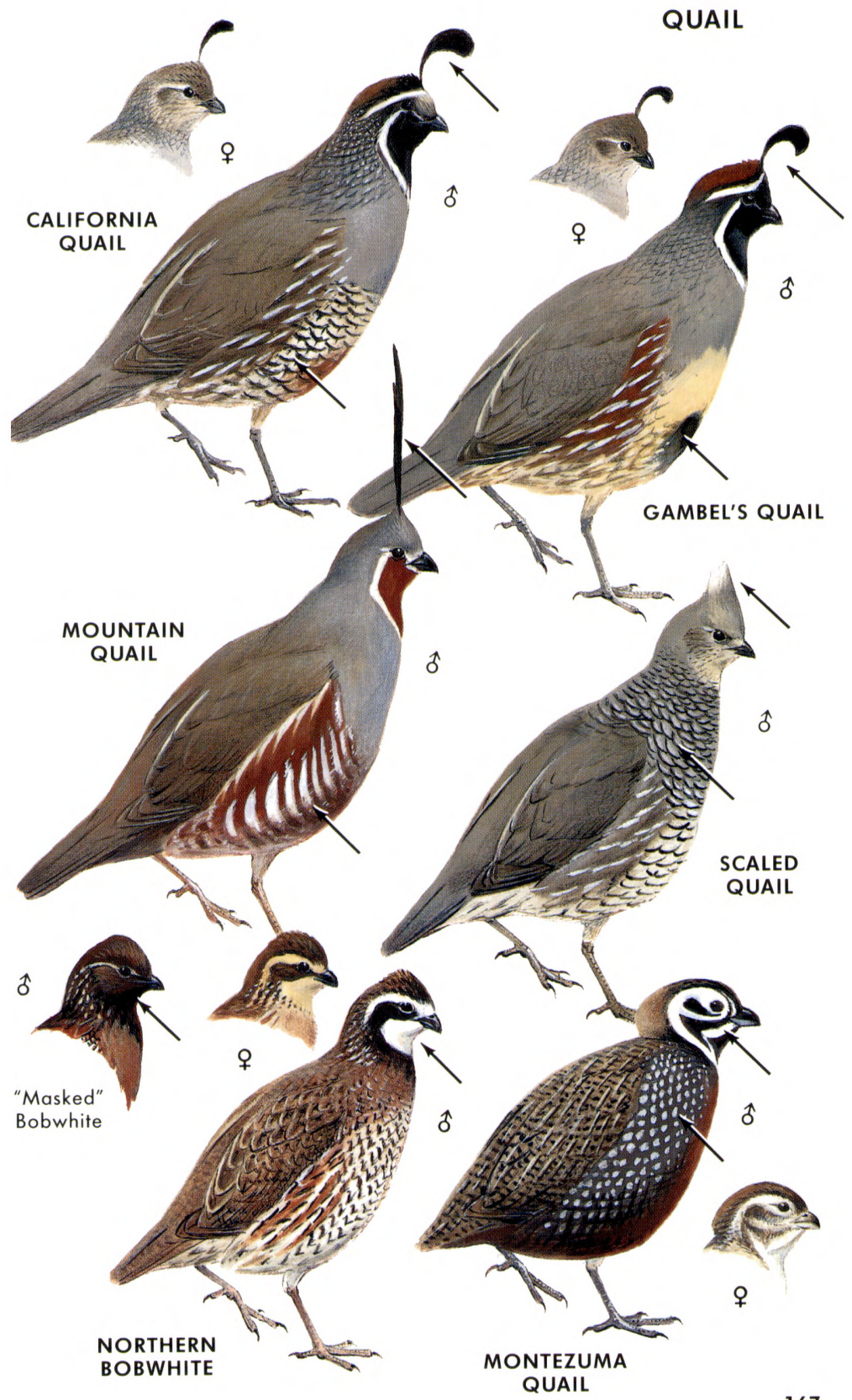


BIRDS OF PREY. We tend to lump all the diurnal (day-flying) raptors with hooked beaks and hooked claws as "birds of prey." Actually, they fall into two quite separate families:

(1) The hawk group (Accipitridae) - kites, eagles, buteos, accipiters, and harriers-of which there are 217 species in the world, 20 in the West +3 or 4 accidentals.

(2) The falcon group (Falconidae) - falcons and caracaras. These are shown on pp. 184-187. There are 52 species in the world, 7 in the West +2 accidentals.

The illustrations in the following pages present the obvious "field marks." For a more in-depth treatment of variable plumages, see $A$ Field Guide to the Hawks (No. 35 in the Field Guide series) by Clark and Wheeler. For the subtleties of "jizz" (general impression and shape) at a distance, study Hawks In Flight by Dunne, Sutton, and Sibley.

The various groups of raptors can be sorted out by their basic shapes and flight style. When not flapping they may alternate between soaring, with wings fully extended and tails fanned, and gliding, with wings slightly pulled back and tails folded. These two pages show some basic silhouettes.

BUTEOS (buzzard hawks) are stocky, with broad wings and wide rounded tails. They soar and wheel high in the open sky.

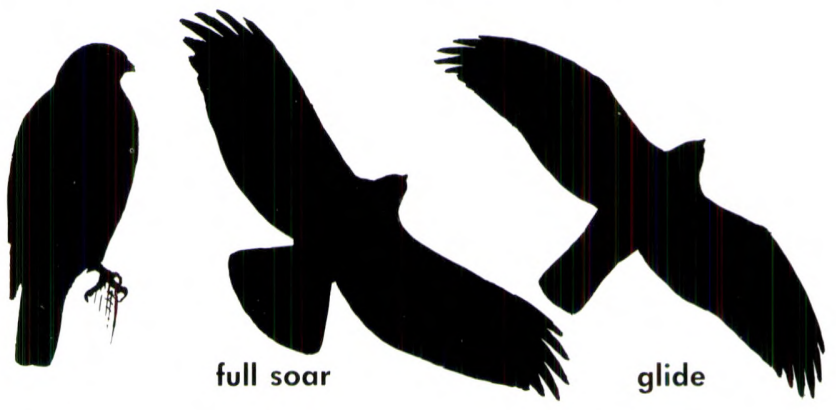

ACCIPITERS (true hawks) have small heads, short rounded wings, and longish tails. They fly with several rapid beats and a glide.
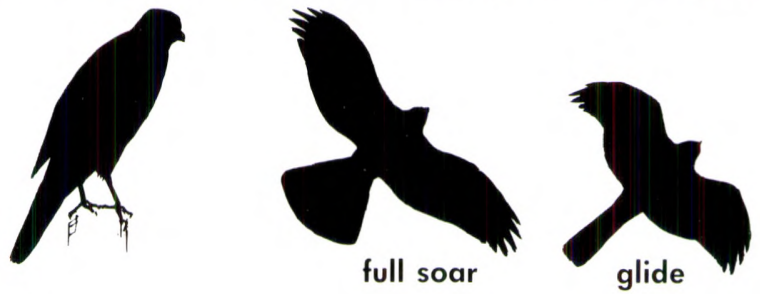
HARRIERS are slim, with slim, round-tipped wings and long tails. They fly in open country and glide low, with a vulture-like dihedral.
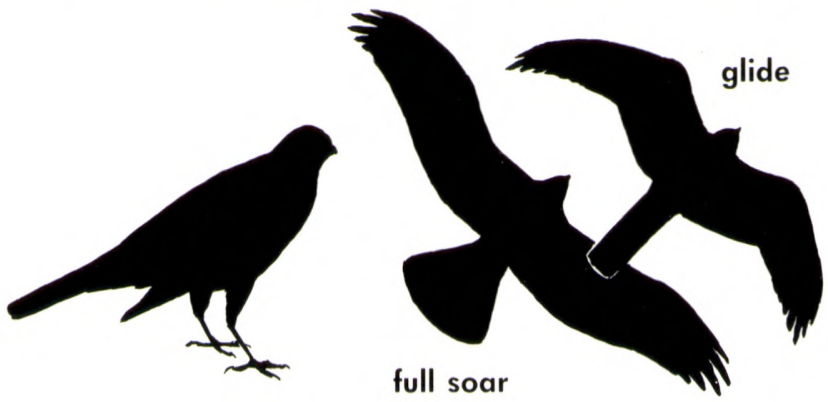

KITES (western species) are falcon-shaped, but unlike falcons, they are buoyant gliders, not power-fliers.
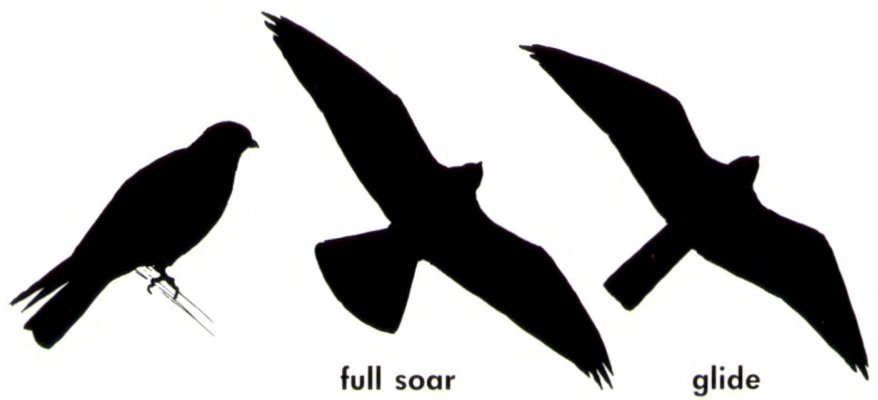

FALCONS have long, pointed wings and long tails. Their wing strokes are strong and rapid.

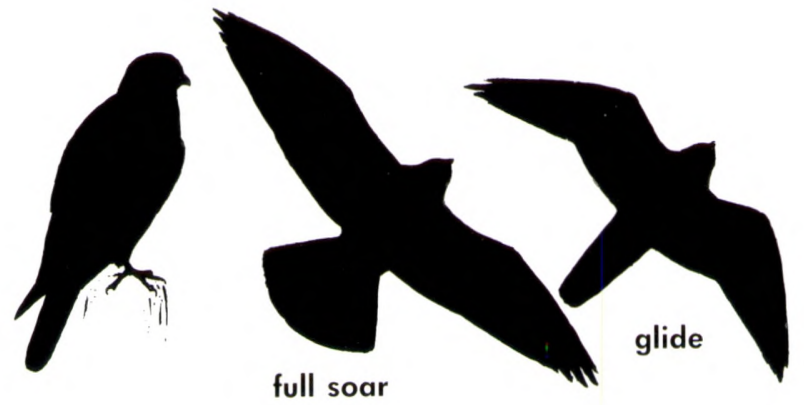


- KITES. Graceful birds of prey, of southern distribution. U.S. species (except Snail Kite of Florida) are falcon-shaped, with pointed wings. Food: Large insects, reptiles, rodents.

\section{WHITE-TAILED KITE Elanus leucurus}

(Black-shouldered Kite) 15-17" (38-43 cm). This whitish kite is falconshaped, with long, pointed wings and a long white tail. Soars and glides like a small gull; often hovers. Adult: Pale gray with a white head, underparts, and tail. A large black patch on the fore edge of the upperwing is obvious in perched birds. Overhead, shows an oval black patch at the carpal joint ("wrist") of the underwing. Immature: Recognizable as this kite, but has a rusty breast, a brown back, and a narrow dark band near the tip of its pale grayish tail.

Voice: A whistled kee kee kee, abrupt or drawn out.

Range: W. Oregon and s. Texas to Chile, Argentina. West: Map 68. Habitat: Open groves, river valleys, marshes, grasslands.

\section{MISSISSIPPI KITE Ictinia mississippiensis}

14" $(35 \mathrm{~cm})$. Falcon-shaped, graceful and gray. Gregarious; spends much time soaring. Adult is dark above, lighter below; head pale gray; tail and underwing blackish. No other falcon- like bird has a black unbarred tail. A broad pale patch shows on the rear edge of the wing (not visible when the bird is overhead). The immature is heavily streaked on its rusty underparts; the tail shows white bars when seen overhead.

Voice: Usually silent; about nest, a two-syllabled phee-phew.

Range: Mainly s. U.S.; winters Cen. and n. S. America. West: Map 69. Habitat: Wooded streams; groves, shelterbelts.

\section{SWALLOW-TAILED KITE Elanoides forficatus}

This raptor of the se. U.S. (not shown) has been recorded as an accidental in New Mexico, Arizona, and Colorado. See eastern Field Guide to the Birds.

- HARRIERS. Slim raptors with slim wings, long tails. Flight low, languid, gliding, with wings in a shallow V. Sexes not alike. Harriers hunt in open country. We have only one species in N. America.

\section{NORTHERN HARRIER Circus cyaneus}

(Marsh Hawk) 171/2-24" (44-60 cm). A slim, long-winged, long-tailed raptor of the open country. In all plumages shows a white rump patch. Males are pale gray, whitish beneath with a gray hood; females are brown with heavy streaks; immature are russet or orangy below. Glides and flies buoyantly and unsteadily low over the ground, with wings slightly above the horizontal, suggesting the Turkey Vulture's dihedral. Overhead, the wing tips of the pale male have a "dipped-in-ink" look, and there is a black border on the trailing edge of each wing.

Voice: A weak, nasal whistle, pee, pee, pee.

Range: Alaska, Canada to s. U.S.; n. Eurasia. Winters to n. S. America, n. Africa. West: Map 71. Habitat: Marshes, fields, prairies. 
KITES, HARRIERS

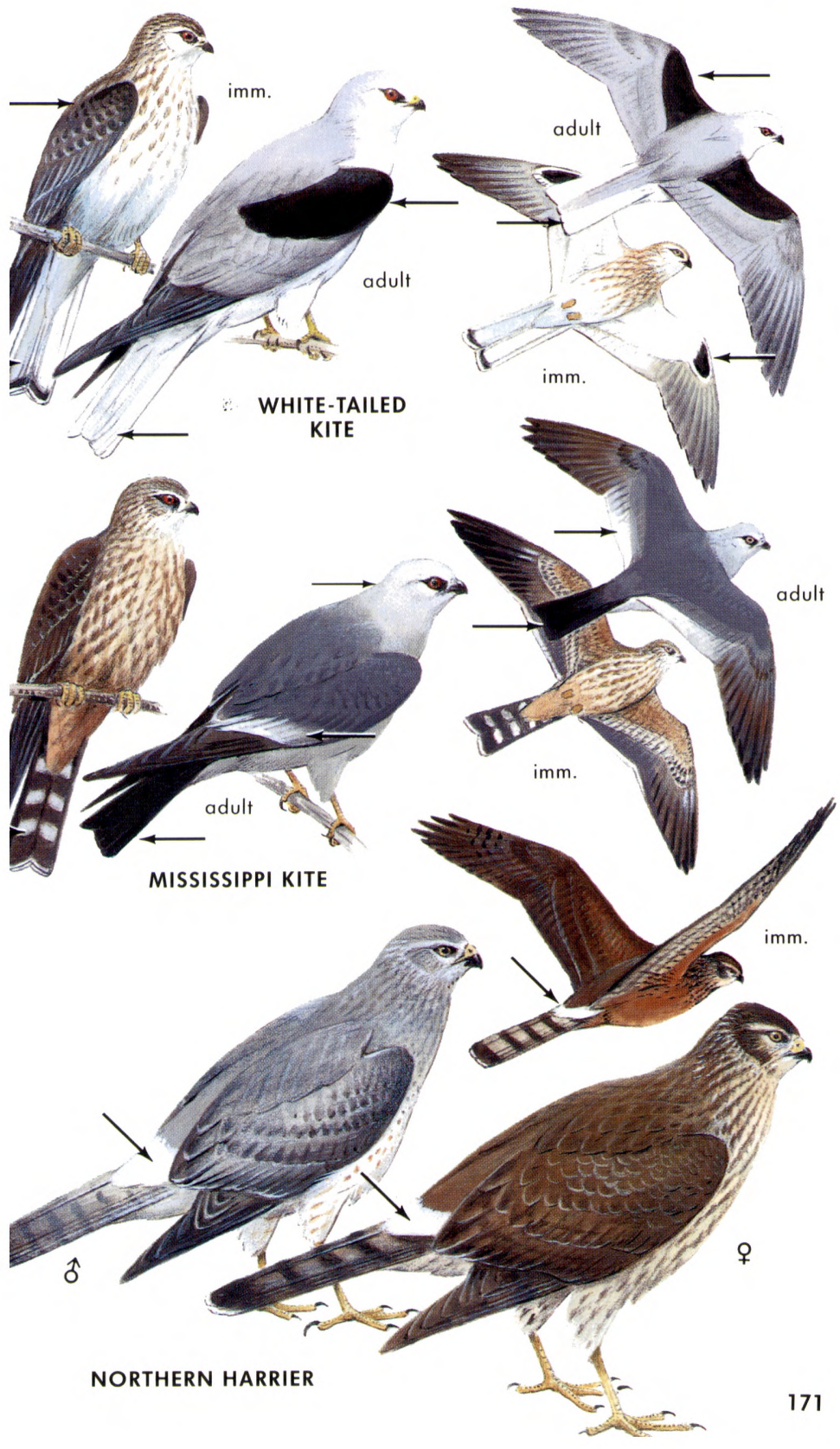


- ACCIPITERS, or "BIRD HAWKS." Long-tailed woodland raptors with rounded wings, adapted for hunting among the trees. Typical flight consists of several quick beats and a glide. Sexes similar; female larger. Size not always reliable in separating the three species; they may almost overlap, but not quite. Food: Chiefly birds, some small mammals.

SHARP-SHINNED HAWK Accipiter striatus

M72

$10-14^{\prime \prime}(25-35 \mathrm{~cm})$. Near the size of a jay; a small, slim-bodied woodland hawk, with a slim tail and short, rounded wings. Flies with several quick beats and a glide. Adult has a dark back, rustybarred breast. Folded tail of male is slightly notched or square (may seem a bit rounded when spread). Head and neck proportionately smaller than Cooper's. Immature is dark brown above, streaked with rusty on underparts.

Similar species: Female Cooper's Hawk is obviously larger, with a well-rounded tail; but male Cooper's and female Sharp-shin may approach each other so closely in size and tail shape that some cannot be safely identified in the field. See A Field Guide to Birds of Prey (Clark and Wheeler) and Hawks in Flight (Dunne, Sibley, and Sutton) for further discussion.

Voice: Like Cooper's Hawk's, but shriller; a high kik, kik, kik.

Range: Tree limit in Alaska, Canada to n. Argentina. Winters from n. U.S. south. West: Map 72. Habitat: Open deciduous woodlands, mixed or coniferous forests, thickets, edges.

COOPER'S HAWK Accipiter cooperii

M73

14-20" $(35-50 \mathrm{~cm})$. A short-winged, long-tailed hawk, very similar to the Sharp-shinned Hawk but larger; female usually is not quite as long as a Crow. The tail of the female is well rounded, even when folded; male's less so. Adult has a proportionately larger head and neck than the Sharp-shin, with more contrast between blackish crown and gray nape. When the bird is gliding the head projects well beyond the wrists of the wing. The white tip on the tail is broader than in the "Sharpie." The immature is brown, streaked on breast, white on belly. No strong white eyestripe as in the Goshawk. Voice: About nest, a rapid kek, kek, kek; suggests a Flicker.

Range: S. Canada to n. Mexico. West: Map 73. Habitat: Mature forest, open woodlands, wood edges, river groves.

NORTHERN GOSHAWK Accipiter gentilis

M74

20-26" (50-65 cm). Adult: A large, robust hawk with a longish tail, rounded wings. Crown and cheek blackish; broad white stripe over the eye. Underparts pale gray, finely barred; back paler and grayer than in Cooper's or Sharp-shin; tail broader. More buteo-like when soaring. Immature: Like an immature Cooper's; usually larger; note pale stripe over the eye, and irregular tail-banding. Striping on underparts covers both breast and belly.

Voice: Kak, kak, kak, or kuk, kuk, kuk, heavier than Cooper's.

Range: Eurasia, northern N. America. West: Map 74. Habitat: Coniferous and deciduous forests, especially in mountains; forest edges; winters in lowlands. 
Accipiters

(true hawks)

have small heads, short rounded

wings, long tails.

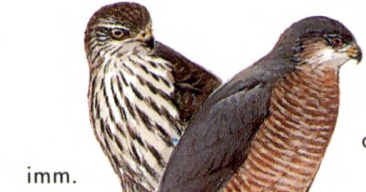

ACCIPITERS

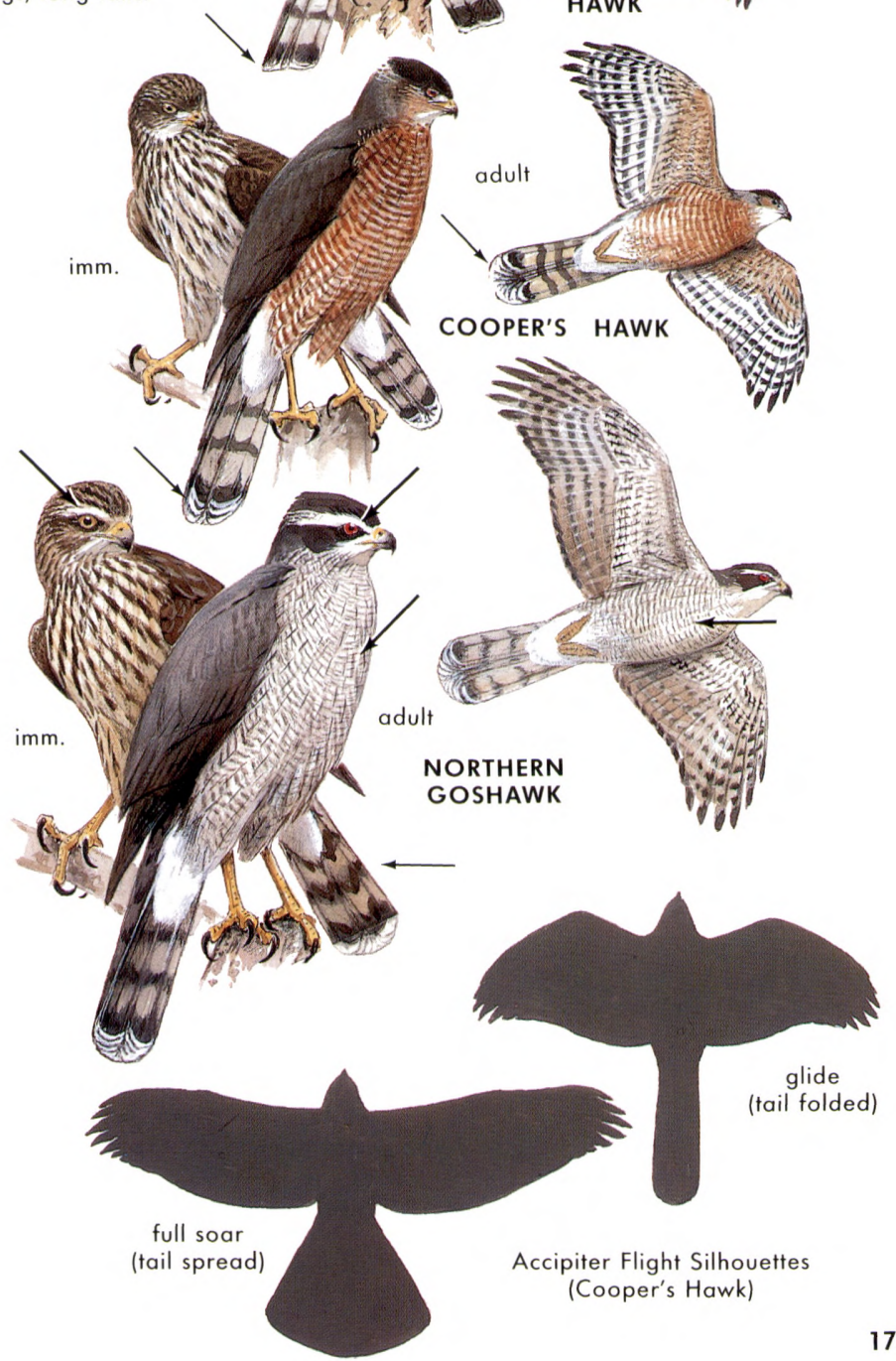


- BUTEOS, or BUZZARD HAWKS. Large, thick-set hawks, with broad wings and wide, rounded tails. Buteos habitually soar high in wide circles. Much variation; sexes similar, females larger. Young birds are usually streaked below. Black morphs often occur. For an in-depth discussion of variant plumages, see A Field Guide to Hawks of North America (Clark and Wheeler). Food: Rodents, rabbits, sometimes small birds, reptiles, grasshoppers.

RED-TAILED HAWK Buteo jamaicensis

M78

19-25" (48-63 cm). When this large, broad-winged, wide-tailed hawk veers while soaring, the rufous on the topside of the tail is evident (on adults). From below the tail is pale, but it may transmit a hint of red. Overhead, a dependable mark on all but blackish birds is a black or dark patagial bar on the fore edge of the wing. Immature birds have grayish tails that may or may not show narrow banding. They also show the patagial bar. Underparts of typical Redtails east of the Rockies are "zoned" (light breast, broad band of streaks across the bellyl, except in some birds of sw. Texas ("Fuertes" Red-tail). On the Great Plains, the pale kriderii form is found. There is much variation further west; these Red-tails tend to be darker. One might encounter the blackish harlani, as well as deep rusty and melanistic birds. The latter usually have the tell tale rust on their tails. Red-tails usually perch conspicuously.

Voice: An asthmatic squeal, keeer-r-r (slurring downward).

Range: Alaska, Canada, to Panama. West: Map 78. Habitat: Open country, woodlands, prairie groves, mountains, plains, roadsides.

"HARLAN'S" RED-TAILED HAWK Buteo jamaicensis harlani

A variable blackish race of the Red-tail; regarded by some as a distinct species. Similar to other melanistic Red-tails, but tail never solid red; usually dirty white, with a longitudinal mottling and freckling of black merging into a dark terminal band, giving a whiterumped look. Some may have a mottling of red on the tail.

Range: Breeds in e. Alaska and nw. Canada. Winters southeastward to Texas and the lower Mississippi Valley.

"KRIDER'S" RED-TAILED HAWK Buteo jamaicensis kriderii

A pale prairie race or form of the Red-tail, with a whitish tail that may be tinged with pale rufous.

Range: Prairies and plains of Canada and north-central U.S. Winters south through the southern plains to Texas, Louisiana.

SWAINSON'S HAWK Buteo swainsoni

M77

$19-22^{\prime \prime}(48-55 \mathrm{~cm})$. A buteo of the plains, proportioned like a Redtail but wings a bit more pointed. When gliding, wings are held slightly above horizontal. Typical adults have a dark breastband. Overhead, buffy wing linings contrast with dark flight feathers. Tail gray above, often becoming white at the base. There are confusing individuals with light breasts, and dark melanistic birds; note the underwing with its dark flight feathers.

Voice: A shrill, plaintive whistle, kreeeeeeer.

Range: Nw. N. America to n. Mexico; winters to Argentina. West: Map 77. Habitat: Plains, range, open hills, sparse trees. 

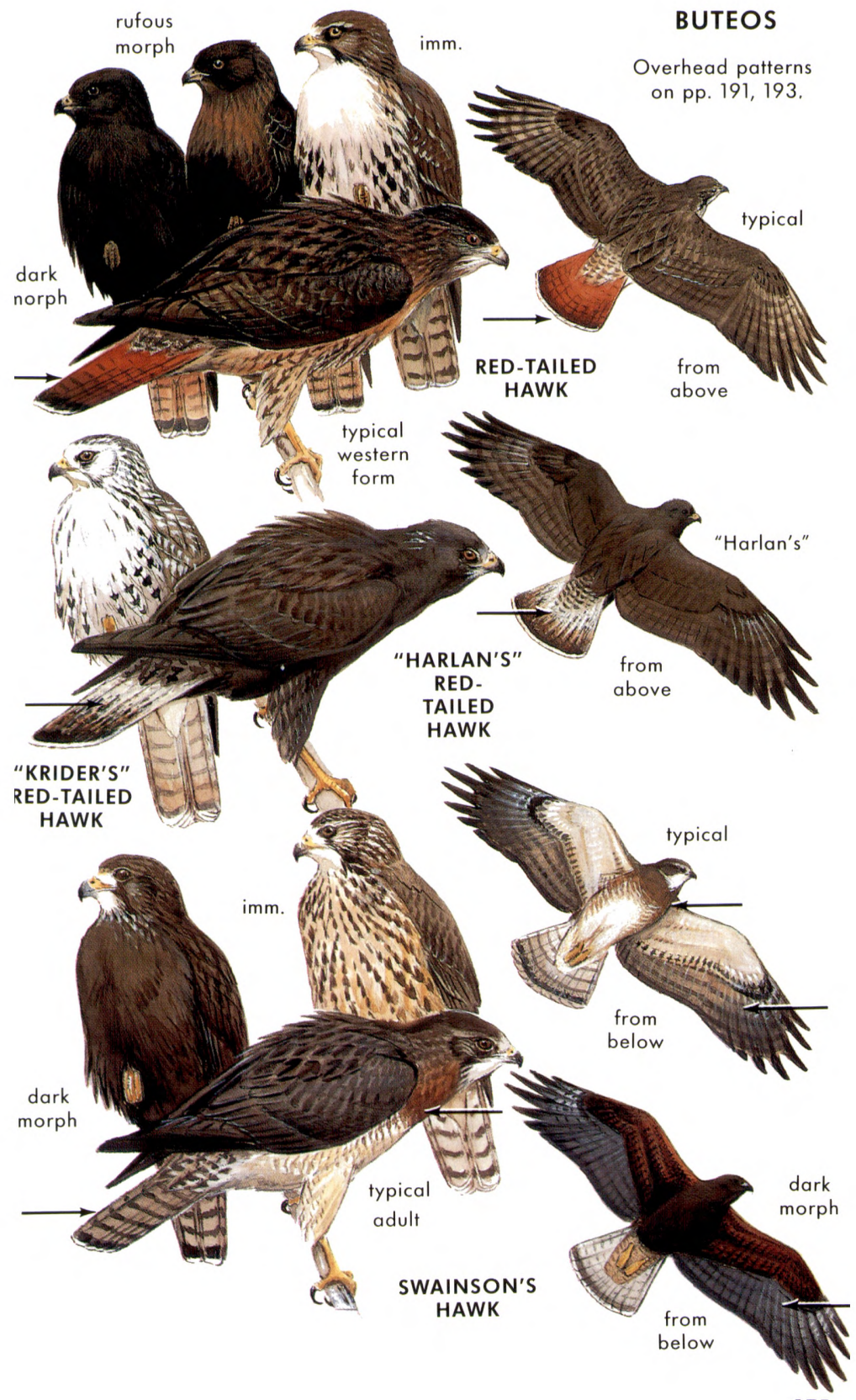
$19-24^{\prime \prime}(48-60 \mathrm{~cm})$. This big hawk of open country habitually hovers on beating wings. A buteo by shape; larger and with somewhat longer wings and tail than the others (except Ferruginous Hawk). Typical birds (but not all adults) show a dark or blotched belly and a black patch at the "wrist" (carpal joint) of the underwing. Tail white, with a broad black band or bands toward the tip. Black morph may lack extensive white on tail, but the broad terminal band and extensive white on the underwing are good points.

Similar species: See (1) Northern Harrier; (2) Golden Eagle.

Range: Arctic; circumpolar. Winters to s. U.S., cen. Eurasia. West: Map 80. Habitat: Tundra escarpments, arctic coasts; in winter, open fields, plains, marshes.

RED-SHOULDERED HAWK Buteo lineatus

M75

$17-24 "(43-60 \mathrm{~cm})$. Adult: Recognized as a buteo by the ample tail and broad wings; as this species by the heavy dark bands across both sides of the tail. Adults have dark rufous shoulders (not always easy to see) and robin-red underparts. In flight, note the translucent patch, or "window," at the base of the primaries. Immature: Streaked, recognized by proportions, tail bands, and, in flight overhead, by the wing "windows."

Similar species: See other reddish-breasted hawks: (1) Adult Broadwing has paler wing linings, broader white bands on tail. See also immature Broad-wing; (2) Cooper's Hawk; (3) Red-tail.

Voice: A two-syllabled scream, kee-yer (dropping inflection).

Range: Se. Canada, e. U.S., California, Mexico. West: Map 75. Habitat: Bottomland woods, wooded rivers.

BROAD-WINGED HAWK Buteo platypterus

M76

$14-19^{\prime \prime}(35-48 \mathrm{~cm})$. A small, chunky buteo, the size of a crow. Note tail banding of adult - white bands about as wide as the black ones. Wing linings white. The rare dark morph, which breeds in Alberta, has dark wing linings, but shows the usual Broad-wing tail pattern. Immature: Tail bands more numerous, restricting the white.

Similar species: Young Red-shouldered Hawk is similar to immature Broad-wing, but the latter is chunkier, with a stubbier tail and shorter wings; the underwing is usually whiter.

Voice: A shrill, high-pitched pweeeeeee (diminuendo).

Range: S. Canada, e. U.S. Winters mainly in Cen. and S. America. West: Map 76. Habitat: Woods, groves.

FERRUGINOUS HAWK Buteo regalis

M79

$23-25^{\prime \prime}(58-63 \mathrm{~cm})$. A large, narrow-winged buteo of the plains. Rufous above, whitish below, with a whitish or pale rufous tail and light patch on upper surface of primaries. Head often quite pale. Overhead, typical adults show a dark $V$ formed by the rufous thighs. Immatures lack this and also the rusty patches on the underwing. They show a white rump and a gray tail. Dark morphs (adults) overhead have dark wing linings, contrasting with white flight feathers and white tails.

Range: Sw. Canada, w. U.S. Winters sw. U.S., n. Mexico. Map 79. Habitat: Plains, prairies. 


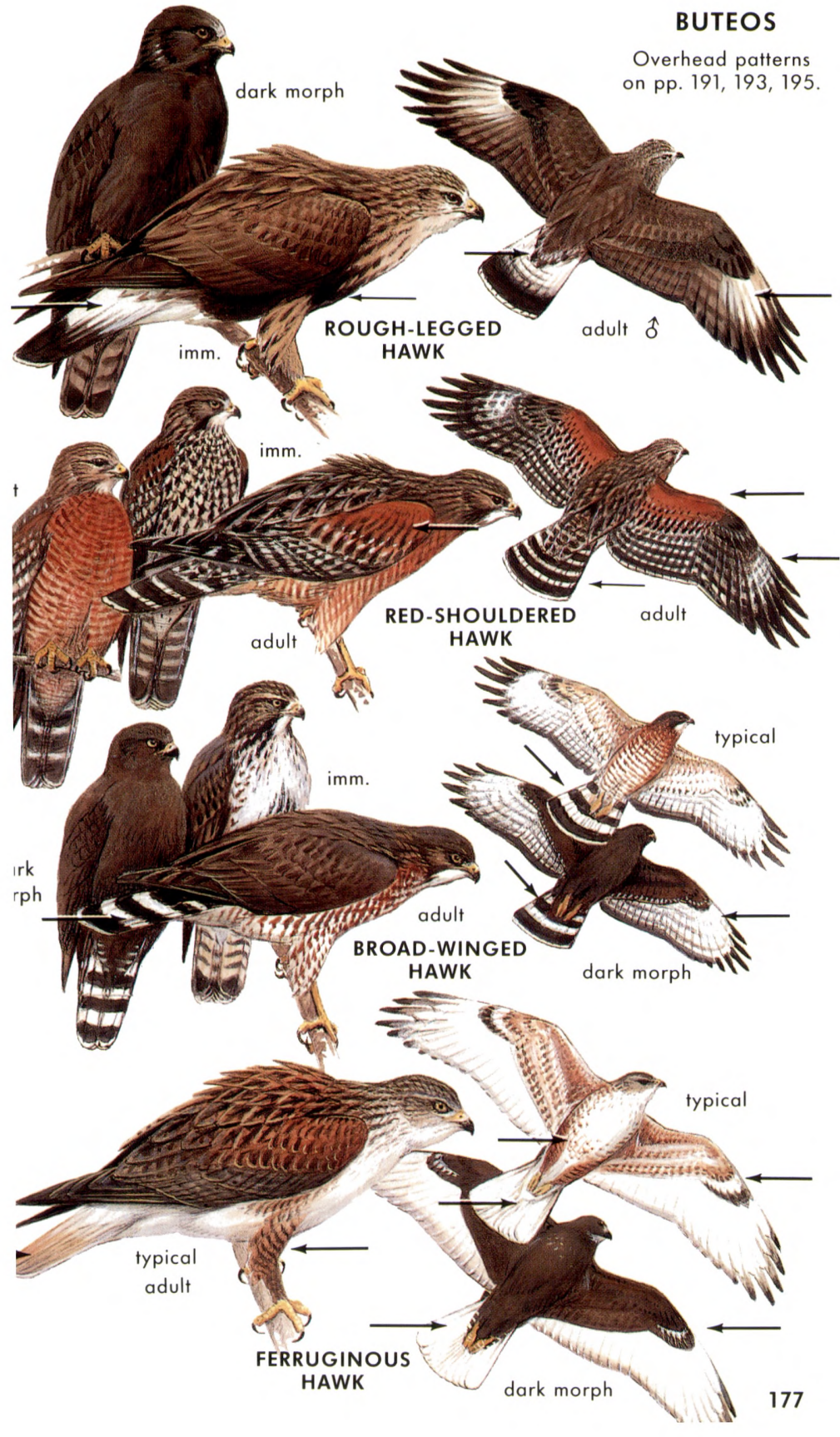


28" $(70 \mathrm{~cm})$; spread $3 \frac{1}{1 / 2}-3 \frac{3}{4} \mathrm{ft}$. A black hawk of the Buteo type, with a flashing white rump and white band at the tip of the tail. Shows chestnut areas on thighs and shoulders-a mark of distinction from other black or melanistic buteos or the much chunkier Black-Hawk. Immature has light, streaked underparts and rusty shoulders; might be confused with Red-shouldered Hawk except for the conspicuous white at the base of the tail. Also known as Bay-winged Hawk.

Range: Sw. U.S. south to Argentina. West: Resident, s. and cen. Arizona, se. New Mexico, w. Texas. Also se. California (Colorado R.), where it formerly bred and has been reintroduced. Casual, s. Nevada, Utah. Habitat: River woods, mesquite, brush, cactus deserts.

ZONE-TAILED HAWK Buteo albonotatus

$181 / 2-21^{1 / 2}{ }^{\prime \prime}(47-54 \mathrm{~cm}) ;$ spread $4 \mathrm{ft}$. A dull black hawk, with more slender wings than most other buteos. Might be mistaken for Turkey Vulture because of its proportions and two-toned underwing, but the hawk head and white tail bands (pale gray on topside) identify the adult. The immature has narrower tail bands and a scattering of small white spots on its black body.

Range: Breeds locally in nw., cen., and se. Arizona, s. and ne. New Mexico, w. Texas (Trans-Pecos) to n. S. America. Casual visitor to s. California (had bred). Accidental, Nevada, Utah. Habitat: River woodlands, desert mountains. canyons.

\section{COMMON BLACK-HAWK Buteogallus anthracinus}

20-23" (50-58 cm); spread $4 \mathrm{ft}$. A black, buteonine hawk with exceptionally wide wings and long, chicken-like yellow legs. Identified by its chunky shape and the broad white band crossing the middle of the tail. In flight, a whitish spot shows near the tip of the wing at the base of the primaries. Immature: Dark-backed with a heavily striped buffy head and underparts; the tail is narrowly banded with five or six dark bands.

Similar species: Whereas the slimmer-winged Zone-tailed Hawk bears a superficial resemblance to a Turkey Vulture, the broader-winged BlackHawk suggests a Black Vulture.

Range: Sw. U.S. to Ecuador. West: Breeds locally in cen. and s. Arizona. Has bred in s. New Mexico. Casual, w. Texas (Trans-Pecos), Utah. Habitat: Wooded stream bottoms.

\section{GRAY HAWK Asturina nitida}

16-18" (40-45 cm); spread $3 \mathrm{ft}$. A small Buteo. Adults are distinguished by their buteo-like proportions, gray back, and thickly barred gray underparts, white band on rump, and widely banded tail (similar to Broadwinged Hawk's). Immature has a narrowly barred tail, striped buffy underparts. Note the relatively short wing, barred thighs, strongly marked buffy face, white bar across rump.

Range: Sw. U.S. to Brazil. West: Breeds locally in se. Arizona, sw. New Mexico; casual, w. Texas. Habitat: Wooded lowland streams.

WHITE-TAILED HAWK Buteo albicaudatus (not shown)

A resident of s. Texas which has occurred accidentally in s. Arizona and New Mexico. See A Field Guide to the Birds of Texas. 


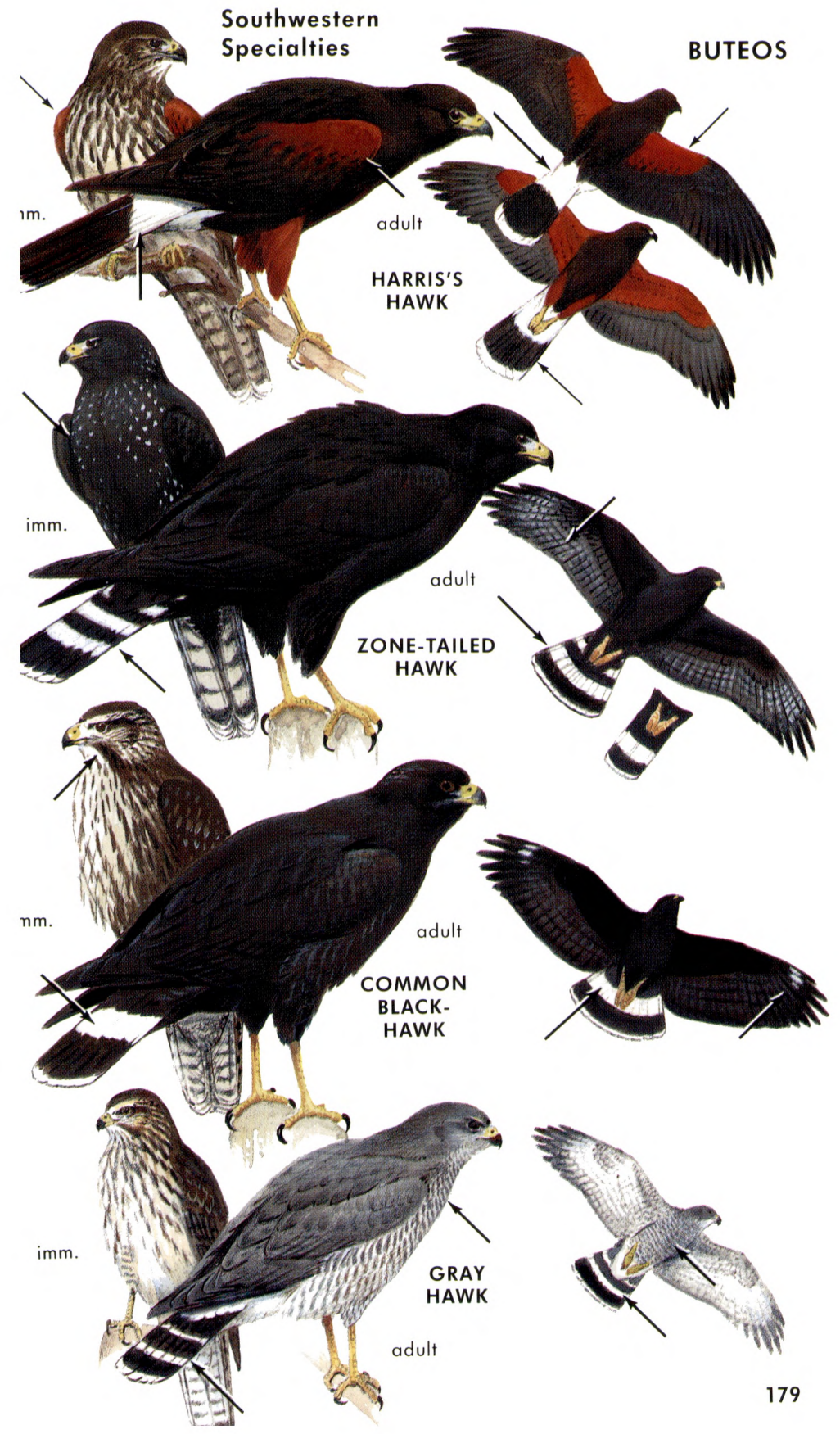


- EAGLES. Subfamily Accipitrinae (in part); shown in flight on p. 189. Eagles are distinguished from buteos, to which they are related, by their much greater size and proportionately longer wings. The powerful bill is nearly as long as the head. Food: Golden Eagle eats chiefly rabbits and large rodents; Bald Eagle, chiefly dead or dying fish.

BALD EAGLE Haliaeetus leucocephalus

M70 30-43" $(75-108 \mathrm{~cm})$; spread 7-8 ft. The national bird of the U.S. The adult, with its white head and white tail, is "all field mark." Bill yellow, massive. The dark immature has a dusky head and tail and a dark bill. It shows considerable whitish in the wing linings and often on the breast (see overhead pattern, p. 189). Variable, depending on age.

Voice: A harsh creaking cackle, kleek-kik-ik-ik-ik, or a lower kakkak-kak.

Range: Alaska, Canada, to s. U.S. West: Map 70. Habitat: Coasts, rivers, large lakes; in migration, also mountains, open country.

GOLDEN EAGLE Aquila chrysaetos

M81

$30-40^{\prime \prime}(75-100 \mathrm{~cm})$. Majestic, the Golden Eagle glides and soars flat-winged with occasional wingbeats. Its greater size and longer wings (spread about $7 \mathrm{ft}$.) set it apart from the large buteos. Adult: Uniformly dark below, or with a slight lightening at the base of the obscurely banded tail. On the hind-neck, a wash of gold. Immature: In flight, more readily identified than the adult; shows a white flash in the wings at the base of the primaries, and a white tail with a broad dark terminal band.

Similar species: (1) Immature Bald Eagle usually has white in the wing linings and often on the body. Tail may be mottled with white at the base, but is not definitely banded. (2) Black morph of Roughlegged Hawk is smaller and has more white on the underwing.

Voice: Seldom heard, a yelping bark, kya; also whistled notes.

Range: Mainly mountain regions of N. Hemisphere. West: Map 81. Habitat: Open mountains, foothills, plains, open country.

WHITE-TAILED EAGLE Haliaeetus albicilla

(Gray Sea Eagle) 30-36" (75-90 cm); spread 71/2-8 ft. This Eurasian eagle is like a pale Bald Eagle, but only the tail is white. The tail is somewhat wedge-shaped. A bird that looks like a Bald Eagle with a light brown head and a yellow bill would be this straggler to the Aleutians of Alaska. It breeds on Attu. Also recorded on Kodiak I.

STELLER'S SEA-EAGLE Haliaeetus pelagicus

$33-41^{\prime \prime}(83-103 \mathrm{~cm})$; spread $8-81 \frac{1}{2} \mathrm{ft}$. This accidental stray from Asia has extensive white shoulders, a massive yellow-orange beak and a deeply wedge-shaped white tail. Immature birds lack the white shoulders, but the massive bill and tail contours would be diagnostic. Casual or accidental in Alaska (Attu, Unalaska, St. Paul, Kodiak I.). 


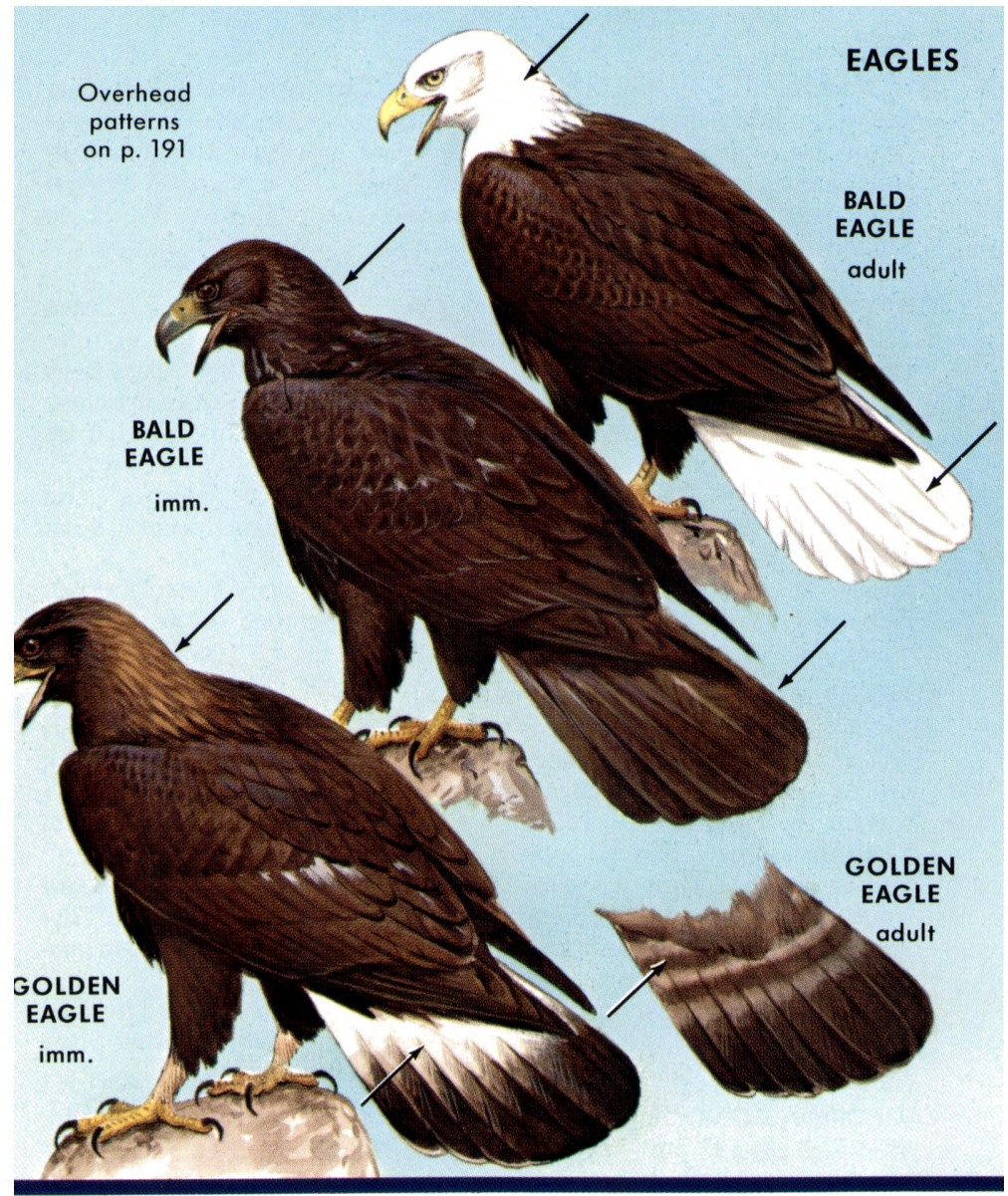

ASIAN STRAYS TO ALASKA

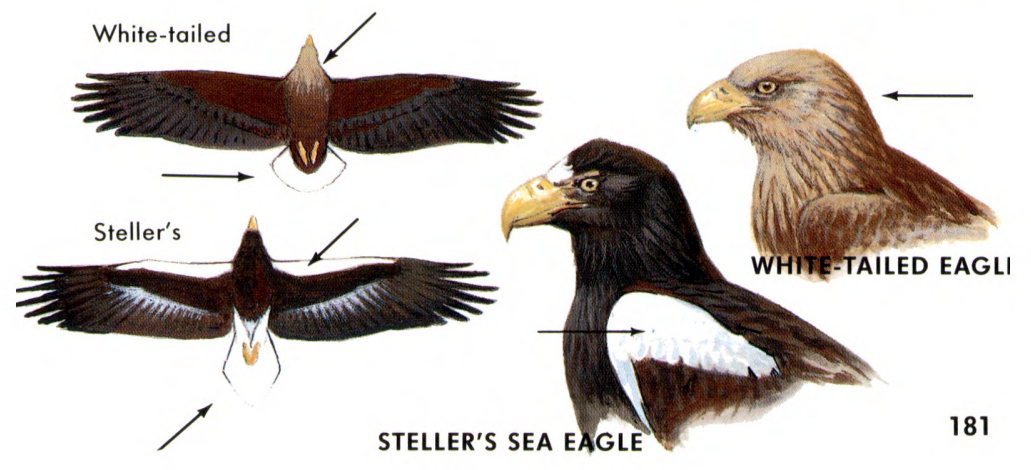


- AMERICAN VULTURES. Family Cathartidae. Blackish, eagle-like birds, often seen soaring high in wide circles. Their naked heads are relatively smaller than those of hawks and eagles. Vultures are often incorrectly called "buzzards." Food: Carrion. Range: S. Canada to Cape Horn. No. of species: World 7; West $21+1$ no longer in the wild but held in captivity).

\section{TURKEY VULTURE Cathartes aura}

M66

26-32" (65-80 cm). Nearly eagle-sized (spread $6 \mathrm{ft}$.). Overhead, note the great two-toned blackish wings (flight feathers paler). Soars with wings in a dihedral (a shallow V); rocks and tilts unsteadily. At close range the small naked red head of the adult is evident; immature birds have blackish heads.

Similar species: See (1) Zone-tailed Hawk, which "mimics" the Turkey Vulture; (2) the Black Vulture; and (3) eagles, which have larger heads, shorter tails, and soar in a flat plane.

Range: S. Canada to Cape Horn. Migratory in North. West: Map 66. Habitat: Usually seen soaring in the sky or perched on dead trees, posts, carrion, or on the ground.

\section{BLACK VULTURE Coragyps atratus}

$23-27^{\prime \prime}(58-68 \mathrm{~cm})$; wingspan less than $5 \mathrm{ft}$. This big black scavenger is readily identified by the short square tail that barely projects beyond the rear edge of the wings, and by the whitish patch toward the wing tip. Legs longer and whiter than Turkey Vulture's. Note the quick labored flapping, alternating with short glides.

Similar species: Turkey Vulture has a longer tail; flaps less, soars more (with a noticeable dihedral). Black Vulture is blacker than Turkey; tail stubby; wings shorter, wider, with a white patch. Caution: Young Turkey Vulture has a blackish head.

Range: Ohio, Pennsylvania to n. Chile, n. Argentina. West: Uncommon local resident in s. Arizona, w. Texas (Big Bend). Habitat: Similar to Turkey Vulture's; avoids higher mountains.

\section{CALIFORNIA CONDOR Gymnogyps californianus}

$45-55^{\prime \prime}(113-138 \mathrm{~cm})$; spread $81 \frac{1}{2}-91 / 2 \mathrm{ft}$. Much larger than the Turkey Vulture; adults have extensive white underwing linings toward the fore edge of the wing. Head yellowish or orange. Young birds are dusky-headed and lack the white wing linings, but are twice the size of the Turkey Vulture and have much broader proportions. The Condor has a flatter wing plane when soaring; it does not rock or tilt. Many Golden Eagles show some white under the wing, but it is placed differently (see p. 189); the shape is also different.

Range: California. Formerly resident mainly in s. Coast Range from se. Monterey Co. to n. Los Angeles Co.; also mountains at s. end of San Joaquin Valley. Now gone in the wild due to capture. All surviving birds are now in zoos in Los Angeles and San Diego. Hopefully, through captive breeding, they may eventually be returned to the wild. Caution: Wild Andean Condors have been released as part of this rehabilitation program. 
- OSPREYS. Subfamily Pandioninae. Formerly considered a monotypic family comprising a single large bird of prey that hovers above the water and plunges feet-first for fish. Sexes alike. Range: All continents except Antarctica. No. of species: World 1; West 1.

OSPREY Pandion haliaetus

21-241/2" (53-61 cm). Large (spread 41/2-6 ft.). Our only raptor that hovers over the water and plunges into it feet-first for fish (Bald Eagle may pick up fish from the surface). Blackish above, white below; head largely white, suggesting a Bald Eagle, but with a broad black cheek patch. Often flies with a kink or crook in the wing, showing a black "wrist" patch below. Immature has a scaly pattern on the back.

Voice: A series of sharp annoyed whistles, cheep, cheep, or yewk, yewk, etc. Near nest, a frenzied cheereek!

Range: Almost cosmopolitan. West: Map 67. Habitat: Rivers, lakes, coasts.

- CARACARAS AND FALCONS. Family Falconidae. Caracaras are large, long-legged birds of prey, some with naked faces. Sexes alike. Food: Our one U.S. species feeds mostly on carrion. Range: S. U.S. to Tierra del Fuego, Falklands. No. of species: World 10; West 1. Falcons suggest kites; they are streamlined birds of prey with pointed wings and longish tails. Food: Birds, rodents, insects. Range: Almost cosmopolitan. No. of species: World 52 ; West $7(+2$ accidental).

\section{CRESTED CARACARA Caracara plancus}

20-25" (50-63 cm). A large, long-legged, dark bird of prey, often seen feeding with vultures; its black crest and red face are distinctive. In flight, its underbody presents alternating areas of light and dark: a white chest, a black belly, and a whitish, dark-tipped tail. Note the combination of the pale wing patches and pale chest. Young birds are browner, streaked on the breast.

Range: Sw. U.S. Texas, Florida to Tierra del Fuego. West: Uncommon resident of s. Arizona; casual or accidental, New Mexico. Habitat: Prairies, rangeland.

GYRFALCON Falco rusticolus

M85

20-25" $(50-63 \mathrm{~cm})$. A very large arctic falcon, larger and more robust and buteo-like than the Peregrine; slightly broader-tailed. Wingbeats deceptively slower. More uniformly colored than the Peregrine, with thinner sideburns. In the Arctic there are black, gray, and white forms; these are color morphs, not races.

Similar species: Peregrine is smaller and more contrastingly patterned, with a dark hood and broad black sideburns. It is slimmer with a more tapered tail.

Range: Arctic regions; circumpolar. West: Map 85. Habitat: Arctic barrens, seacoasts, open mountains. 


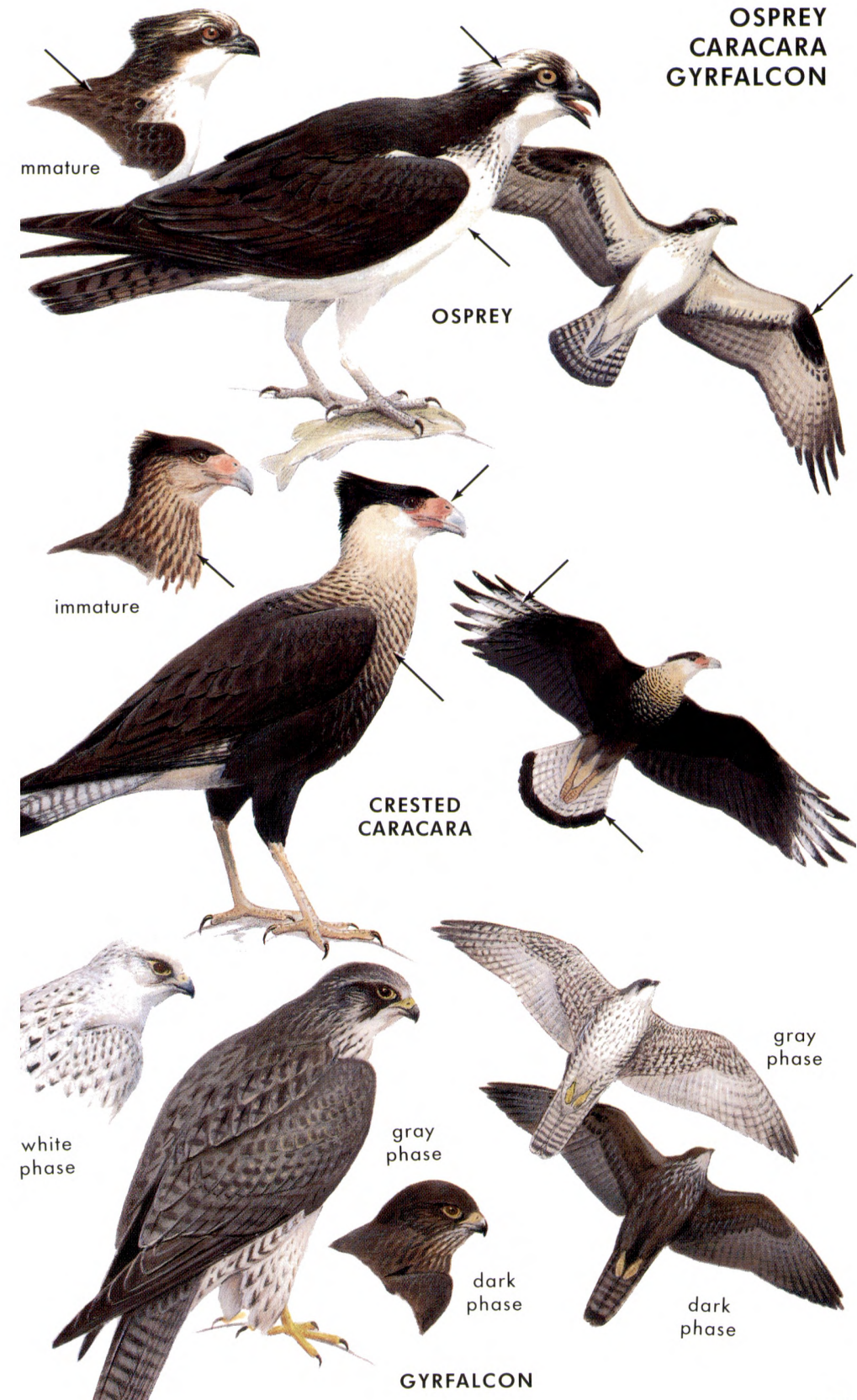


(Pigeon Hawk) 10-131/2" $(25-34 \mathrm{~cm})$. A small compact falcon, the length of a jay; suggests a miniature Peregrine. Male: Blue-gray above, with broad black bands on a gray tail. Female and young: Dusky brown, with banded tails. Both adults and young are boldly striped below. The prairie form is paler, lacking mustaches. Coastal Northwest form is dusky, lacking the light eyebrow stripe.

Range: Northern parts of N. Hemisphere. Winters to n. S. America, n. Africa. West: Map 83. Habitat: Open woods, cliffs, adjacent to grassland, tundra; in migration also foothills, marshes, open country coasts.

AMERICAN KESTREL Falco sparverius

M82

(Sparrow Hawk) 9-12" $(23-30 \mathrm{~cm})$. A swallow-like falcon, the size of a jay. No other small hawk has a rufous back or tail. Males have blue-gray wings. Both sexes have a black and white face with a double mustache. Hovers for prey on rapidly beating wings; kingfisher-like. Sits fairly erect, occasionally lifting its tail.

Similar species: Sharp-shinned Hawk has rounded wings. Both Sharp-shin and Merlin have gray or brown backs and tails.

Voice: A rapid, high klee klee klee or killy killy killy.

Range: Most of N. and S. America. West: Map 82. Habitat: Open country, farmland, cities, wood edges, dead trees, wires, highways.

PEREGRINE FALCON Falco peregrinus

M84

$15-20^{\prime \prime}(38-50 \mathrm{~cm})$; near the size of a crow. Note the wide black "sideburns." Known as a falcon by its pointed wings, narrow tail, and quick wingbeats, not unlike flight of a pigeon. Size and strong face pattern indicate this species. Adults slaty-backed, light-chested, barred and spotted below. Immatures are brown, heavily streaked. The northwestern population pealei, breeding on humid islands off Alaska and British Columbia, is darker and more heavily spotted on the breast.

Voice: At eyrie, a repeated $w e^{\prime} c h e w ;$ a rapid kek kek kek kek.

Range: Nearly worldwide. West: Map 84. Habitat: Open country, cliffs (mountains to coast); sometimes cities. Endangered.

PRAIRIE FALCON Falco mexicanus

M86

$17^{\prime \prime}(43 \mathrm{~cm})$. Like a sandy Peregrine, with a white eyebrow stripe and a narrower mustache. In flight overhead this bird shows blackish patches in the wingpits (see p. 197).

Similar species: Peregrine has a slaty back, more black on the face. Range: Sw. Canada, w. U.S. to s. Mexico. West: Map 86. Habitat: Mountainous grasslands, open hills, plains, prairies.

APLOMADO FALCON Falco femoralis

15-18" $(38-45 \mathrm{~cm})$. A medium-sized falcon, a little smaller than the Peregrine. Note the dark underwing and black belly, contrasting with the white or pale cinnamon breast. Thighs and undertail coverts orange-brown.

Range: U.S.-Mexican border to Patagonia. West: Formerly a very rare local summer resident in s. Arizona, sw. New Mexico, and w. Texas (Big Bend). Recently there has been an attempt to reintroduce it through releases. Habitat: Arid brushy prairie, yucca flats. 



\section{EAGLES AND OSPREY OVERHEAD}

BALD EAGLE Haliaeetus leucocephalus

Text and color plate Adult: White head and white tail.

pp. 180,181 Immature: Some white in wing linings; variable.

GOLDEN EAGLE Aquila chrysaetos

Adult: Almost uniformly dark; wing linings dark.

pp. 180,181 Immature: "Ringed" tail; white patches at base of primaries.

OSPREY Pandion haliaetus

Clear white belly; black wrist patches.

pp. 184,185

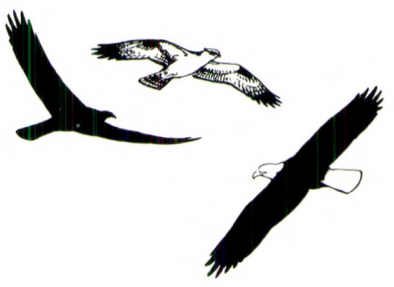

Where the Bald Eagle, Turkey Vulture, and Osprey all are found, they can be separated at a great distance by their manner of soaring: the Bald Eagle with flat wings; the Turkey Vulture with a dihedral; the Osprey often with a kink or crook in the wings. 

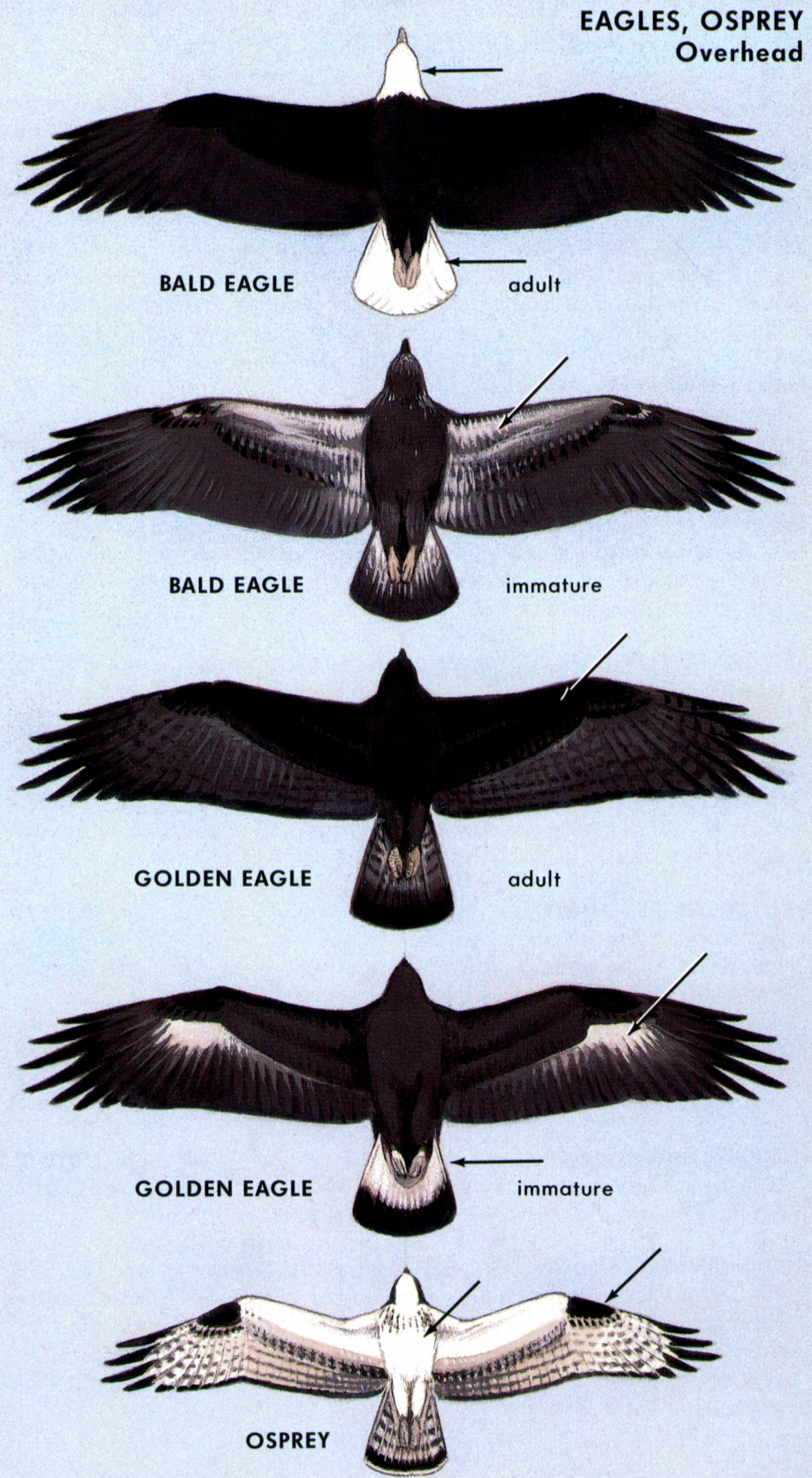


\section{BLACKISH BIRDS OF PREY OVERHEAD}

Text and color plate

CRESTED CARACARA Polyborus plancus Whitish chest, black belly, large pale patches in primaries.

pp. 184,185

ROUGH-LEGGED HAWK Buteo lagopus (dark morph) pp. 176, 177 Dark body and wing linings; whitish flight feathers; tail light from below, with one broad, black terminal band in female; additional bands in male.

FERRUGINOUS HAWK Buteo regalis (dark morph) pp. 176, 177 Similar to dark morph of Rough-leg, but tail whitish, without the dark banding. Note also the white wrist marks, or "commas," as they have been called.

SWAINSON'S HAWK Buteo swainsoni (dark morph) pp. 174, 175 In the dark morph, the wings are usually dark throughout, including the flight feathers, tail narrowly banded. Rufous morph may be rustier, with lighter rufous wing linings.

RED-TAILED HAWK Buteo iamaicensis (dark morph)

pp. 174,175 Chunky; tail reddish above, pale tinged with rusty below; variable. May not always be safely distinguishable underneath from "Harlan's" form of Red-tail.

"HARLAN'S" HAWK Buteo jamaicensis (in part)

pp. 174,175

Similar to dark morph of Red-tail, but tends to be mottled with gray or whitish at the base of the tail.

\section{BROAD-WINGED HAWK}

Buteo platypterus (dark morph)

pp. 192,193

Distinctive tail pattern and flight feathers as in the light morph, but body and wing linings dark. Rare; breeds in Alberta.

ZONE-TAILED HAWK Buteo albonotatus (immature) pp. 178, 179 Longish, two-toned wings (suggesting a Turkey Vulture). Three white tail bands (only one visible on folded tail).

HARRIS'S HAWK Parabuteo unicinctus

pp. 178,179

Chestnut wing linings. A very broad white band at the base of the black tail, and a narrow white terminal band.

COMMON BLACK-HAWK Buteogallus anthracinus

pp. 178,179

Thick-set black wings; light patches near wing tips. A broad white band at mid-tail and a very broad, black subterminal band. Whereas the Zone-tailed Hawk seems to mimic the Turkey Vulture, a deceptive ploy when it is hunting, the chunkier Black-Hawk may be compared to the Black Vulture. 


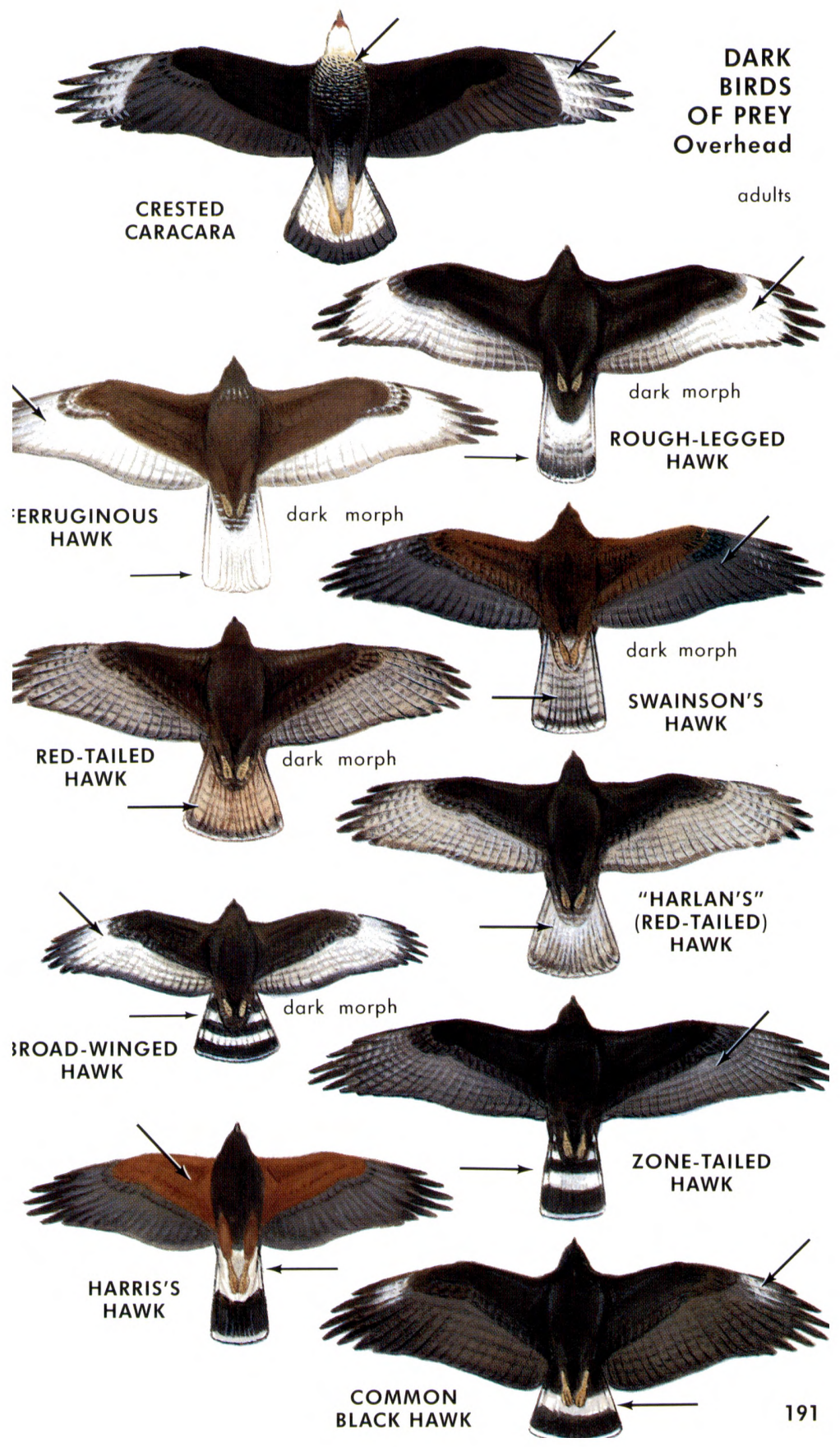




\section{BUTEOS OVERHEAD}

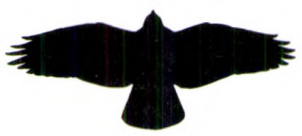

Buteos, or "buzzard hawks," are chunky, with broad wings and broad, rounded tails. They soar and wheel high in the air.

Text and color plate

RED-TAILED HAWK Buteo jamaicensis

pp. 174,175

(Typical western form)

The dark patagial bar at the fore edge of the wing is the best mark from below. Light chest, streaked belly; tail plain, with little or no banding. Immature birds are streaked below and have tail banding. Note always the patagial bar.

SWAINSON'S HAWK Buteo swainsoni

pp. 174, 175

Adult has a dark chest band. Note also the contrast between the light wing linings and dark flight feathers. The immature has a similar look, but has streaks on the underbody.

RED-SHOULDERED HAWK Buteo lineatus

pp. 176, 177

The tail is strongly banded (white bands narrower than the dark ones). The adult is strongly barred with rusty on the body and wing linings. The immature has a striped body. There is a light "window" on the outer wing of adults as well as immatures.

BROAD-WINGED HAWK Buteo platypterus

pp. 176, 177

Smaller and chunkier, with a widely banded tail (white bands wide); underwing pale. Immature: Body striped, tail narrowly banded. The pale underwings may show lighter "windows" near the wing tips.

ROUGH-LEGGED HAWK Buteo lagopus

pp. 176, 177

Note the black carpal patch contrasting with the white flight feathers. A broad, blackish band or cummerbund across the belly is distinctive in most but not all birds. Tail light, with a broad, dark terminal band. Adult males may be darker-chested and have more bands on the tail. 


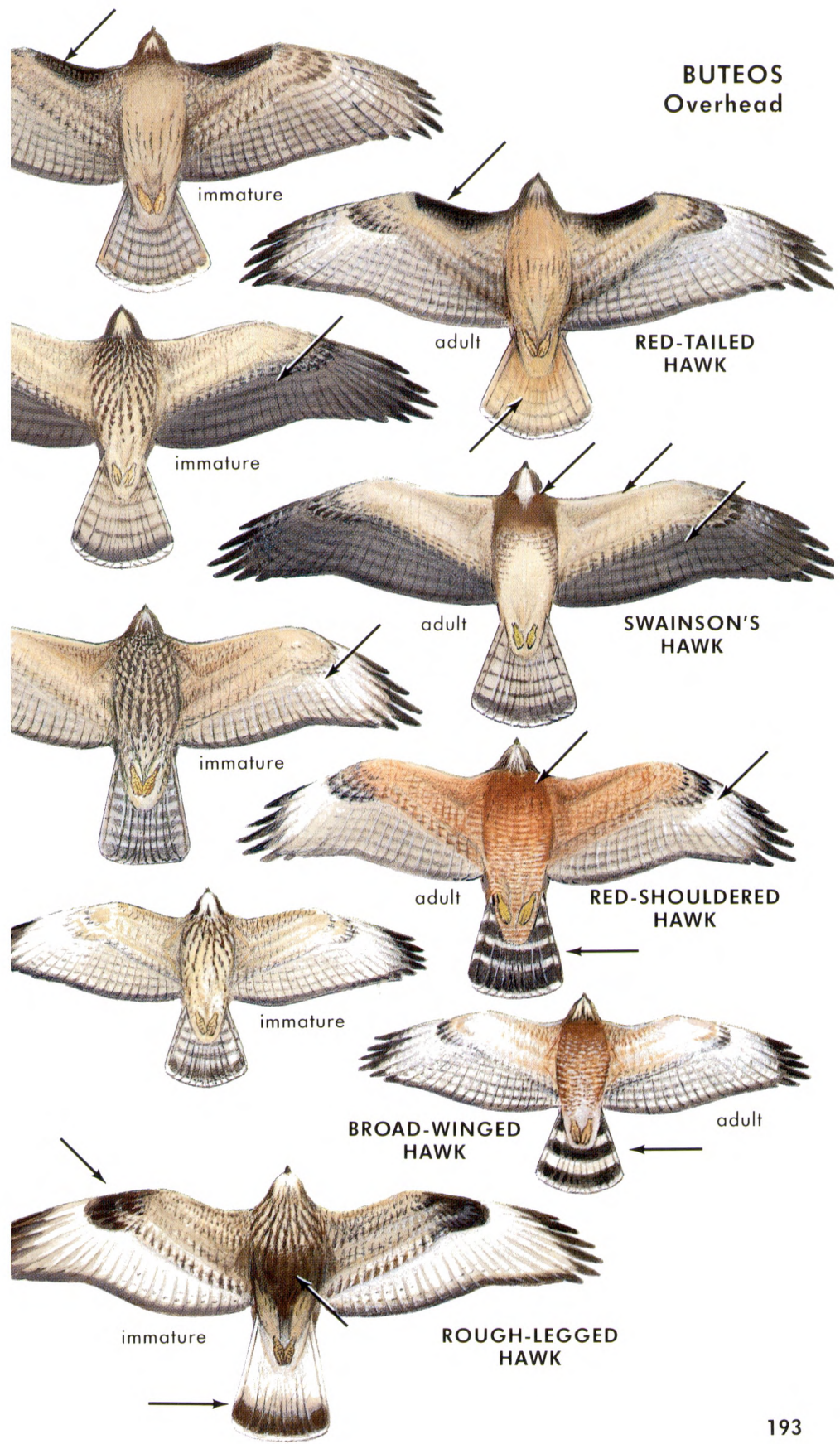


Whitish underparts, with a dark $V$ formed by the legs. Wings and tail longish for a buteo. A bird of arid plains, open range.

GRAY HAWK Asturina nitida

Stocky. Broadly banded tail (suggestive of Broad-wing); gray-barred underparts. Very local in se. Arizona.

\section{WHITE-TAILED HAWK Buteo albicaudatus}

Whitish underparts; white tail with one subterminal black band. Has a gray head. Soars with a marked dihedral. A bird of south Texas, Mexico. Would be a casual or accidental stray if seen in Arizona or New Mexico.

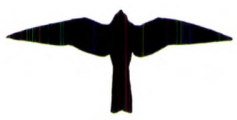

Kites are falcon-shaped, but are buoyant gliders, not power-fliers.

\section{Text and} color plate

WHITE-TAILED KITE Elanus leucurus

pp. 170,171

Falcon-shaped, with a white tail. Note also the conspicuous black carpal spot. Immature: Similar, but with a rusty wash on the chest and a dusky subterminal band on the tail.

MISSISSIPPI KITE Ictinia mississippiensis

Falcon-shaped. Dusky, with a solid black tail.

pp. 170, 171

Immature: Striped below, with white bands on its black tail.

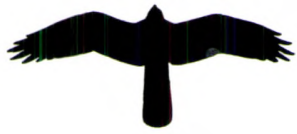

Harriers are slim, with somewhat rounded wings, long tails, and long bodies. They fly low, with a vulture-like dihedral and languid flight.

NORTHERN HARRIER Circus cyaneus

pp. 170,171

Male: Whitish, with black wing tips and trailing edge. Gray hood.

Female: Harrier shape. Brown; heavily streaked. From above, all plumages have a white rump. 

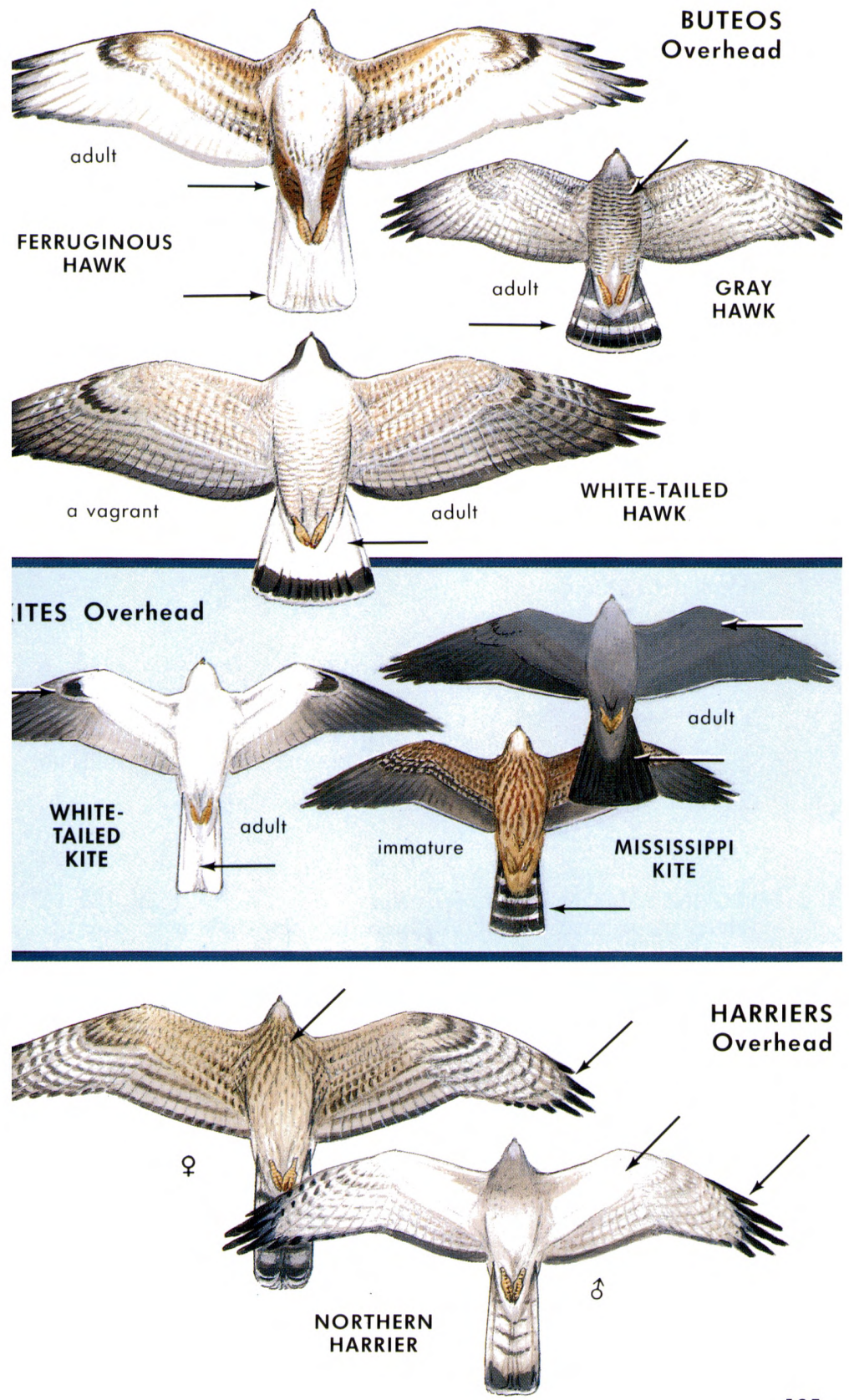


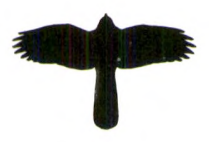

ACCIPITERS have short, rounded wings and long tails. They fly with several rapid beats and a short glide. They are better adapted to hunting in woodlands than most other hawks.

NORTHERN GOSHAWK Accipiter gentilis

Text and color plate

Very large, adult (shown) with a pale, pearly gray breast. A bit more buteo-like than other accipiters. Fluffy white undertail coverts.

COOPER'S HAWK Accipiter cooperii

pp. 172,173

Medium-sized. Near size of a crow; tail rounded. Head larger, more squarish than that of Sharp-shin.

SHARP-SHINNED HAWK Accipiter striatus

pp. 172,173

Small; near size of a jay; tail squarish or notched, but may appear slightly rounded when spread. Head rounder and proportionately smaller than Cooper's.

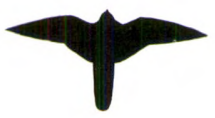

FALCONS have long, pointed wings and long tails. The wing strokes are strong and rapid, but shallow.

PEREGRINE FALCON Falco peregrinus

pp. 186,187

Falcon shape; near size of an American Crow; bold face pattern.

AMERICAN KESTREL Falco sparverius

pp. 186,187

Small size; banded rufous tail.

MERLIN Falco columbarius

Small size, near that of a jay; banded gray tail.

GYRFALCON Falco rusticolus

pp. 186,187

Larger than Peregrine; grayer, without that bird's contrasting pattern. Dark and white phases or morphs also occur. Arctic.

PRAIRIE FALCON Falco mexicanus

pp. 186,187

Size of Peregrine. Dark axillars ("wingpits") and inner coverts. Plains, prairies, open country.

APLOMADO FALCON Falco femoralis

pp. 186,187

Black belly band, light chest. (A Mexican border possibility.) 


\section{ACCIPITERS}
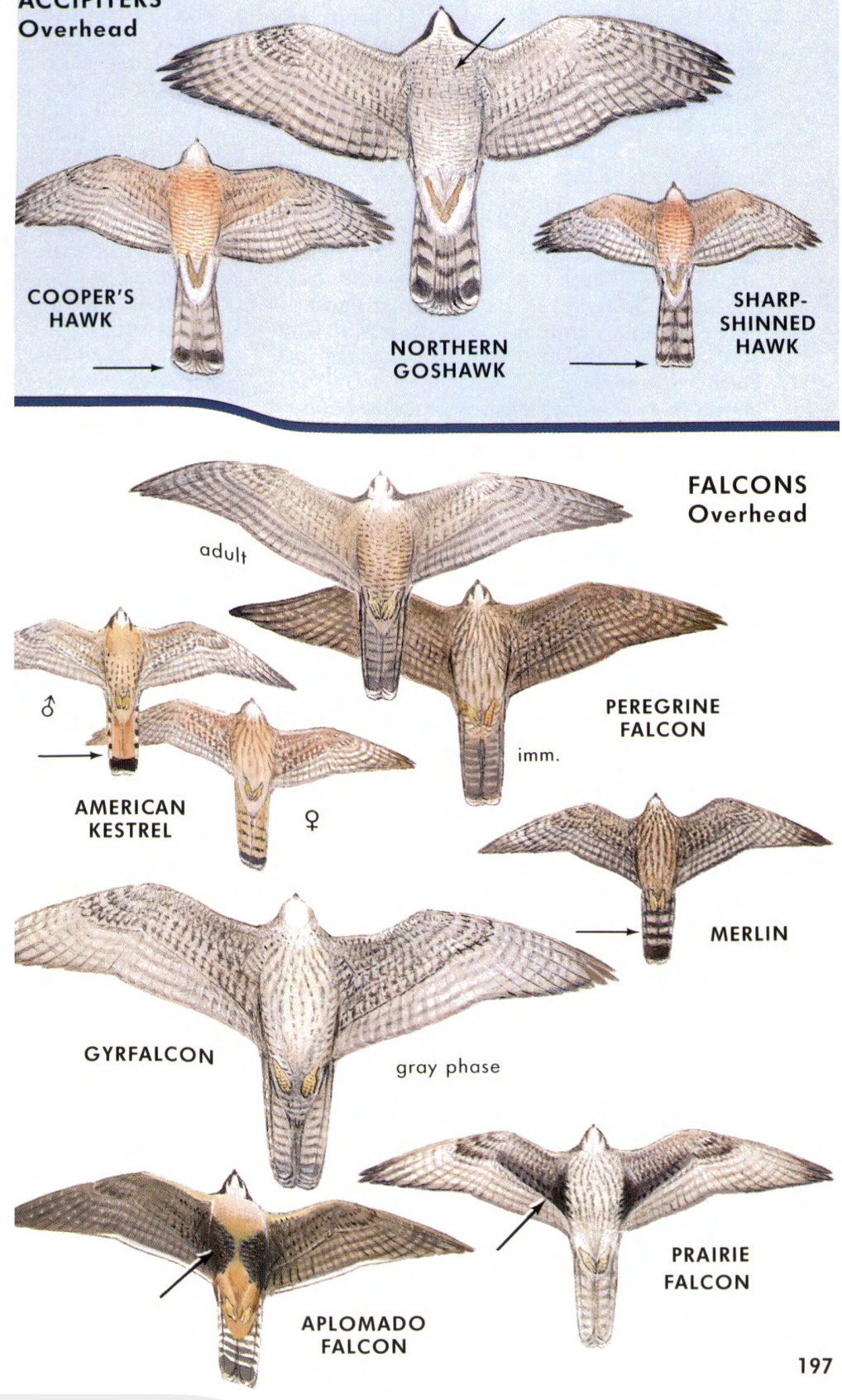


\section{- OWLS. Families Strigidae (Typical Owls) and Tytonidae}

(Barn Owls). Chiefly nocturnal birds of prey, with large heads and flattened faces forming facial disks; large, forward-facing eyes; hooked bills and claws; usually feathered feet (outer toe reversible). Flight noiseless, mothlike. Some species have "horns" or "ears." Sexes similar; female larger. Food: Rodents, birds, reptiles, fish, large insects. Range: Nearly worldwide. No. of species: World 134; West $12(+1$ accidental).

BARRED OWL Strix varia

M203

$17-24^{\prime \prime}(43-60 \mathrm{~cm})$. A large, brown, puffy-headed woodland owl with big, moist brown eyes. Barred across chest and streaked lengthwise on belly; this combination separates it from the Spotted Owl (p. 205), which it might eventually displace in the Northwest.

Voice: Not so deep as Great Horned Owl's. Usually eight accented hoots, in two groups of four: hoohoo-hoohoo, hoohoohoohooaw.

Range: Canada to Honduras. West: Map 203. Habitat: Woodlands, wooded river bottoms, wooded swamps.

BARN OWL Tyto alba

M193

$14-20^{\prime \prime}(35-50 \mathrm{~cm})$. A long-legged, knock-kneed, pale, monkey-faced owl. White heart-shaped face and dark eyes; no ear tufts. Distinguished in flight as an owl by the large head and mothlike flight; as this species, by the unstreaked whitish or pale cinnamon underparts (ghostly at night) and the rusty back.

Similar species: Short-eared Owl (marshes) is streaked, has darker face and underparts, yellow eyes, shorter legs.

Voice: A shrill, rasping hiss or snore: kschh or shiiish.

Range: Nearly worldwide in tropical and temperate regions; in New World from s. Canada to Tierra del Fuego. West: Map 193. Habitat: Woodlands, groves, farms, barns, towns, cliffs.

GREAT GRAY OWL Strix nebulosa

M204

24-33" (60-83 cm). Largest owl; very tame. Dusky gray, heavily striped lengthwise on underparts. Round-headed, without ear tufts; the large, strongly lined facial disks dwarf the yellow eyes. Note the black chin spot bordered by two broad white patches like white mustaches. Tail long for an owl (12"). Often hunts by day.

Voice: A deep, booming whoo-hoo-hoo. Also deep single whoo's.

Range: Boreal forests of N. Hemisphere; rare. West: Map 204. Habitat: Dense conifer forests, adjacent meadows, bogs. Often hunts by day.

SNOWY OWL Nyctea scandiaca

M197

20-27" (50-68 cm). A large white Arctic owl, flecked or barred with dusky. Round head, yellow eyes. Some birds (adult males) are much whiter than others. Day-flying. Perches on dunes, posts, haystacks, ground in open country. Sometimes buildings.

Similar species: (1) Barn-Owl is whitish on underparts only; has dark eyes. (2) All young owls are whitish when in down.

Voice: Usually silent. Flight note when breeding is a loud, repeated krow-ow; also a repeated rick.

Range: Arctic; circumpolar. Has cyclic winter irruptions southward. West: Map 197. Habitat: Prairies, fields, marshes, beaches, dunes; in summer, arctic tundra. 


\section{LARGE OWLS \\ Without ear tufts}
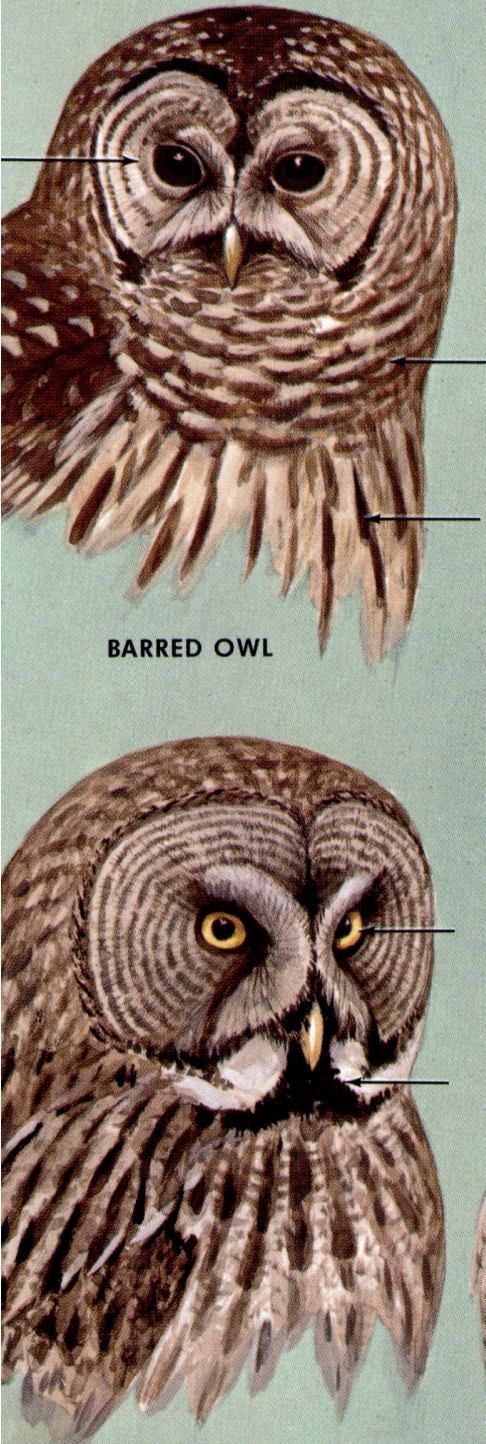

GREAT GRAY OWL
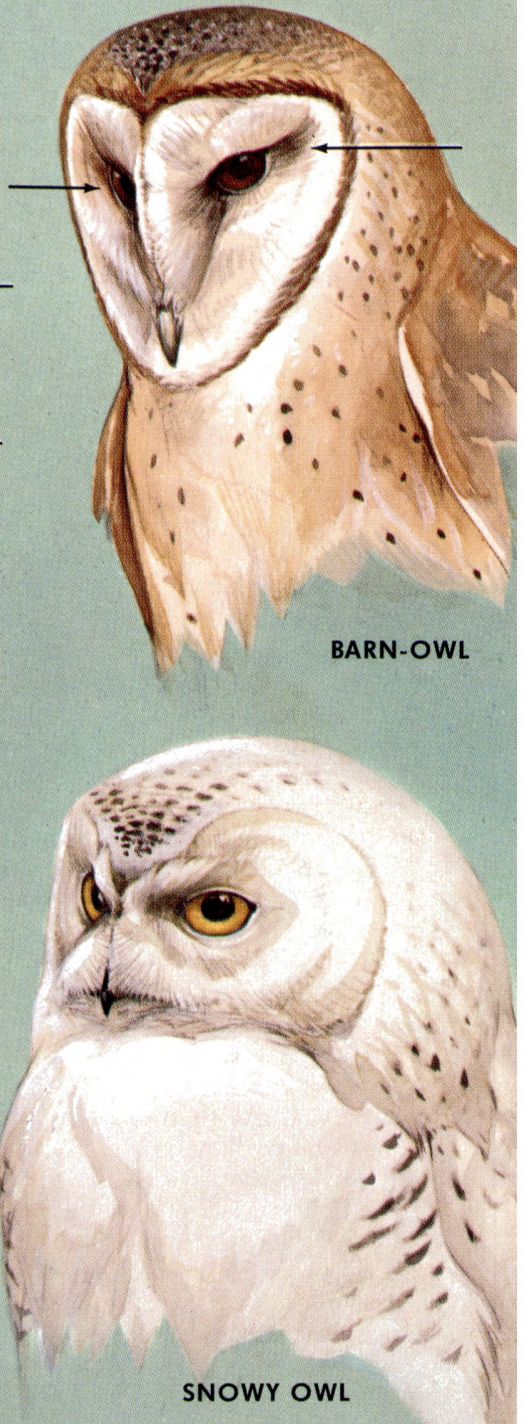
$13-17^{\prime \prime}(33-43 \mathrm{~cm})$. An owl of open country, often abroad by day. Streaked tawny brown color and irregular flopping flight identify it. Large buffy wing patches show in flight and on the underwing, along with a black carpal ("wrist") patch. Dark facial disks emphasize the yellow eyes. Long-ear has similar mothlike flight but is gray.

Voice: An emphatic, sneezy bark: kee-yow!, wow!, or waow!

Range: Nearly worldwide. West: Map 206. Habitat: Prairies, marshes (fresh and salt), dunes, tundra.

WESTERN SCREECH-OWL Otus kennicottii

M195

7-10" $(18-25 \mathrm{~cm})$. A common widespread small owl with conspicuous ear tufts. Usually gray, but those in n. Great Basin population have two color morphs, gray and brown. Those in northern humid regions are usually darker brown; those in arid regions paler, grayer. Voice: A series of hollow whistles on one pitch, running into a tremolo (rhythm of a small ball bouncing to a standstill).

Range: Se. Alaska to cen. Mexico. Map 195. Habitat: Wooded canyons, farm groves, shade trees.

EASTERN SCREECH-OWL Otus asio (not shown)

M195

$7-10^{\prime \prime}(18-25 \mathrm{~cm})$. Two color morphs: red-brown and gray. Like the Western Screech-Owl, but separated by voice and range. Also differs in having a bright red-brown morph.

Voice: A mournful whinny or wail; tremulous, descending in pitch. Sometimes a series of notes on a single pitch.

Range: S. Canada to cen. Mexico. West: Map 195.

WHISKERED SCREECH-OWL Otus trichopsis

$61 / 2-8^{\prime \prime}(16-20 \mathrm{~cm})$. Very similar to the Western Screech-Owl. Has large white spots on scapulars, coarser black spots on underparts, longer facial bristles, yellow-green bill. Readily identified by voice. Voice: Boobooboo-boo, boobooboo-boo, etc.; arrangement of this "code" may vary. At times a repeated, four-syllabled chooyoo-coocooo, vaguely suggestive of White-winged Dove.

Range: Resident from mountains of se. Arizona through Mexico to n. Nicaragua. Habitat: Canyons, pine-oak woods, oaks, sycamores. LONG-EARED OWL Asio otus

M205

$13-16^{\prime \prime}(33-40 \mathrm{~cm})$. A slender, crow-sized owl with long ear tufts. Usually seen "frozen" close to the trunk of a tree. Much smaller than the Great Horned Owl; underparts streaked lengthwise, not barred crosswise. Ears closer together, erectile.

Voice: One or two long hooo's; usually silent.

Range: Canada to sw. and s.-cen. U.S.; Eurasia, n. Africa. West: Map 205. Habitat: Woodlands, conifer groves. Often roosts in groups.

GREAT HORNED OWL Bubo virginianus

M196

18-25" (45-63 cm). The "Cat Owl." A large owl with ear tufts or "horns." Heavily barred beneath; conspicuous white throat bib. In flight, as large as our largest hawks; looks neckless, large-headed. Varies regionally from very dark to very pale.

Voice: Male usually utters five or six resonant hoots: Hoo!, hu-huhu, Hoo! Hoo! Female's hoots are said to be higher, in shorter sequence.

Range: Tree limit in N. America to Tierra del Fuego. West: Map 196. Habitat: Forests, woodlots, streamsides, open country. 


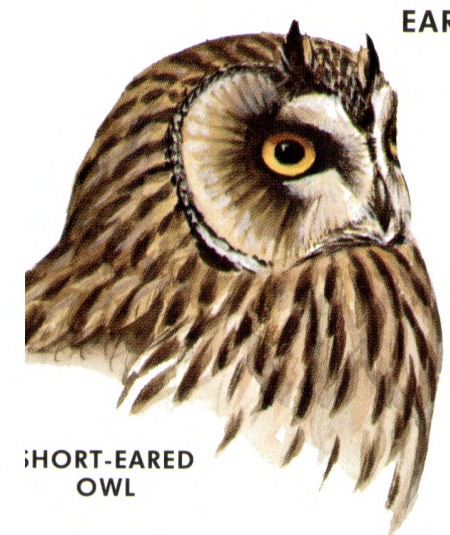

\section{EARED OWLS}
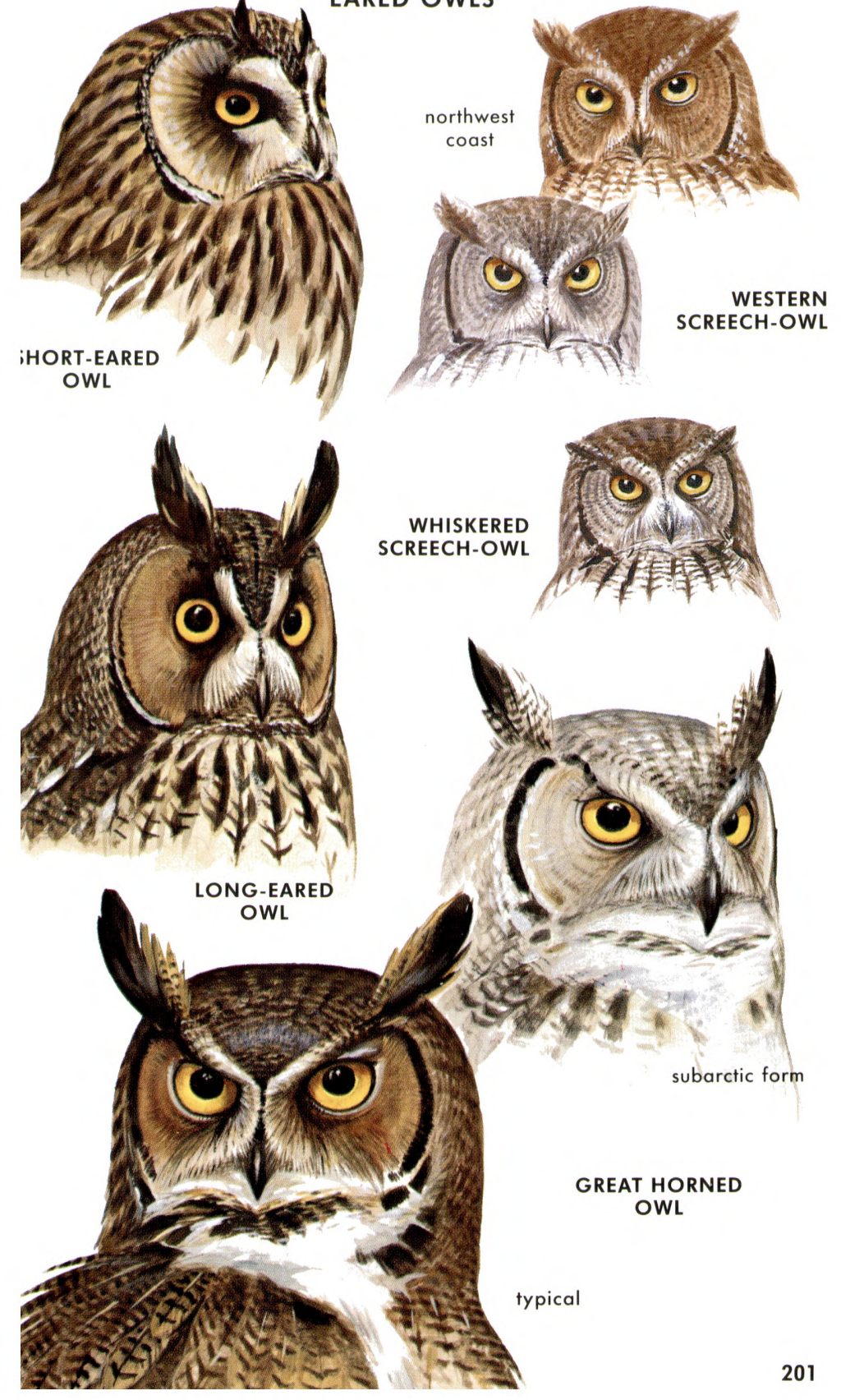
9-10" $(23-25 \mathrm{~cm})$. A small, flat-headed, earless owl. Very tame. Similar to the Saw-whet Owl, but a bit larger; facial disks pale grayish white framed with black; bill a pale horn color or yellowish; forehead thickly spotted with white. Juvenile: Similar to young Sawwhet Owl, but duskier; eyebrows dirty whitish or gray; belly obscurely blotched, not tawny ochre.

Similar species: (1) Saw-whet Owl is smaller. Adult has a blacker bill, lacks black facial frames, and has fine white streaks, not spots, on the forehead. (2) Hawk Owl is larger, grayer, and long-tailed; it is barred below.

Voice: Like a soft, high-pitched bell or dripping of water; an endlessly repeated ting-ting-ting-ting-ting-ting, etc.

Range: Boreal forests of N. Hemisphere. West: Map 200. Habitat: Mixed-wood and conifer forests, muskeg. Winters in valleys, lowlands.

NORTHERN SAW-WHET OWL Aegolius acadicus

M207

$7-81 / 2^{\prime \prime}(18-21 \mathrm{~cm})$. A very tame little owl; smaller than a ScreechOwl, without ear tufts. Underparts have soft blotchy brown streaks. Young birds in summer are chocolate-brown, with conspicuous white eyebrows forming a broad V over the bill; belly tawny ochre. Similar species: Boreal Owl is somewhat larger, has a whitish face framed with black, and a yellowish or pale horn-colored bill.

Voice: Song, a mellow, whistled note repeated mechanically in endless succession, often 100-130 times per minute: too, too, too, too, too, too, too, too, etc. Much faster than Northern Pygmy-Owl's.

Range: Se. Alaska, Canada, w. and ne. U.S. to s. Mexico. West: Map 207. Habitat: Forests, conifers, groves.

BURROWING OWL Athene cunicularia

M201

$9-11^{\prime \prime}(23-28 \mathrm{~cm})$. A small owl of open country, often seen by day standing erect on the ground or on posts. Note the long legs (for an owl). About the size of a Screech-Owl; barred and spotted, with a white chin stripe, round head, and stubby tail. Bobs and bows when agitated.

Voice: A rapid, chattering quick-quick-quick. At night, a mellow co-hoo, higher than Mourning Dove's coo.

Range: Sw. Canada, w. U.S., Florida to s. Argentina. Migratory in North. West: Map 201. Habitat: Open grassland, prairies, farmland, airfields. Nests in burrows in the ground, even in suburbs.

NORTHERN HAWK OWL Surnia ulula

M198

$14 \frac{1}{2}-171 / 2^{\prime \prime}(37-44 \mathrm{~cm})$. A medium-sized, hawklike, day-flying owl (smaller than American Crow), with a long, rounded tail and completely barred underparts. Does not sit as erect as other owls; often perches at the tip of a tree and jerks its tail like a Kestrel. Shrikelike, it flies low, rising abuptly to its perch. Note the broad black sideburns framing the pale face.

Voice: A chattering kikikiki, more like a falcon than an owl. A kestrel-like illy-illy-illy-illy. Also a harsh scream.

Range: Boreal forests of N. Hemisphere. West: Map 198. Habitat: Open conifer forests, birch scrub, tamarack bogs, muskeg. 


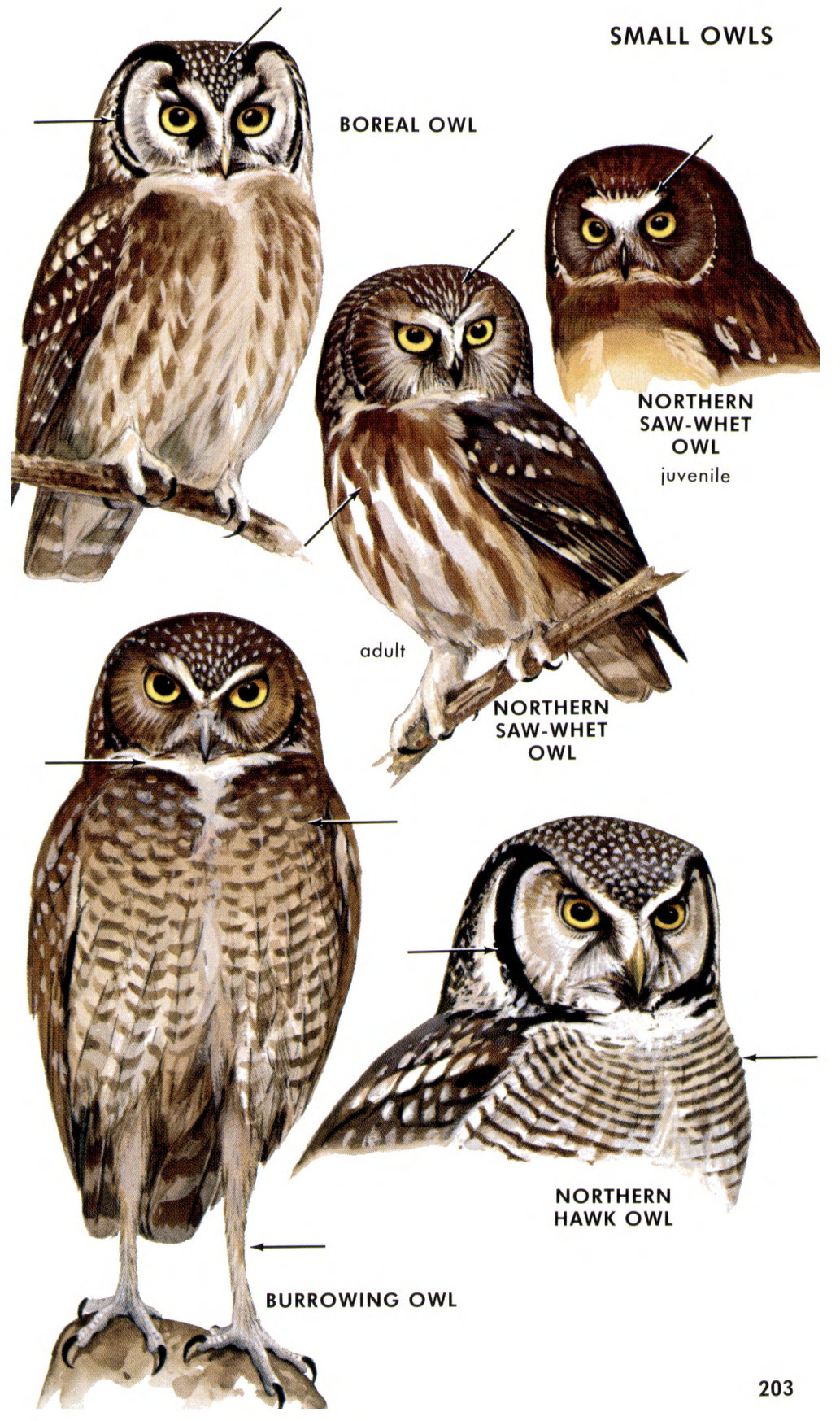


$161 / 2-19^{\prime \prime}(41-48 \mathrm{~cm})$. A large, dark-brown forest owl with a puffy round head. Large dark eyes (all other large N. American owls except Barn and Barred owls have yellow eyes) and heavily spotted chest and barred belly identify this reportedly endangered bird, which may eventually be displaced by the Barred Owl (p. 199).

Voice: High-pitched hoots, like barking of a small dog; usually in groups of three (hoo, hoo-hoo) or four (hoo, who-who-whooo). Also a longer series of rapid hoots in crescendo.

Range: Resident of old forests from sw. British Columbia to cen. Mexico; Map 202. Habitat: Mature old-growth forests, conifers, wooded canyons.

FLAMMULATED OWL Otus flammeolus

M194

$6-7 "(15-18 \mathrm{~cm})$. Smaller than a Screech-Owl. Our only small owl with dark eyes. Largely gray, with tawny scapulars and inconspicuous ear tufts. Southern birds are rustier. A little-known owl.

Voice: A mellow hoot (or hoo-hoot), low in pitch for so small an owl; repeated steadily at intervals of 2-3 seconds.

Range: Southern British Columbia, w. U.S. to Guatemala. West: Map 194. Habitat: Open pine, fir forests in mountains.

ELF OWL Micrathene whitneyi

M200

5-6" (13-15 cm). A tiny, small-headed, short-tailed, earless owl, the size of a chunky sparrow. Underparts softly striped with rusty; "eyebrows" white. Hides by day in woodpecker holes in saguaros, telephone poles, or trees. Found at night by calls.

Voice: A rapid, high-pitched whi-whi-whi-whi-whi-whi or chewkchewk-chewk-chewk, etc., often becoming higher and more yipping or "puppy like," and chattering in the middle of the series.

Range: Sw. U.S. to cen. Mexico. Map 200. Habitat: Saguaro deserts, wooded canyons.

\section{FERRUGINOUS PYGMY-OWL Glaucidium brasilianum}

61/2-7" (16-18 cm). Very similar to Northern Pygmy-Owl; best clue is its desert habitat along the U.S.-Mexican border. Streaking on breast brownish rather than black; crown has fine pale streaks (not dots). Tail rusty, barred with black.

Voice: Chook or took; sometimes repeated monotonously 2-3 times per second. Calls in daytime but more often at night.

Range: Resident from s. Arizona and lower Rio Grande Valley, Texas, to Strait of Magellan. Habitat: Mesquite thickets, desert riverine woods, saguaros. Hunts by day. Often mobbed by birds.

NORTHERN PYGMY-OWL Glaucidium gnoma

M199

$7-71 / 2^{\prime \prime}(18-19 \mathrm{~cm})$. Black patches on each side of the hind-neck suggest "eyes on back of the head." A very small, "earless" owl; brown, with sharply streaked flanks and a rather long barred tail. Frequently heard calling or seen flying in daytime. The spotted head is proportionately smaller than that of a Saw-whet or Screech-Owl. Tail often held at a perky angle.

Voice: A single mellow whistle, hoo, repeated every 2 or 3 seconds. Also a rolling series, ending with $2-3$ deliberate notes: too-too tootoo-too-too-too-too-took-took-took.

Range: Se. Alaska, w. Canada to Honduras. Map 199. Habitat: Open coniferous or mixed woods, wooded canyons. 
- TROGONS. Family Trogonidae. Solitary, brightly colored forest birds with a short neck, stubby bill, long tail, and very small feet. Erect when perched. Trogons flutter when plucking berries. Food: Small fruits, insects. Range: Mainly tropical parts of world. No. of species: World 36; West 2.

\section{EARED TROGON Euptilotis neoxenus}

$12^{1 / 2^{\prime \prime}}(31 \mathrm{~cm})$. This Mexican trogon can be separated from the Elegant Trogon by its black (not yellow) bill, lack of a white band between the green and the red, and a greater amount of white on the underside of the blue tail. "Ears" of male inconspicuous. A very rare visitor to se. Arizona (Chiricahuas).

ELEGANT TROGON Trogon elegans

(Coppery-tailed Trogon) 11-12" $(28-30 \mathrm{~cm})$. Note the erect posture, slightly parrot-like profile, geranium-red belly. Male: Head, chest, and upperparts deep glossy green, separated from the red belly by a narrow white band across the breast. Tail square-tipped, moderately long; bill yellow. Female: Brown, not green; less red on underparts. Note the white mark on the cheek.

Voice: A series of low, coarse notes, suggesting a hen Turkey; kowm kowm kowm kowm kowm kowm or koa, koa, koa, etc.

Range: Breeds from mountains of se. Arizona south to Costa Rica. Winters south of U.S. Casual, sw. New Mexico, Texas (Big Bend). Habitat: Mountain forests, pine-oak or sycamore canyons.

- KINGFISHERS. Family Alcedinidae. Solitary birds with large heads, heron-like bills, and small syndactyl feet (two toes partially joined). Most are fish-eaters, perching above water, or hovering and plunging headfirst. Food: Mainly fish; some species eat insects, lizards. Range: Almost worldwide. No. of species: World 91; West 2.

GREEN KINGFISHER Chloroceryle americana

$7-81 / 2^{\prime \prime}(18-21 \mathrm{~cm})$. Kingfisher shape, small size; flight buzzy, direct. Upperparts deep green with white spots; collar and underparts white, sides spotted. Male has a rusty breastband; female has one or two greenish bands. (Note the switch: In the Belted Kingfisher, the female has the rusty band.)

Voice: A sharp clicking, tick tick tick; also a sharp squeak.

Range: Texas to Argentina. West: Resident in s. Texas north along Rio Grande to Pecos R. Sparse straggler in Arizona (mainly Santa Cruz drainage and San Pedro Valley). Habitat: Rivers, streams.

BELTED KINGFISHER Ceryle alcyon

M223

13 " $(33 \mathrm{~cm})$. Hovering on rapidly beating wings in readiness for the plunge, or flying with uneven wingbeats (as if changing gear), rattling as it goes, the Kingfisher is easily recognized. Perched, it is big-headed and big-billed, larger than a Robin; blue-gray above, with a ragged bushy crest and a broad gray breastband. The female has an additional rusty breastband.

Voice: A loud dry rattle.

Range: Alaska, Canada to s. U.S. Winters to n. S. America. West: Map 223. Habitat: Streams, lakes, bays, coasts; nests in banks, perches on wires. 


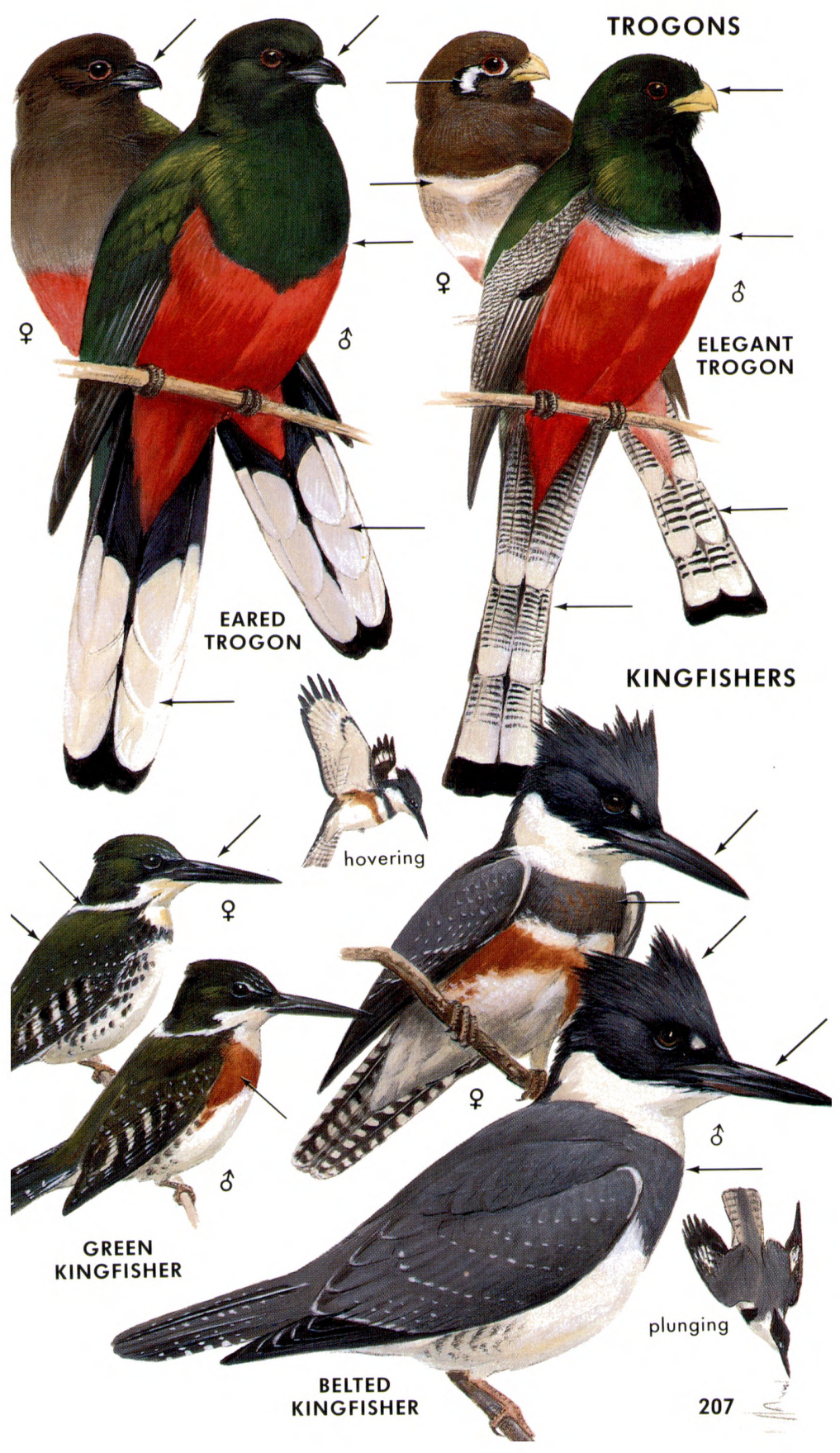


a PIGEONS AND DOVES. Family Columbidae. Plump, fast-

flying birds with small heads and low, cooing voices; they nod their heads as they walk. Two types: (1) birds with fanlike tails (Rock Dove, or Domestic Pigeon); (2) smaller, brownish birds with rounded or pointed tails (Mourning Dove). Sexes similar. Food: Seeds, waste grain, fruits, insects. Range: Nearly worldwide in tropical and temperate regions. No. of species: World 297; West 5 (+3 accidental, 3 introduced). The Red-billed Pigeon (Columba flavirostris) and White-tipped Dove (Leptotila verrauxi) of lower Rio Grande may be vagrants in w. Texas. See Field Guide to the Birds of Texas.

MOURNING DOVE Zenaida macroura

M187

$12^{\prime \prime}(30 \mathrm{~cm})$. The common wild dove. Brown; smaller and slimmer than Rock Dove. Note the pointed tail with large white spots.

Voice: A hollow, mournful coah, cooo, cooo, coo. At a distance only the three coo's are audible.

Range: Se. Alaska, s. Canada to Panama. West: Map 187. Habitat: Farms, towns, open woods, scrub roadsides, grassland.

COMMON GROUND-DOVE Columbina passerina

M189

$6 \frac{1}{2} 2^{\prime \prime}(16 \mathrm{~cm})$. A very small dove, not much larger than a sparrow. Note the stubby black tail, scaly breast, and rounded wings that flash rufous in flight. Feet yellow or pink.

Voice: A soft, monotonously repeated woo-oo, woo-oo, etc. May sound monosyllabic-wOoo, with rising inflection.

Range: Southern U.S. to Costa Rica; n. S. America. West: Map 189. Habitat: Farms, orchards, wood edges, roadsides.

INCA DOVE Columbina inca

M188

$71 / 2^{\prime \prime}(19 \mathrm{~cm})$. A very small, slim dove with a scaly look. Rufous in the primaries (as in Ground-Dove), but has a longer, square-ended tail, with white sides. Voice: A monotonous coo-hoo or no-hope.

Range: Sw. U.S. to nw. Costa Rica. West: Map 188. Habitat: Towns, parks, farms.

WHITE-WINGED DOVE Zenaida asiatica

M186

$11-11 \frac{1}{2} 2^{\prime \prime}(28-29 \mathrm{~cm})$. A dove of the desert, readily known by the large white wing patches. Otherwise similar to the Mourning Dove, but tail rounded, and tipped with broad white corners.

Voice: A harsh cooing, "who cooks for you?"; also, ooo-uh-cuck'oo. Sounds vaguely like the crowing of a young rooster.

Range: Sw. U.S. to n. Chile. West: Map 186. Habitat: River woods, mesquite, saguaros, desert oases, groves, towns.

BAND-TAILED PIGEON Columba fasciata

M185

14-151/2" (35-39 cm). Heavily built; might be mistaken for a Rock

Dove (Domestic Pigeon) except for its woodland or mountain habitat and greater tendency to alight in trees. Note the broad pale band across the end of the fanlike tail. At close range, shows a white crescent on nape. Feet yellow. Bill yellow with dark tip.

Voice: A hollow, owl-like oo-whoo or whoo-oo-whoo, repeated.

Range: Sw. British Columbia through Pacific states and Rockies to Argentina. Map 185. Habitat: Oak canyons, foothills, chaparral, mountain forests; spreads in winter.

RINGED TURTLE-DOVE, SPOTTED DOVE. See p. 210.

PIGEONS, DOVES continued on p. 210. 


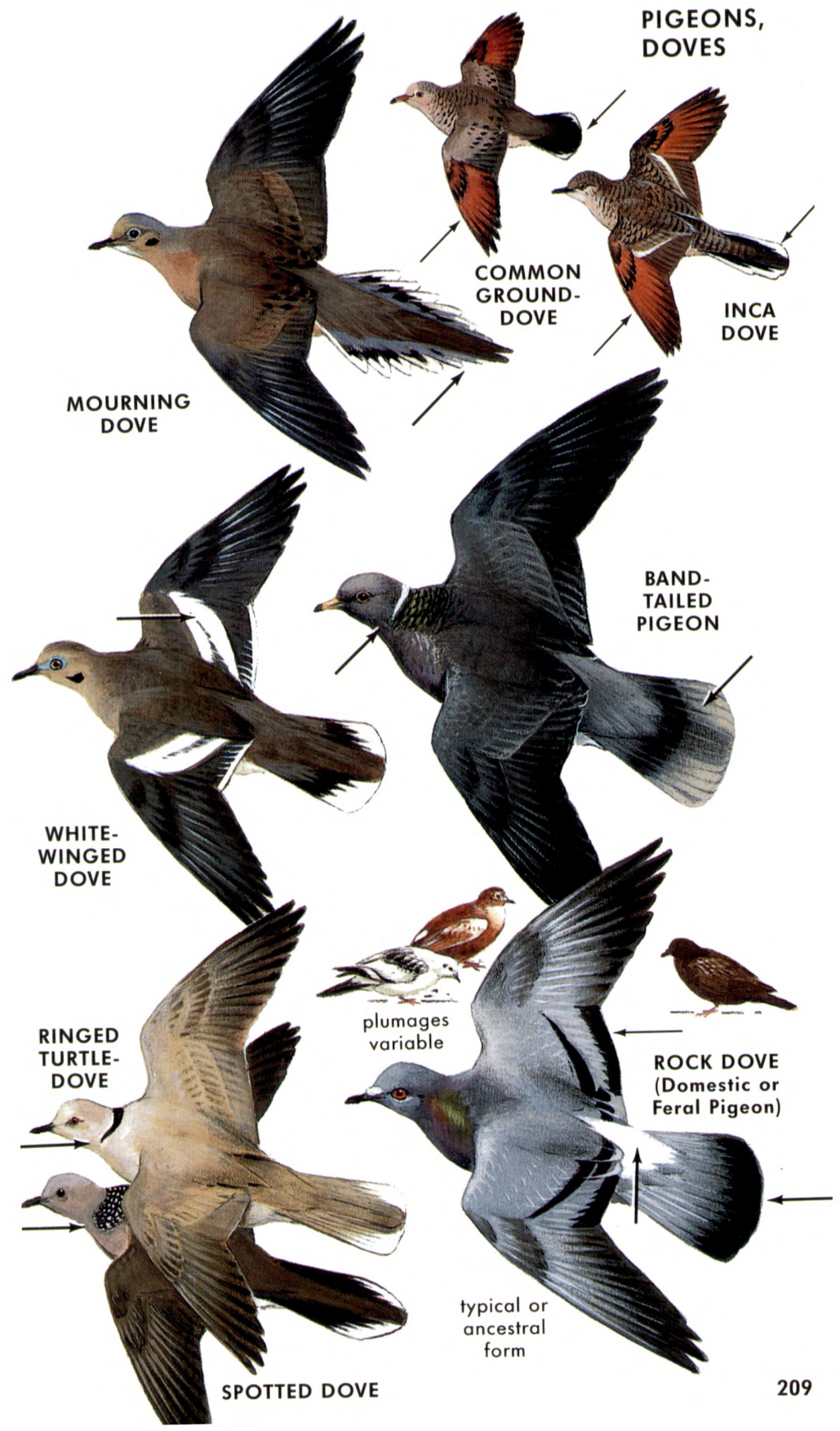


RINGED TURTLE-DOVE Streptopelia risoria

$12 "(30 \mathrm{~cm})$. Near size of Mourning Dove, but paler beige. Note the narrow black ring on the hind-neck. Tail rounded, with much white in the corners. Dark primaries contrast boldly with its pale coloration. A domestic bred variant of the African Turtle-Dove (S. roseogrisea). Seen very locally in city parks in Los Angeles, rarely elsewhere; not established.

Voice: A purring cooing; rising, then dropping in pitch.

SPOTTED DOVE Streptopelia chinensis

$13 "(33 \mathrm{~cm})$. Note the broad collar of black and white spots on the hindneck. A bit larger than the Mourning Dove; tail rounded or blunt-tipped, with much white in the corners. Juvenile birds lack the collar, but may be told by the shape of the spread tail (Mourning Dove's tail is pointed).

Voice: COO-who-coo; resembles cooing of White-winged Dove.

Range: Se. Asia. West: Introduced in Los Angeles; has spread radially to Santa Barbara, Bakersfield, Oceanside, San Diego, s. Arizona. Habitat: Residential areas, parks, river woods.

ROCK DOVE Columba livia

(Domestic Pigeon) 13" (33 cm). Typical birds are gray with a whitish rump, two black wing bars, and a broad, dark tail band. Domestic stock or feral birds may have many color variants.

Voice: Familiar to city dwellers; a soft, gurgling coo-roo-coo.

Range: Old World origin; worldwide in domestication. West: Sustains self in wild about cities, farms, cliffs, bridges.

a PARROTS, PARAKEETS. Family Psittacidae. Noisy and gaudily colored. Compact, short-necked birds with stout, hooked bills. Parakeets are smaller, with pointed tails. Feet zygodactyl (two toes fore, two aft). Range: Worldwide in tropics and subtropics. No. of species: World 271; West 1 formerly (+ at least 6 introduced).

THICK-BILLED PARROT Rhynchopsitta pachyrhyncha

$15-16 \frac{1}{2} 2$ (38-41 cm). A stocky green parrot with a longish tail, heavy black bill, and dark red forehead. In flight, a yellow patch under the wing. Northern and cen. Mexico. Formerly a sporadic visitor to mountains of se. Arizona, sw. New Mexico. Last recorded in the wild in 1922. Recently a small number from Mexico have been released into the Chiricahuas (Arizona) with the hope that a resident population will become established.

- EXOTIC PARROTS. A number of these have been released or have escaped, especially around urban centers in California. Six are shown here.

WHITE-WINGED PARAKEET Brotogeris versicolurus

(S. America) Note the white and yellow wing patch. Local resident of Palo Verdes, Los Angeles; a few elsewhere.

RED-CROWNED PARROT Amazona viridigenalis

(Mexico) Entire crown red (compare Lilac-crowned). A few live in the Los Angeles area. Has nested in San Gabriel Valley.

ROSE-RINGED PARAKEET Psittacula krameri

(India) Narrow rose and black necklace; red bill; slender tail. A few in suburbs on coastal slopes of s. California.

EXOTIC PARROTS continued on p. 212. 
INTRODUCED

PARROTS

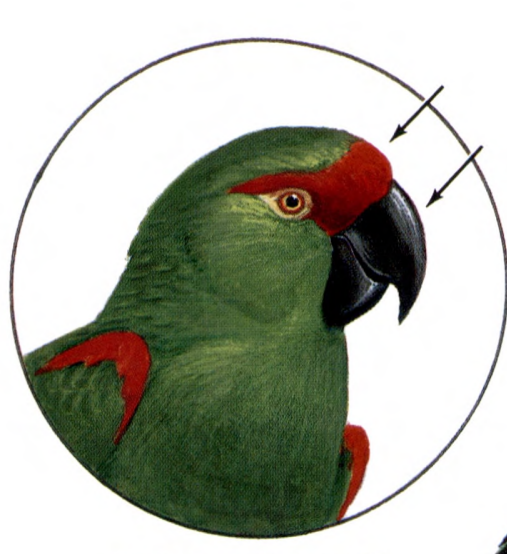

(mostly escapes)

THICK-BILLED PARROT

Formerly a rare or sporadic visitor to Arizona-

recently re-introduced
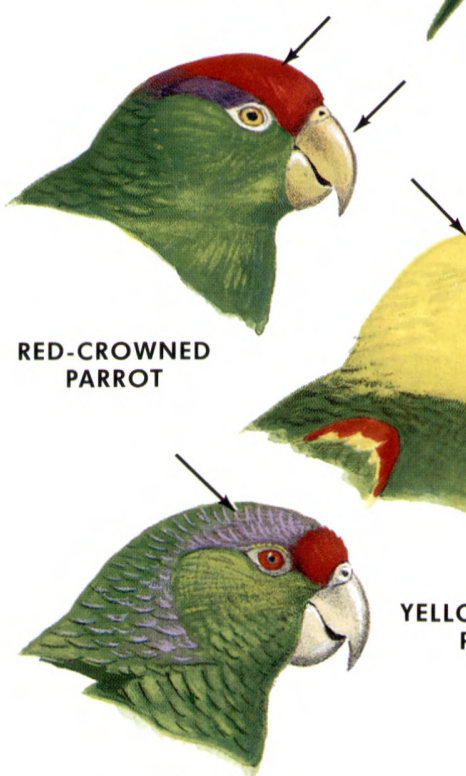

LILAC-CROWNED PARROT

YELLOW-HEADED

PARROT

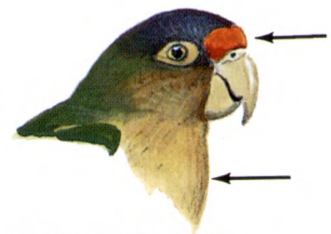

ORANGE-FRONTED

PARAKEET 
EXOTIC PARROTS (continued). See illustrations on p. 211.

YELLOW-HEADED PARROT Amazona oratrix

(Tropical America) Distinctive; breeds locally in and around w. Los Angeles and w. San Gabriel Valley; often seen elsewhere.

LILAC-CROWNED PARROT Amazona finschi

(Mexico) Red forehead, lilac crown, green cheeks, pale bill. A few live in the Los Angeles area. Has nested in San Gabriel Valley.

ORANGE-FRONTED PARAKEET Aratinga canicularis

(Mexico) Orange forehead, brown breast. Local, s. California.

- CUCKOOS, ROADRUNNERS, ANIS. Family Cuculidae. Slender, long-tailed birds; feet zygodactyl (two toes forward, two aft). Sexes alike. Food: Cuckoos eat caterpillars, other insects; roadrunners eat reptiles; anis eat seeds, fruits. Range: Warm and temperate regions of the world. No. of species: World 132, West 4 (+2 accidental, see pp. 352, 353). Our cuckoos are not parasitic.

\section{YELLOW-BILLED CUCKOO Coccyzus americanus}

M191

11-13" $(28-33 \mathrm{~cm})$. Known as a cuckoo by the slim sinuous look, brown back, and white underparts; as this species, by rufous in the wings, large white spots at tips of black undertail feathers, and yellow lower mandible on the slightly curved bill.

Voice: Song, a rapid throaty ka-ka-ka-ka-ka-ka-ka-ka-ka-ka-ka-ka-kowkow-kowlp-kowlp-kowlp - kowlp (retarded toward end).

Range: S. Canada to Mexico, W. Indies. Winters to Argentina. West: Map 191. Habitat: Riverine woodlands, thickets, farms; declining.

BLACK-BILLED CUCKOO Coccyzus erythropthalmus

M190

11-12" (28-30 cm). Similar to Yellow-billed Cuckoo, but bill black; narrow red eye-ring (in adult). No rufous in the wing; undertail spots small. The immature has a yellow eye-ring like the Yellow-billed Cuckoo's, but has an all-black bill.

Voice: A fast, rhythmic cucucu, cucucu, cucucu, etc. The grouped rhythm (three or four) is typical. May sing at night.

Range: S. Canada, cen. and ne. U.S. Winters to Argentina. West: Map 190. Habitat: Wood edges, groves, thickets.

GROOVE-BILLED ANI Crotophaga sulcirostris

13" $(33 \mathrm{~cm})$. A coal-black, grackle-sized bird, with a loose-jointed tail, short wings, and a deep bill with a high, curved, puffin-like ridge. Flight weak; alternately flaps and sails.

Voice: A repeated whee-o or tee-ho, first note slurring up.

Range: Gulf of Mexico to Argentina. West: A very rare but regular stray to s. Arizona; casual or accidental, New Mexico, Colorado, Nevada, s. California.

GREATER ROADRUNNER Geococcyx californianus

M192

$20-24 "(50-60 \mathrm{~cm})$. The cuckoo that runs on the ground (tracks show two toes forward, two aft). A large, slender, streaked bird, with a long, whiteedged tail; shaggy crest; and long legs. White crescent on wing (visible when spread).

Voice: Six to eight low, dove-like coo's, descending in pitch.

Range: Sw. U.S. to cen. Mexico. West: Map 192. Habitat: Deserts; dry, open country with scattered cover, brush. 


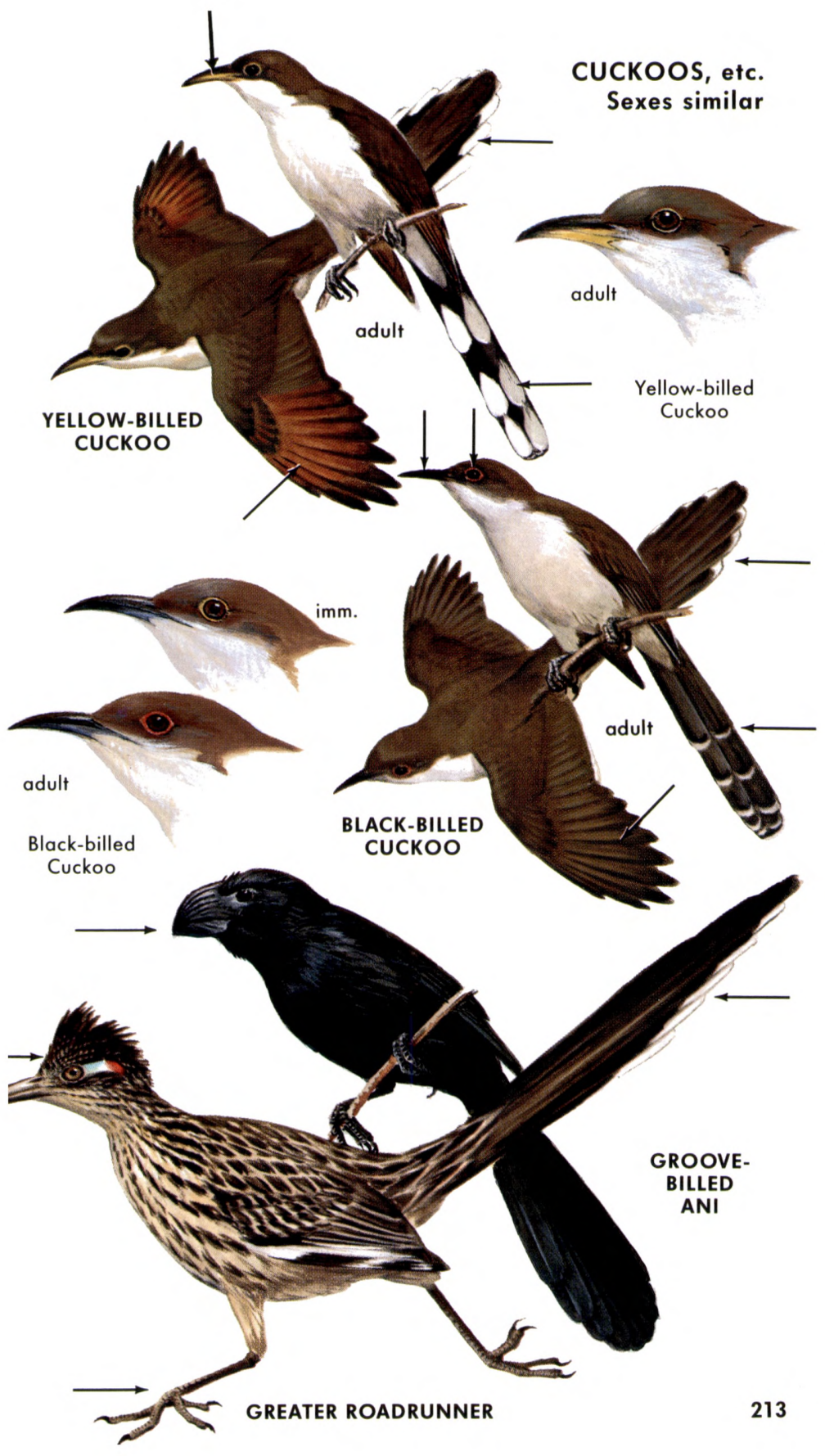


- GOATSUCKERS (NIGHTJARS). Family Caprimulgidae. Nocturnal birds with ample tails, large eyes, tiny bills, large bristled gapes, and very short legs. By day, they rest horizontally on limbs or on the ground, camouflaged by "dead-leaf" pattern. Identified at night by voice. Food: Nocturnal insects. Range: Nearly worldwide in temperate and tropical land regions. No. of species: World 72; West $5(+1$ accidental).

COMMON NIGHTHAWK Chordeiles minor

M209

$91 / 2^{\prime \prime}(24 \mathrm{~cm})$. A slim-winged, gray-brown bird, often seen high in the air; flies with easy strokes, "changing gear" to quicker erratic strokes. Note the broad white bar across the pointed wing. Male has a white bar across its notched tail and a white throat. Prefers dusk, but may be abroad at midday.

Voice: A nasal peent or pee-ik. In aerial display, the male dives, then zooms up sharply with a sudden deep whir of wings.

Range: Canada to Panama. Winters to Argentina. West: Map 209. Habitat: Open country to mountains; open pine woods; often seen in air over cities, towns. Sits on ground, posts, rails, roofs, limbs.

LESSER NIGHTHAWK Chordeiles acutipennis

M208

$8-9 "(20-23 \mathrm{~cm})$. Smaller than the Common Nighthawk; white bar (buffy in female) closer to tip of wing. Readily identified by odd calls and manner of flight-very low, seldom high. Does not powerdive. A bird of lowlands, not mountains.

Voice: A low chuck chuck and a soft purring or whinnying sound, much like the trilling of a toad.

Range: Sw. U.S. to n. Chile, Brazil. West: Map 208. Habitat: Arid scrub, dry grassland, fields, prairie, desert washes.

WHIP-POOR-WILL Caprimulgus vociferus

M211

$91 / 2^{\prime \prime}(24 \mathrm{~cm})$. A voice in the night woods. When flushed by day, flits away on rounded wings, like a large brown moth. Male shows large white tail patches; in female these are buffy.

Voice: At night, a rolling, tiresomely repeated whip' poor-weel', or purple-rib, etc.; accent on first and last syllables.

Range: E. Canada, sw. U.S. to Honduras. Winters from Gulf states to Honduras. West: Map 211. Habitat: Leafy woodlands.

BUFF-COLLARED NIGHTJAR Caprimulgus ridgwayi

$8 \frac{1 / 2}{-9} 9^{\prime \prime}(21-23 \mathrm{~cm})$. Similar to the Whip-poor-will, but with a buff or tawny collar across the hind-neck.

Voice: Staccato, cricketlike notes, terminating with a longer, strongly accented phrase, cuk-cuk-cuk-cuk-cuk-cuk-cuk-cukacheea.

Range: Mainly Mexico (Sonora to Chiapas). West: Guadalupe Canyon (sw. New Mexico and se. Arizona); occasionally elsewhere in se. Arizona. Habitat: Rocky juniper-mesquite slopes.

COMMON POORWILL Phalaenoptilus nuttallii

M210

$7-8$ " $(18-20 \mathrm{~cm})$. Best known by its night cry in arid hills. It appears smaller than a Nighthawk, has more rounded wings (no white bar), and its short, rounded tail has white corners.

Voice: At night, a loud, repeated poor-will or poor-jill.

Range: Se. British Columbia, w. U.S. to cen. Mexico. West: Map 210. Habitat: Dry hills, open brush, dirt roads. 
- HUMMINGBIRDS. Family Trochilidae. The smallest birds. Iridescent, with needle-like bills for sipping nectar. Jewel-like gorgets (throat feathers) adorn most adult males. Hummingbirds hover when feeding; their wing motion is so rapid that the wings appear blurred. They can fly backward. Pugnacious. Food: Nectar (red flowers favored); small insects, spiders. Range: W. Hemisphere; majority in tropics. No. of species: World 308; West $15(+3$ accidental).

ANNA'S HUMMINGBIRD Calypte anna

M217

$31 / 2-4 "(9-10 \mathrm{~cm})$. Male: The only U.S. hummer with a red crown. Throat red. Female: Similar to females of other West Coast hummers; larger, darker green above. Grayer below, with a more heavily spotted throat than female Costa's or Black-chin. Often a central patch of red spots on throat. The only hummingbird commonly found in California in midwinter.

Voice: Feeding note, chick. Song (from a perch), squeaking, grating notes. When diving in its aerial "pendulum display," the male makes a sharp popping sound at the bottom of the arc.

Range: See Map 217. Habitat: Gardens, chaparral, open woods.

BROAD-TAILED HUMMINGBIRD Selasphorus platycercus

M220

$4-4 \frac{1}{2} 2^{\prime \prime}(10-11 \mathrm{~cm})$. The male of this Rocky Mt. species may be known by the sound of its wings, a shrill trilling. Male: Back green; throat bright rose-red. Female: Larger than the female Black-chin; sides tinged with buffy; touch of rufous at basal corners of tail.

Range: Western U.S. to Guatemala. Map 220. Habitat: Mountains.

RUBY-THROATED HUMMINGBIRD Archilochus colubris $\mathbf{M 2 1 5}$

$3-334^{\prime \prime}(8-9 \mathrm{~cm})$. Male of Ruby-throat, an eastern species, has a glowing fiery-red throat, iridescent green back. Note the forked tail. Female lacks the red throat; tail blunt, with white spots.

Similar species: Male Broad-tailed Hummer lacks forked tail.

Range: S. Canada to Gulf states. Winters s. Texas, s. Florida to w. Panama. West: Map 215.

ALLEN'S HUMMINGBIRD Selasphorus sasin

M222

$3 \frac{1}{2} 2^{\prime \prime}(9 \mathrm{~cm})$. Male: Like the Rufous Hummingbird (rufous sides, rump, tail, and cheeks; fiery throat), but the back is green. Female: Indistinguishable in the field from the female Rufous (in the hand, Allen's has narrower outer tail feathers).

Similar species: Male Rufous has the entire back rufous.

Voice: Aerial display of male unlike that of Rufous. Starts "pendulum display" in a shallow arc and after a number of swoops goes into a steep climb and swoops back, with an air-splitting vrrrip. (H. Cogswell).

Range: Breeds in coastal California; winters in nw. Mexico. Map 222. Habitat: Wooded or brushy canyons, parks, gardens; mountain meadows.

RUFOUS HUMMINGBIRD Selasphorus rufus

M221

$3 \frac{1}{1} 2^{\prime \prime}(9 \mathrm{~cm})$. Male: No other North American hummingbird has a rufous back. Upperparts bright red-brown; throat flaming orangered. Aerial display, a closed ellipse, slowing on return climb. Female: Green-backed; dull rufous on sides and at base of tail.

Range: Breeds in nw. N. America; winters in Mexico. Map 221. 


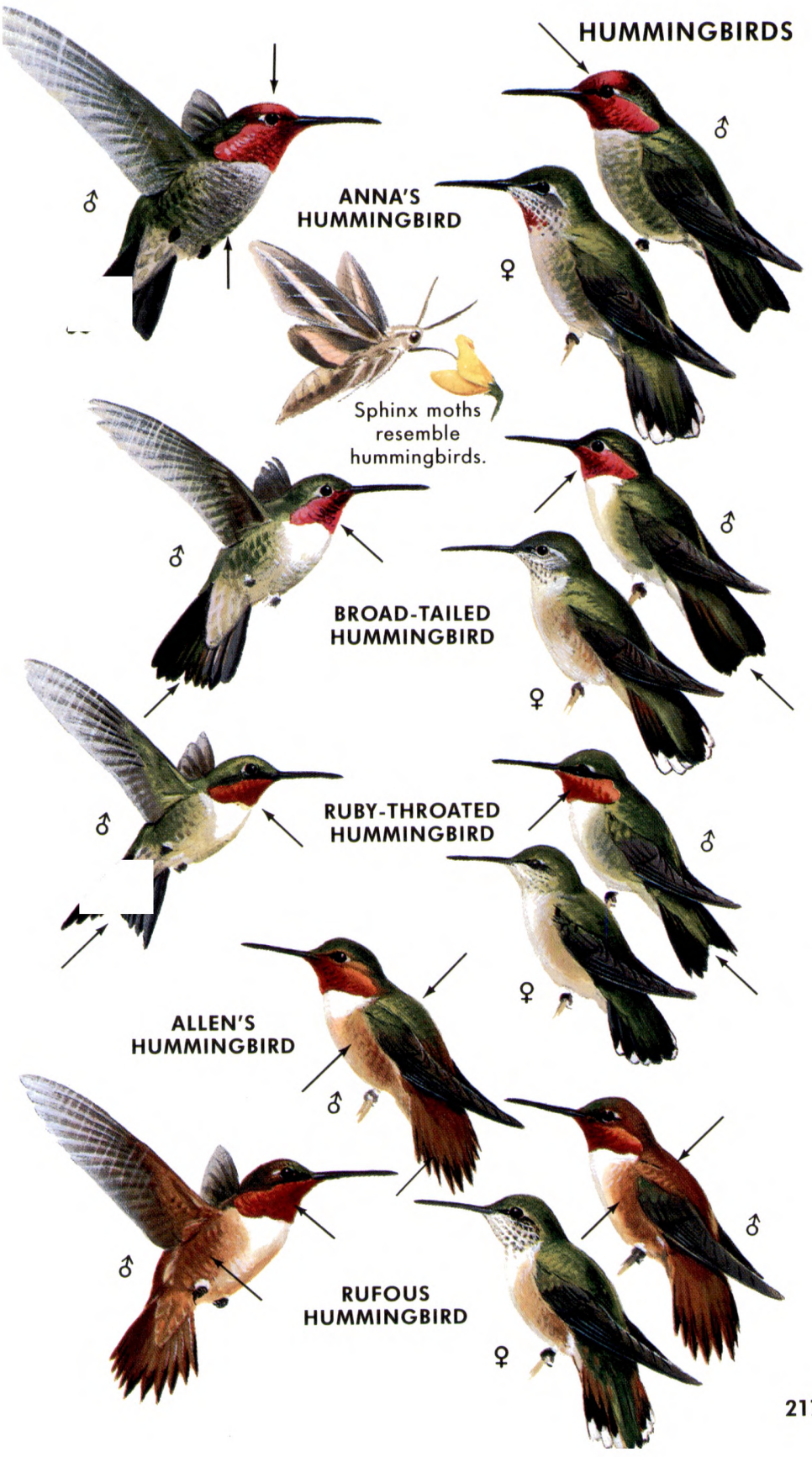


BLUE-THROATED HUMMINGBIRD Lampornis clemenciae

$4 \frac{1}{2}-5^{1} / 2^{\prime \prime}(11-14 \mathrm{~cm})$. Note the big tail with its exceptionally large white patches. Male: A very large hummingbird, with black and white streaks around the eye and a light blue throat; big black tail with large white patches. Female: Large, with evenly gray underparts, white marks on the face, and a big, blue-black tail with large white corners, as in the male.

Voice: Note, a squeaking seek.

Range: Sw. U.S. to s. Mexico. West: Mountains of se. Arizona, extreme sw. New Mexico, w. Texas (Chisos Mts.). Casual or accidental California, Nevada, Utah, Colorado. Habitat: Wooded streams in lower canyons of mountains.

\section{MAGNIFICENT HUMMINGBIRD Eugenes fulgens}

(Rivoli's Hummingbird) 41/2-5" $(11-13 \mathrm{~cm})$. Male: A very large hummingbird with a blackish belly, bright green throat, and purple crown. Looks all black at a distance. Wingbeats discernible; sometimes the bird scales on set wings. Female: Large; greenish above, washed with greenish or dusky below. Known from female Bluethroated by more mottled underparts, spotted throat, dark greenish tail, obscure pale tail corners.

Voice: Note, a thin, sharp chip; distinctive.

Range: Sw. U.S. to $\mathrm{n}$. Nicaragua. West: Breeds or summers in mountains of se. Arizona and locally in sw. New Mexico, w. Colorado, w. Texas. Casual or accidental, Nevada, California, Utah, Wyoming. Habitat: Mountain glades, pine-oak woods, canyons.

\section{BROAD-BILLED HUMMINGBIRD Cynanthus latirostris}

31/4-4" $(8-10 \mathrm{~cm})$. Male: Dark green above and below, with a blue throat (bird may look all black at a distance). Bill bright red, with a black tip. Female: Identified by combination of red bill and unmarked, pearly gray throat; thin white line behind eye. Females of most other hummers have some spots on the throat.

Range: Sw. U.S. to s. Mexico. West: Summers (rarely winters) in s. Arizona; also summers sw. New Mexico, w. Texas (sparse; Big Bend to Alpine); casual, se. California, Utah. Habitat: Desert canyons, mountain slopes, agaves, mesquite.

\section{WHITE-EARED HUMMINGBIRD Hylocharis leucotis}

$3 \frac{1}{1} 2^{\prime \prime}(9 \mathrm{~cm})$. Male: Bill red, with a black tip; broad white stripe behind the eye. Underparts dark greenish, throat blue and green, crown purple. Female: Has the red bill and bold white stripe behind the eye. Note the small green spots on the throat.

Similar species: Male Broad-billed Hummingbird has a well-forked tail and only a touch of white behind the eye. Caution: Female Broad-bill is often mistaken for a female White-eared (red bill and pronounced white eyestripe), but if the throat and underparts are evenly gray, the bird is a female Broad-bill.

Range: Mexican border to Nicaragua. A sparse summer visitor to mountains of se. Arizona. Casual or accidental, sw. New Mexico, w. Texas (Chisos Mts.). Habitat: Pine-oak woods near streams. 


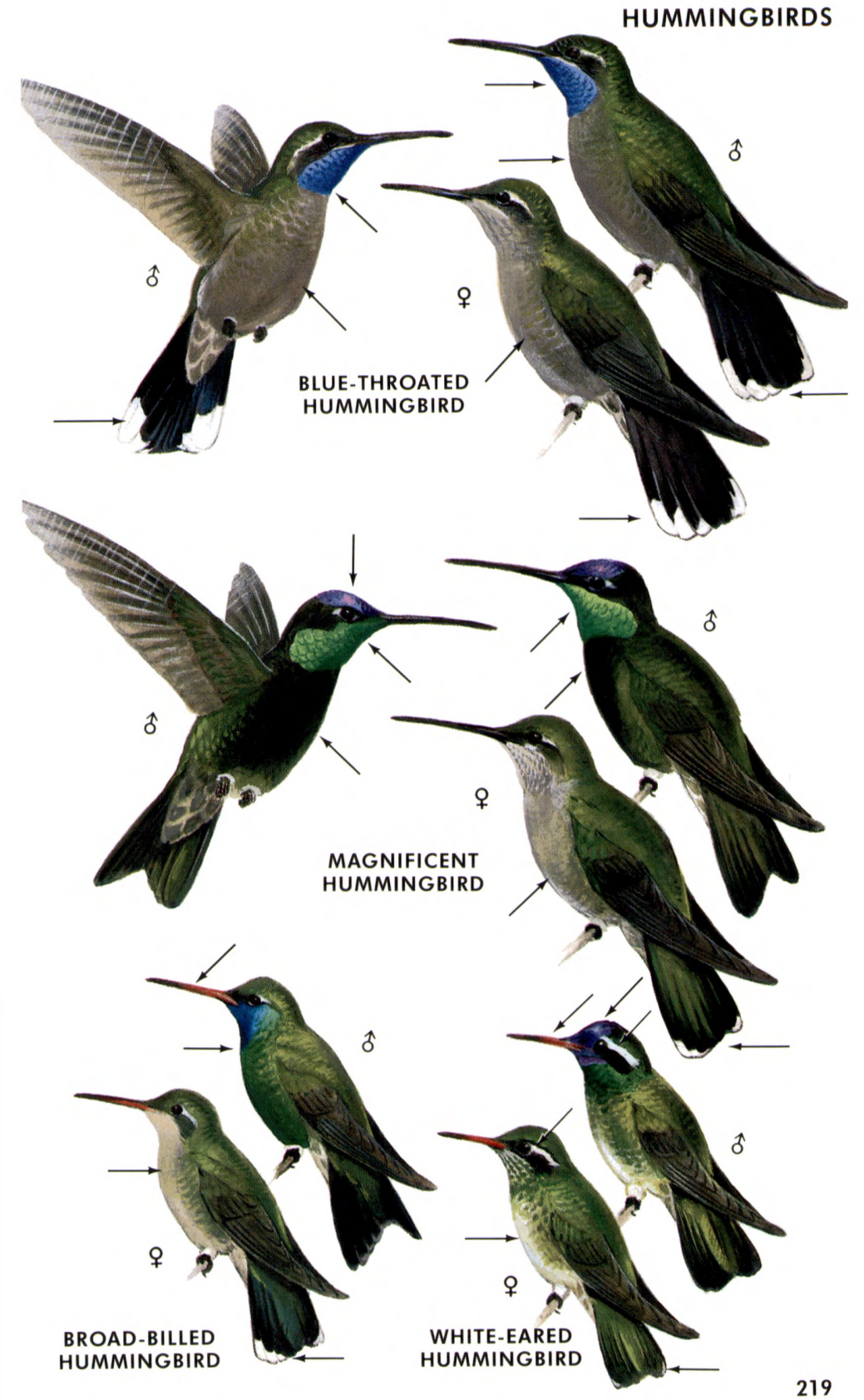


$23 / 4-31 / 4^{\prime \prime}(7-8 \mathrm{~cm})$. The smallest hummer normally found in the U.S. Male: Throat with purple-red rays on white ground (may be folded like a dark inverted $\mathrm{V}$ on a white throat); the only U.S. hummingbird with this effect. Female: Very similar to females of Broad-tailed and Rufous hummingbirds (buffy sides, rufous base of tail), but decidedly smaller; rusty on sides paler.

Range: Sw. Canada to Baja California. Winters in Mexico. Map 219. Habitat: Seldom away from high mountains; canyons, forest glades.

BLACK-CHINNED HUMMINGBIRD Archilochus alexandri M216 $31 / 2^{\prime \prime}(9 \mathrm{~cm})$. Male: Note the black throat and conspicuous white collar. The blue-violet of lower throat shows only in certain lights. Throats of other hummers may look black until they catch the light. Female: Greenish above, whitish below. Cannot safely be told in field from female Costa's or Ruby-throat. Call note, teew.

Range: Western U.S., n. Mexico. Map 216. Habitat: Semi-arid country, river groves, canyons, slopes, chaparral, suburbs.

VIOLET-CROWNED HUMMINGBIRD Amazilia violiceps

$4{ }^{1 / 4^{\prime \prime}}(10 \mathrm{~cm})$. A rather large hummer with immaculate white underparts, including the throat; bill red, with a black tip. Sexes similar, but crown violet-blue in male, dull greenish blue in female and immature. No iridescent gorget on male.

Range: Mainly Sonora to Chiapas. Breeds in Guadalupe Canyon in extreme se. Arizona, sw. New Mexico, rarely elsewhere in se. Arizona. Habitat: Stream groves in canyons, sycamores, agaves.

LUCIFER HUMMINGBIRD Calothorax lucifer

$3 \frac{1}{2} 2^{\prime \prime}(9 \mathrm{~cm})$. Note the decurved bill. Male has a purple throat, rusty or buffy sides. No purple on crown (as in Costa's); tail deeply forked, often folded. Female: Decurved bill, uniform buff breast.

Range: W. Texas to s. Mexico. Breeds in w. Texas (Chisos Mts.), rarely se. Arizona, sw. New Mexico. Habitat: Arid slopes, agaves.

COSTA'S HUMMINGBIRD Calypte costae

M218

$3-3 \frac{1}{2}{ }^{\prime \prime}(8-9 \mathrm{~cm})$. Male: Note the purple or amethyst throat and crown. Feathers of gorget project markedly at sides. Female: Very similar to female Black-chin, but prefers more arid conditions. Voices differ. Often soars from one flower clump to another.

Range: Sw. U.S., nw. Mexico. Map 218. Habitat: Deserts, washes, mesas, sage scrub, arid hillsides.

BUMBLEBEE HUMMINGBIRD Atthis heloisa

$23 / 4^{\prime \prime}(7 \mathrm{~cm})$. Tiny; resembles the Lucifer Hummingbird (elongated purple gorget) but bill short, straight; tail rounded, with a rufous base. Range: Mexico. Accidental, se. Arizona.

\section{PLAIN-CAPPED STARTHROAT Heliomaster constantii}

$41 / 2^{\prime \prime}(11 \mathrm{~cm})$. A large, long-billed hummer, with a red throat, white facial stripes, white rump. Range: Mexico. Casual or accidental stray to se. Arizona (usually at feeders).

BERYLLINE HUMMINGBIRD Amazilia beryllina

$3 \frac{1}{2} 2^{\prime \prime}(9 \mathrm{~cm})$. Male: Glittering green on underparts; deep rich rufous in wings, rump, and tail. Bill partly red. Female: Duller; belly gray. Range: Mexico. West: Sparse visitor and rare breeder in mountains of se. Arizona. 
- WOODPECKERS. Family Picidae. Chisel-billed, wood-boring birds with strong zygodactyl feet (usually two toes front, two rear), remarkably long tongues, and stiff spiny tails that act as props when climbing. Flight usually undulating. Most males have some red on the head. Food: Tree-boring insects; some species eat ants, flying insects, berries, acorns, sap. Range: Mainly wooded parts of the world; absent in Australian region, Madagascar, most oceanic islands. No. of species (including allies): World 212; West $20(+2$ accidental).

PILEATED WOODPECKER Dryocopus pileatus

M238

16-191/2" (40-49 cm). A spectacular black, crow-sized woodpecker, with a flaming red crest. The female has a blackish forehead, lacks red on the mustache. The great size, sweeping wingbeats, and flashing white underwing areas identify the Pileated in flight. The diggings-large oval or oblong holes-indicate its presence.

Voice: Call resembles that of Flicker, but louder, irregular: kik-kikkikkik-kik-kik, etc. Also a more ringing, hurried call that may rise or fall slightly in pitch and volume.

Range: Canada to s. U.S. West: Map 238. Habitat: Conifer, mixed, and hardwood forests; woodlots.

LEWIS'S WOODPECKER Melanerpes lewis

M224

$10^{1 / 2}-11 \frac{1}{1} 2^{\prime \prime}(26-29 \mathrm{~cm})$. A large, dark, black-backed woodpecker, with an extensive pinkish red belly (the only N. American woodpecker so colored). Has a wide gray collar and dark red face patch. The pink underparts and wide black wings are the best marks. Sexes similar. Has straight crow-like flight; fly-catching habit.

Voice: Usually silent. Occasionally a harsh churr or chee-ur.

Range: Sw. Canada, w. U.S. Map 224. Habitat: Scattered or logged forest, river groves, burns, foothills.

RED-HEADED WOODPECKER Melanerpes erythrocephalus

M225

$81 / 2-91 / 2^{\prime \prime}(21-24 \mathrm{~cm})$. A black-backed woodpecker with a head that is entirely red (other woodpeckers may have a patch of red). Back solid black, rump white. Large, square white patches are conspicuous on the wing (making the lower back look white when the bird is on a tree). Sexes similar. Immature is dusky-headed; the large white wing patches identify it.

Similar species: Red-breasted Sapsucker also has an entirely red head but a different range (Pacific states). See p. 227.

Voice: A loud queer or queeah.

Range: East of Rockies from s. Canada to Gulf states. West: Map 225. Habitat: Groves, farm country, orchards, shade trees in towns, large scattered trees.

ACORN WOODPECKER Melanerpes formicivorus

M226 $8-91 / 2^{\prime \prime}(20-24 \mathrm{~cm})$. Note the clownish black, white, and red head pattern. A black-backed woodpecker showing a conspicuous white rump and white wing patches in flight. Both sexes have whitish eyes, red on crown. This woodpecker stores acorns in bark.

Voice: Whack-up, whack-up, whack-up, or ja-cob, ja-cob.

Range: Resident, w. U.S. to Colombia. Map 226. Habitat: Oak woods, groves, mixed forest, oak-pine canyons, foothills. 


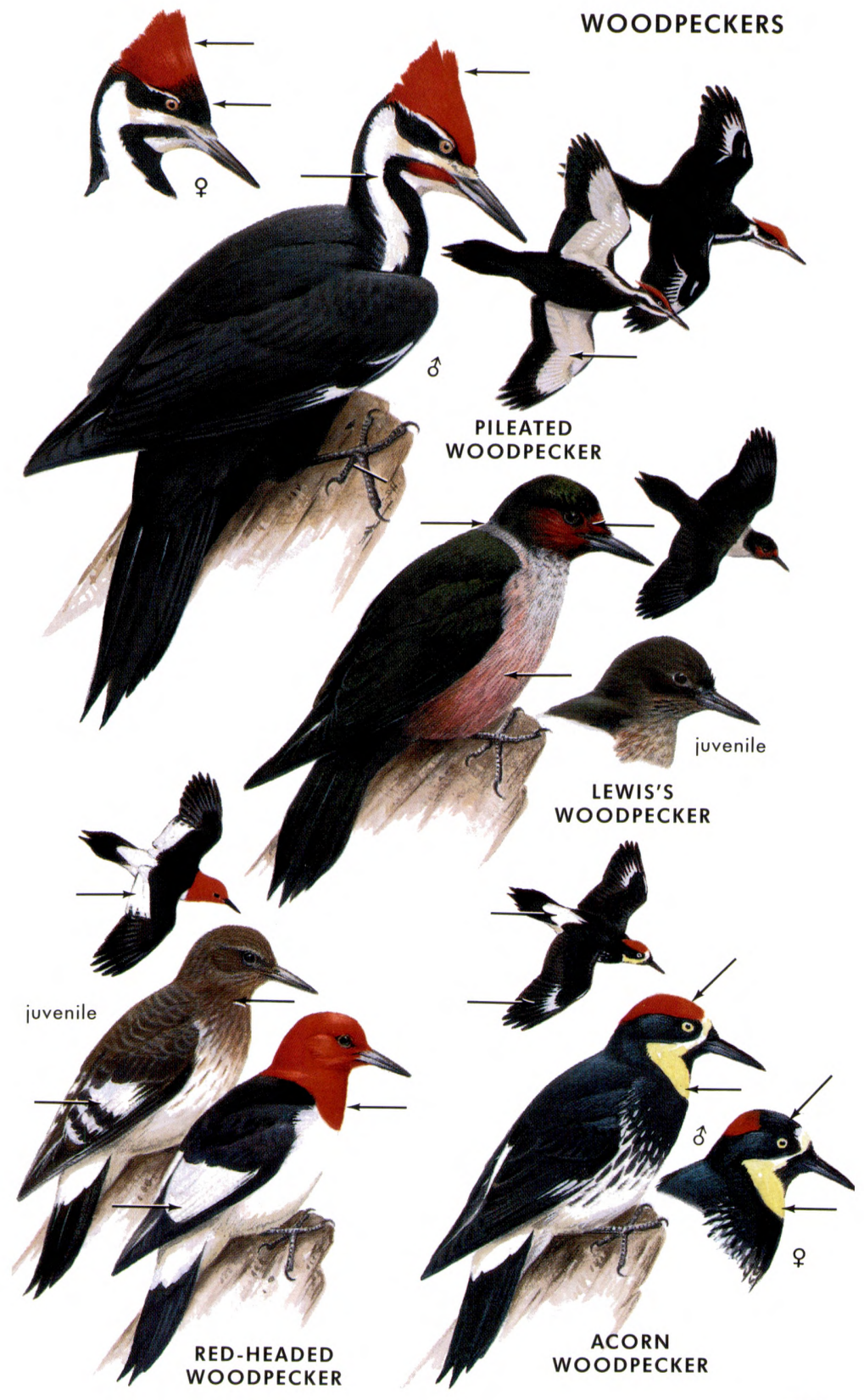


9" $(23 \mathrm{~cm})$. Our only woodpecker with a white head. Male has a red patch on the nape; otherwise black, with a large white patch in the primaries. No white on the rump (as in Acorn).

Voice: A sharp chick, sometimes rapidly repeated, chick-ik-ik-ik; also a rattle similar to Downy Woodpecker's.

Range: Western N. America. Map 234. Habitat: Mountain pine forests.

DOWNY WOODPECKER Picoides pubescens

M232

$61 / 2 "(16 \mathrm{~cm})$. Note the white back and small bill. This industrious bird is like a small edition of the Hairy Woodpecker, which has a large bill. Birds of the humid Pacific Northwest have smoky graybrown underparts. The amount of white spotting in the wings varies regionally, as it does in the next species.

Voice: A rapid whinny of notes, descending in pitch. Note, a flat pick, not as sharp as the Hairy's peek!

Range: Alaska, Canada to s. U.S. West: Map 232. Habitat: Forests, woods, river groves, willows, orchards, shade trees.

HAIRY WOODPECKER Picoides villosus

M233

$91 / 2^{\prime \prime}(24 \mathrm{~cm})$. Note the white back and large bill. The Downy and Hairy are almost identical in pattern, checkered and spotted with black and white; males with a small red patch on back of the head, females without. The Hairy is like an exaggerated Downy, especially the bill. Hairys of the humid northwestern belt have a soiled tinge on the back and smoky underparts.

Similar species: The Downy at close range shows spots on the outer tail feathers. The small bill is the best character.

Voice: A Kingfisher-like rattle, run together more than the call of the Downy. Note, a sharp peek! (Downy says pick.)

Range: Alaska, Canada to Panama. West: Map 233. Habitat: Forests, woodlands, river groves, shade trees.

THREE-TOED WOODPECKER Picoides tridactylus

M235

(Northern Three-toed Woodpecker) 8-91/2" $(20-24 \mathrm{~cm})$. Males of this and the next species are our only woodpeckers that normally have yellow caps. Both have barred sides. This species is distinguished by the irregular white patch on the back (Rockies) or bars (further north). The female lacks the yellow cap and suggests a Downy or Hairy Woodpecker. Note the barred sides.

Similar species: (1) Black-backed Three-toed Woodpecker has a solid black back. (2) Rarely, an immature Hairy Woodpecker has a yellowish or orange cap, but lacks bars on the flanks.

Range: Boreal forests of N. Hemisphere. West: Map 235. Habitat: Conifer forests.

BLACK-BACKED WOODPECKER Picoides arcticus

M236

(Black-backed Three-toed Woodpecker) 9-10" $(23-25 \mathrm{~cm})$. Note the combination of the solid black back and barred sides. Males have yellow caps. This and the preceding species (both have three toes) inhabit the colder boreal forests; their presence can be detected by patches of bark scaled from dead conifers.

Voice: A short, sharp kik or chik. Also in series.

Range: Boreal forests of $\mathrm{n}$. N. America. West: Map 236. Habitat: Forests of firs and spruces. 


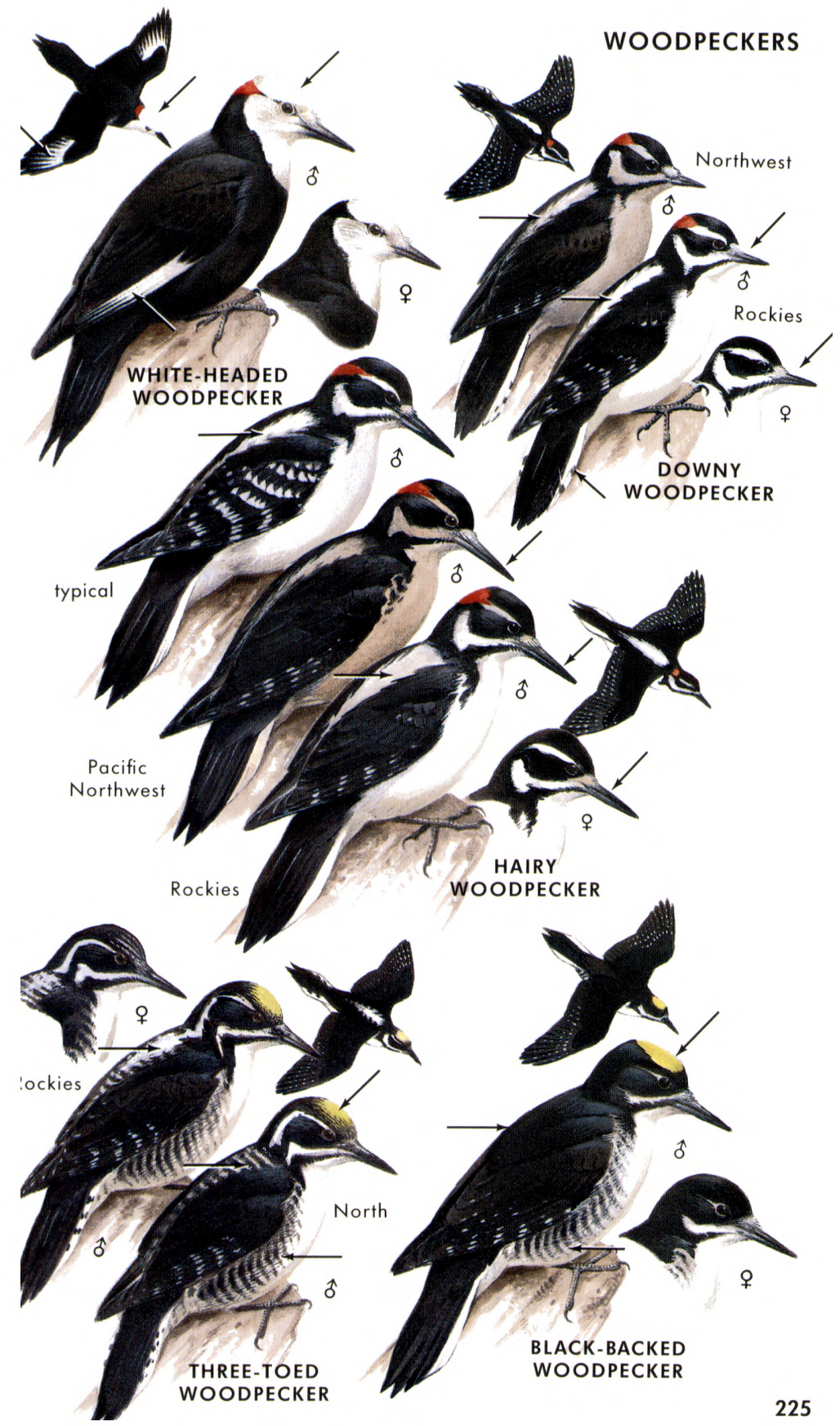


(Including "Yellow-shafted," "Red-shafted," and "Gilded" Flicker.) 12-14" (30-35 cm). In flight, note the conspicuous white rump. This and the barred brown back mark the bird as a Flicker. Close up, it shows a black patch across the chest. Flight deeply undulating. Often hops awkwardly on the ground, feeding on ants. Three basic types are recognized:

(1) "YELLOW-SHAFTED" FLICKER: The northern and eastern form. Overhead, it flashes golden yellow under the wings and tail. Red crescent on nape; the male has a black mustache.

(2) "RED-SHAFTED" FLICKER: The widespread western form. Similar to "Yellow-shafted," but wing and tail linings salmon-red. Both sexes lack red crescent on nape; male has red mustache. Where ranges overlap (western edge of Plains) hybrids occur; these may have orange linings or a combination of characters.

(3) "GILDED" FLICKER: Resident in deserts of se. California (Colorado R.), s. Arizona, Baja California. Wing and tail linings usually yellow, but males have a red mustache. In essence, has head of "Red-shafted" but body of "Yellow-shafted."

Voice: A loud wick wick wick wick wick, etc. Also a loud klee-yer and a squeaky flick-a, flick-a, etc.

Range: Tree limit in Alaska, Canada, south to Nicaragua. West: Map 237. Habitat: Open forests, woodlots, groves, farms, towns, semi-open country. Also saguaros, deserts ("Gilded" Flicker).

WILLIAMSON'S SAPSUCKER Sphyrapicus thyroideus

M230

$91 / 2^{\prime \prime}(24 \mathrm{~cm})$. Male: Black crown, black back, long white shoulder patch. Note white facial stripes, red throat, yellow belly. In flight, black with white rump and shoulder patches. Female: A brownish, "zebra-backed" woodpecker with a white rump, barred sides, brown head, yellow belly. This coloration and evergreen habitat separate it from other zebra-backed woodpeckers.

Voice: A nasal cheeer. Drumming; several rapid thumps followed by three or four slow, accented thumps: -------,-,-,-.

Range: Se. British Columbia, w. U.S.: winters into n. Mexico. Map 230. Habitat: Higher conifer forests, burns.

RED-BREASTED SAPSUCKER Sphyrapicus ruber

M229

$8-9^{\prime \prime}(20-23 \mathrm{~cm})$. This sapsucker of the Pacific region has the entire head and breast bright red. Long white wing patch and other markings much like those of Red-naped and Yellow-bellied sapsuckers, with which it was formerly lumped as a single species. East of Rockies, see Red-headed Woodpecker (p. 223).

Range: Se. Alaska to Baja California. Map 229.

RED-NAPED SAPSUCKER Sphyrapicus nuchalis

M228

$8-9^{\prime \prime}(20-23 \mathrm{~cm})$. Note the longish white wing patch, red forehead and nape. Immature: Brown, with the distinctive white wing patch. Sapsuckers drill orderly rows of small holes in trees for sap.

Voice: A nasal mewing note: cheerrrr. Also drums: several rapid thumps followed by several slow, rhythmic thumps.

Range: Rockies, Great Basin, etc. Winters to cen. Mexico. West: Map 228. Habitat: Woodlands, aspen groves, orchards.

YELLOW-BELLIED SAPSUCKER See text on p. 228. 


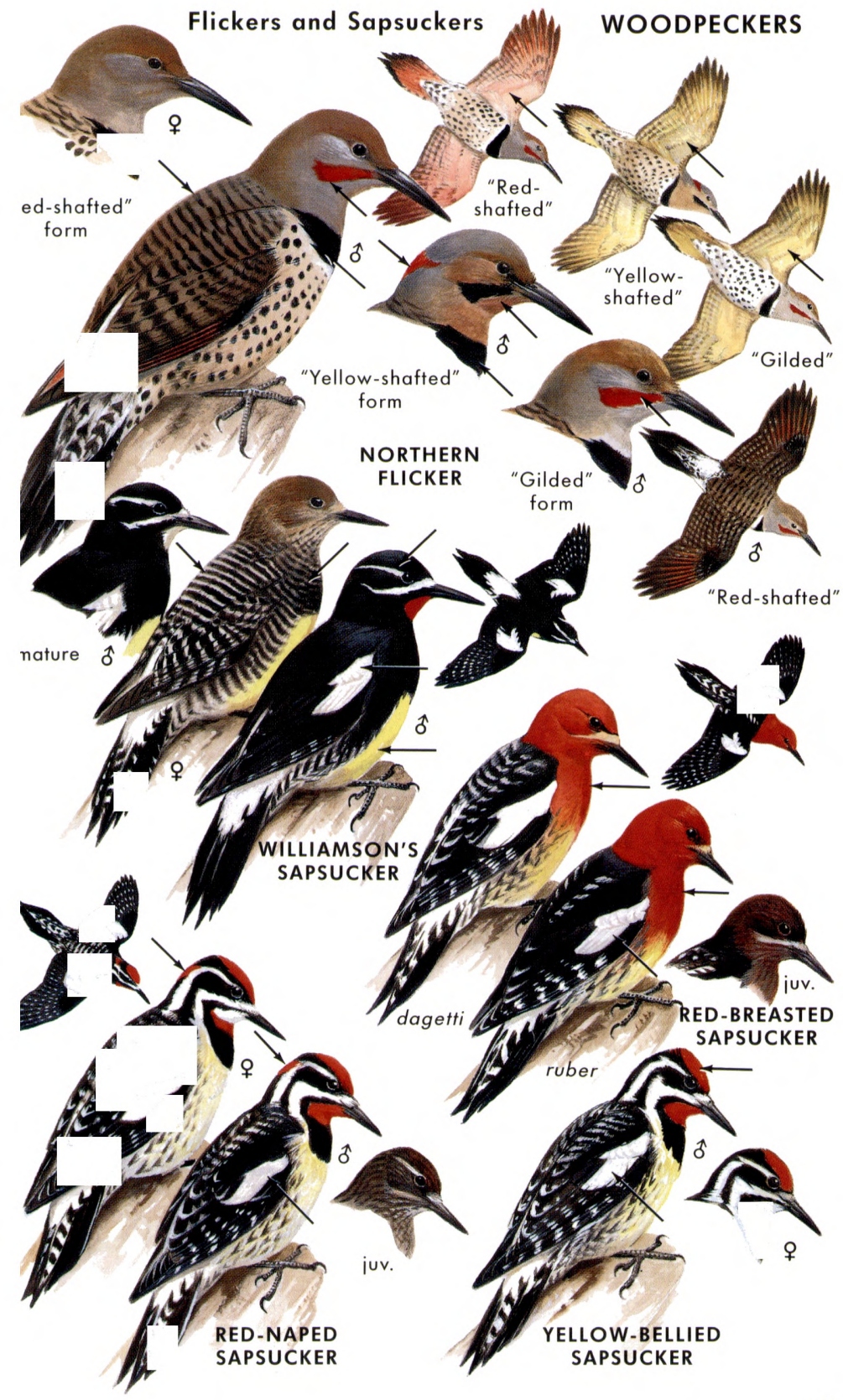


Illus., p. 227. 8-9" $(20-23 \mathrm{~cm})$. This sapsucker replaces the Rednaped Sapsucker to the north and east of the Rockies (Map 228). Differs in lacking red on the nape. Female has a white throat.

NUTTALL'S WOODPECKER Picoides nuttallii

M225

$7-71 / 2$ " $(18-19 \mathrm{~cm})$. The only black and white, "zebra-backed" woodpecker with a black-and-white-striped face normally found in California west of the Sierra. Males have red caps. The similar Ladder-backed Woodpecker lives in arid country; ranges barely overlap (hybrids are known). See Downy Woodpecker.

Voice: A high-pitched whinny or rattle. Note, a low pa-teck.

Range: Resident, California, nw. Baja California. Map 225. Habitat: Wooded canyons and foothills, river woods, groves, orchards.

LADDER-BACKED WOODPECKER Picoides scalaris M231 $6-71 / 2$ " $(15-19 \mathrm{~cm})$. The only black and white, "zebra-backed" woodpecker with a black and white striped face in the more arid country east of the Sierra (Map 231). Males have red caps.

Similar species: Nuttall's Woodpecker is found only in California west of the Sierra, not in the desert. There are minor differences in the face pattern and the amount of black on the back.

Voice: A rattling series; chikikikikikikikikikik; diminishing. Call note, a sharp pick or chik.

Range: Resident, sw. U.S. to ne. Nicaragua. Map 231. Habitat: Deserts, canyons, river woods, groves, dry woods, arid brush.

GILA WOODPECKER Melanerpes uropygialis

M227

$8-10$ " $(20-25 \mathrm{~cm})$. Male: Note the round red cap. A "zebra-backed" woodpecker; in flight, shows a white wing patch. Head and underparts gray-brown. Female: Similar, but without the red cap.

Similar species: The only other woodpeckers resident in the desert where this bird is found are: (1) Flicker (brown); (2) Ladder-backed (striped face). Neither has a white wing patch.

Voice: A rolling churr and a sharp pit or yip.

Range: Resident, sw. U.S. to cen. Mexico. Map 227. Habitat: Desert washes, saguaros, river groves, cottonwoods, towns.

GOLDEN-FRONTED WOODPECKER Melanerpes aurifrons

M227

$81 / 2-10^{1 / 2^{\prime \prime}}(21-26 \mathrm{~cm})$. Male: Note the separated patches of bright color on the head (yellow near bill, poppy-red on crown, orange nape). A "zebra-backed" woodpecker with light underparts and a white rump. Shows a white wing patch in flight. Female: Similar, without the red crown patch; has a yellow-orange nape patch. Young bird lacks color patches on its head.

Voice: A tremulous churrrr. A flicker-like kek-kek-kek-kek, etc.

Range: Sw. Oklahoma, Texas south to Nicaragua. West: Map 227.

Habitat: Mesquite, stream woodlands, groves.

RED-BELLIED WOODPECKER Melanerpes carolinus

$91 / 2-101 / 2$ " (24-26 cm). This eastern "zebra-backed" woodpecker barely crosses the $100^{\circ}$ line into the West. Males have a complete red cap; females are red on the nape only.

Range: Eastern U.S., resident locally west to cen. and n. Texas, w. Oklahoma, s. Colorado.

STRICKLAND'S WOODPECKER See text on p. 230. 
WOODPECKERS

Mostly with
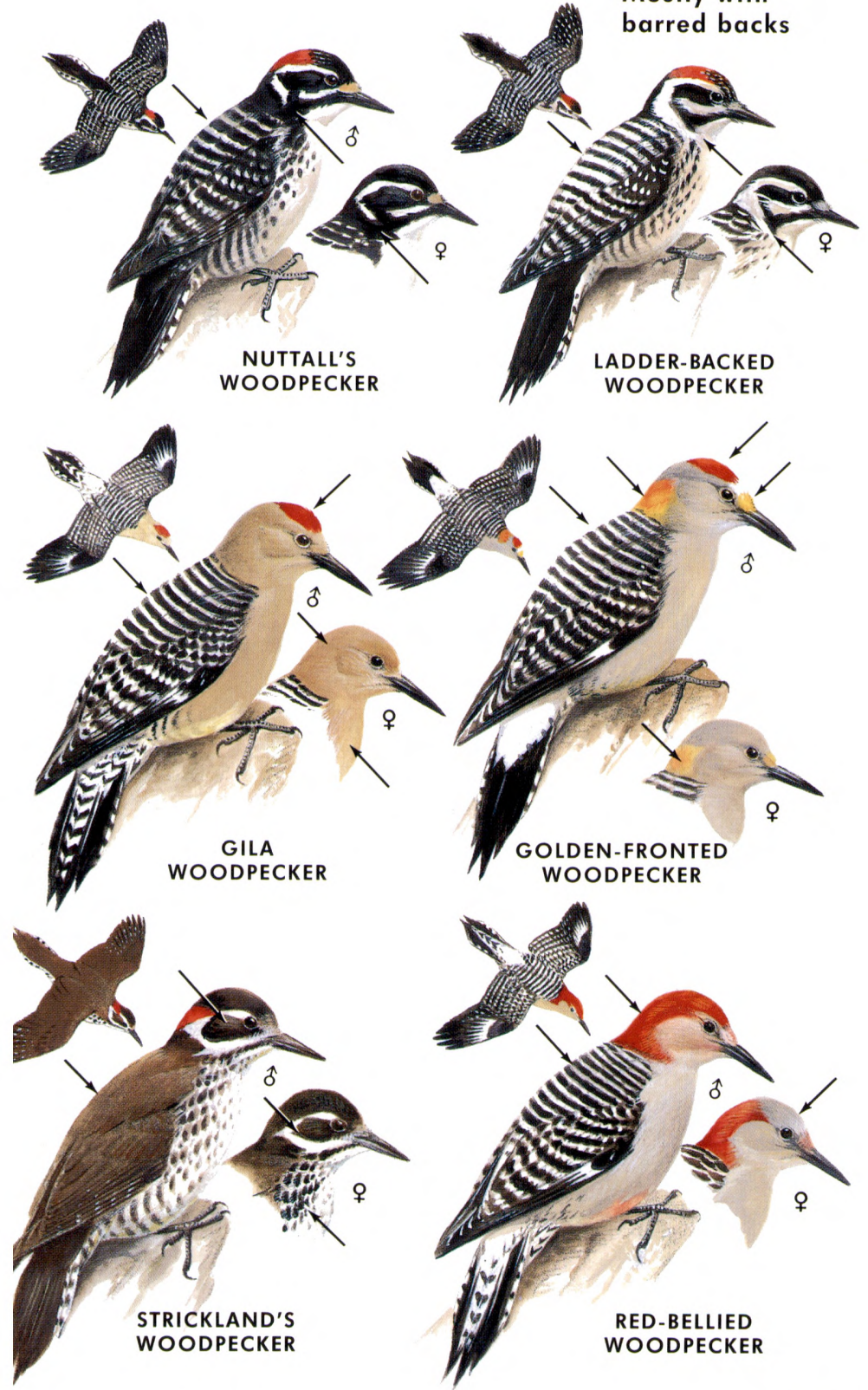

STRICKLAND'S

WOODPECKER 
STRICKLAND'S WOODPECKER Picoides stricklandii (illus., p. 229) (Arizona Woodpecker) 7-8" $(18-20 \mathrm{~cm})$. A dark, brown-backed woodpecker, with a white-striped face; spotted and barred below. Male has a red nape patch. The only U.S. woodpecker with a solid brown back (Flicker has a barred brown back, white rump).

Voice: A sharp spik. A hoarse whinny.

Range: Resident from mountains of se. Arizona and sw. New Mexico south to s.-cen. Mexico. Habitat: Oaks in mountains, pine-oak canyons.

- TYRANT FLYCATCHERS, etc. Family Tyrannidae. Most flycatchers perch quietly, sitting upright on exposed branches, and sally forth to snap up insects. Bill flattened, with bristles at base. Food: Mainly flying insects. Range: New World; majority in tropics. No. of species: World 401; West 35 (+1 accidental).

ROSE-THROATED BECARD Pachyramphus aglaiae

$61 / 2^{\prime \prime}(16 \mathrm{~cm})$. Big-headed and thick-billed. Male: Dark gray above, pale to dusky below, with a blackish cap and cheeks and a lovely rose-colored throat. Female: Brown above, with a dark cap and a light buffy collar around the nape. Underparts strong buff. The becards, a subfamily of the Tyrannidae, were formerly placed in a different family, the cotingas, Family Cotingidae.

Voice: A thin, slurred whistle, seeoo.

Range: Mexican border to Costa Rica. A local summer resident in se. Arizona and lower Rio Grande Valley, Texas. Habitat: Wooded canyons, river groves, sycamores.

SCISSOR-TAILED FLYCATCHER Tyrannus forficatus

M257

$11-15^{\prime \prime}(28-38 \mathrm{~cm})$. A beautiful bird, pale pearly gray, with an $e x-$ tremely long, scissorlike tail that is usually folded. Sides and wing linings salmon-pink. Young birds with shorter tails may suggest Western Kingbird. Hybrids are known.

Voice: A harsh keck or kew; a repeated ka-leep; also shrill, kingbird-like bickerings and stutterings.

Range: Breeds sw. U.S.; winters s. Mexico to Panama. Map 257. Habitat: Semi-open country, ranches, farms, roadsides, wires.

VERMILION FLYCATCHER Pyrocephalus rubinus

M251

$6^{\prime \prime}(15 \mathrm{~cm})$. Male: Crown (often raised in a bushy crest) and underparts flaming vermilion; upperparts and tail dusky to blackish. Immature male: Breast whitish, with some streaks; belly and undertail coverts washed with vermilion. Female: Breast whitish, narrowly streaked; belly washed with pinkish. Immature female: Belly washed with yellow.

Voice: P-p-pit-zee or pit-a-zee.

Range: Sw. U.S. to Argentina. West: Map 251. Habitat: Wooded streams in arid country, dry scrub, desert, savanna, ranches. 


$$
98
$$


$8^{\prime \prime}(20 \mathrm{~cm})$. The white band across the tail tip marks the Eastern Kingbird. Red crown mark is concealed, rarely seen. Often seems to fly quiveringly on "tips of wings." Harasses crows, hawks.

Voice: A rapid sputter of high bickering notes: dzee-dzee-dzee, etc., and kit-kit-kitter-kitter, etc. Also a nasal dzeep.

Range: Cen. Canada to Gulf of Mexico. Winters Colombia to n. Argentina. West: Map 256. Habitat: Wood edges, river groves, farms, shelter belts, orchards, roadsides, fencerows, wires.

WESTERN KINGBIRD Tyrannus verticalis

M255

$8^{\prime \prime}(20 \mathrm{~cm})$. The most widespread kingbird in the West. Like several similar species, it has a yellowish belly and gray head, but the black tail has a narrow white edging on each side.

Voice: Shrill, bickering calls; a sharp whit or whit-ker-whit.

Range: Sw. Canada to n. Mexico. Winters to Costa Rica. West: Map 255. Habitat: Farms, semi-open country, roadsides, wires.

CASSIN'S KINGBIRD Tyrannus vociferans

M254 $8-9^{\prime \prime}(20-23 \mathrm{~cm})$. Like the Western Kingbird but darker, with a darker olive-gray back; no distinct white sides on its black tail (which may be lightly tipped). Cassin's appears to have a whiter chin due to its darker chest.

Similar species: Some Western Kingbirds may lack white sides on the tail, but the paler olive-gray back and paler breast identify them. Cassin's prefers higher altitudes. Calls very different.

Voice: A low, nasal queer or chi-queer or ki-dear; also an excited ki-ki-ki-dear, ki-dear, ki-dear, etc.

Range: Western U.S. to s. Mexico, Guatemala. Map 254. Habitat: Semi-open high country, pine-oak mountains, ranch groves.

THICK-BILLED KINGBIRD Tyrannus crassirostris

$91 / 2 "(24 \mathrm{~cm})$. A large kingbird with an outsize bill; differs from similar kingbirds in having a dark cap and back and whitish underparts. However, autumn birds may be quite yellow below.

Voice: A quick, shrill brrr-zee or purr-eet.

Range: W. Mexico, w. Guatemala. West: Breeds locally in se. Arizona, sw. New Mexico. Casual in fall and winter in sw. Arizona, se. California. Accidental, British Columbia.

TROPICAL KINGBIRD Tyrannus melancholicus

$8-91 / 2^{\prime \prime}(20-24 \mathrm{~cm})$. Very similar to Western and Cassin's kingbirds, but tail notched and dusky brown, without white edgings. Back olive or olive-gray; head gray, with a dark mask through the eye; belly bright yellow. Little or no gray across the breast. Cassin's Kingbirds and also some Western Kingbirds in worn plumage lack white tail sides; but their tails are blacker, without the strong notch.

Voice: A nasal queer or chi-queer, resembling notes of Cassin's Kingbird.

Range: S. Arizona to Argentina. West: Breeds locally and irregularly in se. Arizona. Rare to casual vagrant elsewhere in Southwest and in fall, from coastal California north to British Columbia. Accidental, Alaska. Habitat: River groves, scattered trees. 


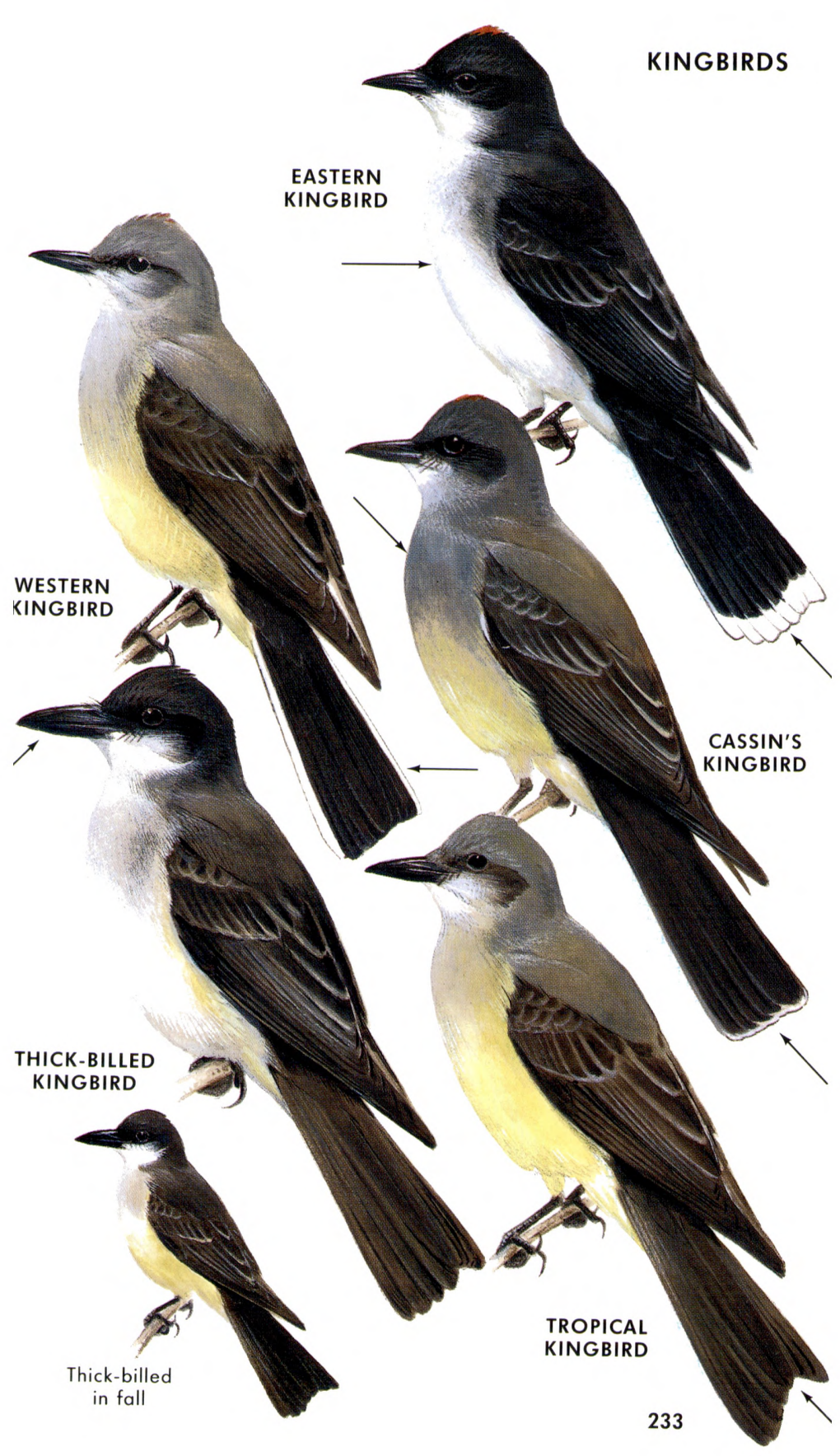


BROWN-CRESTED FLYCATCHER Myiarchus tyrannulus

(Wied's Crested Flycatcher) $81 / 2-91 / 2^{\prime \prime}(21-24 \mathrm{~cm})$. Similar to the Ash-throated Flycatcher, but larger, with a noticeably larger bill. Underparts more yellow; back more olive. Tail rusty, a bit less so than in Ash-throated. These are subtle differences; to tell the two apart it is well to have a good ear.

Voice: A sharp whit and a rolling, throaty purreeer. Voice much more vigorous and raucous than Ash-throated Flycatcher's.

Range: Sw. U.S. to Argentina. West: Breeds s.-cen. Arizona, sw. New Mexico. Casual, se. California, s. Nevada. Winters mostly south of U.S. Habitat: Sycamore canyons; in Arizona, saguaros.

GREAT CRESTED FLYCATCHER Myiarchus crinitus

M253

$8-9^{\prime \prime}(20-23 \mathrm{~cm})$. This kingbird-sized flycatcher with cinnamon wings and tail, very similar to the preceding species, is an eastern bird that normally occurs west of the 100th meridian only in the prairie states and provinces. Note the golden lower mandible.

Voice: A loud, whistled wheeep! Also a rolling prrrrrreet!

Range: S. Canada, e. and cen. U.S. Winters e. Mexico to Colombia. West: Map 253. Habitat: Woodlands, groves.

\section{DUSKY-CAPPED FLYCATCHER Myiarchus tuberculifer}

(Olivaceous Flycatcher) 61/2-7" $(16-18 \mathrm{~cm})$. Similar to the Ashthroated Flycatcher, but considerably smaller; throat a bit grayer, belly brighter yellow, and almost no rusty in the tail. Voice is distinctive.

Voice: A mournful, drawling whistle, slurring down, peeur.

Range: Breeds from mountains of se. Arizona, extreme sw. New Mexico to nw. Argentina. Winters south of U.S. Casual, w. Texas, Colorado, s. California, Nevada. Habitat: Oak slopes, pine-oak canyons, junipers.

ASH-THROATED FLYCATCHER Myiarchus cinerascens

M252

$8^{\prime \prime}(20 \mathrm{~cm})$. A medium-sized flycatcher, smaller than a kingbird, with two white wing bars, a whitish throat, a very pale yellowish belly, and a rufous tail. Head slightly bushy. Except for the prairie and sw. border area, this is the only flycatcher in the West with a rusty tail. Voice: Pwit; also a rolling chi-beer or prit-wheer.

Range: Western U.S. to s. Mexico. West: Map 252. Habitat: Semiarid country, deserts, brush, mesquite, pinyon, juniper, open woods.

SULPHUR-BELLIED FLYCATCHER Myiodynastes luteiventris

$71 / 2-81 / 2^{\prime \prime}(19-21 \mathrm{~cm})$. A large flycatcher with a bright rufous tail and a black patch through the eye; underparts pale yellowish, with black streaks. No other U.S. flycatcher is streaked above and below. Voice: A high, penetrating kee-zee'ick! kee-zee'ick!

Range: Sw. U.S. to Costa Rica. Winters sw. Amazonia, east of Andes. West: Breeds in canyons in s. Arizona. Casual, s. California, sw. New Mexico, w. Texas. Habitat: Sycamore-walnut canyons. 


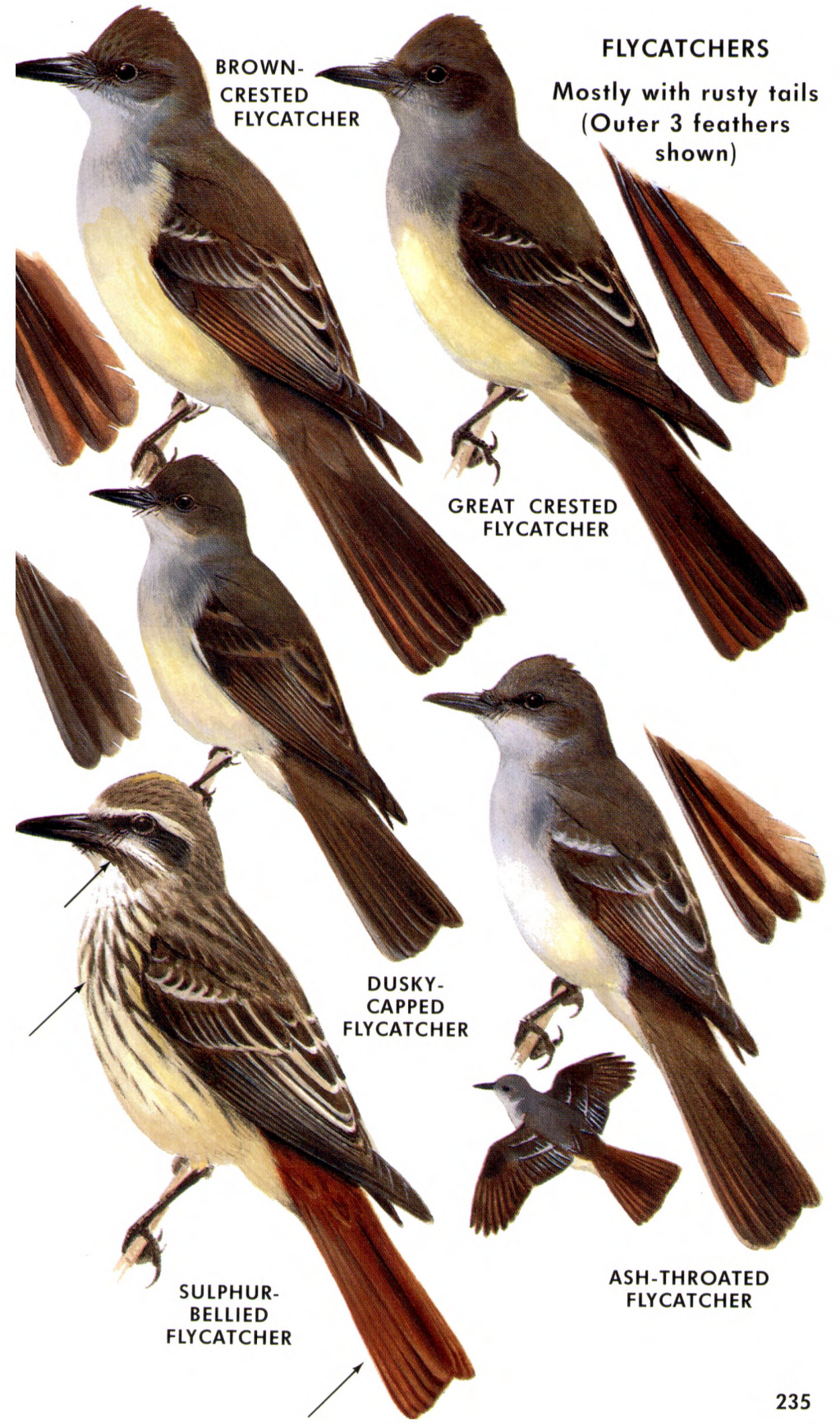


6-61/2" $(15-16 \mathrm{~cm})$. A dusky, sparrow-sized flycatcher with two narrow wing bars but no eye-ring. The slightly larger size and lack of an eye-ring distinguish it from the Empidonax flycatchers.

Voice: A nasal peeyee or peeeer.

Range: Breeds from cen. Alaska to Cen. America; winters from Panama to Peru. Map 240. Habitat: Woodlands, pine-oak forests, open conifers, river groves.

\section{EASTERN WOOD-PEWEE Contopus virens}

Very similar to Western Wood-Pewee; not as strongly olive-gray on breast and sides. Distinguished by voice and range.

Voice: A sweet, plaintive whistle: pee-a-wee, slurring down, then up. Also, pee-ur, slurring down. Very distinctive.

Range: S. Canada, e. U.S. Winters Cen. and S. America. West: Breeds west of $100^{\circ}$ only in the Edwards Plateau, Texas. Sparse migrant e. Colorado; casual west to Montana, Wyoming, Oregon, California.

EASTERN PHOEBE Sayornis phoebe

M249 61/2-7" $(16-18 \mathrm{~cm})$. Note the tail-bobbing. A gray-brown, sparrow-sized flycatcher without an eye-ring or strong wing bars (but may have dull ones, especially in yellowish-bellied young birds). Bill all black. Other small gray flycatchers have conspicuous wing bars.

Voice: Song, a well-enunciated phoe-be, or fi-bree (second note alternately higher or lower). Call note, a sharp chip.

Range: East of Rockies, Canada to s. U.S. Winters to s. Mexico. West: Map 249. Habitat: Streamsides, bridges, farms, roads.

GREATER PEWEE Contopus pertinax

(Coues' Flycatcher) 7-73/4" (18-19 cm). A large gray flycatcher of high mountains near Mexican border. Resembles Olive-sided Flycatcher, but breast more uniformly gray; no white strip down center.

Voice: A thin, plaintive whistle, ho-say, re-ah, or ho-say, ma-re-ah (nickname, "Jose Maria"). Note, pip-pip or pil-pil.

Range: Breeds from cen. and se. Arizona, sw. New Mexico to $\mathrm{n}$. Nicaragua. Winters south of U.S. Accidental, se. California, w. Texas.

Habitat: Pine and pine-oak forests of mountains, canyons.

OLIVE-SIDED FLYCATCHER Contopus cooperi

M239

$7-8 "(18-20 \mathrm{~cm})$. A stout, large-headed flycatcher; often perches at tips of dead trees. Note the large bill and dark chest patches separated by a narrow strip of white (like an unbuttoned vest). A cottony tuft may poke from behind the wing.

Voice: Note, a trebled pip-pip-pip. Song, a spirited whistle, I say' there; middle note highest, last one sliding.

Range: Alaska, Canada, w. and ne. U.S. Winters w. S. America. West: Map 239. Habitat: Conifer forests, burns, slashings. In California also in eucalyptus trees in foothill canyons.

BLACK PHOEBE Sayornis nigricans

M248

61/2-7" (16-18 cm). Our only black flycatcher; belly white. Has the typical phoebe tail- bobbing habit.

Voice: A thin, strident fi-bee, fi-bee; rising, then dropping.

Range: Sw. U.S. to n. Argentina. West: Map 248. Habitat: Shady streams, walled canyons, farmyards, towns; near water.

SAY'S PHOEBE See text on p. 238. 


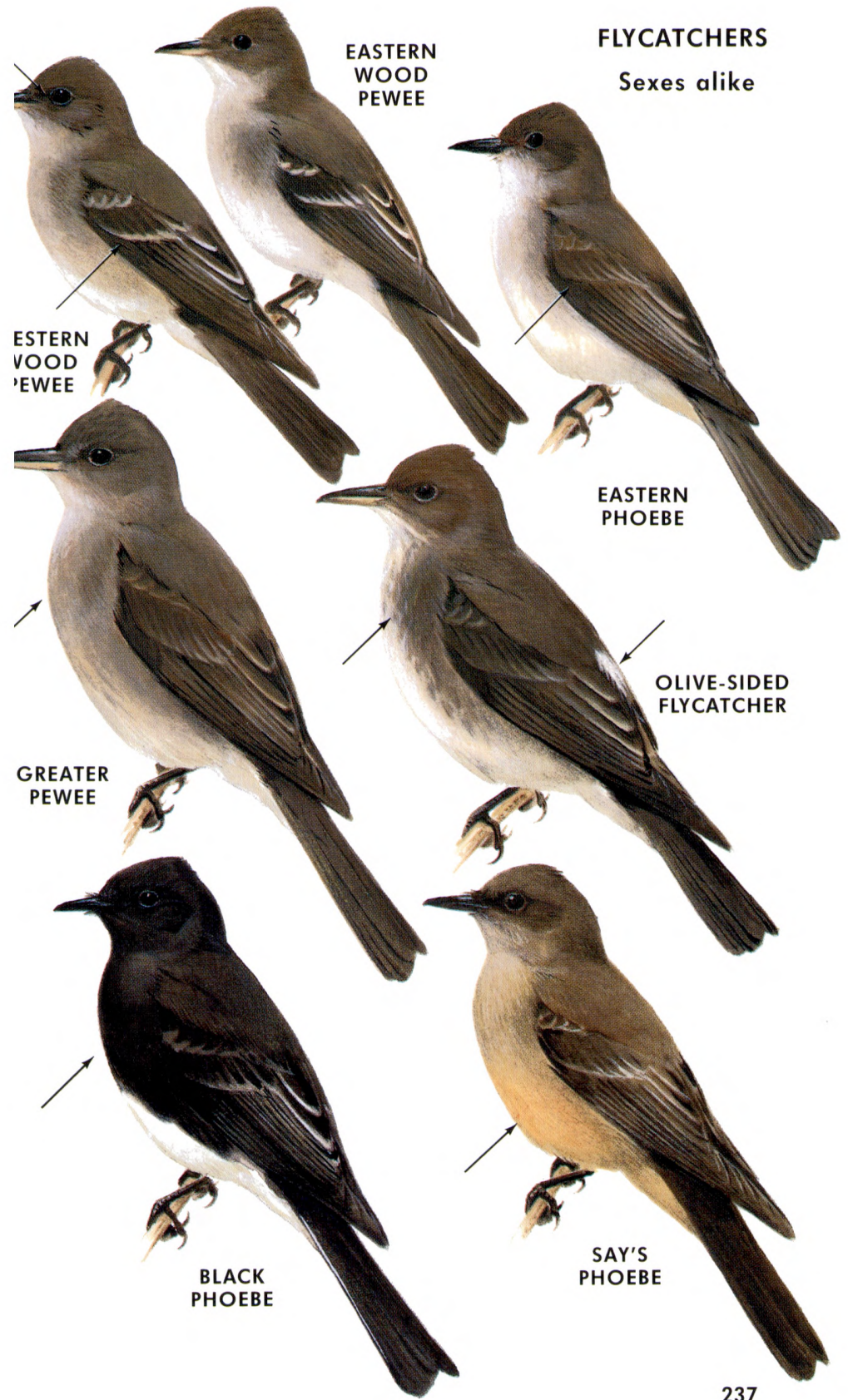


SAY'S PHOEBE Sayornis saya (illus., p. 237)

M250

$7-8$ " $(18-20 \mathrm{~cm})$. A gray-brown flycatcher with a black tail and pale rusty belly, giving it the look of a small Robin.

Voice: A plaintive, down-slurred pweer or pee-ee.

Range: Western N. America. Map 250. Habitat: Scrub, canyons, ranches.

- THE EMPIDONAX COMPLEX. Several small, drab flycatchers share the characters of light eye-ring and two pale wing bars. When breeding, these birds may be separated by voice, habitat, and manner of nesting. Listen to the recordings in A Field Guide to Western Bird Songs. See also A Field Guide to Western Birds' Nests by Hal Harrison. In migration these birds seldom sing or even call, so we are forced to let most of them go simply as "empids." If you wish the challenge of trying to name them in migration, study Kenn Kaufman's Field Guide to Advanced Birding, but first know each one well when it is on its nesting ground, singing and calling.

ALDER FLYCATCHER Empidonax alnorum

M242

$53 / 4^{\prime \prime}(15 \mathrm{~cm})$. Alder and Willow flycatchers, formerly lumped as Traill's, are now regarded as two species. They are almost identical, with little or no eye-ring. Alder is a shade more olive; Willow is slightly darker and browner. They are safely separated only by voice.

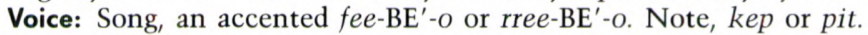
Range: Alaska, Canada, ne. U.S. Winters in South America. West: Map 242. Habitat: Willows, alders, brushy swamps, swales.

WILLOW FLYCATCHER Empidonax traillii

M243

$53 / 4^{\prime \prime}(15 \mathrm{~cm})$. Safely separated from the Alder Flycatcher (with which it was formerly lumped) only by voice and to some extent by breeding habitat. The eye-ring is very narrow or absent.

Voice: Song, a sneezy fitz-bew. Note, whit or weet.

Range: Alaska, Canada to sw. and e.-cen. U.S. Winters s. Mexico to Panama. West: Map 243. Habitat: Somewhat like Alder's (willow thickets, etc.); often in drier situations; more southern.

HAMMOND'S FLYCATCHER Empidonax hammondii

M245

$51 / 2^{\prime \prime}(14 \mathrm{~cm})$. Both Hammond's and Dusky breed in the transition and Canadian zones of the mountains. Hammond's ranges further north and lives at higher altitudes in taller firs, while Dusky prefers chaparral or a mixture of chaparral and conifers. Hammond's is more olive; underparts more yellowish, with a grayer chest. The lower mandible of its smallish bill is mostly dark.

Voice: An abrupt tse-beek. Note, a sharp thin pik, or peek.

Range: E.-cen. Alaska, w. Canada, w. U.S. Winters se. Arizona to Nicaragua. West: Map 245. Habitat: High conifer forests; in migration through lowlands, other trees, thickets.

DUSKY FLYCATCHER Empidonax oberholseri

M246

$53 / 4^{\prime \prime}(15 \mathrm{~cm})$. Very similar to Hammond's Flycatcher (gray throat, etc.), but identified by habitat, voice, white outer tail feathers.

Voice: Three-parted song ends in a high preet. Note, a dry whit.

Range: W. Canada, w. U.S. Winters in Mexico. West: Map 246. Habitat: Breeds in mountain chaparral (Canadian-zone brush) with scattering of trees. Also open conifers in mountains of s. California.

GRAY FLYCATCHER (Text on p. 240.) 


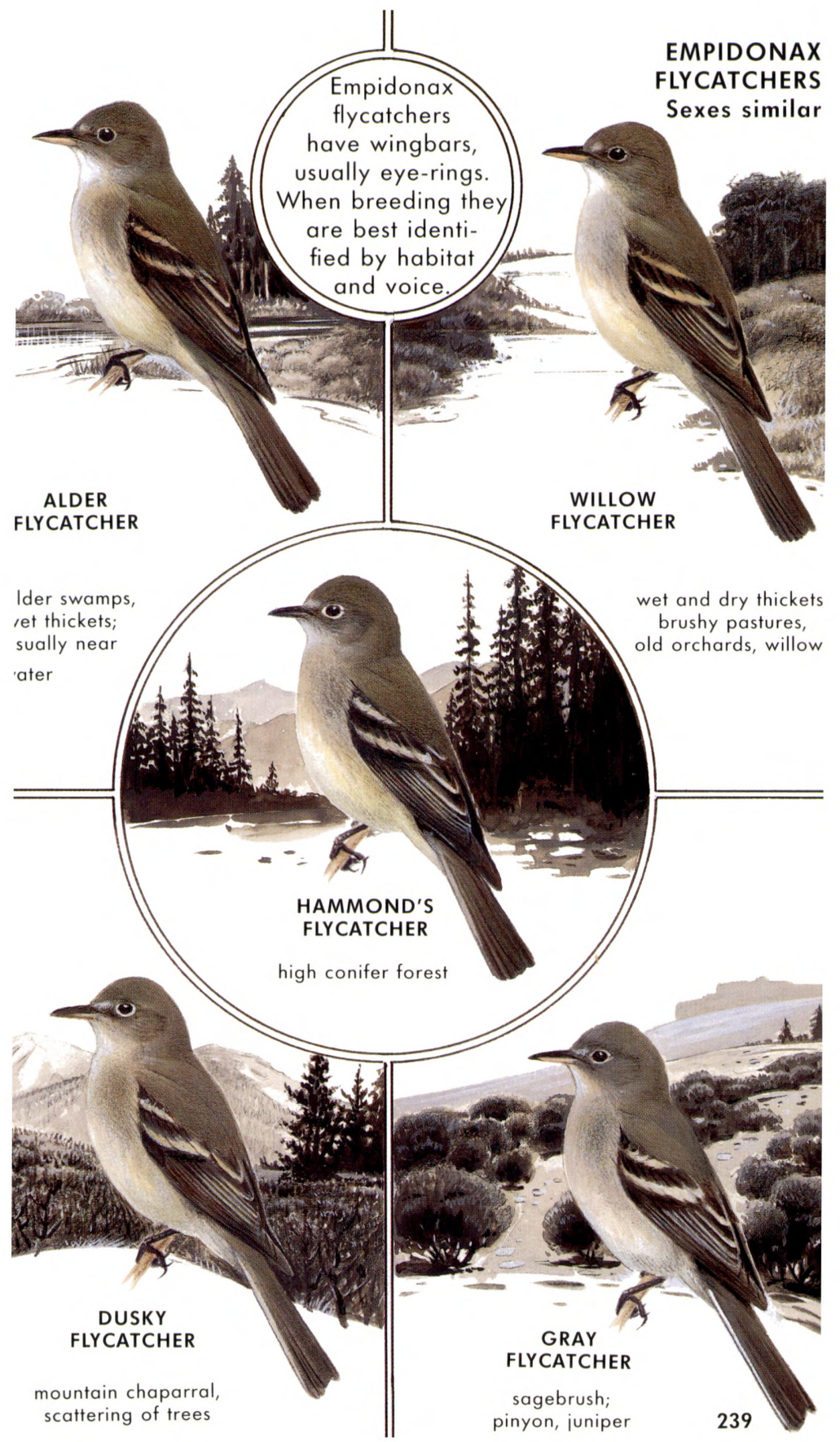


6" $(15 \mathrm{~cm})$. Similar to Dusky or Hammond's, but tentatively identified if the lower mandible is mostly flesh-colored, and if the back is grayer and the underparts whiter with no trace of yellow except in fall. It has a habit of dipping its tail like a phoebe lother empids may flick their tails). Best identified by breeding habitat and voice. Voice: A two-syllabled chewip or cheh-we. Note a dry whit.

Range: Western U.S.; winters to s. Mexico. Map 183. Habitat: Sagebrush; also pinyon and juniper. In winter, willows, brush.

YELLOW-BELLIED FLYCATCHER Empidonax flaviventris

M241

$51 / 2^{\prime \prime}(14 \mathrm{~cm})$. Yellowish underparts (including throat) separate this Canadian species from all other empids except the "Westerns," which have a different range. Other empids may have a tinge of yellow, especially in fall. Eye-ring may be yellowish in this species. Voice: Song, a simple chi-lek; also a rising per-ee.

Range: Canada, ne. U.S. Winters Mexico to Panama. West: Map 241. Habitat: Boreal forests, muskegs, bogs.

LEAST FLYCATCHER Empidonax minimus

M244

$51 / 4^{\prime \prime}(13 \mathrm{~cm})$. An eastern species ranging to the northwest (east of the Rockies). Smaller and grayer than others in its range; whiter below, with a white throat. Actively flicks its wings and tail. Range, habitat, voice, and nest (on a horizontal branch) identify it.

Voice: An emphatic, sharply snapped che-bek'! Note, a dry whit. Range: Canada, n. U.S., east of Rockies. Winters Mexico to Panama. West: Map 244. Habitat: Orchards, groves, poplars, aspens.

"WESTERN" FLYCATCHER Empidonax (two species)

M247

$53 / 4^{\prime \prime}(15 \mathrm{~cm})$. This, the most widely encountered type of empid in the West, has yellowish underparts, including the throat. Others in its range may have a wash of yellow, especially in fall, but their throats are gray or whitish. Eye-ring tends to be tear-shaped. Now split by the A.O.U. into two species, separated by range and call notes of males: PACIFIC-SLOPE FLYCATCHER, E. difficilis - lan upslurred tseep), and CORDILLERAN FLYCATCHER, E. occidentalis, of the Rocky Mt. region - (a two-noted pit-weet). Song of both birds a thin, squeaky pseet-trip-seet!; variable.

Range: Se. Alaska, w. Canada to Honduras. Map 247. Habitat: Moist woods, mixed or conifer forests, shady canyons, groves.

BUFF-BREASTED FLYCATCHER Empidonax fulvifrons

$4 \frac{1}{2}-5^{\prime \prime}(11-13 \mathrm{~cm})$. Easily distinguished from the other more confusing empids by its small size and rich buffy breast.

Voice: An accented chee-lik. Note, a dry pit or whit.

Range: Cen. and se. Arizona, cen.-w. New Mexico to Honduras. Winters from Sonora south. Habitat: Canyons, oak-pines.

NORTHERN BEARDLESS-TYRANNULET Camptostoma imberbe

(Beardless Flycatcher) 41/4" $(11 \mathrm{~cm})$. A very small, nondescript flycatcher that may suggest a kinglet, Bell's Vireo, or immature Verdin. Dull brown wing bars and indistinct eye-ring. Distinguished from "empids" by its smaller size, head, and bill; also by its behavior.

Voice: A thin peeee-yuk. A gentle ee, ee, ee, ee, ee.

Range: Resident from se. Arizona, sw. New Mexico, s. Texas to Costa Rica. Habitat: Low woods, mesquite, stream thickets, lower canyons. Builds a globular nest with entrance on side. 


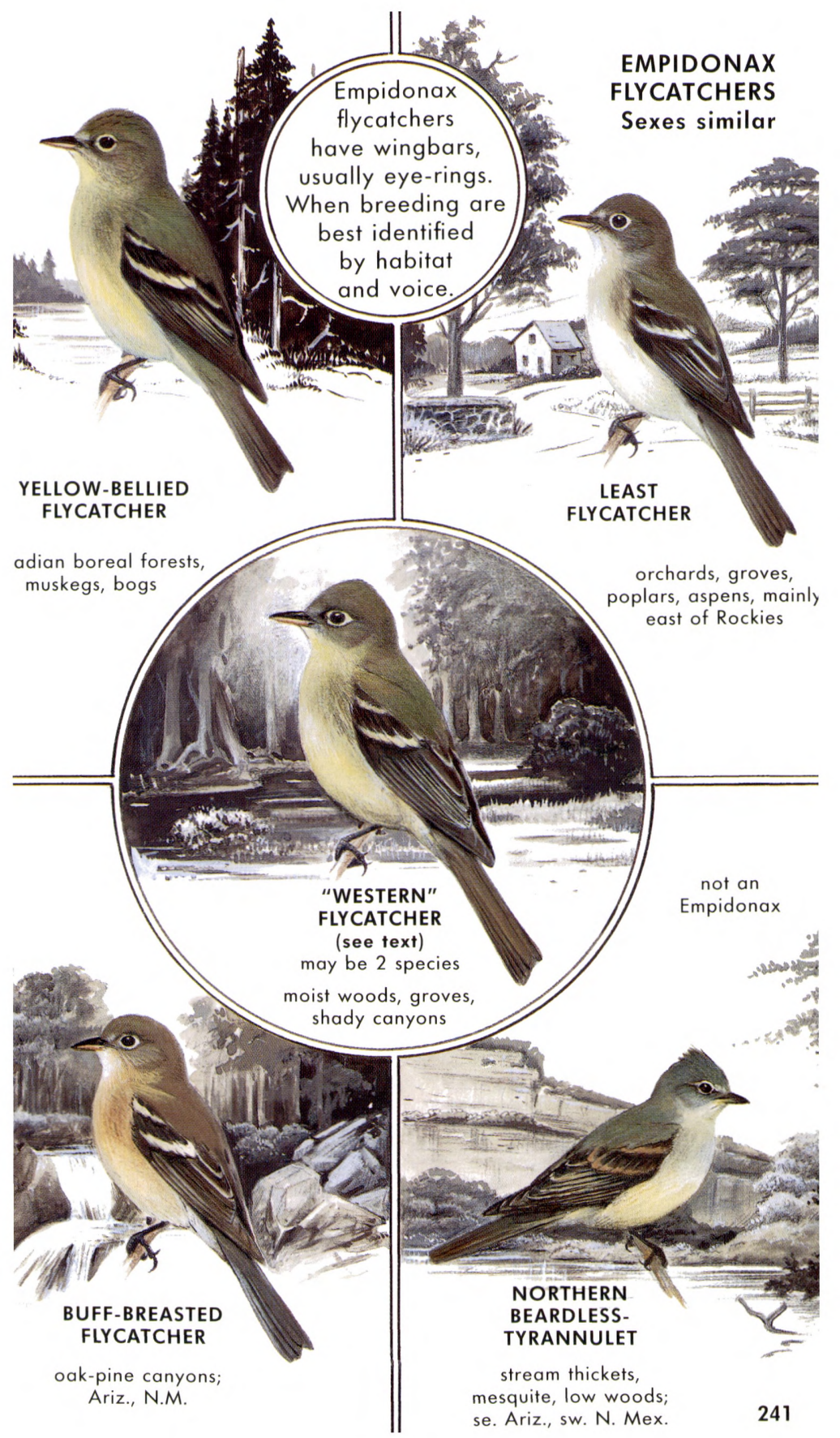


- LARKS. Family Alaudidae. Streaked, brown, terrestrial birds with long hind claws. Gregarious. Larks often sing in high display flight. Food: Seeds, insects. Range: Mainly Old World. No. of species: World 78; West 1 ( +1 introduced).

HORNED LARK Eremophila alpestris

M258

7-8" (18-20 cm). A brown ground bird, with black sideburns, two small black horns, and a black breast splotch. Walks, does not hop. Overhead, pale with a black tail; folds wings after each beat. Female and immature duller. Varies from paler to darker races.

Voice: Song, tinkling, irregular, high-pitched, often prolonged; from ground or high in air. Note, a clear tsee-titi.

Range: Widespread in N. Hemisphere. West: Map 258. Habitat: Prairies, fields, golf courses, airports, shores, tundra.

SKYLARK Alauda arvensis

7-71/2" $(18-19 \mathrm{~cm})$. Slightly larger than a sparrow; brown, strongly streaked; underparts buff-white; breast streaked. Tail has conspicuous white on outer feathers. Short, rounded crest.

Voice: Note, a clear, liquid chir-r-up. Song, in hovering flight, highpitched, with long-sustained runs and trills.

Range: Eurasia, n. Africa. West: Rare spring migrant outer Aleutian Is., Pribilofs. Resident, s. Vancouver I., where introduced. Accidental California. Habitat: Open country, fields.

- WAGTAILS. Family Motacillidae (in part). Old World relatives of pipit (see pp. 224, 245). Strong patterns; slender tails are wagged.

YELLOW WAGTAIL Motacilla flava

$6 \frac{1}{2} "(16 \mathrm{~cm})$. Very slender, long legs; yellow below. Long tail is black with white sides; constantly wagged. Immature: Whitish below; throat outlined in black. Flight undulating.

Voice: A loud, musical tsoueep. Song, tsip-tsip-tsipsi.

Range: Eurasia, w. Alaska. In winter to Africa, India. West: Breeds across n. Alaska to n. Yukon; south through w. Alaska to Nunivak. Habitat: Willow scrub on tundra, marshy country.

BLACK-BACKED WAGTAIL Motacilla lugens

71/4" $(18 \mathrm{~cm})$. Similar to the White Wagtail, but in breeding plumage has a black back, more white in wings. Winter adult and immature: Grayer back, white chest, black necklace; similar to next species.

Range: Ne. Asia. West: Rare but regular in spring in outer Aleutians (has bred), Nome. Casual or accidental along coast to California.

WHITE WAGTAIL Motacilla alba

7" (18 cm). Black and white, with a black chest, throat, and nape; pale gray back. Immature much like Black-backed Wagtail.

Voice: A lively tchizzik. Also an abrupt tchik.

Range: Eurasia. West: Breeds locally in w. Alaska, usually around stone buildings. Habitat: Open country.

GRAY WAGTAIL Motacilla cinerea

7" $(18 \mathrm{~cm})$. In spring, combination of black throat, yellow underparts, and gray back identify this wagtail. Females and winter birds have a whitish throat and are paler below. Wing stripe in flight.

Range: Eurasia. West: Spring visitor in outer Aleutians; casual, Pribilofs, St. Lawrence I. Habitat: Pebbly streams. 

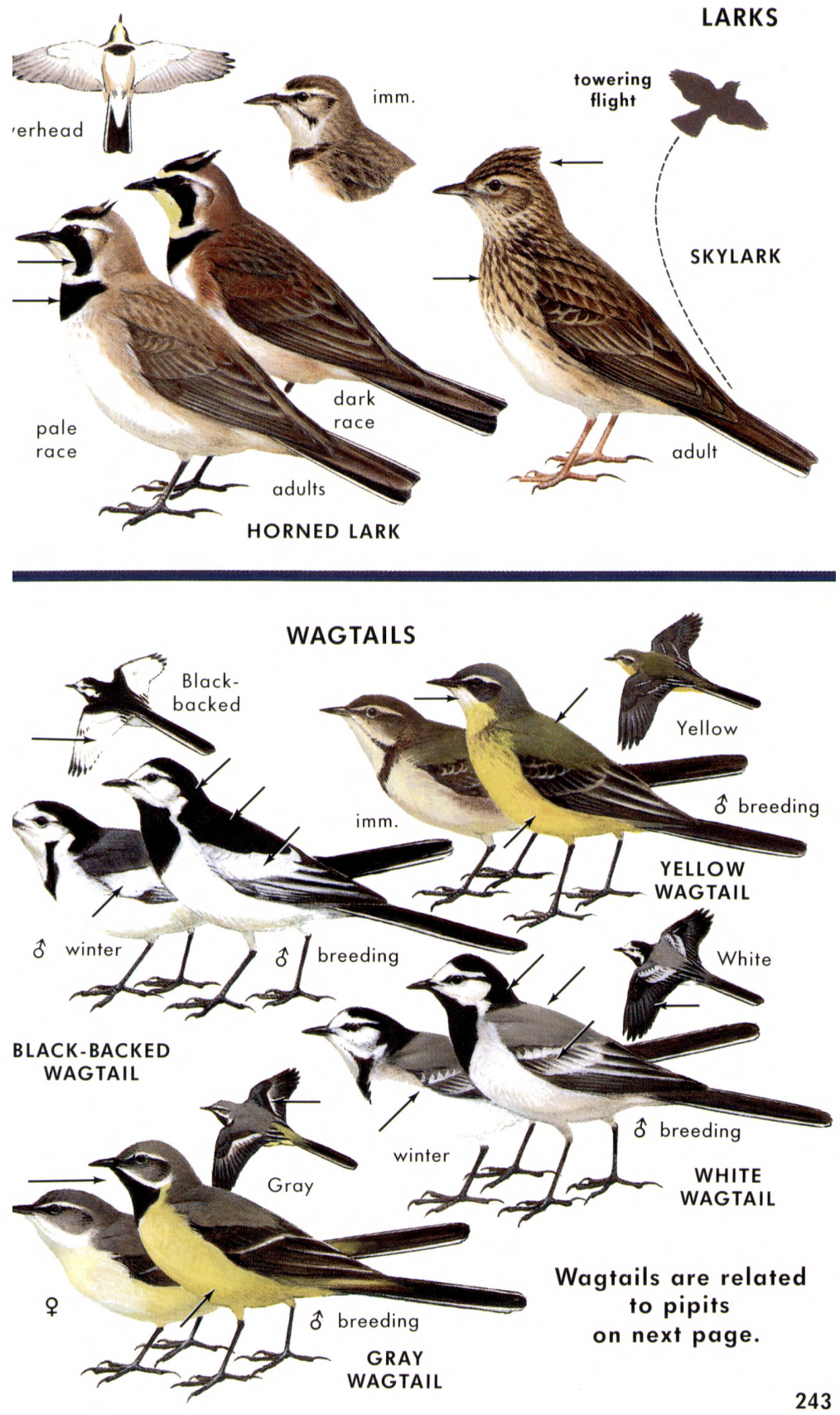
- PIPITS. Family Motacillidae (in part). Streaked brown ground birds with white outer tail feathers, long hind claws, thin bills. They walk briskly instead of hopping and constantly bob their tails. Food: Insects, seeds. Range: Nearly cosmopolitan. No. of pipits in family: World 35; West 3 (+3 casual or accidental).

AMERICAN PIPIT Anthus rubescens

M320

(Water Pipit) 6-7" (15-18 cm). A slender, brown, sparrow-sized bird of open country. Bill slender; underparts buffy with streaks; outer tail feathers white; legs black. Walks, bobbing its tail almost constantly. In flight, dips up and down. Learn the note-Pipits are usually detected as they fly over.

Voice: Note, a thin jeet or jee-eet. In aerial flapping song flight, chwee chwee chwee chwee chwee chwee chwee.

Range: Colder parts of N. Hemisphere. Winters to El Salvador, n. Africa, s. Asia. West: Map 320. Habitat: Tundra, alpine slopes; in migration and winter, plains, bare fields, shores.

SPRAGUE'S PIPIT Anthus spragueii

M321

$6 \frac{1}{2} "(16 \mathrm{~cm})$. Note the pale flesh or yellowish legs. Buffy, with a striped back and white outer tail feathers. Suggests Vesper Sparrow or longspur, but with a thin bill. Back streaked buff and black, cheeks buffy. More solitary than the American Pipit; when flushed, often towers high, then drops.

Similar species: American Pipit has a darker (not strongly striped) back, deeper buff breast, darker cheek, dark legs.

Voice: Sings high in the air; a sweet, thin jingling series, descending in pitch: shing-a-ring-a-ring-a-ring-a (Salt, Wilk).

Range: Prairie provinces of Canada, northern prairie states. West: Map 321. Habitat: Plains, shortgrass prairies.

RED-THROATED PIPIT Anthus cervinus

6" $(15 \mathrm{~cm})$. Male in breeding plumage has a rusty red face and breast, less extensive in females and fall males. In fall, females and immature are heavily striped; may resemble Pechora Pipit.

Voice: Call notes, a hoarse tzeez, and a soft tau.

Range: This basically Eurasian species breeds commonly on the mainland of nw. Alaska. Regular spring migrant, w. Aleutians (Attu, etc.); rare fall migrant through s. California.

PECHORA PIPIT Anthus gustavi

6" $(15 \mathrm{~cm})$. A dark, heavily streaked pipit with pink legs; two pale streaks on the back; buffy outer tail feathers (not white as in Red-throated). Call, a hard pwit, repeated. This Asian stray has been recorded in the outer Aleutians (Attu) and on St. Lawrence I. (Gambell).

OLIVE-BACKED PIPIT Anthus hodgsoni

$6 \frac{1}{2} "(16 \mathrm{~cm})$. Similar to the American Pipit, but legs pinkish. Olive-gray back. Note the strong face pattern; the key mark is a white spot behind the dark ear patch. Call, a loud tseet. This Asian stray is a rare visitor to the outer Aleutians and should be looked for elsewhere in the Bering Sea area.

TREE-PIPIT Anthus trivialis (not shown)

This Eurasian species has been collected once in nw. Alaska. See A Field Guide to the Birds of Britain and Europe. 
- SWIFTS. Family Apodidae. Swallow-like, but structurally distinct, with a flat skull and all four toes pointing forward. Flight very rapid, "twinkling," sailing between spurts; narrow wings often stiffly bowed. Food: Flying insects. Range: Nearly worldwide. No. of species: World 73; West $4(+3$ accidental).

$4 \frac{1}{2 \prime} 2^{\prime \prime}(11 \mathrm{~cm})$. A small, dark, swallow-like bird with no apparent tail (unless spread); "like a cigar with wings." It appears to beat its wings alternately (actually an illusion), unlike the skimming of swallows. It may glide between spurts, the wings bowed in a crescent. The twinkling flight style marks it as a swift; the range, small size, and dingy underparts as this species.

Voice: Loud, rapid, ticking or chippering notes.

Range: Western N. America to Venezuela. Map 213. Habitat: Open sky over woodlands, lakes, and rivers.

CHIMNEY SWIFT Chaetura pelagica

M213

$5-51 / 2^{\prime \prime}(13-14 \mathrm{~cm})$. Larger than Vaux's Swift; darker, especially on underparts and throat. Any small dark swift east of the Rockies would almost certainly be this species.

Range: Eastern N. America. Winters in Peru. West: Map 213. Habitat: Open sky, especially over cities, towns; nests in chimneys.

BLACK SWIFT Cypseloides niger

M212

$7-71 / 2^{\prime \prime}(18-19 \mathrm{~cm})$. A large black swift with a notched tail (sometimes fanned). At close range, a touch of white on the forehead. Flight more leisurely than that of other U.S. swifts.

Voice: A sharp plik-plik-plik-plik-plik, etc. (H. Cogswell).

Range: Se. Alaska to Costa Rica; W. Indies. West: Map 212. Habitat: Open sky; favors mountain country, coastal cliffs; nests in sea cliffs or wet mountain cliffs, often behind waterfalls.

WHITE-THROATED SWIFT Aeronautes saxatalis

M214

6-7" $(15-18 \mathrm{~cm})$. Known from other N. American swifts by its contrasting black and white pattern. Underparts white, with black side patches.

Voice: A shrill, excited jejejejejeje, in descending scale.

Range: From s. British Columbia and w. U.S. to Honduras. West: Map 214. Habitat: Open sky; cruising widely. Breeds mainly in dry mountains, canyons; locally on sea cliffs (California).

COMMON SWIFT Apus apus

$61 / 2^{\prime \prime}(16 \mathrm{~cm})$. This Eurasian swift, recorded as an accidental in the Pribilofs, is entirely blackish except for its white chin. Tail deeply forked. It lacks the white rump patch of the Fork-tailed Swift, another stray from Asia.

FORK-TAILED SWIFT Apus pacificus

$71 / 4^{\prime \prime}(18 \mathrm{~cm})$. A large dark swift with a white throat and deeply forked tail. Shows a white rump (see House Martin, p. 352). Breeds e. Asia; straggler in outer Aleutians and Pribilofs.

WHITE-THROATED NEEDLETAIL Hirundapus caudacutus

$8^{\prime \prime}(21 \mathrm{~cm})$. A very large, dark swift with a broad, white $U$ or $V$ on the undertail coverts. Tail square (not forked); throat white. A pale patch on lower back. Casual in outer Aleutians (Attu, Shemya). 
- SWALLOWS. Family Hirundinidae. Slim, streamlined form and graceful flight characterize these sparrow-sized birds. Long, pointed wings; short bills with very wide gapes; tiny feet. Food: Mostly flying insects. Range: Cosmopolitan except for polar regions, some islands. No. of species: World 81 ; West $8(+1$ accidental).

\section{TREE SWALLOW Tachycineta bicolor}

M260

5-6" (13-15 cm). Steely blue-green-black above, white below. Immature has a dusky brown back and pale smudge across the breast; may be confused with the Rough-winged Swallow (dingy throat) or Bank Swallow (dark breastband). Tree Swallow glides in circles, ending glides with quick flaps and a short climb.

Voice: Cheet or chi-veet; a liquid twitter, weet, trit, weet, etc.

Range: Alaska, Canada to California, cen.-e. U.S. Winters s. U.S. to n. S. America. West: Map 260. Habitat: Open country near water, marshes, meadows, streams, lakes, wires. Roosts in reeds. Nests in holes in trees, birdhouses.

BANK SWALLOW Riparia riparia

M263

41/2-51/2" (11-14 cm). A small, brown-backed swallow. Note the distinct dark breastband. Flight irregular, fluttery.

Voice: A dry, trilled chitter or rattle, brrt or trr-tri-tri.

Range: Widespread in N. Hemisphere. Winters in S. America, Arica, s. Asia. West: Map 263. Habitat: Near water; fields, marshes, streams, lakes. Nests colonially in sand banks.

\section{NORTHERN ROUGH-WINGED SWALLOW}

M262

Stelgidopteryx serripennis

5-53/4" (13-14 cm). Brown-backed; lighter brown than Bank Swallow; throat dusky; no breastband. Flight more like Barn Swallow's; wings pulled back at end of stroke.

Voice: A harsh trrit, rougher than Bank Swallow's.

Range: S. Canada to Costa Rica. Winters Gulf Coast to Panama. West: Map 262. Habitat: Near streams, lakes, river banks. Nests in banks, but not colonially as in Bank Swallow.

VIOLET-GREEN SWALLOW Tachycineta thalassina

M261

$5-5 \frac{1}{2} "(13-14 \mathrm{~cm})$. Note the white patches that almost meet over the base of the tail. Dark and shiny above-adults glossed with green and purple; clear white below. Separated from the Tree Swallow by its greener back and white patches on the sides of its rump. The white of the face partially encircles the eye.

Voice: A twitter; a thin chip; rapid chit-chit-chit wheet, wheet.

Range: Breeds from cen. Alaska, w. Canada, south locally to mountains of Mexico. Winters California, Mexico, Cen. America. West: Map 261. Habitat: Widespread when foraging; nests in holes in trees in open forests, foothill woods, mountains, canyons, cliffs, towns.

CAVE SWALLOW Petrochelidon fulva

5-6" (13-15 cm). Similar to the Cliff Swallow (rusty rump), but face colors reversed; throat and cheeks pale or buffy (not dark), forehead dark chestnut (not pale).

Similar species: Locally, in w. Texas and se. Arizona, a race of the Cliff Swallow occurs in which young birds may be dark on both the forehead and throat.

(continued on p. 250) 
CAVE SWALLOW (continued). See illustration on p. 249.

Voice: A clear weet or cheweet; a loud, accented chu, chu.

Range: S. New Mexico, s.-cen. Texas, Mexico, W. Indies, to Peru. Nests in colonies in limestone caves in se. New Mexico and along s. edge of Edwards Plateau, Texas. Often builds its cuplike nests under bridges. Rapidly expanding range. Accidental, s. Arizona.

\section{PURPLE MARTIN Progne subis}

M259

$7 \frac{1}{2}-81 \frac{1}{2} "(19-21 \mathrm{~cm})$. The largest North American swallow. Male: Uniformly blue-black above and below; no other swallow is dark-bellied. Female: Light-bellied; throat and breast grayish, often with a faint collar. Glides in circles, alternating quick flaps and glides; often spreads its tail. Similar species: Tree Swallow is much smaller than female Purple Martin; immaculate white, no gray on underparts.

Voice: A throaty and rich tchew-wew, etc., or pew, pew. Song gurgling, ending in a succession of rich, low gutturals.

Range: S. Canada to n. Mexico, Gulf states. Winters S. America. West: Map 259. Habitat: Towns, farms, open or semi-open country near water. Attracted to martin houses. In s. Arizona, it nests in saguaros. Local and declining.

\section{CLIFF SWALLOW Petrochelidon pyrrhonota}

5-6" $(13-15 \mathrm{~cm})$. Note the rusty or buffy rump. Overhead, appears square-tailed, with a dark throat patch. Glides in a long ellipse, ending each glide with a roller-coaster-like climb.

Voice: Zaryp; a low chur. Alarm note, keer! Song, creaking notes and guttural gratings; harsher than Barn Swallow's song.

Range: Alaska, Canada to Mexico. Winters s. Brazil to cen. Argentina. West: Map 264. Habitat: Open to semi-open land, farms, cliffs, river bluffs, lakes. Nests colonially on cliffs, barns. When nesting on a barn, the Cliff Swallow is colonial, building "mud jugs" outside, under the eaves. Barn Swallow builds a cuplike open nest, usually but not always inside the barn.

\section{BARN SWALLOW Hirundo rustica}

M265

$6-73 / 4^{\prime \prime}(15-19 \mathrm{~cm})$. Our only swallow that is truly swallow-tailed; also the only one with white tail spots. Blue-black above; cinnamon-buff below, with a darker throat. Juvenile is whitish below. Flight direct, close to the ground; wing tips pulled back at the end of the stroke; not much gliding.

Similar species: Most other N. American swallows have notched (not deeply forked) tails. (1) Cliff Swallow is colonial, building mud jugs under eaves or cliffs. (2) See Cave Swallow.

Voice: A soft vit or kvik-kvik, vit-vit. Also szee-szah or szee. Anxiety note, a harsh, irritated ee-tee or keet. Song, a long musical twitter interspersed with gutturals.

Range: Widespread in N. Hemisphere. Winters Costa Rica to Argentina, Africa, s. Asia. West: Map 265. Habitat: Open or semi-open land; farms, fields, marshes, lakes; often perches on wires; usually near habitation. Builds its cuplike nest inside barns, not in tight colonies under eaves, like Cliff Swallow. 


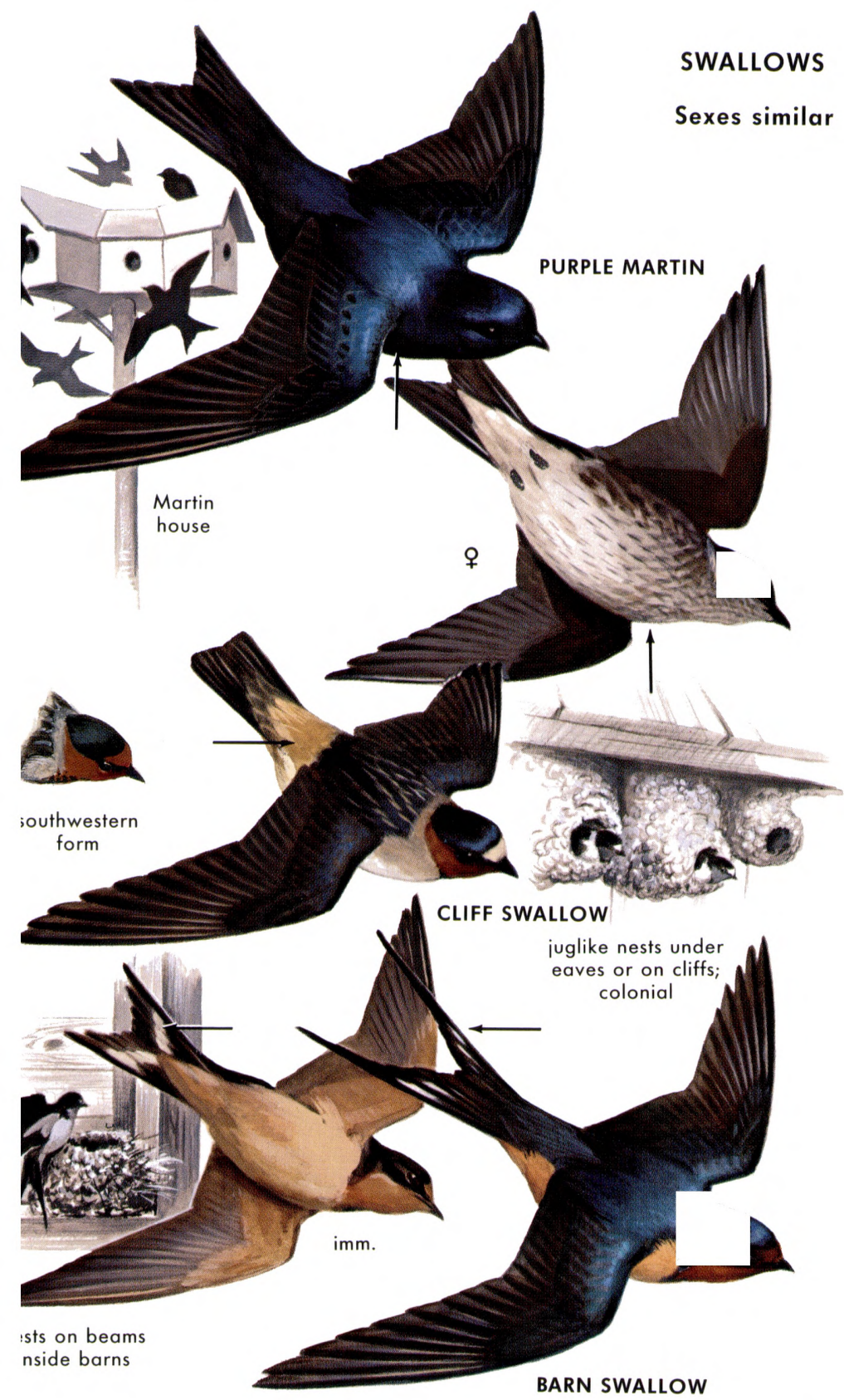


- CROWS, JAYS, etc. Family Corvidae. Large perching birds with strong, longish bills; nostrils covered by forward-pointing bristles. Crows and ravens are very large and black. Jays (pp. 254257) are often colorful (usually blue). Magpies are black and white, with long tails. Sexes alike. Most immatures (not all) resemble adults. Food: Almost anything edible. Range: Worldwide except s. S. America, some islands, Antarctica. No. of species: World 110; West $14(+1$ accidental $)$.

AMERICAN CROW Corvus brachyrhynchos

M274

(Common Crow) 17-21" (43-53 cm). A large, chunky, ebony bird. Completely black; glossed with purplish in strong sunlight. Bill and feet strong and black. Often gregarious.

Similar species: (1) Common Raven is larger, has a wedge-shaped tail. See (2) Chihuahuan Raven and (3) Northwestern Crow.

Voice: A loud caw, caw, caw or cah or kahr; easily imitated.

Range: Canada to s. U.S., n. Baja California. West: Map 274. Habitat: Woodlands, farms, fields, river groves, shores, towns, dumps.

NORTHWESTERN CROW Corvus caurinus

M275

16-17" $(40-43 \mathrm{~cm})$. This small beachcombing crow of the Northwest is smaller than the American Crow and has a quicker wingbeat. It replaces the American Crow on the narrow northwestern coast strip. There is apparently some integration with the American Crow in the Puget Sound area, hence some believe they may be conspecific.

Voice: khaaa or khaaw. Usually more resonant than Common Crow's caw. Also, cowp-cowp-cowp.

Range: Northwest coast. Map 275. Habitat: Near tidewater, shores.

CHIHUAHUAN RAVEN Corvus cryptoleucus

M276

(White-necked Raven). 19-21" $(48-53 \mathrm{~cm})$. Near the size of the American Crow; a small raven of the arid plains. Flies with the typical flat-winged glide of a raven; has a somewhat wedge-shaped tail. White feather bases on the neck and breast sometimes show when the feathers are ruffled by the wind, hence the former name "White-necked Raven."

Voice: A hoarse kraak, flatter and higher than Common Raven's. Range: Sw. U.S. to cen. Mexico. West: Map 276. Habitat: Arid and semi-arid scrub and grassland, desert, yucca, mesquite.

COMMON RAVEN Corvus corax

M277

$22-27^{\prime \prime}(55-68 \mathrm{~cm})$. Note the wedge-shaped tail. Much larger than American Crow; has a heavier voice and is inclined to be not as gregarious, often solitary. Hawklike in flight, it alternates flapping and sailing, gliding on flat wings (Crow glides with a slight upward dihedral). When it is perched and not too distant, note the "goiter" look created by the shaggy throat feathers and the heavier "Romannose" bill.

Voice: A croaking cr-r-ruck or prruk; also a metallic tok.

Range: Widespread in N. America, Eurasia, Africa. West: Map 277. Habitat: Boreal and mountain forests, coastal cliffs, tundra. 


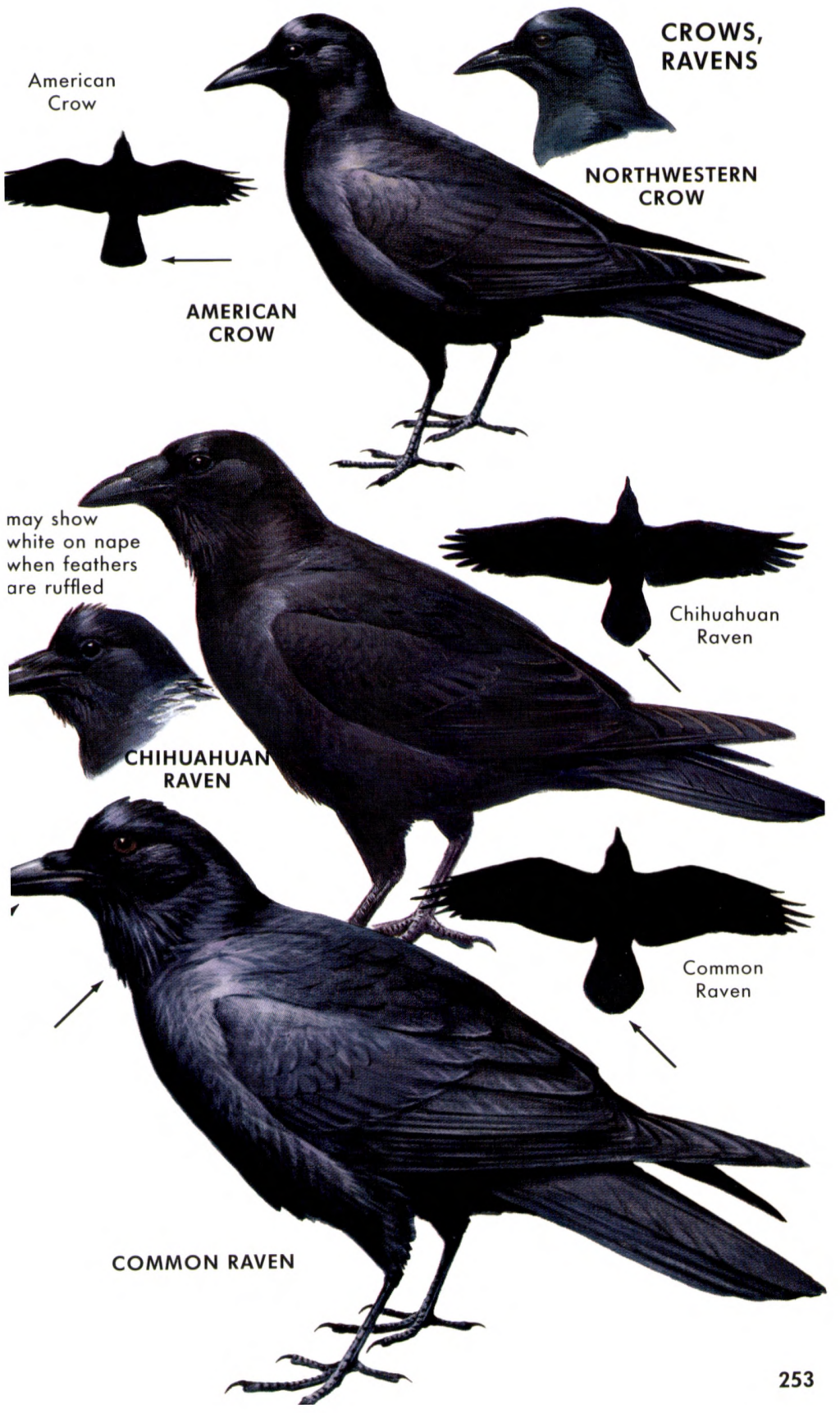


11-13" (28-33 cm). Look for this crestless jay in the oaks. Head, wings, and tail are blue; back pale brownish; white throat with necklace. Near Mexican border, see next species.

Voice: A rough, rasping kwesh ... kwesh. Also a harsh check-checkcheck-check and a rasping zhreek, zhreek.

Range: S. coastal Washington south through California east to Colorado and New Mexico. West: Map 269. Habitat: Foothills, oaks, oak-chaparral, brush, river woods, pinyon, junipers, some suburbs.

MEXICAN JAY Aphelocoma ultramarina

M270

$11^{1 / 2-13 "}(29-33 \mathrm{~cm})$. A blue jay without a crest. Resembles the Scrub Jay, but upperparts and underparts more uniform; back and breast grayer. No strong contrast between throat and breast (as in Scrub Jay, which has a whiter throat and necklace). Also lacks narrow whitish line over eye. In Arizona, juveniles may have yellow bills. Voice very different.

Voice: A rough, querulous wink? wink? or zhenk?

Range: Sw. U.S. to cen. Mexico. Map 270. Habitat: Open oak forests (Arizona); oak-pine woods (w. Texas).

BLUE JAY Cyanocitta cristata

M268

$11-12^{1 / 2}=(28-31 \mathrm{~cm})$. This showy, noisy, crested jay, widespread east of the Rockies (but expanding northwestward), is readily known from Steller's Jay by the white spots in wings and tail, the whitish or dull gray underparts, and the black necklace. Except for Steller's, other western jays lack crests. Has hybridized with Steller's Jay.

Voice: A harsh, slurring jeeah or jay; a musical queedle, queedle; also many other notes. Often mimics cry of Red-tailed Hawk.

Range: S. Canada, mainly east of Rockies to Gulf states. West: Map 268. Habitat: Oak and pine woods, suburban gardens, groves, towns.

STELLER'S JAY Cyanocitta stelleri

M267

12-131/2" (30-34 cm). A large, dark, black and blue bird with a long crest. Foreparts blackish; rear parts (wings, tail, belly) deep blue. In the conifer woodlands between the Rockies and Pacific, this is the resident jay with a crest.

Similar species: (1) Scrub and (2) Gray-breasted jays are paler, lack crests; prefer oaks, scrub. (3) Blue Jay (east of Rockies) is a crested jay but has white spots in the wings and tail. A few wander in winter into $\mathrm{n}$. Rockies (see Map 268).

Voice: A loud shook-shook-shook or shack-shack-shack or wheck-wek-wek-wek-wek or kwesh kwesh kwesh; many other notes. Frequently mimics Red-tailed Hawk, Golden Eagle.

Range: Western N. America south; se. Alaska, sw. Canada south through conifer regions of Pacific states and Rockies to Nicaragua. Map 267. Habitat: Conifer and pine-oak forests.

PINYON JAY Gymnorhinus cyanocephalus

M271

9-1 13/4" (23-30 cm). Looks like a small dull blue crow, but nearer the size of a Robin, with a long sharp bill. Readily told from Scrub Jay by its short tail, uniform blue coloration, and crow-like flight; from Steller's Jay by lack of a crest.

Text continued on p. 256. 

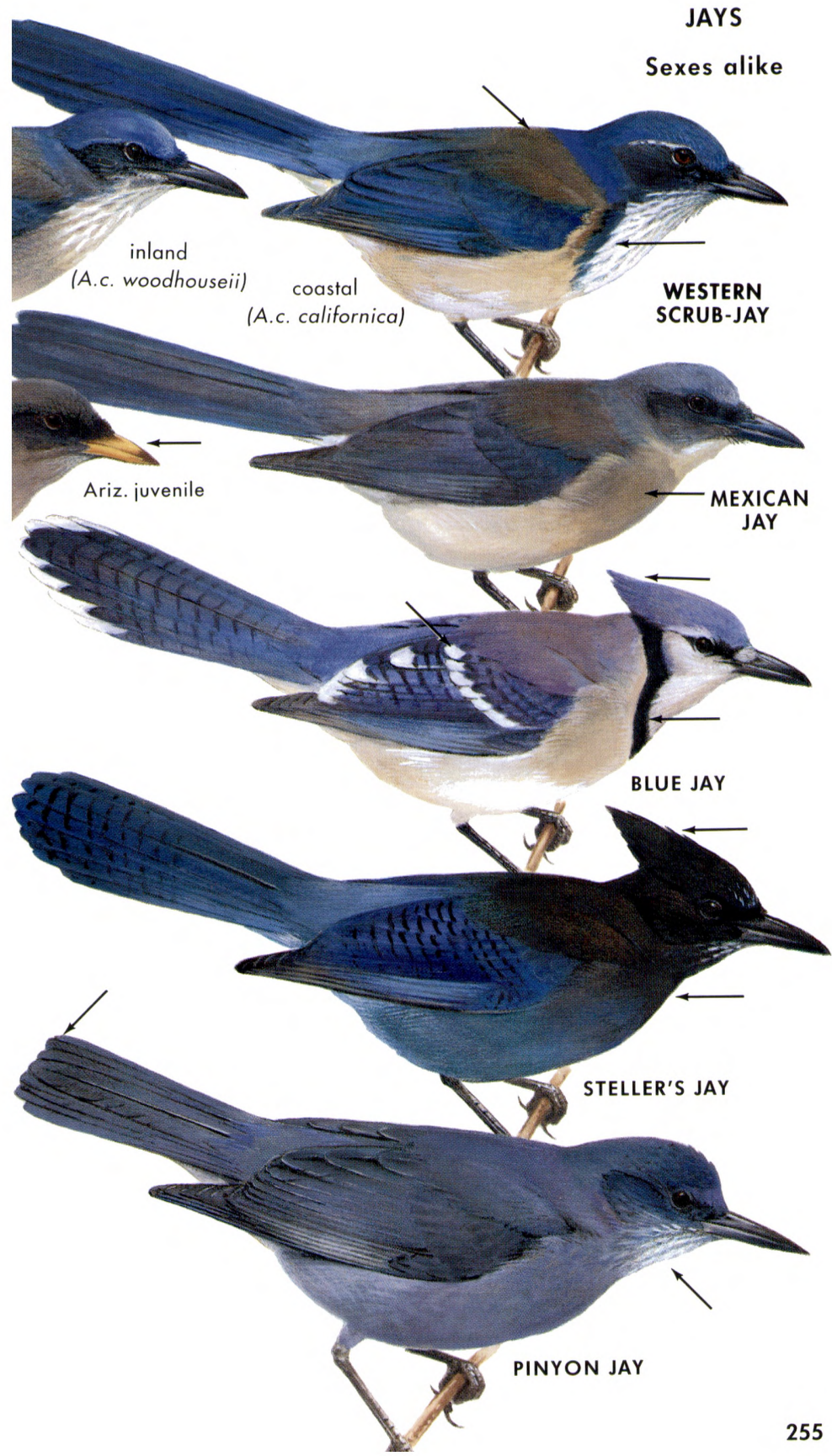
PINYON JAY (continued). See illustration on p. 255.

(Caution: Steller's Jay depresses crest when flying). Pinyon Jays are gregarious, often gathering in large noisy flocks and walking about like small crows.

Voice: A high nasal cawing, kaa-eh, karn-eh (descending inflection); has mewing effect. Also jay-like notes; chattering.

Range: Western U.S., n. Baja California. West: Map 271. Wanders widely. Habitat: Pinyon pines, junipers ("cedars"); ranges into sagebrush.

CLARK'S NUTCRACKER Nucifraga columbiana

M272

$12-13^{\prime \prime}(30-33 \mathrm{~cm})$. Built like a small crow, with a light gray body and large white patches in its black wings and tail. If these patches are seen, it should be confused with no other bird of the high mountains. Tame birds can often be fed by hand.

Similar species: Gray Jay does not have white patches.

Voice: A flat, grating caw, khaaa or khraa.

Range: Sw. Canada, w. U.S. to n. Mexico. West: Map 272. Habitat: High mountains; conifers near tree line; mountain resorts.

GRAY JAY Perisoreus canadensis

M266

$11-13^{\prime \prime}(28-33 \mathrm{~cm})$. A large, fluffy, gray bird of the cool northern forests; larger than a Robin, with a black patch or partial cap across the back of the head and a white forehead (or crown); suggests a huge overgrown chickadee. Juvenile birds in their first summer are a dark sooty color, almost blackish; the only distinguishing mark is a whitish whisker. Called "Whiskey Jack" by woodsmen.

Voice: A soft whee-ah; also many other notes, some harsh.

Range: Boreal forests of N. America. West: Map 266. Habitat: Spruce and fir forests. Becomes tame around mountain resorts.

YELLOW-BILLED MAGPIE Pica nuttalli

M273

16-18" (40-45 cm). Similar to the Black-billed Magpie, but the bill is yellow. At close range shows a crescent of bare yellow skin below the eye.

Voice: Similar to Black-billed Magpie's maag?, etc.

Range: California only; chiefly in Sacramento and San Joaquin valleys and adjacent low foothills; also valleys of Coast Ranges from San Francisco Bay to Santa Barbara Co. West: Map 273. Habitat: Stream groves, scattered oaks, ranches, farms.

BLACK-BILLED MAGPIE Pica pica

M273

171/2-22" (44-55 cm); tail 91/2-12" $(24-30 \mathrm{~cm})$. A large, slender, black and white bird, with a long, wedge-tipped tail. In flight, the iridescent greenish black tail streams behind and large white patches flash in the wings.

Voice: A harsh, rapid queg queg queg queg or wah-wah-wah-wah. Also a querulous, nasal maag? or aag-aag?

Range: Eurasia, w. N. America. West: Map 273. Habitat: Rangeland, brushy country, conifers, streamsides, forest edges, farms. 
- CHICKADEES, TITMICE. Family Paridae. Small, plump, small-billed birds. Acrobatic when feeding. Sexes usually alike. Food: Insects, seeds, acorn mast, berries; at feeders, suet, sunflower seeds. Range: Widespread in N. America, Eurasia, Africa. No. of species: World 62; West 9.

MOUNTAIN CHICKADEE Poecile gambeli M279

5-53/4" (13-14 cm). Similar to the Black-capped Chickadee, but black of cap interrupted by a white line over the eye.

Voice: Song, a clear whistled fee-bee-bee, first note higher; also tsick-zzee-zee-zee, huskier than Black-cap's.

Range: Resident, sw. Canada, w. U.S., n. Baja California. Map 279. Habitat: Mountain forests, conifers; lower levels in winter.

BLACK-CAPPED CHICKADEE Poecile atricapillus

M278

$43 / 4-53 / 4 "(12-14 \mathrm{~cm})$. The small, tame Black-cap can be separated from the other widespread western chickadees by the solid black cap in conjunction with its gray back and buffy sides.

Voice: A clearly enunciated chick-a-dee-dee-dee. Song, a clear whistle, fee-bee-ee or fee-bee, first note higher.

Range: Alaska, Canada, northern half of U.S. West: Map 278. Habitat: Mixed and deciduous woods; willow thickets, groves, shade trees. Visits feeders, eating suet, sunflower seeds.

MEXICAN CHICKADEE Poecile sclateri

M280

5" $(13 \mathrm{~cm})$. Similar to Black-capped Chickadee, but black of throat more extensive, spreading across upper breast. Note the dark gray sides. The only chickadee in its local U.S. range.

Voice: Nasal and husky for a chickadee. A low dzay-dzeee.

Range: Resident, Chiricahuas, se. Arizona; Animas Mts., sw. New Mexico; to Oaxaca. West: Map 280. Habitat: Conifers in mountains.

CHESTNUT-BACKED CHICKADEE Poecile rufescens

M281

$4 \frac{1}{2}-5 "(11-13 \mathrm{~cm})$. The cap, bib, and white cheeks indicate a chickadee; the chestnut back this species. Sides chestnut (or gray, in the race found along the coast of cen. California).

Voice: Hoarser than Black-cap's. No whistled song.

Range: Western N. America. Map 281. Habitat: Moist conifer forests; adjacent oaks, shade trees.

\section{GRAY-HEADED CHICKADEE Poecile cinctus}

(Siberian Tit, an inappropriate name.) 51/2" $(14 \mathrm{~cm})$. This subarctic chickadee can be separated from the Boreal Chickadee by its grayer cap and more extensive white cheeks. Looks smaller-headed, longer-tailed, and not as brown on the flanks; it has a "dusty" appearance.

Voice: A peevish dee-deer or chee-ee.

Range: N. Eurasia, nw. N. America. Very local in n. Alaska from tree limit to cen. Alaska range; also n. Yukon, nw. MacKenzie. Habitat: Spruce forest, streamside thickets.

BOREAL CHICKADEE Poecile hudsonicus

M280

5-5 $\frac{1}{2} "(13-14 \mathrm{~cm})$. The small size, bib, and cap mark it as a chickadee; the dull brown cap, rich brown flanks, and restricted white on its dusky cheeks as this species.

Voice: Notes, slower, more drawling than those of Black-cap.

Range: Boreal woods of Alaska, Canada, ne. U.S. West: Map 280. 

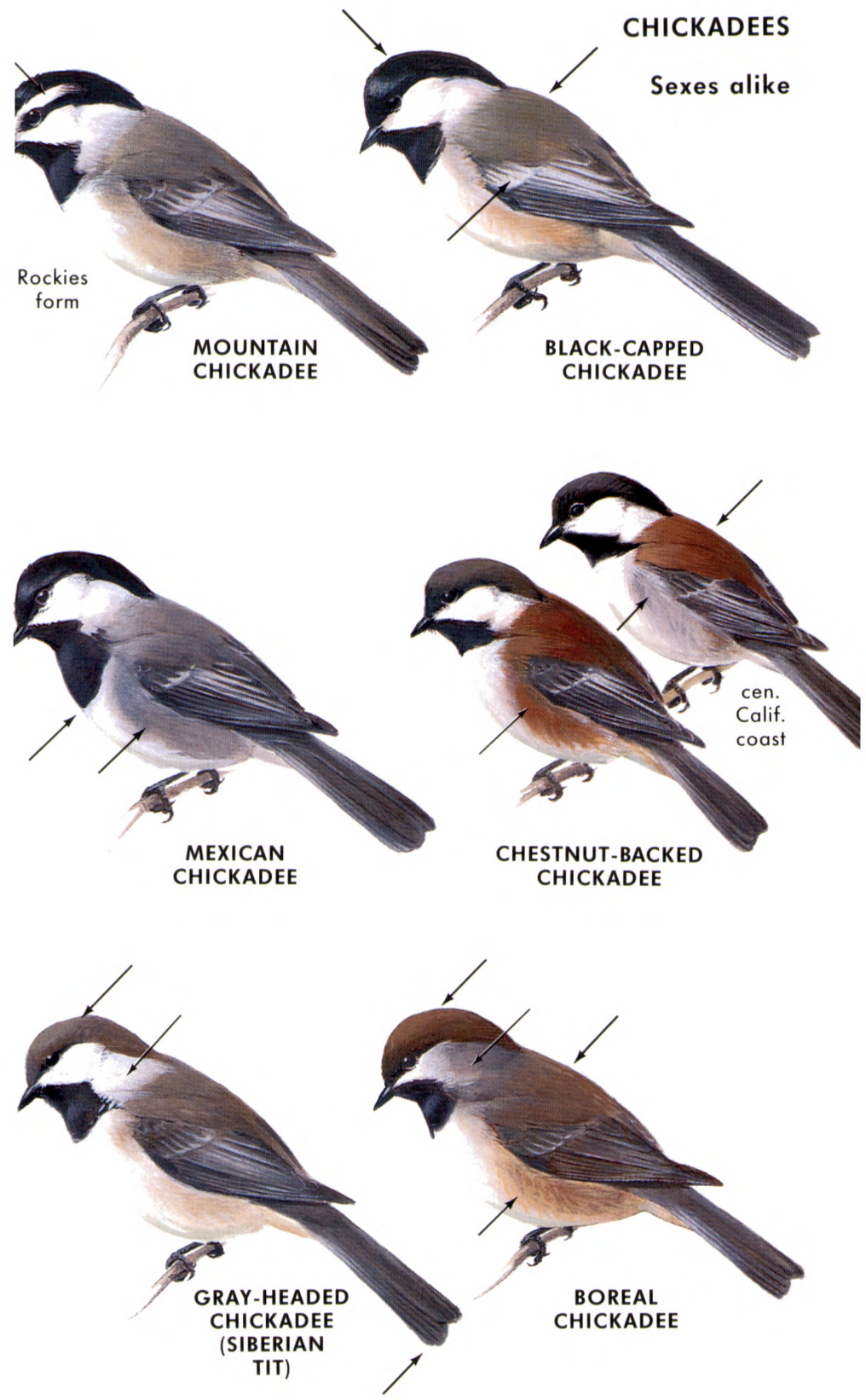
(Black-crested Titmouse) 5-6" (13-15 cm). A small gray bird, which in w. Texas has a black crown and crest. Underparts pale, sides rusty, light spot between the eye and bill. Females may have some gray in the crest. East of our area this species lacks the black on the crest. Young birds (gray-crested) are almost indistinguishable from Oak Titmouse.

Voice: Chickadee-like notes. Song, a whistled peter peter peter peter or hear hear hear hear. Varied.

Range: Eastern N. America to w. Texas, ne. Mexico. The west Texas birds are regarded by some as a distinct species (Parus atricristatus) known as the "Black-crested Titmouse." West: Map 282. Habitat: Oak woods, canyons, cedars, groves, towns.

OAK TITMOUSE Baeolophus inornatus

M282

$5 \frac{1}{2} "(14 \mathrm{~cm})$. The birds bearing the name "titmouse" are our only small, gray-backed birds with pointed crests (female Phainopepla is larger). Previously called Plain Titmouse. Separate mainly by range. Oak Titmouse browner than Juniper Titmouse (B. griseus) which occurs east of California.

Voice: Tchick-a-dee-dee, similar to notes of chickadees. Song, a whistled weety weety or tee-wit tee-wit tee-wit.

Range: Resident, w. U.S. West: Map 282. Habitat: Oak woods, pinyon, juniper; locally river woods, shade trees.

BRIDLED TITMOUSE Baeolophus wollweberi

$4 \frac{1}{2}-5$ " $(11-13 \mathrm{~cm})$. The crest and black-and-white "bridled" face identify this small gray titmouse of the southwestern mountains.

Voice: Similar to that of other titmice and chickadees, but higher. Song, a repeated two-syllabled phrase.

Range: Resident from mountains of se. Arizona, sw. New Mexico to s. Mexico. Habitat: Oak and sycamore canyons, pine-oak woods.

BUSHTIT Psaltriparus minimus Family Aegithalidae

M284

4" $(10 \mathrm{~cm})$. Very small, plain birds that move from bush to tree in straggling flocks, conversing in light gentle notes. Nondescript; gray backs, pale underparts, brownish cheeks, stubby bills, longish tails. Birds in the Rockies and Great Basin have gray crowns. Males of the form known as "Black-eared Bushtit" in sw. New Mexico (San Luis Mts.) and w. Texas (Davis, Chisos Mts.) have black or black-flecked cheeks.

Voice: Insistent light tsit's, lisp's, and clenk's.

Range: Resident, sw. B.C. to Guatemala. West: Map 284. Habitat: Oak scrub, chaparral, mixed woods, pinyons, junipers.

VERDIN Auriparus flaviceps Family Remizidae

M283

4-41/2" (10-11 cm). Tiny, gray, with a yellowish head, rufous bend of wing (often hidden). Juveniles lack these marks.

Similar species: Bushtit is longer-tailed than immature Verdin. Does not usually live in desert valleys; prefers oak slopes. See also Northern Bearless-Tyrannulet (pp. 238-239).

Voice: Insistent see-lip. Rapid chipping. Song, tsee, seesee.

Range: Resident, sw. U.S., n. and w. Mexico. Map 283. Habitat: Brushy desert valleys, mesquite, semi-arid plains and savannas. 

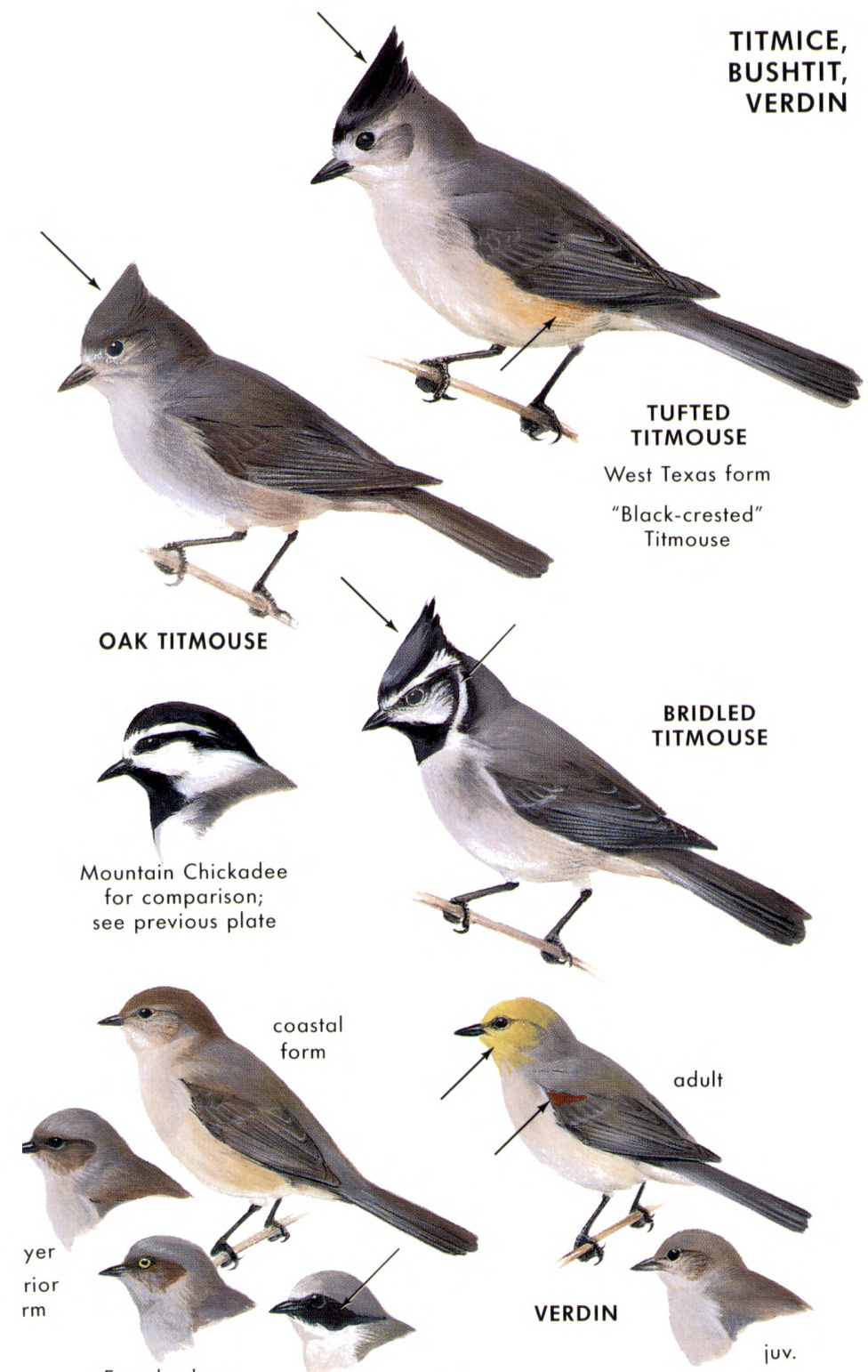

Females have yellow eyes.

"black-eared" plumage, juvenile $\delta$ 
- NUTHATCHES. Family Sittidae. Small, stubby tree-climbers with strong, woodpecker-like bills and strong feet. The short, square-cut tails are not braced like woodpeckers' tails during climbing. Nuthatches habitually go down trees headfirst. Sexes similar. Food: Bark insects, seeds, nuts; attracted to feeders by suet, sunflower seeds. Range: Most of N. Hemisphere. No. of species: World 22; West 3.

WHITE-BREASTED NUTHATCH Sitta carolinensis

M286

$5-6^{\prime \prime}(13-15 \mathrm{~cm})$. Nuthatches climb down trees headfirst. This, the most familiar species, is known by its black cap and beady black eye on a white face. The undertail coverts are chestnut.

Voice: Song, a rapid series of low, nasal, whistled notes on one pitch: whi, whi, whi, whi, whi, whi, or who, who, who, etc. Note, a nasal yank; also a nasal tootoo.

Range: S. Canada to s. Mexico. West: Map 286. Habitat: Forests, woodlots, groves, shade trees; visits feeders.

RED-BREASTED NUTHATCH Sitta canadensis

M285

$4 \frac{1}{2} 2^{\prime \prime}(11 \mathrm{~cm})$. A small nuthatch with a broad black line through the eye and a white line above it. The underparts are washed with rusty. Voice: Call higher, more nasal than that of White-breast; ank or enk, sounding like a baby nuthatch or a tiny tin horn.

Range: Se. Alaska, Canada, w. U.S., ne. U.S. Winters irregularly to s. U.S., nw. Mexico. West: Map 285. Habitat: Conifer forests; in winter, also other trees, may visit feeders.

PYGMY NUTHATCH Sitta pygmaea

M287

$33 / 4-41 / 2^{\prime \prime}(9-11 \mathrm{~cm})$. A very small, pine-loving nuthatch, with a graybrown cap coming down to the eye and a whitish spot on the nape. Usually roams about in little flocks.

Voice: A piping kit-kit---kit or pit-pi-dit-pi-dit. Also a high ki-dee; incessant, sometimes becoming an excited chatter.

Range: Resident from s. British Columbia to cen. Mexico. Map 287. Habitat: Yellow pines, other pines, Douglas fir.

- CREEPERS. Family Certhiidae. Small, slim, stiff-tailed birds, with slender, slightly curved bills that are used to probe the bark of trees. Food: Bark insects. Range: Cooler parts of N. Hemisphere. No. of species: World 7; West 1 .

BROWN CREEPER Certhia americana

M288

$5^{\prime \prime}(13 \mathrm{~cm})$. A very small, slim, camouflaged tree-climber. Brown above, white below, with a slender decurved bill and a stiff tail, which is braced during climbing. Ascends trees spirally from the base, hugging the bark closely.

Voice: Note, a single high, thin seee, similar to the quick trebled note (see-see-see) of the Golden-crowned Kinglet. Song, a thin, sibilant see-ti-wee-tu-wee or "trees, trees, trees, see the trees."

Range: S. Alaska, Canada to Nicaragua. West: Map 288. Habitat: Woodlands, groves, shade trees. 


\section{NUTHATCHES, CREEPERS}

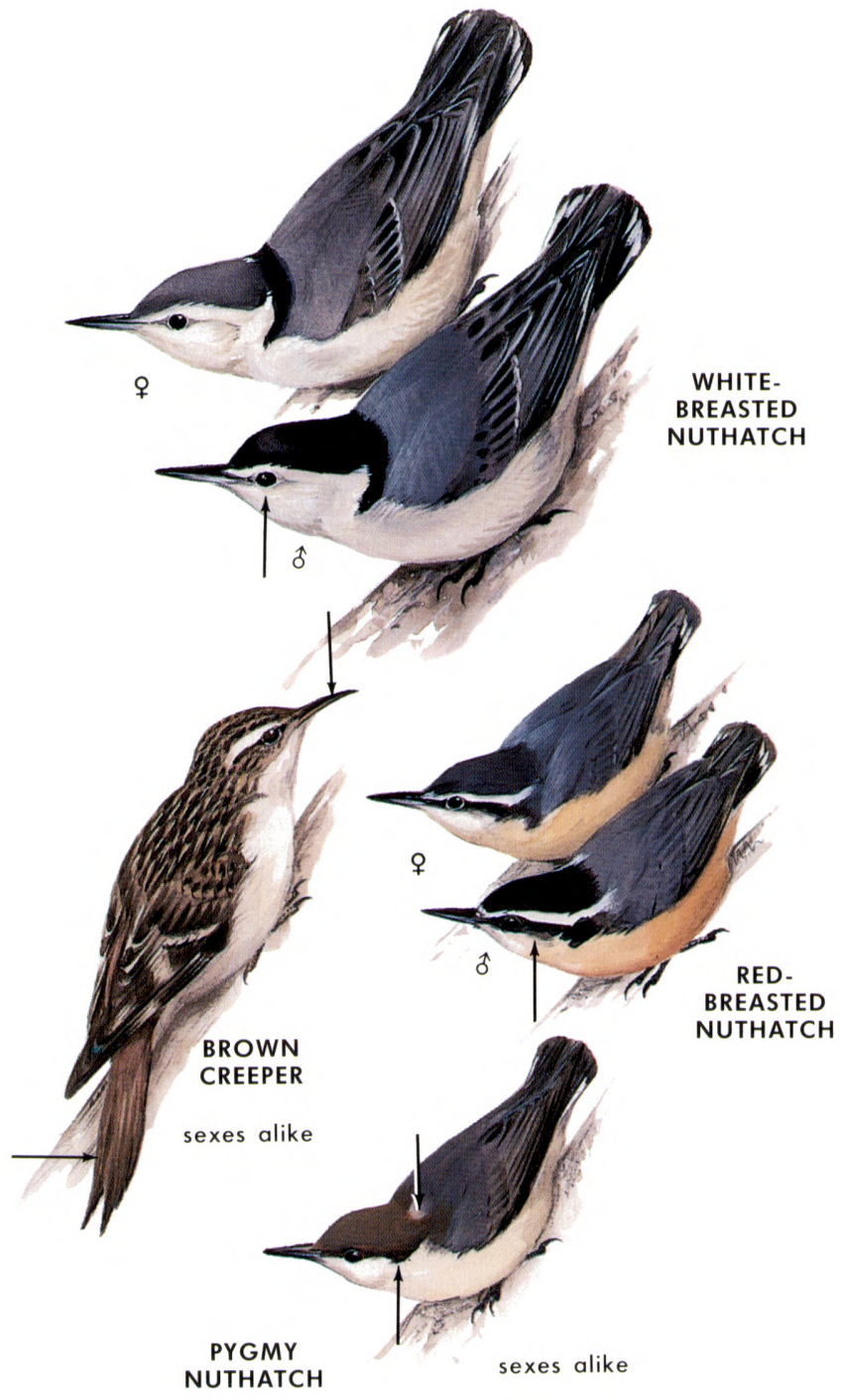


- WRENS. Family Troglodytidae. Small, energetic brown birds; stumpy, with slim, slightly curved bills; tails often cocked. Food: Insects, spiders. Range: N., Cen., and S. America; one (Winter Wren) in Eurasia. No. of species: World 67; West 9.

HOUSE WREN Troglodytes aedon

M293

$4 \frac{1}{2}-5^{\prime \prime}(11-13 \mathrm{~cm})$. A small, energetic gray-brown wren with a light eye-ring and no strong eyebrow stripe. A rustier form in the mountains of se. Arizona, the "Brown-throated Wren," was formerly rated a distinct species; it has a buff eyebrow.

Voice: A stuttering, gurgling song, rising in a musical burst, then falling at the end.

Range: S. Canada to Tierra del Fuego. West: Map 293. Habitat: Open woods, thickets, towns, gardens; often nests in bird boxes.

WINTER WREN Troglodytes troglodytes

M294

4" $(10 \mathrm{~cm})$. A very small, round, dark wren, known from House Wren by its much stubbier tail, stronger eyebrow, and dark, heavily barred belly. Often bobs head. Mouse-like; stays near ground.

Voice: Song, rapid succession of high tinkling warbles, trills. Note, a hard; two-syllabled kip-kip (suggests Song Sparrow's chip).

Range: Northern parts of N. Hemisphere. West: Map 294. Habitat: Woodland underbrush; conifer forests (summer).

BEWICK'S WREN Thryomanes bewickii

M292

$51 / 4^{\prime \prime}(13 \mathrm{~cm})$. Note the longish tail with white corners and the bold white eyebrow stripe. Western races are mouse-brown, less rusty.

Voice: Song suggests Song Sparrow's, but thinner, starting on two or three high notes, dropping lower, ending on a thin trill.

Range: S. Canada to Mexico. West: Map 292. Habitat: Thickets, underbrush, gardens. Often nests in bird boxes.

CAROLINA WREN Thryothorus ludovicianus

$53 / 4^{\prime \prime}(14 \mathrm{~cm})$. A large wren, near the size of a sparrow. Warm rusty brown above, buff below; conspicuous white eyebrow stripe.

Voice: A two- or three-syllabled chant. Variable; tea-kettle, teakettle, tea kettle, or chirpity, chirpity, chirpity, chirp.

Range: Resident, e. U.S., e. Mexico. West: Barely crosses our boundary in n. and w. Texas. Accidental, Wyoming, Colorado, New Mexico. Habitat: Tangles, undergrowth, suburbs, gardens, towns.

MARSH WREN Cistothorus palustris

M295

(Long-billed Marsh Wren) 5" (13 cm). The white stripes on the back and the white eyebrow stripe identify this marsh dweller.

Voice: Song, reedy, gurgling, often ending in a guttural rattle: cutcut-turrrrrrrr-ur; sometimes at night. Note, a low tsuck.

Range: s. Canada to nw. Mexico. Winters to cen. Mexico. West: Map 295. Habitat: Marshes (cattail, bullrush, or brackish).

SEDGE WREN Cistothorus platensis

(Short-billed Marsh Wren) 41/2" (11 cm). Stubbier than a Marsh Wren; buffier, with buffy undertail coverts, streaked crown.

Voice: Song, a dry staccato chattering: chap chap chap chap chap chap chap chapper-rrrrr. Note, a single or double chap.

Range: S. Canada locally to Tierra del Fuego. West: Breeds in e.-cen. Alberta, s. Saskatchewan. Rare migrant on Great Plains; accidental, California. Habitat: Grassy marshes, sedgy meadows. 


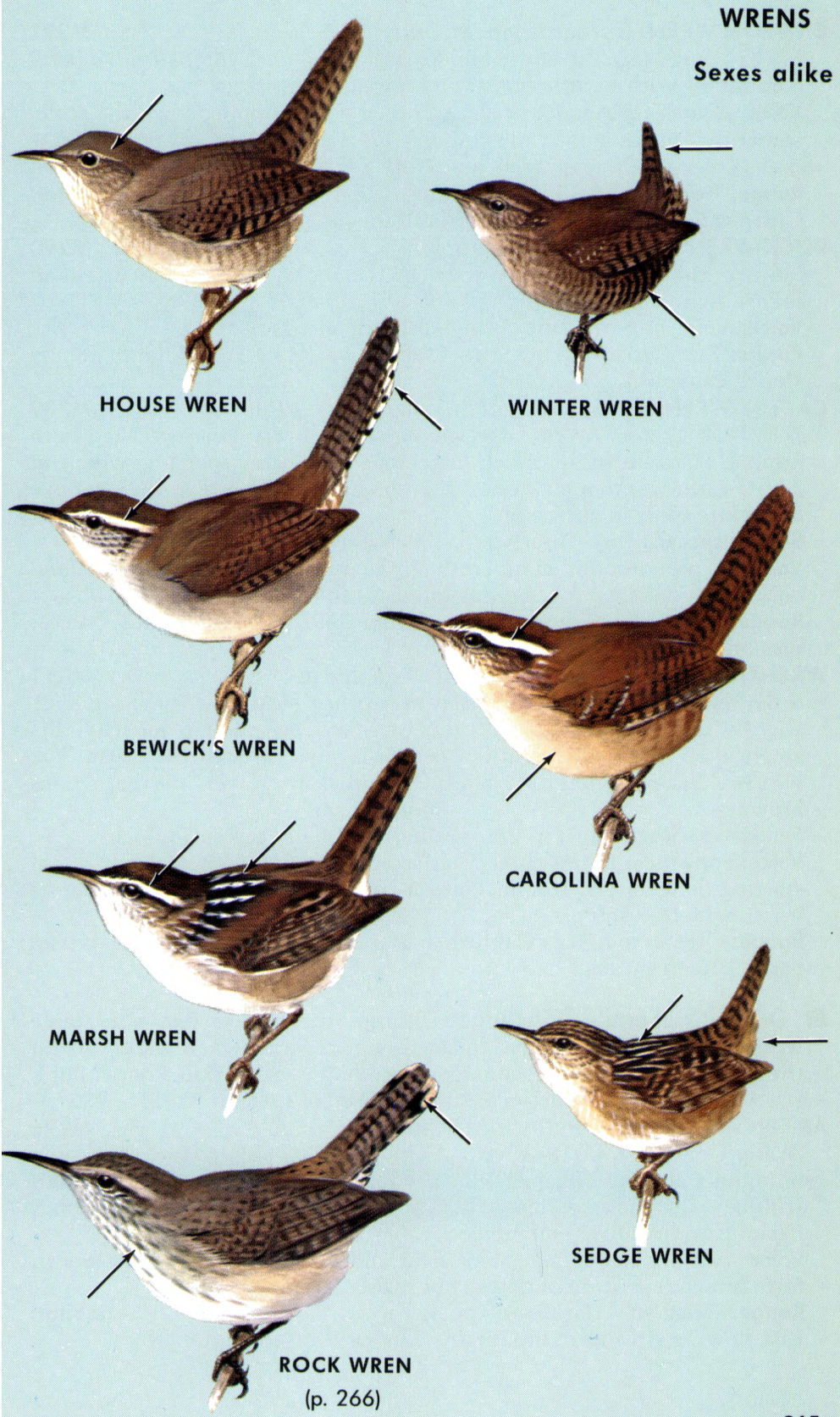


$53 / 4 "(14 \mathrm{~cm})$. Note the white bib. Rusty, with a dark rufous-brown belly contrasting with a white breast and throat.

Voice: A gushing cadence of clear, curved notes tripping down the scale; sometimes picking up at the end: te-you, te-you te-you tew tew tew tew or tee tee tee tee tew tew tew tew. Note a shrill beet.

Range: Resident, sw. British Columbia to s. Mexico. Map 291. Habitat: Cliffs, canyons, rockslides; stone buildings.

ROCK WREN Salpinctes obsoletus

M290

$5 \frac{1}{2}-6 \frac{1}{2} "(14-16 \mathrm{~cm})$. A gray wren of the rocks; has a finely streaked breast, light belly, rusty rump, buffy tail corners.

Voice: Song, a harsh chant. A loud, dry trill; also ti-keer.

Range: Sw. Canada, w. U.S. to Costa Rica. Map 290. Habitat: Rocky slopes, canyons.

CACTUS WREN Campylorhynchus brunneicapillus

M289

$7-83 / 4 "(18-22 \mathrm{~cm})$. A very large wren of arid country. Distinguished from other U.S. wrens by its much larger size and heavy spotting, which in adults gathers into a cluster on the upper breast. White stripe over eye and white spots in outer tail.

Similar species: Sage Thrasher (p. 270) is grayer; no back stripes.

Voice: A monotonous chuh-chuh-chuh-chuh, etc., or chug-chug-chugchug-chug, on one pitch, gaining rapidity; unbird-like.

Range: Sw. U.S. to cen. Mexico. Map 289. Habitat: Cactus, yucca, mesquite; arid brush, deserts.

WRENTIT Chamaea fasciata Family Timaliidae

M311

$6-61 / 2 "(15-16 \mathrm{~cm})$. Far more often heard than seen. The long, rounded, slightly cocked tail and obscurely streaked breast help identify this small, drab bird, which can be seen as it slips through the brush. Eye white. Behavior wren-like. Southern birds are grayer, northern ones browner.

Similar species: Bushtit (p. 260) is smaller; usually travels in flocks.

Voice: Song (heard throughout year), staccato ringing notes on one pitch; starting deliberately, running into a trill. Also a slower, double-noted version. Note, a soft prr.

Range: Oregon to n. Baja California. Map 311. Habitat: Chaparral, brush, parks, garden shrubs.

- DIPPERS. Family Cinclidae. Plump, stub-tailed; like very large wrens. Solitary. Dippers dive and swim under water, where they walk on the bottom. Food: Insects, aquatic invertebrates, small fish. Range: Eurasia, w. N. America, Andes of S. America. No. of species: World 5; West 1.

AMERICAN DIPPER Cinclus mexicanus

M296

(Water Ouzel) 7-81/2" (18-21 cm). A chunky, slate-colored bird of rushing mountain streams. Shaped like a wren (size of a large thrush); tail stubby. Legs pale, eyelids white. Note bobbing motions, slaty color, flashing eyelid. Dives, submerges.

Voice: Note, a sharp zeet. Song clear and ringing, mockingbird-like in form (much repetition of notes), but higher, more wren-like.

Range: Resident, Alaska, w. Canada to w. Panama. Map 296. Habitat: Fast-flowing streams in mountains. Lower levels in winter. 


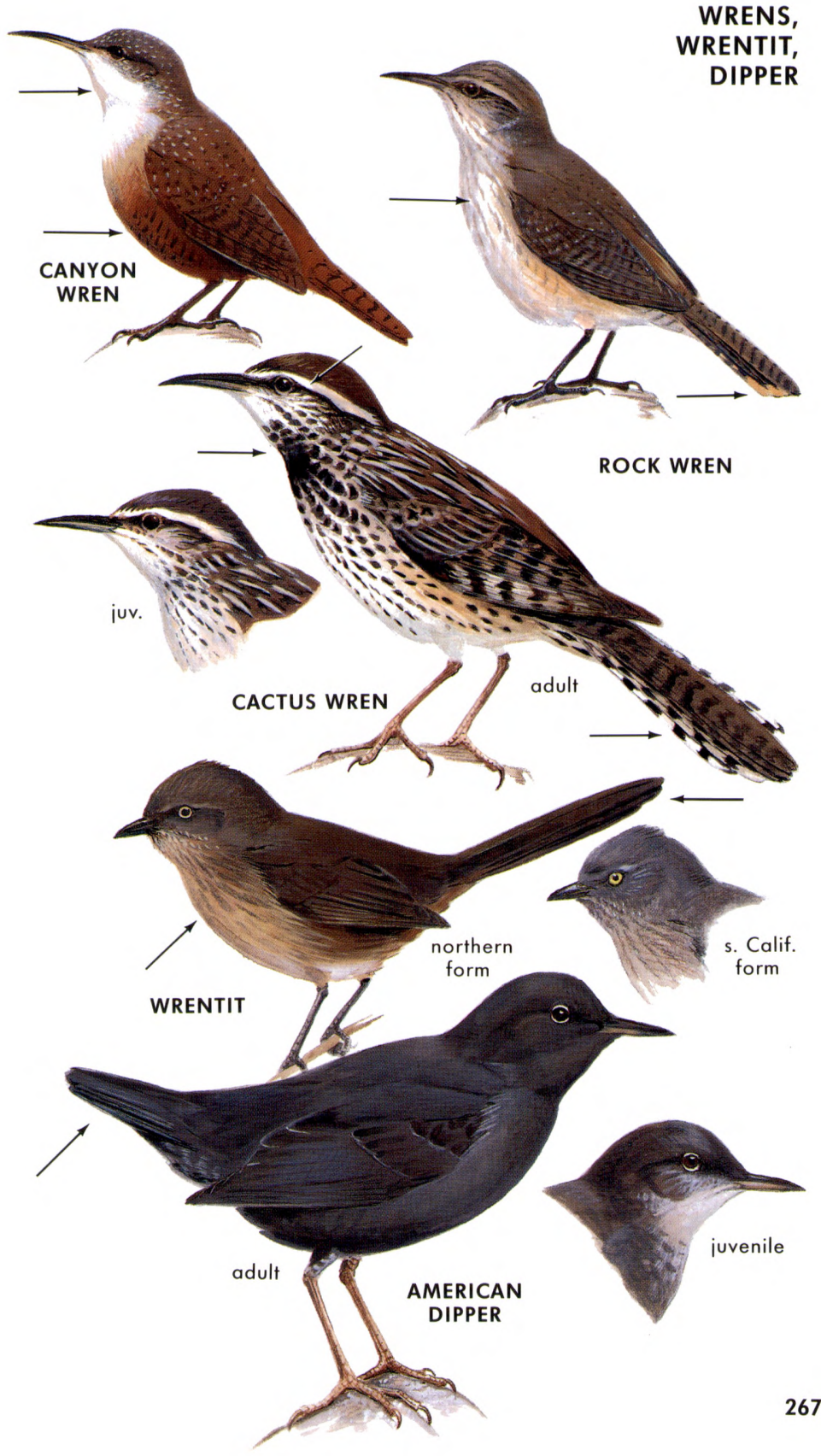


KINGLETS Family Regulidae. Tiny active birds with thin bills. RUBY-CROWNED KINGLET Regulus calendula

4" $(10 \mathrm{~cm})$. A tiny, stub-tailed birdlet; olive-gray with a strong black wing bar below the white ones. Male with a scarlet crown patch (usually concealed; erect when excited). Flicks wings. Broken white eye-ring gives a big-eyed look. Any kinglet without a crown patch and eyestripe is this species. See Hutton's Vireo, p. 284.

Voice: A husky ji-dit. Song, three or four high notes, several lower notes and a chant, tee tee tee-tew tew tew-ti-didee, ti-didee, ti-didee. Variable.

Range: Canada, Alaska, w. U.S. Winters to Guatemala. West: Map 298. Habitat: Conifers; in winter, other woodlands.

GOLDEN-CROWNED KINGLET Regulus satrapa

M297

$3 \frac{1}{2} 2^{\prime \prime}(9 \mathrm{~cm}$ ). Note the bright crown patch (yellow in female, orange in male) bordered by black, and the whitish eyebrow stripe. Kinglets are tiny, olive-gray birds, smaller than most warblers. An upward flick of the wings is characteristic.

Voice: A high, wiry see-see-see. Song, a series of high thin notes, ascending, then dropping into a little chatter.

Range: S. Alaska, Canada to Guatemala. West: Map 297. Habitat: Conifers; in winter, also other trees.

- GNATCATCHERS. Family Sylviidae. (in part Subfamily Polioptilinae). Very small active birds with slender cocked-up tails. Loud songs for their size.

BLUE-GRAY GNATCATCHER Polioptila caerulea

M299

$4 \frac{1}{2} "(11 \mathrm{~cm})$. Suggests a miniature Mockingbird. A tiny, slim mite, smaller than a chickadee; blue-gray above, whitish below, with a narrow white eye-ring. The long, black and white tail is often cocked like a wren's tail and flipped about.

Voice: Note, a thin, peevish zpee or chee. Song, a thin, squeaky, wheezy series of notes, easily overlooked.

Range: S. Utah, s. Ontario to Guatemala. Winters to Honduras. West: Map 299. Habitat: Open woods, oaks, pines, thickets.

BLACK-CAPPED GNATCATCHER Polioptila nigriceps

$4 \frac{1}{2} "(11 \mathrm{~cm})$. Male: In breeding plumage puts on a solid black cap, lacing in winter and in females. Note the largely white undertail (largely black in Black-tailed Gnatcatcher).

Range: W. Mexico. Has bred in s. Arizona.

BLACK-TAILED GNATCATCHER Polioptila melanura

M300

$4 \frac{1}{2} 2^{\prime \prime}(11 \mathrm{~cm})$. Similar to Blue-gray Gnatcatcher, but breeding male has a black cap and much less white on the tail (outer web only). Winter male (without cap) and female are duller than Blue-gray Gnatcatcher. From below, the tail is largely black.

Voice: Note, a thin harsh chee, repeated two or three times (Blue-gray Gnatcatcher usually gives a single note); or pee-ee-ee.

Range: Resident, sw. U.S., n. Mexico. Map 300. Habitat: Desert brush, ravines, dry washes; mesquite, sage.

CALIFORNIA GNATCATCHER Polioptila californica

M300

("Plumbeous Gnatcatcher") Formerly regarded as a race of Black-tailed Gnatcatcher, but dull gray below, less white on the underside of the tail. Resident, se. California and Baja California. 


\section{KINGLETS, GNATCATCHERS}
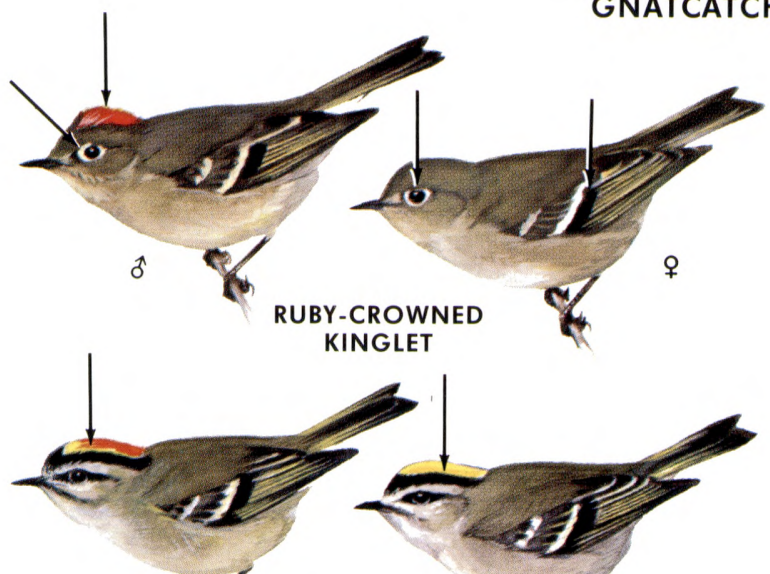

o

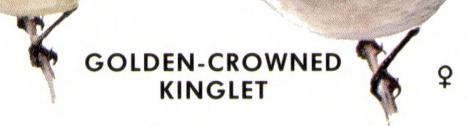

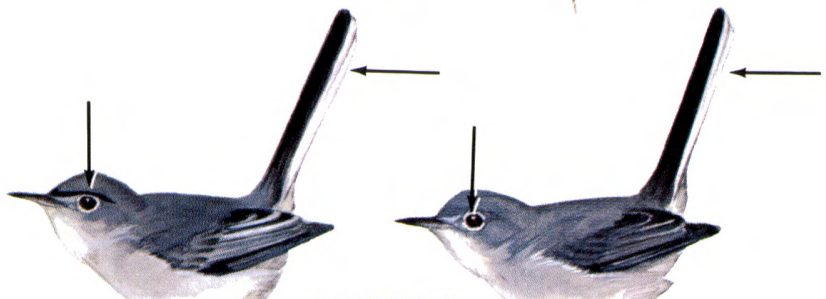

\section{o}

BLUE-GRAY
GNATCATCHER

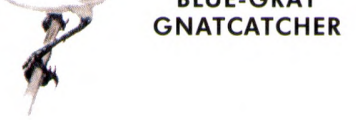

BLACK-CAPPED

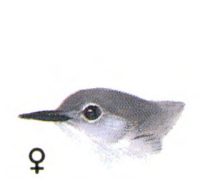

우

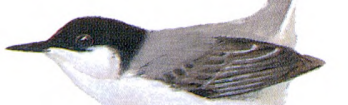

$\hat{o}$ GNATCATCHER

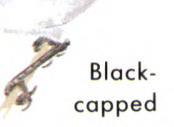

Blve-gray

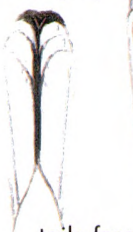

tails from below

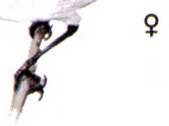

우
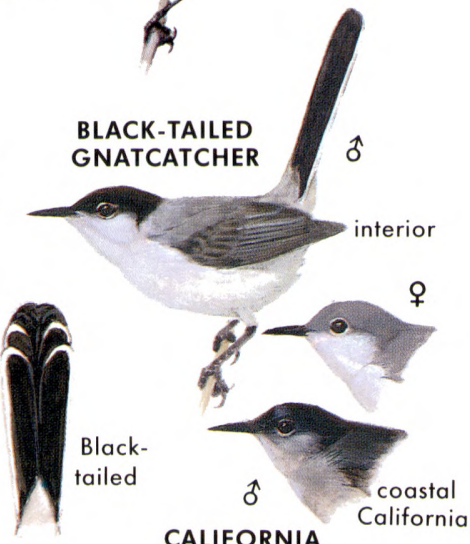

CALIFORNIA GNATCATCHER 
MOCKINGBIRDS AND THRASHERS. Family Mimidae.

Often called "mimic thrushes." Excellent songsters; some mimic other birds. Strong-legged; usually longer-tailed than true thrushes, bill usually more decurved. Food: Insects, fruits. Range: New World; Canada to Argentina. No. of species: World 35; West 9.

BROWN THRASHER Toxostoma rufum

M315

$11 \frac{1}{2} 2^{\prime \prime}(29 \mathrm{~cm})$. Slimmer than a Robin; bright rufous above, heavily striped below. Note also the wing bars, the rather curved bill, the long tail, and the yellow eyes. The various brown thrushes (p. 276) have shorter tails, lack wing bars, are spotted (not striped), and have brown (not yellow) eyes.

Voice: Song, a succession of deliberate notes and phrases resembling the Catbird's song, but more musical and each phrase usually in pairs. Note, a harsh chack!

Range: S. Canada to Gulf states; east of Rockies. West: Map 315. Habitat: Thickets, brush, shrubbery, thorn scrub.

GRAY CATBIRD Dumetella carolinensis

M312

9" $(23 \mathrm{~cm})$. Slate-gray; slim. Note the black cap. Chestnut undertail coverts (may not be noticeable). Flips tail jauntily.

Voice: Catlike mewing; distinctive. Also a grating tcheck-tcheck. Song, disjointed notes and phrases; not repetitous.

Range: S. Canada, e. and cen. U.S. Winters to Panama, W. Indies. West: Map 312. Habitat: Undergrowth, brush, thorn scrub, suburban gardens.

NORTHERN MOCKINGBIRD Mimus polyglottos

M313

9-11" (23-28 cm). Gray; slimmer, longer-tailed than a Robin. Note the large white patches on the wings and tail, conspicuous in flight. Similar species: Shrikes (pp. 280, 281) have black facial masks.

Voice: Song, a varied, prolonged succession of notes and phrases, each repeated a half-dozen times or more before changing. Often heard at night. Many Mockingbirds are excellent mimics of other species. Note, a loud tchack; also chair.

Range: S. Canada to s. Mexico, W. Indies, Hawaii (introduced). West: Map 313. Habitat: Towns, farms, roadsides, thickets.

SAGE THRASHER Oreoscoptes montanus

M314

8-9" (20-23 cm). A bit smaller than a Robin; similar in shape and some actions. Gray-backed, with a heavily streaked breast, white spots at tip of tail. The eyes are pale yellow. Small size, shorter tail, shorter bill, and striped breast distinguish it from other typically western thrashers.

Similar species: (1) See Cactus Wren (pp. 266, 267). (2) Young Mockingbirds, which are spotted below, have large white patches in the wings and tail. (3) See also Bendire's Thrasher (pp. 272, 273).

Voice: Song, clear, ecstatic warbled phrases, sometimes repeated in thrasher fashion; more often continuous, suggestive of a Blackheaded Grosbeak. Note, a blackbird-like chuck.

Range: Sw. Canada, w. U.S. Map 314. Habitat: Sagebrush, brushy slopes, mesas; in winter, also deserts. 

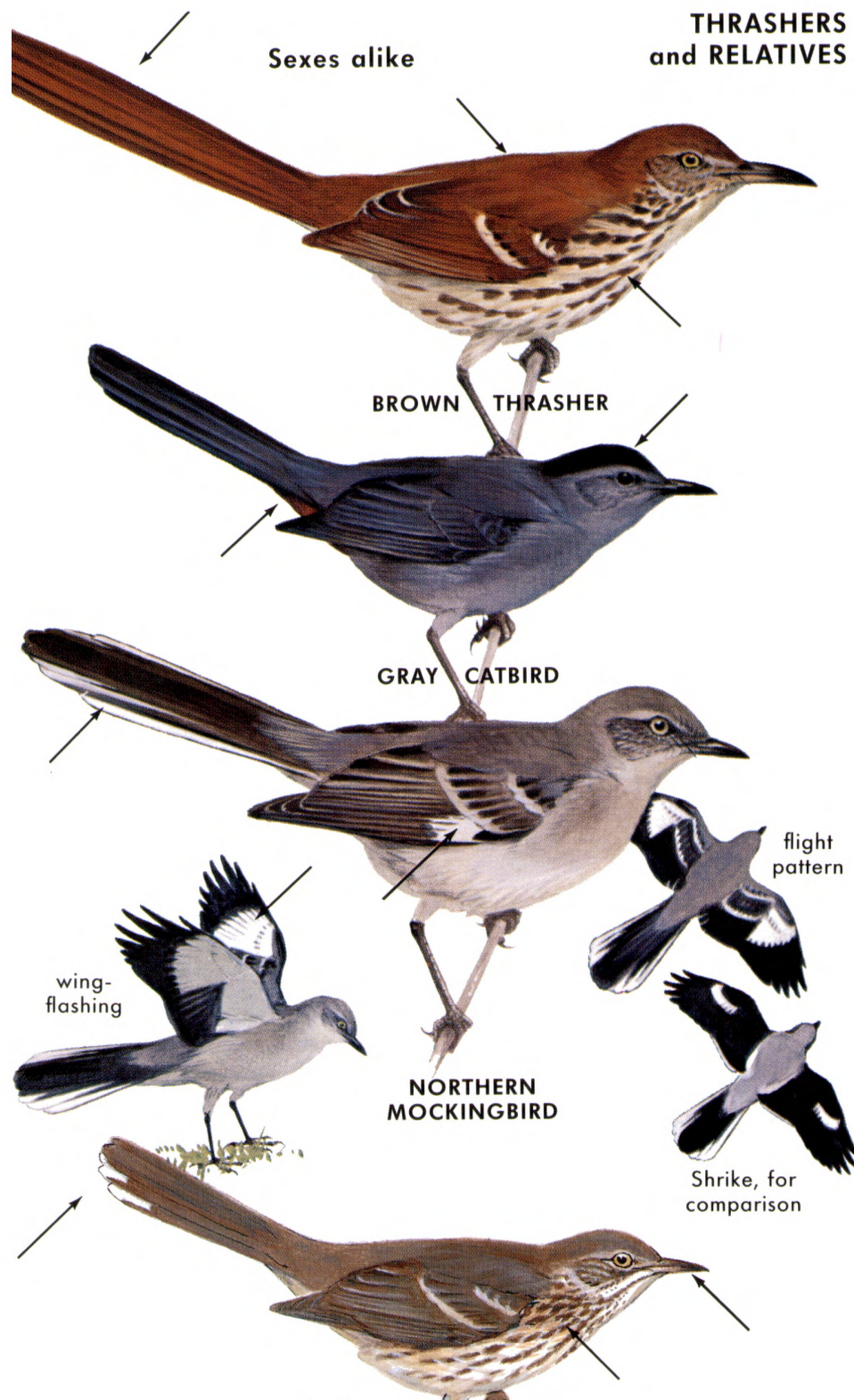

SAGE THRASHER 
11-13" (28-33 cm). A large, dull gray-brown thrasher, with a pale cinnamon belly and undertail coverts; tail long; bill sickle-shaped. The eyes are dark brown. It is the only thrasher of this type in California west of the desert divides (except very locally, where Le Conte's and Crissal thrashers overlap).

Voice: Note, a dry chak, also a sharp g-leek. Song, a long, sustained series of notes and phrases, some musical, some harsh. Phrases may be repeated once or twice, but not several times as in Mockingbird; song more leisurely than Mocker's.

Range: California, n. Baja California. Map 317. Habitat: Chaparral, foothills, valley thickets, parks, gardens.

CRISSAL THRASHER Toxostoma crissale

M318

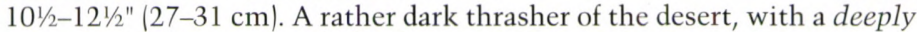
curved bill. Note the dark chestnut undertail coverts (or crissum), darker than in other thrashers. No breast spots. The eyes are dull yellowish.

Voice: Song sweeter and less spasmodic than in other thrashers. Note, pichoory or chideary, repeated two or three times.

Range: Sw. U.S. to cen. Mexico. Map 318. Habitat: Dense brush along desert streams, mesquite thickets.

LE CONTE'S THRASHER Toxostoma lecontei

M319

10-11" (25-28 cm). A very pale thrasher of the desert, with a darker tail. The eyes are dark.

Similar species: (1) Crissal and California thrashers are much darker overall. (2) The other thrashers have spotted breasts.

Voice: Song (Jan.-Mar.) similar to songs of most other thrashers. Note, $t i$ rup, rising on second syllable.

Range: Sw. U.S., nw. Mexico. Map 319. Habitat: Desert flats with sparse bushes, Atriplex.

CURVE-BILLED THRASHER Toxostoma curvirostre

M317

91/2-111/2" (24-29 cm). This, the commonest desert thrasher, can be told from the others that have well-curved bills by the mottled breast, which is indistinct in the westernmost form, palmeri. Some individuals have narrow white wing bars. Eyes pale orange. Juvenile has yellow eyes, straighter bill.

Voice: Note, a sharp, liquid whit-wheet! (like a whistle to attract attention). Song, a musical series of notes and phrases, almost grosbeak-like in quality but faster. Not much repetition.

Range: Resident, sw U.S. to s. Mexico. map 317. Habitat: Deserts, arid brush.

BENDIRE'S THRASHER Toxostoma bendirei

M316

9-11" (23-28 cm). Of the various drab desert thrashers, this one may be know by its shorter, more robin-like bill (lower mandible quite straight). Breast highly spotted. Eyes usually yellow.

Similar species: Curve-billed Thrasher usually has a longer, more curved bill; more blurry spotting; more orange eyes. Caution: Young Curve-bill may have a bill as short as Bendire's, and yellow eyes.

Voice: Song, a continuous, clear, double-noted warble, not broken into phrases. Note, a soft tirup.

Range: Sw. U.S. to Sinaloa, Mexico. Map 316. Habitat: Desert, farmland; cholla, thorny bushes. 

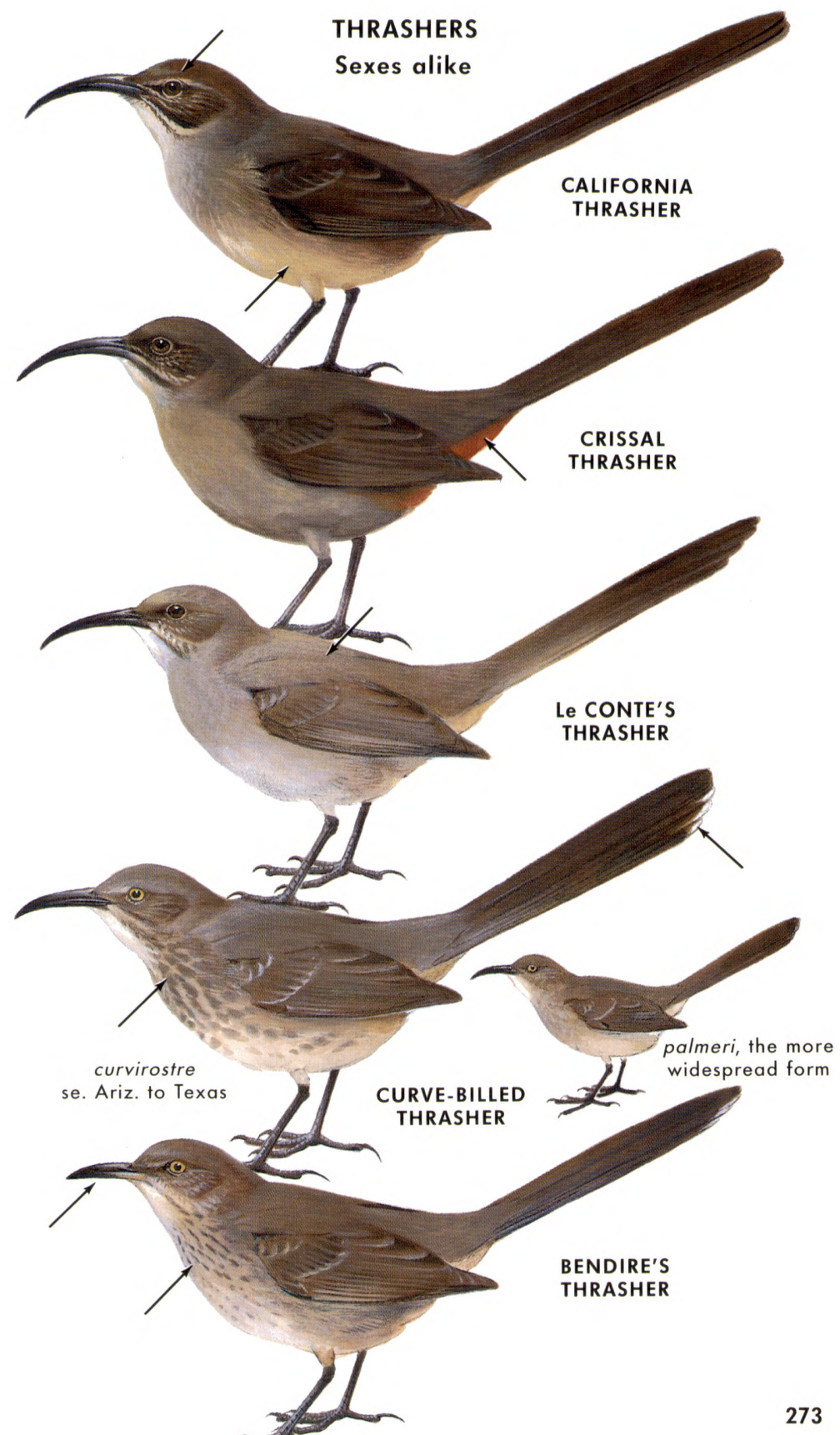


\section{- THRUSHES. Family Turdidae}

Large-eyed, slender-billed, usually strong-legged songbirds. Most species that bear the name "thrush" are brown-backed, with spotted breasts. Robins and bluebirds, etc., suggest their relationship through their speckle-breasted young. Thrushes are often fine singers. Food: Insects, worms, snails, berries, fruits. Range: Nearly worldwide. No. of species: World 316; West 14 (+6 casual or accidental).

AMERICAN ROBIN Turdus migratorius

M309

9-11" $(23-28 \mathrm{~cm})$. A very familiar bird, often seen walking with an erect stance on lawns. Recognized by its dark gray back and brick-red breast. Dark stripes on a white throat. The head and tail of the male are blackish; those of the female grayer. The young bird has a speckled breast, but the rusty wash identifies it.

Voice: Song, a clear caroling; short phrases, rising and falling, often prolonged. Notes, tyeep and tut-tut-tut.

Range: Alaska, Canada to s. Mexico. West: Map 309. Habitat: Cities, towns, farmland, lawns, shade trees, forests; in winter, berry-bearing trees.

VARIED THRUSH IXoreus naevius

M310

9-10" $(23-25 \mathrm{~cm})$. Similar to the American Robin, but with an orangish eyestripe, orange wing bars, and a wide black band (male) or gray band (female) across the rusty breast. Young: Breastband imperfect or speckled; rusty wing bars and eyestripe distinguish it from a young Robin.

Voice: A long, eerie, quavering, whistled note, followed, after a pause, by one on a lower or higher pitch. A liquid chup.

Range: Alaska, w. Canada, nw. U.S. Map 310. Habitat: Thick, wet forest, conifers; in winter, woods, ravines, thickets.

\section{RUFOUS-BACKED ROBIN Turdus rufopalliatus}

9" $(23 \mathrm{~cm})$. This rare Mexican visitor is like a pale American Robin (extensive cinnamon underparts, grayish head, wings, and tail), but with a rufous back and no white around the eye. A timid skulker.

Range: Western and S. Mexico. West: A rare but regular fall-winter visitor to s. Arizona. Accidental, Texas, California.

TOWNSEND'S SOLITAIRE Myadestes townsendi

M304

$8 "(20 \mathrm{~cm})$. A slim gray bird with a white eye-ring, white sides on the tail, and buffy wing patches. The pattern in the wing and tail give it a nottoo-remote resemblance to a Mockingbird, but note the eye-ring, darker breast, and especially the buff wing patches.

Range: Alaska, nw. Canada, w. U.S., n. Mexico. Map 304. Habitat: Conifer forests in mountains, rocky cliffs, thickets; in winter, chaparral, pinyon-juniper, open woods, wooded streams. 


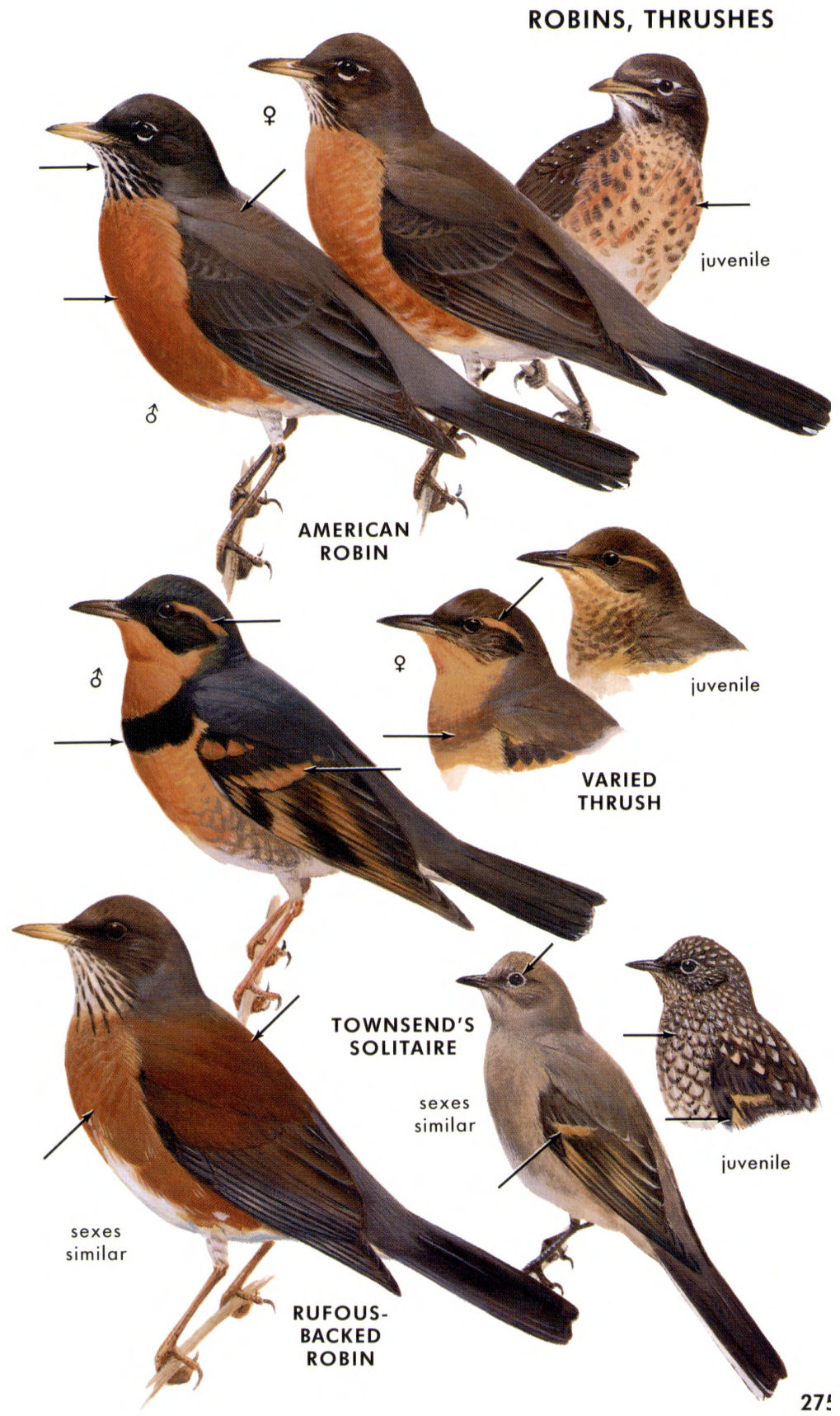


$61 / 2-71 / 2^{\prime \prime}(16-19 \mathrm{~cm})$. Note the uniform brown cast above and the grayish tones on the flanks. No strong eye-ring (may have a dull whitish ring). Of all our brown thrushes, the least spotted; the spots may be indistinct in eastern birds, which are more tawny above than birds of the western mountains, which are darker brown.

Voice: Song, liquid, breezy, ethereal; wheeling downward: vee-ur, vee-ur, veer, veer. Note, a low phew or view.

Range: S. Canada, n. and cen. U.S. Winters from Colombia to Brazil. West: Map 305. Habitat: Damp deciduous woods.

SWAINSON'S THRUSH Catharus ustulatus

M307

$7^{\prime \prime}(18 \mathrm{~cm})$. This spotted thrush is marked by its conspicuous buffy eye-ring, buff on cheeks and upper breast. Gray-cheeked Thrush has a less conspicuous eye-ring.

Voice: Song, breezy, flutelike phrases, each phrase sliding upward. Note, whit, or foot. Migrants at night (in sky), a short heep, or queeah.

Range: Alaska, Canada, w. and ne. U.S. Winters Mexico to Peru. West: Map 307. Habitat: Spruce forests; in migration, other woods.

GRAY-CHEEKED THRUSH Catharus minimus

M306 $7-8^{\prime \prime}(18-20 \mathrm{~cm})$. A dull gray-brown thrush, distinguished from Swainson's by its grayish cheeks and less conspicuous eye-ring.

Voice: Song, thin and nasal; suggests Veery's, but often rising abruptly at close (Veery's goes down): whee-wheeoo-titi-whee. Note, vee- $a$ or quee- $a$, higher and more nasal than Swainson's note.

Range: Ne. Siberia, Alaska, Canada, ne. U.S. Winters from W. Indies and Costa Rica to Brazil. West: Map 306. Habitat: Boreal forests, tundra scrub; in migration, other woodlands.

HERMIT THRUSH Catharus guttatus

M308

7" $(18 \mathrm{~cm})$. A spot-breasted brown thrush with a rufous tail. When perched, it has a habit of cocking its tail and dropping it slowly.

Similar species: Fox Sparrow (some races have a rusty tail) is heavily streaked rather than spotted; note the conical bill.

Voice: Note, a low chuck; also a scolding tuk-tuk-tuk and a harsh pay. Song, clear, ethereal, flutelike; three or four phrases at different pitches, each with a long introductory note.

Range: Alaska, Canada, w. and ne. U.S. Winters U.S. to El Salvador. West: Map 308. Habitat: Conifer or mixed woods, forest floor; in winter, woods, thickets, parks.

\section{WOOD THRUSH Hylocichla mustelina}

$8^{\prime \prime}(20 \mathrm{~cm})$. Rusty-headed. Smaller than a Robin; plumper than the other brown thrushes, distinguished by the deepening rufous about the head, the striped cheeks, and the rounder, more numerous breast spots.

Range: Breeds se. Canada, e. and cen. U.S.; a very rare or casual stray in most western states west to Idaho, Oregon, and California. 


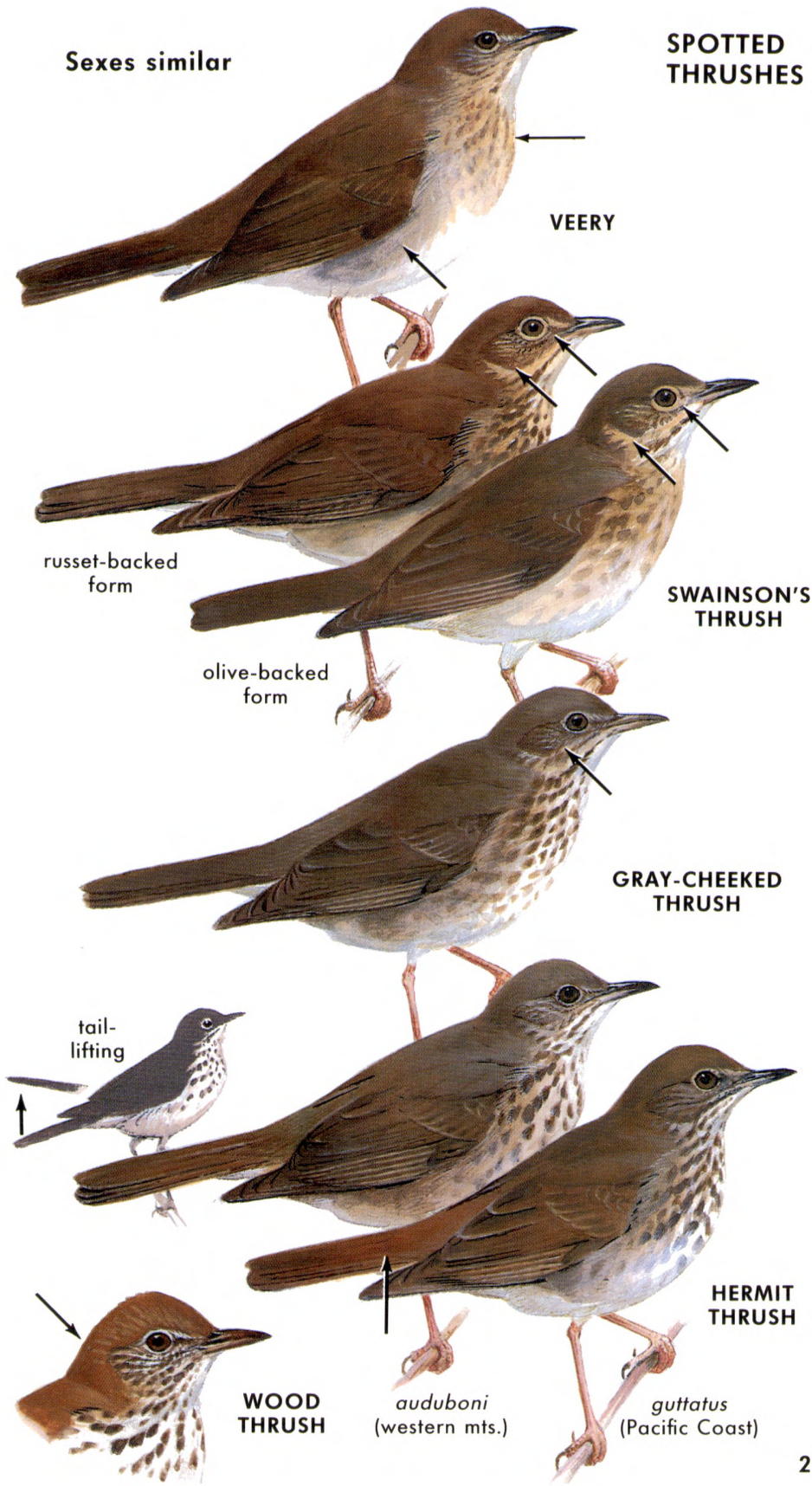


$61 / 2-7^{\prime \prime}(16-18 \mathrm{~cm})$. A bit larger than a sparrow; appears roundshouldered when perched. Head, wings, and tail blue; breast and back rusty red. (In some birds the back is partially or wholly blue.) Throat blue. Females are paler, duller, with rusty breast, grayish throat and belly. Young birds are speckle-breasted, grayish, devoid of red, but with some telltale blue in wings and tail.

Similar species: (1) Lazuli Bunting has white wing bars. (2) Male Mountain Bluebird has a blue breast (see also female).

Voice: A short pew or mew. Also a hard, chattering note.

Range: Breeds from s. British Columbia, western U.S. to mountains of cen. Mexico. Map 302. Habitat: Scattered trees, open conifer forests, farms; in winter, semi-open terrain, brush, deserts.

EASTERN BLUEBIRD Sialia sialis

M301

7" $(18 \mathrm{~cm})$. Similar to Western Bluebird but throat rusty, not blue. Belly and undertail whiter, not as gray. Western Bluebird has a blue throat and usually some rust color on the back. Female duller than male; has a rusty throat and breast, white belly. Juvenile: Specklebreasted; similar to juvenile Western Bluebird.

Voice: Note, a musical chur-wi. Song, 3 or 4 gurgling notes.

Range: East of Rockies; s. Canada to Gulf states; also se. Arizona to Nicaragua. West: Map 301. Habitat: Open country with scattered trees; farms, roadsides.

MOUNTAIN BLUEBIRD Sialia currucoides

M303

7" $(18 \mathrm{~cm})$. Male: Turquoise blue, paler below; belly whitish. No rusty. Female: Dull brownish, with a touch of blue on rump, tail, and wings. Has a straighter posture than female Western Bluebird and lacks rusty wash on gray-brown breast.

Voice: A low chur or phew. Song, a short, subdued warble.

Range: Alaska, w. Canada to sw. U.S. West: Map 303. Habitat: Open country with some trees; in winter, also treeless terrain.

BLUETHROAT Luscinia svecica

$5 \frac{1 / 2 "}{}(14 \mathrm{~cm})$. A small, sprightly bird; when flirted, the tail shows a chestnut base. Male in summer: Blue throat patch, with a reddish spot and a reddish band separating the blue from the white. Female has a white throat with a dark necklace.

Voice: A sharp tac and a soft wheet. Song, repetitious notes, musical and varied; often a cricketlike note.

Range: Eurasia, Alaska; winters to India, n. Africa. West: Breeds in n. and w. Alaska from Brooks Range to Seward Peninsula. Habitat: Dwarf willow, thick brush.

NORTHERN WHEATEAR Oenanthe oenanthe

$6^{\prime \prime}(15 \mathrm{~cm})$. A small, dapper bird of arctic barrens, flitting from rock to rock, fanning its tail and bobbing. Note the white rump and sides of the tail. The black on the tail forms a broad inverted T. Breeding male has a blue-gray back, black wings, and a black ear patch. Female and autumn male are buffier, with a brown back.

Voice: Note, a hard chak-chak or chack-weet, weet-chack.

Range: Eurasia, Alaska, Canada, Greenland. Migrates to Africa, India. West: Breeds from n. Alaska, n. Yukon to coastal Alaska, sw. Yukon. Accidental, British Columbia, Oregon, n. California. 
- SHRIKES. Family Laniidae. Songbirds with hook-tipped bills, hawk-like behavior. Shrikes perch watchfully on treetops, wires; often impale prey on thorns, barbed wire. Food: Insects, lizards, mice, small birds. Range: Widespread in Old World; 2 in N. America. No. of species: World 74; West $2(+1$ accidental).

NORTHERN SHRIKE Lanius excubitor

M325

$9-10^{\prime \prime}(23-25 \mathrm{~cm})$. Similar to the Loggerhead Shrike; note the faintly barred breast and the pale base of the lower mandible. Bill longer, more hooked. Juvenile: Brown, with fine bars on breast.

Similar species: Adult Loggerhead Shrike has a solid black bill; black mask meets over base of bill. Juvenile may have faint bars, but is grayer than the young Northern.

Voice: Song, a disjointed, thrasher-like succession of harsh notes and musical notes. Note, shek-shek; a grating jaaeg.

Range: N. America, Eurasia, n. Africa. West: Map 325. Habitat: Semi-open country with lookout posts; trees, scrub.

LOGGERHEAD SHRIKE Lanius ludovicianus

M326

9" $(23 \mathrm{~cm})$. Big-headed, slim-tailed; gray, black, and white, with a black mask. Sits quietly on wires or bush tops; taking off, flies low with flickering flight showing white patches, then swoops upward to its perch. Suggests a Mockingbird (p. 271).

Voice: Song, harsh, deliberate notes and phrases, repeated 3-20 times, suggesting Mockingbird's song; queedle, queedle, over and over, or tsurp-see, tsurp-see. Note, shack shack.

Range: S. Canada to s. Mexico. West: Map 326. Habitat: Semi-open country with lookout posts; wires, trees, scrub.

- STARLINGS. Family Sturnidae. A varied family; some blackbird-like. Usually short-tailed, sharp-billed. Gregarious. Food: Insects, seeds, berries. Range: Widespread in Old World. No. of species: World 109; West 2 (introduced).

EUROPEAN STARLING Sturnus vulgaris

M327

$71 / 2-81 / 2$ " (19-21 cm). A gregarious, garrulous, short-tailed "blackbird"; shape of a meadowlark. In flight, looks triangular; flies swiftly and directly. In spring iridescent; bill yellow. In winter, heavily speckled; bill dark, changing to yellow in spring. Young Starling is dusky, a bit like female Cowbird, but tail shorter, bill longer.

Voice: A harsh tseeeer; a whistled whooee. Also clear whistles, clicks, chuckles; sometimes mimics other birds.

Range: Eurasia, n. Africa. Introduced N. America and elsewhere. West: Map 327. Habitat: Cities, parks, farms, open groves, fields.

CRESTED MYNA Acridotheres cristatellus

$10^{1 / 2 "}(26 \mathrm{~cm})$. A large, chunky, short-tailed bird; black, with large white wing patches; bill yellow; legs yellow. The forehead is adorned with a short bushy crest.

Voice: Starling-like; repeated phrases. An accomplished mimic.

Range: Se. Asia. Introduced in Philippines and British Columbia. West: Resident in and near Vancouver, British Columbia; local, s. Vancouver I. Casual, w. Washington, nw. Oregon. 


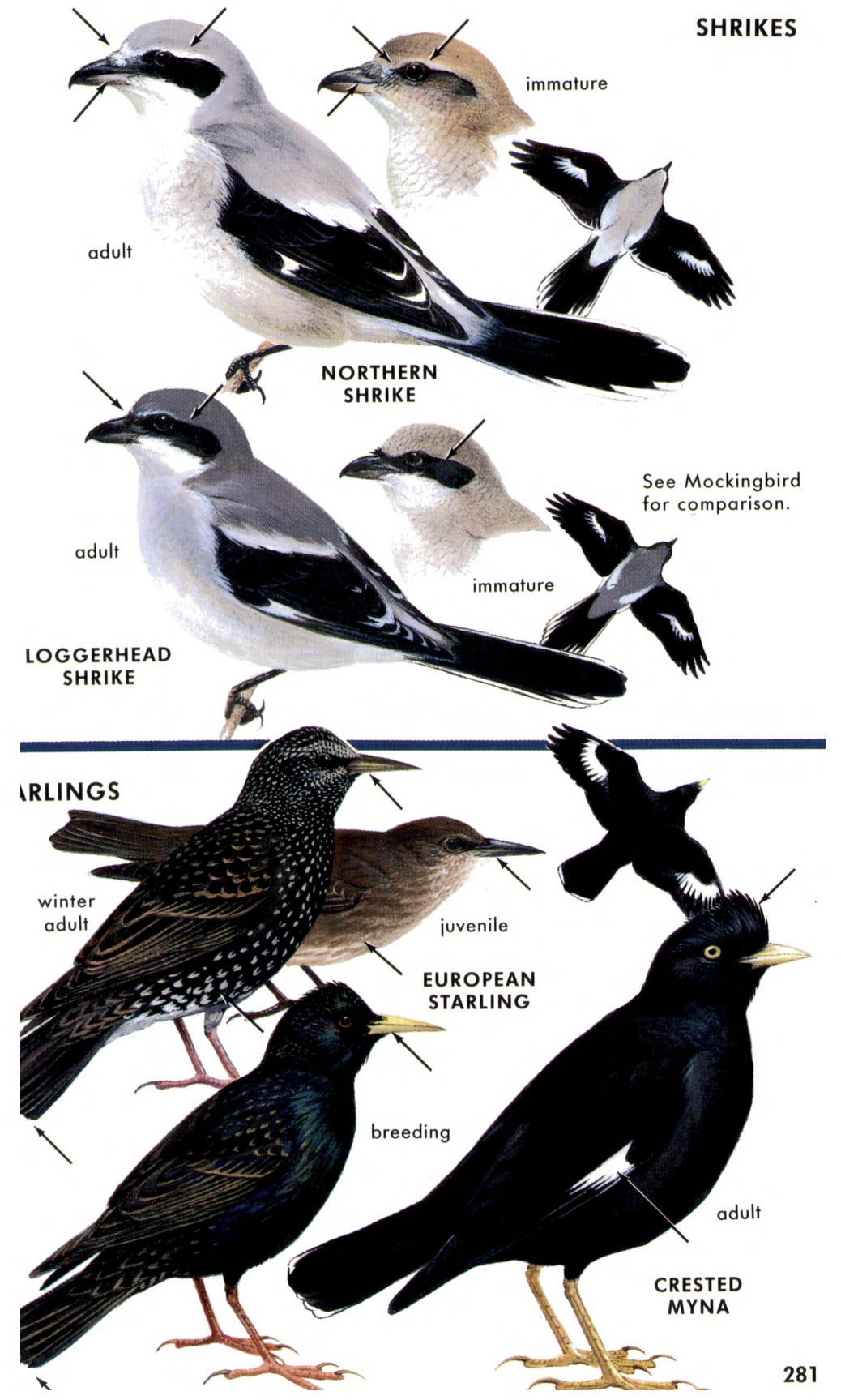


- WAXWINGS. Family Bombycillidae. The sleekest birds; a pointed crest may be raised or lowered. Waxy red tips on secondaries in most individuals. Gregarious. Food: Berries, insects. Range: N. Hemisphere. No. of species: World 3; West 2.

CEDAR WAXWING Bombycilla cedrorum

M323

$7^{\prime \prime}(18 \mathrm{~cm})$. Note the yellow band at the tip of the tail. A sleek, crested, brown bird, larger than a House Sparrow. Adults usually have waxy red tips on the secondaries. Differs from Bohemian Waxwing in having yellow on the belly, white (not rusty) undertail coverts. Juvenile is grayer, softly streaked below. Waxwings are gregarious; they fly and feed in compact flocks. Although they are berry-eaters, they often indulge in fly-catching.

Voice: A high, thin lisp or zeee; sometimes slightly trilled.

Range: Se. Alaska, Canada, to s.-cen. U.S. Winters s. Canada to Panama. West: Map 323. Habitat: Open woodlands, fruiting trees, orchards; in winter, widespread, including towns; nomadic.

BOHEMIAN WAXWING Bombycilla garrulus

M322

$8^{\prime \prime}(20 \mathrm{~cm})$. Similar to the Cedar Waxwing (yellow tip on tail), but larger and grayer, with no yellow on belly; wings with strong white or white and yellow markings. Note the deep rusty undertail coverts (these are white in Cedar Waxwing). Often travels in large nomadic flocks.

Voice: Zreee, rougher than thin note of Cedar Waxwing.

Range: N. Eurasia, nw. N. America. Winters to s. Eurasia, ne. and sw. U.S. West: Map 322. Habitat: In summer, boreal forests, muskeg; in winter, widespread in search of berries, especially in towns where plantings and fruiting trees attract them.

- SILKY-FLYCATCHERS. Family Ptilogonatidae. Slim, crested, waxwing-like birds. Range: Sw. U.S. to Panama. Food: Berries, mistletoe; insects. No. of species: World 4; West $1(+1$ accidental).

PHAINOPEPLA Phainopepla nitens

M324

7-73/4" $(18-19 \mathrm{~cm})$. Male: A slim, glossy black bird with a slender crest. White wing patches are conspicuous in flight. Female: Dark gray with a slender crest; wing patches light gray, not conspicuous. Eats berries but also catches flies.

Similar species: (1) Cedar Waxwing is much browner than female Phainopepla, has a yellow tailband. (2) Mockingbird (white wing patches) is gray with much white in the tail.

Voice: Note, a soft low wurp. Song, a weak, casual warble, wheezy and disconnected.

Range: Sw. U.S. to s. Mexico. Map 324. Habitat: Desert scrub, mesquite, oak foothills, mistletoe, pepper trees. 


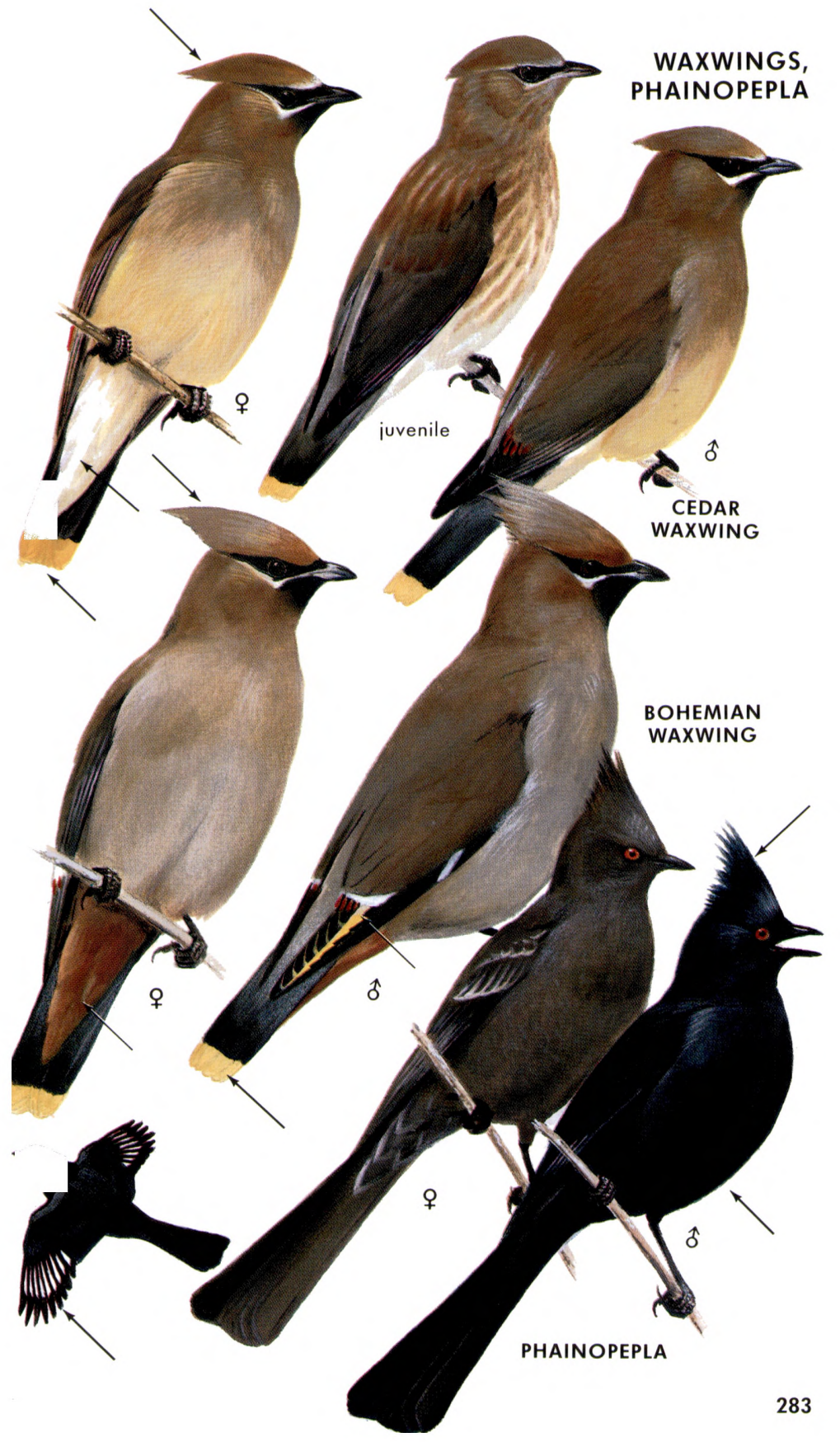


- VIREOS. Family Vireonidae. Small, olive- or gray-backed birds, much like wood warblers, usually less active. Bills with a more curved ridge and slight hook. May be divided into those with wing bars (and "spectacles") and those without (these have eyestripes). Food: Mostly insects. Range: Canada to Argentina. No. of species: World 43; West $91+1$ accidental).

BLUE-HEADED VIREO Vireo solitarius

M330

5-6" (13-15 cm). White "spectacles," gray head, olive or gray back, snowwhite throat. Two wing bars. See variation opposite. Split off from Blueheaded is Plumbeous Vireo (V. plumbeus) of the Great Basin area and Cassin's Vireo (V. cassinii) of the West Coast.

Voice: Song, sweet whistled phrases; short deliberate pauses.

Range: Canada to El Salvador. Winters to s. U.S. to Nicaragua, Cuba. West: Map 330. Habitat: Mixed conifer-deciduous woods.

BLACK-CAPPED VIREO Vireo atricapillus

$4 \frac{1}{2} "(11 \mathrm{~cm})$. A small, sprightly vireo; top and sides of head glossy black in male, slate gray in female. Two wing bars. White "spectacles" formed by eye-ring and loral patch; eyes red.

Voice: Song, hurried, harsh; phrases remarkable for restless, almost angry quality. Alarm note, a harsh chit-ah.

Range: Breeds sw. Kansas, cen. Oklahoma, w. and cen. Texas (through Edwards Plateau and Big Bend) to Coahuila, Mexico. Winters in w. Mexico. Habitat: Oak scrub, brushy hills, rocky canyons.

YELLOW-THROATED VIREO Vireo flavifrons

$5 "(13 \mathrm{~cm})$. Note the bright yellow throat, yellow "spectacles," and white wing bars. See Pine Warbler (white tail spots, streaks).

Voice: Song, similar to Red-eyed Vireo's, but has a burry quality.

Range: Breeds e. U.S., se. Canada. West: Rare migrant east of Rockies; casual west to Utah, Nevada, California.

BELL'S VIREO Vireo bellii

M328

$4 \frac{1}{2}-5$ " (11-13 cm). Small, grayish; nondescript. One or two light wing bars, pale yellowish-washed sides. Distinguished from Warbling Vireo by the wing bar(s) and whitish eye-ring. Flicks tail.

Voice: Sings as if through clenched teeth; husky phrases at short intervals: cheedle cheedle chee? cheedle cheedle chew!

Range: Cen. and sw. U.S., n. Mexico. Winters Mexico to Nicaragua. West: Map 328. Habitat: Willows, streamsides.

HUTTON'S VIREO Vireo huttoni

M331

$4 \frac{1}{4}-4 \frac{3}{4} "(11-12 \mathrm{~cm})$. Note the incomplete eye-ring, broken by a dark spot above the eye. A small, olive-brown vireo with two broad white wing bars, a partial eye-ring, and a large light loral spot. Suggests a Rubycrowned Kinglet, but Hutton's Vireo is slightly larger, has a heavier bill, and lacks the dark wing bar. Does not twitch its wings like a kinglet.

Voice: A double-noted zu-weep (rising inflection), sometimes oft-repeated; vireo quality. A hoarse, deliberate day dee dee.

Range: Sw. British Columbia to Guatemala. Map 331. Habitat: Woods and adjacent brush; prefers oaks.

WHITE-EYED VIREO Vireo griseus (not shown)

Eastern. Barely reaches 100th meridian in Texas. Casual or accidental in Southwest (Colorado, Utah, New Mexico, Arizona, California). See A Field Guide to the Birds (Eastern). 

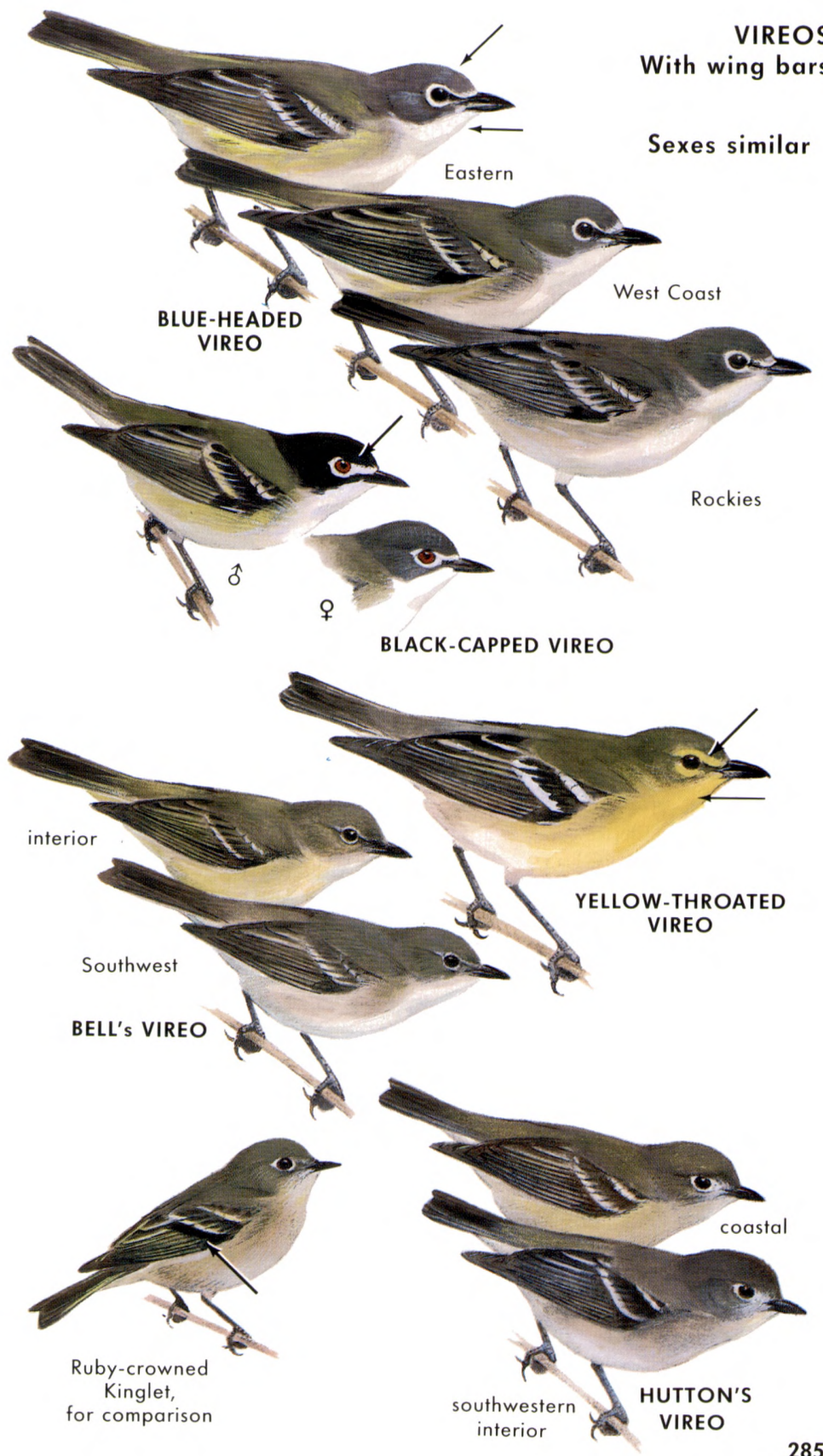
$6 "(15 \mathrm{~cm})$. Note the gray cap contrasting with the olive back, and the strong, black-bordered white eyebrow stripe. The red iris may not be obvious at a distance. The iris is brown in immature birds in fall.

Voice: Song, abrupt phrases, repeated as often as 40 times per minute; monotonous. Note, a nasal, whining chway.

Range: Canada to Gulf states. Winters in Amazon basin. West: Map 334. Habitat: Woodlands, shade trees, groves.

\section{YELLOW-GREEN VIREO Vireo flavoviridis}

6" $(15 \mathrm{~cm})$. Very similar to Red-eyed Vireo (both in behavior and voice), but strong yellow tones on underparts; back greener; head stripes less distinct. Some authors lump the two species.

Range: Rio Grande delta, n. Mexico, to Panama. Winters in S. America. West: Casual fall visitor to southern and coastal California; recorded in summer in s. Arizona.

PHILADELPHIA VIREO Vireo philadelphicus

M333

$43 / 4^{\prime \prime}(12 \mathrm{~cm})$. This warbler-like vireo combines unbarred wings and strongly yellow-tinged underparts, especially on the breast.

Similar species: (1) Warbling Vireo usually lacks yellow (but may have a tinge on the sides). Note the dark loral spot (between eye and bill) in the Philadelphia. (2) Fall Tennessee Warbler (p. 300) has clear white (not yellow) undertail coverts.

Voice: Song similar to Red-eyed Vireo's; higher, slower.

Range: S. Canada, ne. edge of U.S. Winters in Cen. America. West: Map 333. Habitat: Second-growth woodlands, poplars, willows, alders.

WARBLING VIREO Vireo gilvus

M332

$5^{\prime \prime}(13 \mathrm{~cm})$. In this very plain vireo, note the whitish breast and the lack of black borders on the eyebrow stripe.

Similar species: (1) Philadelphia Vireo is yellowish below, has dark lores. (2) Red-eyed Vireo has black borders on the eyebrow stripe.

Voice: Song distinctive; a languid warble, unlike broken phrases of other vireos; suggests Purple Finch's song, but less spirited, with burry undertone. Note, a wheezy querulous twee.

Range: Canada to s. U.S., cen. Mexico. Winters Mexico to Nicaragua. West: Map 332. Habitat: Deciduous and mixed woods, aspen groves, poplars, shade trees.

GRAY VIREO Vireo vicinior

M329

$5-53 / 4^{\prime \prime}(13-14 \mathrm{~cm})$. This plain, gray-backed vireo of arid mountains has a narrow white eye-ring but differs from other vireos with eyerings by having no wing bars or only one faint bar. Though drab, it has character, flopping its tail like a gnatcatcher.

Similar species: Bell's Vireo (p. 285) usually has two wing bars (sometimes only one). Habitat different (low stream edges).

Voice: Song similar to Solitary Vireo's, but more rapid, "patchy." Range: Sw. U.S. to cen. Mexico. Map 329. Habitat: Brushy mountain slopes, mesas, open chaparral, scrub oak, junipers. 

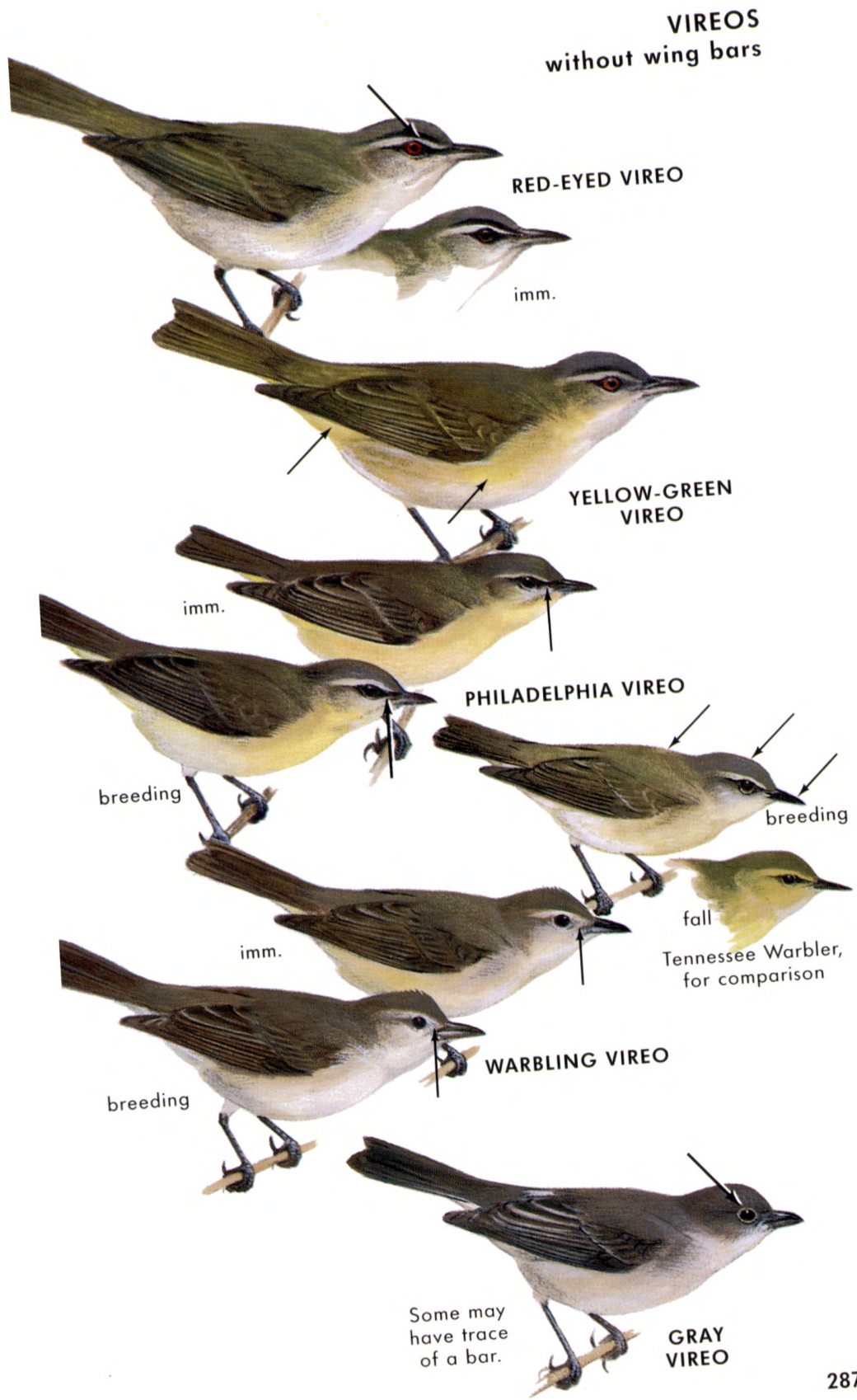
- WOOD WARBLERS. Family Parulidae. Subfamily Parulinae. Active, brightly colored birdlets, usually smaller than sparrows, with thin, needle-pointed bills. The majority have some yellow. Identification in autumn is often difficult. Food: Mainly insects. Range: Alaska and Canada to n. Argentina. No. of species: World 114; West 53 (including several that are purely casual or accidental, categories that are hard to define because recent intensive field work has shown they may be rare but regular as vagrants at certain coastal points and desert oases).

MAGNOLIA WARBLER Dendroica magnolia

M342

43/4" (12 cm). The "Black-and-yellow" Warbler. Upperparts blackish, with large white patches on wings and tail; underparts yellow, with heavy black stripes. Note the black tail crossed midway by a broad white band (from beneath, the tail is white with a broad black tip). Immature has weak breast stripes, but the tail pattern is distinctive.

Voice: Song suggests Yellow Warbler's but is shorter; weeta weeta weetsee (last note rising), or weeta weeta wit-chew.

Range: Canada, ne. U.S. Winters Mexico, W. Indies to Panama. West: Map 342. Habitat: Low conifers, except in migration.

\section{YELLOW-RUMPED WARBLER Dendroica coronata}

M344

(Including "Audubon" and "Myrtle" Warblers.) 5-6" (13-15 cm). Note the bright yellow rump and the note (a loud check or tchip). Male in spring: Blue-gray above; heavy black breast patch (like an inverted U); throat, crown, side patches yellow. "Audubon" form (Western U.S., sw. Canada) differs from "Myrtle" form (Alaska, Canada, e. U.S.) in having a yellow throat, large white wing patches. Female in spring: Brown, not gray; pattern similar except for wing patch (has two white bars). Winter adults and young: Brownish above; whitish below, streaked; throat yellowish (sometimes $\mathrm{dim}$ ) in western "Audubon" form, rump yellow.

Voice: Song, junco-like but two-parted, rising or dropping in pitch, seetseet-seet-seet-seet, trrrrrrrr. Note, a loud check.

Range: Breeds Alaska, Canada, ne. and w. U.S. to Guatemala; winters to Panama. West: Map 344. Habitat: Conifer forests. In winter, varied; open woods, brush, thickets, gardens, even beaches.

CANADA WARBLER Wilsonia canadensis

M361

5-53/4" (13-14 cm). The "necklaced" warbler. Male: Solid gray above; bright yellow below, with necklace of short black stripes. Female and immature: Similar; necklace fainter or lacking. All have yellow "spectacles." No white in wings or tail.

Voice: Song, a staccato burst, irregularly arranged. Chip, chupety sweeditchety (Gunn). Note, tchip.

Range: Canada, e. U.S. Winters Oaxaca, Mexico, to e. Peru. West: Map 361. Habitat: Forest undergrowth, shady thickets. 

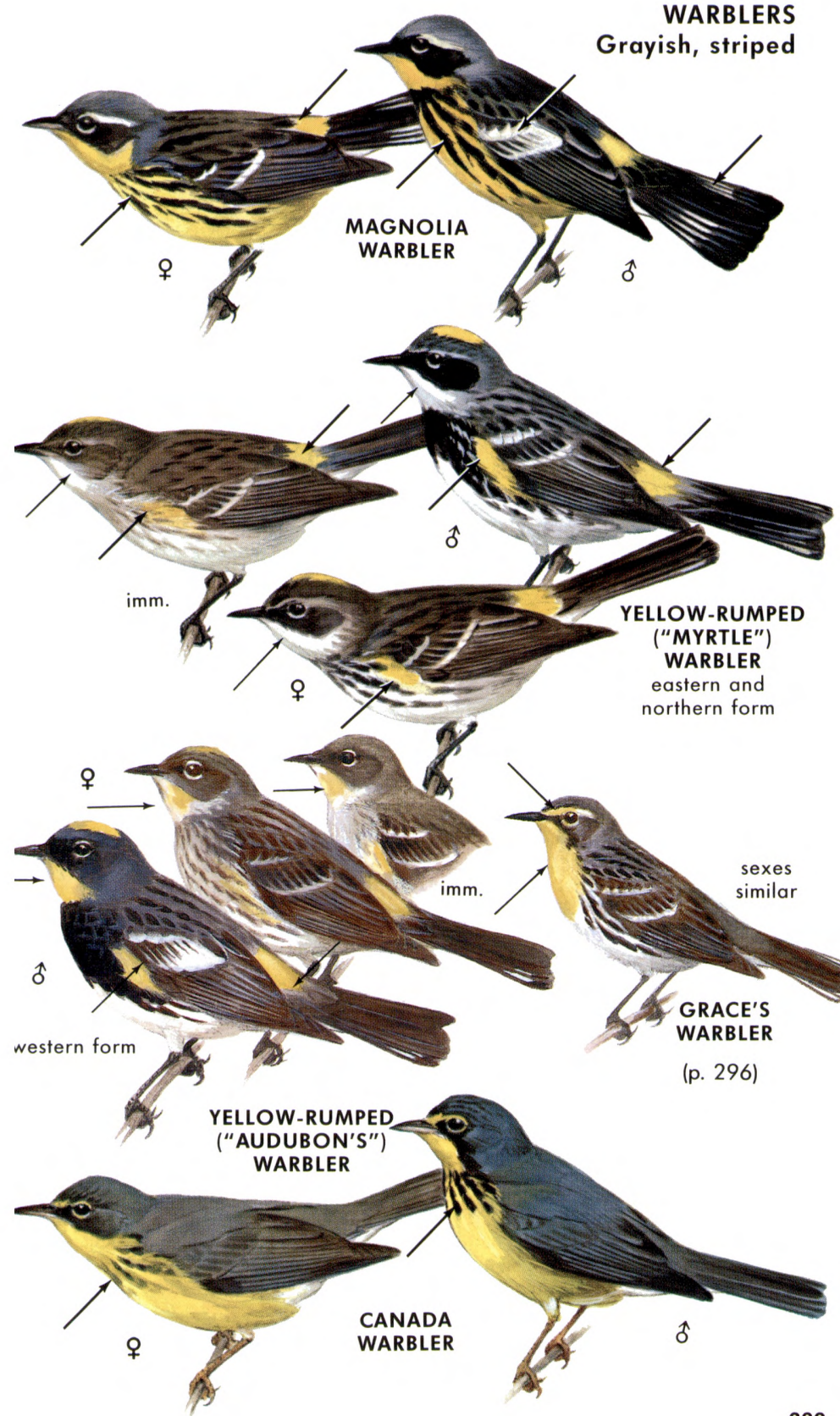
$4 \frac{1}{2}-5^{\prime \prime}(11-13 \mathrm{~cm})$. Male: Easily distinguished by the black and yellow pattern of the head, with a blackish cheek patch; underparts yellow, with striped sides. Female: Throat largely yellow, not black; may be known by the well-defined dark cheek patch, bordered by yellow as in the male.

Similar species: Hermit Warbler lacks black cheek and crown.

Voice: Song, similar to Black-throated Gray's: dzeer dzeer dzeer tseetsee or weazy, weazy, seesee. "The first 3 or 4 notes similar in pitch, with a wheezy, buzzy quality, followed by 2 or more highpitched sibilant notes" (H. H. Axtell).

Range: Breeds nw. N. America. Winters south to Nicaragua. Map 346. Habitat: Tall conifers, cool fir forests; in winter, also oaks, madroñas, laurels.

HERMIT WARBLER Dendroica occidentalis

M347

$43 / 4^{\prime \prime}(12 \mathrm{~cm})$. Note the bright yellow face set off by the black throat and nape and dark gray back. In the female the black of the throat is much reduced or wanting, but the yellow face, gray back, and whitish underparts identify it.

Similar species: (1) Male Townsend's Warbler has black cheek patches. Female has olive back, yellow breast. (2) In Canada (east of Rockies) see Black-throated Green Warbler.

Voice: Song, three high lisping notes followed by two abrupt lower ones: sweety, sweety, sweety, chup'chup' or seedle, seedle, seedle, chup' chup'. Abrupt end notes distinctive.

Range: Pacific states. Winters Mexico to California. Map 347. Habitat: Conifer forests; in migration, conifers and deciduous woods.

BLACK-THROATED GREEN WARBLER Dendroica virens

M347

$4 \frac{1}{2}-5^{\prime \prime}(11-13 \mathrm{~cm})$. Male: The bright yellow face is framed by the black throat and olive-green crown. Female: Recognized by the yellow face; much less black on the throat.

Similar species: Hermit Warbler (Pacific states) has yellow on crown, lacks eye stripe. Back gray; no black on sides.

Voice: A lisping, dreamy zoo zee zoo zoo zee or zee zee zee zee zoo $z e e$; the zee notes on same pitch, the zoo notes lower.

Range: Canada, ne. U.S. and south in mountains to Georgia. Winters s. Texas to Venezuela. West: Map 347. Habitat: Mainly conifers.

GOLDEN-CHEEKED WARBLER Dendroica chrysoparia

$4 \frac{1}{2}-5^{\prime \prime}(11-13 \mathrm{~cm})$. Breeds in the "cedar" hills of the Edwards Plateau, Texas; the warbler with yellow cheeks and a black throat usually found there. Male: Similar to Black-throated Green Warbler, but with a black back and blacker line through the eye. Female: Back olive-green; similar to a female Black-throated Green, but belly snowy white (lacking tinge of yellow).

Voice: Song, a hurried tweeah, tweeah, tweesy (H. P. Attwater) or bzzzz, laysee, daysee (E. Kincaid).

Range: Breeds only in Texas; mainly on Edwards Plateau; west to San Angelo, Rocksprings. Winters s. Mexico to Nicaragua. Habitat: Junipers, oaks; also streamside trees. Endangered. 

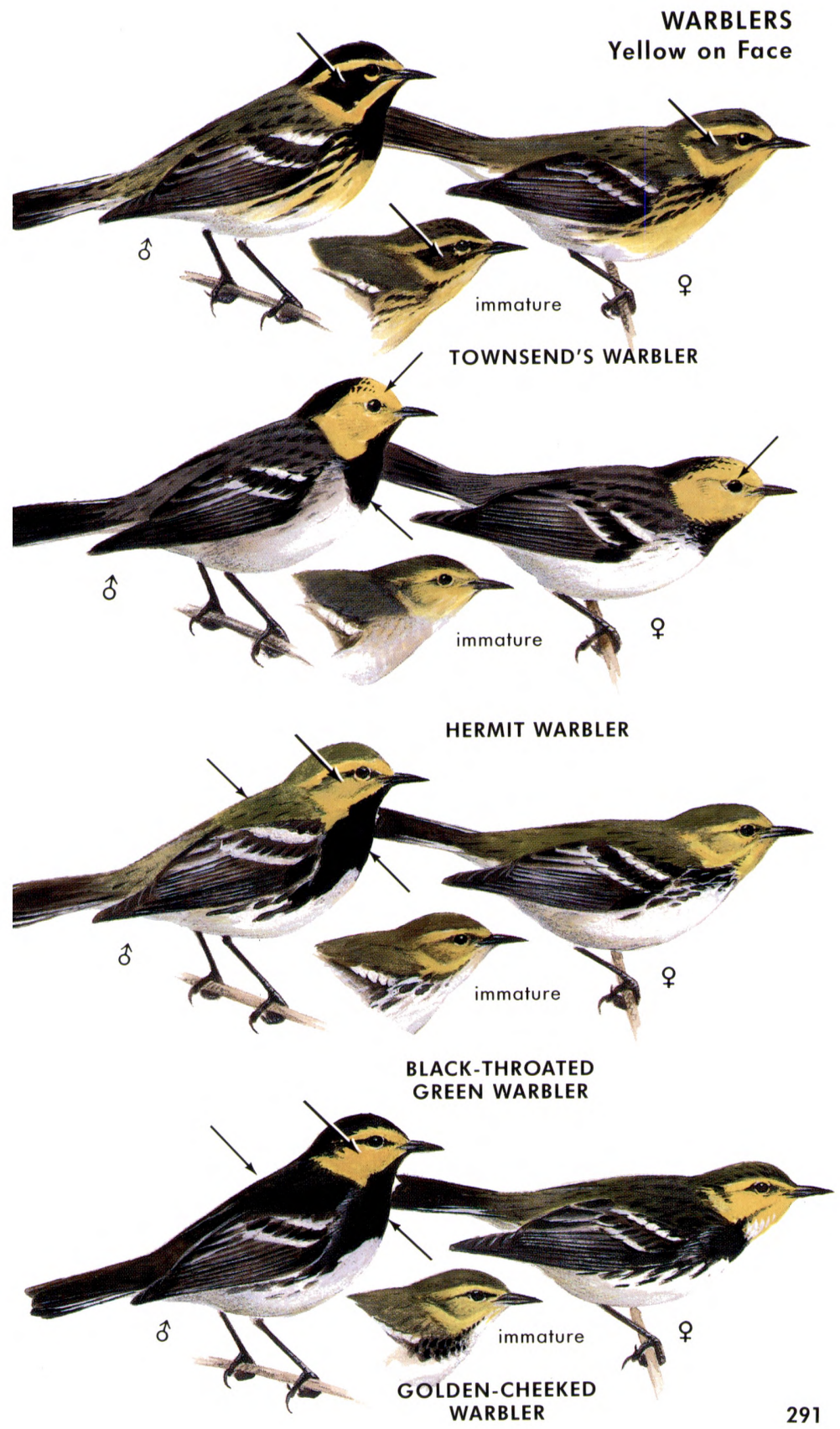
$41 / 2-51 / 2^{\prime \prime}(11-14 \mathrm{~cm})$. Creeps along trunks and branches. Striped lengthwise with black and white; has a striped crown and white stripes on its back. Female lacks the black throat and cheek.

Voice: Song, a thin weesee weesee weesee weesee weesee weesee; suggests one of Redstart's songs, but higher-pitched, longer.

Range: Canada to Gulf states. Winters s. U.S. to n. S. America. West: Map 352. Habitat: Woods; trunks, limbs of trees.

BLACKPOLL WARBLER Dendroica striata

M351

$5^{\prime \prime}(13 \mathrm{~cm})$. Male, spring: A striped gray warbler with a black cap, white cheeks. Female, spring: Less heavily streaked, lacking the black cap; greenish gray above, whitish below, streaked. Autumn: Olive above, greenish yellow below, faintly streaked; two wing bars; white undertail coverts; usually pale yellowish legs. Fall Baybreasted Warbler (p. 295) has dark legs.

Voice: Song, a thin, deliberate, mechanical zi-zi-zi zi-zi-zi-zi-zi-zi on one pitch, becoming stronger, then diminishing.

Range: Alaska, Canada, ne. U.S. Winters in tropical S. America. West: Map 351. Habitat: Conifers; broadleaf trees in migration.

BLACK-THROATED GRAY WARBLER Dendroica nigrescens M345 $4 \frac{1}{2}-5^{\prime \prime}(11-13 \mathrm{~cm})$. Male: Gray, with a black throat, cheek, and crown patches separated by white. Female: Slaty crown and cheek; light throat. Suggests Black-and-white Warbler, but lacks the white stripes on the back and crown.

Voice: Song a buzzy chant, zeedle zeedle zeedle zeet' che (next to last or last note higher). Variable; "full of Z's."

Range: Western N. America. Map 345. Winters s. California to s. Mexico. Habitat: Dry oak slopes, pinyons, junipers, open mixed woods.

\section{BLACK-THROATED BLUE WARBLER Dendroica caerulescens}

$5-5 \frac{1}{2} 2^{\prime \prime}(13-14 \mathrm{~cm})$. Male: Clean-cut; upperparts deep blue; throat and sides black, belly white; wing with white spot. Female: Brownbacked, with a light line over the eye and a small white wing spot. Immature and fall female may lack this white "pocket handkerchief," but note the dark cheek.

Voice: Song, a husky, lazy zur, zur, zur, zreee, or beer, beer, beer, bree (ending higher). May be shortened to two or three notes.

Range: Eastern N. America. Winters W. Indies. West: Casual migrant along w. edge of Plains from Alberta to Texas Panhandle; a few recorded west to Oregon, California, mainly in fall.

CERULEAN WARBLER Dendroica cerulea

$4 \frac{1}{2} 2^{\prime \prime}(11 \mathrm{~cm})$. Male: Blue above, white below. Note the narrow black ring across the chest. Female: Blue-gray and olive-green above, whitish below; two white wing bars, whitish eyebrow.

Similar species: Female suggests (1) Tennessee Warbler (p. 301), which has no wing bars, or (2) a fall Blackpoll, but has a more conspicuous eyebrow; lacks stripes on the back.

Voice: Rapid buzzy notes on the same pitch, followed by a longer note on a higher pitch: zray zray zray zreeeee.

Range: Eastern U.S.; winters Colombia to Bolivia. West: Accidental stray west to Colorado, Nevada, Arizona, California. 


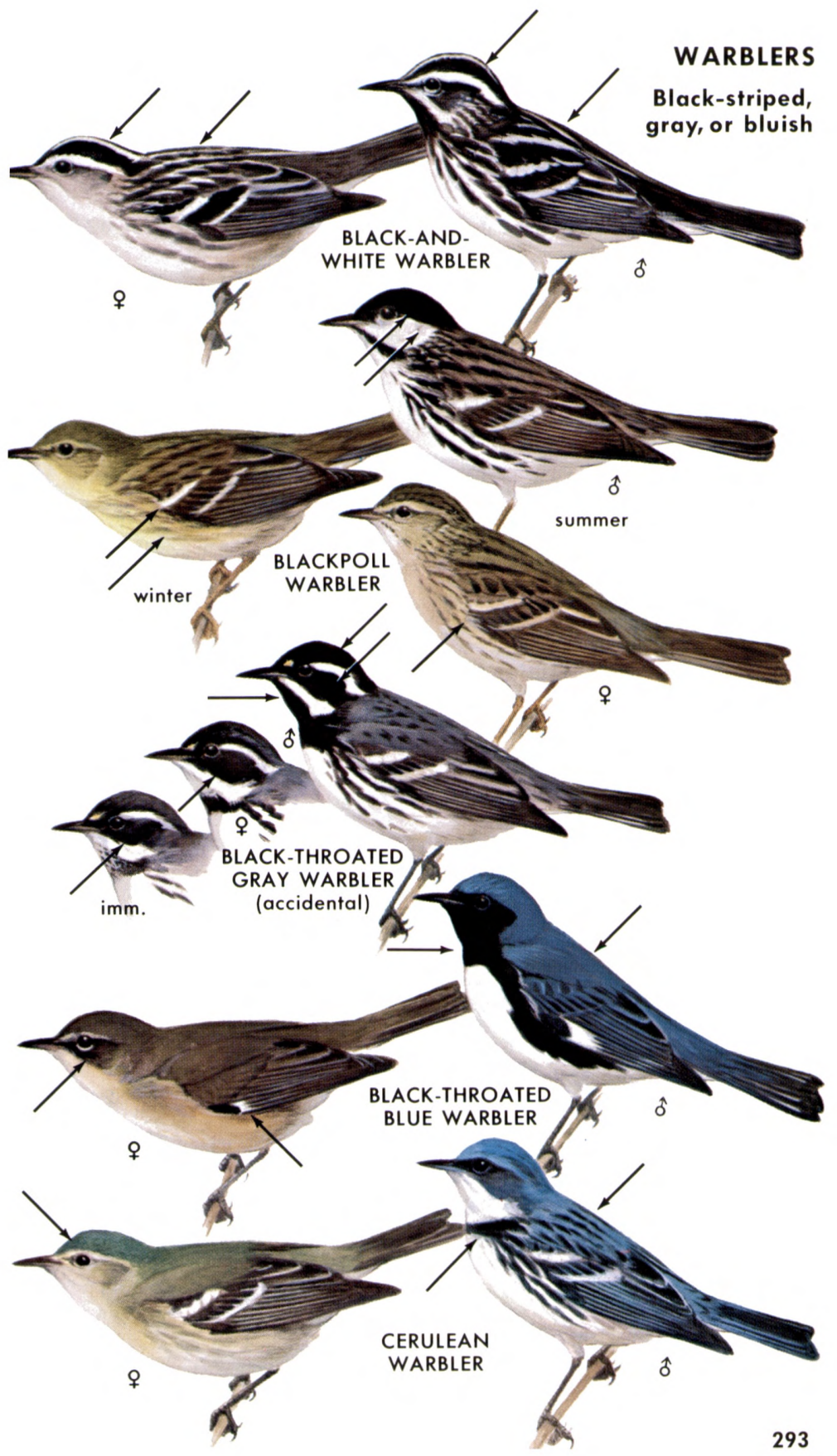


5" (13 cm). Male, breeding: Note the chestnut cheeks. Yellow below, striped with black; rump yellow, crown black. Female and autumn birds: Lack chestnut cheeks; duller, breast often whitish, streaked. Note the dull patch of yellow behind the ear.

Voice: Song, a very high, thin seet seet seet seet. May be confused with song of Bay-breasted or Black-and-white Warbler.

Range: Canada, ne. edge of U.S. Winters in Caribbean area. West: Map 343. Habitat: Spruce forest; broadleaf trees in migration.

CHESTNUT-SIDED WARBLER Dendroica pensylvanica

M341

$4 \frac{1}{2}-5 \frac{1}{2} 2^{\prime \prime}(11-14 \mathrm{~cm})$. Adult, breeding: Identified by combination of yellow crown, chestnut sides. Autumn: Lemon-greenish above, whitish below; narrow white eye-ring, two pale yellow wing bars. Adults retain some chestnut, immatures do not.

Voice: Song, similar to Yellow Warbler's: see see see see Miss Beech'er or please please pleased to meet'cha; penultimate note accented, last note dropping. Also a more rambling song.

Range: Mainly s. Canada, ne. U.S. Winters se. Mexico to n. S. America. West: Map 341. Habitat: Slashings, bushy pastures.

BAY-BREASTED WARBLER Dendroica castanea

M350

5-6" (13-15 cm). Male, spring: Dark-looking, with a chestnut throat, upper breast, and sides. Note the large spot of pale buff on the neck. Female, spring: Paler, more washed out. Autumn: Olivegreen above; two white wing bars; dull buff-white below. May have trace of bay on sides. Buff undertail coverts, dark legs. Fall Blackpoll (p. 293) usually has pale legs.

Voice: A high, sibilant tees teesi teesi; resembles song of Black-andwhite Warbler; thinner, shorter, more on one pitch.

Range: Canada, ne. edge of U.S. Winters Panama to Venezuela. West: Map 350. Habitat: Woodlands, conifers in summer.

BLACKBURNIAN WARBLER Dendroica fusca

5" (13 cm). The "Fire Throat." Male, spring: Black and white, with flame orange on head and throat. Female and autumn birds: Paler orange on throat. Note the yellow head stripes, pale back stripes.

Voice: Song, zip zip zip titi tseeeeee, ending on a very high, upslurred note (inaudible to some ears). Also a two-parted teetsa teetsa teetsa teetsa zizizizizi, more like Nashville's.

Range: Canada, e. U.S. Winters Costa Rica to Bolivia. West: Breeds locally in cen. Saskatchewan, cen. Alberta. Rare migrant on Plains west to Rockies; each year a few strays reach California coast. Habitat: Woodlands; conifers in summer.

AMERICAN REDSTART Setophaga ruticilla

M353

$5^{\prime \prime}(13 \mathrm{~cm})$. Butterfly-like; actively flitting, with drooping wings and spread tail. Male: Black; bright orange patches on wings and tail. Female: Olive-brown; yellow flash-patches on wings and tail. Immature male: Like female, but tinged with orange on the chest.

Voice: Songs (often alternated), zee zee zee zee zwee (last note higher), tsee tsee tsee tsee tsee-o (last syllable dropping), and teetsa teetsa teetsa teetsa teet (notes paired).

Range: Canada, e. U.S. Winters Mexico, W. Indies to nw. Brazil. West: Map 353. Habitat: Second-growth woods, river groves. 


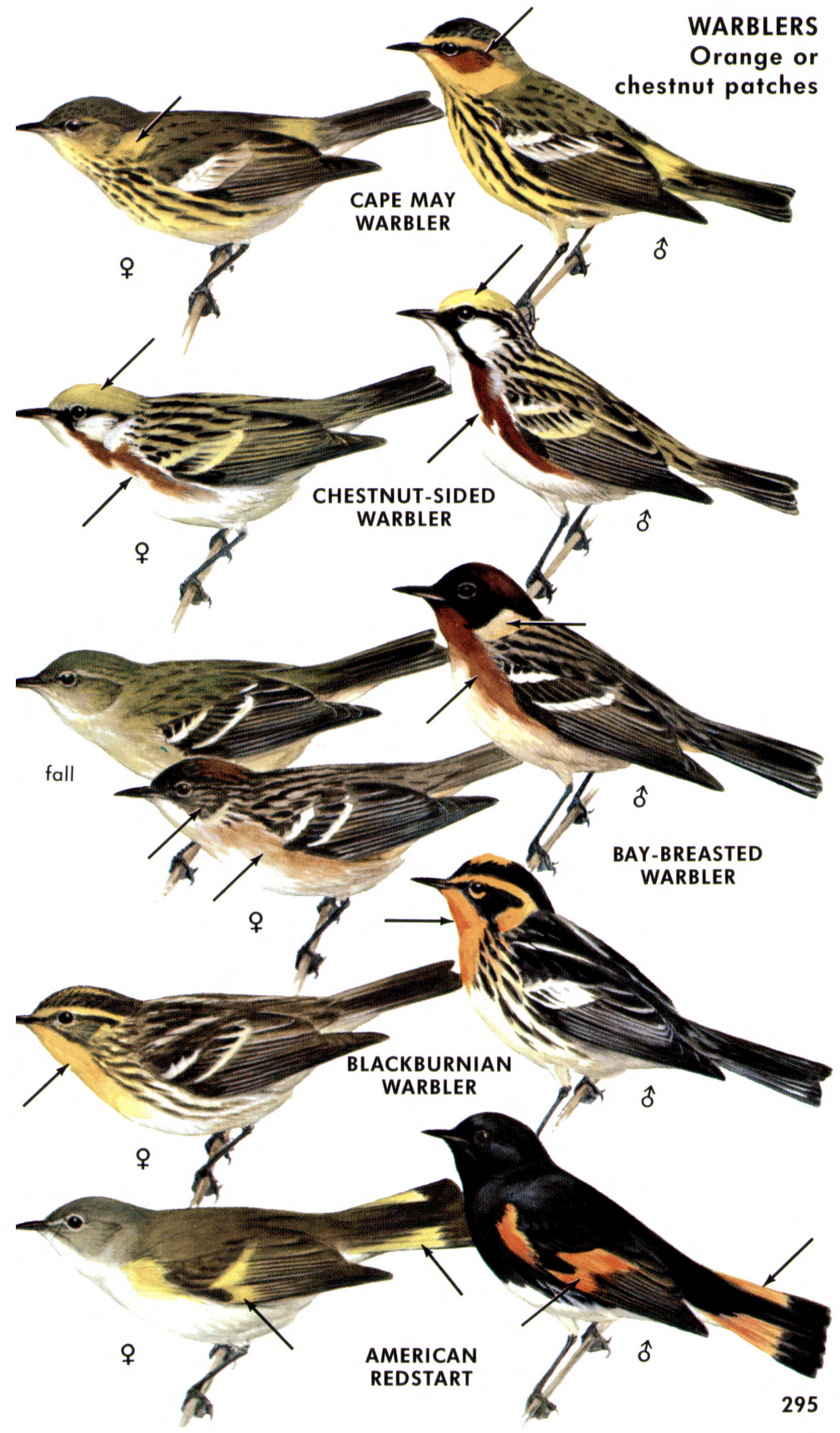


$5 \frac{1}{2} "(14 \mathrm{~cm})$. Beautiful; postures with half-spread wings and tail, showing off large white patches. Black head and upperparts; large bright red patch on lower breast. Also called Painted Whitestart.

Voice: Song, a repetitious weeta weeta weeta wee or weeta weeta chilp chilp chilp. Note, an unwarbler-like clee-ip.

Range: Sw. U.S. to n. Nicaragua. Map 363. Habitat: Oak canyons, pineoak forests in mountains.

RED-FACED WARBLER Cardellina rubrifrons

M362

$5-5 \frac{1}{2} 2^{\prime \prime}(13-14 \mathrm{~cm})$. The only U.S. warbler with a bright-red face. It has a gray back, a black patch on the head, and a white nape.

Voice: A clear, sweet song, similar to that of Yellow Warbler.

Range: Sw. U.S. to Durango, Mexico. Map 362. Winters Mexico, Guatemala. Habitat: Open pine-oak forests in high mountains.

OLIVE WARBLER Peucedramus taeniatus

\section{Family Peucedramidae}

41/2"-5" (11-13 cm). Male: Note the orange-brown head and chest and the black ear patch. Female: Duller crown, nape olive, breast yellowish. It has the dusky ear patch.

Voice: Song, a ringing peter peter peter peter. Variable.

Range: Sw. U.S. to Nicaragua. Map 365. Habitat: Pine and fir forests of high mountains.

COLIMA WARBLER Vermivora crissalis

$5 \frac{1}{2} 2^{\prime \prime}(14 \mathrm{~cm})$. Found in the high Chisos Mts. in Texas. Drab, with a yellow rump and undertail coverts. Larger than Virginia's Warbler; sides brownish; lacks yellow on the breast.

Voice: Song, "a simple trill, like that of Chipping Sparrow but more musical and ending in two lower notes" (J. Van Tyne).

Range: Breeds in w. Texas (Chisos Mts.), n.-cen. Mexico. Winters in Mexico to Colima, Guerrero. Habitat: Oak-pine canyons.

GRACE'S WARBLER Dendroica graciae

M348

41/2-5" (11-13 cm). Gray-backed, with a yellow throat, two wing bars, yellowish eyebrow stripe, stripes on sides. Resembles Yellow-throated Warbler, which has a white patch behind the ear.

Voice: Cheedle cheedle che che che che, etc. (ends in a trill).

Range: Breeds from sw. U.S. to n. Nicaragua. Map 348. Winters south of U.S. Habitat: Pine-oak forests of mountains.

VIRGINIA'S WARBLER Vermivora virginiae

M338

4-41/2" (10-11 cm). Male: A small gray warbler, with a yellowish rump and undertail coverts, narrow white eye-ring, rufous spot on the crown (usually concealed), and touch of yellow on the breast. Flicks tail. Female duller. Immature may lack the yellow.

Voice: Song, loose, colorless notes on nearly the same pitch; chlip-chlipchlip-chlip- chlip-wick-wick.

Range: Sw. U.S. Map 338. Winters in s. Mexico. Habitat: Oak canyons, brushy slopes, pinyons.

LUCY'S WARBLER Vermivora luciae

M339

4" $(10 \mathrm{~cm})$. A small desert warbler; known by its chestnut rump patch.

White eye-ring, small patch of chestnut on the crown.

Voice: A high weeta weeta weeta che che che che, on two pitches.

Range: Breeds sw. U.S., nw. Mexico. Map 339. Habitat: Mesquite along desert streams and washes; willows, cottonwoods. 


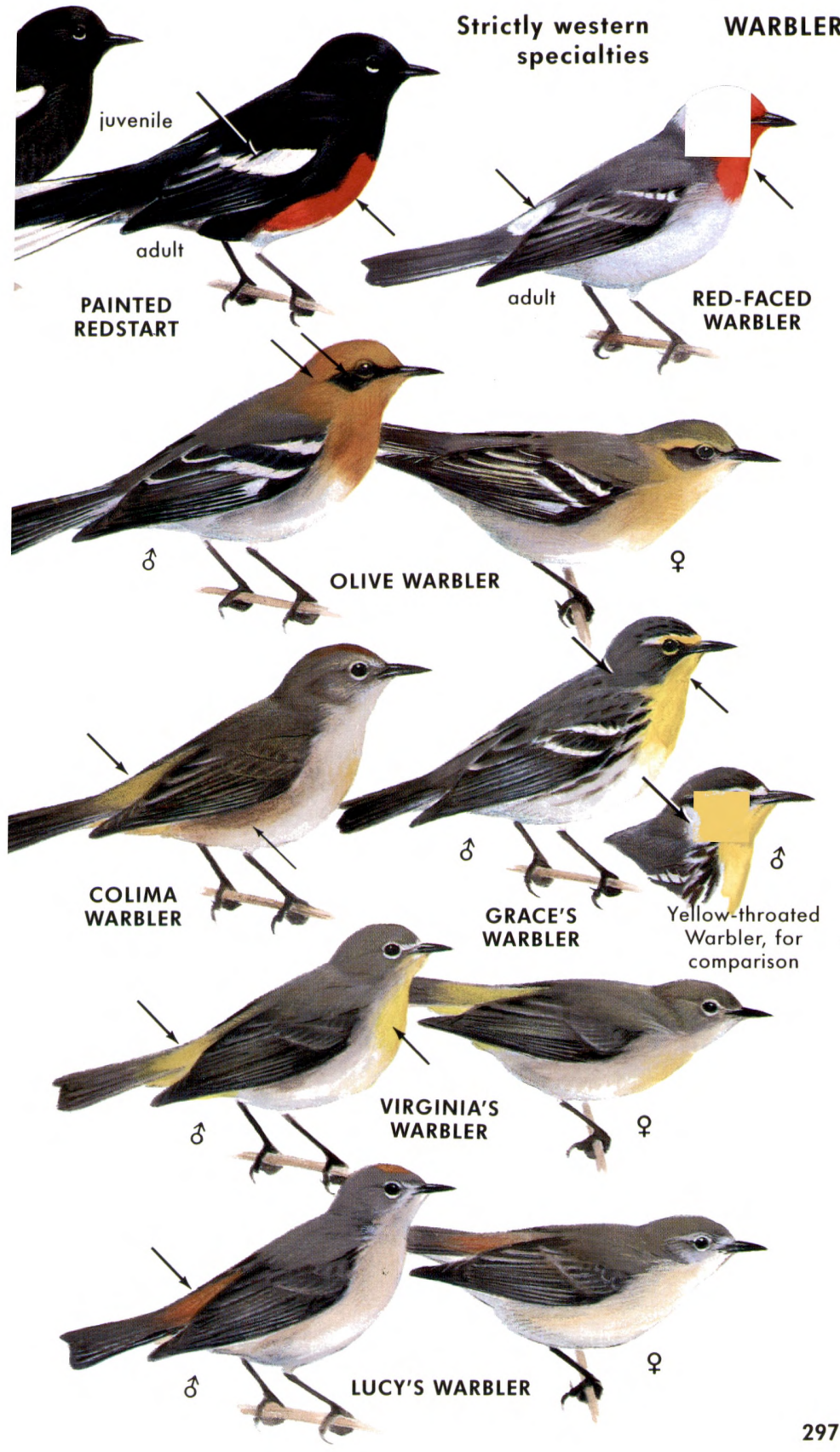


$43 / 4^{\prime \prime}(12 \mathrm{~cm})$. Note the white eye-ring in combination with the yellow throat. Head gray, contrasting with the olive-green back. No wing bars. The yellow undertail coverts are separated from the yellow of the belly by a white area. Males may show a dull chestnut crown patch (seldom visible).

Similar species: Male Connecticut Warbler also has a complete white eye-ring and lacks wing bars, but its throat is grayish.

Voice: Song, two-parted: seebit, seebit, seebit, seebit, tititititi (ends like Chipping Sparrow's song).

Range: S. Canada, w. and n. U.S. Winters to Honduras. West: Map 337. Habitat: Cool, open mixed woods with undergrowth; forest edges, bogs.

CONNECTICUT WARBLER Oporornis agilis

M356

$5 \frac{1}{4}-6^{\prime \prime}(13-15 \mathrm{~cm})$. Similar to MacGillivray's and Mourning warblers (gray hood, yellow and olive body), but note the complete white eye-ring. Fall female and young are duller and lack the gray hood, but have a suggestion of one (a brownish stain across the upper breast). The eye-ring is always present. This species walks.

Similar species: (1) Breeding Mourning Warbler lacks eye-ring (in fall, often has a broken one). Breeding male has a black throat. The yellow undertail coverts reach the middle of the tail (nearly to the end in Connecticut). (2) Nashville Warbler also has an eye-ring, but the bird is much smaller. It has a yellow throat and is more active. Voice: A repetitious chip-chup-ee, chip-chup-ee, chip-chup-ee, chip, or sugar-tweet, sugar-tweet, sugar-tweet (W. Gunn).

Range: Cen.-s. Canada, cen.-n. U.S. Winters n. S. America. West: Map 356. Habitat: Poplar bluffs, muskeg, mixed woods near water; in migration, undergrowth. Feeds mostly on the ground.

MOURNING WARBLER Oporornis philadelphia

M357

$5-53 / 4^{\prime \prime}(13-14 \mathrm{~cm})$. Similar to MacGillivray's Warbler, but the male has no eye-ring. Female and immature may have a very light broken eye-ring and are therefore very difficult to separate from MacGillivray's. See basic ranges on maps.

Voice: Song, chirry, chirry, chorry, chorry (chorry lower). Considerable variation.

Range: Canada, ne. U.S. Winters Nicaragua to nw. Amazonia. West: Map 357. Habitat: Clearings, thickets, slashings, undergrowth.

MacGILLIVRAY'S WARBLER Oporornis tolmiei

M358

$4 \frac{3}{4}-51 \frac{1}{2 \prime}(12-14 \mathrm{~cm})$. Male: Olive above, yellow below, with a slategray hood (blackish on the throat) completely encircling the head and neck. Partial white eye-ring is broken fore and aft. Female: Similar, but the hood is much paler, washed out on the throat. Immature may have only a suggestion of the hood and is difficult to separate from immature Mourning Warbler, which breeds in Canada east of the Rockies.

Voice: Song, a rolling chiddle-chiddle-chiddle, turtle-turtle, last notes dropping; or sweeter-sweeter-sweeter, sugar-sugar.

Range: Breeds w. N. America. Map 358. Winters Sonora to w. Panama. Habitat: Low dense undergrowth; shady thickets. 

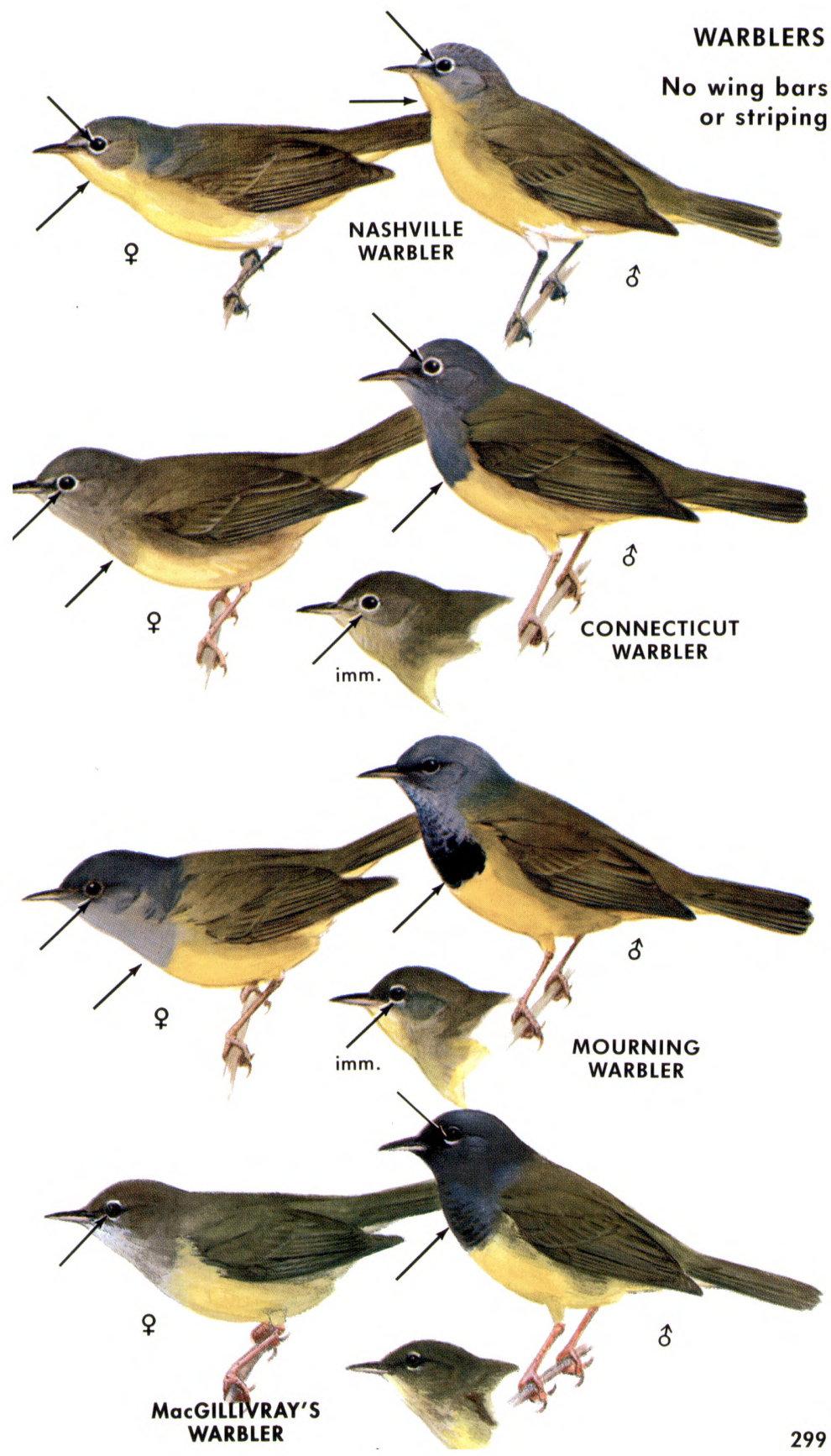
$5 "(13 \mathrm{~cm})$. No other warbler is so extensively yellow. Even the tail spots are yellow (other warblers have white tail spots or none). Male has rusty breast streaks (in female, these are faint or lacking).

Voice: Song, a bright cheerful tsee-tsee-tsee-tsee-titi-wee or weet weet weet weet tsee tsee, given rapidly. Variable.

Range: Alaska, Canada to Peru. Winters Mexico to Peru. West: Map 340. Habitat: Bushes, swamp edges, streams, gardens.

PALM WARBLER Dendroica palmarum

M349

$41 / 2-51 / 2 "(11-14 \mathrm{~cm})$. Note the constant bobbing of the tail. Brown above; yellowish or whitish below, narrowly streaked; yellow undertail coverts, white spots in tail corners. In spring, has a chestnut cap (obscure in fall, winter). Sexes similar.

Voice: Song, weak, repetitious notes: zhe-zhe-zhe-zhe-zhe-zhe.

Range: Canada, ne. edge of U.S. Winters in s. U.S., Caribbean area. West: Map 349. Habitat: Wooded borders of muskeg (summer). In migration, low trees, bushes, ground. A ground-loving warbler.

ORANGE-CROWNED WARBLER Vermivora celata

M336

43/4-51/2" (11-14 cm). Dingy, without wing bars or other distinctive marks; olive-green above, greenish yellow below. Note the faint breast streaks and lack of wing bars. "Orange" of crown is seldom visible. In fall and winter many birds are quite gray.

Similar species: Autumn Tennessee Warbler has white undertail coverts. Voice: Song, a colorless trill, becoming weaker toward the end. Often changes pitch, rising then dropping.

Range: Alaska, Canada, w. U.S. Winters to Guatemala. West: Map 336. Habitat: Brushy clearings, aspens, undergrowth.

TENNESSEE WARBLER Vermivora peregrina

M335

$43 / 4 "(12 \mathrm{~cm})$. Quite plain. Male, spring: Note the white eyebrow stripe and gray head contrasting with its greenish back. Female, spring: Similar; head less gray, underparts slightly yellowish. Fall: Greenish; note the unstreaked yellowish breast, strong yellowish eyebrow stripe, and trace of a wing bar. A vireo-like species.

Similar species: (1) Autumn Orange-crowned Warbler has yellow undertail coverts. (2) See also vireos without wing bars (pp. 286, 287).

Voice: Song, staccato, two- or three-parted: ticka ticka ticka ticka, swit swit, chew-chew-chew-chew-chew (Gunn). Suggests Nashville Warbler's song, but louder, more tirelessly repeated.

Range: Canada, ne. edge of U.S. Winters Mexico to Venezuela. West: Map 335. Habitat: Deciduous and mixed forests; in migration, groves, brush.

\section{ARCTIC WARBLER Phylloscopus borealis Family Sylviidae}

43/4" (12 cm). A small, plain, Old World warbler. Dull greenish brown above, whitish below; light stripe over eye, a trace of a narrow whitish wing bar; pale legs. Sexes similar. Keep in mind Orange-crowned and Tennessee warblers.

Voice: Song, a repeated tchick followed by a short trill.

Range: Near tree limit, n. Eurasia, Alaska. Winters tropical Asia. West: Breeds in w. Alaska from w. Brooks Range, Colville R., south to Katmai, Mt. McKinley, Denali. Habitat: Willow scrub. 


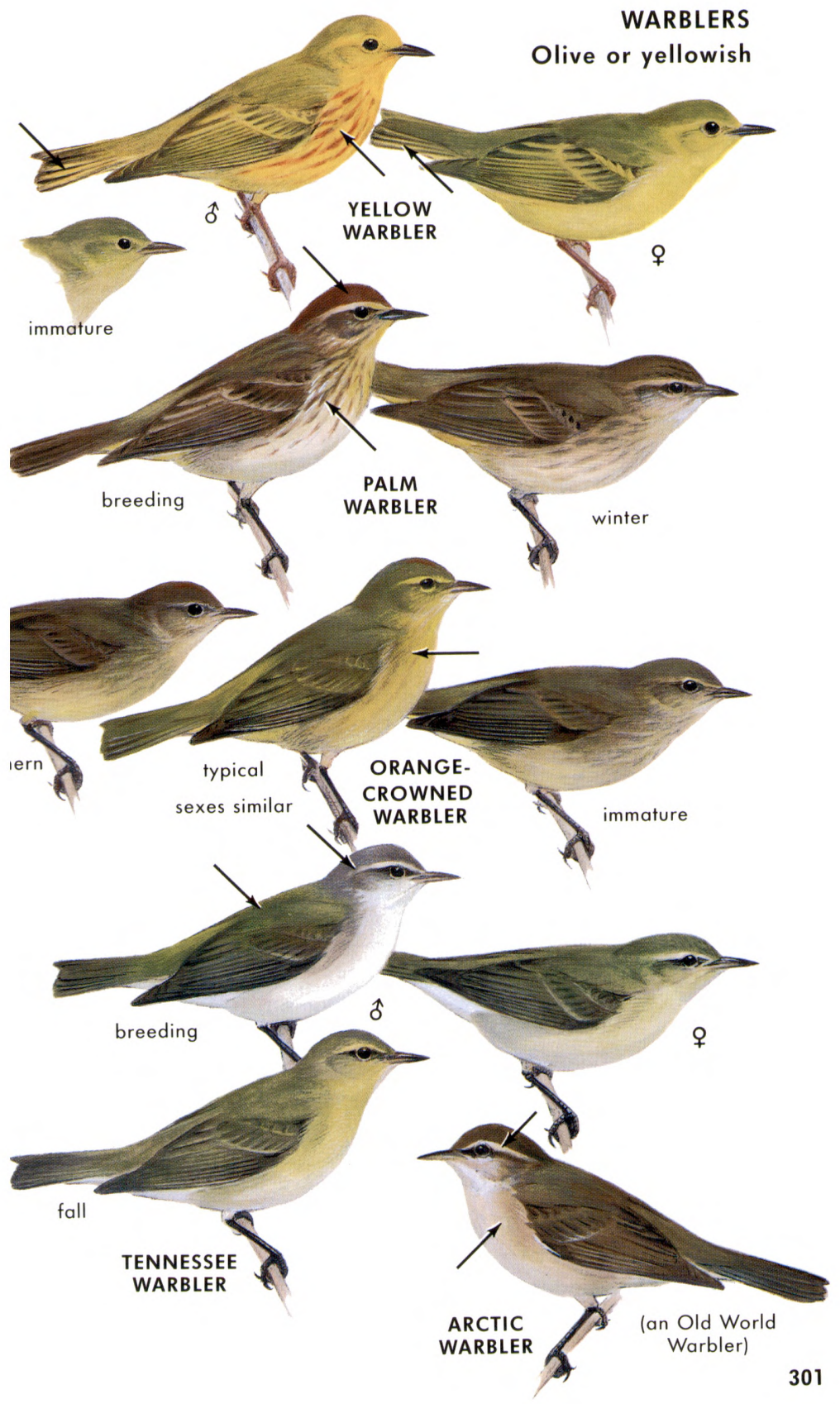


$4 \frac{1}{2}-5 \frac{1}{2} 2^{\prime \prime}(11-14 \mathrm{~cm})$. Wren-like. Male with a black (Lone Ranger) mask, yellow throat. Female and immature: Olive-brown, with a rich yellow throat, buffy yellow breast; no black mask. Known from similar warblers by its whitish belly, tan sides, and habitat.

Voice: A bright rapid chant, witchity-witchity-witchity-witch; sometimes witchy-witchy-witchy-witch. Note, a husky tchep.

Range: Canada to s. Mexico. Winters s. U.S. to W. Indies, Panama. West: Map 359. Habitat: Swamps, marshes, wet thickets, edges.

YELLOW-BREASTED CHAT Icteria virens

M364

$7 "(18 \mathrm{~cm})$. Note the white "spectacles," bright yellow throat and breast. No wing bars. Size (very large for a warbler), bill, long tail, actions, and habitat suggest a mimic thrush.

Voice: Repeated whistles, alternating with harsh notes and soft caw's. Suggests a Mockingbird, but repertoire more limited; much longer pauses between phrases. Single notes: whoit, kook, etc.

Range: S. Canada to cen. Mexico. Winters s. U.S. to Panama. West: Map 364. Habitat: Brushy tangles, briars, stream thickets.

WILSON'S WARBLER Wilsonia pusilla

M360

$43 / 4^{\prime \prime}(12 \mathrm{~cm})$. Male: Golden, with a round black cap. Female may show trace of a cap; immature does not. They are small, goldenlooking birds with a yellow stripe above the beady eye.

Voice: Song, a thin, rapid little chatter, dropping in pitch at the end: chi chi chi chi chi chet chet.

Range: Alaska, Canada, w. and ne. U.S. Winters Mexico to Panama. West: Map 360. Habitat: Thickets along wooded streams, moist tangles, low shrubs, willows, alders.

HOODED WARBLER Wilsonia citrina

$51 / 2^{\prime \prime}(14 \mathrm{~cm})$. The black hood or cowl of the male encircles the yellow face and forehead. Female and young lack the hood, although the yellow face may be sharply outlined in some females. Aside from white tail spots, they may lack other marks.

Range: E. and cen. U.S. Winters in Cen. America. West: Casual or accidental vagrant in most western states. Habitat: Forest undergrowth.

\section{NORTHERN PARULA Parula americana}

$4 \frac{1}{2 \prime}{ }^{\prime \prime}(11 \mathrm{~cm})$. Bluish, with a yellow throat and breast and two white wing bars. A suffused greenish patch on back. The male's best mark is a dark breastband (indistinct or lacking in the female).

Voice: Song, a buzzy trill or rattle that climbs the scale and trips over the top: zeeeeeeeee-up. Also zh-zh-zh-zheeeeee.

Range: Se. Canada, e. U.S. Winters Florida, Mexico to W. Indies, Nicaragua. West: Rare or casual vagrant west to Pacific states, but found annually in California (has bred there).

\section{NORTHERN WATERTHRUSH}

OVENBIRD Seiurus aurocapillus

Text on p. 304.

M354

$6^{\prime \prime}(15 \mathrm{~cm})$. When breeding, more often heard than seen. Usually seen walking on pale pinkish legs on the leafy floor of the woods. Suggests a small thrush, but striped rather than spotted beneath. Orangish patch on the crown. Song, an emphatic teach'er, $T E A C H^{\prime} E R, \boldsymbol{T E A C H} \boldsymbol{E} \boldsymbol{R}$, etc., in crescendo. In some areas, monosyllabic, TEACH, TEACH, TEACH, etc.

(continued on p. 304) 


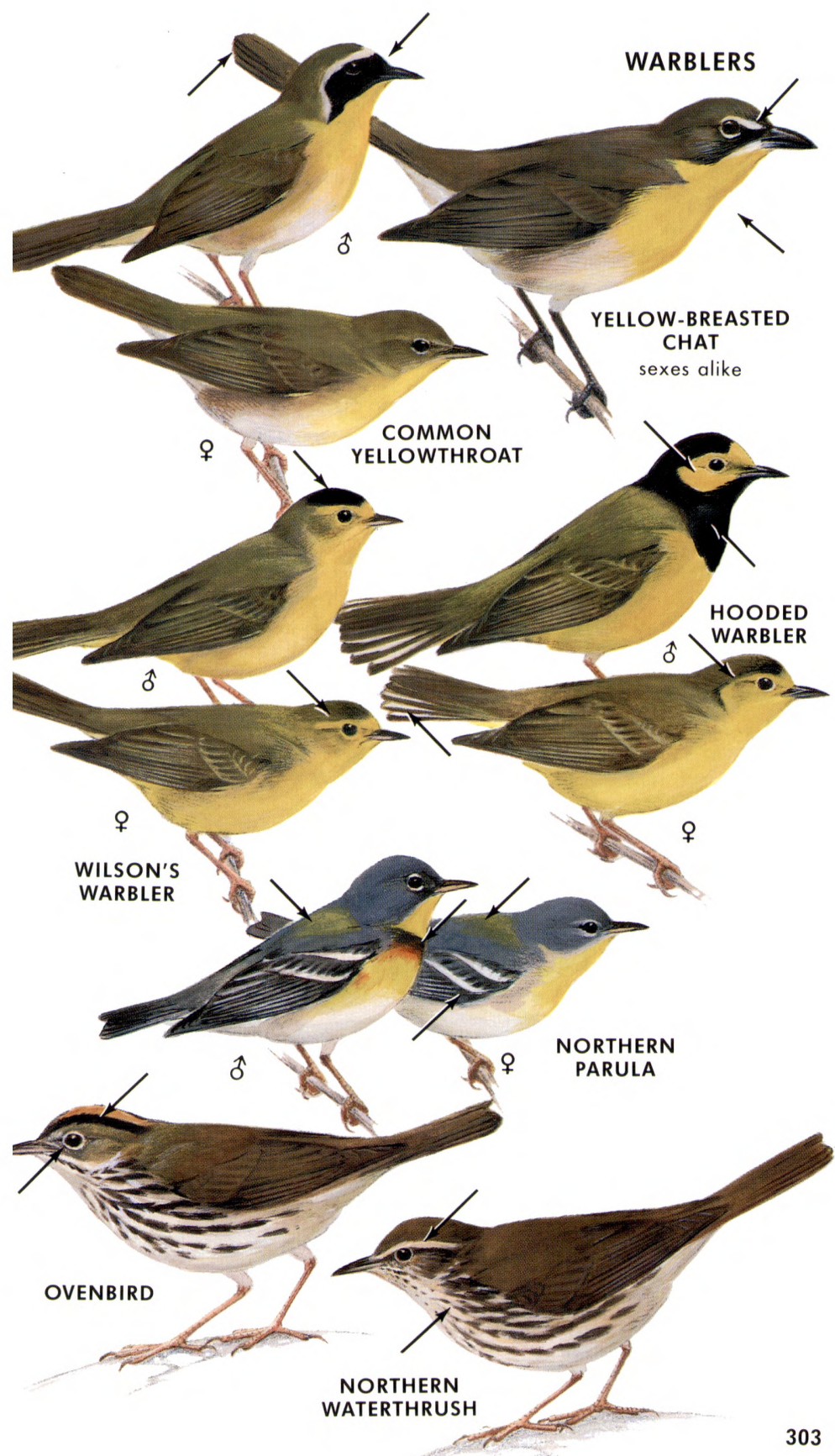


OVENBIRD (continued). Range: S. Canada, U.S. mainly east of Rockies. Winters se. U.S. to n. S. America. West: Map 354. Habitat: Near ground in leafy woods; in migration, thickets.

NORTHERN WATERTHRUSH Seiurus noveboracensis

M355

(Illustrated on p. 303.) 6" (15 cm). Suggests a small thrush. Walks along the water's edge and teeters like a Spotted Sandpiper. Brownbacked, with striped underparts, strong eyebrow stripe.

Voice: Note, a sharp chip. Song, a vigorous, rapid twit twit twit sweet sweet sweet chew chew chew (chew's drop in pitch).

Range: Alaska, Canada, n. edge of U.S. Winters mainly in tropics. West: Map 355. Habitat: Swampy or wet woods, streamsides, lake shores; in migration, also thickets.

n MISCELLANEOUS STRAY WARBLERS FROM THE EAST. For further details see the eastern Field Guide to the Birds.

\section{PROTHONOTARY WARBLER Protonotaria citrea}

$5 \frac{1}{2 \prime}{ }^{\prime \prime}(14 \mathrm{~cm})$. A bird of wooded swamps. Head and breast deep yellow. Wings blue-gray, with no bars. Female duller. Casual stray, Colo., N.M., Ariz., Calif. Accidental, Ore., Wash.

PINE WARBLER Dendroica pinus

$5-5 \frac{1}{1} 2^{\prime \prime}(13-14 \mathrm{~cm})$. Yellow-breasted, with white wing bars; no other obvious field marks. Breast dimly streaked; back unstreaked. White spots in tail corners. Female duller; autumn birds often obscure (see eastern Field Guide). Casual west to Great Plains. Accidental, coast of Calif. Not always in pines.

BLUE-WINGED WARBLER Vermivora pinus

$4 \frac{1}{2}-5^{\prime \prime}(11-13 \mathrm{~cm})$. Face and underparts yellow; wings blue-gray, with two white bars. Note the narrow black mark through the eye. Accidental, Colo., Utah, N.M., Ariz., Calif.

WORM-EATING WARBLER Helmitheros vermivorus

$5-5 \frac{1}{2} 2^{\prime \prime}(13-14 \mathrm{~cm})$. A modest forager of leafy wooded slopes. Dull olive, with black stripes on a buffy head. Breast rich buff. Accidental, Wyo., Nev. Casual stray w. Texas, Colo., N.M., Ariz., Calif., Nev., Wyo., Sask.

PRAIRIE WARBLER Dendroica discolor

$5^{\prime \prime}(13 \mathrm{~cm})$. Bobs its tail (like Palm Warbler). Yellow below; black stripes confined to the sides. Two black face marks; one through the eye, one below. Very rare but regular fall vagrant, Calif. Accidental, Ore., Mont., Colo., Ariz., N.M.

KENTUCKY WARBLER Oporornis formosus

$5 \frac{1}{2} 2^{\prime \prime}(14 \mathrm{~cm})$. Black sideburns below the eyes; yellow "spectacles." Casual stray through sw. border states to Calif. Accidental, Nev., Colo., Wyo., Mont., Sask., Alaska.

GOLDEN-WINGED WARBLER Vermivora chrysoptera

$5-5 \frac{1}{2} 2^{\prime \prime}(13-14 \mathrm{~cm})$. Note the combination of yellow wing patch and black throat (female, gray); also yellow forehead, black ear patch. Accidental, Idaho, Ore., Colo., N.M., Ariz., Calif.

YELLOW-THROATED WARBLER Dendroica dominica

$5-5 \frac{1}{2} 2^{\prime \prime}(13-14 \mathrm{~cm})$. Very similar to Grace's Warbler, but note the white patch behind the ear. Creeps about branches. Accidental west to Rocky Mt. states; very rare in Southwest to Calif. 


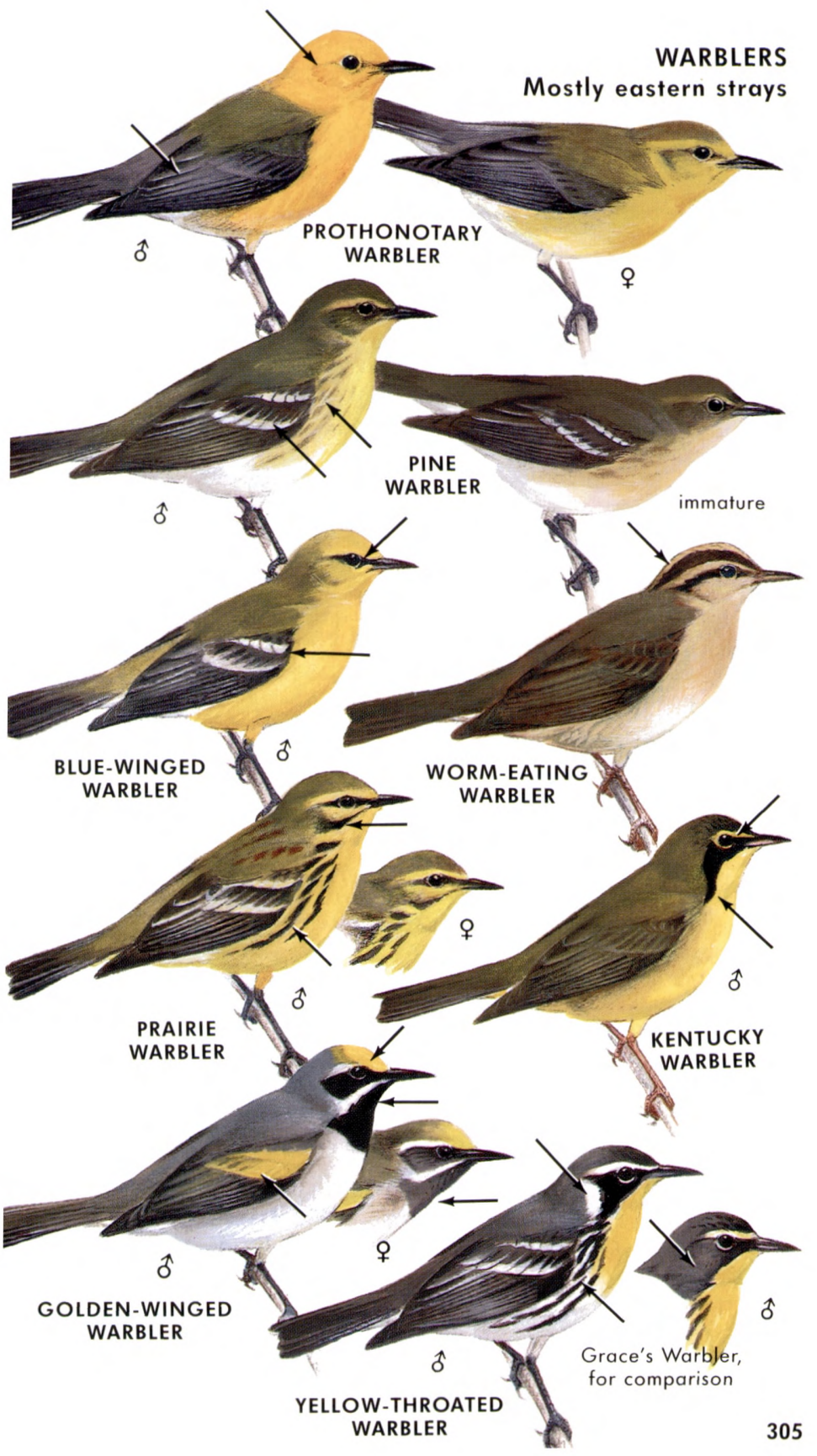


- BLACKBIRDS, ORIOLES, etc. Family Icteridae. Subfamily Icterinae. A varied group of birds with conical, sharp-pointed bills and rather flat profiles. Collectively known as "icterids." Some are black and iridescent; others, such as orioles (p. 313), are highly colored. Sexes usually not alike. Food: Insects, small fruits, seeds, waste grain, small aquatic life. Range: New World; most in tropics. No. of species: World 94; West 16 (+2 casual or accidental).

BREWER'S BLACKBIRD Euphagus cyanocephalus

M421

9" $(23 \mathrm{~cm})$. A very common and familiar blackbird. Male: All black, with a whitish eye; in good light, purplish reflections may be seen on the head and greenish reflections on the body. Female: Brownish gray, with a dark eye.

Similar species: Breeding male Rusty Blackbird has dull greenish head reflections (hard to see); the bill is longer. Female Rusty has a light eye. Unlike the Rusty (both sexes), Brewer's does not acquire an extensive rusty look in fall and winter (but may have a trace).

Voice: Song, a harsh wheezy, creaking ksh-eee. Note, chack.

Range: Sw. Canada, w. and n.-cen. U.S. Winters to s. Mexico. West: Map 421. Habitat: Fields, prairies, farms, parks.

RUSTY BLACKBIRD Euphagus carolinus

M420

9" $(23 \mathrm{~cm})$. Rusty only in fall or winter; otherwise suggests Brewer's Blackbird. Male, spring: A Robin-sized blackbird with a pale yellow eye. Black head of breeding male may show faint greenish gloss (not purplish). Female, spring: Slate-colored, with a light eye. Fall and winter adults: Washed with rusty; males barred below.

Voice: Note, a loud chack. "Song," a split creak, like a rusty hinge: kusha-lee, alternating with ksh-lay.

Range: Alaska, Canada, ne. edge of U.S. Winters mainly to se. U.S. West: Map 420. Habitat: River groves, wooded swamps; muskeg.

COMMON GRACKLE Quiscalus quiscula

M423

11-131/2" (28-34 cm). Male: A large very iridescent, yellow-eyed blackbird, larger than a Robin, with a long, wedge-shaped or keel-shaped tail. Flight more level than that of other blackbirds. Iridescent purple on head, deep bronze on back. Females are somewhat smaller and duller; juveniles are sooty, with dark eyes.

Voice: Note, chuck or chack. "Song," a split rasping note.

Range: Canada, U.S., mainly east of Rockies. West: Map 423. Habitat: Croplands, towns, groves, streamsides.

GREAT-TAILED GRACKLE Quiscalus mexicanus

M422

Male, 18" (45 cm); female, 14" (35 cm). Male, a very large, purple-glossed blackbird, much larger than the Common Grackle and with a longer, more ample tail. Female is much smaller than the male; brown, with a pale breast. Adults have yellow eyes.

Voice: A harsh check check check; also a high kee-kee-kee-kee. Shrill, discordant notes, whistles, and clucks. A rapid, upward-slurring ma-ree.

Range: Sw. U.S. to Peru. West: Map 422. Habitat: Groves, thickets, farms, towns, city parks. 

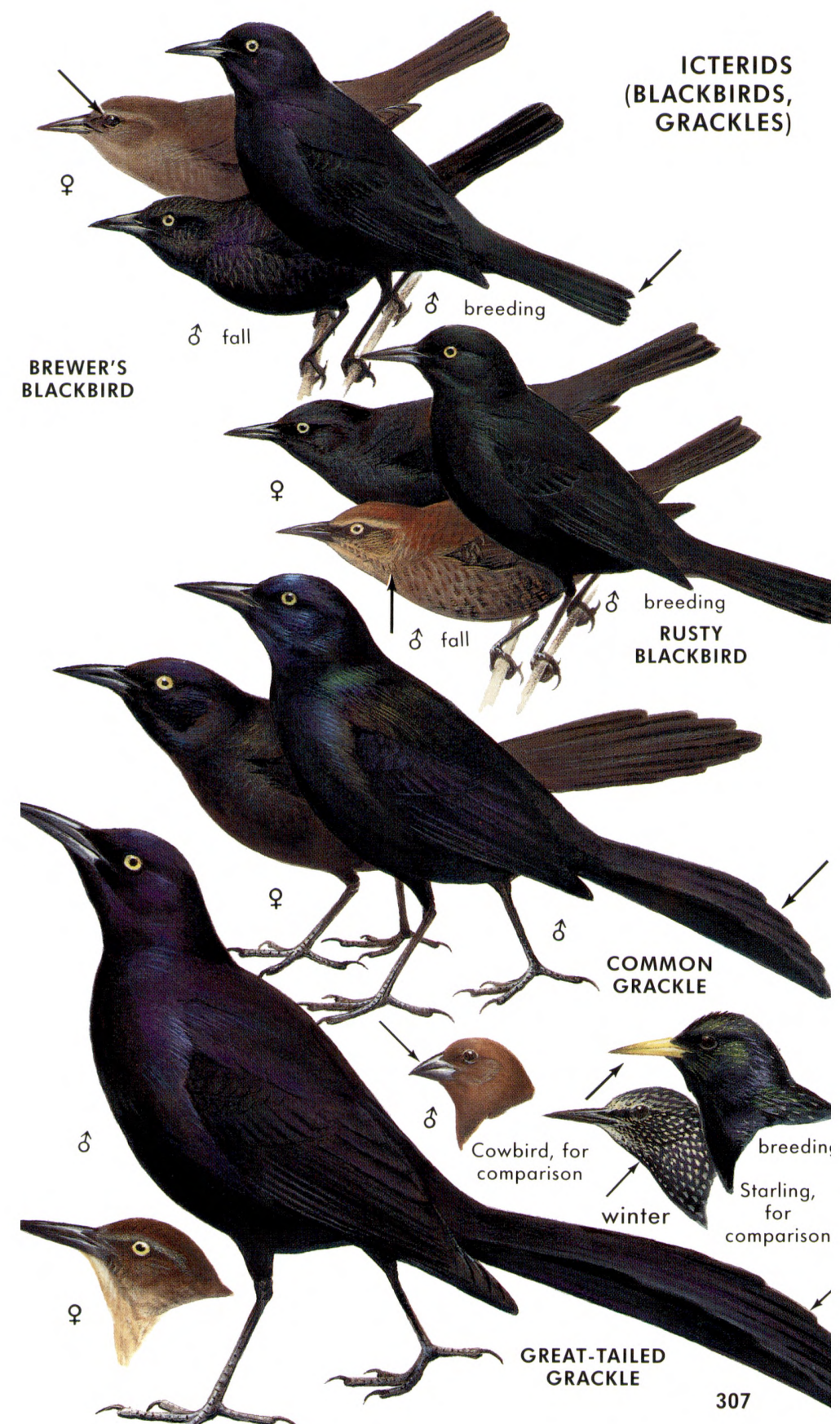
$7-91 / 2^{\prime \prime}(18-24 \mathrm{~cm})$. Male: Black, with bright red epaulets, most conspicuous in spring display. Much of the time the scarlet is concealed and only the yellowish margin shows. Immature male: Sooty brown, mottled, but with red shoulders. Female: Brownish, with a sharply pointed bill, "blackbird" appearance, and well-defined dark stripings below; may have pinkish tinge around throat. Gregarious, traveling and roosting in flocks. One race, the "Bicolored Blackbird" of cen. California, has solid red epaulets without the yellow border. Voice: Notes, a loud check and a high, slurred tee-err. Song, a liquid, gurgling konk-la-ree or o-ka-lay.

Range: Canada to W. Indies, Costa Rica. West: Map 415. Habitat: Breeds in marshes, brushy swamps, hayfields; forages also in cultivated land, along edges of water, etc.

TRICOLORED BLACKBIRD Agelaius tricolor

M416

$71 / 2-9$ " $(19-23 \mathrm{~cm})$. Male: Similar to the Red-winged Blackbird, but the red shoulder patch is darker, with a conspicuous white margin. Female: Much darker than most races of the Red-wing; bill thicker at the base, more sharply pointed. Highly gregarious. Nests in dense colonies often numbering many thousands, whereas the Red-wing is territorial.

Voice: More nasal than Red-wing's: on-ke-kaangh. A nasal kemp. Range: Breeds from s. Oregon to nw. Baja California. Map 416. Habitat: Cattail or tule marshes; forages in fields, farms.

\section{YELLOW-HEADED BLACKBIRD}

Xanthocephalus xanthocephalus

8-11" (20-28 cm). Male: A Robin-sized marsh blackbird, with an orange-yellow head and breast; in flight, shows a white wing patch. Female: Smaller and browner; most of the yellow is confined to the throat and chest; lower breast streaked with white. Gregarious.

Voice: Song, low, hoarse rasping notes produced with much effort; suggests rusty hinges. Note, a low kruck or kack.

Range: S. Canada, w. U.S., upper Mississippi Valley to nw. Mexico. Winters sw. U.S., Mexico. West: Map 419. Habitat: Fresh marshes. Forages in fields, open country.

вOвOLINK Dolichonyx oryzivorus

M414

$6-8^{\prime \prime}(15-20 \mathrm{~cm})$. Male, spring: Our only songbird that is solid black below and largely white above, suggesting a dress suit on backward. Has a buff-yellow nape. Female and autumn male: A bit larger than a House Sparrow; rich buff, with dark stripings on crown and back. Bill is more like a sparrow's than a blackbird's.

Similar species: (1) Male Lark Bunting has white confined to wings; (2) female Red-wing is heavily striped below and has a longer bill. Voice: Song, in hovering flight and quivering descent, ecstatic and bubbling: starts with low, reedy notes and rollicks upward. Flight note, a clear pink, often heard overhead in migration.

Range: S. Canada, n. U.S. Winters in s. S. America. West: Map 414. Habitat: Hayfields, meadows. In migration, marshes. 


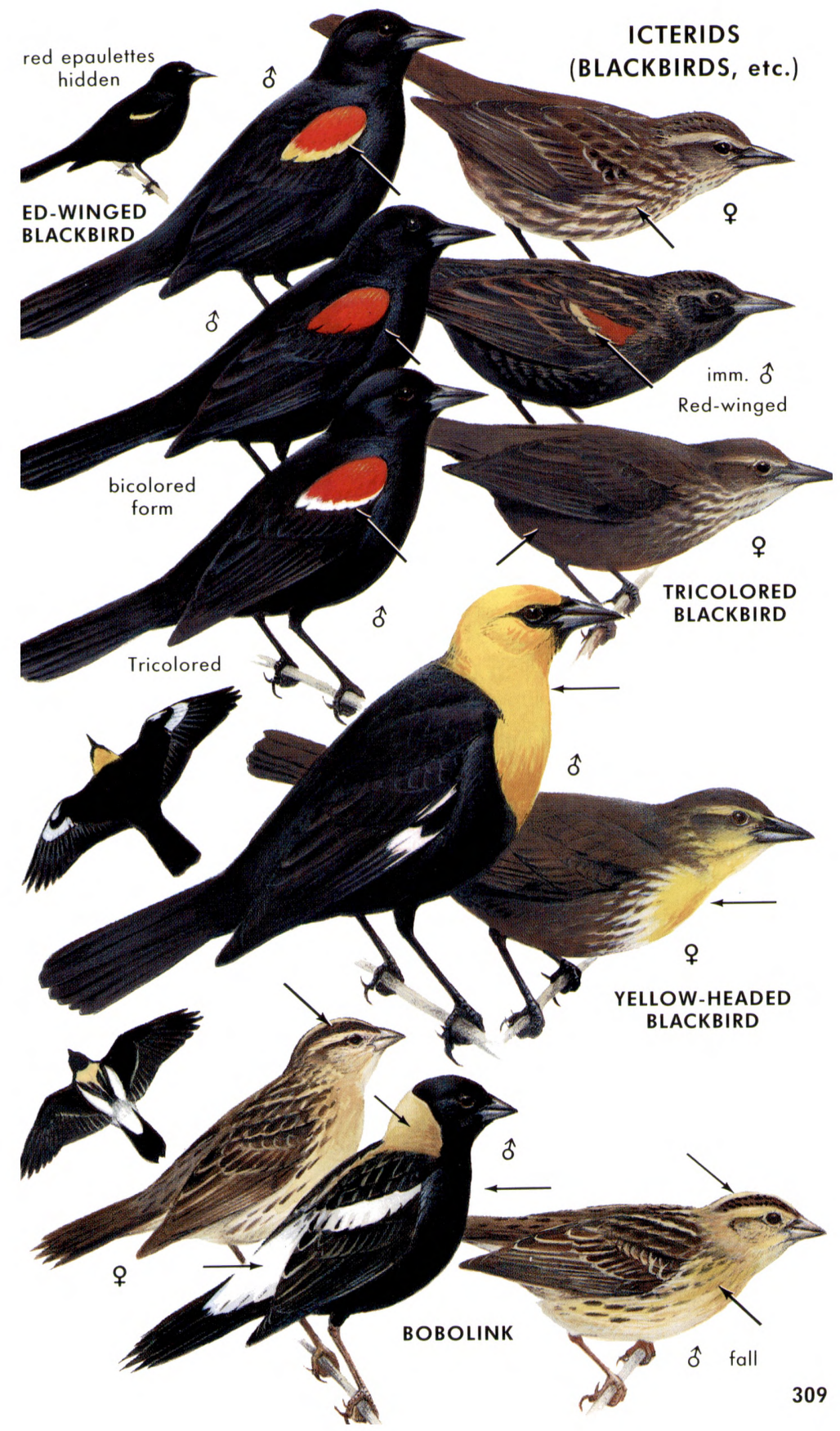


$9^{\prime \prime}(23 \mathrm{~cm})$. Nearly identical with Western Meadowlark; darker brown above; yellow of throat does not invade the cheek. Easily recognized by song. Pale southwestern form has more white in the tail.

Voice: Song, unlike the flutelike gurgling of Western Meadowlark, is composed of two clear, slurred whistles, musical and pulled out, tee-yah, tee-yair (last note skewy and descending). Note, a rasping or buzzy dzrrt; also a guttural chatter.

Range: Se. Canada through e. and cen. U.S. to Brazil. West: Map 417. Habitat: Open fields and pastures, meadows, prairies.

WESTERN MEADOWLARK Sturnella neglecta

M418

$9^{\prime \prime}(23 \mathrm{~cm})$. In grassy country, a chunky brown bird flushes, showing a conspicuous patch of white on each side of its short wide tail. Several rapid wingbeats alternate with short glides. Should it perch on a post, the glass reveals a bright yellow breast crossed by a black $V$. Walking, the bird flicks its tail open and shut. Starling shape.

Voice: Song variable; 7-10 flutelike notes, gurgling and doublenoted, unlike the clear whistles of Eastern Meadowlark. Note, chupp, lower than the rasping dzrrt of Eastern Meadowlark.

Range: Sw. Canada, through w. U.S. to highlands of cen. Mexico. West: Map 418. Habitat: Grasslands, cultivated fields and pastures, meadows, prairies.

BROWN-HEADED COWBIRD Molothrus ater

M424

7" $(18 \mathrm{~cm})$. A rather small blackbird with a short, sparrow-like bill. Male: Black, with a brown head. Female: Mouse-gray with a lighter throat; note the short finch-like bill. Juvenile: Paler than femalebuffy gray, with soft breast streaks; often seen being fed by smaller birds whose nests have been parasitized. Young males in late summer molt may be bizarrely patterned with tan and black. When flocking or with other blackbirds, Cowbirds are smaller and feed on the ground with their tails lifted high.

Similar species: Gray female Cowbird can be told from (1) female Brewer's and (2) female Rusty Blackbird by its stubby bill and smaller size. (3) Young Starling has a longer bill and a shorter tail. Voice: Flight call, weee-titi (high whistle, two lower notes). Song, a bubbly and creaky glug-glug-gleeee. Note, chuck.

Range: S. Canada to Mexico. West: Map 424. Habitat: Farms, fields, barnyards, roadsides, wood edges, river groves.

BRONZED COWBIRD Molothrus aeneus

$61 / 2-83 / 4^{\prime \prime}(16-22 \mathrm{~cm})$. Male: Larger than Brown-headed Cowbird; does not have a brown head. Bill longer. Red eye can be seen only at close range. In breeding season, a conspicuous ruff on the nape. Female: Smaller, with a smaller ruff; dull blackish, much like male, not gray like female of other Cowbird.

Voice: High-pitched mechanical creakings.

Range: Southwestern U.S. to w. Panama. Summers in extreme se. California, cen. and s. Arizona, sw. New Mexico, s. Texas (north to Eagle Pass). Winters in s. Arizona (rarely), s. Texas. Habitat: Croplands, brush, semi-open country, feedlots. 


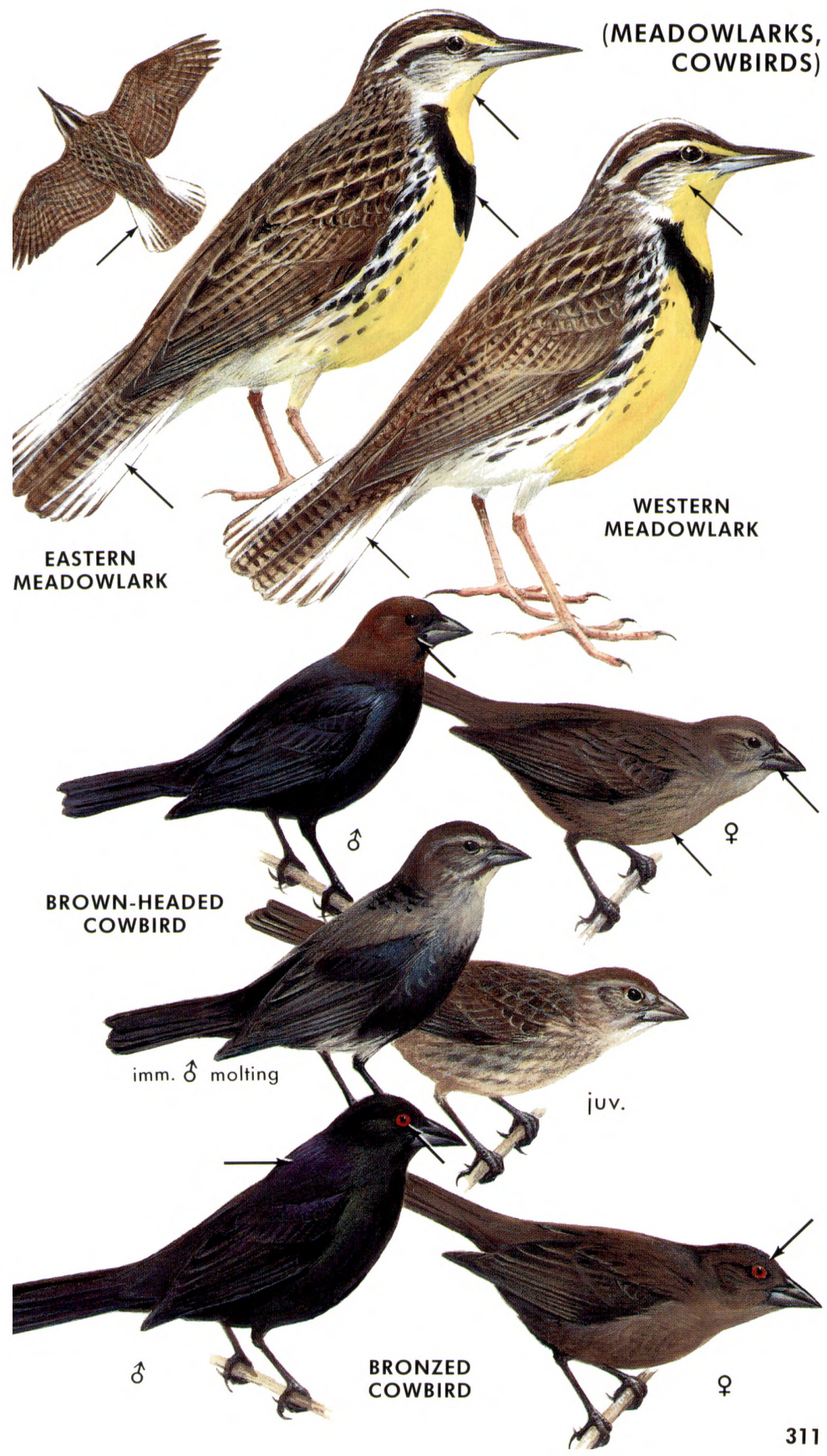


- ORIOLES. Smaller, slimmer than a Robin; a brightly colored genus (Icterus) of subfamily Icterinae (blackbirds, etc.).

BALTIMORE ORIOLE Icterus galbula

M426

7-8" (18-20 cm). Male: Flame-orange and black, with a solid black head. Female and young: Olive-brown above, burnt orange-yellow below; two white wing bars. Some females may have traces of black on the head, suggesting the hood of the male.

Note: This eastern form of the Northern Oriole was formerly regarded as a separate species; systematists may yet restore it.

Voice: S. Rich, piping whistles. Note, a low, whistled hewli.

Range: S. Canada, e. and cen. U.S. Winters se. U.S. to Venezuela. West: Map 426. Habitat: Open woods, elms, shade trees.

BULLOCK'S ORIOLE Icterus bullockii

M426

$7-81 / 2 "(18-21 \mathrm{~cm})$. The western form. Male: Differs from male "Baltimore" by orange cheeks, large white wing patches, tail pattern. Female: Differs from female "Baltimore" by grayer back, whiter belly. Immature male: Similar to female, but throat black.

Voice: Accented double notes and one or two piping notes.

Range: Breeds sw. Canada, w. U.S., n. Mexico. Winters s. U.S. to Guatemala. West: Map 426. Breeds east to Great Plains (S. Dakota, cen. Nebraska, w. Kansas, w. Oklahoma), where it may hybridize with "Baltimore" Oriole.

HOODED ORIOLE Icterus cucullatus

M425

$7 \frac{1}{2} "(19 \mathrm{~cm})$. Male: Orange and black, with a black throat and an orange crown. In winter, back obscurely scaled. Female: Similar to female Bullock's Oriole, but entire underparts yellowish; bill longer, more curved. Back olive-gray; head and tail more yellowish.

Voice: Song, throaty notes and piping whistles: chut chut chut whew whew; opening notes throaty. Note, a sharp eek or wheenk.

Range: Breeds sw. U.S. to s. Mexico. Map 425. Winters in Mexico; rarely sw. U.S. Habitat: Open woods, shade trees, palms.

SCOIT'S ORIOLE Icterus parisorum

M427

73/4" (19 cm). Male: Solid black head and back and lemon-yellow pattern distinguish it. Female: More greenish yellow beneath than most other females (except Orchard Oriole). Immature male: Throat black; similar to other young male orioles, but more black on face.

Voice: Song, rich whistles; suggests Western Meadowlark.

Range: Sw. U.S., n. Mexico. Map 427. Habitat: Dry woods and scrub in desert mountains, yucca "forests," Joshua-trees, pinyons.

ORCHARD ORIOLE Icterus spurius

M416

6-7" (15-18 cm). Male: An all-dark oriole. Rump and underparts deep chestnut. Female, young: Olive-green above, yellowish below; two white wing bars. Immature male: Black bib down to chest.

Voice: A fast-moving outburst interspersed with piping whistles and guttural notes. Suggests Purple Finch's song.

Range: Se. Canada, e. and cen. U.S. to cen. Mexico. Winters from Sinaloa to Venezuela. West: Map 416. Habitat: Wood edges, orchards, shade trees. 


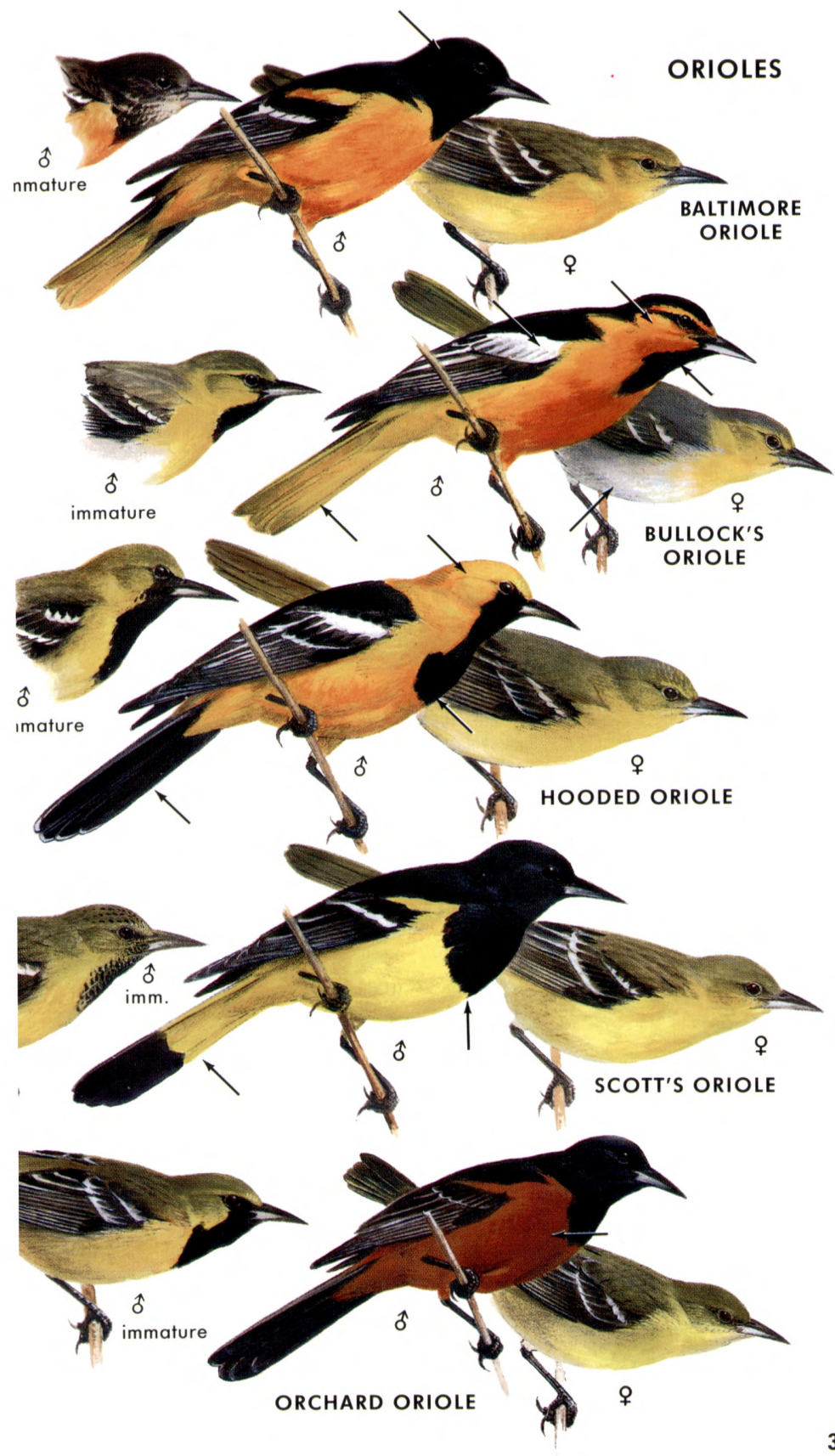


- TANAGERS. Family Thraupidae (in part). Subfamily Thraupinae. Male tanagers are brightly colored; females of our species are greenish above and yellow below, suggesting large, thick-billed vireos. Females may be confused with female orioles, but have darker cheeks and most species lack wing bars. The rather stout bills are notched. Food: Insects, fruits. Range: New World; most species in tropics. No. of species: World 215; West 4.

WESTERN TANAGER Piranga ludoviciana

M368

7" $(18 \mathrm{~cm})$. The only U.S. tanager with strong wing bars. Male: Yellow, with a black back, wings, and tail, two wing bars, and a red head. The red disappears in autumn and winter. Female: Yellowish below; dull olive above, with white and yellow wing bars. Resembles female orioles (pp. $312,313)$, but the tail and sides of the face are darker, and the bill is less sharply pointed.

Voice: Song, short phrases; similar to Robin's in form, but less sustained, hoarser. Note, a dry pi-tic or pit-i-tic.

Range: Western N. America; winters w. Mexico to Costa Rica. Map 368. Habitat: Open conifer or mixed forests; widespread in migration.

SUMMER TANAGER Piranga rubra

M367

7-73/4" (18-19 cm). Male: Rose-red all over, with a yellowish bill; no crest. Female: Olive above, deep yellow below; yellowish bill. Young males acquiring adult plumage may be patched with red, yellow and green.

Similar species: (1) Male Cardinal has a crest and a black face. (2) Hepatic Tanager is darker, with a blackish bill.

Voice: Note, a staccato pi-tuk or pik-i-tuk-i-tuk. Song, robin-like phrases, less nasal and resonant than Scarlet Tanager's.

Range: Cen. and s. U.S. to n. Mexico. Winters Mexico to Brazil. West: Map 367. Habitat: Woods, groves (especially oaks).

HEPATIC TANAGER Piranga flava

M366

71/2" (19 cm). Male: Darker than Summer Tanager; orange-red, with a dark ear patch, blackish bill. Male Summer Tanager is rosier, has a pale yellow bill. Female: Known from female Summer Tanager by its more orange-yellow throat, gray ear patch, blackish bill.

Voice: Song, very similar to Black-headed Grosbeak's (Summer Tanager sounds more like a Robin). Call note, a single chuck.

Range: Breeds sw. U.S. to Argentina. Winters mainly south of U.S. Map 366. Habitat: Open mountain forests, oaks, pines.

SCARLET TANAGER Piranga olivacea

7" (18 cm). Male: Flaming scarlet, with jet-black wings and tail. Female, immature, and winter male: Dull greenish above, yellowish below; has dark brownish or blackish wings; normally no wing bars, but young birds may. Molting male patched with red.

Voice: Song, four or five short phrases, robin-like but hoarse (suggesting a Robin with a sore throat). Note, chip-burr.

Range: Se. Canada, e. U.S. Winters S. America. West: Breeds east of 100th meridian. In migration, a few wander onto Great Plains from Saskatchewan to Texas Panhandle. Rare or casual stray to sw. states, especially California. Accidental in Northwest to British Columbia, Alaska. Habitat: Forests and shade trees (especially oaks). 


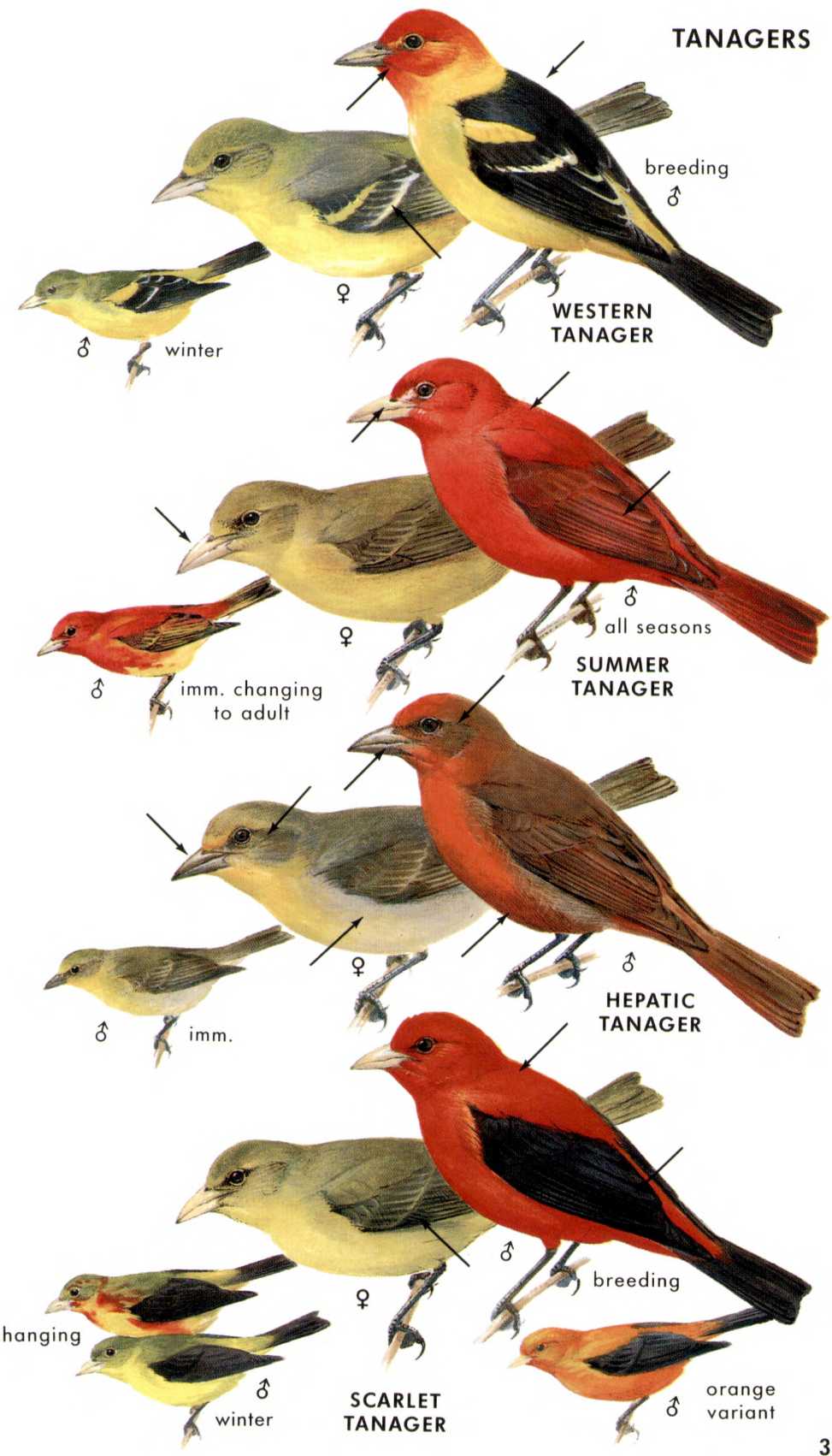




\section{- SPARROWS. Family Emberizidae.}

WHITE-THROATED SPARROW Zonotrichia albicollis

M404

61/2-7" (16-18 cm). A gray-breasted sparrow, similar to White-crown but browner, with a well-defined white throat patch and a yellow spot between the eye and bill. Bill blackish, not pink. Polymorphic; adults with black and white head stripes mate with birds having brown and tan head stripes. Winter: Duller; head stripes vary.

Voice: Song, several clear pensive whistles, easily imitated; one or two clear notes, followed by three quavering notes on a different pitch. Note, a slurred tseet; also a hard chink.

Range: Canada, ne. U.S. Winters to s. U.S., ne. Mexico (rarely). West: Map 404. Habitat: Thickets, brush, undergrowth of conifer and mixed woodlands. Patronizes bird feeders.

WHITE-CROWNED SPARROW Zonotrichia leucophrys

M406

61/2-71/2" $(16-19 \mathrm{~cm})$. Adult: Clear grayish breast and puffy crown striped with black and white. Bill pink or yellowish. Immature: Browner, with head stripes of dark red-brown and light buff; bill pinkish. In birds of high Sierra and Rockies, the white eyestripe extends from the eye instead of from the bill.

Voice: Song, one or more clear, plaintive whistles, followed by husky trilled whistles. Variable; many local dialects.

Range: Across Canada to Alaska; south through w. U.S. Winters w. and s. U.S., Mexico, Cuba. West: Map 406. Habitat: Brushland, forest edges, thickets, chaparral, gardens, parks; in winter also farms and desert washes. Patronizes feeders.

GOLDEN-CROWNED SPARROW Zonotrichia atricapilla

M405

6-7" $(15-18 \mathrm{~cm})$. Similar to White-crowned Sparrow, but without white head stripes; instead a dull yellow central crown stripe, usually bordered broadly with black. Immature birds and some winter adults may look like large female House Sparrows, but are longer-tailed and darker, usually with a dull yellow suffusion on the forecrown. Some lack the yellow and have little to distinguish them except the fine streaking on the crown.

Voice: Song, 3-5 high whistled notes of plaintive minor quality, coming down the scale, "oh-dear-me." Sometimes a faint trill.

Range: Nw. N. America, wintering through Pacific states. Map 405. Habitat: Boreal scrub, spruce; in winter, similar to that of White-crown, but Golden-crown favors denser shrubs.

HARRIS'S SPARROW Zonotrichia querula

M407

$71 / 2 "(19 \mathrm{~cm})$. Large, size of Fox Sparrow. In breeding plumage, has a black crown, face, and bib encircling a pink bill. In winter adults, the black crown is scaled with gray. First-winter young have white on the throat, less black on the crown, buffy brown on the rest of the head; blotched and streaked on the breast. In the second winter the chin is black.

Voice: Song has quavering quality of White-throat's: clear whistles on same pitch, or one or two at one pitch, the rest slightly lower; general effect minor. Alarm note, wink.

Range: N.-cen. Canada. Winters s.-cen. U.S. West: Map 407. Habitat: Stunted boreal forest; in winter, brush, open woods. 


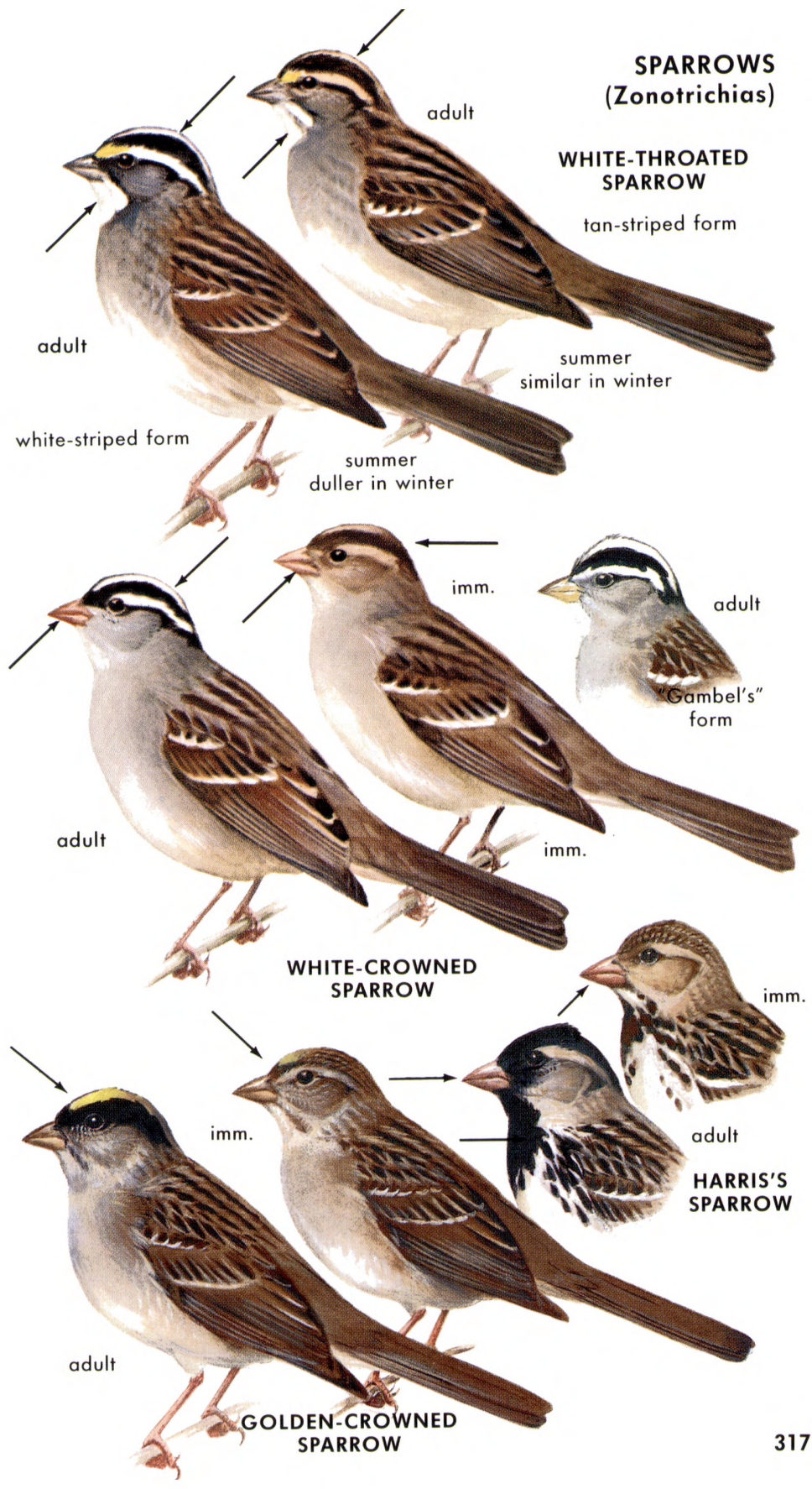


$51 / 2-6 \frac{1}{2} "(14-16 \mathrm{~cm})$. Note the black tail with much white in the corners; also the single dark central breast spot and quail-like head pattern, with the chestnut ear patch and striped crown. Young birds are duller; finely streaked on the sides of the breast.

Voice: A broken song; clear notes and trills with pauses between; characterized by buzzing and churring passages.

Range: S. Canada south (west of Appalachians) to n. Mexico. Winters s. U.S. to El Salvador. West: Map 391. Habitat: Open country with bushes, trees; pastures, farms, roadsides.

SAGE SPARROW Amphispiza belli

M393

5-6" $(13-15 \mathrm{~cm})$. A gray sparrow of arid brush. Note the combination of a single breast spot and heavy dark "whiskers" on each side of the throat. Dark cheek, white eye-ring, touch of whitish over the eye. "Bell's" Sparrow, a race resident west of the Sierra in California, was until recently regarded as a distinct species. It is much darker, with heavier black whiskers.

Voice: Song, four to seven notes, tsit-tsoo-tseee-tsay (third note highest). Or, $t$ sit, tsit, tsi you, tee a-tee.

Range: Western U.S. to n. Mexico. Map 393. Habitat: Dry brushy foothills; chaparral, sage; in winter, also deserts.

FIVE-STRIPED SPARROW Aimophila quinquestriata

6" $(15 \mathrm{~cm})$. A rare Mexican sparrow. Dusky, with five white stripes on the head (white throat, eyebrows, and jaw lines) and a single black spot on the dark gray breast.

Range: Very local in se. Arizona; found in dense shrubs on dry canyon slopes, rocky arid hillsides.

BLACK-THROATED SPARROW Amphispiza bilineata

M392

$43 / 4-5 \frac{1}{4}$ " $(12-13 \mathrm{~cm})$. Note the face pattern. A pretty, gray desert sparrow, with white face stripes and a jet-black throat and chest. Young birds lack the black throat, but have a similar cheek pattern; the breast is finely streaked.

Similar species: (1) Young birds somewhat resemble Sage Sparrow. (2) Black-throated Gray Warbler (similar face pattern) has wing bars and a thin, warbler-like bill (see p. 293).

Voice: Song, a sweet cheet cheet cheeeeeee (two short, clear opening notes and a fine trill on a lower or higher pitch).

Range: Western U.S., n. Mexico. Map 392. Habitat: Arid brush, creosotebush deserts, "cholla gardens."

BLACK-CHINNED SPARROW Spizella atrogularis

M389

5-51/2" (13-14 cm). A somewhat junco-like sparrow (with no white in the tail); it has a streaked brown back, but head and underparts are gray. In the male the pinkish bill is encircled by a black chin and facial patch. Females lack the black and can be told by the unmarked gray head and breast, striped brown back.

Voice: Song, a series of notes on about the same pitch, or descending slightly; starts with several high, thin, clear notes and ends in a rough trill, sweet, sweet, sweet, weet-trrrrrrr.

Range: Sw. U.S. to s. Mexico. West: Map 389. Habitat: Brushy mountain slopes, open chaparral, sagebrush. 


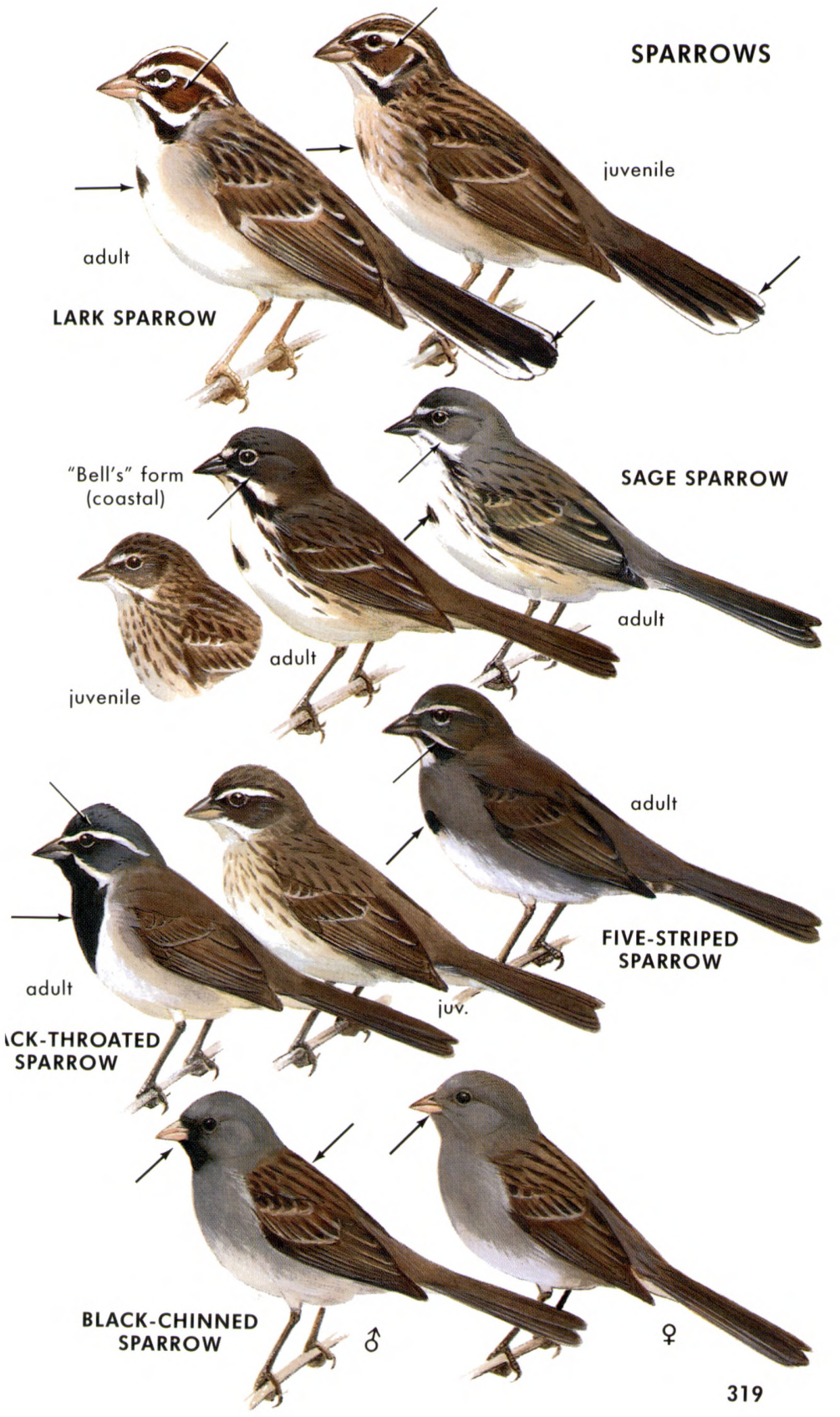


51/4" $(13 \mathrm{~cm})$. Breeding: A small, gray-breasted sparrow with a bright rufous cap, a black line through the eye, and a white line over it. Winter: Browner, not so gray-breasted; cap and eyebrow line duller. Immature: Browner; light crown stripe, gray rump.

Similar species: See Clay-colored Sparrow.

Voice: Song, a chipping rattle on one pitch. Note, a dry chip.

Range: Canada to Nicaragua. Winters s. U.S. to Nicaragua. West: Map 385. Habitat: Open woods, conifers, especially yellow pine, Douglas fir; orchards, farms, towns.

FIELD SPARROW Spizella pusilla

M388

$5^{\prime \prime}(13 \mathrm{~cm})$. Note the pink bill of this rusty-capped sparrow. A narrow light eye-ring gives it a big-eyed expression. It has rather rusty upperparts and a clear breast; facial striping less noticeable than on the other rusty-capped sparrows. The juvenile has a finely streaked breast; note the eye-ring.

Voice: Song, opening on deliberate, sweet, slurring notes, speeding into a trill (which ascends, descends, or stays on the same pitch). Note, tsee; has a querulous quality.

Range: Se. Canada, U.S. (east of Rockies). Winters to ne. Mexico. West: Map 388. Habitat: Bushy pastures, brush, scrub, feeders.

SWAMP SPARROW Melospiza georgiana

M403

$5-5 \frac{3}{4^{\prime \prime}}(13-14 \mathrm{~cm})$. A rather stout, dark, rusty-winged sparrow with a dull gray breast, outlined white throat, rusty cap. No prominent wing bars. Winter birds and immatures are dimly streaked and have little rusty on the striped crown. They are sometimes misidentified as Lincoln's Sparrow (p. 324).

Voice: Song, a loose trill, similar to Chipping Sparrow's, but slower, sweeter, and stronger (sometimes on two pitches simultaneously). Note, a hard chink similar to White-throat's.

Range: Canada (east of Rockies), ne. U.S. Winters s. U.S., n. Mexico. West: Map 403. Habitat: Fresh marshes with tussocks, bushes, or cattails; sedgy swamps.

AMERICAN TREE SPARROW Spizella arborea

M384 $6-61 / 2^{\prime \prime}(15-16 \mathrm{~cm})$. To identify this bird of the North, note the single dark spot or "stickpin" on the breast, and the red-brown cap. Bill dark above, yellow below; two white wing bars.

Voice: Song, sweet, variable, opening on one or two high clear notes. Note, tseet; feeding note, a musical teelwit.

Range: Alaska, n. Canada. Winters s. Canada to cen. U.S. West: Map 384. Habitat: Arctic scrub, willow thickets; in winter, brushy roadsides, weedy edges, marshes; may patronize feeders.

\section{RUFOUS-CROWNED SPARROW Aimophila ruficeps}

M383

$5-6^{\prime \prime}(13-15 \mathrm{~cm})$. A dark sparrow of the arid Southwest, with a plain dusky breast, rufous cap, and rounded tail. Note the black whisker bordering the throat.

Voice: Song, stuttering, gurgling. Note, a nasal dear, dear, dear.

Range: Sw. U.S. Map 383. Habitat: Grassy or rocky slopes with sparse low bushes; open pine-oak woods. 

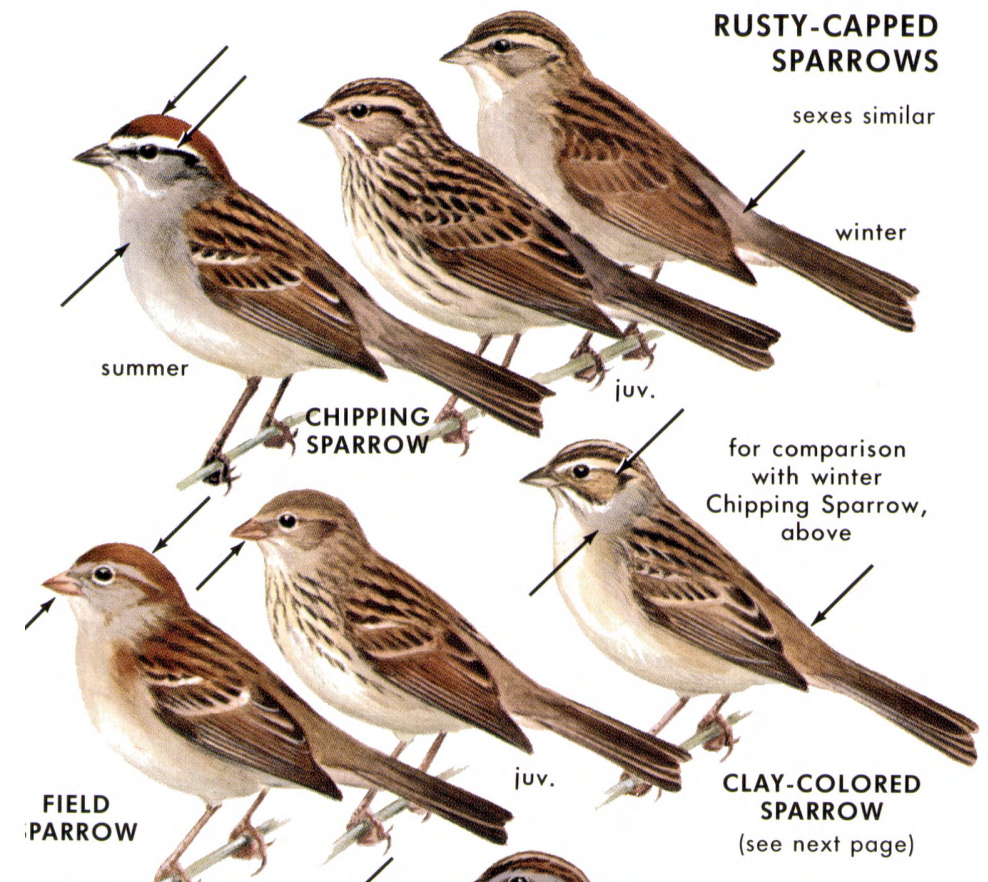
$51 / 4^{\prime \prime}(13 \mathrm{~cm})$. Like a pale Chipping Sparrow, but buffier, with a sharply outlined ear patch. Chipping and Clay-colored sparrows are more obscure in fall and winter, with similar head markings, but the rump is brown in Clay-color, gray in Chipping.

Voice: Unbirdlike; 3-4 low, flat buzzes: bzzz, bzzz, bzzz.

Range: W. and cen. Canada, n.-cen. U.S. In winter, s. U.S. to Mexico. West: Map 386. Habitat: Scrub, brushy prairies, jack pines.

RUFOUS-WINGED SPARROW Aimophila carpalis

$5-51 / 2^{\prime \prime}(13-14 \mathrm{~cm})$. An Arizona specialty. Suggests a Chipping Sparrow, but tail not notched. Double black "whiskers;" gray stripe through rufous crown. Rufous shoulder not easily seen.

Voice: Song, one or two sweet introductory notes and a rapid series of musical chips on one pitch.

Range: Resident from cen. to s. Arizona (local) and Sonora to Sinaloa. Habitat: Tall desert grass, thorn brush, desert hackberry.

BREWER'S SPARROW Spizella breweri

M387

$51 / 4^{\prime \prime}(13 \mathrm{~cm})$. A small pale sparrow of the sagebrush. Clear-breasted; resembles a Chipping Sparrow but sandier; crown finely streaked, with no hint of a median line (as in Chipping and Clay-colored sparrows in fall and winter).

Voice: Song, long, musical buzzy trills on different pitches; sounds like a Chipping Sparrow trying to sing like a Canary.

Range: Breeds w. Canada, w. U.S. Winters s. U.S. to n. Mexico. Map 387. Habitat: Sagebrush, brushy plains; also near tree line in $\mathrm{n}$. Rockies; in winter, also weedy fields.

GRASSHOPPER SPARROW Ammodramus savannarum $4 \frac{1}{2}-51 / 4^{\prime \prime}(11-13 \mathrm{~cm})$. A little sparrow of open fields, with a short sharp tail, flat head, and yellow shoulder (hard to see). Crown with a pale median stripe; note the relatively unstriped buffy breast. However, the juvenile (p. 327) has a streaked breast.

Voice: A thin dry buzz, pi-tup zeeeeeeeeeeee.

Range: S. Canada to s. U.S., W. Indies; also Mexico to Ecuador. West: Map 397. Habitat: Grassland, hayfields, prairies.

BOTTERI'S SPARROW Aimophila botterii

51/4-61/4" (13-16 cm). Very local; nondescript. Cassin's Sparrow, breeding in the same habitat, is almost identical, but grayer. Botteri's has a buffy breast, plain brown tail. Best told by voice.

Voice: Song, a constant tinkling and "pitting," sometimes running into a dry trill on same pitch. Very unlike song of Cassin's.

Range: Se. Arizona (local), s. tip of Texas to Costa Rica. Winters south of U.S. Habitat: In Arizona, desert grass.

CASSIN'S SPARROW Aimophila cassinii

M382

$51 / 2^{\prime \prime}(14 \mathrm{~cm})$. A drab sparrow of open arid country; underparts dingy without markings, or with faint streaking on flanks. Pale or whitish tips on gray-brown outer tail feathers. Best clue is the "skylarking" song. Botteri's Sparrow (very local) does not skylark.

Voice: Song, one or two short notes, a high sweet trill, and two lower notes: ti ti tseeeeeee tay tay; vaguely suggests Savannah Sparrow. Often "skylarks" in the air, giving trill at climax.

Range: Sw. U.S., ne. Mexico. Map 382. Habitat: Grassland, bushes. 
$63 / 4-71 / 2^{\prime \prime}(17-19 \mathrm{~cm})$. Larger than a House Sparrow; most forms have a rusty rump and tail. Action towhee-like, kicking among dead leaves. Breast heavily streaked with triangular spots, shaped like inverted $\mathrm{V}^{\prime} \mathrm{s}$; these often cluster in a large blotch on the upper breast. Fox Sparrows vary widely. Many races; can be roughly divided into three basic types: (1) bright rusty (northern and eastern); (2) dusky head, back, and upper breast (humid Northwest); (3) grayheaded, large yellowish bills (Rockies, Great Basin, Sierra). It is frustrating to try to separate them further; in winter they intermingle. Voice: Song, brilliant and musical; a varied arrangement of short clear notes and sliding whistles.

Range: Alaska, Canada; western mountains to cen.-w. U.S. Winters to s. U.S. West: Map 400. Habitat: Wooded undergrowth, brush.

SONG SPARROW Melospiza melodia

M401

$5-61 / 2^{\prime \prime}(13-16 \mathrm{~cm})$. The heavy breast streaks merge into a large central spot. The bird pumps its rounded tail as it flies. Young birds, more finely streaked, often lack the central spot. Song Sparrows vary widely in color and size, as shown opposite, from typical birds, to small pale forms in the sw. deserts, and very large dark forms in Alaska and Aleutians. Many races are recognized by taxonomists.

Voice: Song, a variable series of notes, some musical, some buzzy; usually starts with three or four bright repetitious notes, sweet sweet sweet, etc. Call note, a low, nasal tchep.

Range: Alaska, Canada to cen. Mexico. West: Map 401. Habitat: Thickets, brush, marshes, roadsides, gardens.

LINCOLN'S SPARROW Melospiza lincolnii

M402

$5 \frac{1}{2}$ " $(14 \mathrm{~cm})$. A skulker, "afraid of its shadow." Similar to a Song Sparrow, but trimmer, side of face grayer, breast streaks much finer and often not aggregated into a central spot. Note the band of creamy buff across the breast and the narrow eye-ring.

Similar species: Immature or winter Swamp Sparrow, sometimes mistaken for Lincoln's Sparrow, has a duller breast, with blurry streaks. Lincoln's is grayer, with a more striped crown.

Voice: Song, sweet and gurgling; suggests both House Wren's and Purple Finch's; starts with low passages, rises abruptly, drops.

Range: Alaska, Canada, w. and ne. U.S. Winters s. U.S. to Panama. West: Map 402. Habitat: Willow and alder thickets, muskeg, brushy bogs. In winter, thickets, weeds, bushes.

VESPER SPARROW Pooecetes gramineus

M390

$6^{\prime \prime}(15 \mathrm{~cm})$. The white outer tail feathers are conspicuous when the bird flies. Otherwise it suggests a grayish Song Sparrow, but has a whitish eye-ring. Bend of wing chestnut.

Similar species: Other sparrow-like field birds with white tail sides are pipits, longspurs, and Lark Sparrow.

Voice: Song, throatier than a Song Sparrow's; usually begins with two clear minor notes, followed by two higher ones.

Range: Canada to cen. U.S. Winters to s. Mexico. West: Map 390. Habitat: Meadows, fields, prairies, roadsides. 

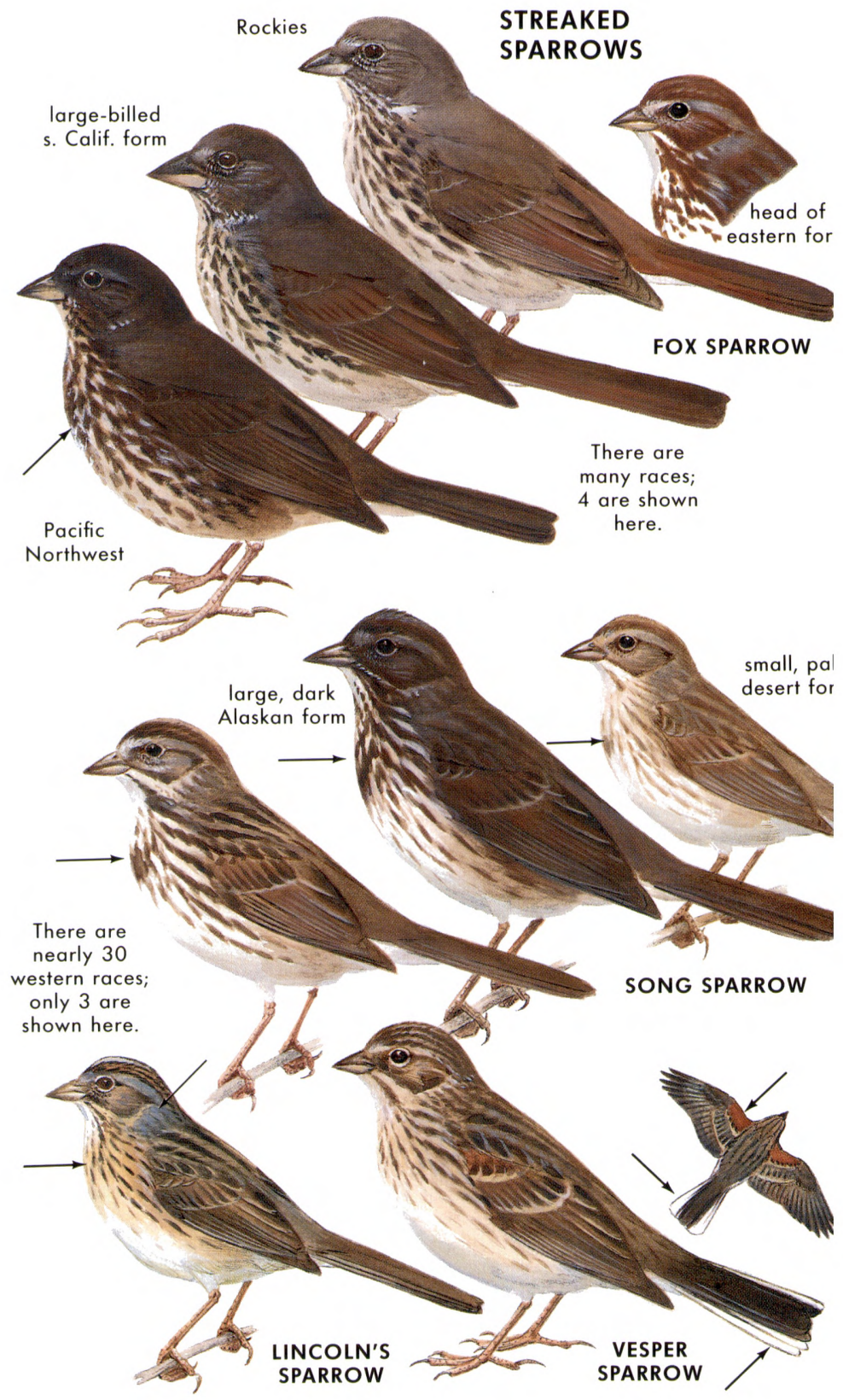
$4 \frac{1}{2}-53 / 4 "(11-14 \mathrm{~cm})$. This streaked open-country sparrow suggests a Song Sparrow, but usually has a yellowish eyebrow stripe, whitish stripe through the crown, a short notched tail, pinker legs. Some birds may lack the yellowish on the eyebrow. The tail notch is an aid to recognition when flushing sparrows (Song Sparrow's tail is longer, rounded). A small dark race, "Belding's Sparrow" (beldingi), resident in salt marshes of $\mathrm{s}$. California was formerly regarded as a species. Its breast streaks are heavier, the median line on the crown is indistinct, the legs browner. A larger Mexican race, "Large-billed Sparrow" (rostratus), which winters north to cen. California, is pale without well-defined markings on the back and crown; the breast streaks are more diffuse. It too was regarded as a species.

Voice: Song, a dreamy, lisping tsit-tsit-tsit, tseeee-tsaay (last note lower). Note, a light tsip.

Range: Alaska, Canada to Guatemala. Winters to Honduras, W. Indies. West: Map 395. Habitat: Open fields, meadows, salt marshes, prairies, dunes, shores.

LE CONTE'S SPARROW Ammodramus leconteii

M398

$4 \frac{1}{2}-5 \frac{1}{2} 2^{\prime \prime}(11-14 \mathrm{~cm})$. A sharp-tailed sparrow of weedy prairie marshes. Note the bright buff-ochre eyebrow stripe and breast (with streaks confined to the sides). Other points are the pinkish-brown nape, white stripe through the crown, strong stripes on the back.

Voice: Song, two extremely thin, grasshopper-like hisses.

Range: S.-cen. Canada to n. prairie states. Winters se. U.S. West: Map 398. Habitat: Tall grass, weedy hayfields, marshes.

BAIRD'S SPARROW Ammodramus bairdii

M396

$51 / 4 "(13 \mathrm{~cm})$. An elusive prairie sparrow. Light breast crossed by a narrow band of fine black streaks. Head yellow-brown, streaked. The key mark is a broad ochre median crown stripe.

Similar species: Savannah Sparrow has more extensive streaking; strip on midcrown is narrower (whitish, not ochre).

Voice: Song begins with 2-3 high musical zip's, and ends with a trill on a lower pitch; more musical than Savannah's.

Range: N. Great Plains. Winters sw. U.S., n. Mexico. West: Map 396. Habitat: Native longgrass prairies; local.

\section{NELSON'S SHARP-TAILED SPARROW Ammodramus nelsoni}

5-6" (13-15 cm). A marsh sparrow. Note the bright ochre-orange on the face, completely surrounding the gray ear patch. Breast very warm ochre, with faint blurry streaks, mostly on the sides. Back sharply striped with white.

Similar species: Le Conte's Sparrow of the prairies has sharp stripes on the sides, a white median stripe through the crown.

Voice: Song, a gasping buzz, tuptup-sheeeeeeeee.

Range: Canadian prairies; Atlantic Coast. Winters mainly on Atlantic and Gulf coasts. West: Breeds ne. British Columbia, Great Slave Lake to cen. Alberta; e. Montana, North Dakota. Very rare winter visitor to California coast. Habitat: Prairie marshes, muskeg; in winter, coastal marshes. 


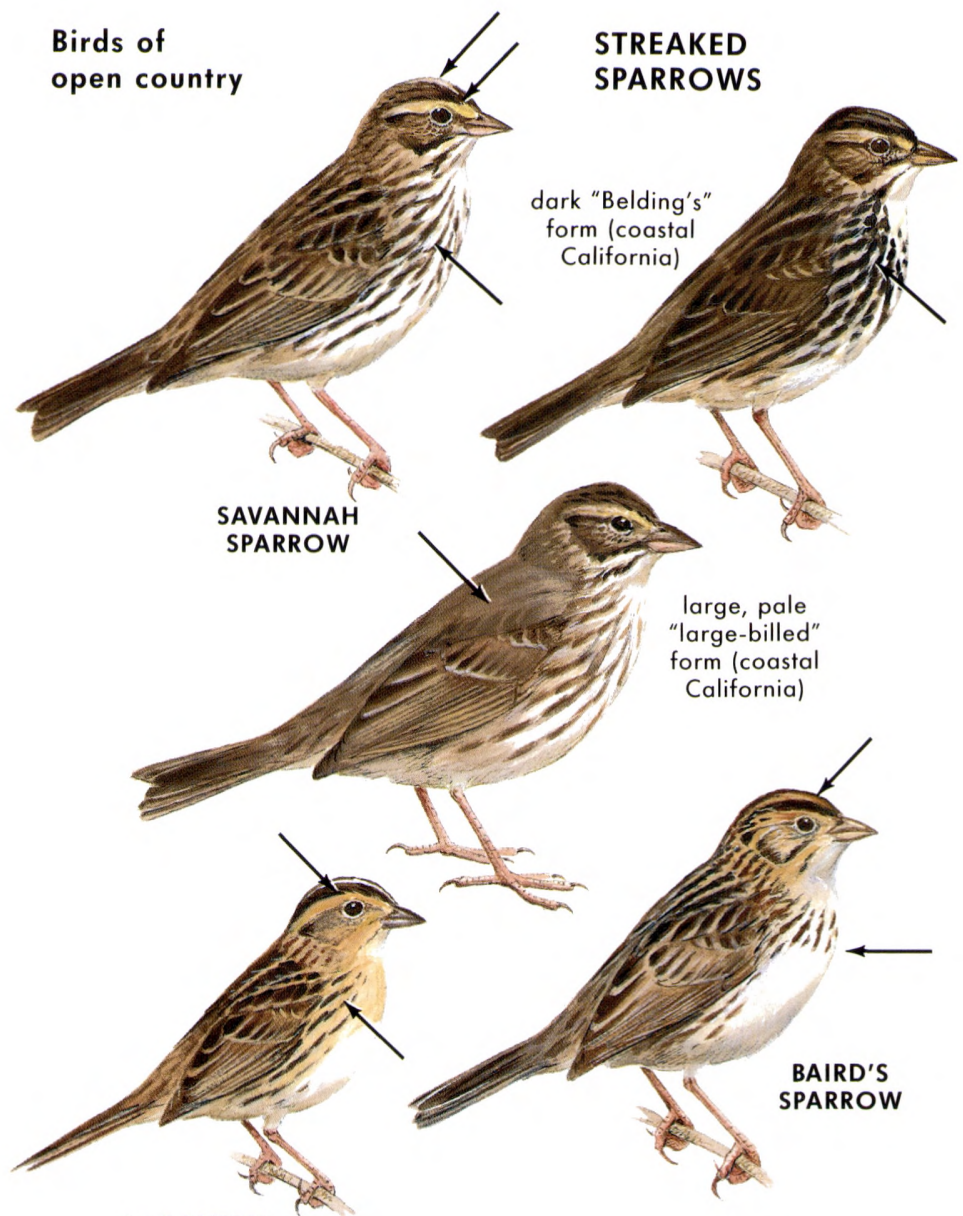

Le CONTE'S

SPARROW

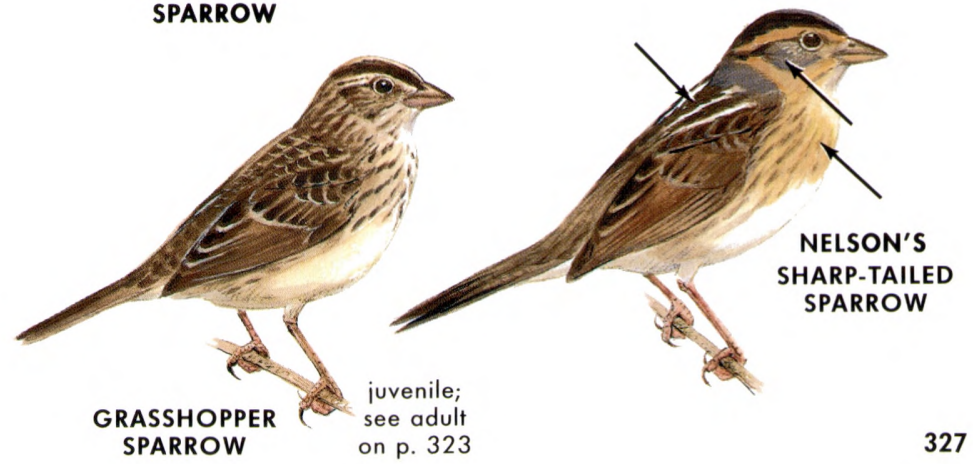


$61 / 2^{\prime \prime}(16 \mathrm{~cm})$. Lapland Longspurs, like Horned Larks, the pipits, and the other longspurs, are birds of open country; in flight, they appear to have shorter tails. Male, breeding: The black face outlined with white is distinctive. Rusty collar. Male, winter: Sparse black streaks on the sides, a rusty nape, and a smudge across the breast help identify it. Female, breeding: Resembles a winter male. Female, winter: More nondescript; note the tail pattern (opposite).

Similar species: (1) Other longspurs have more white in the tail (see opposite). (2) Pipits and Horned Lark have thin bills.

Voice: A musical teew; also a rattle and a whistle, ticky-tick-tew. Song in display flight, vigorous, musical.

Range: Arctic, circumpolar. Winters from s. Canada to s. U.S. West: Map 410. Habitat: In summer, tundra; in winter, fields, prairies.

CHESTNUT-COLLARED LONGSPUR Calcarius ornatus

M412

$51 / 2-61 / 2^{\prime \prime}(14-16 \mathrm{~cm})$. Male, breeding: Solid black below, except on the throat and lower belly; nape chestnut. Female and winter: Sparrow-like; the best field mark is the tail pattern (a dark triangle on a white tail).

Voice: Song, short, feeble, but musical; suggestive of Western Meadowlark's. Note, a finch-like ji-jiv or kittle.

Range: S. Canadian prairies; n. prairie states. Winters sw. U.S., n. Mexico. West: Map 412. Habitat: Plains, prairies.

McCOWN'S LONGSPUR Calcarius mccownii

M409

$6 "(15 \mathrm{~cm})$. Male, breeding: Crown and patch on breast black, tail largely white. Hind-neck gray (brown or chestnut in other longspurs). Female and winter male: Sparrow-like; note the tail pattern (an inverted $\mathrm{T}$ of black on white).

Similar species: (1) Male Chestnut-collared Longspur in summer has a chestnut collar, black belly. (2) Horned Lark (similar breast splotch) has a thin bill, yellow throat.

Voice: Song in display flight, clear sweet warbles, suggestive of Lark Bunting. Note, a dry rattle, softer than Lapland's. Also a soft pink. Range: Prairies of s.-cen. Canada, n.-cen. U.S. Winters sw. U.S. to n. Mexico. West: Map 409. Habitat: Plains, prairies.

SMITH'S LONGSPUR Calcarius pictus

M411

6" $(15 \mathrm{~cm})$. A buffy longspur; warm buff on entire underparts. Tail edged with white, as in Vesper Sparrow (no dark band at tip). Male, breeding: Deep buff; ear patch with a white spot, strikingly outlined by a black triangle. Female and winter: Less distinctive; buffish breast lightly streaked; some males may show a white shoulder.

Similar species: See (1) Vesper Sparrow (p. 324), (2) Sprague's Pipit (p. 244), and (3) other longspurs (study the tail diagrams opposite). Voice: Rattling or clicking notes in flight (has been likened to the winding of a cheap watch). Song, sweet, warbler-like, terminating in $w e^{\prime}$ chew. Does not sing in flight.

Range: N. Alaska to Hudson Bay. Winters s.-cen. U.S. West: Map 411. Habitat: Prairies, fields, airports; in summer, tundra. 


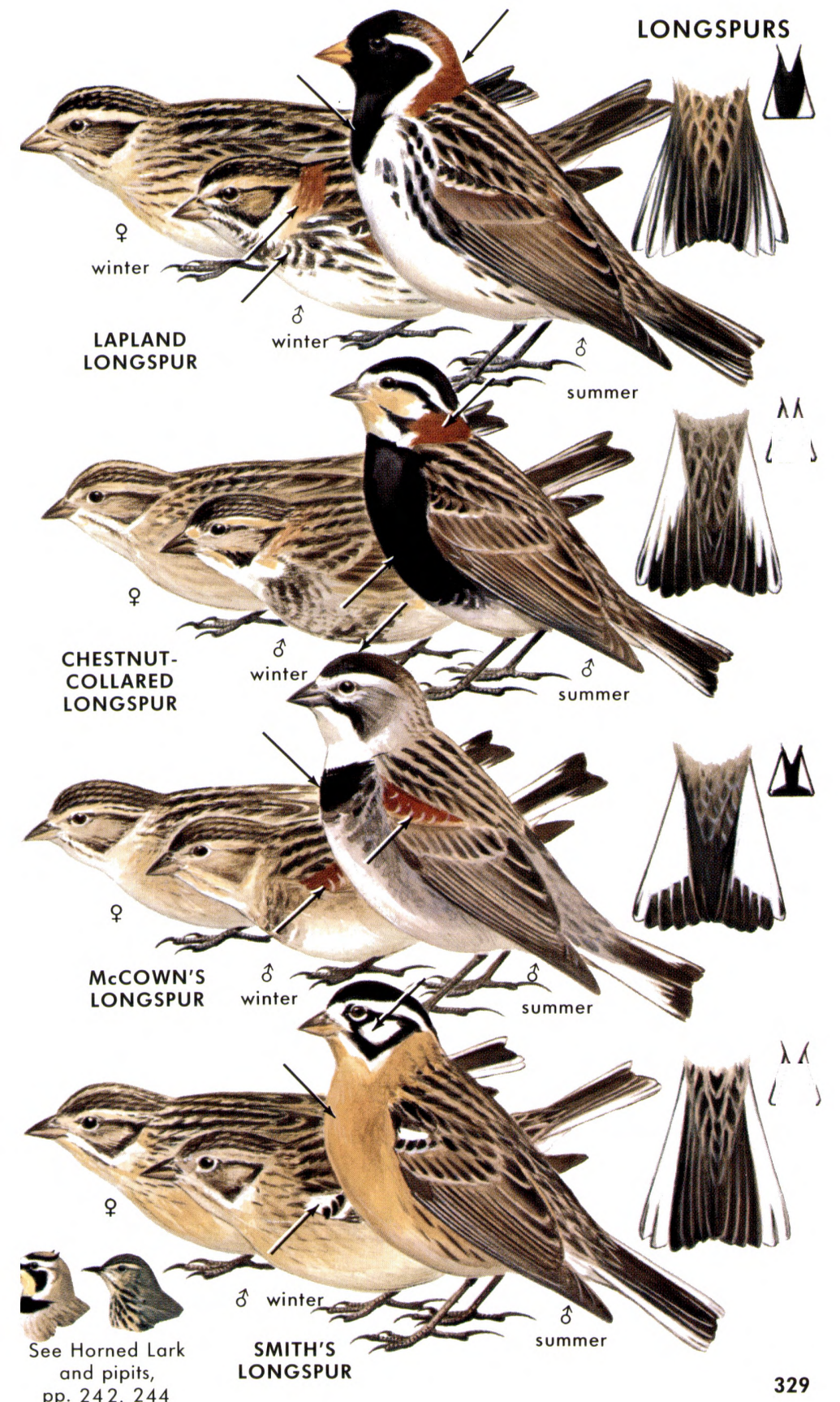


$7-81 \frac{1}{21}(18-21 \mathrm{~cm})$. Smaller and more slender than a Robin, this towhee rummages noisily among the dead leaves. It is readily recognized by its rufous sides. Male: Head and chest black; sides robin-red, belly white, back heavily spotted with white. It flashes large white patches in the tail corners. Eye fiery red. Female: Similar, but dusky brown where the male is black. Juvenile, summer: Streaked below, like a large sparrow, but with the flash pattern in the tail. There are 5 races that can be separated in the field.

Voice: Song, a drawn-out, buzzy chweeeeee. Sometimes chup chup chup zeeeeeee, variable. Note, a cat-like guee or cheeee.

Range: Great Plains West. S. Canada south to Guatemala. West: Map 379. Habitat: Open woods, undergrowth, brushy edges.

CALIFORNIA TOWHEE Pipilo crissalis

M380

(Brown Towhee) 81/2-10" $(21-25 \mathrm{~cm})$. A common, dull brown, ground-loving bird, with a moderately long dark tail; suggests a very plain, slim, overgrown sparrow. Note the pale rusty undertail coverts and the streaked buffy or rusty throat.

Similar species: See (1) Canyon Towhee and (2) Abert's Towhee. Most thrashers (pp. 272-273) are larger, with slim curved bills.

Voice: Note, a metallic chink. Song, a rapid chink-chink-ink-ink-inkink-ink-ink on one pitch. Often ends in a trill.

Range: Resident from sw. Oregon to Baja California. Map 380. Habitat: Brushy, stony area, open chaparral, open woods, canyons, pinyon, junipers, gardens.

CANYON TOWHEE Pipilo fuscus

M380

Formerly regarded as conspecific with the preceding species under the name of "Brown Towhee"; it has now been split. Paler and grayer than California Towhee, with a rufous crown and black spot on the breast. Vocalizations differ.

Range: Resident from Arizona, n. New Mexico, Colorado, w. Texas to s. Mexico. Map 380. Habitat: Similar to California Towhee's, but drier.

ABERT'S TOWHEE Pipilo aberti

M381

8-9" $(20-23 \mathrm{~cm})$. A shy, skulking desert species, similar to the California Towhee, but paler and browner, the entire underparts buffy brown. Note the black patch embracing the base of the bill.

Voice: Note, a sharp peek. Song similar to Canyon Towhee's.

Range: Resident sw. U.S., nw. Mexico. Map 381. Habitat: Desert streams, brush, mesquite.

GREEN-TAILED TOWHEE Pipilo chlorurus

M378

$61 / 2 "(16 \mathrm{~cm})$. This slender finch-like bird of the mountains may be known by its rufous cap, conspicuous white throat, black mustache, gray chest, and plain olive-green upperparts.

Voice: A cat-like mewing note, and a chink like that of California Towhee. Song variable; opening with sweet notes, followed by burry notes; weet-churr-cheeeeee-churr.

Range: Breeds w. U.S. Map 378. Winters sw. U.S. to s. Mexico. Habitat: Dry brush mountain slopes, low chaparral, open pines, sage, manzanita, riverine woods. 


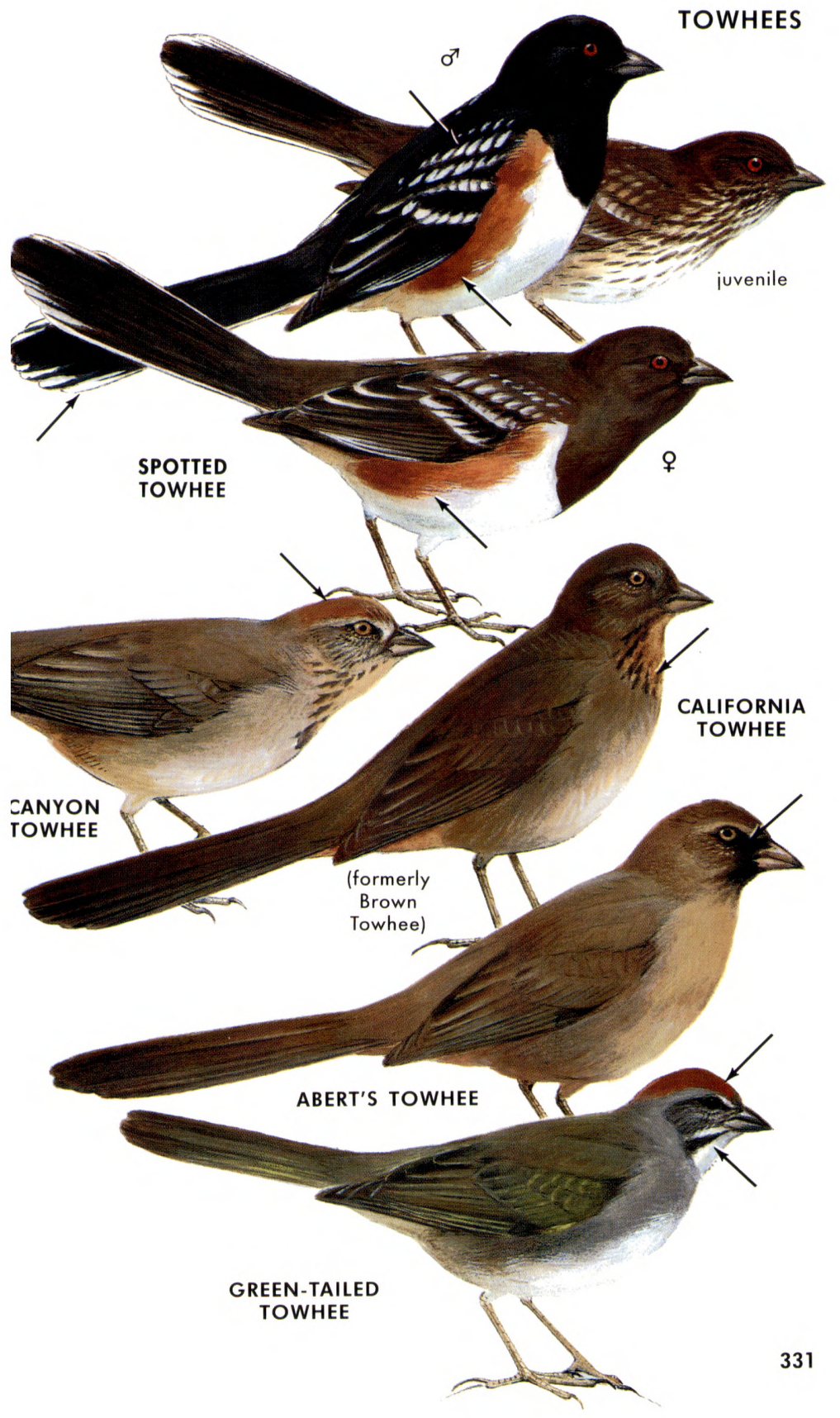


$51 / 2-6^{3} / 4^{\prime \prime}(14-17 \mathrm{~cm})$. This hooded, sparrow-shaped bird is characterized by white outer tail feathers that flash conspicuously as it flies away. The bill and belly are usually whitish. Males may have dark hoods; females and immatures are duller. The juvenile bird in summer is finely streaked on the breast, hence its white outer tail feathers might even suggest a Vesper Sparrow.

Note: Until recently this species was divided into four full species (plus several subspecies) in N. America. Some have gray sides, others rusty or "pinkish." They tend to hybridize or intergrade and are now lumped as one highly complex species. Treated separately, the main forms were known as follows:

(1) "OREGON JUNCO" (J. h. oreganus) of se. coastal Alaska, sw. Canada southward in Pacific states to Baja California and in Rockies to s. Idaho, n. Wyoming. Male rusty-backed, with a black head and buffy or rusty sides.

(2) "GRAY-HEADED JUNCO" (J. h. caniceps) of the Great Basin and s. Rockies. Rufous back like that of "Oregon Junco," but differs in having gray sides and a gray head.

(3) "SLATE-COLORED JUNCO" (J. h. hyemalis), the northern and eastern form, wintering mainly east of the Rockies, sparingly westward. A gray junco with a gray back and white belly. The uniform coloration, lacking rusty or brown areas, is distinctive.

(4) "WHITE-WINGED JUNCO" (J. h. aikeni), of the Black Hills area. A large pale form with a gray back; it usually has two whitish wing bars and exhibits considerably more white in the tail (four outer feathers on each side).

Voice: Song, a loose trill, suggestive of Chipping Sparrow's song, but more musical. Note, a light smack; also clicking or tickering notes.

Range: Breeds Alaska, Canada; south in mountains to n. Georgia, sw. U.S. Winters to Gulf states, n. Mexico. West: Map 408. Habitat: Conifer and mixed woods. In winter, open woods, undergrowth, roadsides, brush; also patronizes feeders.

\section{YELLOW-EYED JUNCO Junco phaeonotus}

(Mexican Junco) $5^{1 / 2-61 / 2^{\prime \prime}}(14-16 \mathrm{~cm})$. Our only junco with yellow eyes. It also lacks the hooded effect and is whitish-throated. Walks rather than hops. The combination of grayish sides and bright rufous back distinguishes this pale-breasted species from all other juncos except the "Gray-headed" form of the Dark-eyed Junco.

Voice: Song, musical, unjunco-like; more complicated, threeparted: chip chip chip, wheedle wheedle, che che che che che.

Range: Resident in high mountains of se. Arizona, extreme sw. New Mexico; south to Guatemala. Habitat: Conifer forests, pineoak woods. 


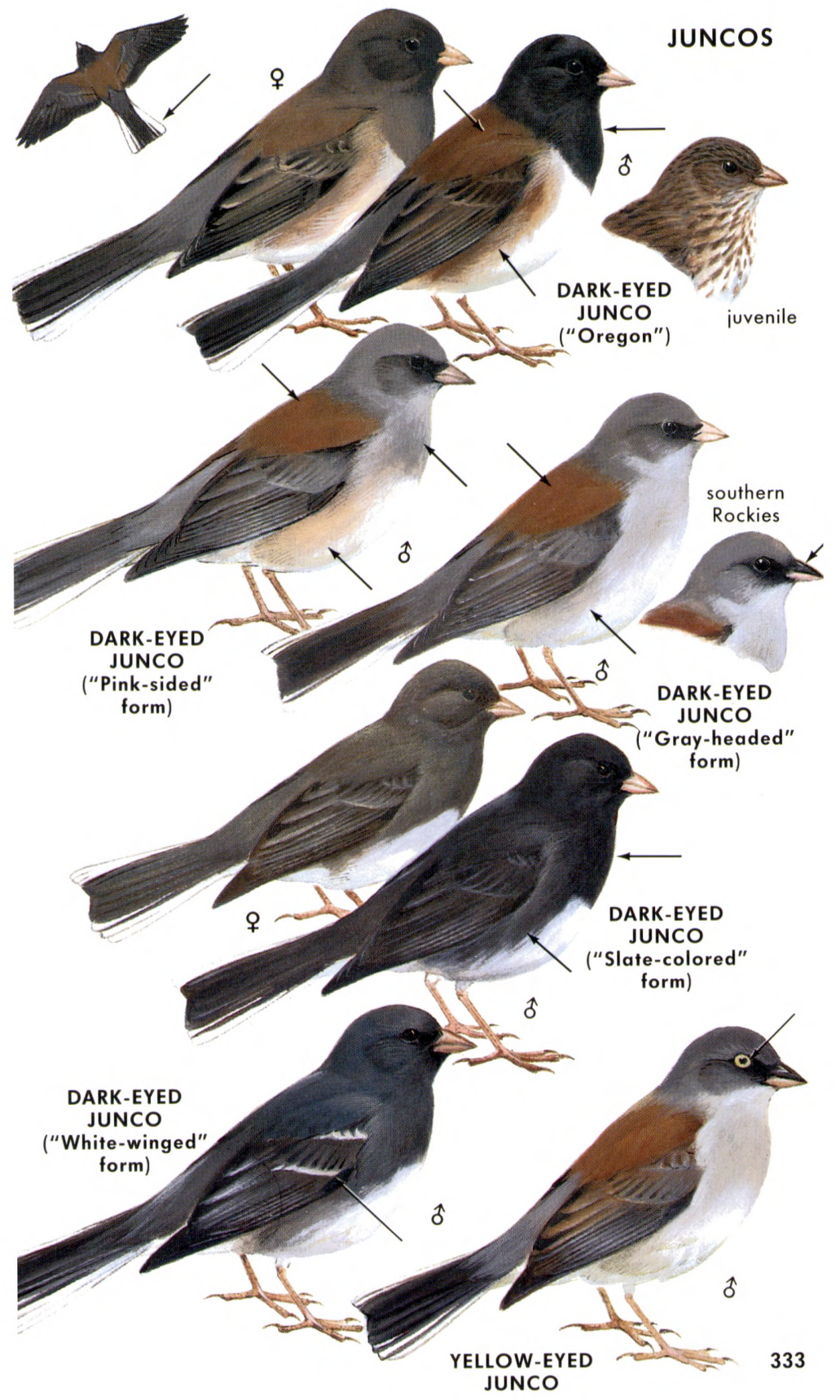




\section{- BUNTINGS. Family Emberizidae (in part).}

SNOW BUNTING Plectrophenax nivalis

M413

6-71/2" (15-19 cm). Snow Buntings often swirl over snowy fields in large flocks. No other songbird (except McKay's Bunting) shows so much white. In winter some individuals, especially females, may look quite brown, but when they fly their flashing white wing patches identify them. Overhead, Snow Buntings look almost entirely white, whereas American Pipits and Horned Larks are black-tailed. In summer in the Arctic the male has a black back, contrasting with its white head and underparts.

Voice: Note, a sharp, whistled teer or tew; also a rough, purring brrt. Song, a musical ti-ti-chu-ree, repeated.

Range: Arctic, circumpolar; in winter to cen. Eurasia, cen. U.S. West: Map 413. Habitat: Prairies, fields, dunes, shores. In summer, tundra.

McKAY'S BUNTING Plectrophenax hyperboreus

7" $(18 \mathrm{~cm})$. An Alaskan specialty. The male in breeding plumage is almost pure white, except for the ends of the primaries and scapulars and the tips of the central tail feathers. Females show some dark on the back. In winter, there are light touches of brown, but less than in the Snow Bunting.

Similar species: Breeding male Snow Bunting has a black back. Females and winter birds are much browner.

Voice: Song of male is said to suggest an American Goldfinch.

Range: Breeds mainly on Hall I. and St. Matthew I. in Bering Sea; rarely on Pribilofs and St. Lawrence I. Winters to coast of w. Alaska, Nunivak; casual, Aleutians, coastal s. Alaska; accidental, Vancouver I., Washington, Oregon. Habitat: Tundra, barrens, shores.

- FINCHES. Family Fringillidae (in part).

M428

At one time considered full species, then classified as 3 races, RosyFinches have now regained full species status. Sparrow-sized birds of snow fields, mountain tops, and rocky islands off Alaska. They do not hop, they walk. Brownish or black with pink wash to wings, rump, and belly. Two have gray head patches.

Voice: All 3 have high chirping notes suggestive of a House Sparrow.

GRAY-CROWNED ROSY-FINCH Leucosticte tephrocotis

6" $(15 \mathrm{~cm})$. Gray cap, with brown throat and chest. Widespread in Alaska, Canada, and nw. U.S. (Aleutian birds are largest). "Hepburn's" and "Pribilof" races have black throats.

BROWN-CAPPED ROSY-FINCH Leucosticte australis

$5.5^{\prime \prime}(14 \mathrm{~cm})$. Male lacks gray cap and black forehead. High mountains of s. Wyoming, Colorado, n. New Mexico.

BLACK ROSY-FINCH Leucosticte atrata

$5.5^{\prime \prime}(14 \mathrm{~cm})$. Male with gray cap and black rather than brown on neck and underbelly. Sw. Montana, cen. Idaho, w. Wyoming, ne. Nevada, n. Utah. 


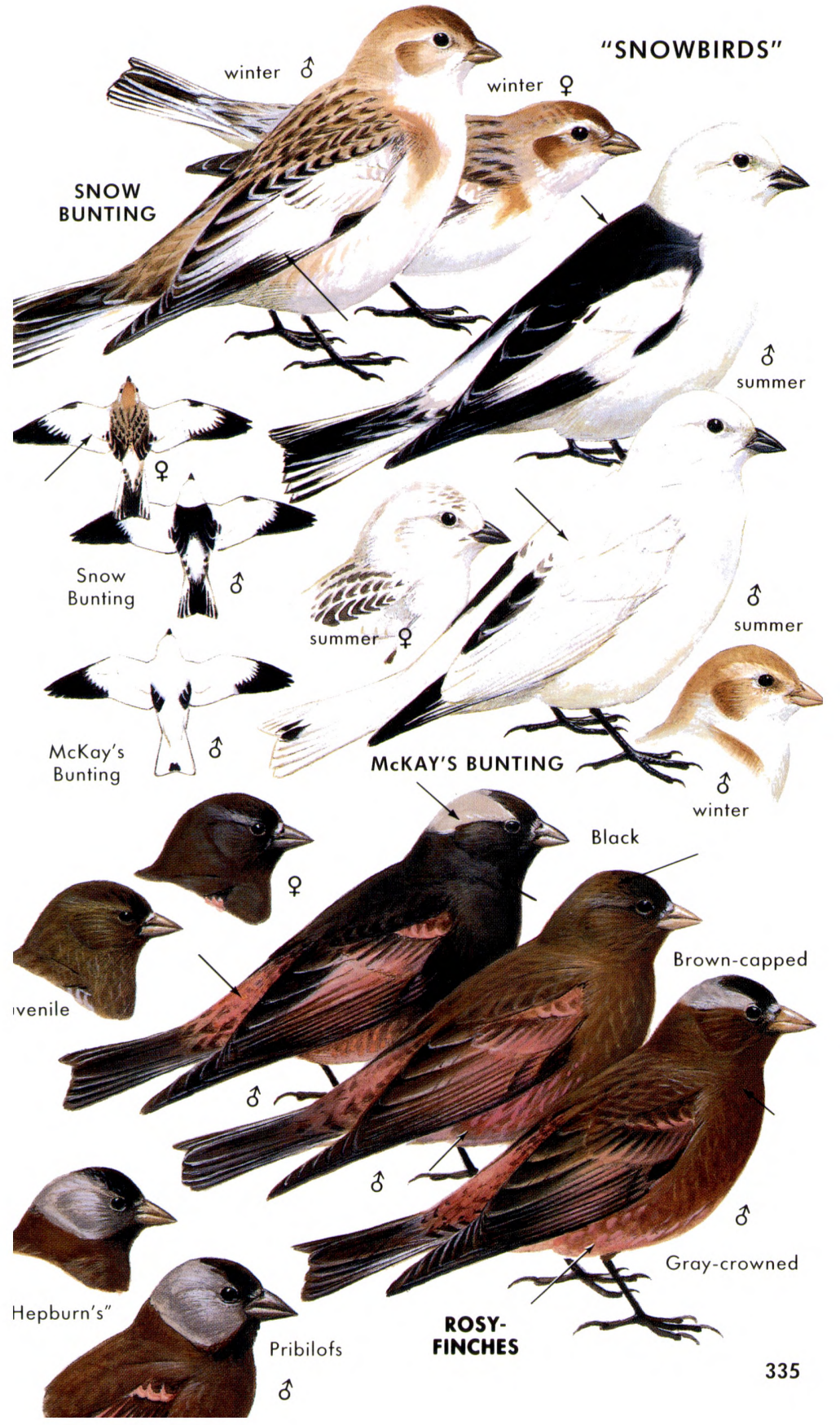


- GROSBEAKS. Family Cardinalidae (in part). Finch-like birds, larger than sparrows, with thick, strong triangular bills adapted for seed-cracking. See also pp. 338,340 .

ROSE-BREASTED GROSBEAK Pheucticus ludovicianus

M371

$7-8 \frac{1}{2} "(18-212 \mathrm{~cm})$. Size and shape of Black-headed Grosbeak. Male: Black and white, with a large triangle of rose-red on the breast and a thick pale bill. In flight, a pattern of white flashes across the black upper plumage; from below, rose-red wing linings. Female: Streaked, like a large sparrow or female Purple Finch; recognized by the large "grosbeak" bill, white wing bars, striped crown, broad white eyebrow stripe, and dark cheek. Wing linings yellow. Differs from the female Black-headed Grosbeak in being heavily striped on the underparts.

Voice: Song very similar to Black-headed Grosbeak's; resembles Robin's song, but mellower (suggesting a Robin that has taken voice lessons). Note, a metallic kik or kek.

Range: S. Canada, e. and cen. U.S. Winters W. Indies, Mexico to e. Peru. West: Map 371. Habitat: Deciduous woods, orchards, groves.

BLACK-HEADED GROSBEAK Pheucticus melanocephalus

M372

61/2-73/4" (16-19 cm). A stocky bird, larger than a sparrow, with an outsized bill. Male: Breast, collar, and rump dull orange-brown. Otherwise, the black head; bold, black and white wing and tail pattern; and pale bill are similar to those of its eastern counterpart, the Rose-breasted Grosbeak. Female: Largely brown, with sparrow-like streaks above; head strongly patterned with light stripes and dark ear patch. Breast strongly washed with ochre-brown; streaks on sides fine, nearly absent across the chest. Female Rose-breast is more heavily striped below, lacks the strong ochre.

Voice: Song, rising and falling passages; resembles a Robin's song but more fluent and mellow. Note, a flat ik or eek.

Range: Sw. Canada, w. U.S. to s. Mexico. Winters in Mexico. Map 372. Sometimes hybridizes with Rose-breasted Grosbeak where ranges overlap.

PYRRHULOXIA Cardinalis sinuatus

M370

$7 \frac{1}{2} "-81 / 2 "(19-21 \mathrm{~cm})$. Male: A Slender, gray and red bird, with a crest and a red, stubby, almost parrot-like bill. The rose-colored breast and crest suggest a Cardinal, but the gray back and yellow bill set it apart. Female: Note the yellow bill. The gray back, buff breast, and touch of red in the wings and crest separate it from the female Cardinal, which is browner with a reddish bill.

Voice: Song, a clear quink quink quink quink quink, on one pitch; also a slurred, whistled what-cheer, what-cheer, etc., thinner and shorter than Cardinal's song.

Range: Sw. U.S. to cen. Mexico. Map 370. Habitat: Mesquite, thorn scrub, deserts. 


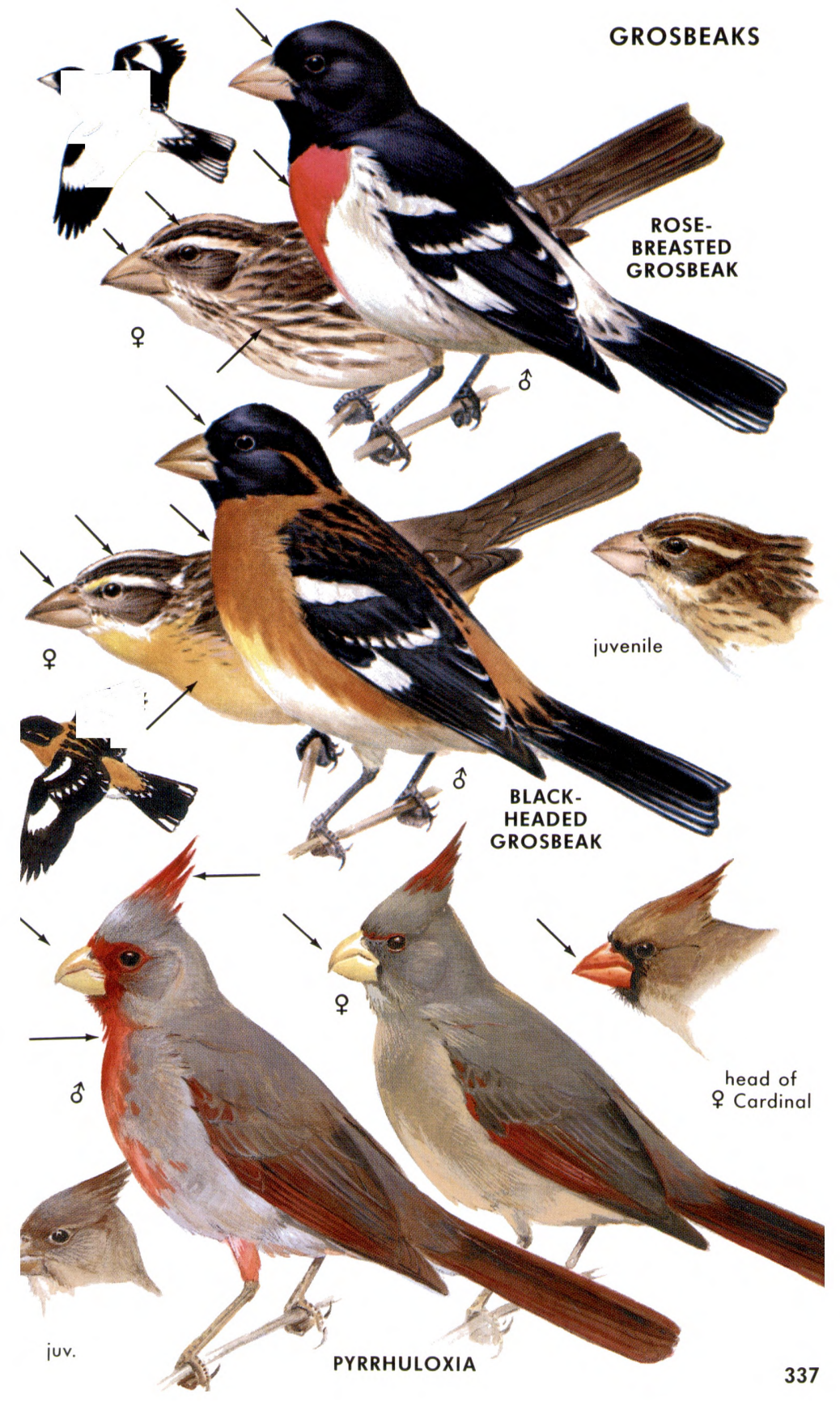


6-71/2" (15-19 cm). Male: Deep dull blue, with a thick bill, two broad tan wing bars. Often flips tail. Immature male, a mixture of brown and blue. Female: About size of Cowbird; warm brown, lighter below, with two tan wing bars; rump tinged with blue.

Similar species: Indigo Bunting is smaller, lacks the wing bars.

Voice: A warbling song, phrases rising and falling; suggests Purple or House Finch; slower, more guttural. A sharp chink.

Range: Cen. U.S. to Costa Rica. Winters Mexico to Panama. West: Map 373. Habitat: Brush, roadsides, streamside thickets.

INDIGO BUNTING Passerina cyanea

$51 / 2^{\prime \prime}(14 \mathrm{~cm})$. Male: A small finch; rich deep blue all over. In autumn more like the brown female, but usually with some blue in the wings and tail. Female: A small, plain brown finch; breast paler, with faint streaks; no strong wing bars or other obvious marks. May hybridize with Lazuli Bunting where their ranges overlap.

Voice: Song, lively, high, and strident; measured phrases, usually paired: sweet-sweet, chew-chew, etc. Note, a sharp, thin spit.

Range: Breeds se. Canada, U.S. west to Great Plains and recently through New Mexico and Arizona locally to se. California (Colorado R.). Rare or casual elsewhere in West. Winters from se. U.S., Mexico to nw. Colombia. Habitat: Brushy pastures, bushy wood edges.

LAZULI BUNTING Passerina amoena

M374

5-51/2" (13-14 cm). Male: A small, turquoise-blue finch, suggesting a Bluebird, but with two white wing bars. Female: A small finch with an unstreaked brown back, a trace of blue in wings and tail, and two pale wing bars (stronger than in female Indigo Bunting). Hybrids are frequent where range overlaps that of Indigo.

Voice: Song, similar to Indigo Bunting's, but faster.

Range: Sw. Canada, w. U.S. Winters in Mexico. Map 374. Habitat: Open brush, streamside shrubs.

PAINTED BUNTING Passerina ciris

M376

$51 / 2^{\prime \prime}(14 \mathrm{~cm})$. The most gaudily colored North American songbird. Male: A patchwork of blue-violet on head, green on back, red on rump and underparts. Female: Very plain; greenish above, paling to lemon-green below; no other small finch is so uniformly green.

Voice: Song, a wiry warble; suggests song of Warbling Vireo.

Range: S. U.S., ne. Mexico. Winters to Panama. West: Map 376. Habitat: Woodland edges, roadsides, brush, towns, gardens.

VARIED BUNTING Passerina versicolor

M375

$4 \frac{1}{2}-51 / 2^{\prime \prime}(11-14 \mathrm{~cm})$. Male: A small dark finch with a plum-purple body (looks black at a distance). Crown, face, and rump blue, with a bright red patch on the nape; "colored like an Easter egg." Female: A small, plain gray-brown finch with lighter underparts. No strong wing bars, stripes, or distinctive marks of any kind.

Similar species: Male Painted Bunting has a bright red breast. Female Indigo is browner, with a hint of breast streaks.

Voice: Song thin, bright, more distinctly phrased, less warbled than Painted Bunting's; notes not as paired as in Lazuli's.

Range: Breeds sw. U.S. to Guatemala. Map 375. Winters from n. Mexico south. Habitat: Streamside thickets, brush. 
$71 / 2-9^{\prime \prime}(19-23 \mathrm{~cm})$. Male: An all-red bird with a pointed crest and a black patch at the base of its heavy, triangular red bill. Female: Buff-brown, with some red on the wings and tail. The crest, dark face, and heavy red bill are distinctive. Immature: Similar to the female, but with a blackish bill (see Pyrrhuloxia, p. 337, and Hepatic Tanager, p. 315).

Similar species: Male Summer and Hepatic tanagers, the other allred birds of the Southwest, have no crests.

Voice: Song, clear, slurred whistles; repeated. Several variations: what-cheer cheer cheer, etc.; whoit whoit whoit or birdy birdy birdy, etc. Note, a short, light tik.

Range: S. Quebec to Gulf states; sw. U.S., Mexico to Belize. West: Map 369. Habitat: Woodland edges, thickets, suburban gardens, towns, bird feeders.

FINCHES. Family Fringillidae. These birds have seed-cracking bills of three main types: (1) very large and grosbeak-like, as in the Evening Grosbeak; (2) rather canary-like, as in most of the lesser finches such as the Goldfinch; and (3) cross-tipped, as in the two crossbills. Until recently, all the other grosbeaks as well as the sparrows and buntings were also put into this family, but now they are lumped with such unlikely associates as the tanagers, warblers, blackbirds, and orioles in the catch-all family Emberizidae. See the Systematic Checklist, pp. 409-416.

\section{RED CROSSBILL Loxia curvirostra}

M433

$51 / 2-61 / 2^{\prime \prime}(14-16 \mathrm{~cm})$. Near the size of a House Sparrow, with a heavy head and short tail. Note the crossed mandibles. The sound when it cracks the cones of evergreens often betrays its presence. It acts like a small parrot as it dangles while feeding. Male: Dull red, brighter on the rump; wings and tail blackish. Young males are more orange. Female: Dull olive-gray; yellowish on the rump and underparts. Juvenile: Striped above and below, suggesting a large Pine Siskin; note the bill.

Voice: Note, a hard jip-iip or jip-jip-jip. Song, finch-like warbled passages, iip-jip-jip-jeeaa-jeeaa; trills, chips.

Range: Conifer forests of N. Hemisphere. In N. America, south in mountains to Nicaragua; in East, locally to s. Appalachians. Erratic wanderings in winter. West: Map 433. Habitat: Conifers.

WHITE-WINGED CROSSBILL Loxia leucoptera M434 $6-6^{3} / 4^{\prime \prime}(15-17 \mathrm{~cm})$. Note the wing bars and crossed mandibles. Male: Dull rose-pink, with black wings crossed by two broad white wing bars; tail black. Female: Olive-gray, with a yellowish rump similar to female Red Crossbill's, but with two broad white wing bars. The wing bars are often quite evident in flight and help pick out this species in mixed flocks of crossbills.

Voice: Notes, a liquid peet and a dry chif-chif. Song, a succession of loud trills on different pitches.

Range: Boreal forests of N. Hemisphere. Also Hispaniola. West: Map 434. Habitat: Spruce and fir forests, hemlocks. 


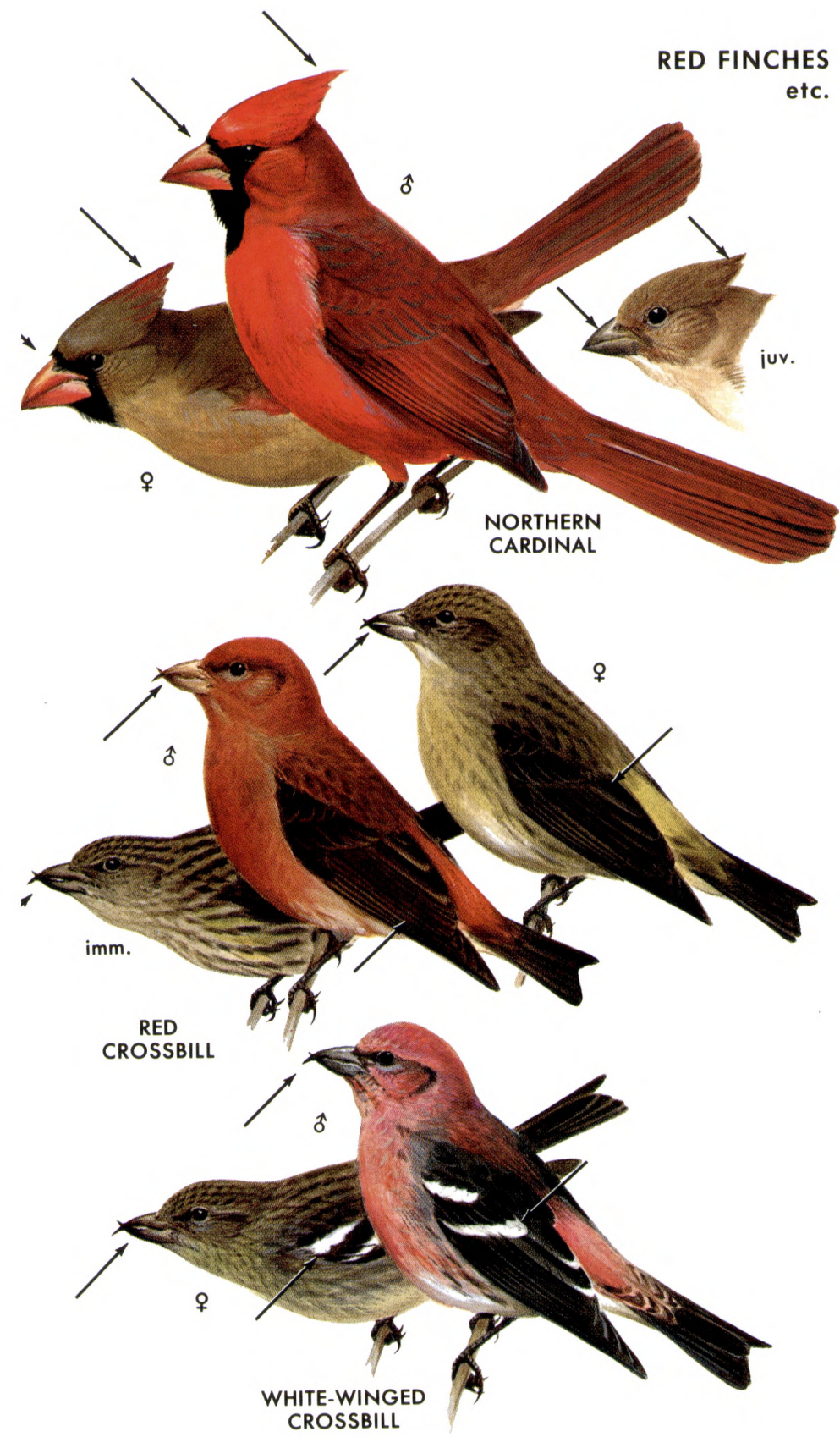


$5-5 \frac{1}{2} "(13-14 \mathrm{~cm})$. Note the bright red cap on the forehead of this little winter finch. Gray-brown, streaked; note the black chin and dark flank streaks. Male has a pink breast. Among the more typical Redpolls, look for "frostier" birds. If the rump is without streaks and the bill is smaller, the bird is a "Hoary" Redpoll-until recently designated a species (Carduelis hornemanni), but now regarded as a northern population of the Common Redpoll.

Voice: In flight, a rattling chet-chet-chet-chet. Song, a trill, followed by the rattling chet- chet-chet-chet.

Range: Circumboreal. West: Map 435. Habitat: Birches, tundra scrub. In winter, weeds, brush.

HOUSE FINCH Carpodacus mexicanus

M432

5-53/4" (13-14 cm). Male: Bright red breast, forehead, stripe over the eye and rump. Resembles male Purple and Cassin's finches but slighter; male brighter red. Note the dark stripes on the sides and belly. The striped brown female is separated from female Purple and Cassin's finches by its smaller head, bill, and bland face (no heavy mustache or dark cheek patch). Some males may be orange.

Voice: Song, bright, loose and disjointed; often ends in a nasal wheer. Notes suggest a House Sparrow's, but more musical.

Range: British Columbia to s. Mexico. Introduced in e. U.S.; spreading. West: Map 432. Habitat: Cities, suburbs, farms, canyons; feeders.

PURPLE FINCH Carpodacus purpureus

M430

$5 \frac{1}{2}-6^{\prime \prime}(14-15 \mathrm{~cm})$. Like a sparrow dipped in raspberry juice. Male: Dull rose-red, brightest on the head, chest, and rump. Female and immature: Heavily striped, brown; similar to a female House Finch, but note the broad dark jaw stripe, dark ear patch, and broad light stripe behind the eye.

Voice: Song, a fast lively warble; note, a dull metallic tick.

Range: Canada, Pacific states, n. Baja California, ne. U.S. Winters to S. U.S. West: Map 430. Habitat: Woods, groves, suburbs, feeders.

CASSIN'S FINCH Carpodacus cassinii

M431

6-61/2" $(15-16 \mathrm{~cm})$. Male: Very similar to Purple Finch, but red of breast paler; squarish red crown patch contrasts abruptly with the brown of the nape; bill has a straighter ridge. Note, a musical chidiup. Female: Whiter underparts, sharper stripings, streaked undertail coverts, and bill shape distinguish it from female Purple Finch.

Range: Sw. Canada, w. U.S. Winters to mountains of Mexico. Map 431. Habitat: Conifers in high mountains; lower levels in winter.

PINE GROSBEAK Pinicola enucleator

M429

8-10" (20-25 cm). Near size of Robin; a large, tame "winter" finch with a stubby bill, longish tail. Not a true Grosbeak. Flight undulates deeply. Male, adult: Dull rose-red, dark wings with two white bars. Male, immature: Similar to the gray female, but with a touch of russet on the head and rump. Female: Gray, with two white wing bars; head and rump tinged with dull yellow.

Voice: Call, a whistled tee-tew-tew, suggesting that of Greater Yellowlegs, but finch-like; also a musical chee-vli.

Range: Boreal forests of N. Hemisphere; winters irruptively southward. West: Map 429. Habitat: Conifers; in winter, other trees. 


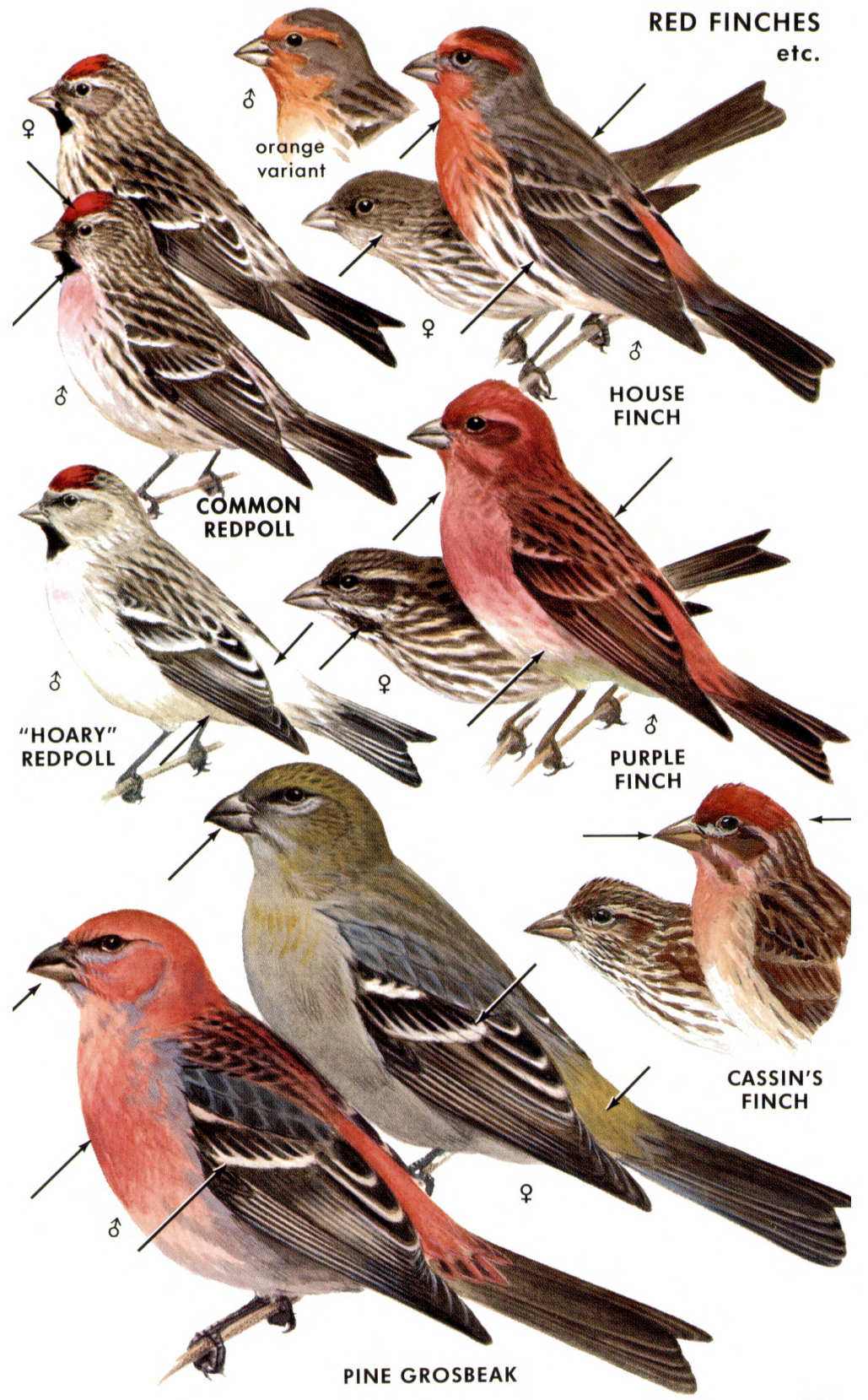


8" $(20 \mathrm{~cm})$. Size of a starling. A chunky, short-tailed finch with a very large, pale, conical bill. Male: Dull yellow, with a dark head, yellow eyebrow, and black and white wings; suggests an overgrown Goldfinch. Female: Silver-gray, with enough yellow, black, and white to be recognized. Gregarious. Undulating flight, shape, and large white wing patches identify them.

Voice: A ringing, finch-like clee-ip; a high, clear thew.

Range: Spruce belt of Canada, ne. and w. U.S. to Oaxaca. Winters to se. U.S., Mexico. West: Map 440. Habitat: Conifer forests; in winter, box-elders and other maples; also fruiting shrubs; often swarm at feeding trays. AMERICAN GOLDFINCH Carduelis tristis

M439 5" (13 cm). Male, summer: A small yellow bird with black wings; tail and forehead also black. Female, summer: Dull yellow-olive; darker above, with blackish wings and conspicuous wing bars. Goldfinches are distinguished from other small, olive-yellow birds (warblers, etc.) by their short, conical bills. Winter, both sexes: Much like summer female, but gray-brown; yellow on throat.

Voice: Song, clear, light, canary-like. In undulating flight, each dip is punctuated by ti-dee'-di-di or per-chik-o-ree, or "po-ta-to-chip."

Range: S. Canada to s. U.S., n. Baja California. West: Map 439. Habitat: Patches of thistles and weeds, dandelions on lawns, roadsides, open woods, edges; in winter, also feeders.

LESSER GOLDFINCH Carduelis psaltria

M437

33/4-41/4" $(9-11 \mathrm{~cm})$. Male: A very small finch with a black cap, black or greenish back, and bright yellow underparts; white on the wings. Black cap retained in winter. Males of race psaltria (s. Rockies) have black backs; males of western race hesperophilus have greenish backs. Female: Similar to American Goldfinch, but smaller, more greenish; rump dark (not pale).

Voice: Sweet, plaintive notes tee-yee (rising) and tee-yer (dropping). Song, more phrased than American Goldfinch's.

Range: Breeds from w. U.S. to Peru. Map 437. Habitat: Open brushy country, open woods, wooded streams, gardens.

LAWRENCE'S GOLDFINCH Carduelis lawrencei

M438

$4 \frac{1}{2} 2^{\prime \prime}(11 \mathrm{~cm})$. In all plumages known by the large amount of yellow in the wings. Male has a black face (including chin).

Voice: Song similar to that of American Goldfinch. Call note, distinctive: tink-oo, syllables emphasized equally.

Range: Breeds n. California to n. Baja California. Winters sw. U.S., nw. Mexico. Map 438. Habitat: Oak-pine woods, chaparral.

PINE SISKIN Carduelis pinus

M436

41/2-5" (11-13 cm). Size of a Goldfinch. A small, dark, heavily streaked finch with a deeply notched tail, sharply pointed bill. A touch of yellow in the wings and at the base of the tail (not always evident). Most Siskins are detected by voice, flying over.

Voice: Call, a loud chlee-ip; also a light tit-i-tit; a buzzy shreeeee. Song suggests Goldfinch's, but coarser, wheezy.

Range: S. Canada to s. U.S. Winters to cen. Mexico. West: Map 436. Habitat: Conifers, mixed woods, alders, weedy areas, feeders. 

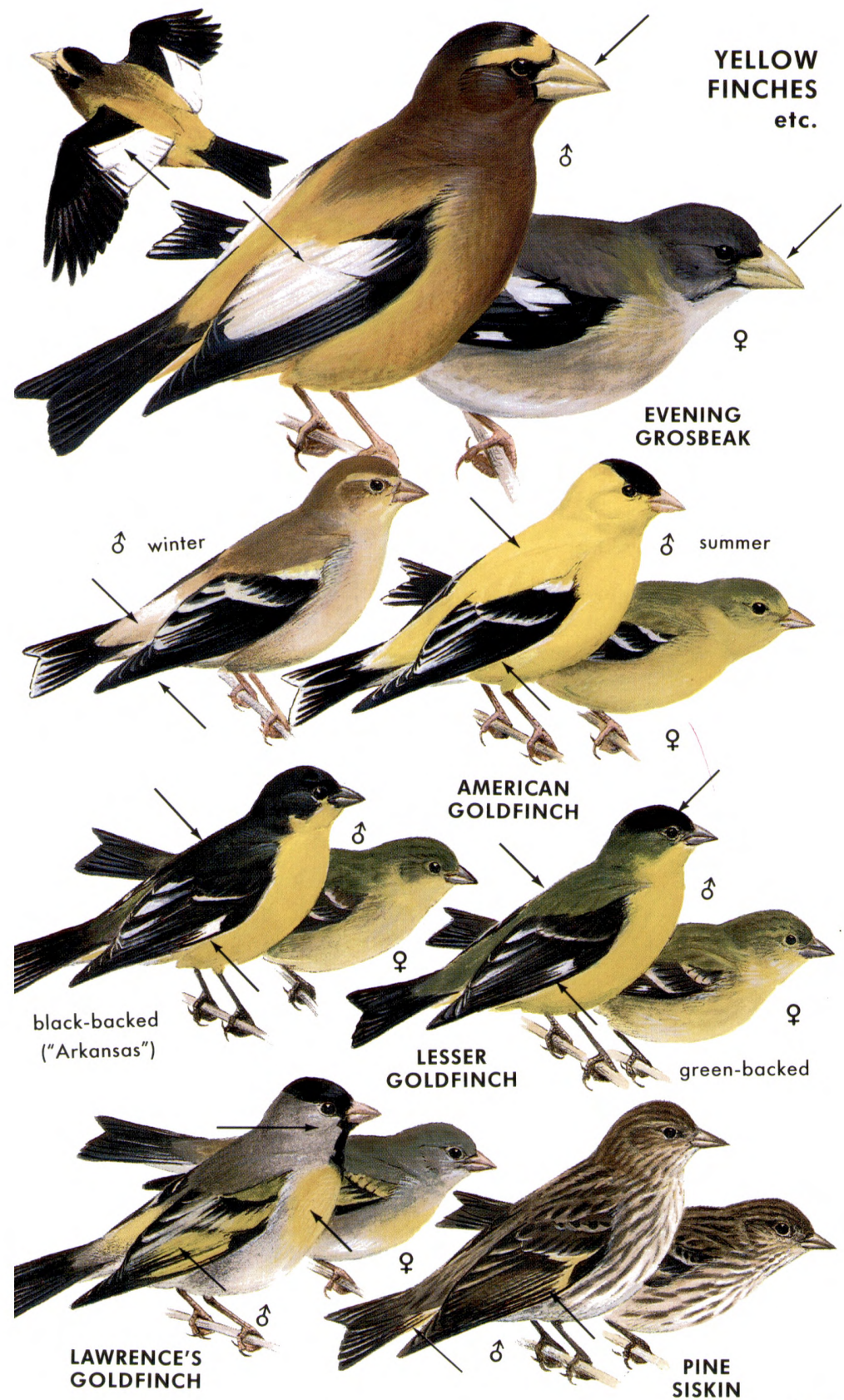
- OLD WORLD SPARROWS. Family Passeridae. Old World sparrows, unrelated to our native sparrows, which are lumped with the Emberizidae. Food: Insects, seeds. Range: Widespread in Old World; 301 species (sparrow-weavers, 35); West 2 (introduced).

HOUSE SPARROW Passer domesticus

M441

6" $(15 \mathrm{~cm})$. Familiar to everyone. Sooty city birds often bear little resemblance to clean country males with the black throat, white cheeks, chestnut nape. Females and young lack the black throat, have a dingy breast, rusty wings, and dull eyestripe.

Range: Eurasia, n. Africa. Introduced N. and S. America, S. Africa, Australia. West: Map 441. Habitat: Cities, farms.

EURASIAN TREE SPARROW Passer montanus (not shown)

$5 \frac{1}{2} "(14 \mathrm{~cm})$. Both sexes resemble male House Sparrow, but black throat patch smaller. Key mark is a black ear spot. Crown brown. Illustrated in the eastern Field Guide.

Range: Eurasia. Introduced; local resident in vicinity of St. Louis, Missouri. West: Reported recently from s. Vancouver I.

\section{MISCELLANEOUS SPARROW-LIKE SPECIES.}

\section{BROWN-HEADED COWBIRD Molothrus ater}

$7 "$ (18 cm). The gray-brown female and the juvenile with its soft streaking may be taken for sparrows of some sort because of their short, finchlike bills. See fuller coverage on p. 310 .

DICKCISSEL Spiza americana

M377

6-7" (15-18 cm). A grassland bird; often travels in large flocks. Sits on fenceposts. Male: Suggests a miniature Meadowlark (black bib, yellow chest). In fall the bib is obscure or lacking. Female: Very much like a female House Sparrow, but paler, with a lighter stripe over the eye, touch of yellow on the breast, and a bluish bill. The chestnut shoulder is also an aid.

Voice: Song, a staccato dick-ciss-ciss-ciss or chup-chup-klip-klip-klip. A short buzzing call is often heard at night in migration.

Range: S. Canada and interior of U.S. Winters mainly from Mexico to $\mathrm{n}$. S. America. Very rare migrant and winter visitor to California. West: Map 377. Habitat: Alfalfa and other fields, meadows, prairies.

BOBOLINK Dolichonyx oryzivorus

Because of the short bill, female Bobolinks and autumn males may suggest sparrows or finches. They are a bit larger than House Sparrows; rich buff, with dark stripings on the crown and back. For a fuller discussion, see p. 308.

LARK BUNTING Calamospiza melanocorys

M394

7" $(18 \mathrm{~cm})$. A prairie bird. Gregarious. Male in spring: Black, with large white wing patches (male Bobolink has white patches on the body, not on the wings). Female, young, and winter male: Brown, streaked; pattern suggests female Purple Finch. Usually some birds in the flock show whitish wing patches.

Voice: Song, cardinal-like slurs, unmusical chat-like $c h u g$ 's; piping whistles and trills; each note repeated 3-11 times.

Range: Prairies of s. Canada to n. Texas. Winters sw. U.S. to cen. Mexico. West: Map 394. Habitat: Plains, prairies. 


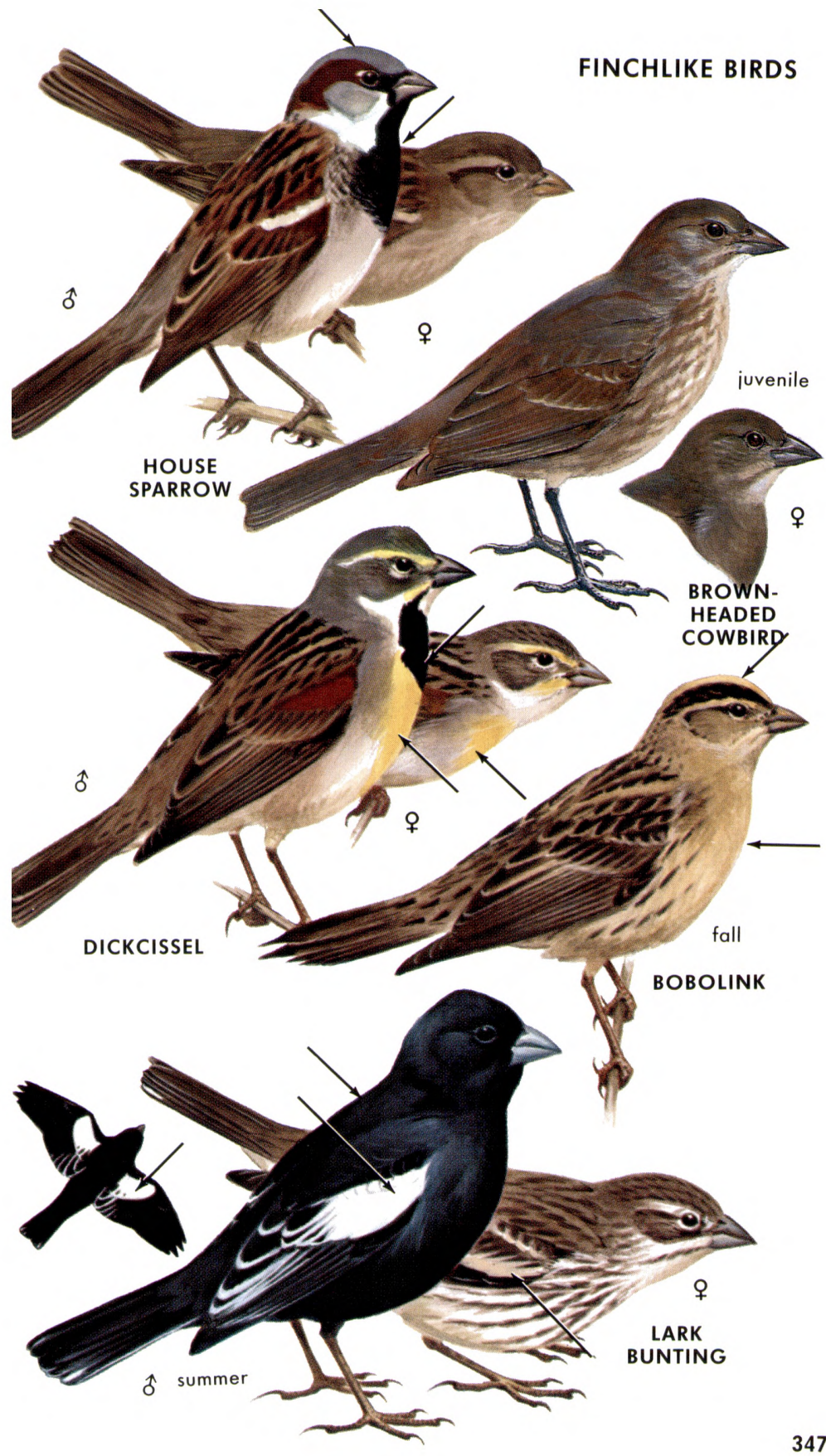


- MISCELLANEOUS STRAYS FROM MEXICO. The birds shown opposite and on the next plate may be found by the birder who travels to Mexico to sample its rich avifauna. On very rare occasion, one of these strays from the neotropics slips across the border to our side. Arizona has been especially favored. A few other Mexican rarities or accidentals have been treated earlier in this book-the Eared Trogon (p. 206), a few hummingbirds (pp. 220221), and the Rufous-backed Robin (pp. 274-275). Still others may eventually be added to our U.S. list by perceptive birders. To prepare for the unexpected, study A Field Guide to Mexican Birds.

STREAK-BACKED ORIOLE Icterus pustulatus (Scarlet-headed Oriole) 8 " $(20 \mathrm{~cm})$. The breeding adult has a striped back. Much white in the wing. Otherwise resembles Hooded Oriole. Male is basically yellow-orange, head becoming almost red. Female is duller, back more olivaceous, but the streaking is still obvious. West: Sparse wanderer in fall and winter to s. Arizona (where it has visited hummingbird feeders around Tucson). Casual stray, s. California.

\section{BLACK-VENTED ORIOLE Icterus wagleri}

$71 / 2-9^{\prime \prime}(19-23 \mathrm{~cm})$. This black-hooded oriole differs from the yellow and black Scott's Oriole in being more orangish, with no white in the wing. Note the black vent (undertail coverts), all-black tail. Sexes alike. West: Accidental, w. Texas (Big Bend, San Ygnacio).

\section{RUFOUS-BACKED ROBIN Turdus rufopalliatus}

9" $(23 \mathrm{~cm})$. Like a pale American Robin, but with a rufous back and no white around the eye. West: Rare fall and winter visitor s. Arizona. Accidental, Texas, New Mexico, California. See also p. 275.

AZTEC THRUSH Ridgwayia pinicola

$81 / 2^{\prime \prime}(21 \mathrm{~cm})$. A robin-like thrush with a dark hood, white belly, white rump. Wings strikingly patched with white. Male, blackish on head, breast, and back; female brownish. West: Casual stray near Mexican border of w. Texas (Big Bend) and mountains of se. Arizona.

FLAME-COLORED TANAGER Piranga bidentata

(Stripe-backed Tanager) 6-71/2" $(15-19 \mathrm{~cm})$. The male is fire-red with a striped back, dusky ear patch and two whitish wing bars. Dark tail tipped in corners with white. The female looks somewhat like a female Western Tanager (two white wing bars), but the striped back is a giveaway. West: Accidental, se. Arizona (Chiricahua Mts., where a male apparently nested with a female Western Tanager).

YELLOW GROSBEAK Pheucticus chrysopeplus

$81 / 2^{\prime \prime}(21 \mathrm{~cm})$. Size and shape of Black-headed Grosbeak; male golden yellow and black, suggesting an overblown Goldfinch except for the large, black grosbeak bill. Female duller, with a streaked back and crown. West: Casual vagrant in summer, s. Arizona.

RUDDY GROUND-DOVE Columbina talpacoti

6-7" (15-18 cm). Male, a small, reddish-looking dove with a light blue-gray crown and black underwing coverts. The dull gray-brown female resembles the Common Ground-Dove somewhat, but lacks the scaly appearance on the sides of the breast. West: Accidental, California, Arizona, New Mexico, Texas. 


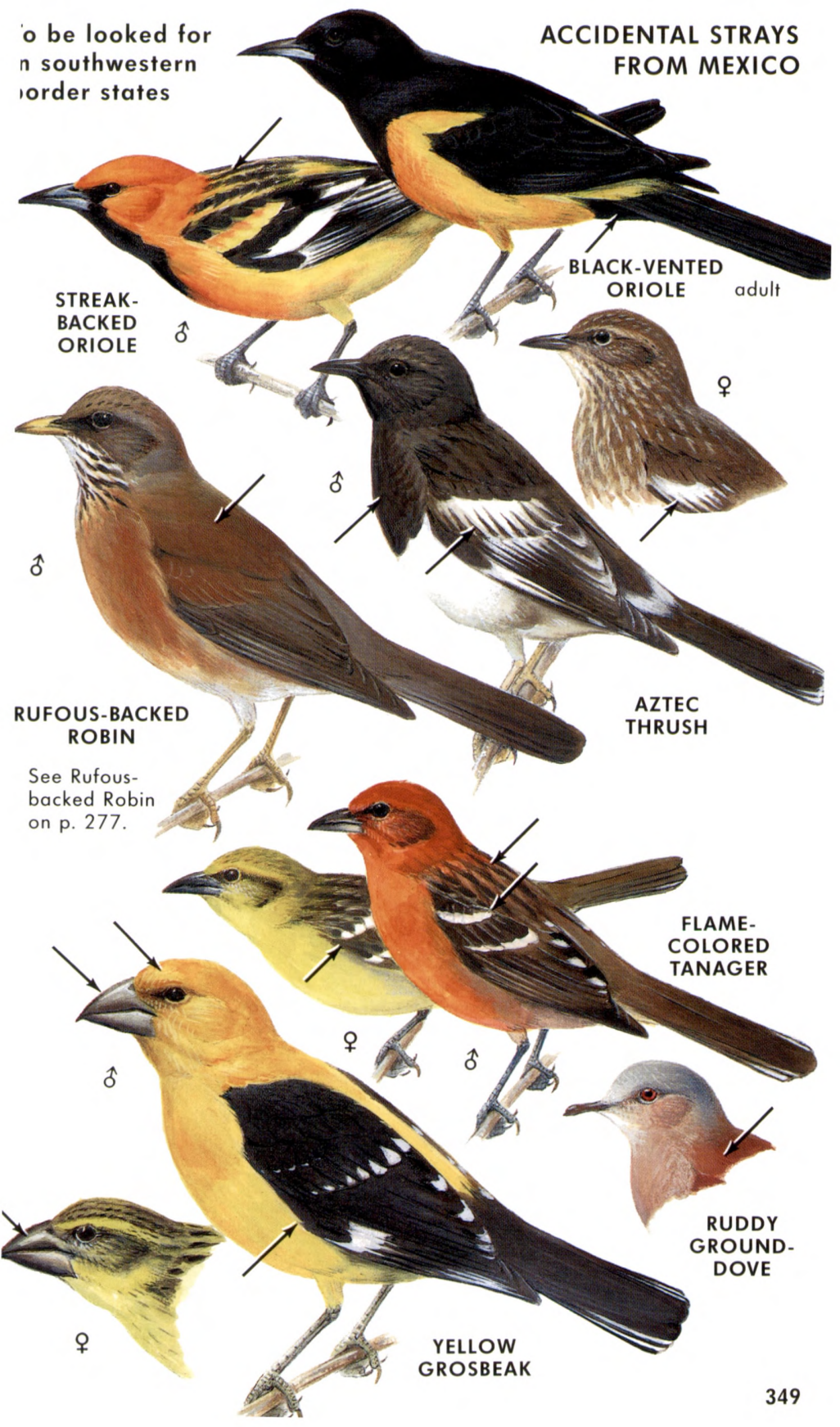


4-43/4" (10_12 cm). Note the chestnut crescent on a yellow breast, and the strong white eyebrow stripe on a gray head. Back olive-green. West: Accidental, Texas, s. Arizona.

RUFOUS-CAPPED WARBLER Basileuterus rufifrons

41/2-5" (11-13 cm). Rufous cap and cheek separated by a white eyebrow stripe. Breast yellow, upperparts olive. West: Casual, w. Texas, s. Arizona (has bred).

FAN-TAILED WARBLER Euthlypis lachrymosa

51/2-6" (14-15 cm). A large warbler, blackish above, yellow below. Note the yellow crown spot and tawny orange wash on the breast. Flicks its long, fan-shaped, white-tipped tail a great deal. West: Accidental, se. Arizona.

SLATE-THROATED REDSTART Myioborus miniatus

5" (13 cm). Very much like Painted Redstart, but lacks the white wing patch. Breast orange-red rather than rose-red. Female has a salmon-pink breast. West: Accidental, New Mexico, s. Arizona.

XANTUS'S (BLACK-FRONTED) HUMMINGBIRD Hylocharis xantusii

$3 \frac{1}{2} "(9 \mathrm{~cm})$. A female of this Baja California species has occurred once in s. California, where it actually nested and laid eggs that did not hatch. Female resembles White-eared Hummingbird, but has buff underparts, rusty sides of tail. The male has a green throat, cinnamon belly, chestnut tail, and white strip behind the eye.

Note: On p. 221, see other rare or vagrant hummingbirds from Mexico (Berylline, Bumblebee, and Plain-capped Starthroat).

NUTTING'S FLYCATCHER Myiarchus nuttingi

7" (18 cm). Similar to Ash-throated Flycatcher (p. 234), but a shade smaller, and a bit browner above. Interior of mouth orange. Probably not safely separable in the field except by voice-a clear, whistled peer; suggests voice of Dusky-capped Flycatcher, but higher, less plaintive. West: Accidental, s. Arizona, w. Texas (Big Bend).

GRAY SILKY-FLYCATCHER Ptilogonys cinereus

71/2-81/2" (19-21 cm). Related to the Phainopepla. A slim, crested, waxwing-like bird with a long, strikingly patterned black and white tail and yellow undertail coverts. Male: gray; female: brown. West: Accidental, s. Texas (confirmed by photograph), se. Ariz., s. Calif.(?).

CRIMSON-COLLARED GROSBEAK Rhodothraupis celaeno

7-8" (18-20 cm). Male: A blackish grosbeak with a dark red collar encircling the black head and chest. The red underparts are often spotted or blotched with black. Female and immature: Patterned like the male, but dull green replaces the red. West: Casual stray, s. Texas just south of our area.

MOTTLED OWL Ciccaba virgata (not shown)

12-15" (30-38 cm). This dark Mexican owl, unlike the somewhat larger Barred Owl, is uniformly dark above (with fine mottlings). Streaked lengthwise below. No ear tufts. Eyes brown. West: A road-killed specimen has been recorded from s. Texas near the Rio Grande, but south of our area.

IMPERIAL WOODPECKER Campephilus imperialis (not shown)

$21 "(53 \mathrm{~cm})$. This very large (near extinct) woodpecker was possibly seen but not confirmed in Big Bend National Park in 1958. See illustration in A Field Guide to Mexican Birds. 

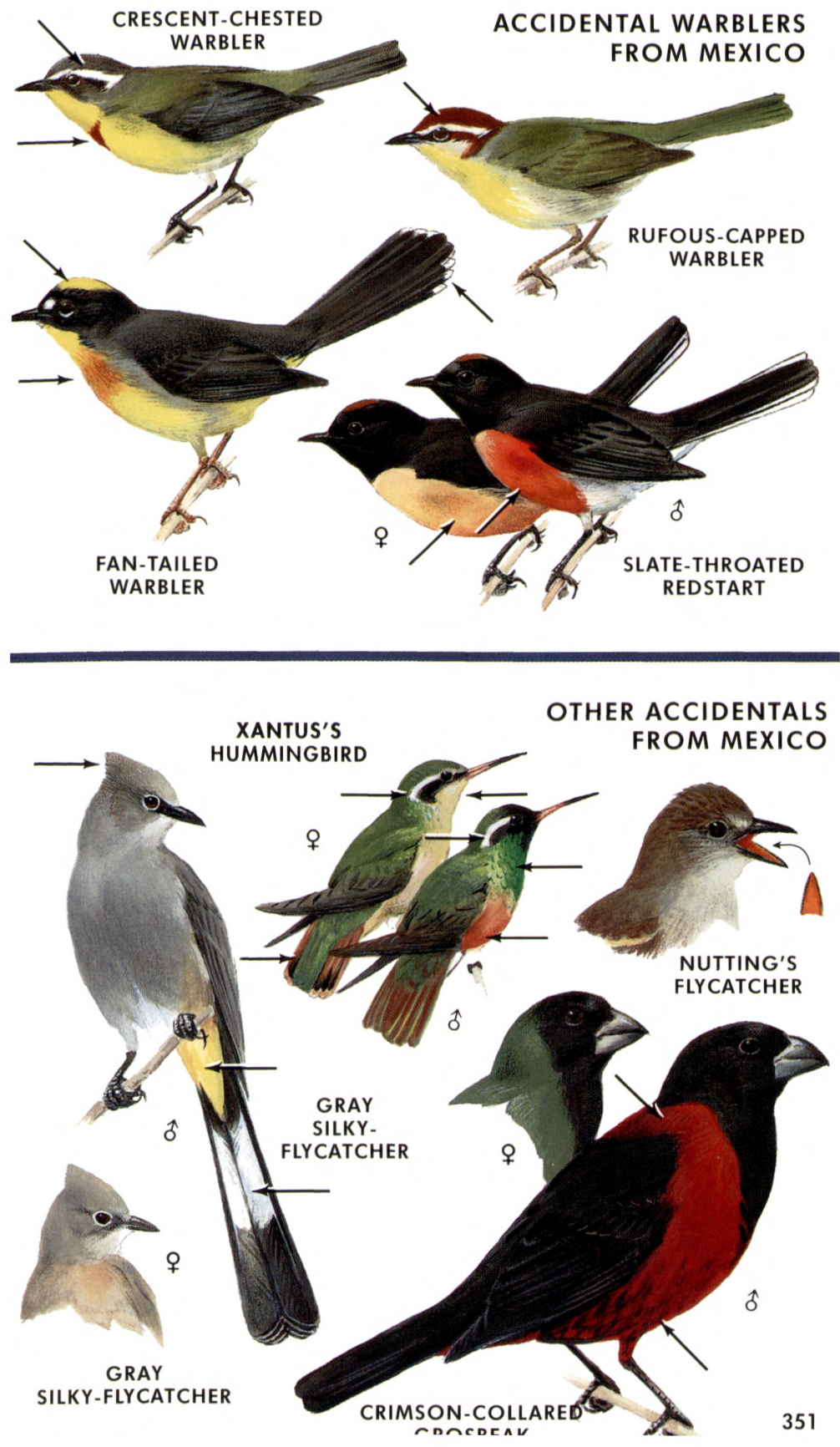
- ALASKAN STRAYS FROM ASIA. On the next three plates a number of rarities from Asia are shown. Whereas the shores and islands of/the Bering Sea have produced most records, a very few have occurred south along the Pacific Coast. A few other Alaskan strays have been shown on previous plates: waterfowl (pp. 49, 63); sandpipers (pp. 151, 153, 155, 157); wagtails (p. 243); pipits (p. 245); swifts (p. 247). For further information, consult A Field Guide to the Birds of Britain and Europe. For other possibilities, see A Field Guide to the Birds of Japan (Wild Bird Society of Japan).

\section{COMMON HOUSE-MARTIN Delichon urbica}

$8 "(20 \mathrm{~cm})$. Like a Tree Swallow with a white patch completely across the rump. West: Accidental, Bering Sea area (Nome, St. Paul I., St. Matthew I.).

EYEBROWED THRUSH Turdus obscurus

$7 \frac{1}{2} "(19 \mathrm{~cm})$. Robin-like; smaller, with reddish confined to the sides. Gray back and breast; white eyebrow, chin and belly. West: Rare in spring, w. Aleutians, casual, Pribilofs, w. and n. Alaska.

FIELDFARE Turdus pilaris

$10 "(25 \mathrm{~cm})$. Robin-like, with a heavily striped tawny breast. Back rusty; head, rump gray. West: Accidental, n. Alaska, St. Lawrence I.

DUSKY THRUSH Turdus naumanni

9" $(23 \mathrm{~cm})$. Robin-like. Head and underparts dusky; heavily scaled. Rufous wings. West: Casual, w. Aleutians and St. Lawrence I.; accidental, n. Alaska (Pt. Barrow).

\section{BROWN SHRIKE Lanius cristatus}

8" $(20 \mathrm{~cm})$. A small shrike, brown above, white below, with a dark mask. West: Accidental, w. Aleutians, St. Lawrence I., Anchorage, Alaska; also California (Farallons).

\section{STONECHAT Saxicola torquata}

5" $(13 \mathrm{~cm})$. Small, plump, upright. Male has a black head and throat, white half-collar, rusty breast. West: Accidental, St. Lawrence I.

\section{EURASIAN WRYNECK Jynx torquilla}

61/2" (16 cm). Woodpecker-like; mottled gray-brown, underparts finely barred. West: Accidental, nw. Alaska (Seward Peninsula).

\section{HOOPOE Upupa epops}

$11^{\prime \prime}(28 \mathrm{~cm})$. Pinkish brown with boldly barred, black and white wings and tail and a long erectile crest (usually depressed). West: Accidental, w. Alaska (Old Chevak).

\section{ORIENTAL TURTLE-DOVE Streptopelia orientalis}

$13 "(33 \mathrm{~cm})$. Striped patch on neck; rufous in wings. West: Accidental, Attu, Probilofs.

\section{COMMON CUCKOO Cuculus canorus}

13" (33 cm). Slender; looks falconlike. Gray, with barred underparts. Rufous morph of female (rare) is barred except on rump. West: Rare overshoot in outer Aleutians, Pribilofs. Accidental, mainland of w. Alaska.

\section{ORIENTAL CUCKOO Cuculus saturates}

13" (33 cm). Darker than the Common Cuckoo, with a shorter bill and wider bars on the belly. Rufous morph of the female has heavier barring; has strong barring on the rump. West: Very rare vagrant (June-July) in outer Aleutians. 


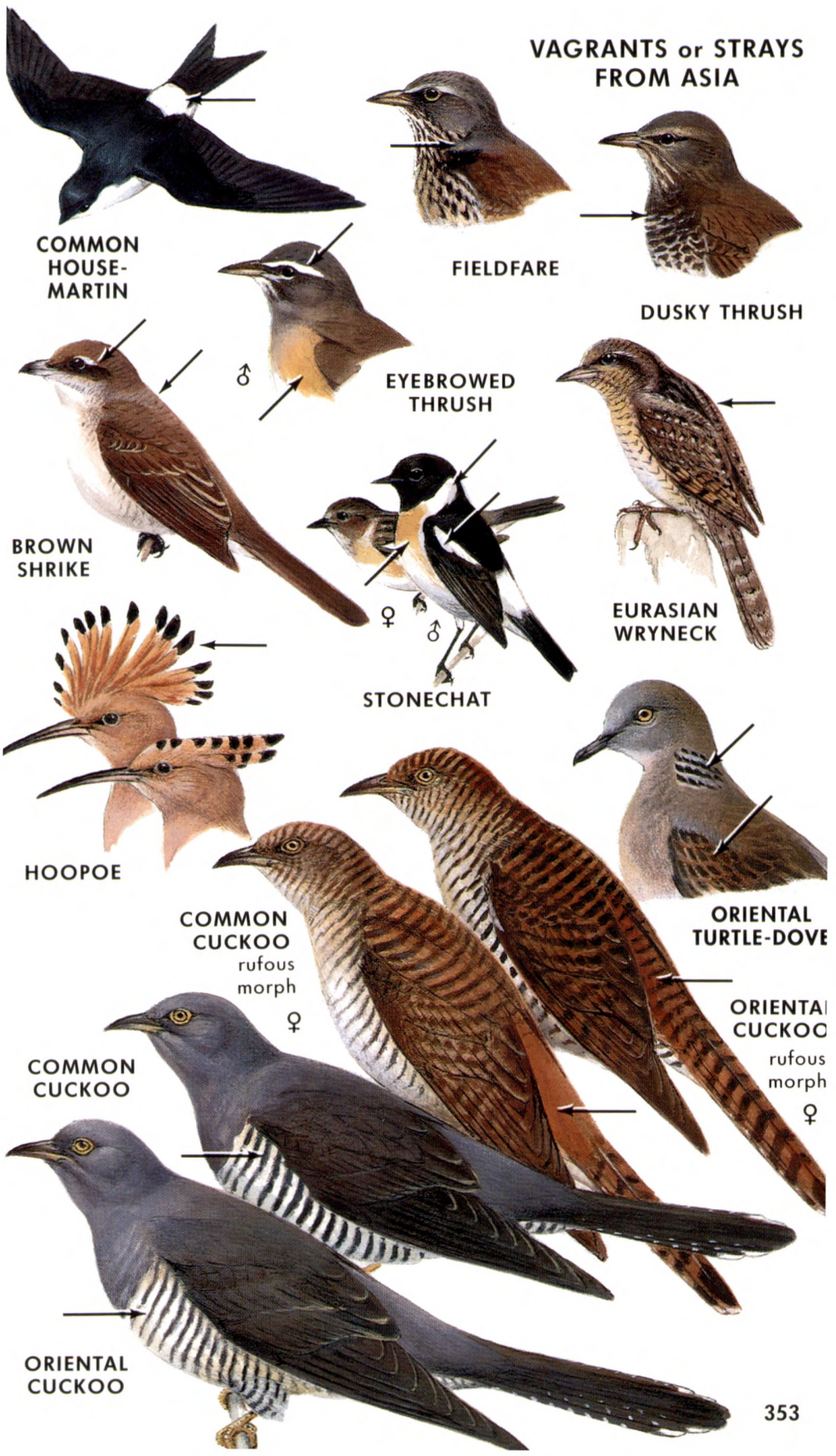




\section{LANCEOLATED WARBLER Locustella lanceolata}

$4 \frac{1}{2} "(11 \mathrm{~cm})$. Small skulking. Streaked brown upperparts, band of fine streaks on whitish breast. Light eyebrow stripe, white throat. West: Casual or accidental, outer Aleutians (Attu).

\section{MIDDENDORFF'S GRASSHOPPER-WARBLER Locustella ochotensis}

$6 \frac{1}{2}{ }^{\prime \prime}(16 \mathrm{~cm})$. A rather large Old World warbler; brown above, white below, with tan sides and a tapered white-tipped tail. Light eyebrow. West: Summer and fall vagrant to Bering Sea Islands (Attu, Nunivak, Pribilofs, St. Lawrence I.).

\section{DUSKY WARBLER Phylloscopus fuscatus}

$4 \frac{1}{2} "(11 \mathrm{~cm})$. A small, very plain Old World warbler; dusky-brown above, no wing bars. Whitish below, with buffy eyebrows, sides, and undertail coverts. West: Casual or accidental in fall, Gambell, outer Aleutians; accidental, California.

\section{SIBERIAN BLUE ROBIN Luscinia cyane}

$5 \frac{1}{2} "(14 \mathrm{~cm})$. Dull blue above, pure white below, separated by black on the sides of the face and neck. Female: Brown above, mottled buff below, tail bluish. West: Accidental, outer Aleutians (Attu).

SIBERIAN RUBYTHROAT Luscinia calliope

6" $(15 \mathrm{~cm})$. Small and dark; note the ruby-red throat, gray breast. White eyebrows and whiskers. Female has a white throat. West: Rare but regular migrant, w. Aleutians; casual, Pribilofs, St. Lawrence I.

RED-FLANKED BLUETAIL Tarsiger cyanurus

$51 / 2 "(14 \mathrm{~cm})$. Male: Deep blue above with bright orange-red flanks, white throat. Female: Dusky brown, with a dark chest, white throat, orange flanks. West: Accidental, outer Aleutians (Attu).

RED-BREASTED FLYCATCHER Ficedula parva

$4 \frac{1}{2} "(11 \mathrm{~cm})$. A tiny flycatcher. Male: Orange throat, gray cheeks, narrow eye-ring, white tail patches. Female: Browner, without the orange throat. West: Casual, w. Aleutians; accidental, St. Lawrence I.

GRAY-SPOTTED FLYCATCHER Muscicapa griseisticta

51/2" (14 cm). Empidonax-like. Strongly streaked breast and flanks. West: Rare, irregular, perhaps regular (May-June), w. Aleutians.

SIBERIAN FLYCATCHER Muscicapa sibirica (Sooty Flycatcher)

5" $(13 \mathrm{~cm})$. Suggests a sooty Empidonax flycatcher (eye-ring, wing bar, etc.). Note the broad dark band across the breast. West: Accidental, w. Aleutians.

\section{ASIAN BROWN FLYCATCHER Muscicapa dauurica}

5" $(13 \mathrm{~cm})$. Similar to Siberian Flycatcher, but smaller, and much paler on the breast. West: Accidental, w. Aleutians (Attu).

NARCISSUS FLYCATCHER Ficedula narcissina

5" (13 cm). Black back, orange throat (male), yellow rump and eyebrow, white wing patch. West: Accidental, w. Aleutians (Attu).

\section{GREAT TIT POecile major}

$5 \frac{1}{2} "(14 \mathrm{~cm})$. A large "chickadee" with a black stripe extending from its black throat through its whitish underparts. West: Accidental, Little Diomede I. (at a feeder).

SIBERIAN ACCENTOR Prunella montanella (Family Prunellidae)

$5 \frac{1}{2} "(14 \mathrm{~cm})$. Dark cheeks separate ochre eyebrows from the bright ochre-buff throat and underparts. Sides striped; bill warbler-like. West: Casual fall visitor, Nunivak I., St. Lawrence I. and mainland Alaska. Accidental, Washington. 
YELLOW-BREASTED BUNTING Emberiza aureola

$5 \frac{1}{2} "(14 \mathrm{~cm})$. Male has a black head, chestnut band across its yellow breast. West: Accidental, Attu, Buldir, St. Lawrence I.

RUSTIC BUNTING Emberiza rustica

$53 / 4 "(15 \mathrm{~cm})$. A rusty, sparrow-like bird with a rusty breast band, black crown, and black cheek outlined in white. Female has a light spot on its brown cheek patch. Regular but scarce; mainly in spring, outer Aleutians. West: Casual, St. Lawrence I. Accidental, British Columbia, Oregon, California.

LITTLE BUNTING Emberiza pusilla

5" $(13 \mathrm{~cm})$. Suggests a Savannah Sparrow, but the rufous crown and rufous cheek patches are outlined with black. West: Accidental, outer Aleutians, Chukchi Sea.

REED BUNTING Emberiza schoeniclus

6" $(15 \mathrm{~cm})$. Male has a black head and bib, white collar and malar stripe in summer. Rusty wings. West: Casual or accidental in spring in outer Aleutians.

\section{PALLAS'S BUNTING Emberiza pallasi}

$5 \frac{1}{2} 2^{\prime \prime}(14 \mathrm{~cm})$. Similar to Reed Bunting, but smaller. Shoulders blue-gray, lacking the bright rusty tone. Upper ridge of bill straight. Rump paler. West: Accidental, n. Alaska (St. Lawrence I., Barrow).

GRAY BUNTING Emberiza variabilis

6" (15 cm). Male: Dark slate gray above and below. Female: Dark brown, paler below; chestnut rump, no white in tail. West: Accidental, outer Aleutians.

HAWFINCH Coccothraustes coccothraustes

7" $(18 \mathrm{~cm})$. A chunky finch with a massive bill and a short tail. Bold white patches high on black wings. Female paler; less rufous on crown.

West: A rare stray, mainly in spring, Bering Sea area (Aleutians, Pribilofs, St. Lawrence I.).

EURASIAN BULLFINCH Pyrrhula pyrrhula

53/4" $(15 \mathrm{~cm})$. A stubby-billed finch with a black cap and a white rump. Male: Rose-red breast and cheeks. Female: Similar pattern, but breast is warm pinkish brown. West: Casual stray in Bering Sea islands (outer Aleutians, Nunivak I., St. Lawrence I.). Accidental in winter on mainland Alaska.

\section{ORIENTAL GREENFINCH Carduelis sinica}

6" $(15 \mathrm{~cm})$. An olive and brown, siskin-like bird without striping. Large yellow patches on wings and tail. Female browner than male. West: Rare vagrant, outer Aleutians. Accidental, California.

BRAMBLING Fringilla montifringilla

$53 / 4^{\prime \prime}(15 \mathrm{~cm})$. Tawny breast and shoulders, white rump. Male in summer has black head and back. West: Rare stray, Bering Sea area (Aleutians, Pribilofs, St. Lawrence I.), and various points in Alaska. Accidental, British Columbia, Manitoba, Washington, Oregon, California, Nevada, Montana, Wyoming, Utah, Colorado.

\section{COMMON ROSEFINCH Carpodacus erythrinus}

$5 \frac{3}{4}$ " $(15 \mathrm{~cm})$. Resembles Purple Finch, but without the facial striping. Upper ridge of bill more curved. West: Rare in spring in outer Aleutians (Purple Finch does not occur within 2,000 miles). Casual, St. Paul, Gambell. Accidental on mainland Alaska. 


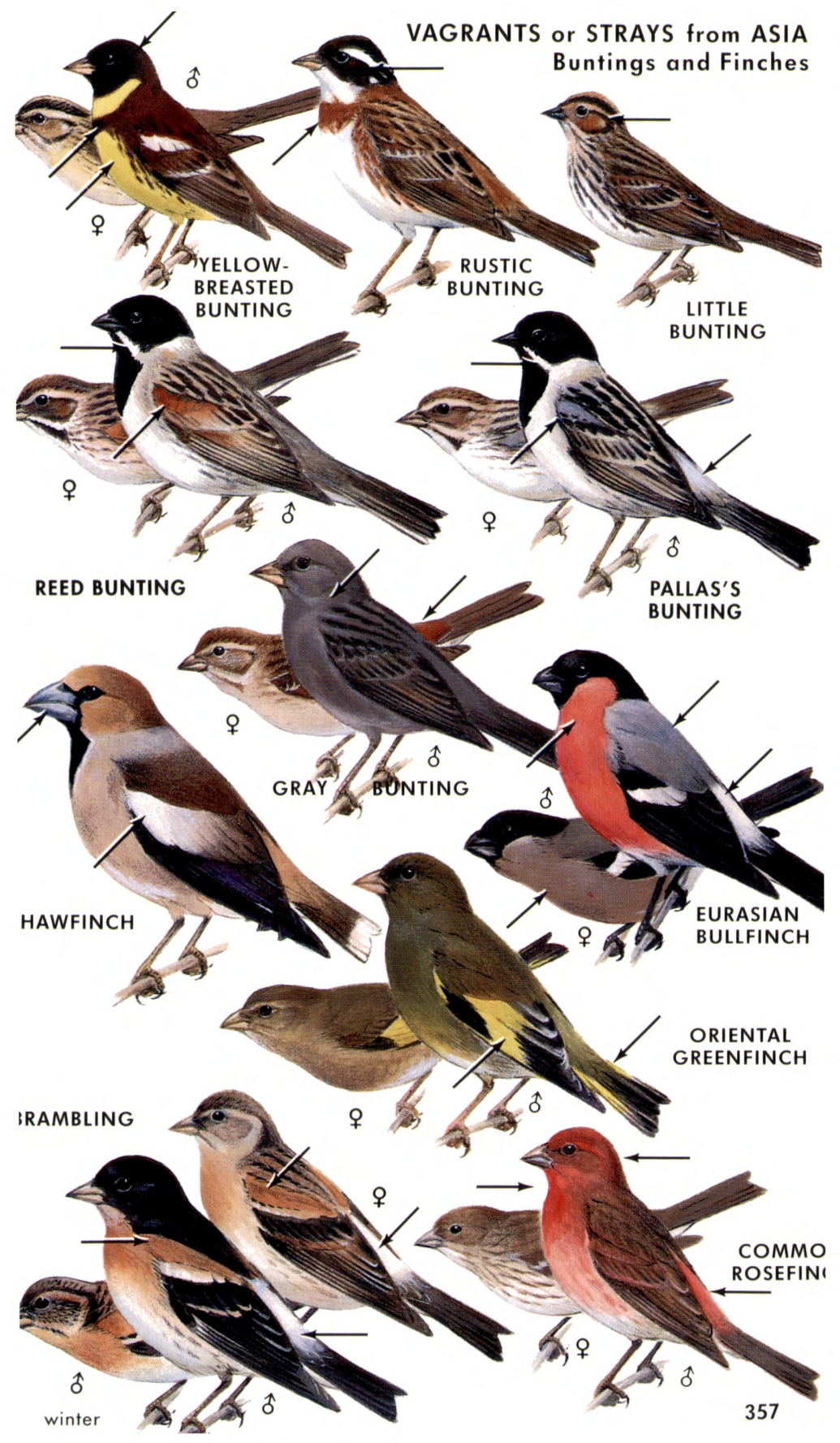


OTHER ASIAN STRAYS (not shown). The following species have been recorded only once or twice in Alaska and (with two exceptions) are not illustrated in this book. They could occur again, as could others. For further possibilities, see A Field Guide to the Birds of Japan (Wild Bird Society of Japan).

CHINESE EGRET Egretta eulophotes

See illus., p. 113. When breeding, resembles Snowy Egret (black legs, yellow feet), but bill yellow, lores dark. This endangered Asiatic has occurred once in the w. Aleutians (Aggatu I.).

YELLOW BITTERN Ixobrychus sinensis

14" (36 cm). Rather like our Least Bittern. Has occurred as an accidental at Attu in the Aleutians, where Least Bittern would not occur.

\section{GREYLAG GOOSE Anser anser}

An unconfirmed sighting of this large, pale gray Eurasian goose was reported at Attu.

\section{EURASIAN KESTREL Falco tinnunculus}

Larger than the American Kestrel, with a longer tail, which in males is gray. Wings largely rufous (blue-gray in American). Female Eurasian Kestrel has only one black facial bar. West: Accidental, w. Aleutians (where American Kestrel would not occur).

EURASIAN HOBBY Falco subbuteo

Near size of a Merlin; suggests a small Peregrine. Slaty-backed, heavily striped below, with rufous "trousers"; narrow mustache. West: Accidental at sea near Aleutians, Pribilofs.

EURASIAN COOT Fulica atra

See illus. of head, p. 63. Similar to the American Coot, but with an entirely white frontal shield above the bill. No white on the undertail coverts. West: Accidental, Pribilofs.

\section{BLACK-WINGED STILT Himantopus himantopus}

Like the Black-necked Stilt, but head and neck largely white, without black pattern. West: Accidental, Nizki I., Alaska.

\section{BLACK-TAILED GULL Larus crassirostris}

A medium-sized gull with a dark mantel and a broad black band across the white tail. Yellow legs: yellow bill with a black ring and red tip. West: Accidental, w. Aleutians; also San Diego, California (perhaps an escape?).

\section{ORIENTAL SCOPS-OWL Otus sunia}

Resembles a small Screech-Owl. West: Accidental, w. Aleutians (nearly 2,000 miles west of Screech-Owl's normal range).

JUNGLE NIGHTJAR Caprimulgus indicus

Similar to a Nighthawk (white bar near wing tip), but grayer, tail rounded, breast not barred. West: Accidental, w. Aleutians.

\section{GREAT SPOTTED WOODPECKER Dendrocopos major}

Size of a Hairy Woodpecker, with a black back separating the large white scapular patches. Undertail coverts crimson. West: Accidental outer Aleutians (Attu). 


\title{
Range Maps
}

\author{
B Y VIRGINIA MARIE PETERSON
}
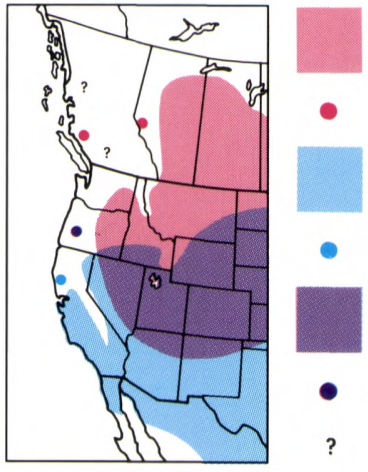

$\begin{array}{ll}\text { Red } & =\text { Breeding } \\ \text { Red Dot } & =\begin{array}{l}\text { Colony or } \\ \text { Isolated Breeding }\end{array} \\ \text { Blue } & =\text { Winter } \\ \text { Blue Dot } & =\text { Local Wintering } \\ \text { Purple } & =\text { Resident Year-round }\end{array}$

Purple Dot $=$ Local Year-round

Question

Mark

$=$ Possible Breeding

The maps on the following pages are approximate, giving the general outline of the range of each species. Within these broad outlines may be many gaps-areas that are ecologically unsuitable for the species. A Marsh Wren must have a marsh, a Meadowlark a meadow, a Ruffed Grouse a woodland or a forest. Certain species may be extremely local or sporadic for reasons that are not clear. Some birds are extending their ranges, a few explosively. Others are declining or even disappearing from large areas where they were formerly found. Some of these increases and declines, as well as extralimital occurrences, are noted on the maps. The maps are based on data from many state and regional publications and modified by the observations of a myriad of birders as reported in American Birds, Birding, NARBA, Western Birds, and various other journals and checklists.

Winter ranges are not as definite as breeding ranges. A species may exist at a very low density near the northern limits of its winter range, surviving in mild seasons through December but often succumbing to the bitter conditions of January and February.

The maps are specific only for the area covered by this Field Guide. The Mallard, for example, is found over a large part of the globe. Its world range is briefly stated in the main text. The map shows only its range in western North America. The maps are in phylogenetic sequence (see the Systematic Checklist on p. 409) and are not arranged in the arbitrary visual order in which the species appear in this book. The small page number under the map number refers back to the main text.

Note: The Aleutian Chain, extending for another 1,000 miles to the west, is not shown, but pertinent information applying to these islands is included on the maps. 

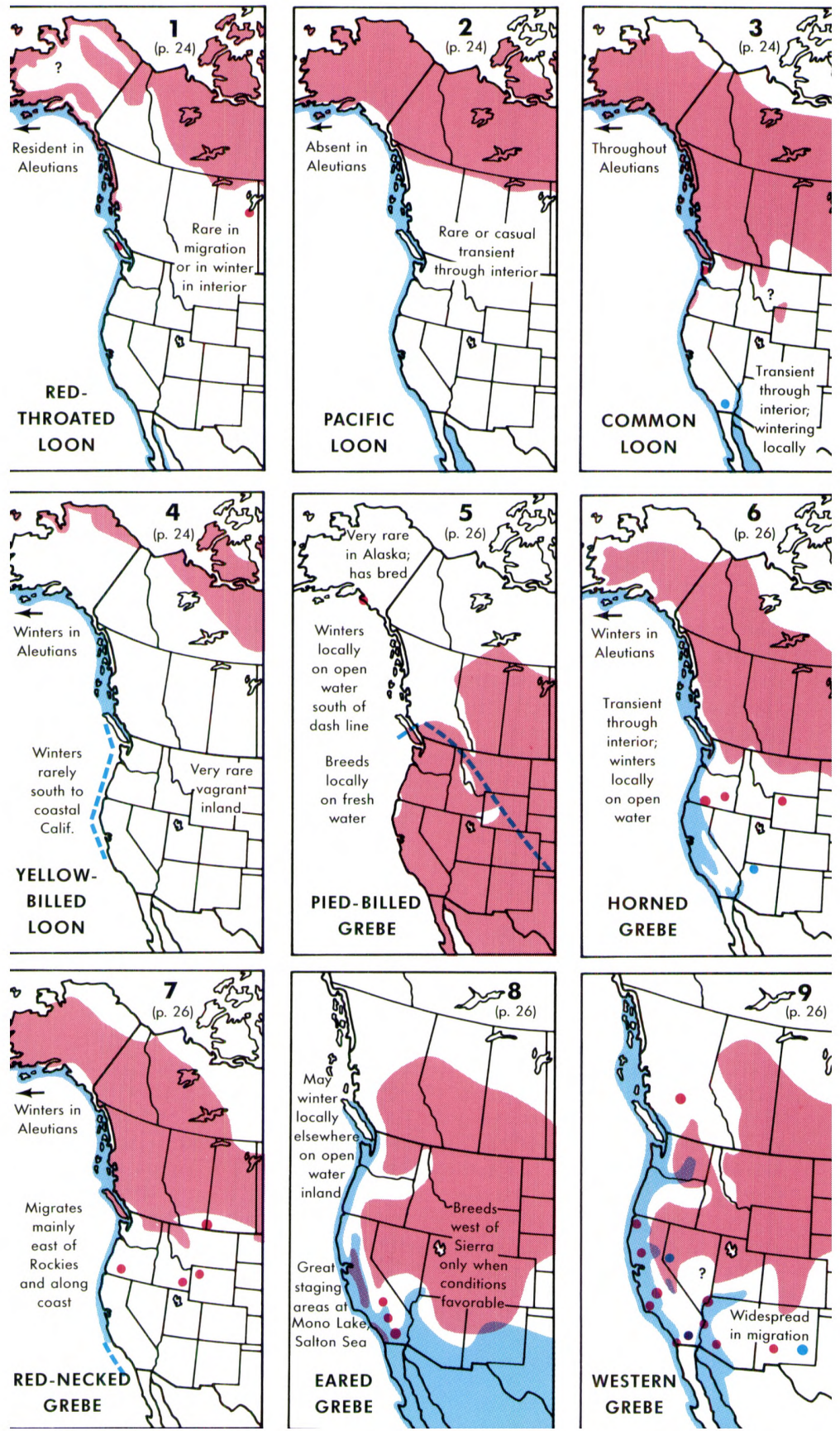

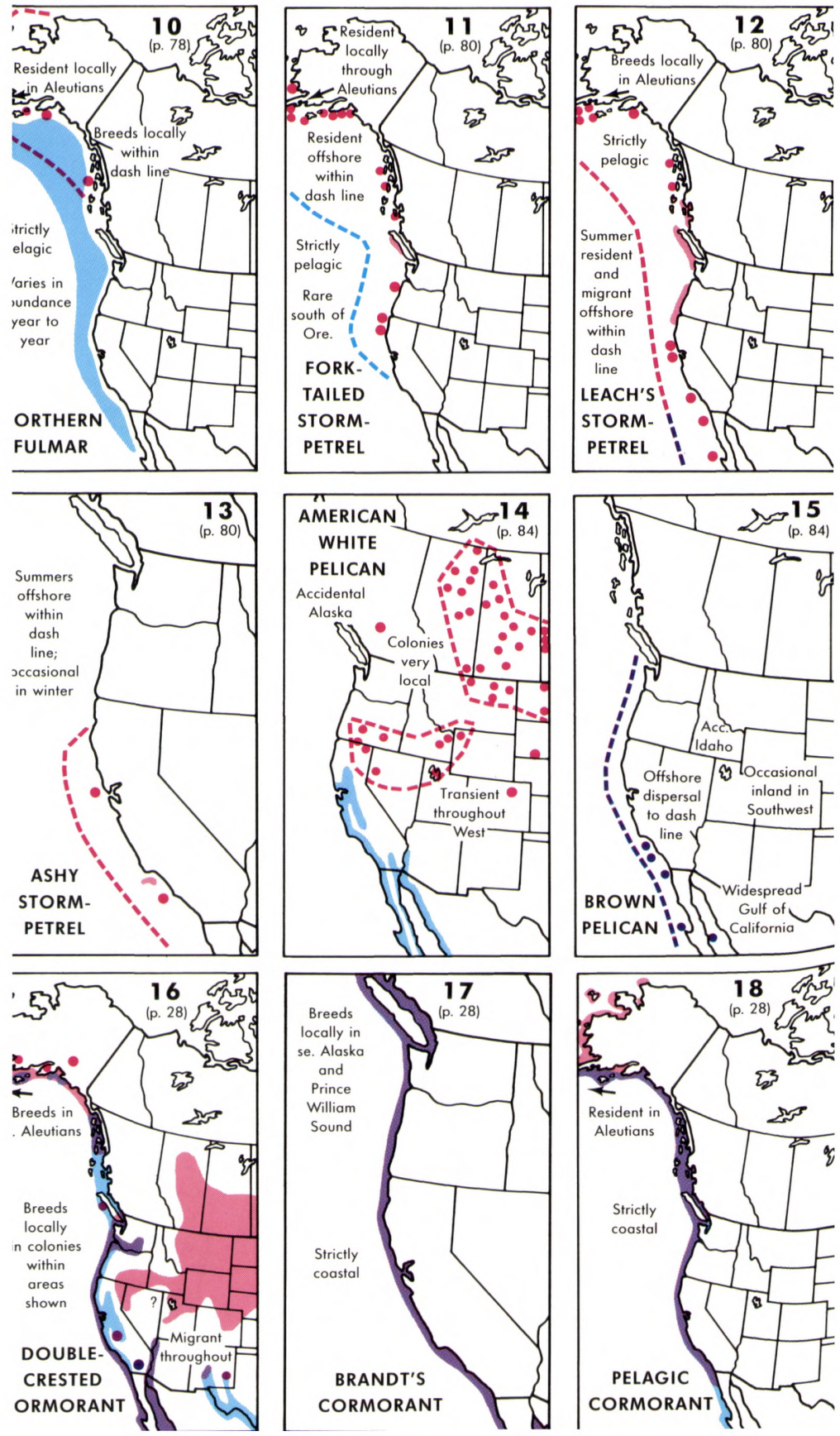

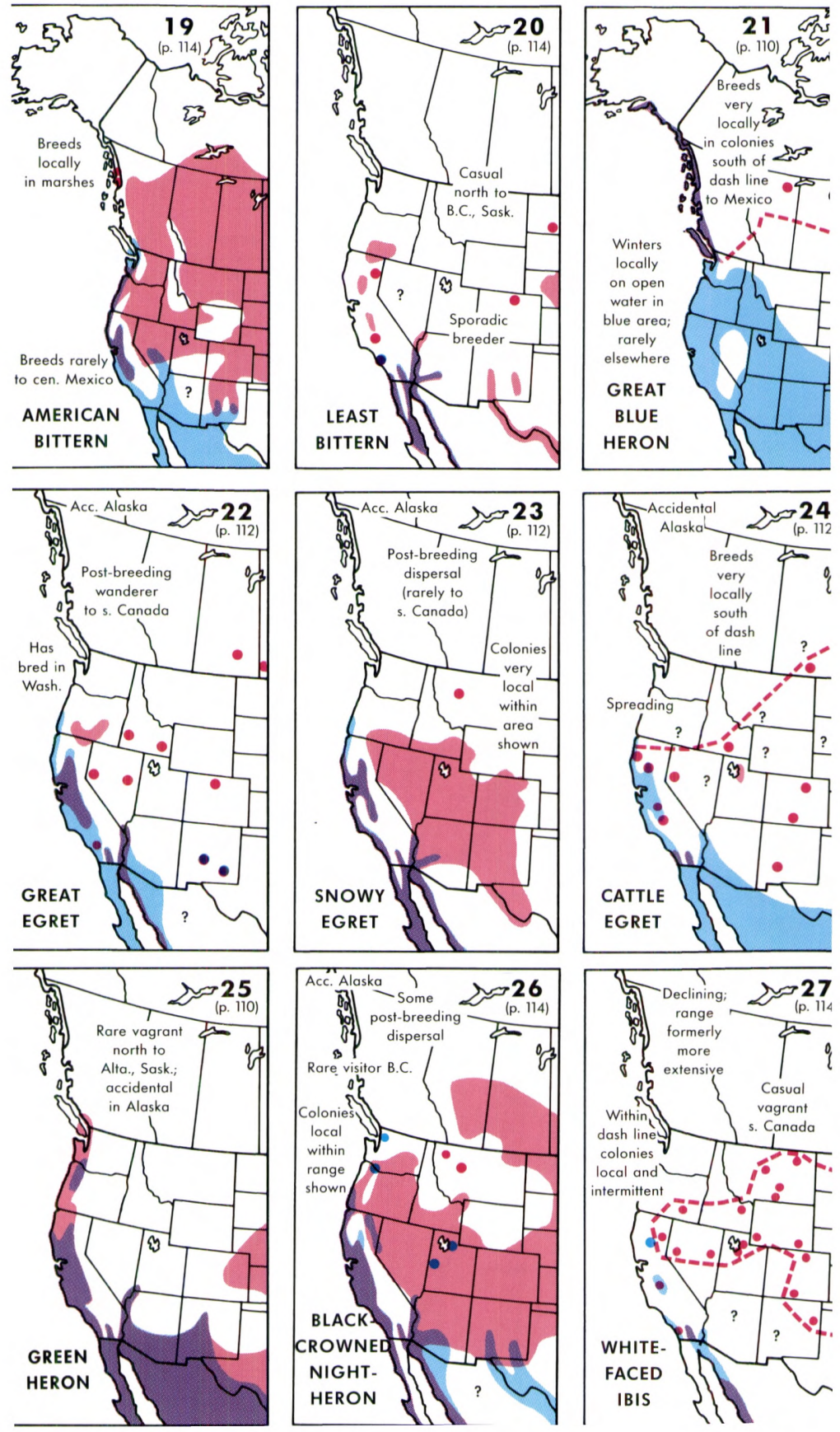

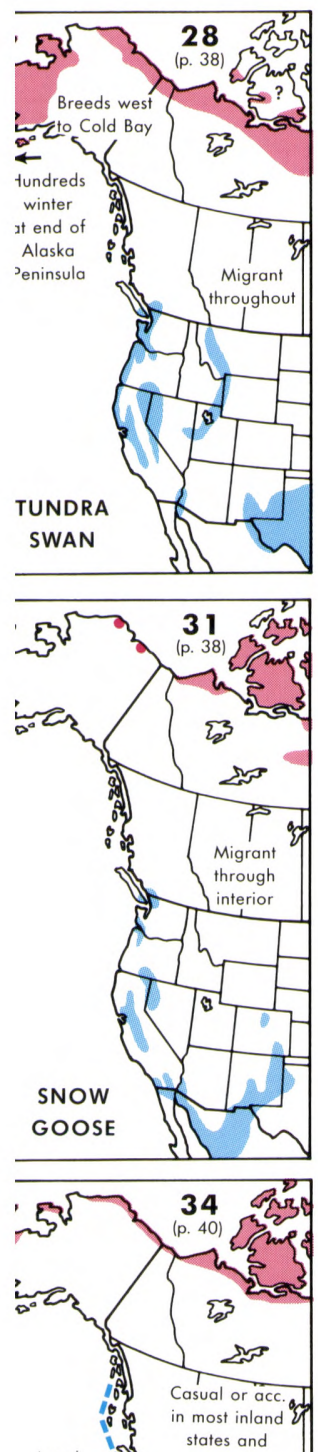

Local $\begin{aligned} & \text { states and } \\ & \text { provinces }\end{aligned}$

incentrations

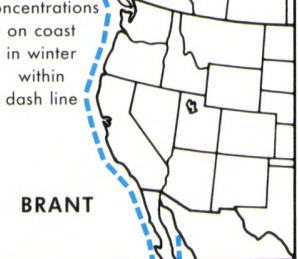

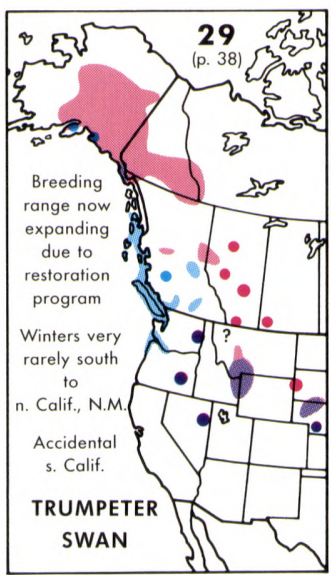
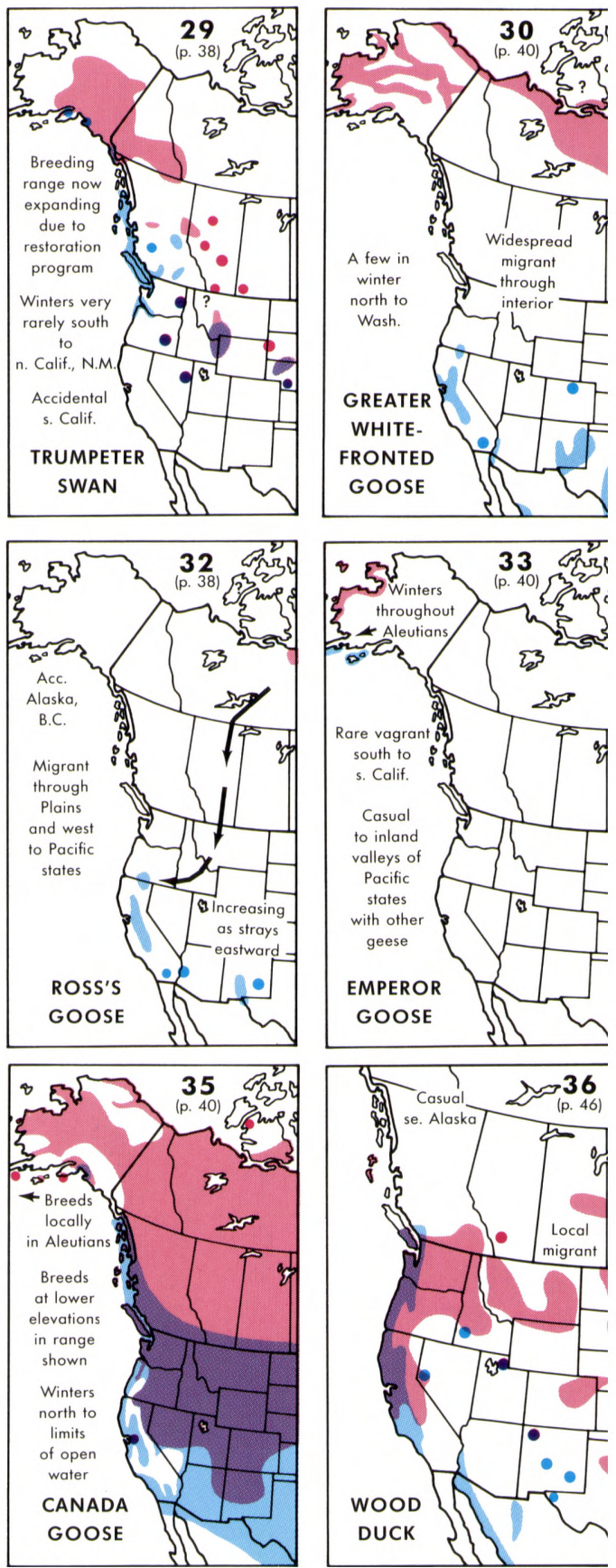

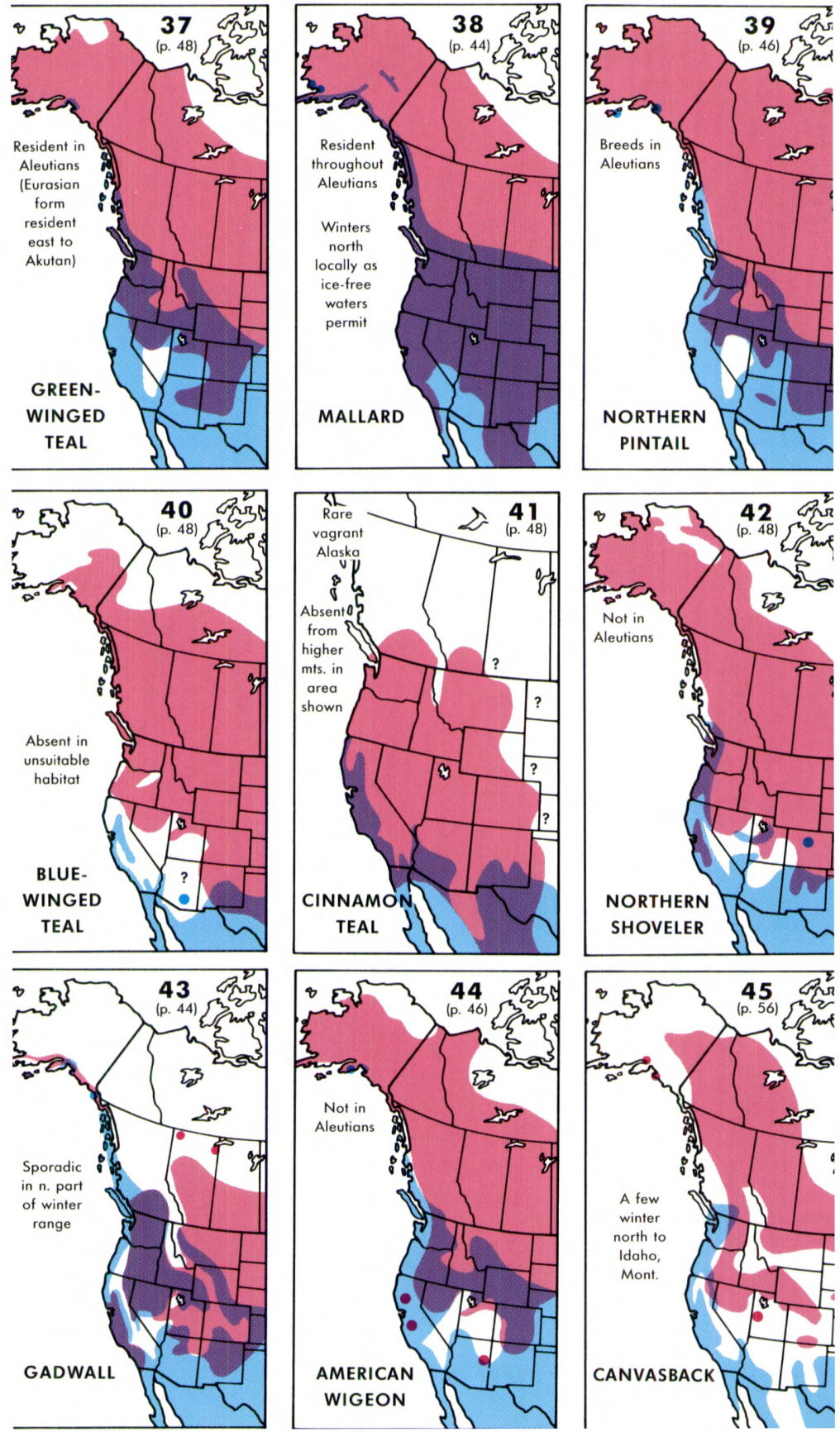

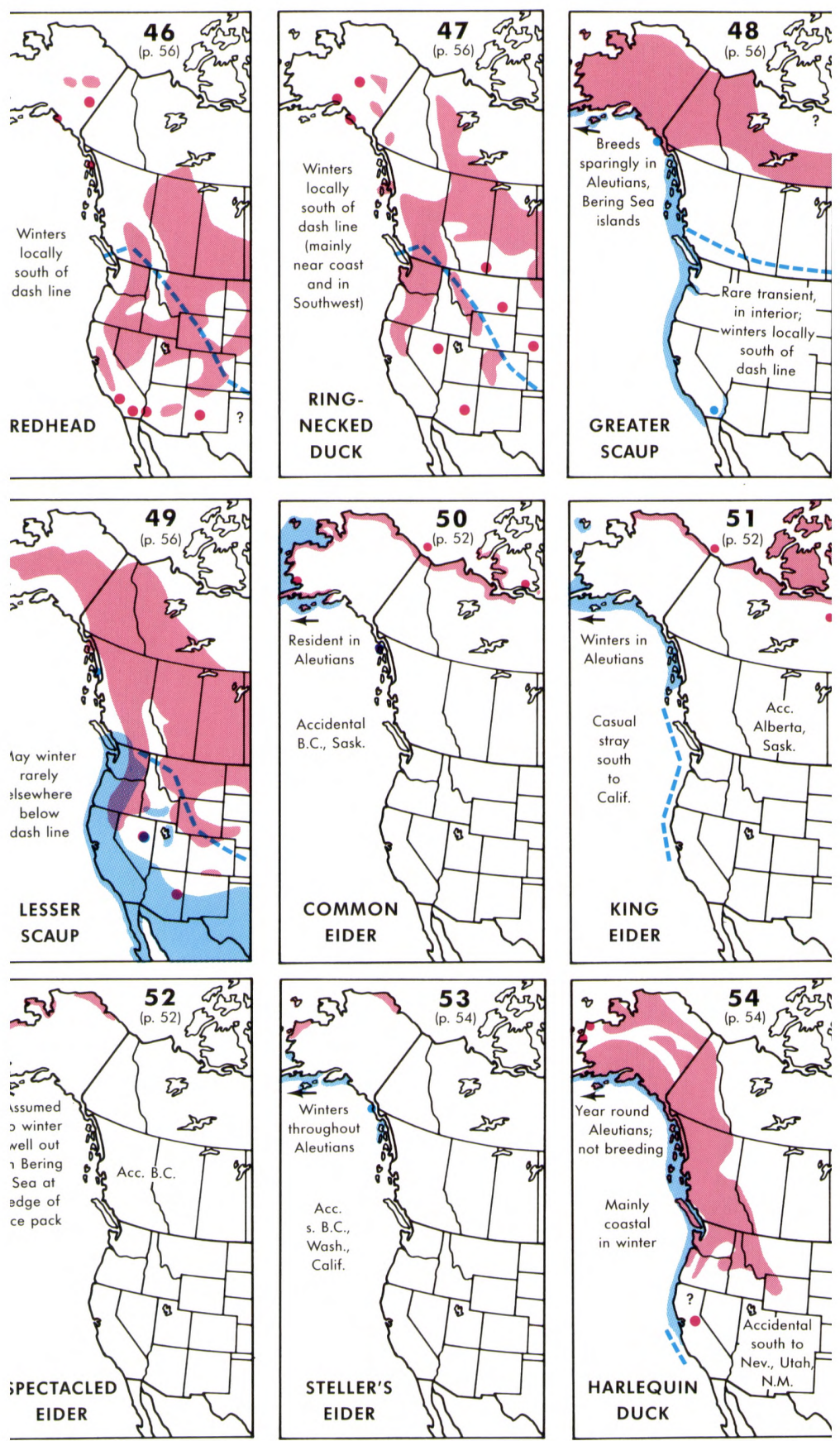

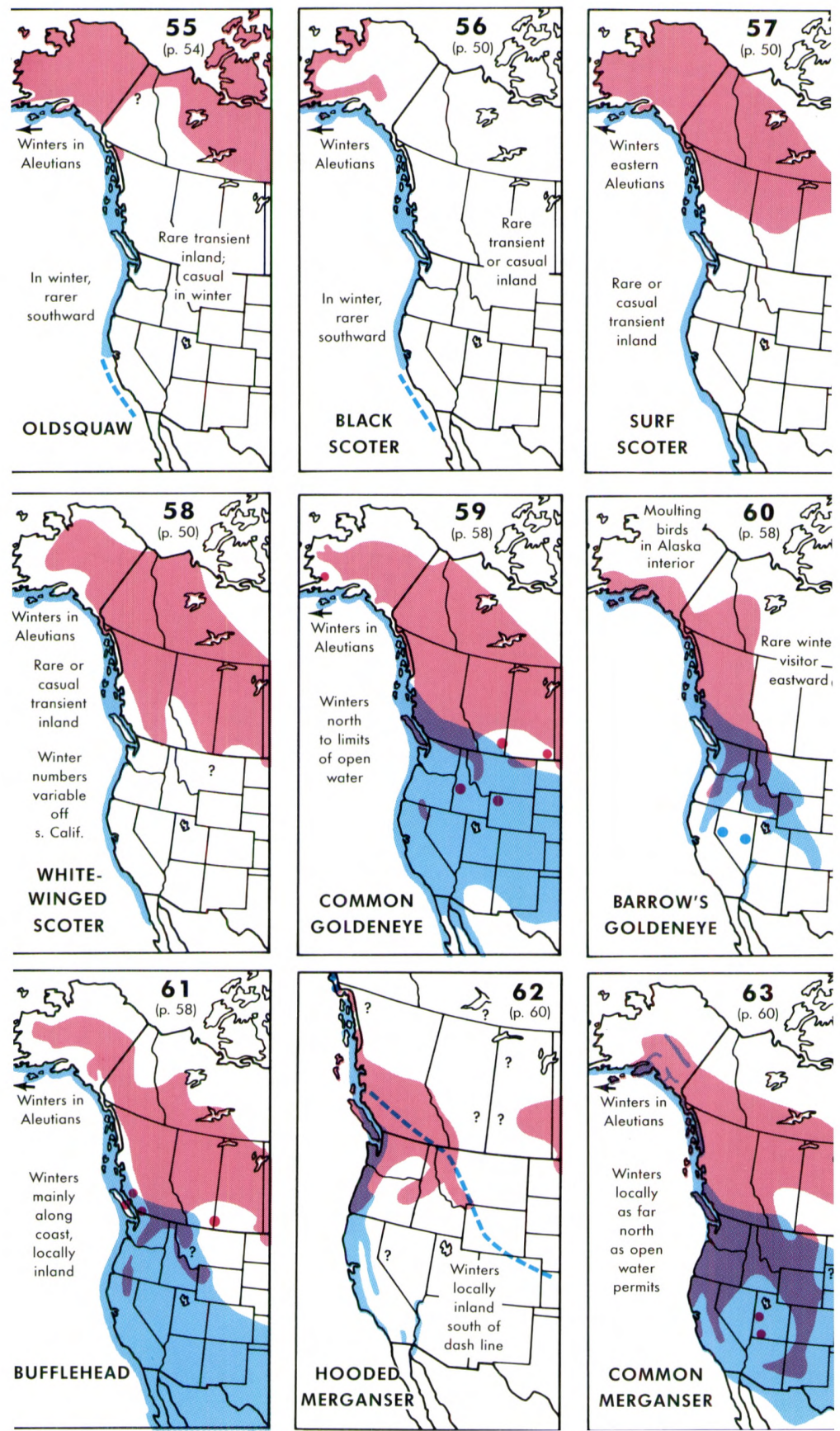

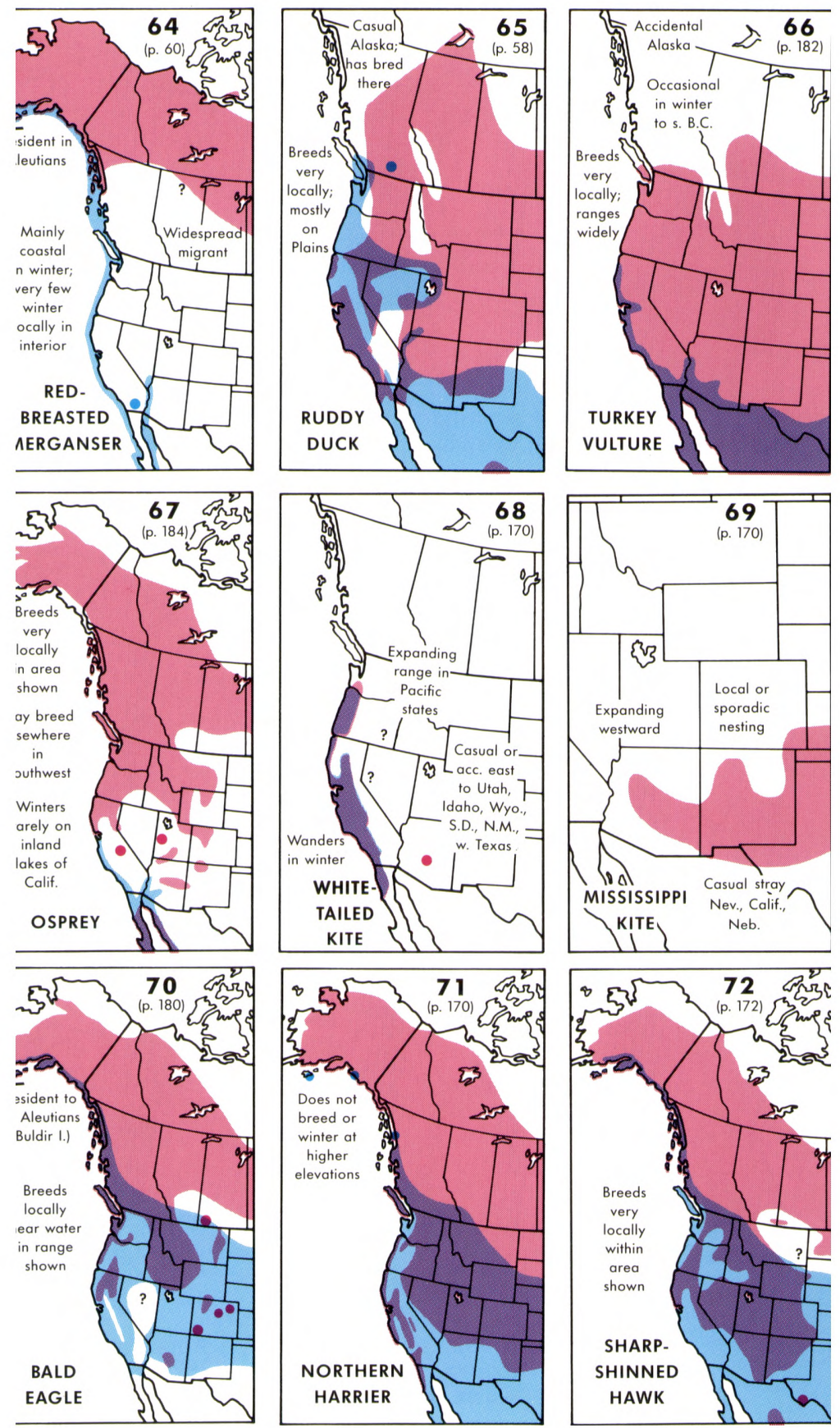

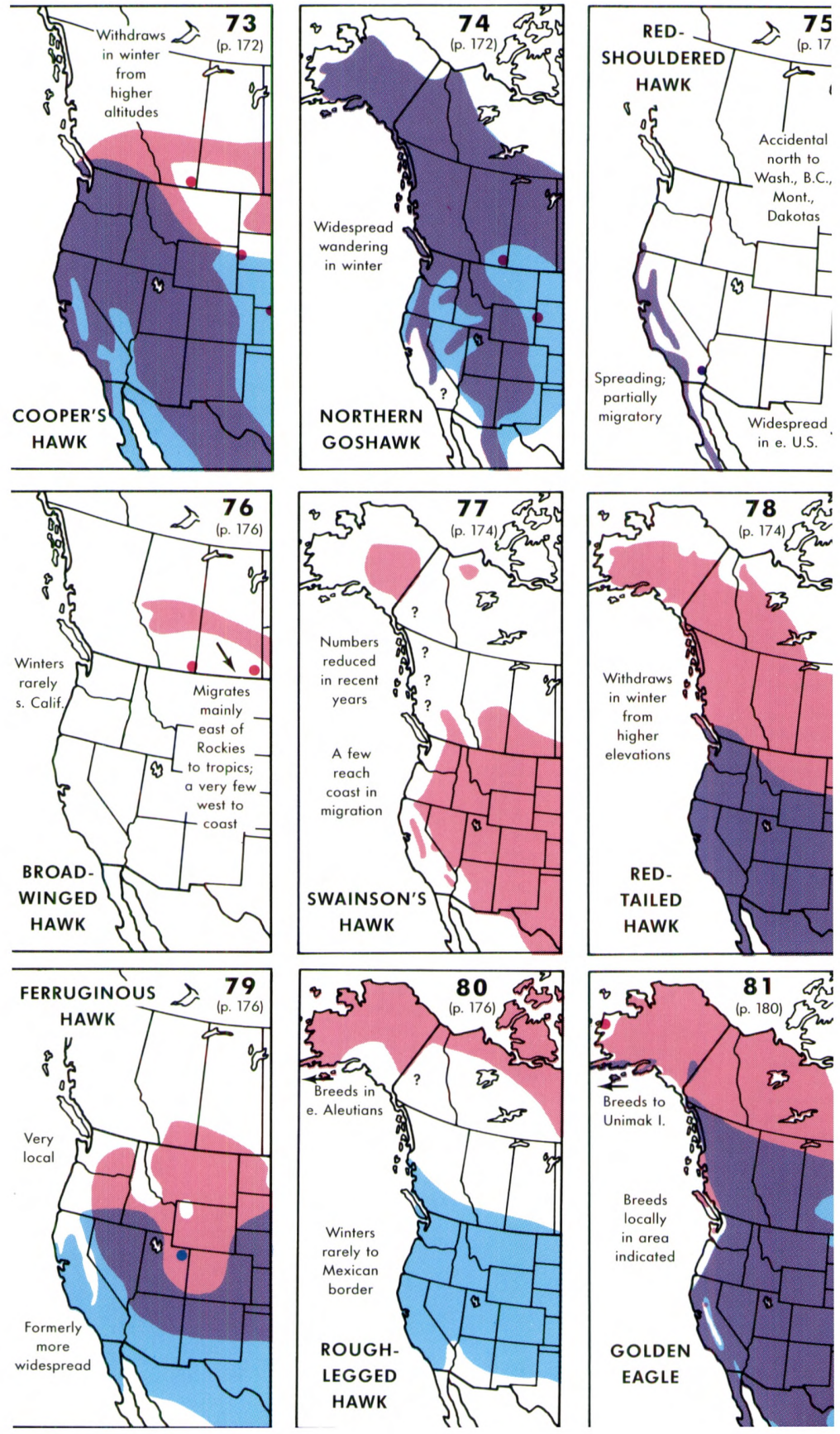

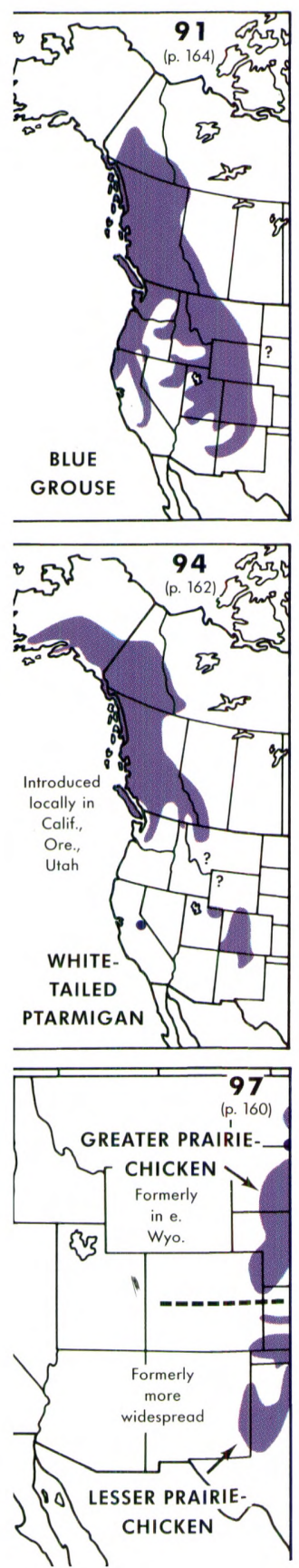
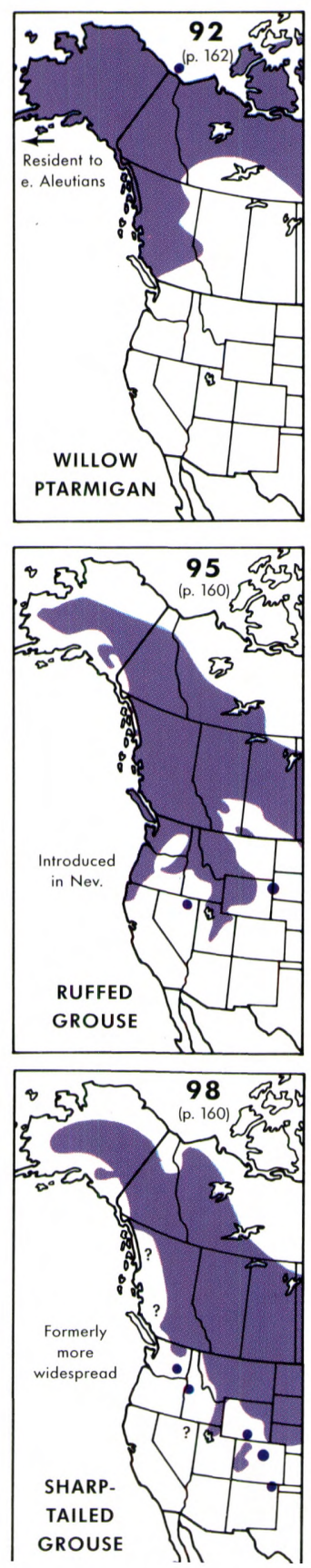
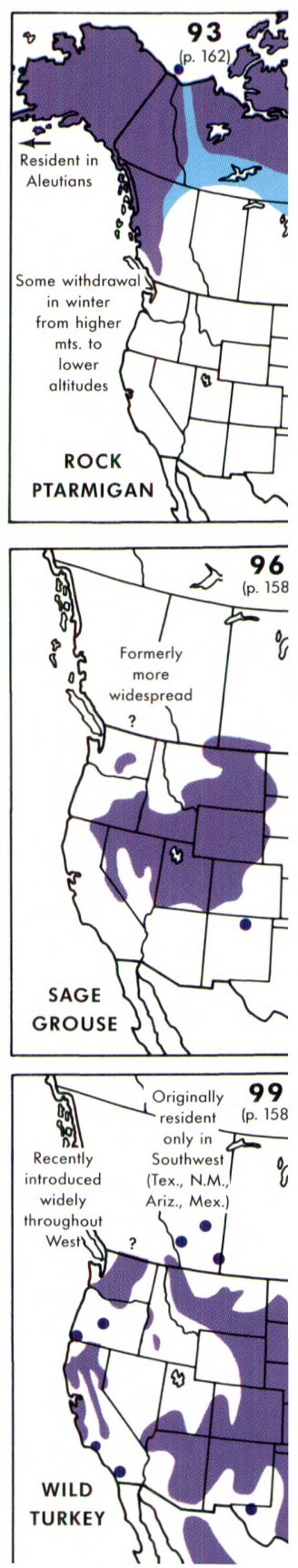

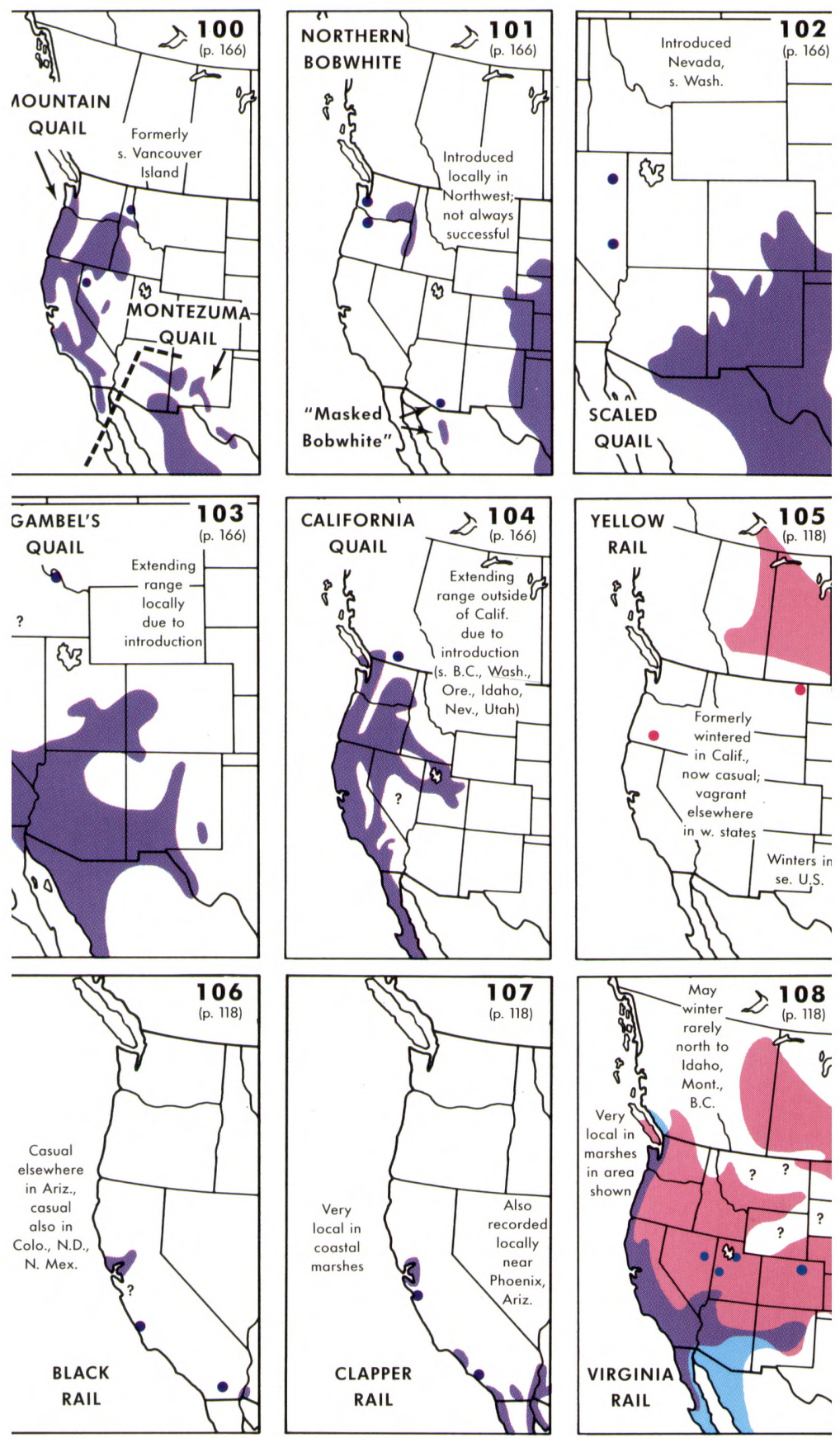

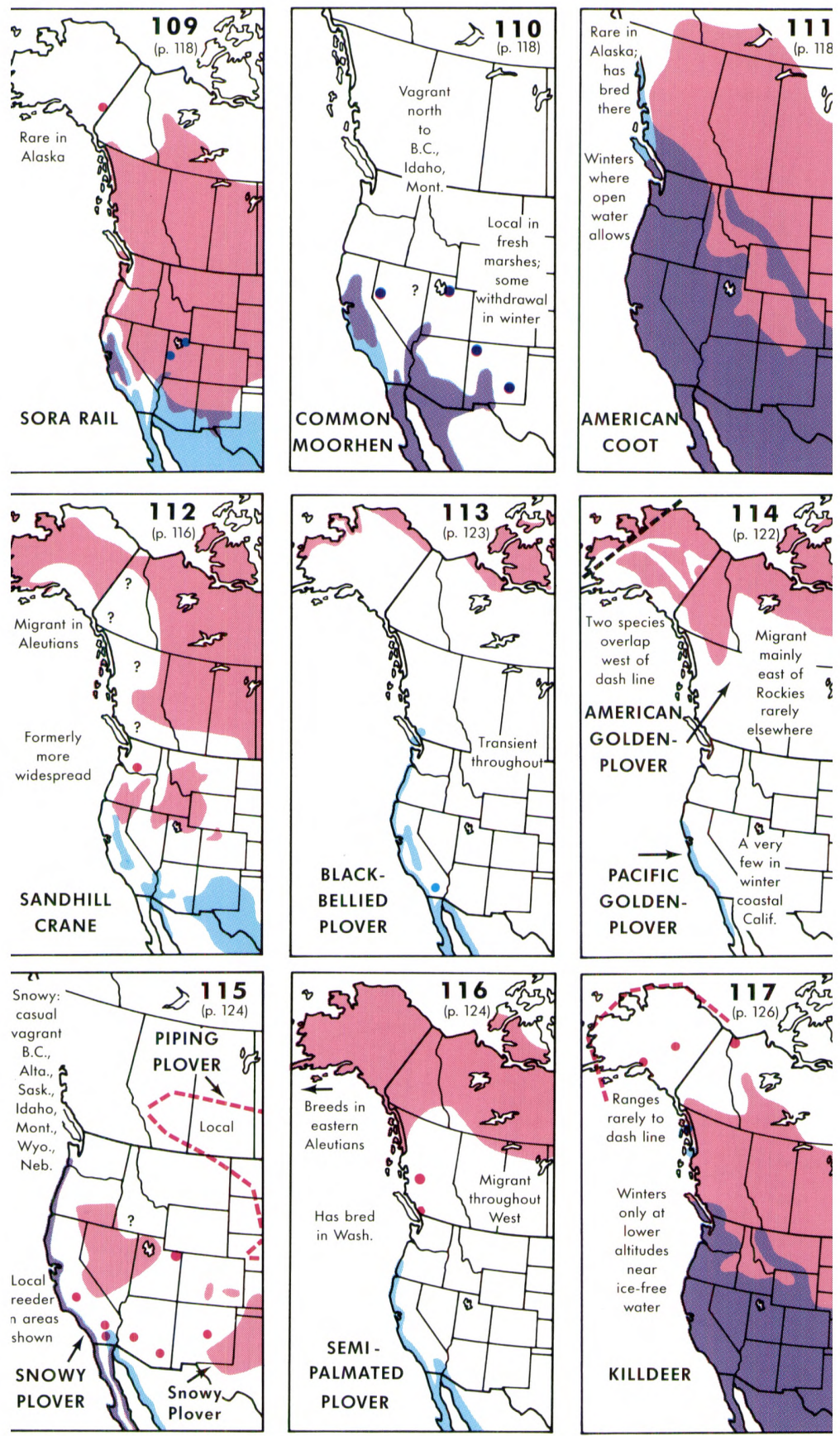

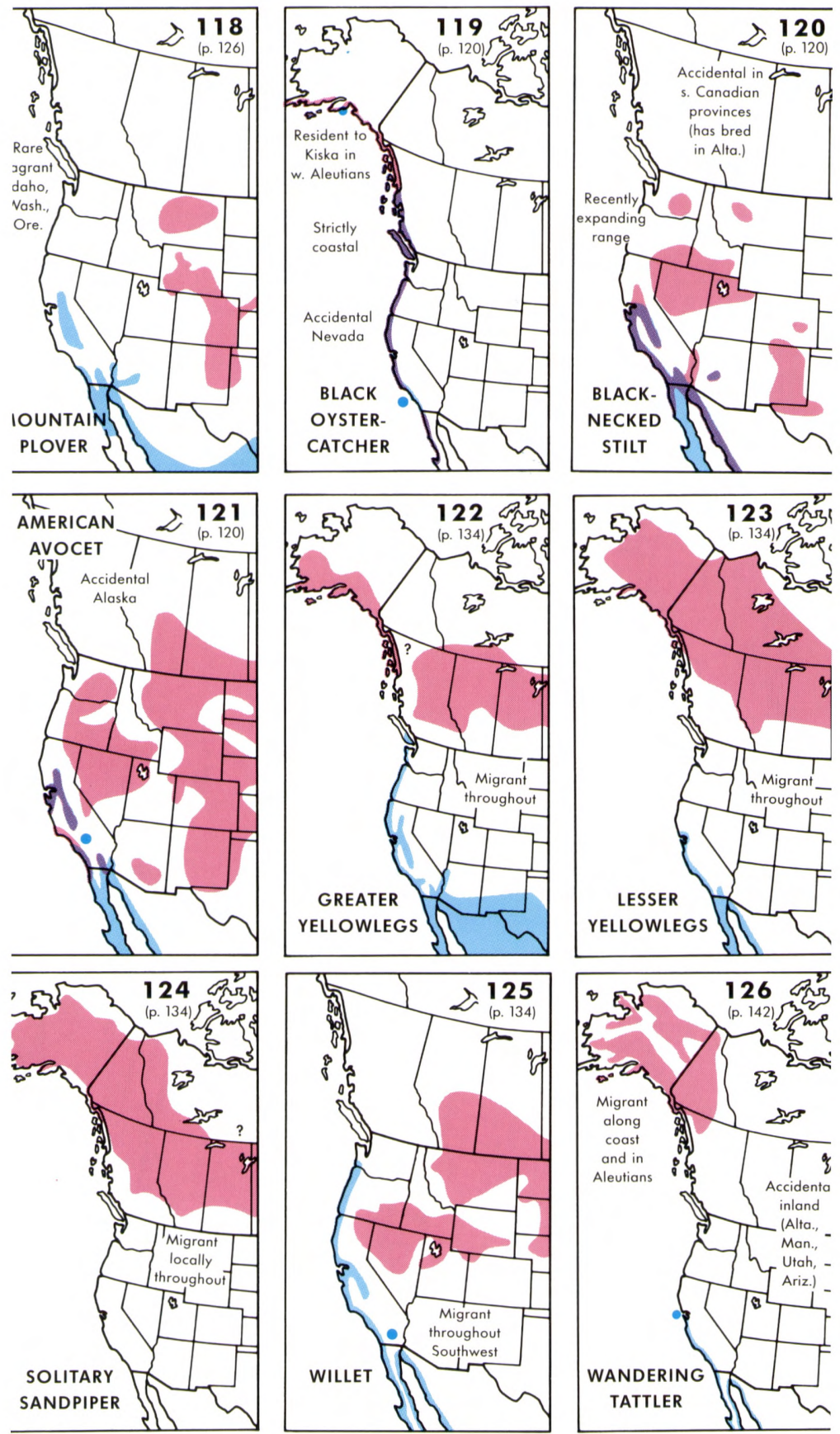

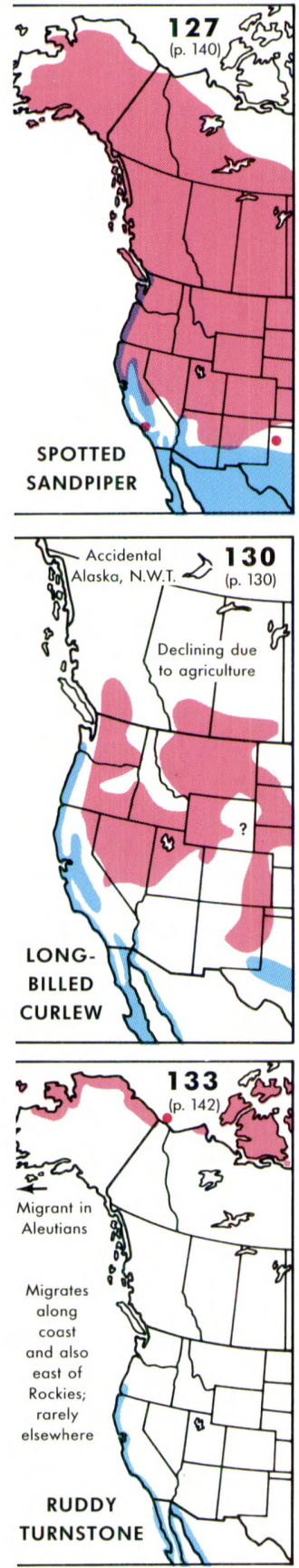
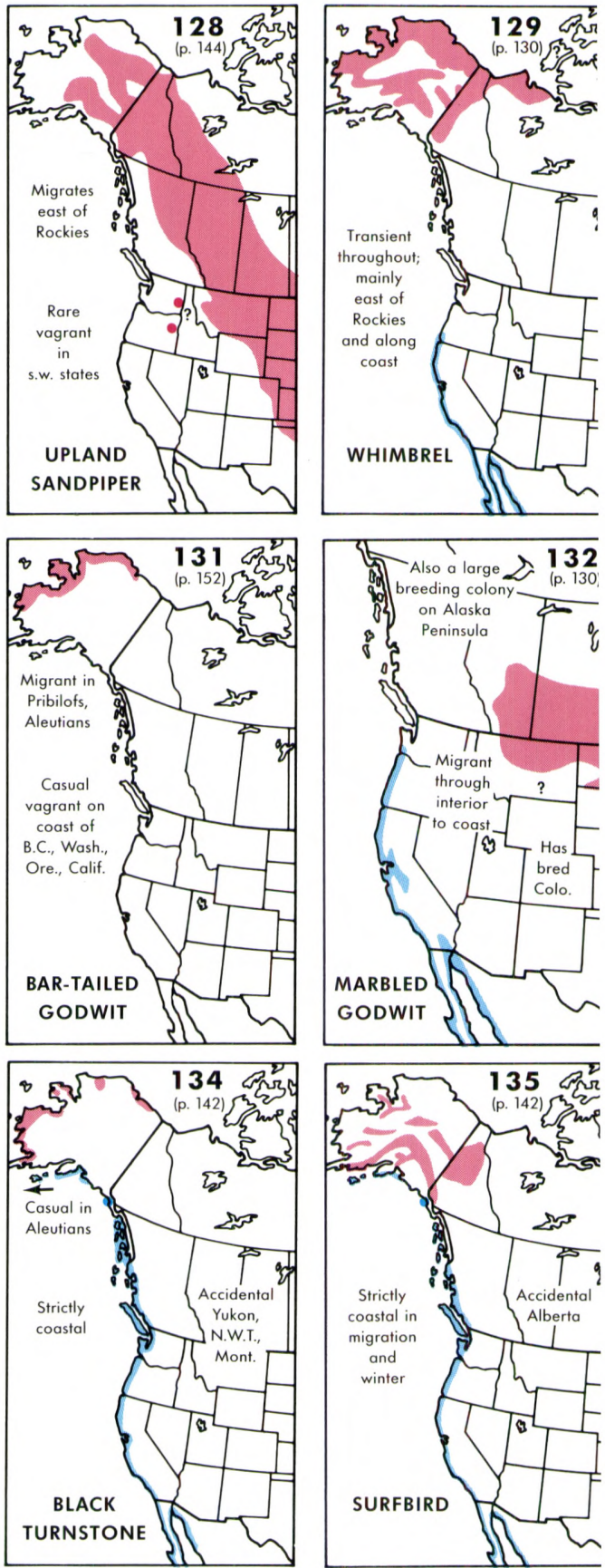

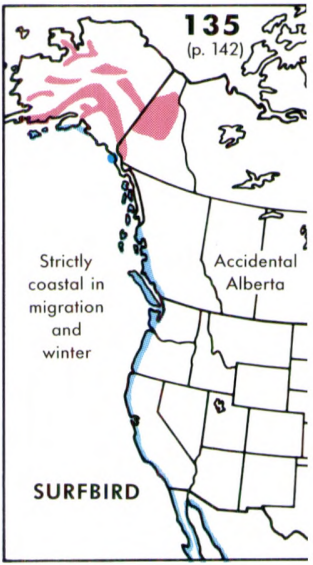

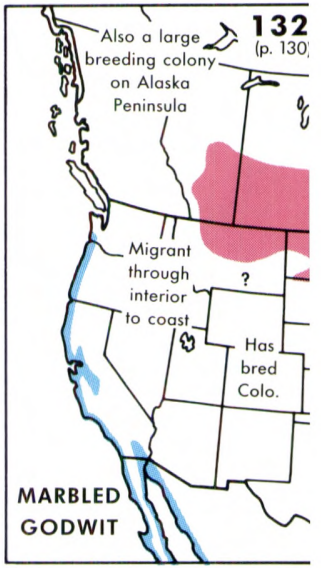



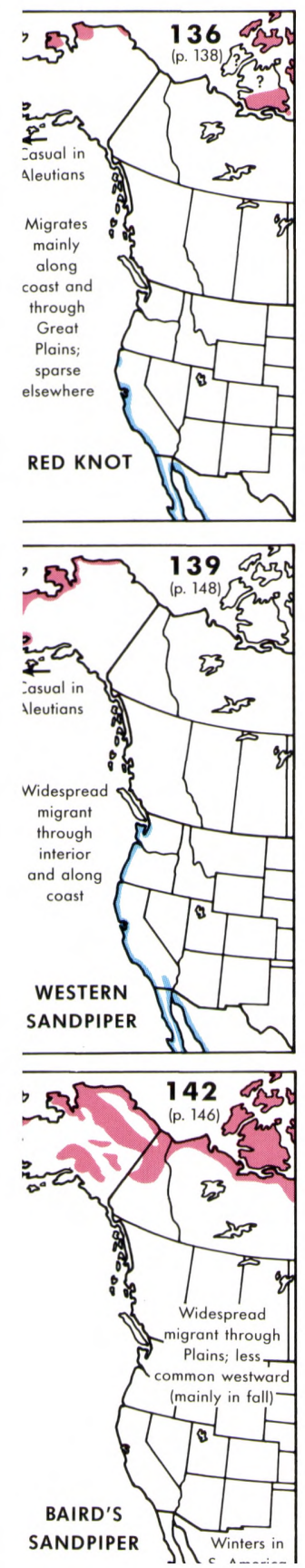
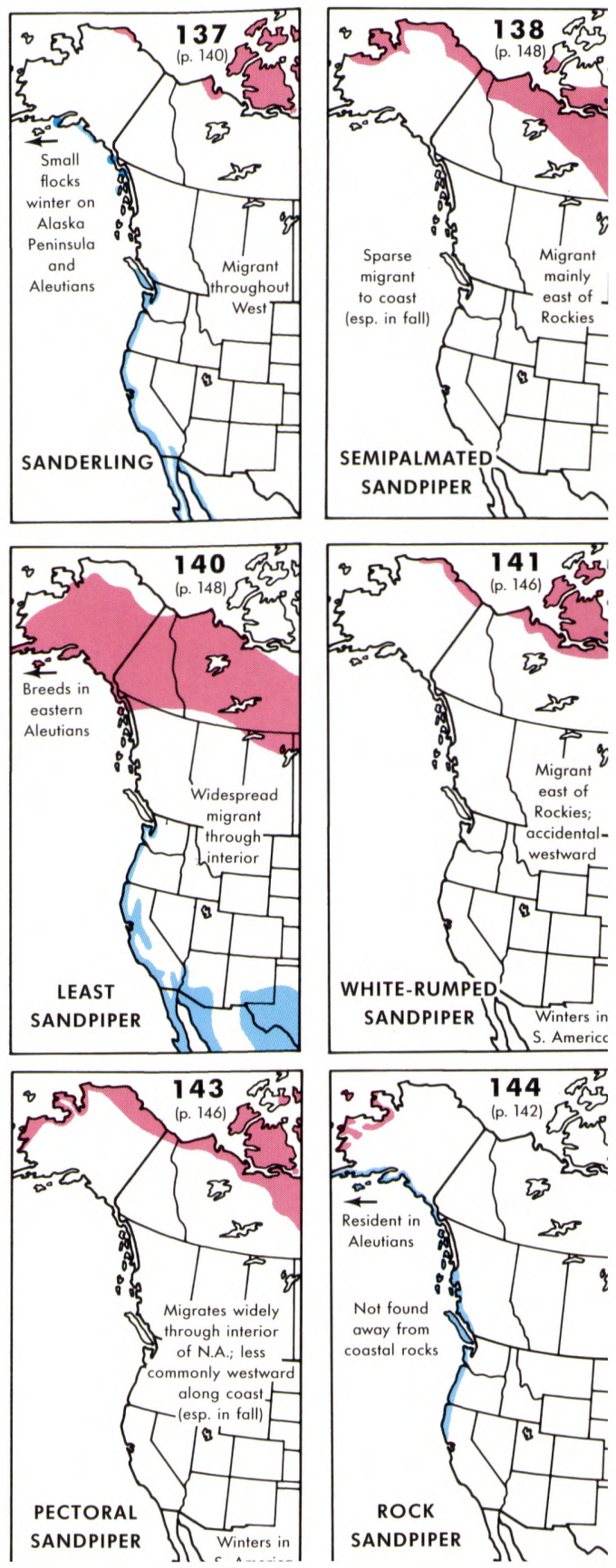

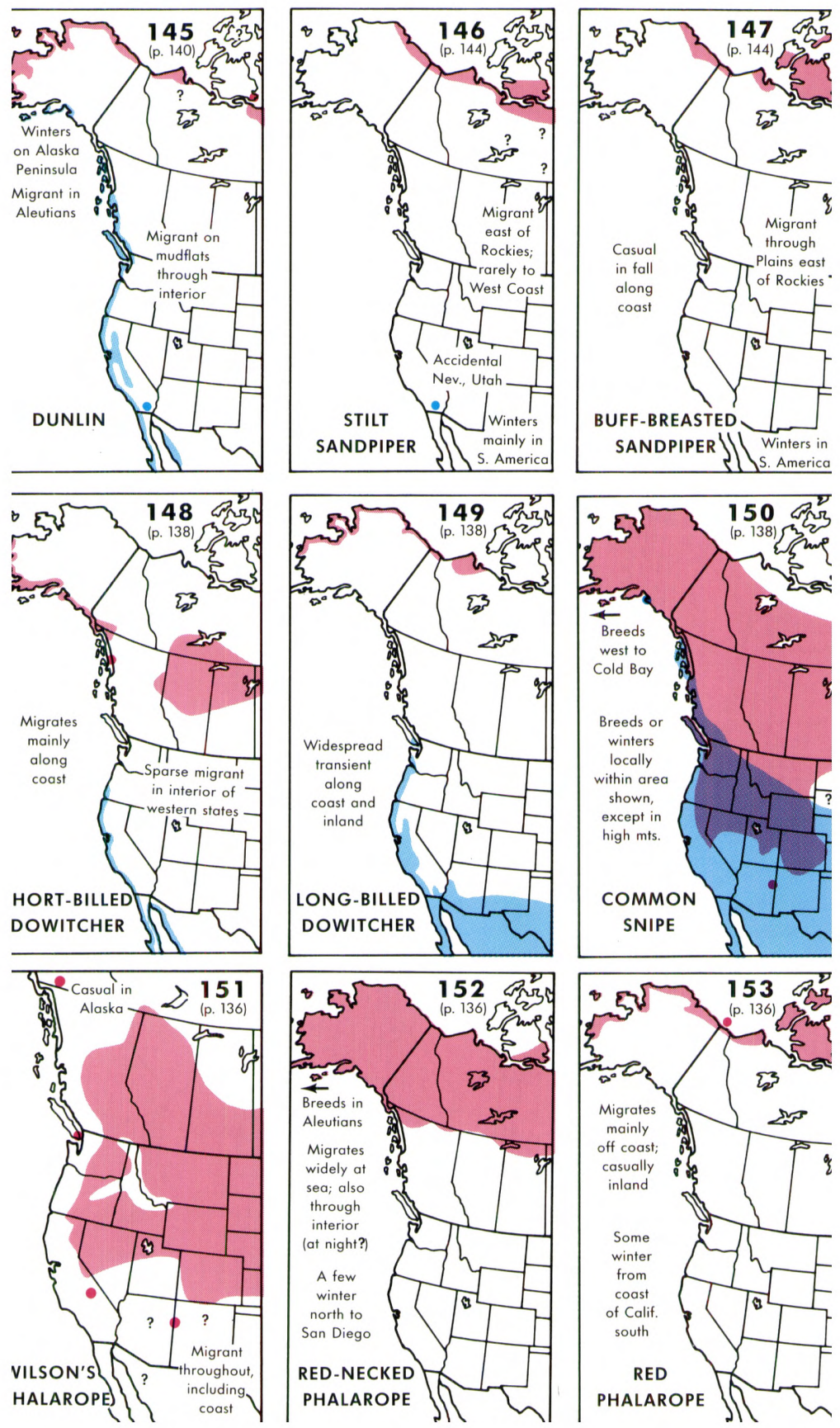

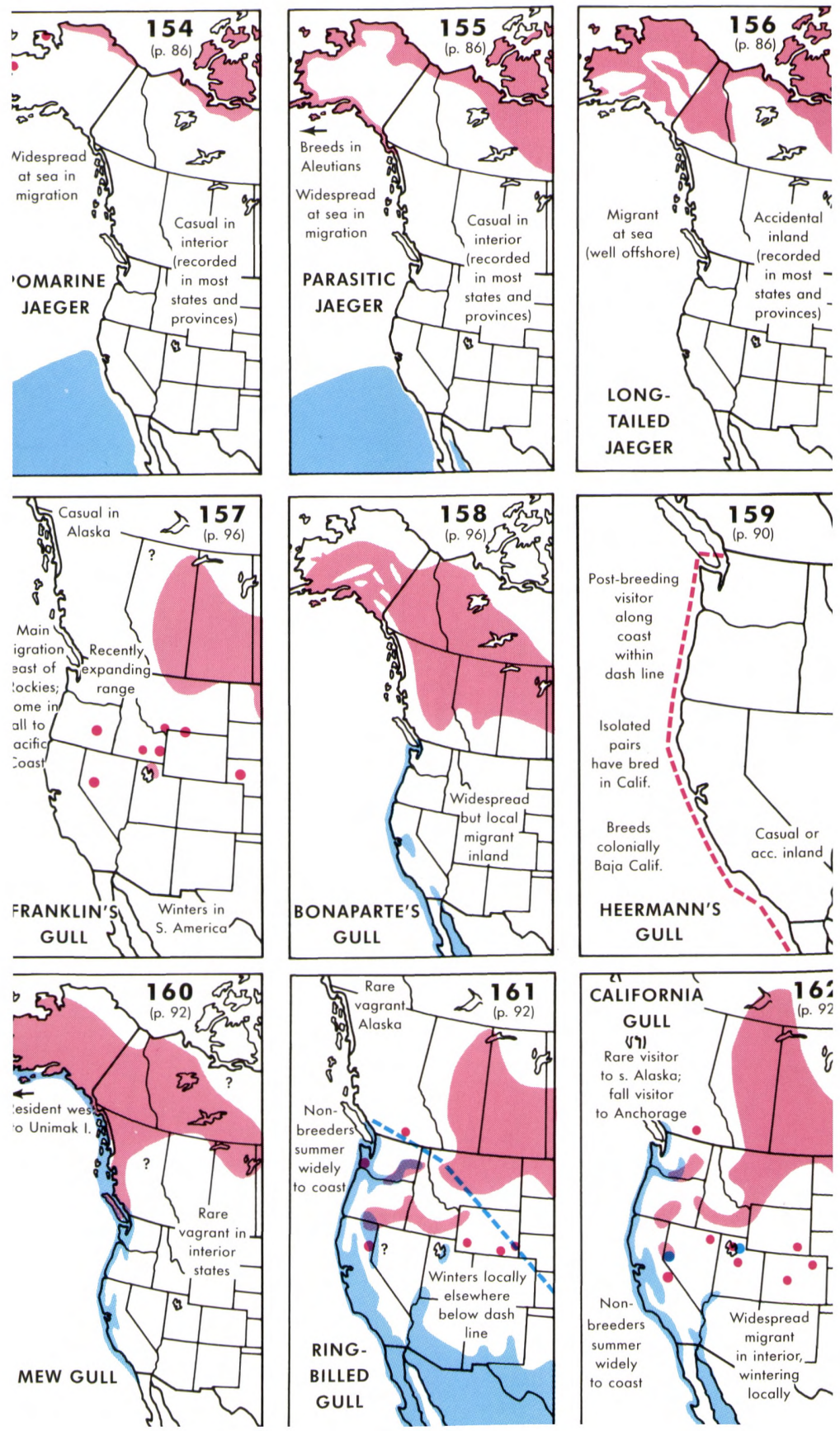

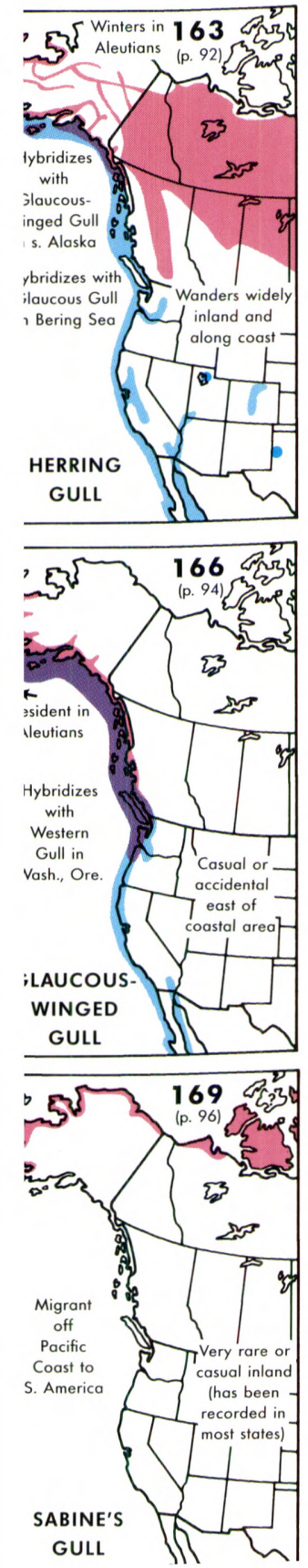
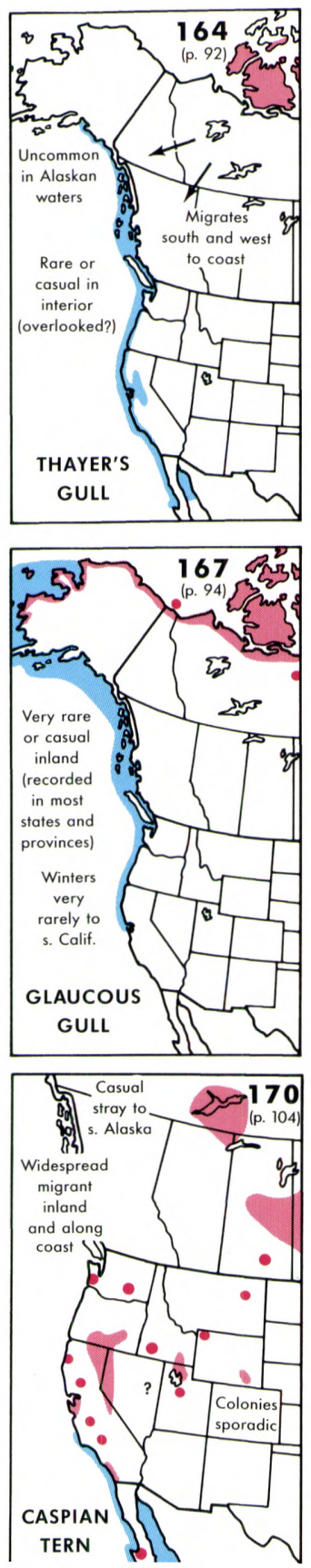
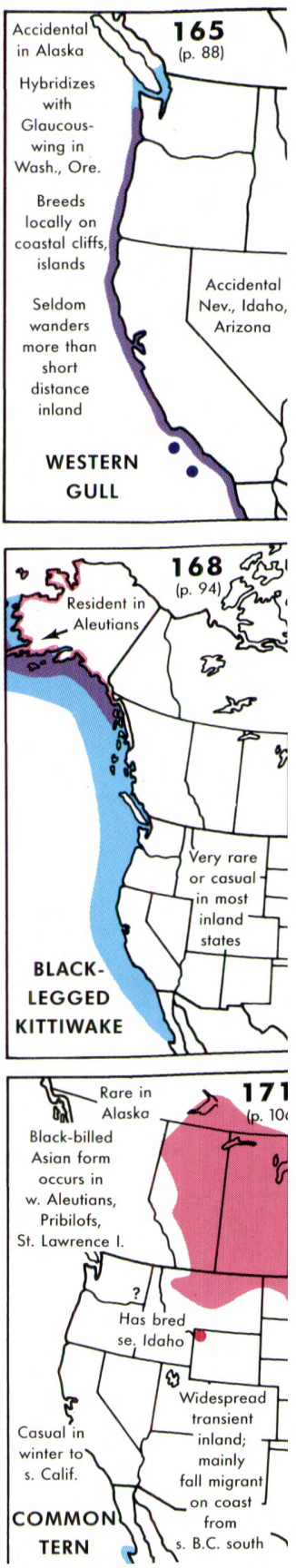

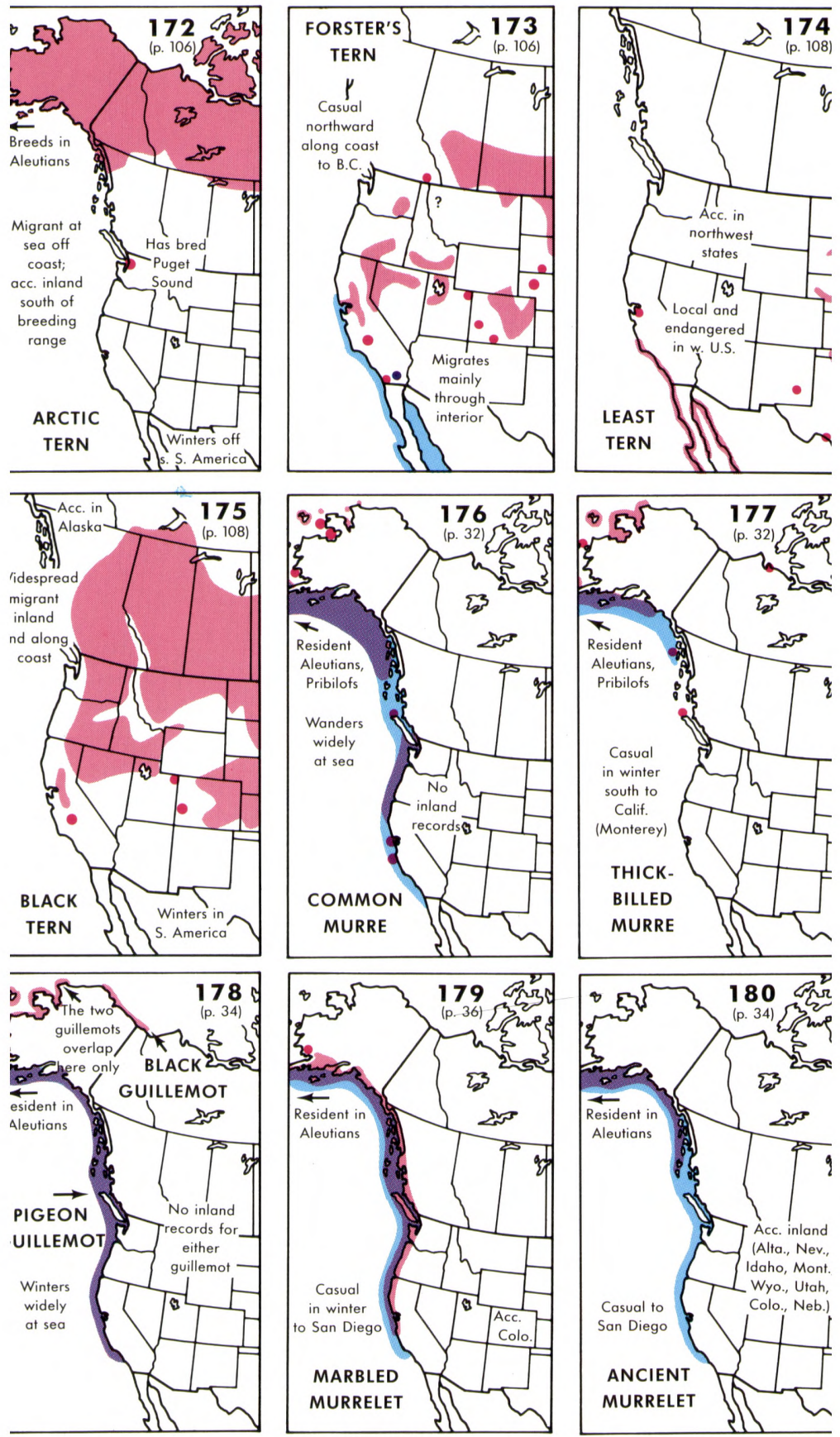

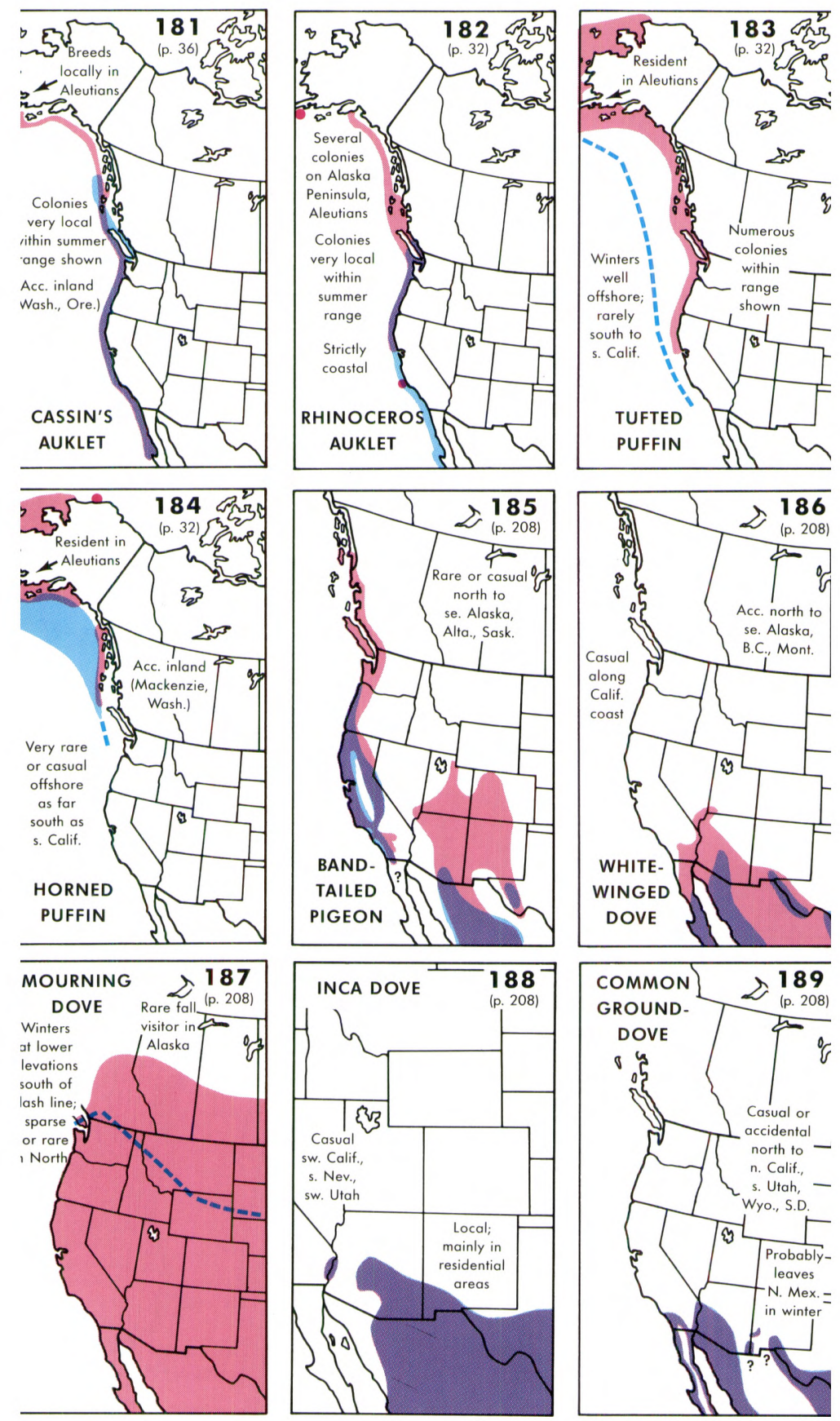

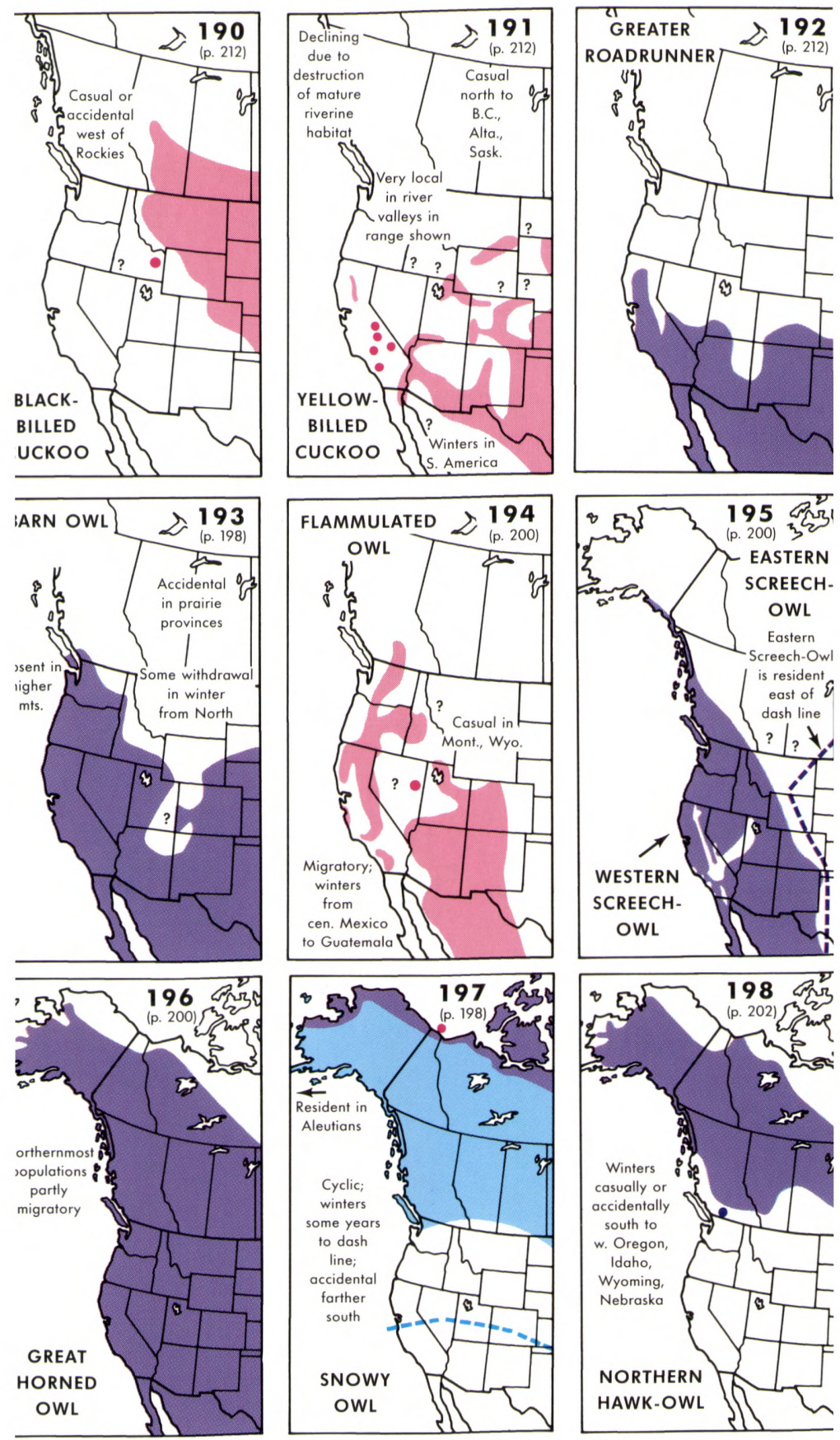

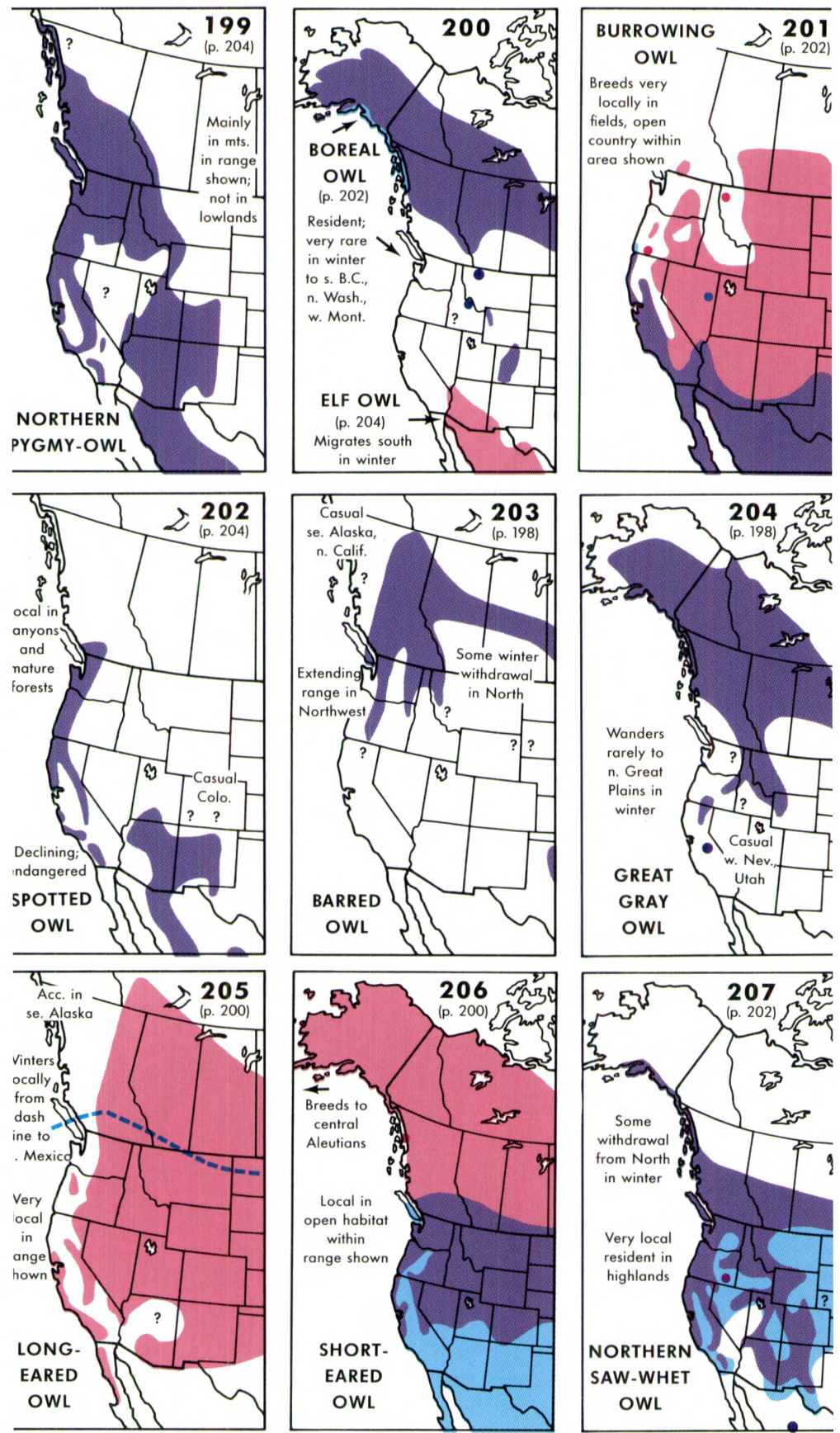

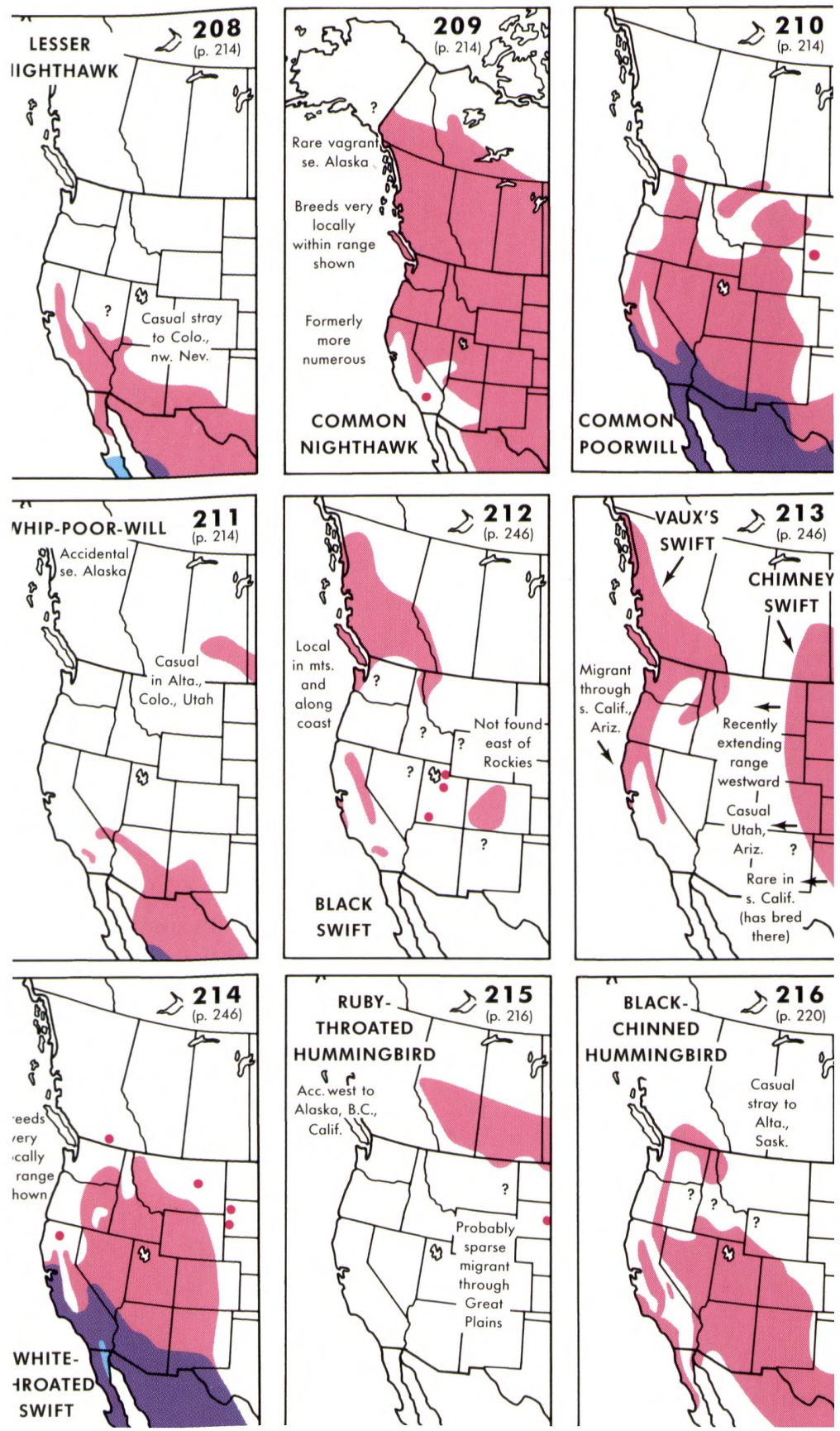

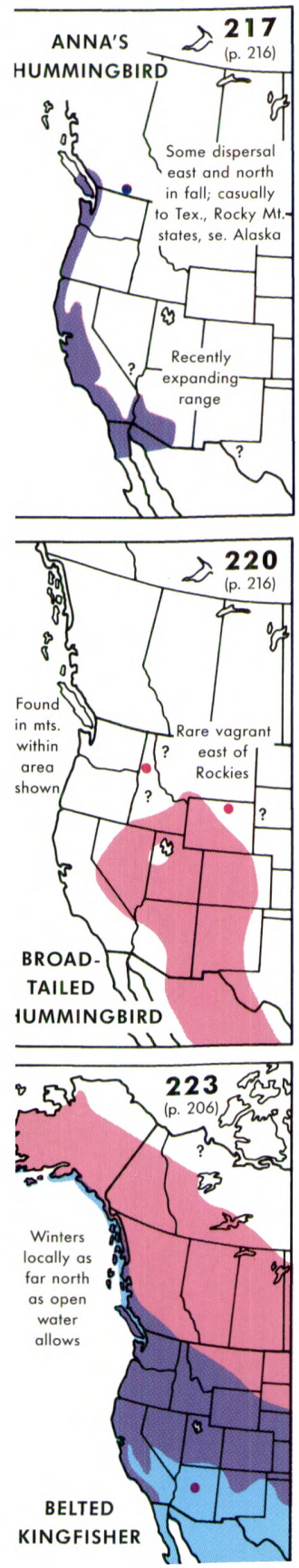
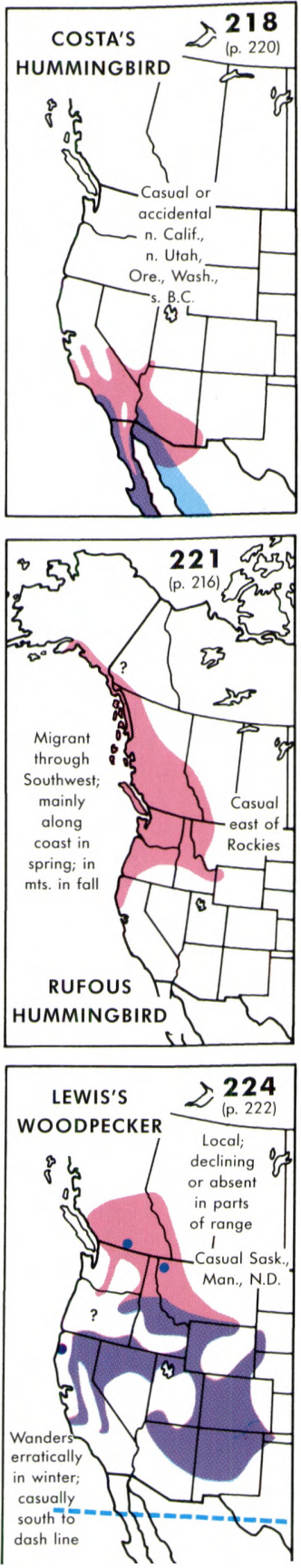
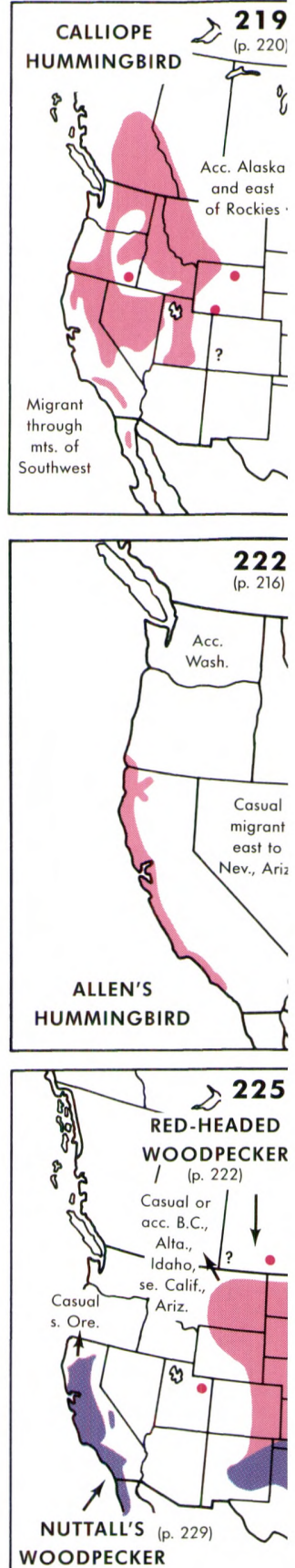

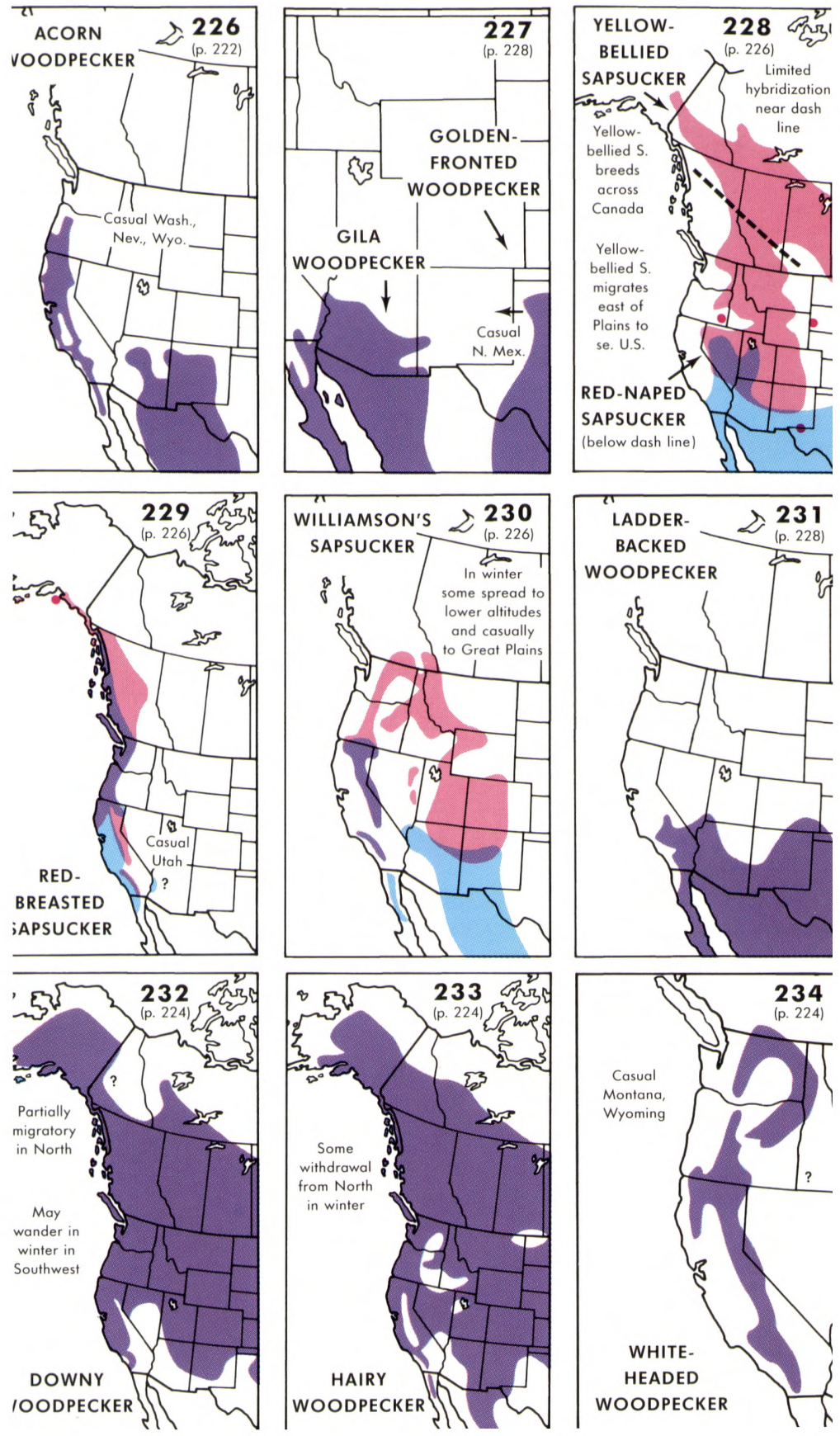

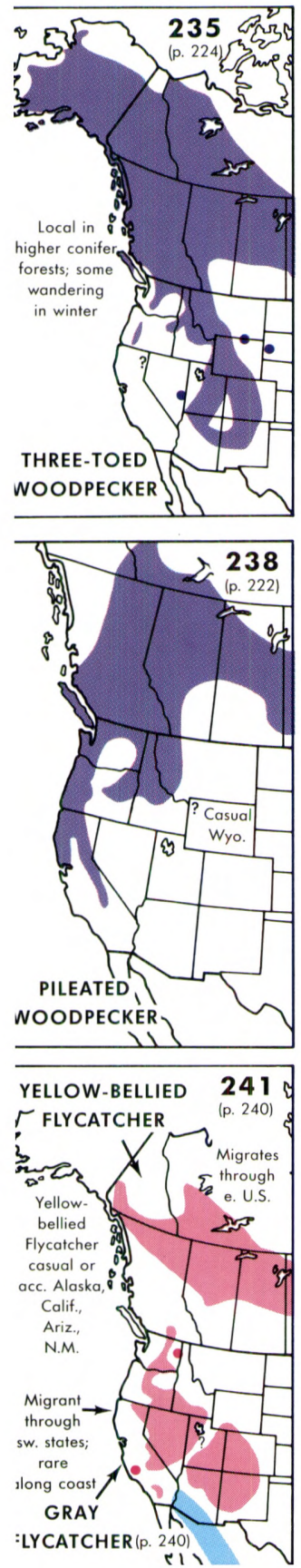
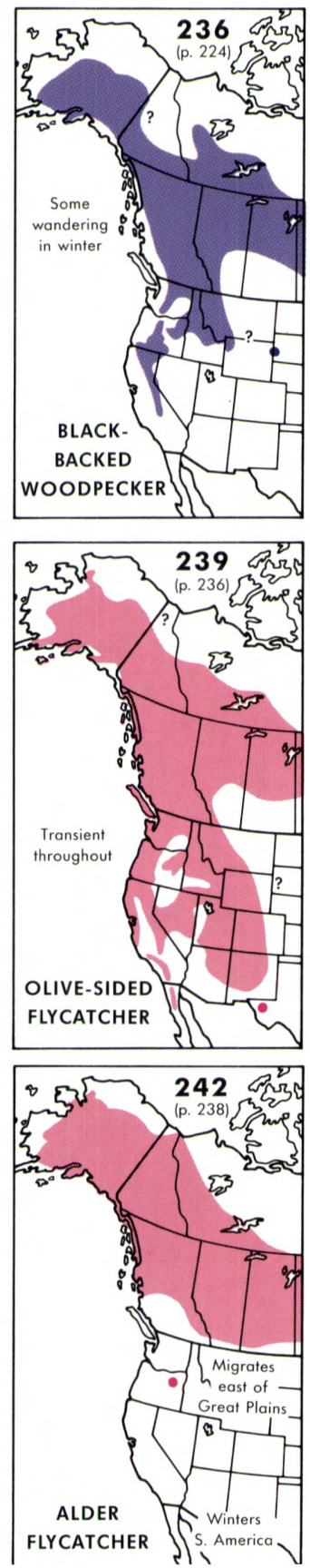
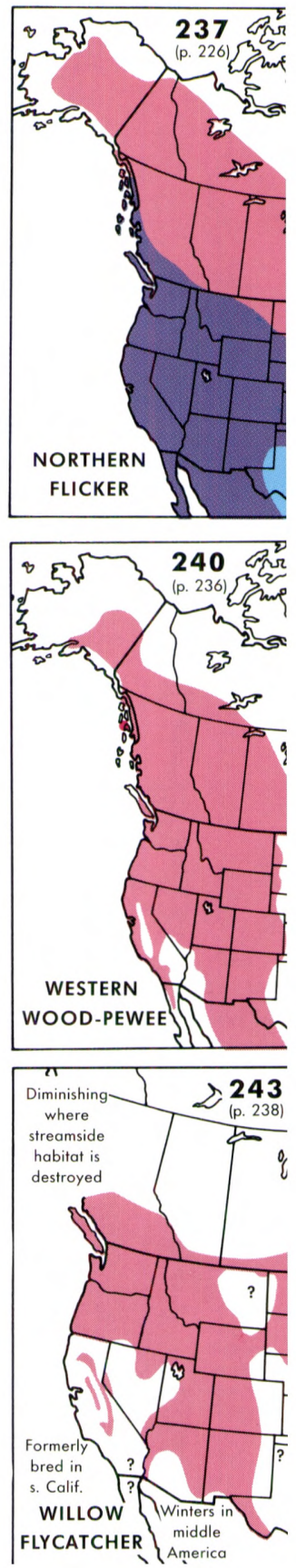

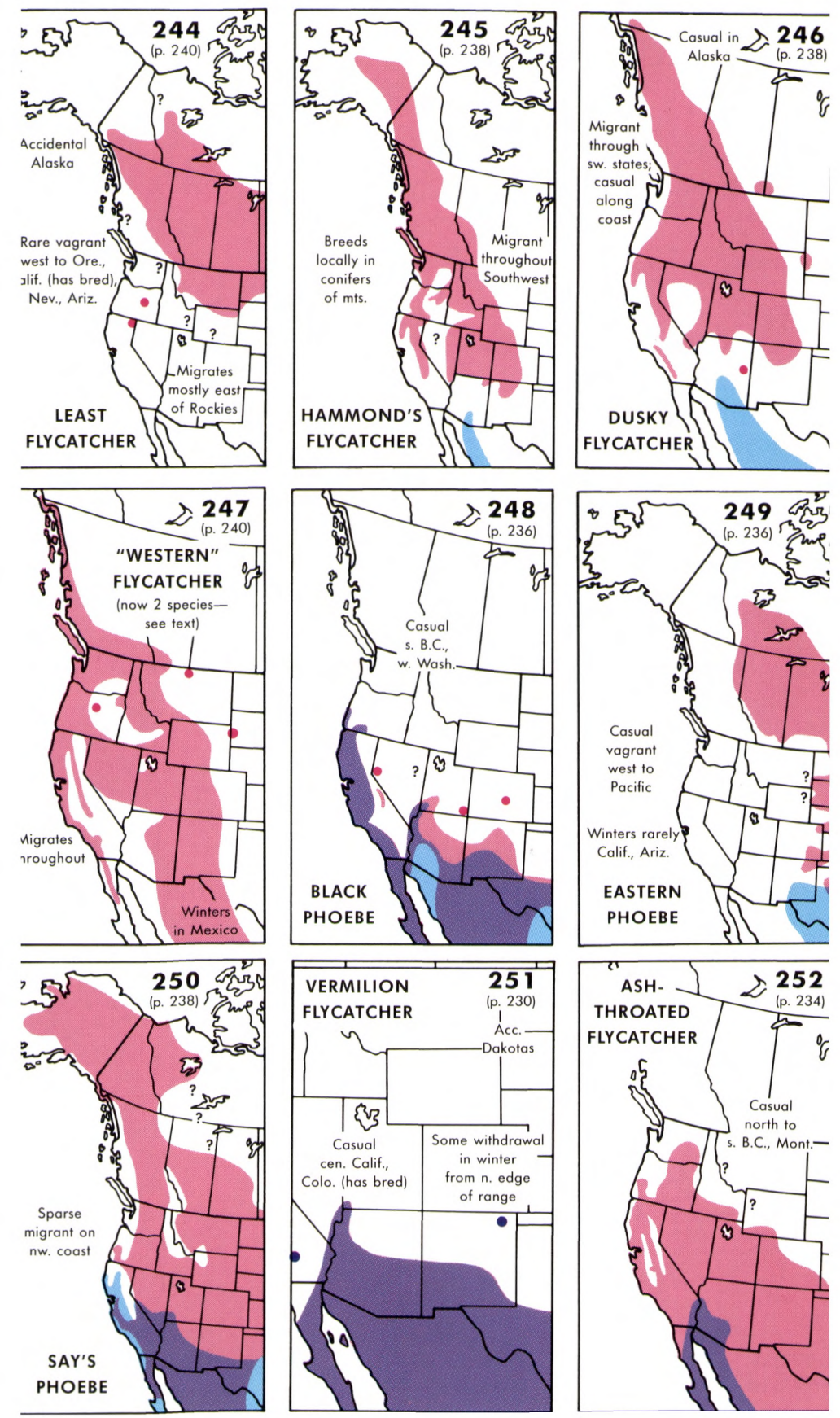

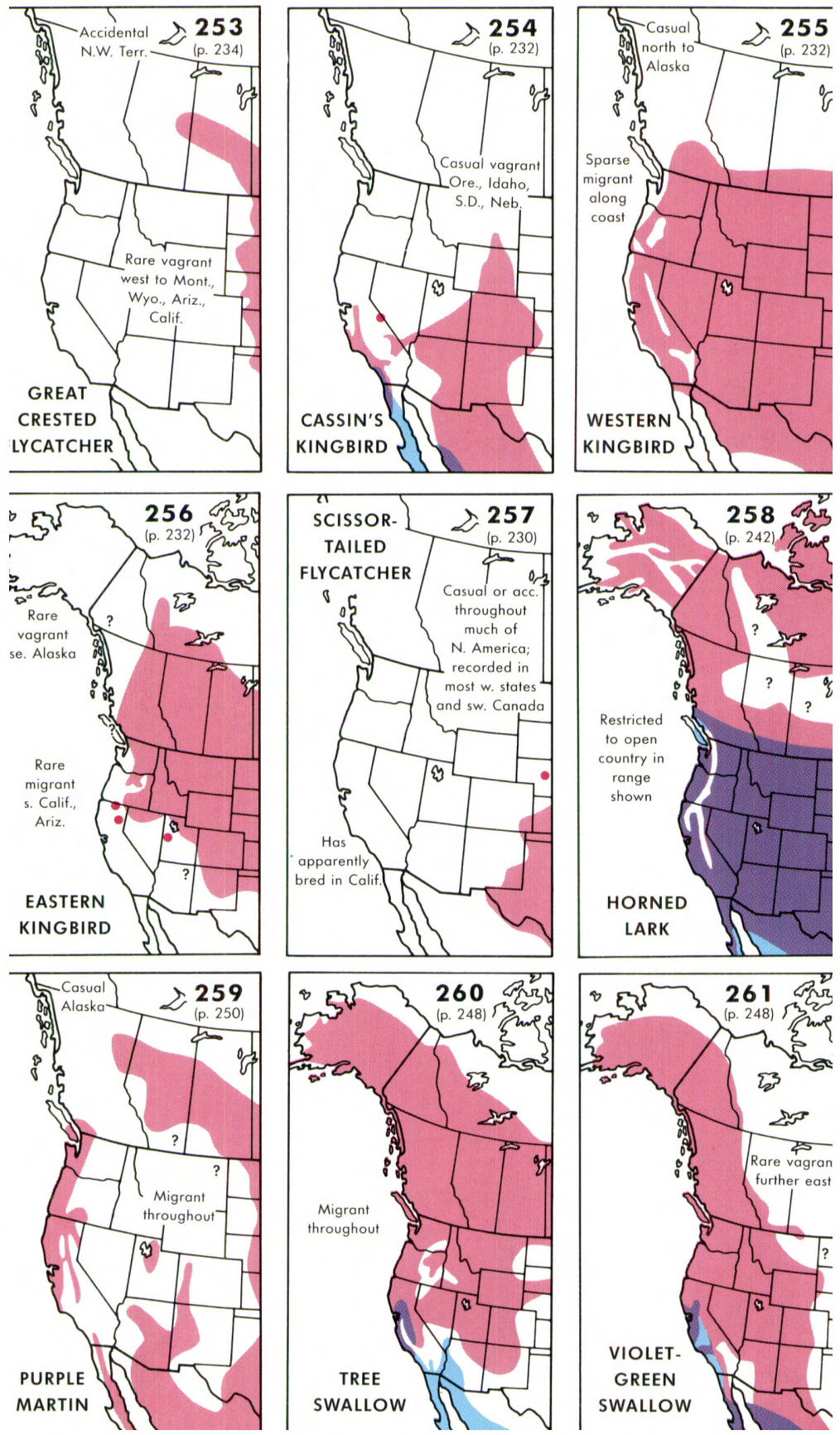

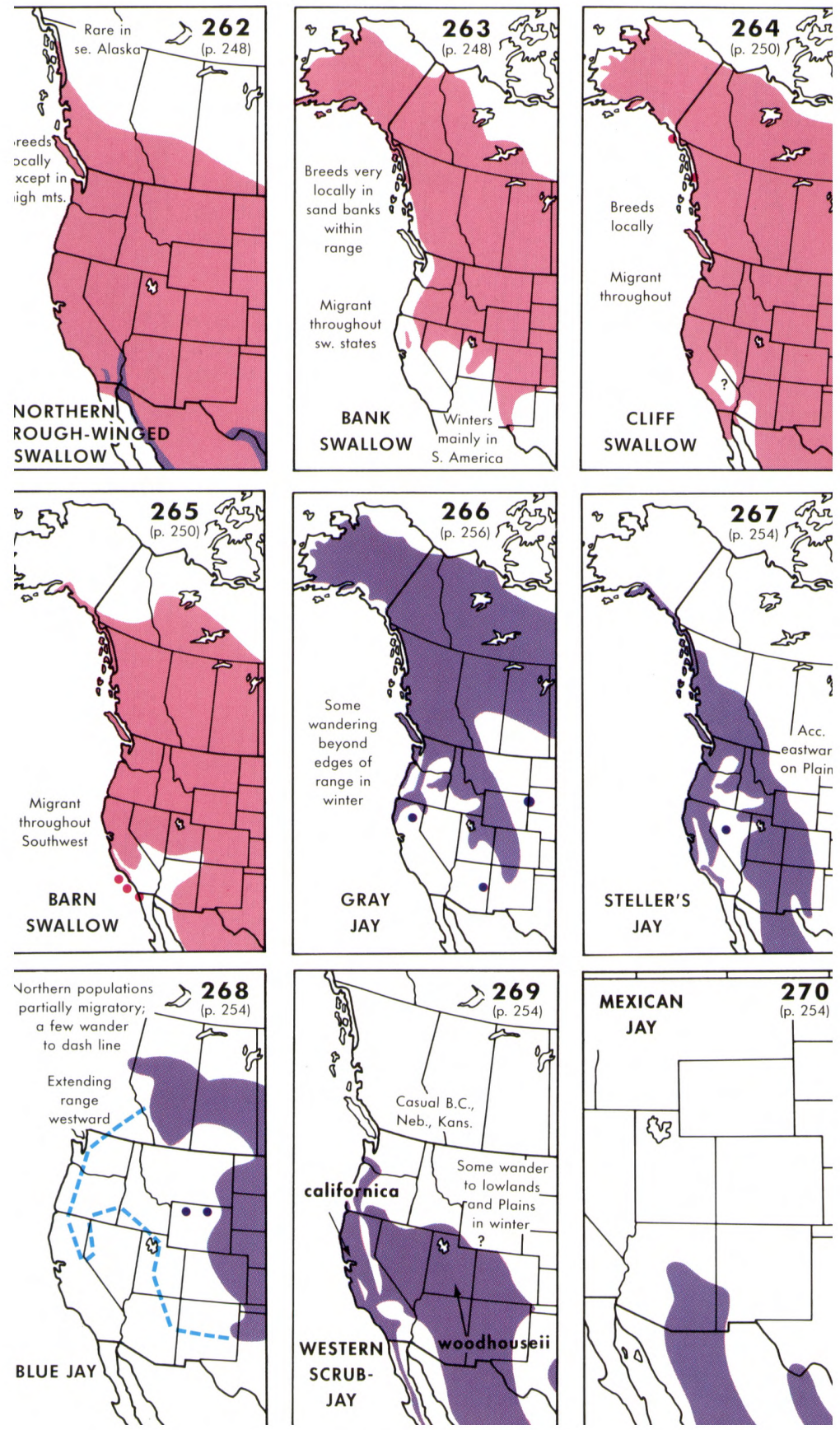

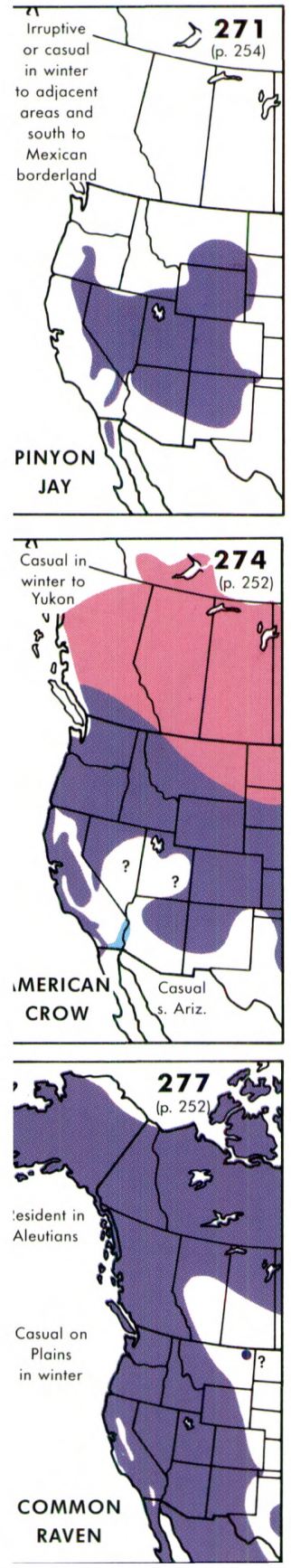
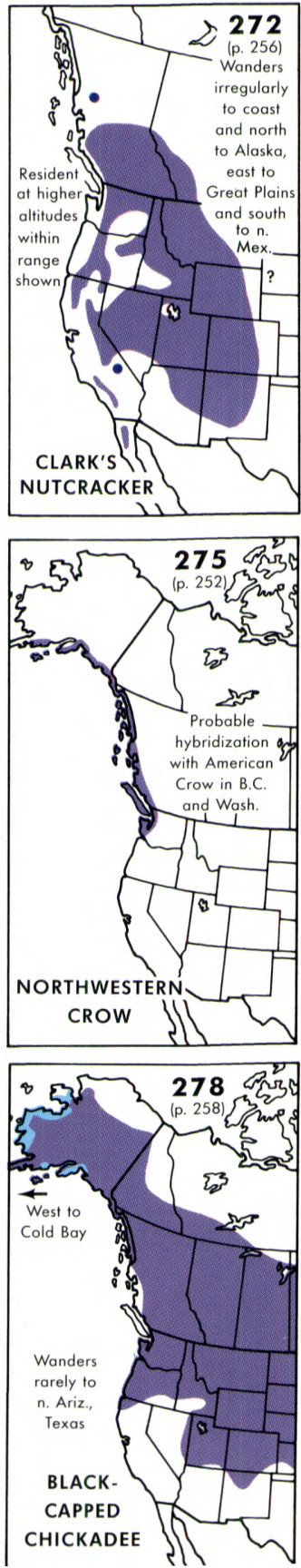
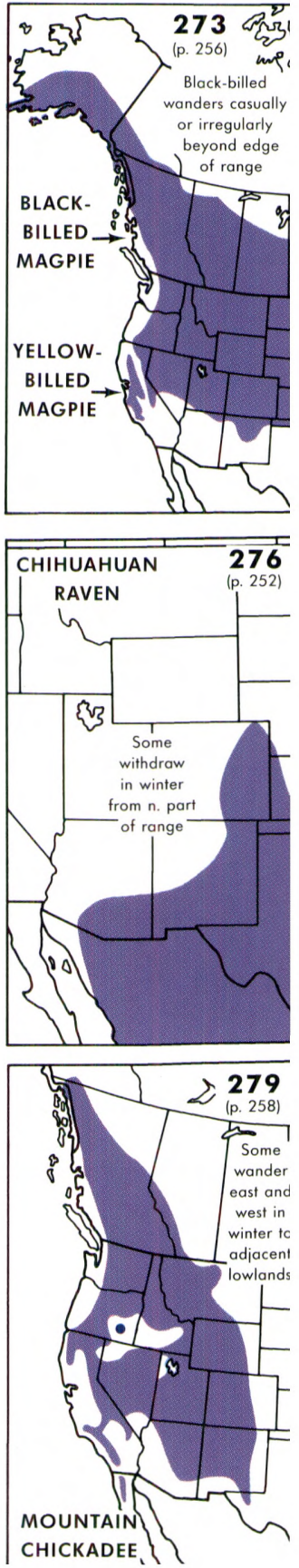

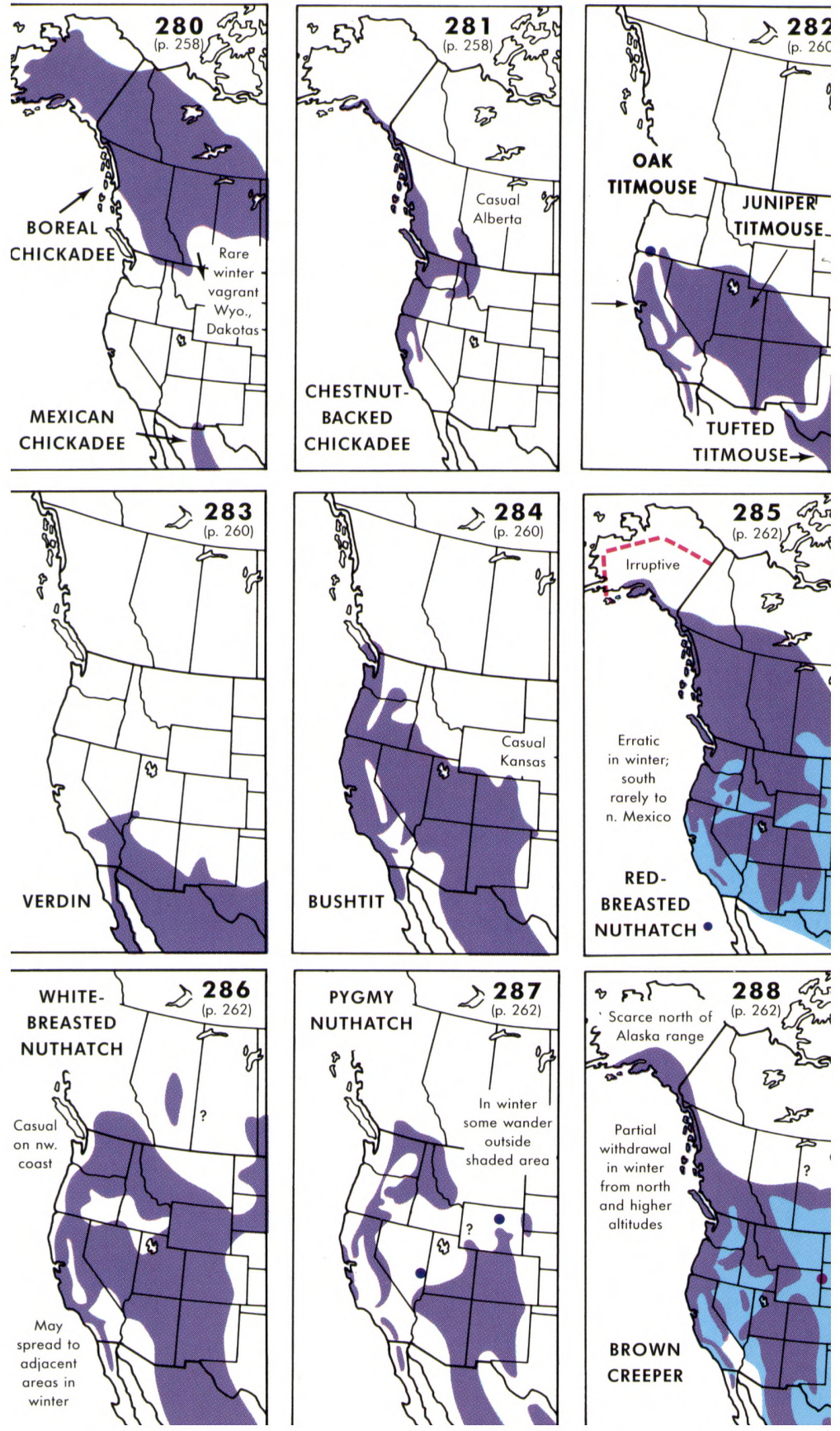

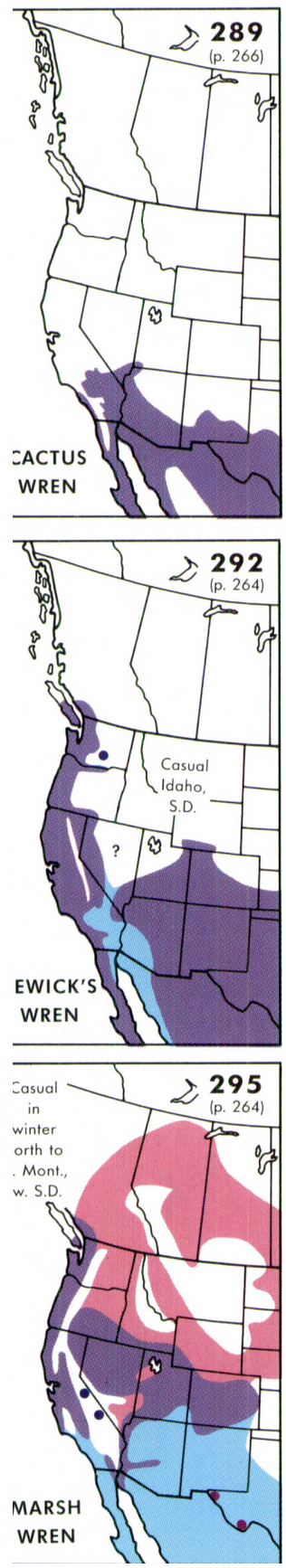
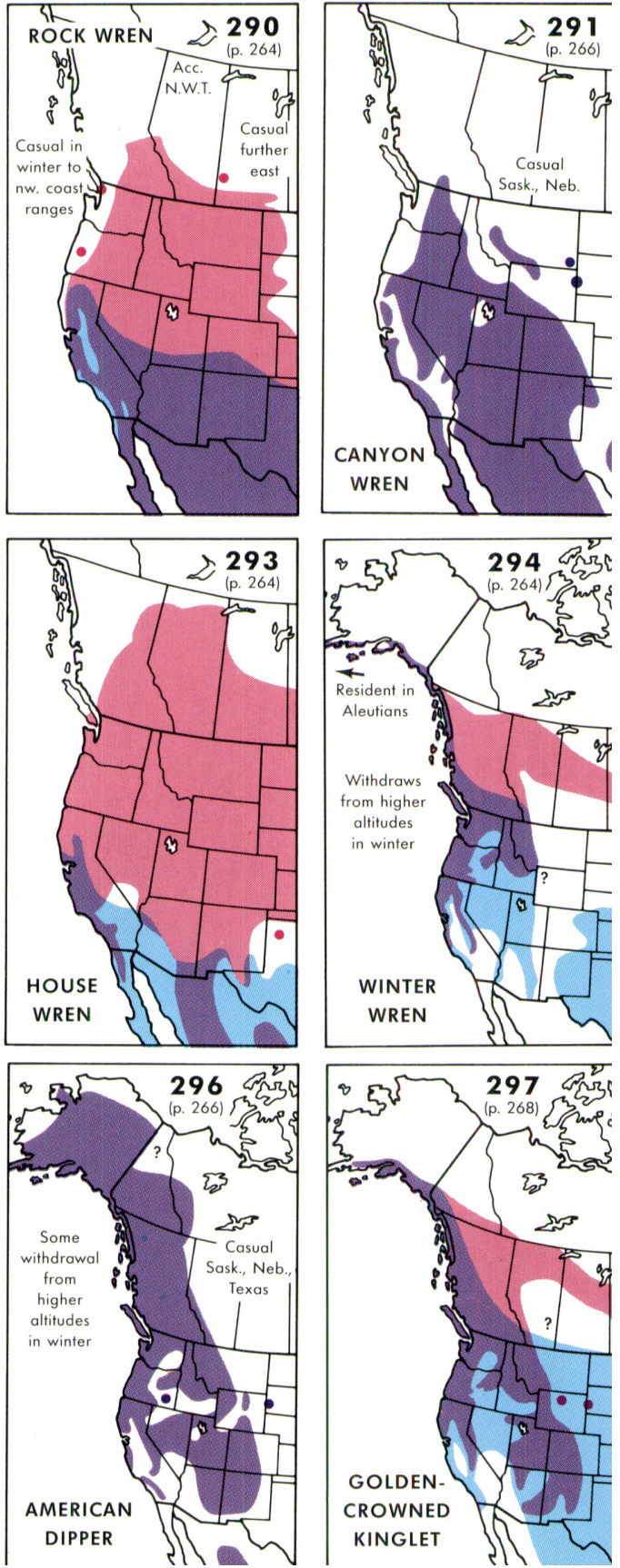

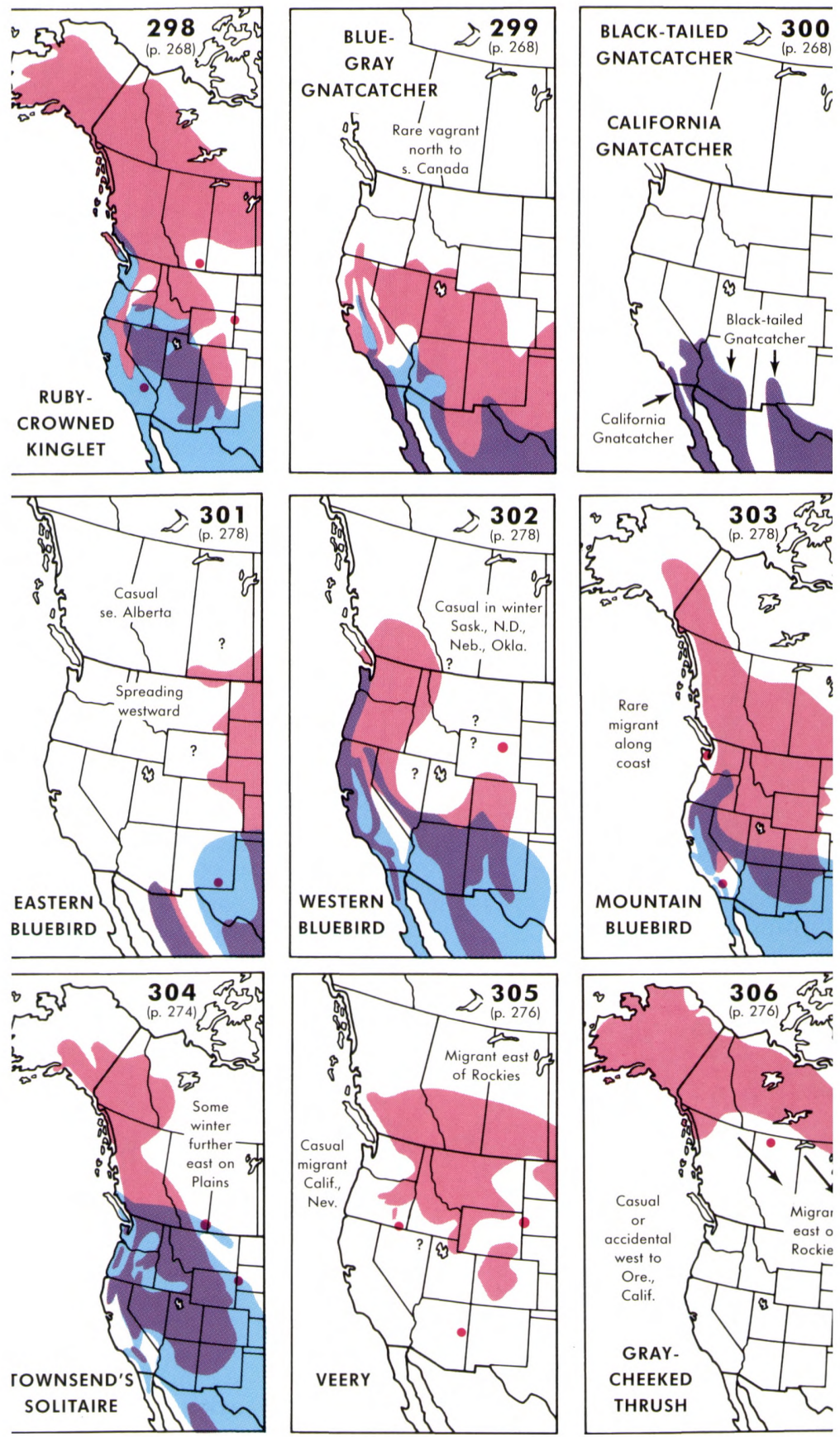

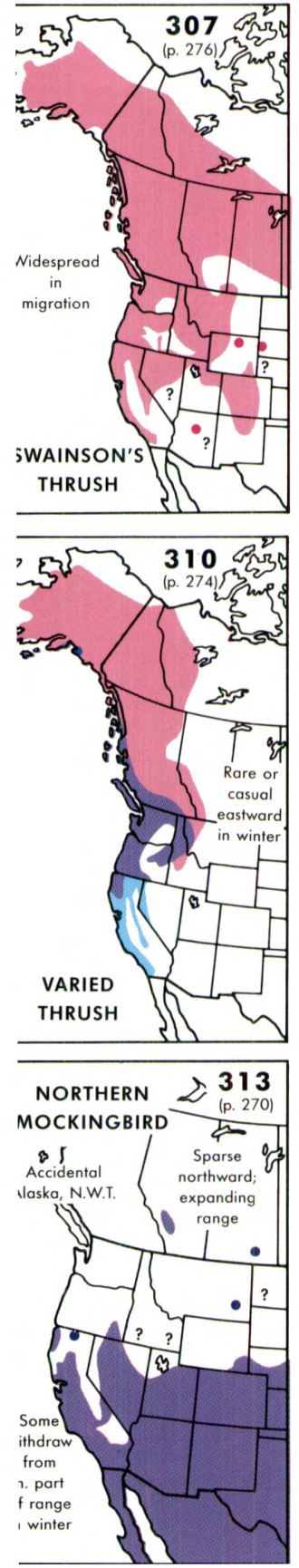
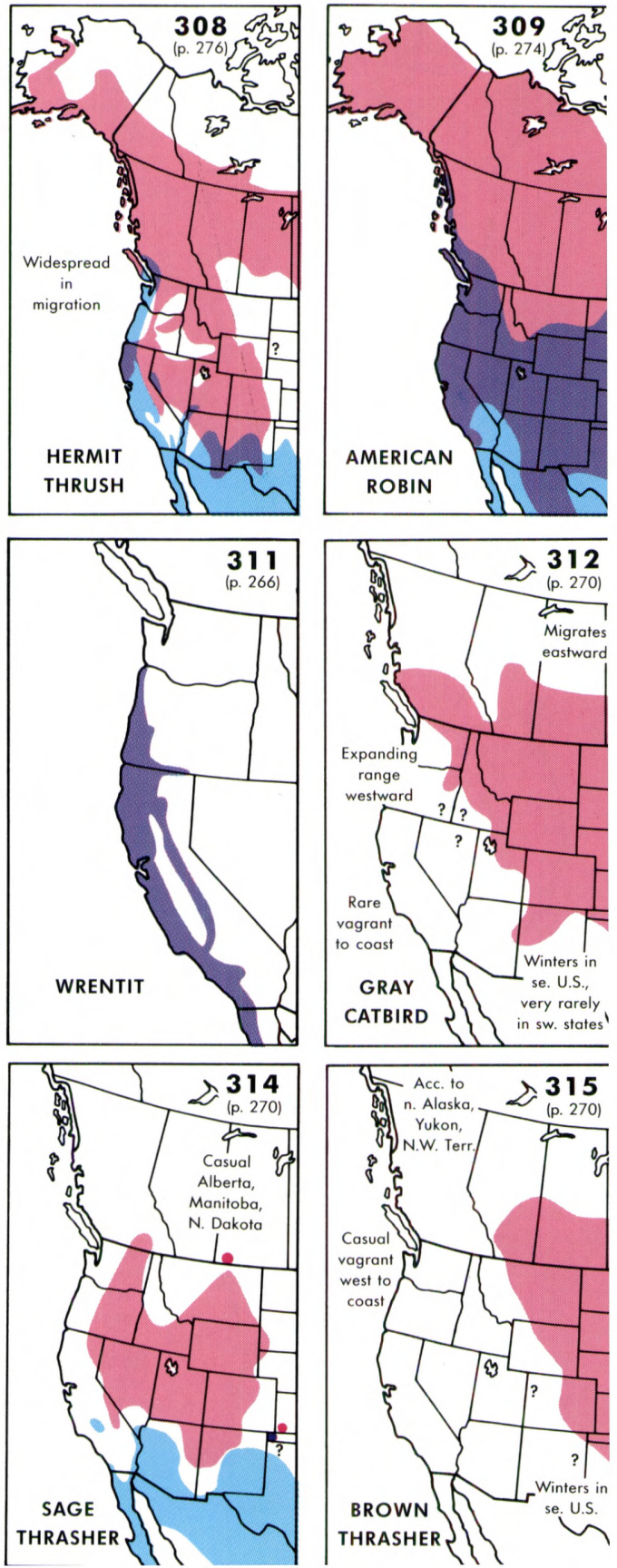

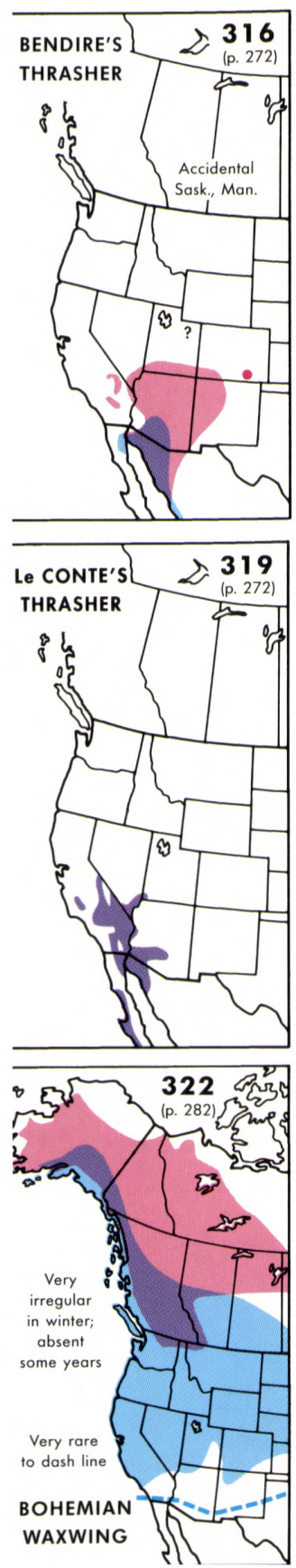
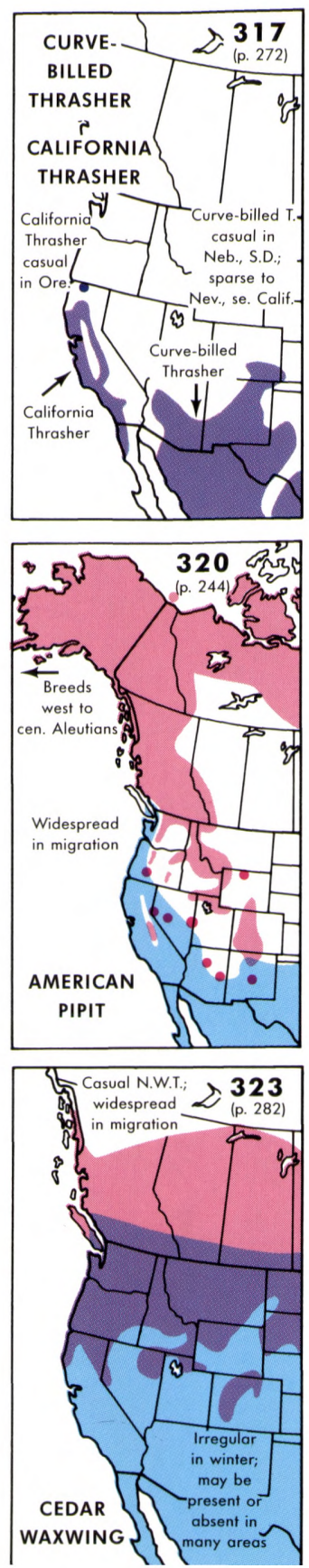
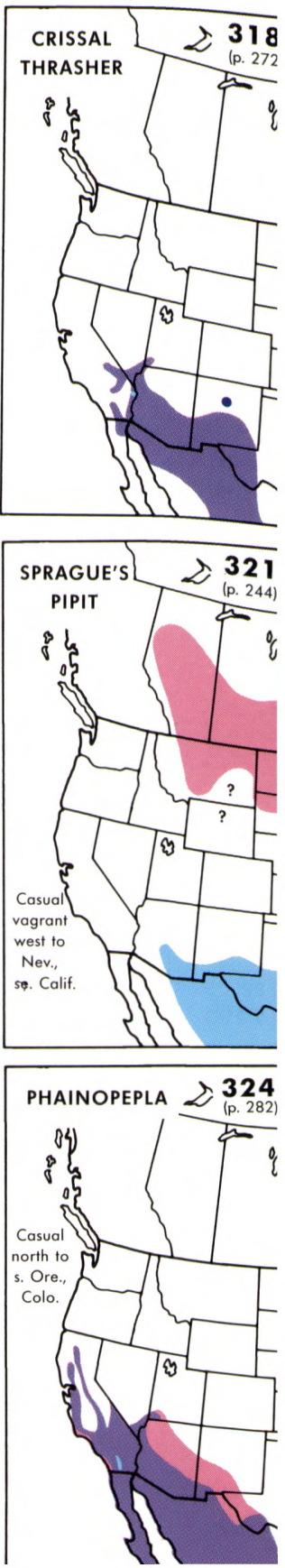

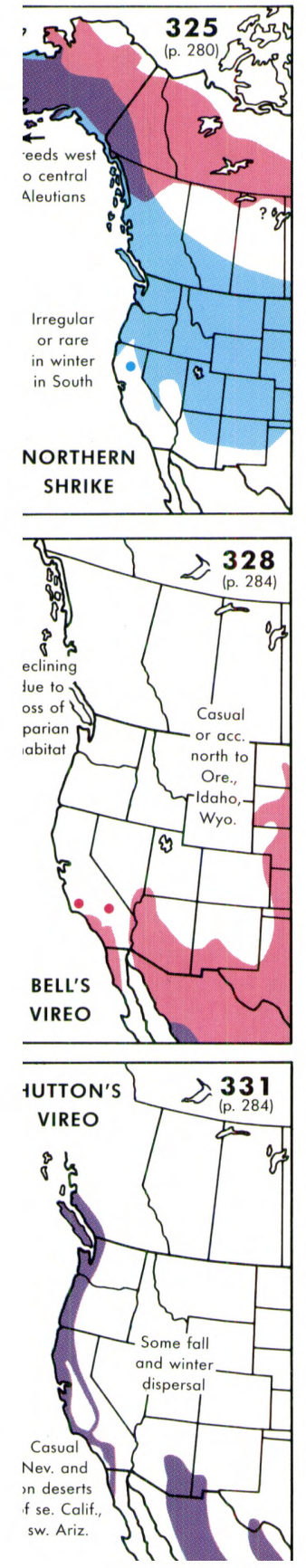
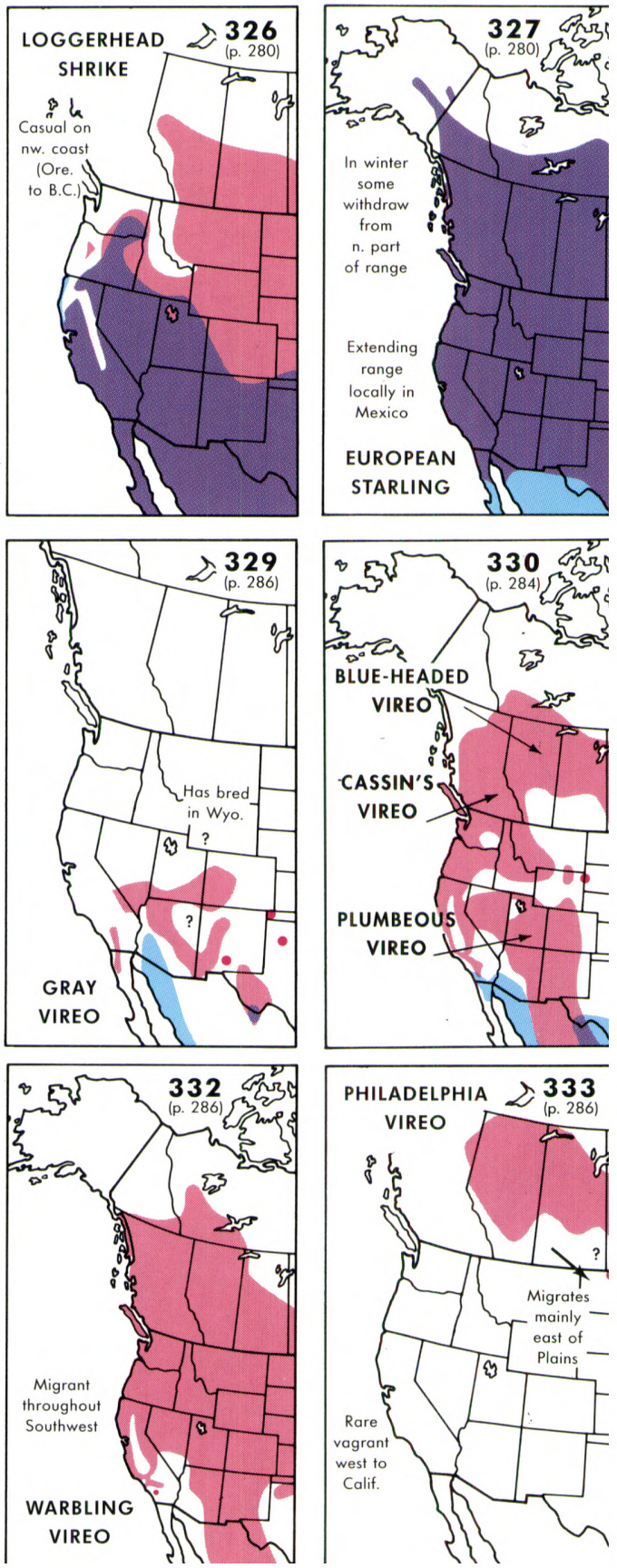

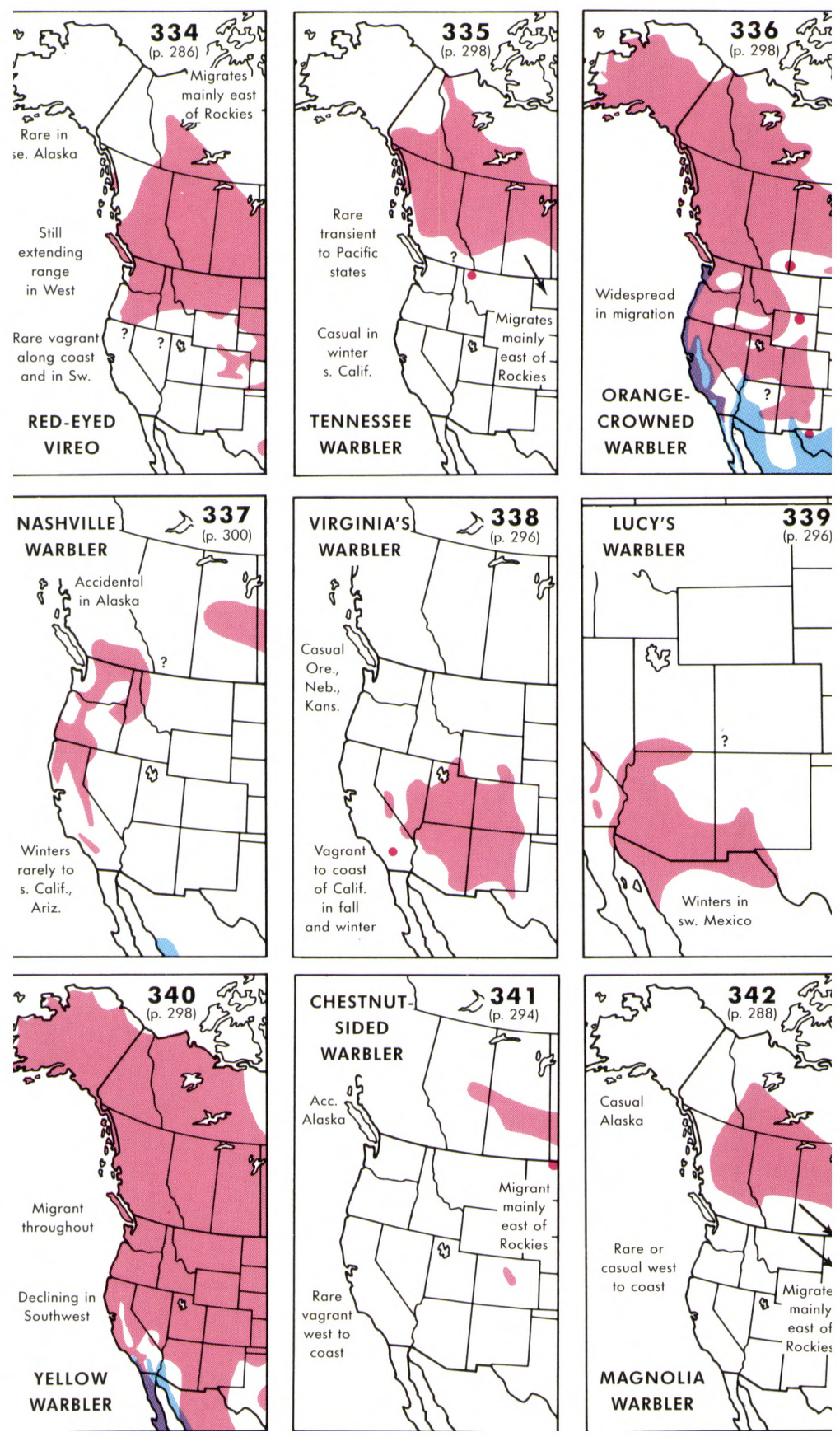

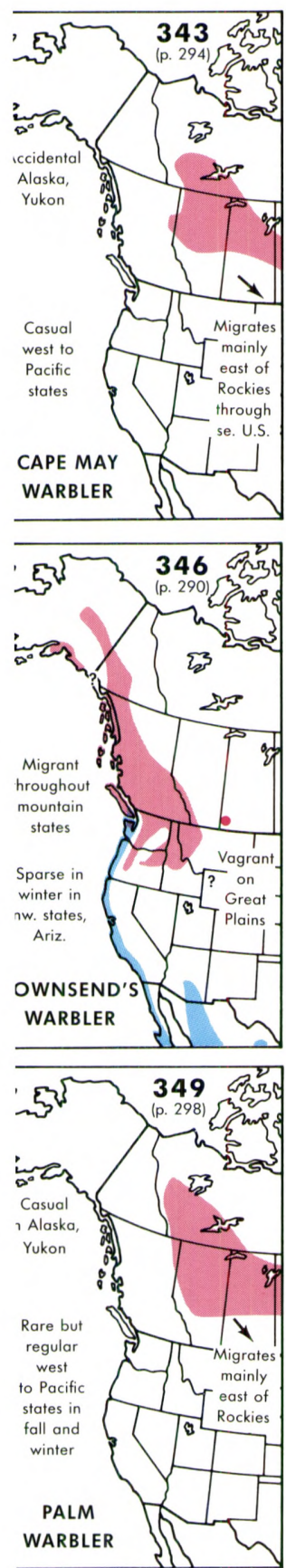
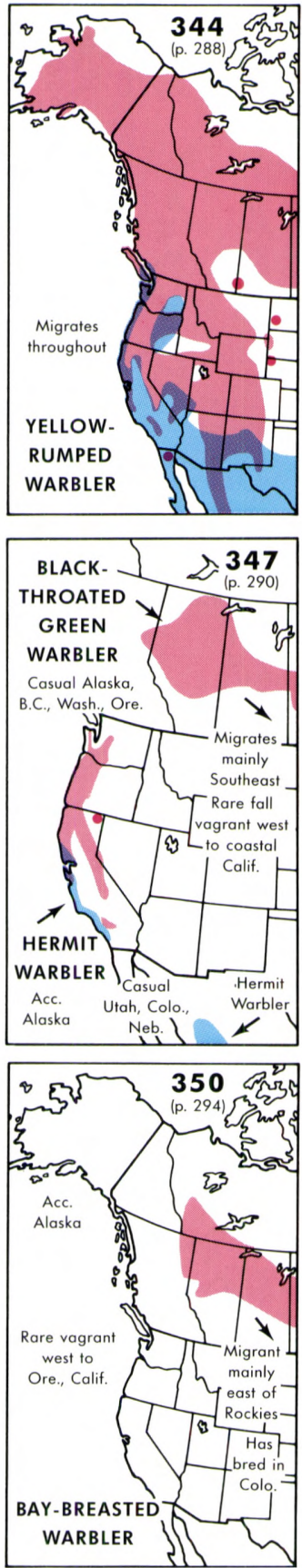
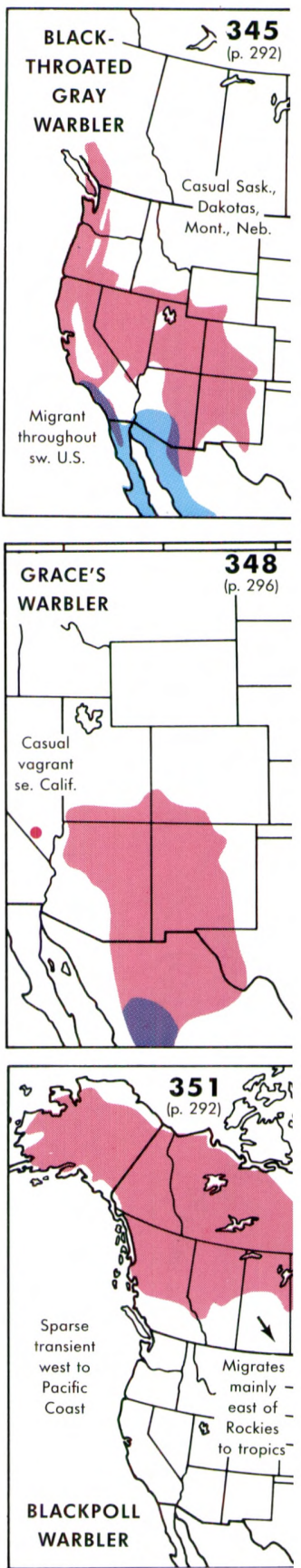

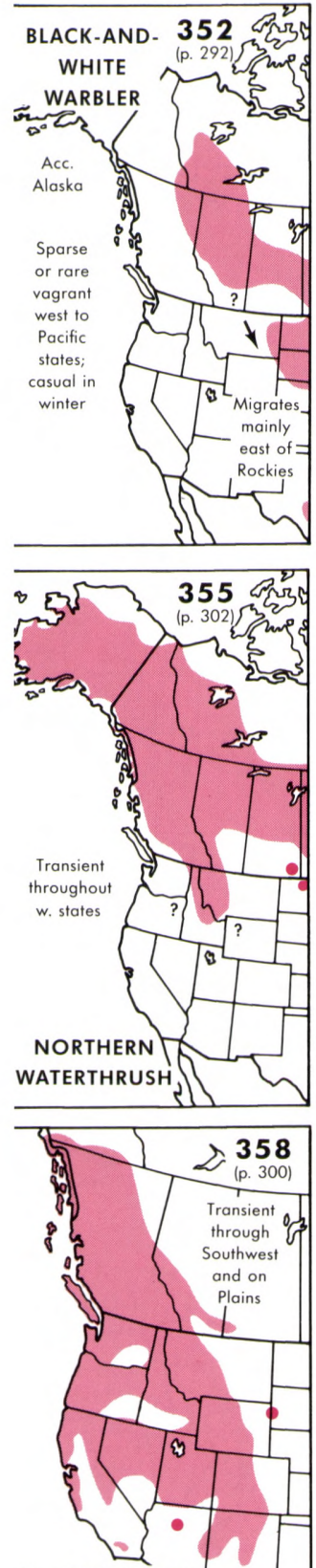

MacGILLIVRAY'S ?

WARBLER
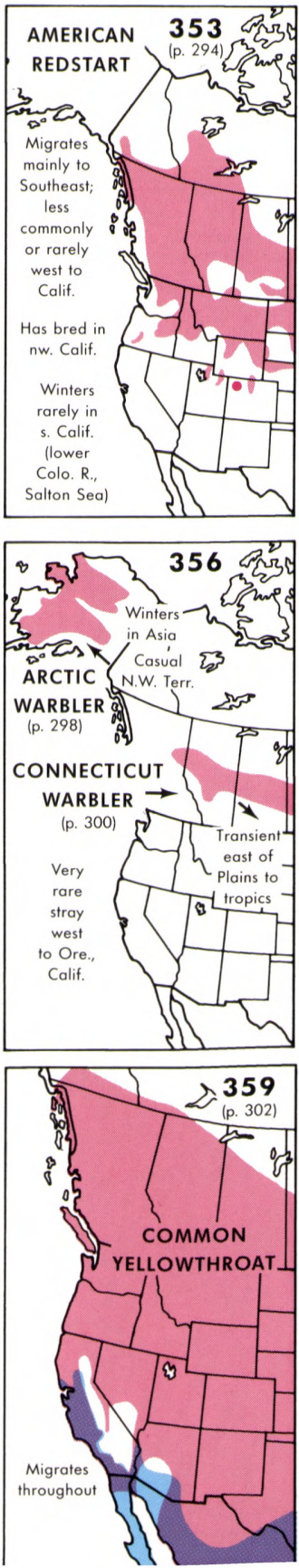
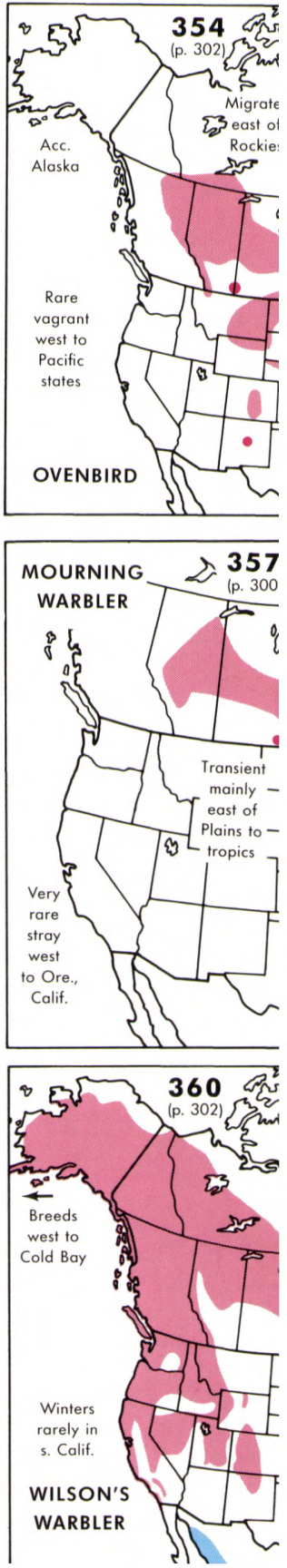

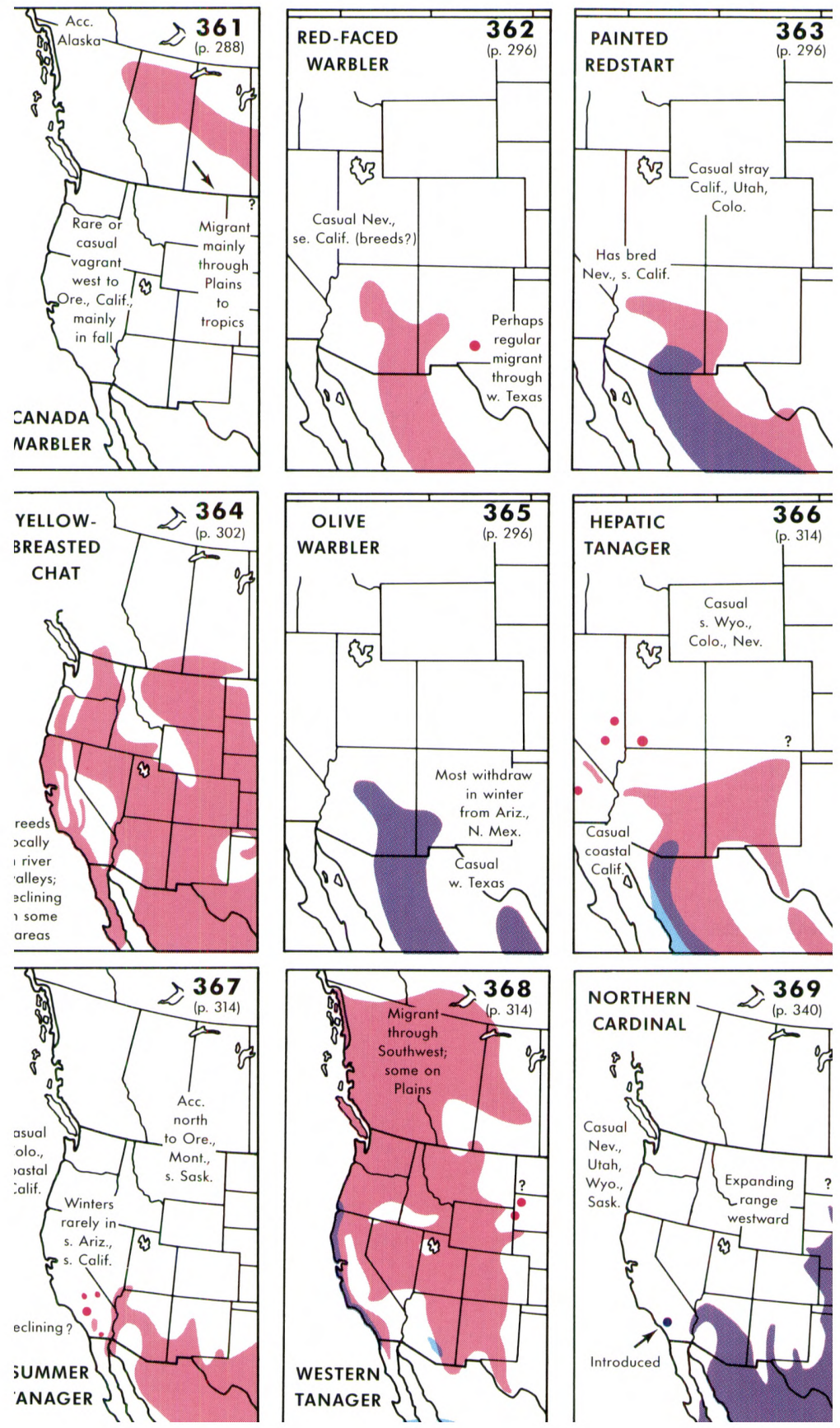

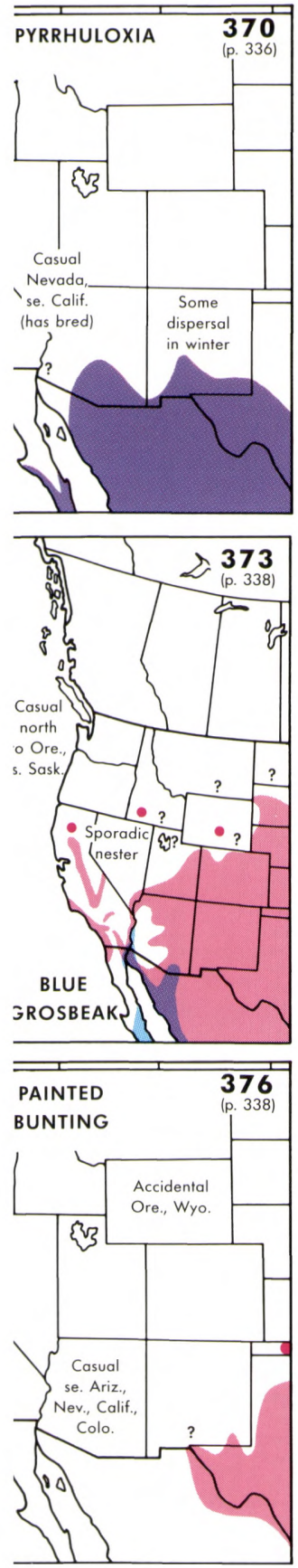
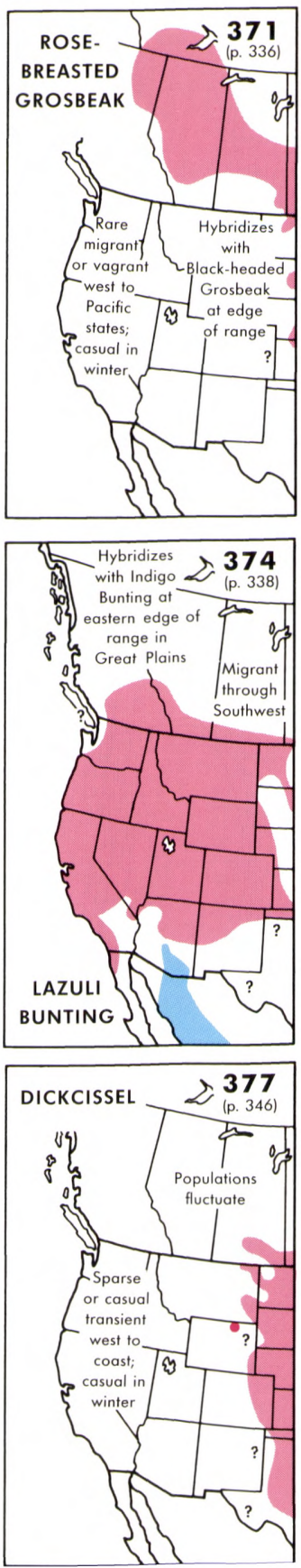
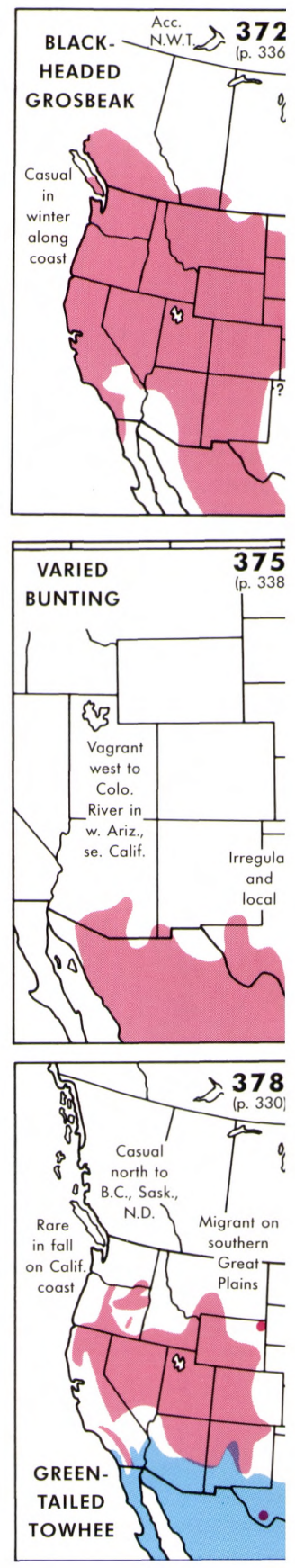

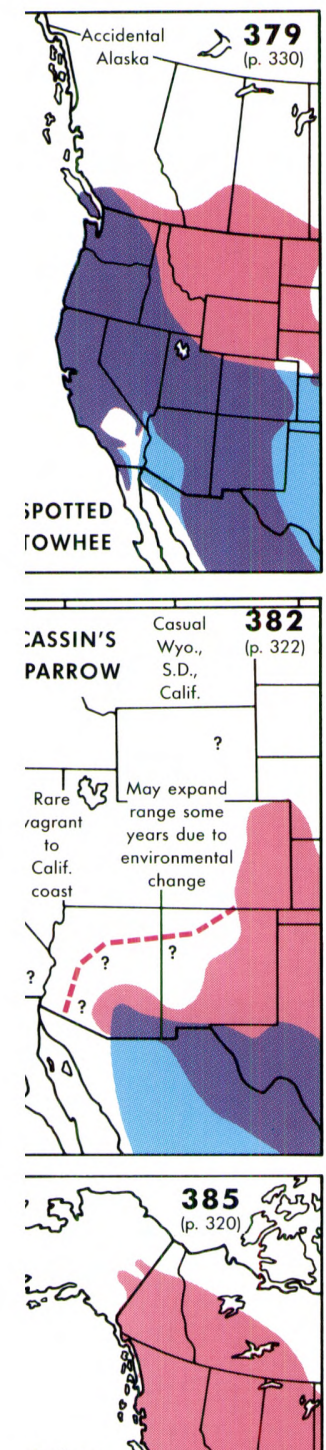

Declining in some areas

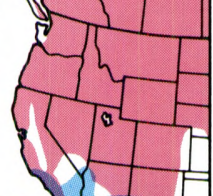

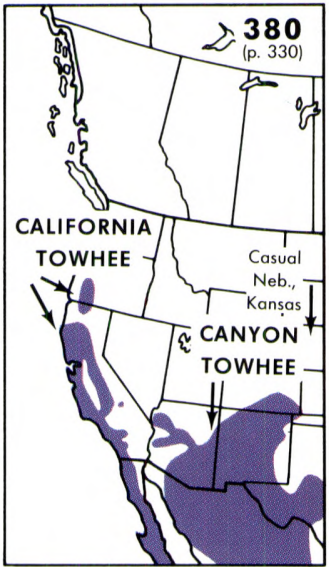
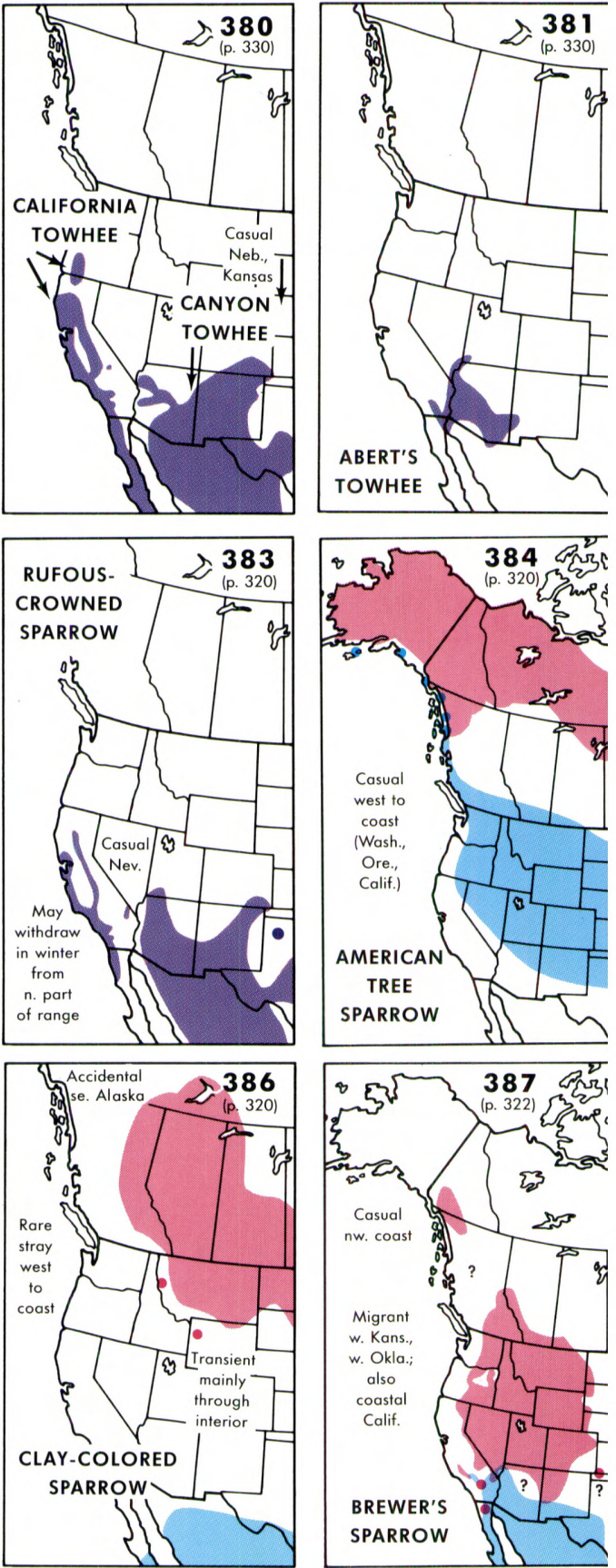

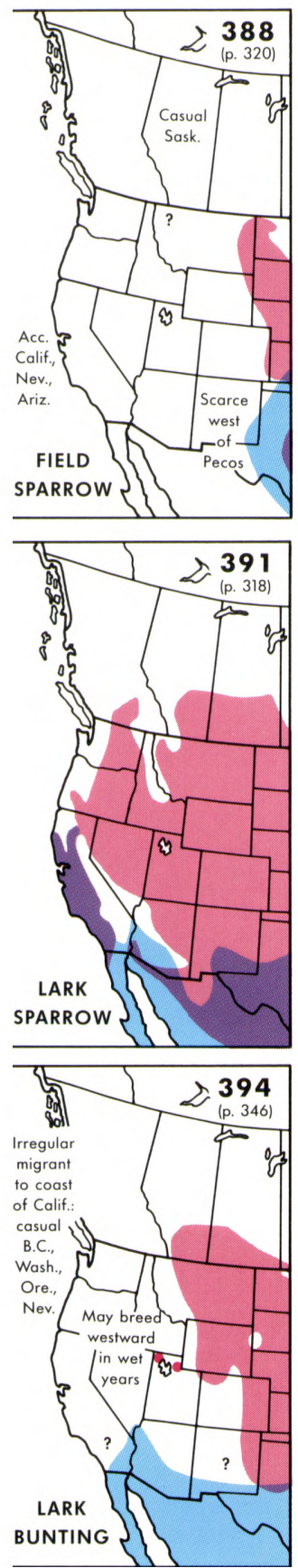
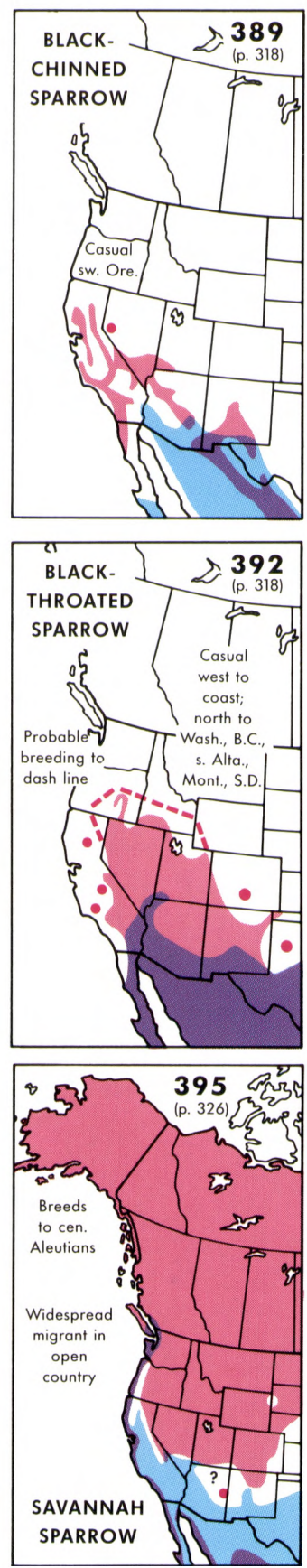
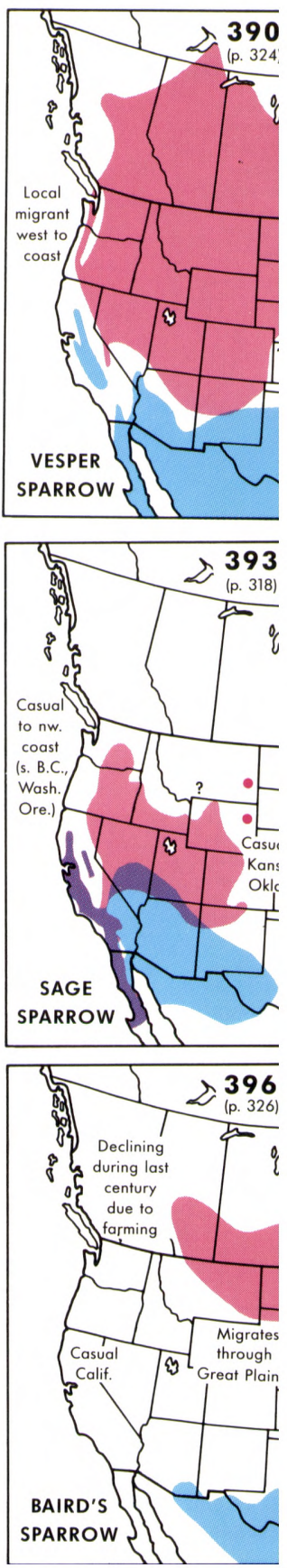

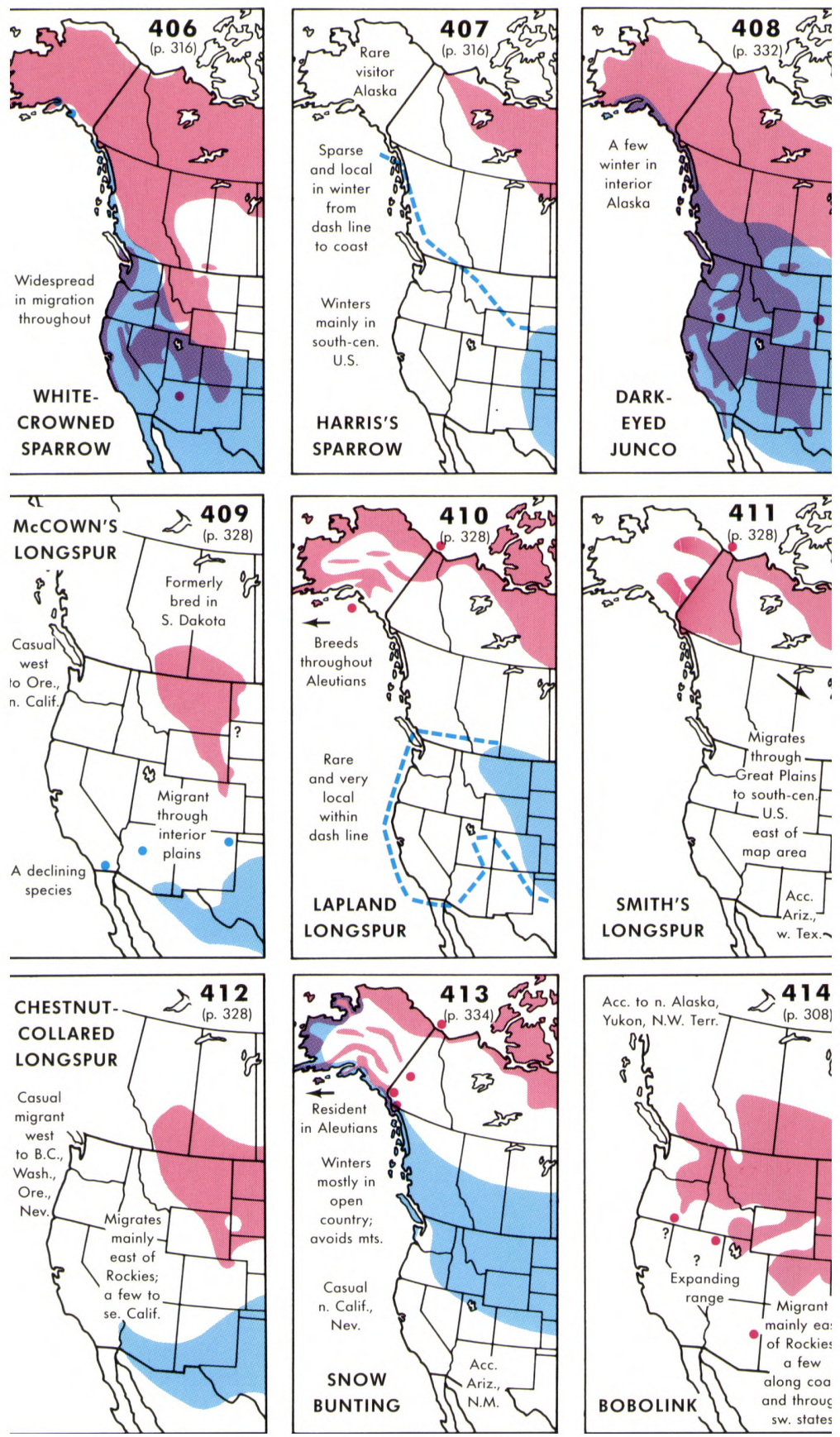

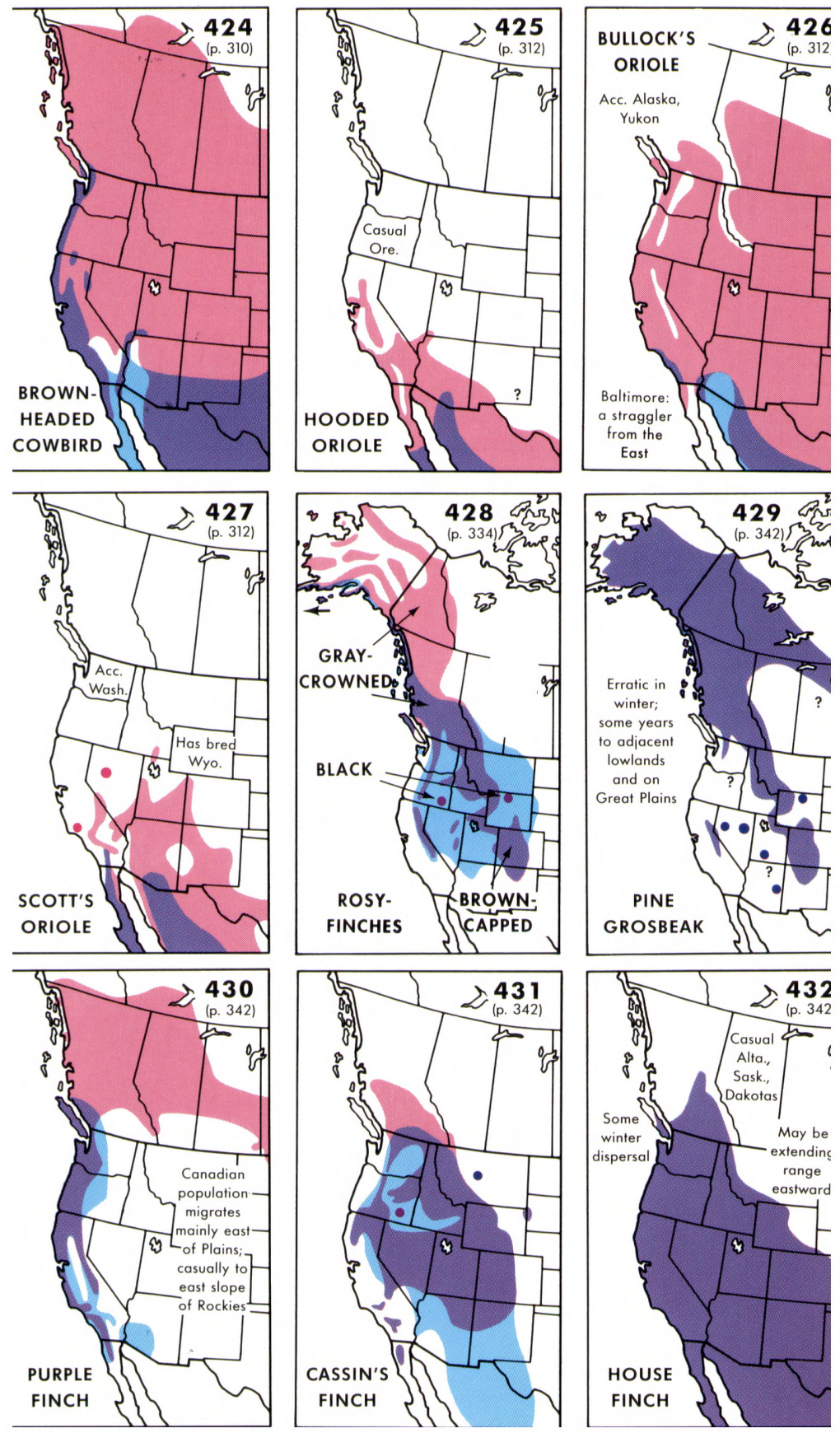

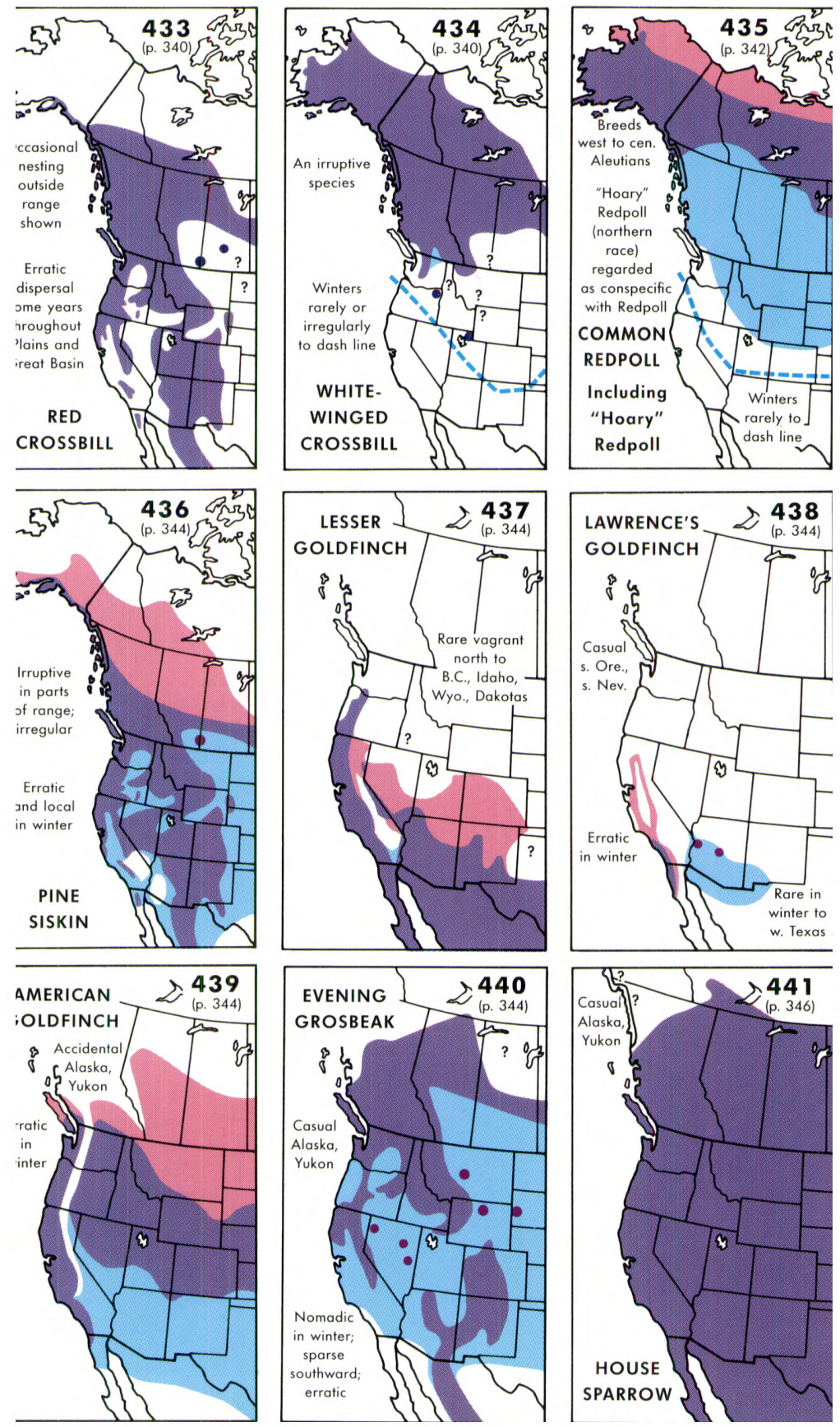


\section{Systematic Checklist}

Keep a "Life List." Check the birds you have seen.

This list covers the western part of the continent east to the 100th meridian on the Great Plains. It includes only those species that are described and illustrated in this Field Guide, but excludes most of those strays from Mexico or Asia that are shown or listed on pp. $348-58$ and the escaped parrots shown on p. 211, as well as a few other accidental vagrants covered elsewhere in the pages of this book. However, space is left at the end of the Checklist for listing any such species that you may observe. Accidentals are defined as those birds that have been recorded less than a dozen times within our area; this is an arbitrary category that could change over the years with increased observation.

For a convenient and complete continental list, the A.B.A. Checklist, prepared by the Checklist Committee of the American Birding Association (P.O. Box 6599, Colorado Springs, Colo. 80934), is recommended. It lists every species recorded north of the Mexican border, East and West, including the accidentals.

In the following list, birds are grouped first under orders (identified by the Latin ending -formes), followed by families (-dae ending), sometimes subfamilies (-nae ending), or tribes (-ni ending), and then species. Scientific names of genera and species are not given here but will be found in the species accounts throughout this book. The vernacular names are those endorsed by the Checklist Committee of the American Birding Association (A.B.A). They are essentially the same as those adopted in the Checklist of the American Ornithologists' Union (A.O.U.). So that there will be no confusion, names used in the previous edition of this Field Guide that differ from those in current usage are included in parentheses. All scientific names are the latest official ones decreed by the A.O.U. Checklist Committee (and accepted by the A.B.A.).

Gaviiformes

LOONS: Gaviidae

RED-THROATED LOON

ARCTIC LOON

PACIFIC LOON

COMMON LOON

YELLOW-BILLED LOON

\section{Podicipediiformes}

GREBES: Podicipedidae PIED-BILLED GREBE

HORNED GREBE
RED-NECKED GREBE

EARED GREBE

WESTERN GREBE

CLARK'S GREBE

Procellariiformes

ALBATROSSES: Diomedeidae SHORT-TAILED ALBATROSS BLACK-FOOTED ALBATROSS LAYSAN ALBATROSS

SHEARWATERS, PETRELS: Procellariidae NORTHERN FULMAR 
MOTTLED PETREL

PINK-FOOTED SHEARWATER FLESH-FOOTED SHEARW. BULLER'S SHEARWATER SOOTY SHEARWATER SHORT-TAILED SHEARW. BLACK-VENTED SHEARW.

STORM-PETRELS: Hydrobatidae WILSON'S STORM-PETREL FORK-T. STORM-PETREL LEACH'S STORM-PETREL ASHY STORM-PETREL BLACK STORM-PETREL LEAST STORM-PETREL

\section{Pelecaniformes}

TROPICBIRDS: Phaethontidae RED-B. TROPICBIRD

BOOBIES: Sulidae

BLUE-FOOTED BOOBY BROWN BOOBY

PELICANS: Pelecanidae AM. WHITE PELICAN BROWN PELICAN

CORMORANTS: Phalacrocoracidae DOUBLE-CR. CORMORANT NEOTROPIC CORMORANT BRANDT'S CORMORANT PELAGIC CORMORANT RED-FACED CORMORANT

FRIGATEBIRDS: Fregatidae MAGNIFICENT FRIGATEBIRD

\section{Ciconiiformes}

HERONS, BITTERNS: Ardeidae AMERICAN BITTERN LEAST BITTERN GREAT BLUE HERON GREAT EGRET LITTLE EGRET SNOWY EGRET LITTLE BLUE HERON TRICOLORED HERON REDDISH EGRET CATTLE EGRET GREEN HERON BLK.-C. NIGHT-HERON Y. - C. NIGHT-HERON

IBISES, etc.: Threskiornithidae WHITE IBIS WHITE-FACED IBIS ROSEATE SPOONBILL

STORKS: Ciconiidae WOOD STORK

\section{Anseriformes}

WATERFOWL: Anatidae WHISTLING DUCKS: Dendrocygnini FULVOUS WHISTLING-DUCK BLACK-BELLIED WH.-DUCK

SWANS: Cygnini TUNDRA SWAN WHOOPER SWAN TRUMPETER SWAN
GEESE: Anserini

BEAN GOOSE

GR. WHITE-FRONTED GOOSE SNOW GOOSE

ROSS'S GOOSE EMPEROR GOOSE BRANT CANADA GOOSE

DUCKS: Anatinae WOOD DUCK GREEN-WINGED TEAL BAIKAL TEAL FALCATED DUCK AMERICAN BLACK DUCK MALLARD

NORTHERN PINTAIL GARGANEY BLUE-WINGED TEAL CINNAMON TEAL NORTHERN SHOVELER GADWALL

EURASIAN WIGEON AMERICAN WIGEON COMMON POCHARD CANVASBACK REDHEAD RING-NECKED DUCK TUFTED DUCK GREATER SCAUP LESSER SCAUP COMMON EIDER KING EIDER SPECTACLED EIDER STELLER'S EIDER HARLEQUIN DUCK OLDSQUAW BLACK SCOTER SURF SCOTER WHITE-WINGED SCOTER COMMON GOLDENEYE BARROW'S GOLDENEYE BUFFLEHEAD SMEW HOODED MERGANSER COMMON MERGANSER RED-BR. MERGANSER RUDDY DUCK

Falconiformes

AM. VULTURES: Cathartidae BLACK VULTURE TURKEY VULTURE

HAWKS, etc.: Accipitridae OSPREY

WHITE-TAILED KITE MISSISSIPPI KITE BALD EAGLE WHITE-TAILED EAGLE NORTHERN HARRIER SHARP-SHINNED HAWK COOPER'S HAWK NORTHERN GOSHAWK COMMON BLACK-HAWK HARRIS'S HAWK 
GRAY HAWK

RED-SHOULDERED HAWK

BROAD-WINGED HAWK

SWAINSON'S HAWK

ZONE-TAILED HAWK

RED-TAILED HAWK

FERRUGINOUS HAWK ROUGH-LEGGED HAWK

GOLDEN EAGLE

CARACARAS, FALCONS: Falconidae CRESTED CARACARA AMERICAN KESTREL MERLIN

PEREGRINE FALCON

GYRFALCON

PRAIRIE FALCON

\section{Galliformes}

FOWL-LIKE BIRDS: Phasianidae GRAY PARTRIDGE

CHUKAR

RING-NECKED PHEASANT

SPRUCE GROUSE

BLUE GROUSE

WILLOW PTARMIGAN

ROCK PTARMIGAN

WH.-TAILED PTARMIGAN

RUFFED GROUSE

SAGE GROUSE

GR. PRAIRIE-CHICKEN

L. PRAIRIE-CHICKEN

SHARP-TAILED GROUSE

WILD TURKEY

MONTEZUMA QUAIL

NORTHERN BOBWHITE

SCALED QUAIL

GAMBEL'S QUAIL

CALIFORNIA QUAIL

MOUNTAIN QUAIL

\section{Gruiformes}

RAILS, etc.: Rallidae

YELLOW RAIL

BLACK RAIL

CLAPPER RAIL

VIRGINIA RAIL

SORA

PURPLE GALLINULE COMMON MOORHEN AMERICAN COOT

CRANES: Gruidae SANDHILL CRANE WHOOPING CRANE

\section{Charadriiformes}

PLOVERS: Charadriidae BLACK-BELLIED PLOVER AM. GOLDEN-PLOVER PACIFIC GOLDEN-PLOVER MONGOLIAN PLOVER SNOWY PLOVER WILSON'S PLOVER SEMIPALMATED PLOVER
PIPING PLOVER

KILLDEER

MOUNTAIN PLOVER

EURASIAN DOTTEREL

OYSTERCATCHERS: Haematopodidae BLACK OYSTERCATCHER

STILTS, AVOCETS: Recurvirostridae BLACK-NECKED STILT

AMERICAN AVOCET

SANDPIPERS, PHALAROPES: Scolopacidae COMMON GREENSHANK GREATER YELLOWLEGS LESSER YELLOWLEGS SPOTTED REDSHANK WOOD SANDPIPER SOLITARY SANDPIPER WILLET WANDERING TATTLER GRAY-TAILED TATTLER COMMON SANDPIPER SPOTTED SANDPIPER TEREK SANDPIPER UPLAND SANDPIPER WHIMBREL

BR.-THIGHED CURLEW FAR EASTERN CURLEW LONG-BILLED CURLEW BLACK-TAILED GODWIT HUDSONIAN GODWIT BAR-TAILED GODWIT MARBLED GODWIT RUDDY TURNSTONE BLACK TURNSTONE SURFBIRD RED KNOT SANDERLING SEMIPALM. SANDPIPER WESTERN SANDPIPER RED-NECKED STINT TEMMINCK'S STINT LONG-TOED STINT LEAST SANDPIPER WHITE-R. SANDPIPER BAIRD'S SANDPIPER PECTORAL SANDPIPER SHARP-TAILED SANDPIPER PURPLE SANDPIPER ROCK SANDPIPER DUNLIN CURLEW SANDPIPER STILT SANDPIPER BUFF-BR. SANDPIPER RUFF SHORT-BILLED DOWITCHER LONG-BILLED DOWITCHER COMMON SNIPE WILSON'S PHALAROPE RED-NECKED PHALAROPE RED PHALAROPE

JAEGERS, SKUAS, GULLS, TERNS,

SKIMMERS: Laridae POMARINE JAEGER PARASITIC JAEGER LONG-TAILED JAEGER 
SOUTH POLAR SKUA

LAUGHING GULL

FRANKLIN'S GULL

LITTLE GULL

BLACK-HEADED GULL

BONAPARTE'S GULL

HEERMANN'S GULL

MEW GULL

RING-BILLED GULL CALIFORNIA GULL

HERRING GULL

THAYER'S GULL

SLATY-BACKED GULL

YELLOW-FOOTED GULL

WESTERN GULL

GLAUCOUS-WINGED GULL

GLAUCOUS GULL

BLACK-L. KITTIWAKE

RED-L. KITTIWAKE

ROSS'S GULL

SABINE'S GULL

IVORY GULL

GULL-BILLED TERN

CASPIAN TERN

ROYAL TERN

ELEGANT TERN

COMMON TERN

ARCTIC TERN

FORSTER'S TERN

LEAST TERN

ALEUTIAN TERN

BLACK TERN

BLACK SKIMMER

AUKS, etc.: Alcidae

COMMON MURRE

THICK-BILLED MURRE

BLACK GUILLEMOT

PIGEON GUILLEMOT

MARBLED MURRELET

KITTLITZ'S MURRELET

XANTUS'S MURRELET

CRAVERI'S MURRELET

ANCIENT MURRELET

CASSIN'S AUKLET

PARAKEET AUKLET

LEAST AUKLET

WHISKERED AUKLET

CRESTED AUKLET

RHINOCEROS AUKLET

TUFTED PUFFIN

HORNED PUFFIN

\section{Columbiformes}

PIGEONS, DOVES: Columbidae ROCK DOVE

BAND-TAILED PIGEON RINGED TURTLE-DOVE SPOTTED DOVE

WHITE-WINGED DOVE MOURNING DOVE

INCA DOVE

COMMON GROUND-DOVE
Cuculiformes

CUCKOOS, ROADRUNNERS, ANIS: Cuculidae

COMMON CUCKOO

BLACK-BILLED CUCKOO

YELLOW-BILLED CUCKOO

GREATER ROADRUNNER

GROOVE-BILLED ANI

\section{Strigiformes}

BARN OWLS: Tytonidae

BARN OWL

TYPICAL OWLS: Strigidae FLAMMULATED OWL EASTERN SCREECH-OWL WESTERN SCREECH-OWL WHISKERED SCREECH-OWL GREAT HORNED OWL SNOWY OWL NORTHERN HAWK OWL NORTHERN PYGMY-OWL FERRUGINOUS PYGMY-OWL ELF OWL

BURROWING OWL SPOTTED OWL BARRED OWL GREAT GRAY OWL LONG-EARED OWL SHORT-EARED OWL BOREAL OWL

N. SAW-WHET OWL

Caprimulgiformes

GOATSUCKERS: Caprimulgidae LESSER NIGHTHAWK COMMON NIGHTHAWK COMMON POORWILL BUFF-COLLARED NIGHTJAR WHIP-POOR-WILL

\section{Apodiformes}

SWIFTS: Apodidae BLACK SWIFT CHIMNEY SWIFT VAUX'S SWIFT WHITE-THROATED SWIFT

HUMMINGBIRDS: Trochilidae BROAD-BILLED HUMMINGBIRD WHITE-EARED HUMMINGBIRD BERYLLINE HUMMINGBIRD VIOLET-CR. HUMMINGBIRD BLUE-THR. HUMMINGBIRD MAGNIFICENT HUMMINGBIRD LUCIFER HUMMINGBIRD RUBY-THROATED HUMMINGBIRD

BLK.-CHINNED HUMMINGBIRD ANNA'S HUMMINGBIRD COSTA'S HUMMINGBIRD CALLIOPE HUMMINGBIRD BROAD-TAILED HUMMINGBIRD

RUFOUS HUMMINGBIRD ALLEN'S HUMMINGBIRD 
Trogoniformes

TROGONS: Trogonidae

ELEGANT TROGON

\section{Coraciiformes}

KINGFISHERS: Alcedinidae BELTED KINGFISHER GREEN KINGFISHER

WOODPECKERS: Picidae

LEWIS'S WOODPECKER

RED-HEADED WOODPECKER ACORN WOODPECKER GILA WOODPECKER GOLDEN-FR. WOODPECKER RED-B. WOODPECKER YELLOW-B. SAPSUCKER RED-NAPED SAPSUCKER RED-BR. SAPSUCKER WILLIAMSON'S SAPSUCKER LADDER-BACKED WOODP NUTTALL'S WOODPECKER DOWNY WOODPECKER HAIRY WOODPECKER STRICKLAND'S WOODP. WHITE-HEADED WOODP. THREE-TOED WOODPECKER BLACK-BACKED WOODP. NORTHERN FLICKER PILEATED WOODPECKER

\section{Passeriformes}

FLYCATCHERS: Tyrannidae NORTHERN BEARDLESSTYRANNULET OLIVE-SIDED FLYCATCHER GREATER PEWEE WESTERN WOOD-PEWEE EASTERN WOOD-PEWEE YELLOW-BELLIED FLYC. ALDER FLYCATCHER WILLOW FLYCATCHER LEAST FLYCATCHER HAMMOND'S FLYCATCHER DUSKY FLYCATCHER GRAY FLYCATCHER PACIFIC-SLOPE FLYC. CORDILLERAN FLYC. BUFF-BREASTED FLYC. BLACK PHOEBE EASTERN PHOEBE VERMILION FLYCATCHER DUSKY-CAPPED FLYC. ASH-THROATED FLYC. GREAT CRESTED FLYC. BROWN-CRESTED FLYC. SULPHUR-BELLIED FLYC. TROPICAL KINGBIRD CASSIN'S KINGBIRD THICK-BILLED KINGBIRD WESTERN KINGBIRD EASTERN KINGBIRD SCISSOR-TAILED FLYCATCHER ROSE-THROATED BECARD
LARKS: Alaudidae SKYLARK HORNED LARK

SWALLOWS: Hirundinidae PURPLE MARTIN TREE SWALLOW VIOLET-GREEN SWALLOW N. ROUGH-WINGED SWALLOW BANK SWALLOW CLIFF SWALLOW CAVE SWALLOW BARN SWALLOW

JAYS, MAGPIES, CROWS: Corvidae GRAY JAY

STELLER'S JAY

BLUE JAY

WESTERN SCRUB-JAY MEXICAN JAY PINYON JAY CLARK'S NUTCRACKER BLACK-BILLED MAGPIE YELLOW-BILLED MAGPIE AMERICAN CROW NORTHWESTERN CROW CHIHUAHUAN RAVEN COMMON RAVEN

CHICKADEES, TITMICE: Paridae BLACK-CAPPED CHICKADEE MEXICAN CHICKADEE MOUNTAIN CHICKADEE GRAY-H. CHICKADEE BOREAL CHICKADEE CHESTNUT-B. CHICKADEE BRIDLED TITMOUSE OAK TITMOUSE TUFTED TITMOUSE

VERDIN: Remizidae VERDIN

BUSHTIT: Aegithalidae BUSHTIT

NUTHATCHES: Sittidae RED-BR. NUTHATCH WHITE-BR. NUTHATCH PYGMY NUTHATCH

CREEPERS: Certhiidae BROWN CREEPER

WRENS: Troglodytidae CACTUS WREN ROCK WREN CANYON WREN CAROLINA WREN BEWICK'S WREN HOUSE WREN WINTER WREN SEDGE WREN MARSH WREN

DIPPERS: Cinclidae AMERICAN DIPPER

KINGLETS: Regulidae GOLDEN-CR. KINGLET RUBY-CROWNED KINGLET

GNATCATCHERS: Sylviidae ARCTIC WARBLER CALIFORNIA GNATCATCHER 
BLUE-GR. GNATCATCHER BL.-TAILED GNATCATCHER BL.-CAPPED GNATCATCHER GRAY-SPOTTED FLYC.

THRUSHES: Turdidae SIBERIAN RUBYTHROAT BLUETHROAT NORTHERN WHEATEAR EASTERN BLUEBIRD WESTERN BLUEBIRD MOUNTAIN BLUEBIRD TOWNSEND'S SOLITAIRE VEERY

GRAY-CHEEKED THRUSH SWAINSON'S THRUSH HERMIT THRUSH EYEBROWED THRUSH DUSKY THRUSH RUFOUS-BACKED ROBIN AMERICAN ROBIN VARIED THRUSH

WRENTITS: Timaliidae WRENTIT

MIMIC THRUSHES: Mimidae GRAY CATBIRD N. MOCKINGBIRD SAGE THRASHER BROWN THRASHER BENDIRE'S THRASHER CURVE-BILLED THRASHER CALIFORNIA THRASHER CRISSAL THRASHER Le CONTE'S THRASHER

WAGTAILS, PIPITS: Motacillidae YELLOW WAGTAIL WHITE WAGTAIL BLACK-BACKED WAGTAIL OLIVE-BACKED PIPIT RED-THROATED PIPIT AMERICAN PIPIT SPRAGUE'S PIPIT

WAXWINGS: Bombycillidae BOHEMIAN WAXWING CEDAR WAXWING

SILKY-FLYCATCHERS: Ptilogonatidae PHAINOPEPLA

SHRIKES: Laniidae NORTHERN SHRIKE LOGGERHEAD SHRIKE

STARLINGS: Sturnidae EUROPEAN STARLING CRESTED MYNA

VIREOS: Vireonidae WHITE-EYED VIREO BELL'S VIREO BLACK-CAPPED VIREO GRAY VIREO BLUE-HEADED VIREO YELLOW-THR. VIREO HUTTON'S VIREO WARBLING VIREO PHILADELPHIA VIREO RED-EYED VIREO YELLOW-GREEN VIREO
WOOD WARBLERS: Parulidae GOLDEN-WINGED WARBLER TENNESSEE WARBLER

ORANGE-CR. WARBLER NASHVILLE WARBLER VIRGINIA'S WARBLER COLIMA WARBLER LUCY'S WARBLER NORTHERN PARULA YELLOW WARBLER CHESTNUT-SIDED WARBLER MAGNOLIA WARBLER CAPE MAY WARBLER BLK.-THR. BLUE WARBLER YELLOW-RUMPED WARBLER BLK.-THR. GRAY WARBLER TOWNSEND'S WARBLER HERMIT WARBLER BLK.-THR. GREEN WARBLER GOLDEN-CHEEKED WARBLER BLACKBURNIAN WARBLER YELLOW-THR. WARBLER GRACE'S WARBLER PRAIRIE WARBLER PALM WARBLER BAY-BREASTED WARBLER BLACKPOLL WARBLER CERULEAN WARBLER BLACK-AND-WHITE WARBLER AMERICAN REDSTART PROTHONOTARY WARBLER WORM-EATING WARBLER OVENBIRD NORTHERN WATERTHRUSH KENTUCKY WARBLER CONNECTICUT WARBLER MOURNING WARBLER MacGILLIVRAY'S WARBLER COMMON YELLOWTHROAT HOODED WARBLER WILSON'S WARBLER CANADA WARBLER RED-FACED WARBLER PAINTED REDSTART YELLOW-BREASTED CHAT

OLIVE WARBLER: Peucodramidae OLIVE WARBLER

TANAGERS: Thraupidae HEPATIC TANAGER SUMMER TANAGER SCARLET TANAGER WESTERN TANAGER

GROSBEAKS, BUNTINGS, etc.: Cardinalidae NORTHERN CARDINAL PYRRHULOXIA ROSE-BR. GROSBEAK BLACK-HEADED GROSBEAK BLUE GROSBEAK LAZULI BUNTING INDIGO BUNTING VARIED BUNTING PAINTED BUNTING DICKCISSEL 
TOWHEES, SPARROWS, etc.: Emberizidae GREEN-TAILED TOWHEE SPOTTED TOWHEE CALIFORNIA TOWHEE CANYON TOWHEE ABERT'S TOWHEE BOTTERI'S SPARROW CASSIN'S SPARROW RUFOUS-WING. SPARROW RUFOUS-CROWN. SPARROW AMERICAN TREE SPARROW CHIPPING SPARROW CLAY-COLORED SPARROW BREWER'S SPARROW FIELD SPARROW BLACK-CHINNED SPARROW VESPER SPARROW LARK SPARROW BLACK-THR. SPARROW SAGE SPARROW FIVE-STRIPED SPARROW LARK BUNTING SAVANNAH SPARROW BAIRD'S SPARROW GRASSHOPPER SPARROW LE CONTE'S SPARROW NELSON'S SHARP-TAILED SPARROW FOX SPARROW SONG SPARROW LINCOLN'S SPARROW SWAMP SPARROW WHITE-THR. SPARROW GOLDEN-CR. SPARROW WHITE-CR. SPARROW HARRIS'S SPARROW DARK-EYED JUNCO YELLOW-EYED JUNCO McCOWN'S LONGSPUR LAPLAND LONGSPUR SMITH'S LONGSPUR CHESTNUT-C. LONGSPUR
RUSTIC BUNTING SNOW BUNTING

McKAY'S BUNTING

BLACKBIRDS, ORIOLES, etc.: Icteridae BOBOLINK

RED-WINGED BLACKBIRD EASTERN MEADOWLARK WESTERN MEADOWLARK YELLOW-H. BLACKBIRD RUSTY BLACKBIRD BREWER'S BLACKBIRD GREAT-TAILED GRACKLE COMMON GRACKLE BRONZED COWBIRD BROWN-HEADED COWBIRD ORCHARD ORIOLE HOODED ORIOLE STREAK-BACKED ORIOLE BALTIMORE ORIOLE BULLOCK'S ORIOLE SCOTT'S ORIOLE

FINCHES: Fringillidae BRAMBLING GRAY-CROWNED ROSY-FINCH BLACK ROSY-FINCH BROWN-CAPPED ROSY-FINCH PINE GROSBEAK COMMON ROSEFINCH PURPLE FINCH CASSIN'S FINCH HOUSE FINCH RED CROSSBILL WHITE-W. CROSSBILL COMMON REDPOLL PINE SISKIN LESSER GOLDFINCH LAWRENCE'S GOLDFINCH AMERICAN GOLDFINCH EVENING GROSBEAK

OLD WORLD SPARROWS: Passeridae HOUSE SPARROW

ACCIDENTALS, STRAYS, AND OTHERS 


\section{Key Sources for Further Reference}

The Field Guides (listed on p. 1) have a basic function - to make it easier to name things. They stress field marks, the "trademarks of nature," by which one species can be known from another. Obviously you own this Field Guide and probably its eastern counterpart. Two excellent guides covering all of North AmericaEast and West - in single, pocket-sized books, are the Birds of North America (Golden Press) by Robbins, Singer, Bruun, and Zim, and the National Geographic Society's Birds of North America. Both are illustrated with well-executed artwork. The several Audubon Society bird guides are lavishly illustrated with fine photographs and some drawings. Especially recommended is the threevolume Master Guide to Birding (Knopf) by John Farrand, et al. You will also profit from The Western Bird Watcher by Kevin Zimmer, and Paul Johnsgaard's several books on bird families. A well-written book that helps mid-level or advanced birders put their act together is The Complete Birder (HMCo.) by Jack Connor, and for the serious birder who is challenged by difficult identification problems, the ultimate authority is A Field Guide to Advanced Birding (HMCo.) by Kenn Kaufmann. Should you want more than names, the Stokes' nature guides to Bird Behavior are the next step.

Books on attracting birds are many and so are "where to go" Baedeckers, but what else might you add to your basic bird library? I cannot list all state or regional works here. No single book can give all the answers, although the massive Encyclopedia of North American Birds (Knopf) by John Terres goes a long way. Another good encyclopedic handbook is The Birdwatcher's Companion (Hill and Wang) by Christopher Leahy. The Audubon Society's Handbook for Birders (Scribner's) by Stephen Kress is a good general guide to observing birds. The standard species-by-species reference is the Handbook of North American Birds (Yale University Press) by Ralph Palmer. This covers the innumerable details in several volumes. Canadians will also want The Birds of Canada by Earl Godfrey. However, the ideal supplement to your favorite field guide is The Birder's Handbook (Simon and Schuster) by Ehrlich, Dobkin, and Wheye. It is a mine of information that is beautifully boiled down, but, handy as it is, it still won't quite fit the pocket.

In addition to the academic ornithological journals, the Auk, Condor, and Wilson Bulletin, and the more popular magazines such as Bird Watcher's Digest, Birder's World, The Living Bird, and Wildbird, there are literally hundreds of journals, newsletters, and checklists published by regional or local bird clubs, but every serious birder should subscribe to American Birds, published by the National Audubon Society, 950 Third Avenue, New York, N.Y. 10022. Bimonthly, it monitors migration, breeding, population trends, and accidentals for every section of North America. Susan Drennan, the editor, has prepared a selection of the best state and regional books in a Special Book Supplement. Birders who wish to keep up-to-date on the sporting or competitive aspects of their hobby might also subscribe to Birding (American Birding Association, P.O. Box 6599, Colorado Springs, Colo. 80934). 


\section{Index}

Accentor, Siberian, 354

Accipiter cooperii, 172, 196, M73 gentilis, 172, 196, M74 striatus, 172, 196, M72

Accipitridae, 168

Acridotheres cristatellus, 280

Actitis hypoleucos, 154 macularia, 140, M127

Aechmophorus clarkii, 26 occidentalis, 26, M9

Aegithalidae, 260

Aegolius acadicus, 202, M207 funereus, 202, M200

Aeronautes saxatalis, 246, M214

Aethia cristatella, 34

psittacula, 34

pusilla, 36

pygmaea, 34

Agelaius phoeniceus, 308, M415 tricolor, 308, M416

Aimophila botterii, 322

carpalis, 322

cassinii, 322, M382

quinquestriata, 318

ruficeps, 320, M383

Aix sponsa, 46, 66, M36

Ajaia ajaja, 112, 114

Alauda arvensis, 242

Alaudidae, 242

Albatross(es), 74

Black-footed, 74

Laysan, 74

Short-tailed, 74

Shy, 74

Wandering, 74

Alcedinidae, 206

Alcidae, 32

Alcids. See Auks, 32.

Alectoris chukar, 164, M88 rufa, 164

Alle alle, 36

Amazilia beryllina, 220 violiceps, 220

Amazona finschi, 212 ochrocephala, 212 viridigenalis, 210

Ammodramus bairdii, 326, M396 leconteii, 326, M398

nelsoni, 326, M399 savannarum, 322, M397

Amphispiza belli, 318, M393

bilineata, 318, M392

Anas acuta, 46, 66, M39

americana, 46, 66, M44

clypeata, 48, 66, M42

crecca, 48, 66, M37

cyanoptera, 48, M41

discors, 48, 66, M40

falcata, 48,62

formosa, 48, 62

penelope, 46

platyrhynchos, 44, 68, M38

poecilorhyncha, 62

querquedula, 48, 62

rubripes, 44, 68

strepera, 44, 66, M43

Anatidae, 38-72

Ani, Groove-billed, 212

Anser anser, 358

albifrons, 40, 42, M30

fabalis, 40, 62

Anthus cervinus, 244

gustavi, 244

hodgsoni, 244

rubescens, 244, M320

spragueii, 244, M321

trivialis, 244

Aphelocoma californica, 254, M269 ultramarina, 254, M270

Aphriza virgata, 142, M135

Apodidae, 246

Apus apus, 246

pacificus, 246

Aquila chrysaetos, 180, M81

Arating a canicularis, 212

Archilochus alexandri, 220, M216 colubris, 216, M215

Ardea alba, 112 herodias, 110, M21

Ardeidae, 110

Arenaria interpres, 142, M133 melanocephala, 142, M134

Asio flammeus, 200, M206 otus, 200, M205

Asturina nitida, 178, 194

Athene cunicularia, 202, M201

Atthis heloisa, 220

Auklet(s), Cassin's, 36, M181 
Auklet(s), cont.

Crested, 34

Least, 36

Parakeet, 34

Rhinoceros, 32, M182

Whiskered, 34

Auks, 32

Auriparus flaviceps, 260, M283

Avocet(s), 120

American, 120, M121

Aythya affinis, 56, 72, M49

americana, 56, 72, M46

collaris, 56, 72, M47

ferina, 62

fuligula, 56, 62

marila, 56, 72, M48

valisineria, 56, 72, M45

Baeolophur bicolor, 260, M282

inornatus, 260, M282

wollweberi, 260

Barn Owls, 198

Bartramia longicauda, 144, M128

Basileuterus rufifrons, 350

Beardless-Tyrannulet, Northern, 238

Becard, Rose-throated, 230

Bittern(s), American, 114, M19

Least, 114, M20

Yellow, 358

Blackbird(s), 306

Brewer's, 306, M421

Red-winged, 308, M415

Rusty, 306, M420

Tricolored, 308, M416

Yellow-headed, 308, M419

Bluebird(s), Eastern 278, M301

Mountain, 278, M303

Western, 278, M302

Bluetail, Red-flanked, 354

Bluethroat, 278

Bobolink, 308, 346, M414

Bobwhite, "Masked." See Northern, 166.

Northern, 166, M101

Bombycilla cedrorum, 282, M323 garrulus, 282, M322

Bombycillidae, 282

Bonasa umbellus, 160, M95

Booby(ies), 82

Blue-footed, 82

Brown, 82

Masked, 82

Red-footed, 82

Botaurus lentiginosus, 114, M19

Brachyramphus brevirostris, 36 marmoratus, 36, M179

Brambling, 356

Brant, 40, 42, M34

Black. See Brant, 40, 42.
Branta bernicla, 40, 42, M34

canadensis, 40, 42, M35

Brotogeris versicolurus, 210

Bubo virginianus, 200, M196

Bubulcus ibis, 112, M24

Bucephala albeola, 58, 72, M61

clangula, 58, 72, M59

islandica, 58, M60

Bufflehead, 58, 72, M61

Bullfinch, Eurasian, 356

Bunting(s), 338, 356

Gray, 356

Indigo, 338

Lark, 346, M394

Lazuli, 338, M374

Little, 356

McKay's, 334

Painted, 338, M376

Pallas's, 356

Reed, 356

Rustic, 356

Snow, 334, M413

Varied, 338, M375

Yellow-breasted, 356

Bushtit, 260, M284

Black-eared. See Bushtit, 260.

Buteo albicaudatus, 178, 194

albonotatus, 178, 190

jamaicensis, 174, 190, 192, M78

lagopus, 176, 190, 192, M80

lineatus, 176, 192, M75

platypterus, 176, 192, M76

regalis, 176, 190, 194, M79

swainsoni, 174, 190, 192, M77

Buteogallus anthracinus, 178, 190

Butorides virescens, 110

Calamospiza melanocorys, 346, M394

Calcarius lapponicus, 328, M410

mccownii, 328, M409

ornatus, 328 , M412

pictus, 328, M411

Calidris acuminata, 146

alba, 140, M137

alpina, 140, M145

bairdii, 146, M142

canutus, 138, M136

ferruginea, 154

fuscicollis, 146, M141

himantopus, 134, 144, M146

mauri, 148, M139

melanotos, 146, M143

minuta, 150

minutilla, 148, M140

ptilocnemis, 142, M144

pusilla, 148, M138

ruficollis, 150

subminuta, 150 
temminckii, 150

tenuirostris, 154

Callipepla californica, 166, M104 gambelli, 166, M103 squamata, 166, M102

Calonectris leucomelas, 78

Calothorax lucifer, 220

Calypte anna, 216, M217 costae, 220, M218

Campephilus imperialis, 350

Camptostoma imberbe, 240

Campylorhynchus brunneicapillus, 266, M289

Canvasback, 56, 72, M45

Caprimulgidae, 214

Caprimulgus indicus, 358 ridgwayi, 214 vociferus, 214

Caracara, Crested, 184, 190

Caracara plancus, 184, 190

Cardellina rubrifrons, 296, M362

Cardinal, Northern, 340, M369

Cardinalidae, 336-40

Cardinalinae. See Grosbeaks, Buntings, 336-340, 356.

Cardinalis cardinalis, 340, M369 sinuatus, 336, M370

Carduelis flammea, 342, M435 hornemanni, 342

lawrencei, 344, M438

pinus, 344, M436

psaltria, 344, M437

sinica, 356

tristis, 344, M439

Carpodacus cassinii, 342, M431

erythrinus, 356

mexicanus, 342, M432

purpureus, 342, M430

Catbird, Gray, 270, M312

Catharacta maccormicki, 86

Cathartes aura, 182, M66

Cathartidae, 182

Catharus fuscescens, 276, M305 guttatus, 276, M308 minimus, 276, M306 ustulatus, 276, M307

Catherpes mexicanus, 266, M291

Catoptrophorus semipalmatus, 132, 134, M125

Cepphus columba, 34, M178 grylle, 34, M178

Centrocercus urophasianus, 158, M96

Cerorhinca monocerata, 32, M182

Certhia americana, 262, M288

Certhiidae, 262

Ceryle alcyon, 206, M223

Chaetura pelagica, 246, M213 vauxi, 246, M213

Chamaea fasciata, 266, M311
Charadriidae, 122

Charadrius alexandrinus, 124, M115

dubius, 124

hiaticula, 124

melodus, 124, M115

mongolus, 126

montanus, 126, M118

morinellus, 126

semipalmatus, 124, M116

vociferus, 126, M117

wilsonia, 124

Chat, Yellow-breasted, 302, M364

Chen caerulescens, 38, 40, 42, M31

canagica, 40, 42, M33

rossii, 38, 42, M32

Chickadee(s), 258

Black-capped, 258, M278

Boreal, 258, M280

Chestnut-backed, 258, M281

Gray-headed, 258

Mexican, 258, M280

Mountain, 258, M279

Chlidonias leucopterus, 108 niger, 108, M175

Chloroceryle americana, 206

Chondestes grammacus, 318, M391

Chordeiles acutipennis, 214, M208 minor, 214, M209

Chukar, 164, M88

Ciccaba virgata, 350

Ciconiidae, 116

Cinclidae, 266

Cinclus mexicanus, 266, M296

Circus cyaneus, 170, 194, M71

Cistothorus palustris, 264, M295 platensis, 264

Clangula hyemalis, 54, 70, M55

Coccothraustes coccothraustes, 356 vespertinus, 344, M440

Coccyzus americanus, 212, M191 erythropthalmus, 212, M190

Colaptes auratus, 226, M237

Colinus virginianus, 166, M101

Columba fasciata, 208, M185

flavirostris, 208

livia, 210

Columbidae, 208

Columbina inca, 208, M188 passserina, 208, M189 talpacoti, 348

Common Redpoll, 342, M435

Condor, California, 182

Contopus cooperi, 236, M239 pertinax, 236 sordidulus, 236, M240 virens, 236

Coot(s), American, 64, 118, M111 Eurasian, 62, 358

Coragyps atratus, 182 
Cormorant(s), 28, 30

Brandt's, 28, 30, M17

Double-crested, 28, 30, M16

Neotropic, 28

Pelagic, 28, 30, M18

Red-faced, 28

Corvidae, 252

Corvus brachyrhynchos, 252, M274

caurinus, 252, M275

corax, 252, M277

cryptoleucus, 252, M276

Coturnicops noveboracensis, 118, M105

Cowbird(s), Bronzed, 310

Brown-headed, 310, 346, M424

Crane(s), 116

Common, 116

Sandhill, 116, M112

Whooping, 116

Creeper(s), 262

Brown, 262, M288

Crossbill(s), Red, 340, M433

White-winged, 340, M434

Crotophaga sulcirostris, 212

Crow(s), 252

American, 252, M274

Northwestern, 252, M275

Cuckoo(s), 352

Black-billed, 212, M190

Common, 352

Oriental, 352

Yellow-billed, 212, M191

Cuculidae. See Cuculus, 352.

Cuculus canorus, 352 saturatus, 352

Curlew(s), Bristle-thighed, 132, 152

Eskimo, 130, 152

Far Eastern, 152

Little, 152

Long-billed, 130, 132, M130

Cyanocitta cristata, 254, M268 stelleri, 254, M267

Cygnus buccinator, 38, M29 columbianus, 38, 42, M28

cygnus, 38

olor, 38

Cyanthus latirostris, 218

Cypseloides niger, 246, M212

Cyrtonyx montezumae, 166, M100

Delichon urbica, 352

Dendragapus obscurus, 164, M91

Dendrocygna autumnalis, 42, 68 bicolor, 42, 68

Dendroica caerulescens, 292

castanea, 294, M350

cerulea, 292

chrysoparia, 290

coronata, 288, M344 discolor, 304

dominica, 304

fusca, 294

graciae, 296, M348

magnolia, 288, M342

nigrescens, 292, M345

occidentalis, 290, M347

palmarum, 300, M349

pensylvanica, 294, M341

petechia, 298, M340

pinus, 304

striata, 292, M351

tigrina, 294, M343

townsendi, 290, M346

virens, 290, M347

Dickcissel, 346, M377

Diomedea exulans, 74

Diomedeidae, 74

Dipper(s), 266

American, 266, M296

Dolichonyx oryzivorus, 308, 346, M414

Dotterel, Eurasian, 126

Dove(s), 208

Common Ground-, 208, M189

Inca, 208, M188

Mourning, 208, M187

Oriental Turtle-, 352

Ringed Turtle-, 210

Rock, 210

Ruddy Ground-, 348

Spotted, 210

White-tipped, 208

White-winged, 208, M186

Dovekie, 36

Dowitcher(s), Long-billed, 138, M149

Short-billed, 138, M148

Dryocopus pileatus, 222, M238

Duck(s), 44-72

American Black, 44, 68

Black-bellied Tree-. See WhistlingDuck, Black-bellied, 42.

Falcated, 48, 62

Fulvous Tree-. See Whistling-Duck, Fulvous, 42, 68.

Harlequin, 54, 70, M54

"Mexican." See Mallard, 44.

Ring-necked, 56, 72, M47

Ruddy, 58, 72, M65

Spot-billed, 62

Tufted, 56, 62

Wood, 46, 66, M36

Dumetella carolinensis, 270, M312

Dunlin, 140, M145

Eagle(s), 180

Bald, 180, 188, M70

Golden, 180, 188, M81

Steller's Sea-, 180 
White-tailed, 180, 188

Egret(s), Cattle, 112, M24

Chinese, 112, 358

Common. See Great, 112.

Great, 112, M22

Reddish, 110

Snowy, 112, M23

Egretta caerulea, 110, 112

eulophotes, 112, 358

rufescens, 110

thula, 112, M23

tricolor, 110

Eider(s), Common, 74, 70, M50

King, 52, 70, M51

Spectacled, 52, M52

Steller's, 54, M53

Elanus leucurus, 170, 194, M68

Emberiza aureola, 356

pallasi, 356

pusilla, 356

rustica, 356

schoeniclus, 356

variabilis, 356

Emberizidae, 316-36

Emberizinae. See Towhees, Sparrows, etc., 316-334.

Empidonax alnorum, 238, M242

difficilis, 240, M247

flaviventris, 240, M241

fulvifrons, 240

hammondii, 238, M245

minimus, 240, M244

oberholseri, 238, M246

occidentalis, 240, M247

traillii, 238, M243

wrightii, 238, 240, M241

Eremophila alpestris, 242, M258

Eudocimus albus, 112

Eugenes fulgens, 218

Euphagus carolinus, 306, M420 cyanocephalus, 306, M421

Euptilotis neoxenus, 206

Eurynorhynchus pygmeus, 150

Euthlypis lachrymosa, 350

Falcipennis canadensis, 164, M90

Falco columbarius, 186, 196, M83 femoralis, 186, 196

mexicanus, 186, M86

peregrinus, 186, 196, M84

rusticolus, 184, 196, M85

sparverius, 186, 196, M82

subbuteo, 358

tinnunculus, 358

Falcon(s), 186

Peregrine, 186, 196, M84

Prairie, 186, M86

Falconidae, 184

Ficedula narcissina, 354
Fieldfare, 352

Finch(es), 340

Black Rosy. See Rosy, 334.

Brown-capped Rosy. See Rosy, 334.

Cassin's, 342, M431

Gray-crowned Rosy. See Rosy, 334.

House, 342, M432

Purple, 342, M430

Rosy, 334, M428

Finches (true), 334, 340-344

Flicker, "Gilded." See Northern, 226.

Northern, 226, M237

"Red-shafted." See Northern, 226.

"Yellow-shafted." See Northern, 226.

Flycatcher(s), 236

Alder, 238, M242

Ash-throated, 234, M252

Asian Brown, 354

Beardless. See Tyrannulet, Northern Beardless-, 240.

Brown-crested, 234

Buff-breasted, 240

Cordilleran, 240, M247

Coues'. See Pewee, Greater, 236.

Dusky, 238, M246

Dusky-capped, 234

Gray, 238, 240, M241

Gray-spotted, 354

Great Crested, 234, M253

Hammond's, 238, M245

Least, 240, M244

Narcissus, 354

Nutting's, 350

Olivaceous. See Dusky-capped, 234.

Olive-sided, 236, M239

Pacific-slope, 240, M247

Red-breasted, 354

Scissor-tailed, 230, M257

Siberian, 354

Sulphur-bellied, 234

Traill's. See Alder and Willow, 238.

Vermilion, 230, M251

Western, 240, M247

Wied's Crested. See Brown-crested, 234.

Willow, 238, M243

Yellow-bellied, 240, M241

Fratercula cirrhata, 32, M183

corniculata, 32, M184

Fregata magnificens, 84 minor, 84

Fregatidae, 84

Frigatebird(s), 84

Great, 84

Magnificent, 84

Fringilla montifringilla, 356

Fringillidae, 340 
Fulica atra, 62, 358

americana, 64, 188, M111

Fulmar, Northern, 78, M10

Fulmarus glacialis, 78, M10

Gadwall, 44, 66, M43

Gallinago gallinago, 138, M150

Gallinula chloropus, 64, 118, M110

Gallinule, Common. See Moorhen, Common, 64.

Purple, 64

Garganey, 48, 62

Gavia adamsii, 24, M4

arctica, 24, 30

immer, 24, 30, M3

pacifica, 24, 30, M2

stellata, 24, 30, M1

Gaviidae, 24

Geese, 38, 40, 42

Geococcyx californianus, 212, M192

Geothlypis trichas, 302, M359

Glareola maldivarum, 156

Glaucidium brasilianum, 204 gnoma, 204, M199

Gnatcatcher(s), Black-capped, 268

Black-tailed, 268, M300

Blue-gray, 268, M299

California, 268, M300

Goatsucker(s), 214

Godwit(s), Bar-tailed, 152, M131

Black-tailed, 152

Hudsonian, 130, 132

Marbled, 130, 132, M132

Goldeneye(s), Barrow's, 58, M60 Common, 58, 72, M59

Goldfinch(es), American, 344, M439

"Arkansas." See Lesser, 344.

"Green-backed." See Lesser, 344.

Lawrence's, 344, M438

Lesser, 344, M437

Goose, Bean, 40, 62

Canada, 40, 42, M35

Emperor, 40, 42, M33

Greater White-fronted, 40, 42, M30

Greylag, 358

Ross's, 38, 42, M32

Snow, 38, 40, 42, M31

Goshawk, Northern, 172, 196, M74

Grackle(s), Common, 306, M423

Great-tailed, 306, M422

Grebe(s), 26

Clark's, 26

Eared, 26, M8

Horned, 26, M6

Least, 26

Pied-billed, 26, M5

Red-necked, 26, M7

Western, 26, M9

Greenfinch, Oriental, 356
Greenshank, Common, 156

Grosbeak(s), Black-headed, 336, M372

Blue, 338, M373

Crimson-collared, 350

Evening, 344, M440

Pine, 342, M429

Rose-breasted, 336, M371

Yellow, 348

Grouse, Blue, 164, M91

Franklin's. See Spruce, 164.

Ruffed, 160, M95

Sage, 158, M96

Sharp-tailed, 160, M98

Spruce, 164, M90

Gruidae, 116

Grus americana, 116

canadensis, 116, M112

grus, 116

Guillemot(s), Black, 34, M178

Pigeon, 34, M178

Guiraca caerulea, 338, M373

Gull(s), 88

Black-headed, 96, 102

Black-tailed, 358

Bonaparte's, 96, 102, M158

California, 92, 100, M162

Franklin's, 96, 102, M157

Glaucous, 94, 98, M167

Glaucous-winged, 94, 98, M166

Heermann's, 90, 98, M159

Herring, 92, 100, M163

Ivory, 94, 102

Laughing, 96, 102

Little, 96, 102

Mew, 92, 100, M160

Ring-billed, 92, 100, M161

Ross's, 90, 102

Sabine's, 96, 102, M169

Slaty-backed, 90

Thayer's, 92, 100, M164

Western, 88, 90, 98, M165

Yellow-footed, 90

Gymnogyps californianus, 182

Gymnorhinus cyanocephalus, 254, M271

Gyrfalcon, 184, 196, M85

Haematopodidae, 120

Haematopus bachmani, 120, M119 palliatus, 120

Haliaeetus albicilla, 180

leucocephalus, 180, 188, M70

pelagicus, 180

Harrier, Northern, 170, 194, M71

Hawfinch, 356

Hawk(s), 172

Broad-winged, 176, 192, M76

Common Black-, 178, 190

Cooper's, 172, 196, M73 
Ferruginous, 176, 190, 194, M79

Gray, 178, 194

"Harlan's." See Red-tailed, 174.

Harris's, 178, 190

"Krider's." See Red-tailed, 174.

Marsh. See Harrier, Northern, 170.

Pigeon. See Merlin, 186.

Red-shouldered, 176, 192, M75

Red-tailed, 174, 190, 192, M78

Rough-legged, 176, 190, 192, M80

Sharp-shinned, 172, 196, M72

Swainson's, 174, 190, 192, M77

White-tailed, 178, 194

Zone-tailed, 178, 190

Heliomaster constantii, 220

Helmitheros vermivorus, 304

Heron(s), 110

Great Blue, 110, M21

Green, 110, M25

Little Blue, 110, 112

Louisiana. See Tricolored, 110.

Tricolored, 110

Heteroscelus brevipes, 156

incanus, 142, M126

Himantopus himantopus, 358 mexicanus, 120, M120

Hirundapus caudacutus, 246

Hirundinidae, 248

Hirundo rustica, 250, M265

Histrionicus histrionicus, 54, 70, M54

Hobby, Eurasian, 358

Hoopoe, 352

Hummingbird(s), 218

Allen's, 216, M222

Anna's, 216, M217

Berylline, 220

Black-chinned, 220, M216

Blue-throated, 218

Broad-billed, 218

Broad-tailed, 216, M220

Bumblebee, 220

Calliope, 220, M219

Costa's, 220, M218

Lucifer, 220

Magnificent, 218

Rivoli's. See Magnificent, 218.

Ruby-throated, 216, M215

Rufous, 216, M221

Violet-crowned, 220

White-eared, 218

Xantus's, 350

Hydrobatidae, 80

Hylocharis leucotis, 218

xantusii, 350

Hylocichla mustelina, 276

Ibis(es), 112

White, 112

White-faced, 114, M27
Icteria virens, 302, M364

Icteridae, 306-313

Icterinae. See Blackbirds, Orioles, etc., 306.

Icterus cucullatus, 312, M425

galbula, 312, M426

parisorum, 312, M427

pustulatus, 348

spurius, 312, M416

wagleri, 348

Ictinia mississippiensis, 170, 194, M69

Ixobrychus exilis, 114, M20

sinensis, 358

Ixoreus naevius, 274, M310

Jaeger(s), 86

Long-tailed, 86, M156

Parasitic, 86, M155

Pomarine, 86, M154

Jay(s), 254

Blue, 254, M268

Gray, 256, M266

Mexican, 254, M270

Pinyon, 254, M271

Steller's, 254, M267

Western Scrub-, 254, M269

Junco(s), 332

Dark-eyed, 332, M408

"Gray-headed." See Dark-eyed (in part), 332.

"Oregon." See Dark-eyed (in part), 332.

"Slate-colored." See Dark-eyed (in part), 332.

"White-winged." See Dark-eyed (in part), 332.

Yellow-eyed, 332

Junco hyemalis, 332, M408

phaeonotus, 332

Jynx torquilla, 352

Kestrel(s), American, 186, 196, M82

Eurasian, 358

Killdeer, 126, M117

Kingbird(s), Cassin's, 232, M254

Eastern, 232, M256

Thick-billed, 232

Tropical, 232

Western, 232, M255

Kingfisher(s), 206

Belted, 206, M223

Green, 206

Kinglet(s), Golden-crowned, 268, M297

Ruby-crowned, 268, M298

Kite(s), 170

Mississippi, 170, 194, M69

Swallow-tailed, 170 
Kite(s), cont.

White-tailed, 170, 194, M68

Kittiwake(s), Black-legged, 94, 102, M168

Red-legged, 94, 102

Knot(s), Great, 154

Red, 138, M136

Lagopus lagopus, 162, M92

leucurus, 162, M94

mutus, 162, M93

Lampornis clemenciae, 218

Laniidae, 280

Lanius cristatus, 352 excubitor, 280, M325

ludovicianus, 280, M326

Laridae, 86

Lark(s), 242

Horned, 242, M258

Larus argentatus, 92, 100, M163

atricilla, 96, 102

californicus, 92, 100, M162

canus, 92, 100, M160

crassirostris, 358

delawarensis, 92, 100, M161

glaucescens, 94, 98, M166

heermanni, 90, 98, M159

hyperboreus, 94, 98, M167

livens, 90

minutus, 96, 102

occidentalis, $88,90,98$, M165

pipixcan, 96, 102, M157

philadelphia, 96, 102, M158

ridibundus, 96, 102

schistisagus, 90

thayeri, 92, 100, M164

Laterallus jamaicensis, 118, M106

Leptotila verreauxi, 208

Leucosticte atrata, 334, M428 australis, 334,M428

tephrocotis, 334, M428

Limicola falcinellus, 150

Limnodromus griseus, 138, M148 scolopaceus, 138, M149

Limosa fedoa, 130, 132, M132

haemastica, 130, 132

lapponica, 132, 152, M131

limosa 130,152

Locustella lanceolata, 354 ochotensis, 354

Longspur(s), 328

Chestnut-collared, 328, M412

Lapland, 328, M410

McCown's, 328, M409

Smith's, 328, M411

Loon(s), 24, 30

Arctic, 24

Common, 24, 30, M3

Pacific, 24, 30, M2

Red-throated, 24, 30, M1
Yellow-billed, 24, M4

Lophodytes cucullatus, 60, 68, M62

Loxia curvirostra, 340, M433 leucoptera, 340, M434

Luscinia calliope, 354 cyane, 354 svecica, 278

Lymnocryptes minimus, 156

Magpie(s), Black-billed, 256, M273 Yellow-billed, 256, M273

Mallard, 44, 68, M38

Martin(s), Common House-, 352 Purple, 250, M259

Meadowlark(s), 310 Eastern, 310, M417

Western, 310, M418

Melanerpes aurifrons, 28, M227 carolinus, 228 erythrocephalus, 222, M225 formicivorus, 222, M226 lewis, 222, M224 uropygialis, 228, M227

Melanitta fusca, 50, 70, M58 perspicillata, 50, 70, M57 nigra, 50, 70, M56

Meleagris gallopavo, 158, M99

Melospiza georgiana, 320, M403 lincolnii, 324, M402 melodia, 324, M401

Merganser(s), Common, 60, 68, M63 Hooded, 60, 68, M62

Red-breasted, 60, 68, M64

Mergellus albellus, 62

Mergus merganser, 60, 68, M63 serator, 60, 68, M64

Merlin, 186, 196, M83

Micrathene whitneyi, 204, M200

Mimidae (mimic-thrushes), 270

Mimus polyglottos, 270, M313

Mniotilta varia, 292, M352

Mockingbird(s), 270

Northern, 270, M313

Molothrus aeneus, 310 ater, 310, 346, M424

Moorhen, Common, 64, 118, M110

Motacilla alba, 242

cinerea, 242

flava, 242

lugens, 242

Motacillidae, 242, 244

Murre(s), Common, 32, M176

Thick-billed, 32, M177

Murrelet(s), Ancient, 34, M180

Craveri's, 36

Kittlitz's, 36

Marbled, 36, M179

Xantus's, 36

Muscicapa daunrica, 354 griseisticta, 354 
sibirica, 354

Muscicapidae, 268-278

Myadestes townsendi, 274, M304

Mycteria americana, 116

Myiarchus cinerascens, 234, M252

crinitus, 234, M253

nuttingi, 350

tuberculifer, 234

tyrannulus, 234

Myioborus miniatus, 350 pictus, 296, M363

Myiodynastes luteiventris, 234

Myna, Crested, 280

Needletail, White-throated, 246

Nighthawk(s), Common, 214, M209 Lesser, 214, M208

Night-Heron(s), Black-crowned, 114, M26

Yellow-crowned, 114

Nightjar(s), Buff-collared, 214 Jungle, 358

Nucifraga columbiana, 256, M272

Numenius americanus, 130, 132, M130

borealis, 130, 152

madagascariensis, 152

minutus, 152

phaeopus, 130, 132, M129

tahitiensis, 132, 152

Nutcracker, Clark's, 256, M272

Nuthatch(es), 262

Pygmy, 262, M287

Red-breasted, 262, M285

White-breasted, 262, M286

Nyctanassa violacea, 114, M27

Nyctea scandiaca, 198, M197

Nycticorax nycticorax, 114, M26

Oceanites oceanicus, 80

Oceanodroma castro, 80

furcata, 80, M11

homochroa, 80, M13

leucorhoa, 80, M12

melania, 80

microsoma, 80

tethys, 80

Oenanthe oenanthe, 278

Oldsquaw, 54, 70, M55

Old World Sparrow(s), 346

Oporornis agilis, 298, M356

formosus, 304

philadelphia, 298, M357

tolmiei, 298, M358

Oreortyx pictus, 166, M100

Oreoscoptes montanus, 270, M314

Oriole(s), 312

Baltimore, 312

Black-vented, 348

Bullock's, 312
Hooded, 312, M425

Orchard, 312, M416

Scott's, 312, M427

Streak-backed, 348

Osprey, 184, 188, M67

Otus asio, 200, M195

flammeolus, 204, M194

kennicottii, 200, M195

sunia, 358

trichopsis, 200

Ovenbird, 302, M354

Owl(s), 198

Barn, 198, M193

Barred, 198, M203

Boreal, 202, M200

Burrowing, 202, M201

Eastern Screech-, 204, M195

Elf, 204, M200

Ferruginous. See Ferruginous Pygmy-, 204.

Flammulated, 204, M194

Great Gray, 198, M204

Great Horned, 200, M196

Long-eared, 200, M205

Mottled, 350

Northern Hawk, 202, M198

Northern Pygmy-, 204, M199

Northern Saw-whet, 202, M207

Oriental Scops-, 358

Short-eared, 200, M206

Snowy, 198, M197

Spotted, 204, M202

Western Screech-, 200, M195

Whiskered Screech-, 198

Oystercatcher(s), 120

American, 120

Black, 120, M119

Pachyramphus aglaiae, 230

Pagophila eburnea, 94, 102

Pandion haliaetus, 184, 188, M67

Parabuteo unicinctus, 178, 190

Parakeet(s)

Orange-fronted, 212

Rose-ringed, 210

White-winged, 210

Paridae, 258

Parrot(s), 210

Lilac-crowned, 212

Red-crowned, 210

Thick-billed, 210

Yellow-headed, 212

Partridge(s), Gray, 164, M87

Red-legged, 164

Parula, Northern, 302

Parula americana, 302 superciliosa, 350

Parulidae, 288-305

Parulinae. See Warblers, 288.

Parus major, 354 
Passer domesticus, 346, M441 montanus, 346

Passerculus sandwichensis, 326, M395

Passerella iliaca, 324, M400

Passeridae, 346

Passerina amoena, 338, M374 ciris, 338, M376

cyanea, 338 versicolor, 338, M375

Pelecanidae, 84

Pelecanus erythrorhynchos, 84, M14 occidentalis, 84, M15

Pelican(s), 84 American White, 84, M14 Brown, 84, M15

Perdix perdix, 164, M87

Perisoreus canadensis, 256, M266

Petrel(s), 76

Cook's, 78

Mottled, 78

Murphy's, 78

Solander's, 78

Stejneger's, 78

See also Storm-Petrels, 80.

Petrochelidon fulva, 248 pyrrhonota, 250, M264

Peucedramus taeniatus, 296, M365

Pewee(s), Greater, 326

Eastern Wood-, 236

Western Wood-, 236, M240

Phaethon aethereus, 82

lepturus, 82

rubricauda, 82

Phaethontidae, 82

Phalacrocoracidae, 28

Phalacrocorax auritus, 28, 30, M16 brasilianus, 28

pelagicus, 28, 30, M18

penicillatus, 28, 30, M17

urile, 28

Phalaenoptilus nuttallii, 214, M210

Phainopepla, 282, M324

Phainopepla nitens, 282, M324

Phalarope(s), 134, 136

Northern. See Red-necked, 136.

Red, 136, M153

Red-necked, 136, M152

Wilson's, 134, 136, M151

Phalaropus fulicaria, 136, M163 lobatus, 136, M152

tricolor, 134, 136, M151

Phasianidae, 158

Phasianus colchicus, 158, M89

Pheasant, Ring-necked, 158, M89

Pheucticus chrysopeplus, 348

ludovicianus, 336, M371

melanocephalus, 336, M372

Philomachus pugnax, 144
Phoebastria albatrus, 74

immutabilis, 74

nigripes, 74

Phoebe(s), Black, 236, M248

Eastern, 236, M249

Say's, 237, 238, M250

Phylloscopus borealis, 300 fuscatus, 354

Pica nuttalli, 256, M273 pica, 256, M273

Picidae, 222

Picoides albolarvatus, 224, M234 arcticus, 224, M236

nuttallii, 228, M225

pubescens, 224, M232

scalaris, 228, M231

stricklandi, 228

tridactylus, 224, M235

villosus, 224, M233

Pigeon(s), 208

Band-tailed, 208, M185

Red-billed, 208

Pinicola enucleator, 342, M429

Pintail, Northern, 46, 66, M39

Pipilo aberti, 330, M381

chlorurus, 330, M378

crissalis, 330, M380

fuscus, 330, M380

maculatus, 330, M379

Pipit(s), 244

American, 244, M320

Olive-backed, 244

Pechora, 244

Red-throated, 244

Sprague's, 244, M321

Tree-, 244

Piranga bidentata, 348

flava, 314, M366

ludoviciana, 314, M368

olivacea, 314

rubra, 314, M367

Plectrophenax hyperboreus, 334 nivalis, 334, M413

Plegadis chihi, 114, M27

Plover(s), 122

American Golden-, 122, M114

Black-bellied, 122, M113

Common Ringed, 124

Mongolian, 126

Mountain, 126, M118

Pacific Golden-, 122, M114

Piping, 124, M115

Semipalmated, 124, M116

Snowy, 124, M115

Upland. See Sandpiper, Upland, 144.

Wilson's, 124

Pluvialis dominica, 122, M114

fulva, 122, M114 
squatarola, 122, M113

Pochard, Common, 62

Podicepedidae, 26

Podiceps auritus, 26, M6 grisegena, 26, M7 nigricolis, 26, M7

Podilymbus podiceps, 26, M5

Poecile atricapillus, 258, M278 cinctus, 258

gambeli, 258, M279

hudsonicus, 258, M280

rufescens, 258, M281

sclateri, 258, M280

Polioptila caerulea, 268, M299

californica, 268, M300

melanura, 268, M300

nigriceps, 268

Polioptilini. See Kinglets, Gnatcatchers, Old World Warblers, 268.

Polysticta stelleri, 54, M53

Pooecetes gramineus, 324, M390

Poorwill, Common, 214, M210

Porphyrula martinica, 64

Porzana carolina, 118, M109

Prairie-Chicken(s), Greater, 160, M97

Lesser, 160, M97

Pratincole, Oriental, 156

Procellariidae, 76

Progne subis, 250, M259

Protonotaria citrea, 304

Prunella montanella, 354

Prunellidae, 354

Psaltriparus minimus, 260, M284

Psittacidae, 210

Psittacula krameri, 210, 211

Ptarmigan, Rock, 162, M93

White-tailed, 162, M94

Willow, 162, M92

Pterodroma cookii, 78

inexpectata, 78

longirostris, 78

solandri, 78

ultima, 78

Ptilogonatidae, 282

Ptilogonys cinereus, 350

Ptychoramphus aleuticus, 36, M181

Puffin(s), Horned, 32, M184

Tufted, 32, M183

Puffinus bulleri, 76

carneipes, 76

creatopus, 76

griseus, 76

opisthomelas, 76

pacificus, 78

tenuirostris, 76

Pyrocephalus rubinus, 230, M251

Pyrrhula pyrrhula, 356

Pyrrhuloxia, 336, M370
Quail, California, 166, M104

Gambel's, 166, M103

Harlequin. See Montezuma, 166.

Montezuma, 166, M100

Mountain, 166, M100

Scaled, 166, M102

Quiscalus mexicanus, 306, M422 quiscula, 306, M423

Oxyura jamaicensis, 58, 72, M65

Rail(s), 118

Black, 118, M106

Clapper, 118, M107

King, 120

Virginia, 118, M108

Yellow, 118, M105

Rallidae, 118

Rallus elegans, 120

limicola, 118, M108

longirostris, 118, M107

Raven(s), Chihuahuan, 252, M276

Common, 252, M277

White-necked. See Chihuahuan

Recurvirostra americana, 120, M121

Recurvirostridae, 120

Redhead, 56, 72, M46

"Hoary" Redpoll. See Common Redpoll, 342 .

Redshank, Spotted, 156

Redstart(s), American, 294, M353

Painted, 296, M363

Slate-throated, 350

Regulidae, 268

Regulus calendula, 268, 284, M298 satrapa, 268, M297

Remizidae, 260

Rhodothraupis celaeno, 350

Rhodostethia rosea, 90, 102

Rhynchopsitta pachyrhyncha, 210

Ridgwayia pinicola, 348

Riparia riparia, 248, M263

Rissa brevirostris, 94 tridactyla, 94, 102, M168

Roadrunner, Greater, 212, M192

Robin(s), American, 274, M309

Rufous-backed, 274, 348

Siberian Blue, 354

Rosefinch, Common, 356

Rubythroat, Siberian, 354

Ruff, 144

Rynchops niger, 108

Salpinctes obsoletus, 266, M290

Sanderling, 140, M137

Sandpiper(s), 134

Baird's, 146, M142

Broad-billed, 150

Buff-breasted, 144, M147 
Sandpiper(s), cont.

Common, 154

Curlew, 154

Green, 154

Least, 148, M140

Marsh, 156

Pectoral, 146, M143

Rock, 142, M144

Rufous-necked. See Stint, Rufousnecked, 150 .

Semipalmated, 148, M138

Solitary, 134, M124

Spoonbill, 150

Spotted, 140, M127

Stilt, 134, 144, M146

Terek, 154

Upland, 144, M128

Western, 148, M139

White-rumped, 146, M141

Wood, 154

Sapsucker|s|, Red-breasted, 226, M229

Red-naped, 226, M228

Williamson's, 226, M230

Yellow-bellied, 226, M228

Saxicola torquata, 352

Sayornis nigricans, 236, M248

phoebe, 236, M249

saya, 238, M250

Scaup(s), Greater, 56, 72, M48

Lesser, 56, M49

Scolopacidae, 128

Scolopax minor, 138

Scoter, Common. See Black, 50.

Black, 50, 70, M56

Surf, 50, 70, M57

White-winged, 50, 70, M58

Seiurus aurocapillus, 302, M354 noveboracensis, 304, M355

Selasphorus platycercus, 216, M220 rufus, 216, M221

sasin, 216, M222

Setophaga ruticilla, 294, M353

Shearwater(s), 76

Black-vented, 76

Buller's, 76

Flesh-footed, 76

Manx. See Black-vented, 76.

New Zealand. See Buller's, 76.

Pale-footed. See Flesh-footed, 76.

Pink-footed, 76

Short-tailed, 76

Slender-billed. See Short-tailed, 76.

Sooty, 76

Streaked, 78

Wedge-tailed, 78

Shoveler, Northern, 48, 66, M42

Shrike(s), 280

Brown, 352
Loggerhead, 280, M326

Northern, 280, M325

Sialia currucoides, 278, M303

mexicana, 278, M302

sialis, 278, M301

Silky-Flycatcher, Gray, 350

Siskin, Pine, 344, M436

Sitta canadensis, 262, M285

carolinensis, 262, M286

pygmaea, 262, M287

Sittidae, 262

Skimmer(s), 108

Black, 108

Skua(s), 86

South Polar, 86

Skylark, 242

Smew, 62

Snipe(s), Common, 138, M150 Jack, 156

Solitaire, Townsend's, 274, M304

Somateria fischeri, 52, M52

mollissima, 52, M50

spectabilis, 52, M51

Sora, 118, M109

Sparrow(s), 316

American Tree, 320, M384

Baird's, 326, M396

"Belding's." See Savannah (in part), 326.

Black-chinned, 318, M389

Black-throated, 318, M392

Botteri's, 322

Brewer's, 322, M387

Cassin's, 322, M382

Chipping, 320, M385

Clay-colored, 320, 322, M386

Eurasian Tree, 346

Field, 320, M388

Five-striped, 318

Fox, 324, M400

"Gambel's." See White-crowned (in part), 316 .

Golden-crowned, 316, M405

Grasshopper, 322, M397

Harris's, 316, M407

House, 346, M441

Le Conte's, 326, M398

Lincoln's, 324, M402

"Large-billed." See Savannah (in part), 326.

Lark, 318, M391

Nelson's Sharp-tailed, 326

"Nuttall's." See White-crowned (in part), 316.

Rufous-crowned, 320, M383

Rufous-winged, 322

Sage, 318, M393

Savannah, 326, M395

Song, 324, M401 
Swamp, 320, M403

Vesper, 324, M390

White-crowned, 316, M406

White-throated, 316, M404

Sphyrapicus nuchalis, 226, M228

ruber, 226, M229

thyroideus, 226, M230

varius, 228, M228

Spiza americana, 346, M377

Spizella arborea, 320, M384

atrogularis, 318, M389

breweri, 322, M387

pallida, 322, M386

passerina, 320, M385

pusilla, 320, M388

Spoonbill, Roseate, 112, 114

Starling, European, 280, M327

Starthroat, Plain-capped, 220

Stelgedopteryx serripennis, 248, M262

Stellula callipe, 220, M219

Stercorarius longicaudus, 86, M156 parasiticus, 86, M155 pomarinus, 86, M154

Sterna aleutica, 108 antillarum, 108, M174

caspia, 104, M170

elegans, 104

forsteri, 106, M173

hirundo, 106, M171

maxima, 104

nilotica, 104

paradisaea, 106, M172

Stilt|s), 120

Black-necked, 120, M120

Black-winged, 358

Stint(s), Little, 150

Long-toed, 150

Red-necked, 150

Temminck's, 150

Stonechat, 352

Stork, Wood, 116

Storm-Petrel(s) (formerly Petrels), 80

Ashy, 80, M13

Band-rumped, 80

Black, 80

Fork-tailed, 80, M11

Galápagos. See Wedge-rumped, 80.

Leach's, 80, M12

Least, 80

Wedge-rumped, 80

Wilson's, 80

Streptopelia chinensis, 210

orientalis, 352

risoria, 210

Strigidae, 198

Strix nebulosa, 198, M204 occidentalis, 204, M202

varia, 198, M203
Sturnidae, 280

Sturnella magna, 310, M417 neglecta, 310, M418

Sturnus vulgaris, 280, M327

Sula dactylatra, 82 leucogaster, 82 nebouxii, 82 sula, 82

Sulidae, 82

Surfbird, 142, M135

Surnia ulula, 202, M198

Swallow(s), 248

Bank, 248, M263

Barn, 250, M265

Cave, 248

Cliff, 250, M264

Northern Rough-winged, 248, M262

Tree, 248, M260

Violet-green, 248, M261

Swan(s), 38, 42

"Bewick's" See Tundra, 38.

Mute, 38

Trumpeter, 38, M29

Tundra, 38, 42, M28

Whistling. See Tundra, 38, 42.

Whooper, 38

Swift|s), 246

Black, 246, M212

Chimney, 246, M213

Common, 246

Fork-tailed, 246

Vaux's, 246, M213

White-throated, 246, M214

Sylviidae, 268, 300

Synthliboramphus antiquus, 34, M180

craveri, 36

hypoleucus, 36

Tachybaptus dominicus, 26

Tachycineta bicolor, 248, M260 thalassina, 248, M261

Tanager(s), 314

Flame-colored, 348

Hepatic, 314, M366

Scarlet, 314

Summer, 314, M367

Western, 314, M368

Tarsiger cyanurus, 354

Tattler, Gray-tailed, 156

Wandering, 142, M126

Teal(s), Baikal, 48, 62

Blue-winged, 48, 66, M40

Cinnamon, 48, M41

Eurasian. See Green-winged, 48.

Green-winged, 48, 66, M37

Tern(s), 104

Aleutian, 108 
Tern(s), cont.

Arctic, 106, M172

Black, 108, M175

Caspian, 104, M170

Common, 106, M171

Elegant, 104

Forster's, 106, M173

Gull-billed, 104

Least, 108, M174

Royal, 104

White-winged, 108

Thalassarche cauta, 74

Thrasher(s), Bendire's, 272, M316

Brown, 270, M315

California, 272, M317

Crissal, 272, M318

Curve-billed, 272, M317

Le Conte's, 272, M319

Sage, 270, M314

Thraupidae, 314

Thraupinae, 314

Threskiornithidae, 112

Thursh(es), 274

Aztec, 348

Dusky, 352

Eyebrowed, 352

Gray-cheeked, 276, M306

Hermit, 276, M308

Swainson's, 276, M307

Varied, 274, M310

Wood, 276

Thryomanes bewickii, 264, M292

Thryothorus ludovicianus, 264

Tinaliidae, 266

Tit, Great, 354

Siberian. See Chickadee, Grayheaded, 258

Titmice, 260

Titmouse, "Black-crested," 260

Bridled, 260

Oak, 260, M282

Tufted, 260, M282

Towhee(s), 330

Abert's, 330, M381

Brown. See California and Canyon towhees, 330.

California, 330, M380

Canyon, 330, M380

Green-tailed, 330, M378

Spotted, 330, M379

Toxostoma bendirei, 272, M316

crissale, 272, M318

curvirostre, 272, M317

lecontei, 272, M319

redivivum, 272, M317

rufum, 270, M315

Tringa erythropus, 156

flavipes, 134, M123

glareola, 154 melanoleuca, 134, M122

nebularia, 156

ocropus, 154

solitaria, 134, M124

stagnatalis, 156

Trochilidae, 216

Troglodytes aedon, 264, M293

troglodytes, 264, M294

Troglodytidae, 264

Trogon(s), 206

Coppery-tailed. See Elegant, 206.

Eared, 206

Elegant, 206

Trogon elegans, 206

Trogonidae, 206

Tropicbird(s), 82

Red-billed, 82

Red-tailed, 82

White-tailed, 82

Tryngites subruficollis, 144

Turdidae, 274

Turdus migratorius, 274, M309

naumanni, 352

obscurus, 352

pilaris, 352

rufopalliatus, 274, 348

Turkey, Wild, 158, M99

Turnstone(s), Black, 142, M134 Ruddy, 142, M133

Tympanuchus cupido, 160, M97 pallidicinctus, 160, M97 phasianellus, 160, M98

Tyrannidae, 230

Tyrannulet, Northern Beardless-, 238

Tryannus crassirostris, 232

forficatus, 230, M257

melancholicus, 232

tyrannus, 232, M256

verticalis, 232, M255

vociferans, 232, M254

Tyrant-Flycatchers, 230

Tytonidae, 198

Upupa epops, 352

Upupidae, 352

Uria aalge, 32, M176 lomvia, 32, M177

Veery, 276, M305

Verdin, 260, M283

Vermivora celata, 300, M336

chrysoptera, 304

crissalis, 296

luciae, 296, M339

peregrina, 300, M335

pinus, 304

ruficappilla, 298, M337

virginiae, 296, M338

Vireo(s), 284 
Bell's, 284, M328

Black-capped, 284

Blue-headed, 284, M330

Gray, 286, M329

Hutton's, 284, M331

Philadelphia, 286, M333

Red-eyed, 286, M334

Warbling, 286, M332

White-eyed, 284

Yellow-green, 286

Yellow-throated, 284

Vireo atricapillus, 284

bellii, 284, M328

flavifrons, 284

flavoviridis, 286

gilvus, 286, M332

griseus, 284

huttoni, 284, M331

olivaceus, 286, M334

philadelphicus, 286, M333

solitarius, 284, M330

vicinior, 286, M329

Vireonidae, 284

Vulture(s), 182

Black, 182

Turkey, 182, M66

Wagtail(s), 242

Black-backed, 242

Gray, 242

White, 242

Yellow, 242

Warbler(s), Arctic, 300

"Audubon's." See Yellow-rumped, 288.

Bay-breasted, 294, M350

Blackburnian, 294

Blackpoll, 292, M351

Black-throated Blue, 292

Black-throated Gray, 292, M345

Black-throated Green, 290, M347

Black-and-white, 292, M352

Blue-winged, 304

Canada, 288, M361

Cape May, 294, M343

Cerulean, 292

Chestnut-sided, 294, M341

Colima, 296

Connecticut, 298, M356

Crescent-chested, 350

Dusky, 354

Fan-tailed, 350

Golden-cheeked, 290

Golden-winged, 304

Grace's, 296, M348

Hermit, 290, M347

Hooded, 302

Kentucky, 304

Lanceolated, 354
Lucy's, 296, M339

MacGillivray's, 298, M358

Magnolia, 288, M342

Middendorff's Grasshopper-, 354

Mourning, 298, M357

"Myrtle." See Yellow-rumped, 288.

Nashville, 298, M337

Olive, 296, M365

Orange-crowned, 300, M336

Palm, 300, M349

Pine, 304

Prairie, 304

Prothonotary, 304

Rufous-capped, 350

Red-faced, 296, M362

Tennessee, 300, M335

Townsend's, 290, M346

Virginia's, 296, M338

Wilson's, 302, M360

Worm-eating, 304

Yellow, 300, M340

Yellow-rumped, 288, M344

Yellow-throated, 304

Waterthrush, Northern, 304, M355

Waxwing(s), 282

Bohemian, 282, M322

Cedar, 282, M323

Wheatear, Northern 278

Whimbrel, 130, 132, M129

Whip-poor-will, 214, M211

Ridgway's. See Nightjar, Buff-collared, 214.

Whistling-Duck(s),

Black-bellied, 42

Fulvous, 42, 68

Wigeon(s), American, 46, 66, M44 Eurasian, 46

Willet, 132, 134, M125

Wilsonia canadensis, 288, M361

citrina, 302

pusilla, 302, M360

Woodcock, American, 138

Woodpecker(s), 222

Acorn, 222, M226

Arizona. See Strickland's, 228.

Black-backed, 224, M236

Downy, 224, M232

Gila, 228, M227

Golden-fronted, 228, M227

Great Spotted, 358

Hairy, 224, M233

Imperial, 350

Ladder-backed, 228, M231

Lewis's, 222, M224

Nuttall's, 228, M225

Pileated, 222, M238

Red-bellied, 228

Red-headed, 222, M225

Strickland's, 228 
Wren(s), 264

Three-toed, 224, M235

White-headed, 224, M234

Bewick's, 264, M292

"Brown-throated." See House, 264.

Cactus, 266, M289

Canyon, 266, M291

Carolina, 264

House, 264, M293

Long-billed Marsh. See Marsh, 264.

Marsh, 264, M295

Rock, 266, M290

Sedge, 264

Short-billed Marsh. See Sedge, 264.

Winter, 264, M294

Wrentit, 266, M311

Wryneck, Eurasian, 352
Xanthocephalus xanthocephalus, 308, M419

Xema sabini, 96, 102, M169

Xenus cinereus, 154

Yellowlegs, Greater, 134, M122

Lesser, 134, M123

Yellowthroat, Common, 302, M359

Zenaida asiatica, 208, M186 macroura, 208, M187

Zonotrichia albicollis, 316, M404 atricapilla,316, M405 leucophrys, 316, M406 querula, 316, M407

\section{CONSERVATION NOTE}

Birds contribute to our pleasure and standard of living. But they are also sensitive indicators of the environment, a sort of "ecological litmus test." Help support the cause of wildlife conservation by taking an active part in the efforts of the National Wildlife Federation, as well as the work of the National Audubon Society, the Sierra Club, the Nature Conservancy, and your state or local Audubon or natural history societies. On the international level, don't forget the International Council for Bird Preservation (ICBP) and the World Wildlife Fund (WWF).

The Roger Tory Peterson Institute of Natural History is oriented toward fact-finding and teaching, emphasizing hands-on field work by those who teach, rather than the methodology of the classroom or laboratory. It is not an activist organization like those mentioned above, but is supportive of their work through education and enlightenment. 


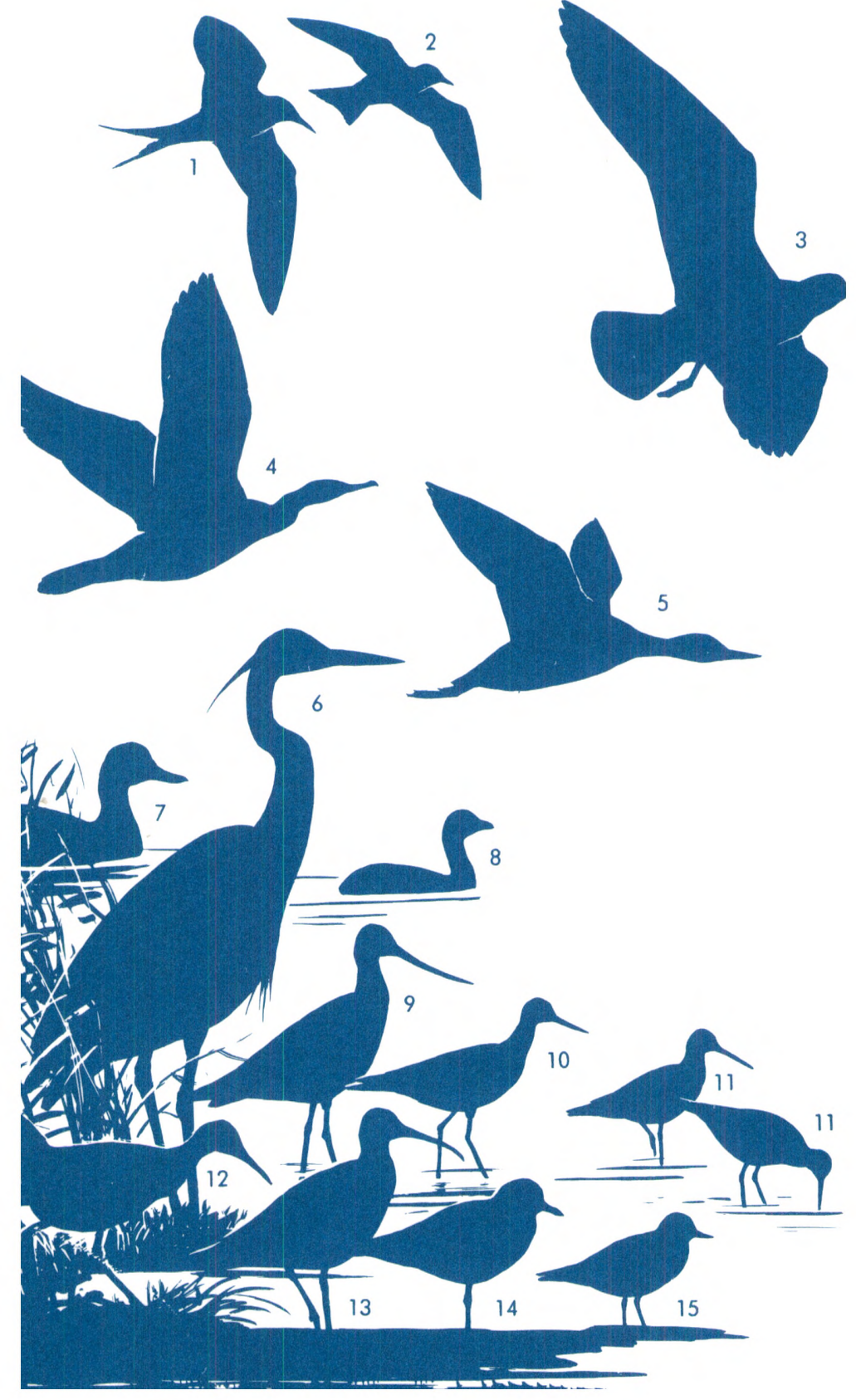

